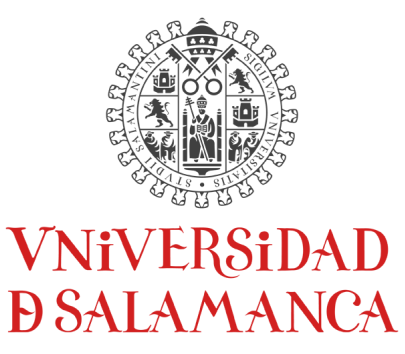

Departamento de Biblioteconomía y Documentación

\title{
Sitios web y aplicaciones nativas para móviles en bibliotecas.
}

El caso de la Biblioteca de la Universidad de Salamanca

TESIS DOCTORAL

Natalia Arroyo Vázquez

Salamanca, 2015 



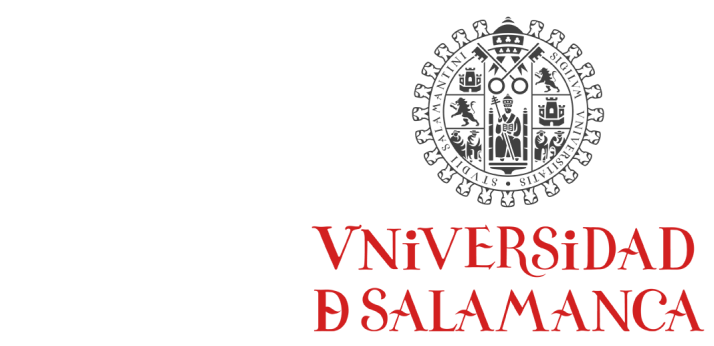

Departamento de Biblioteconomía y Documentación

\section{Sitios web y aplicaciones nativas para móviles en bibliotecas.}

El caso de la Biblioteca de la Universidad de Salamanca

TESIS DOCTORAL

Presentada para la obtención del grado de Doctora en Documentación

Natalia Arroyo Vázquez

Doctoranda
José Antonio Merlo Vega

Director 


\section{TESIS DOCTORAL}

\section{Título}

Sitios web y aplicaciones nativas para móviles en bibliotecas. El caso de la Biblioteca de la Universidad de Salamanca

\section{Doctoranda}

Natalia Arroyo Vázquez

\section{Director}

José Antonio Merlo Vega

\section{Departamento}

Biblioteconomía y Documentación

\section{Programa}

Metodología y líneas de investigación en Biblioteconomía y Documentación

\section{Descriptores}

Dispositivos móviles, smartphones, tabletas, web móvil, aplicaciones nativas, apps, catálogo, OPAC, bibliotecas. 


\title{
Sitios web y aplicaciones nativas para móviles en bibliotecas.
}

\author{
El caso de la Biblioteca de la Universidad de Salamanca
}

TESIS DOCTORAL

Natalia Arroyo Vázquez

Salamanca, 2015 



\section{Agradecimientos}

Al Servicio de Bibliotecas de la Universidad de Salamanca su inestimable colaboración.

A la empresa Obture Code, encargada del desarrollo de la aplicación Biblio USAL, por su ayuda en la recopilación de datos.

A las bibliotecas que respondieron amablemente a las cuestiones planteadas. 



\section{Índice de contenidos}

Parte I. Presentación............................................................................................... 13

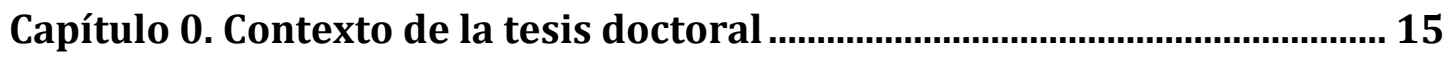

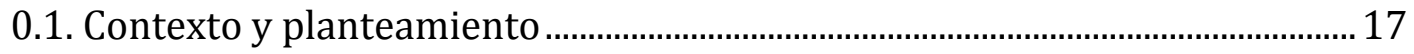

0.2. Metodología y desarrollo de la investigación ........................................................18

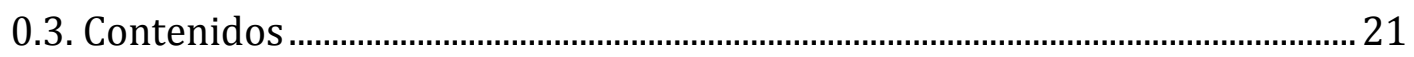

0.4. Análisis de la bibliografía sobre dispositivos móviles en bibliotecas .......... 23

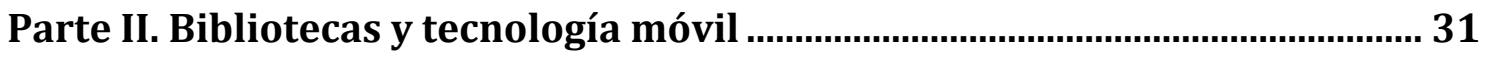

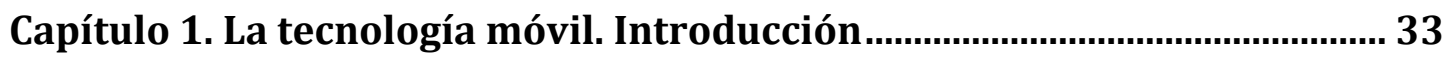

1.1. Los dispositivos móviles......................................................................................... 35

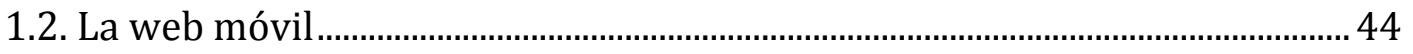

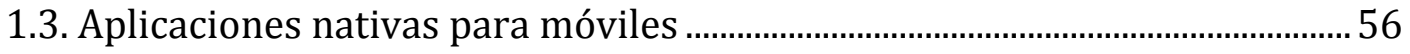

Capítulo 2. Tecnología móvil en bibliotecas. Estado de la cuestión ............... 59

2.1. Introducción al uso de dispositivos móviles en bibliotecas...............................61

2.2. La web móvil en las bibliotecas ...............................................................................

2.3. Aplicaciones nativas ............................................................................................... 137

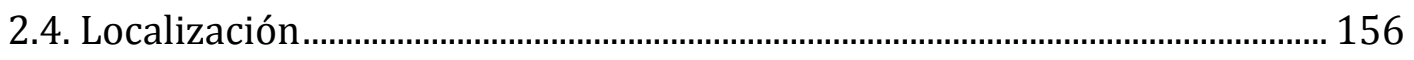

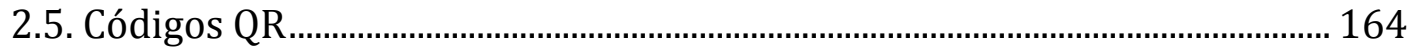

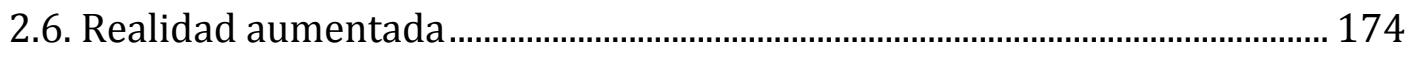

2.7. Near Field Communication (NFC) …………………………………………. 188

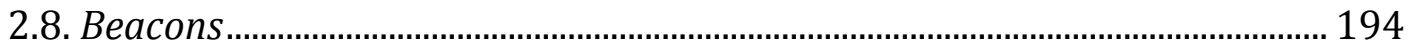

2.9. Otros servicios basados en dispositivos móviles.............................................. 196

Parte III. Sitios web, aplicaciones nativas y catálogos móviles ........................211

Capítulo 3. Metodología del trabajo de investigación ...................................213

3.1. Contexto y objetivos de la investigación............................................................. 215

3.2. Análisis de sitios web, aplicaciones nativas y catálogos móviles en bibliotecas: metodología ......................................................................................... 217

3.3. Biblioteca de la Universidad de Salamanca: metodología............................... 270 
Capítulo 4. Sitios web para dispositivos móviles. Resultados ......................277

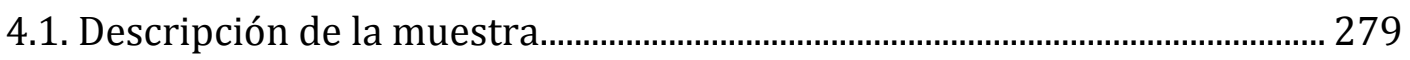

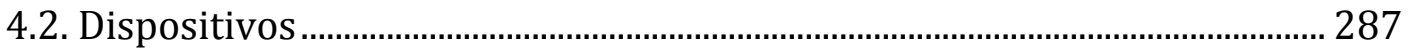

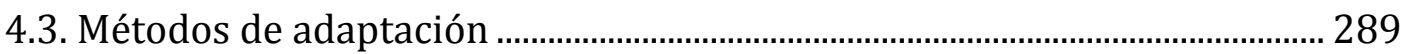

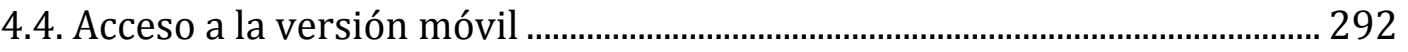

4.5. Diseño de la interfaz ........................................................................................... 297

4.6. Lenguajes de marcado, metadatos y analíticas................................................... 303

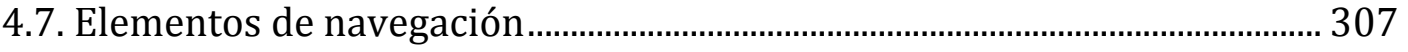

4.8. Aprovechamiento de las funciones del dispositivo......................................... 314

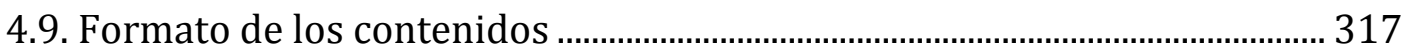

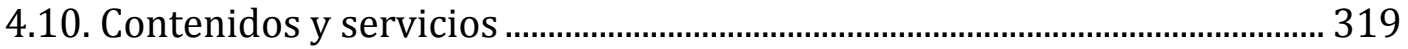

4.11. Ajuste a las características del dispositivo....................................................... 331

4.12. Buenas prácticas ............................................................................................ 333

Capítulo 5. Aplicaciones nativas en bibliotecas. Resultados ..........................337

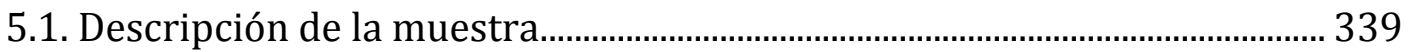

5.2. Dispositivos y sistemas operativos ……....................................................... 349

5.3. Información de la tienda de aplicaciones .............................................................. 352

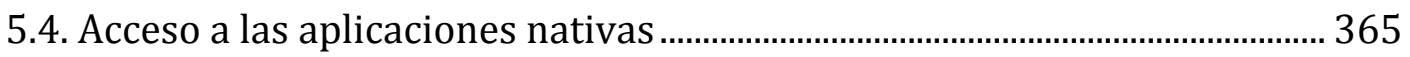

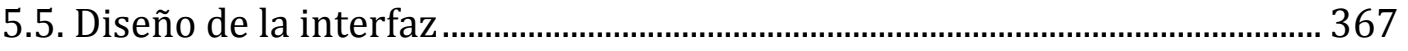

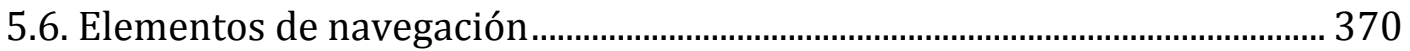

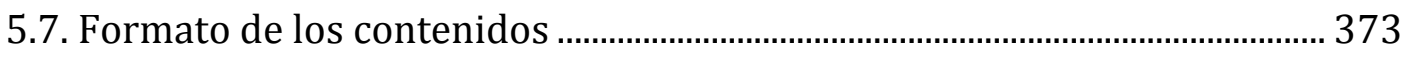

5.8. Aprovechamiento de las funciones del dispositivo........................................... 375

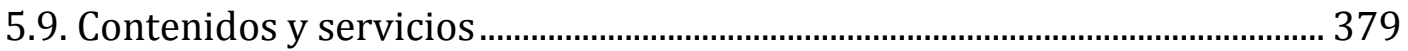

5.10. Ajuste a las características del dispositivo..................................................... 385

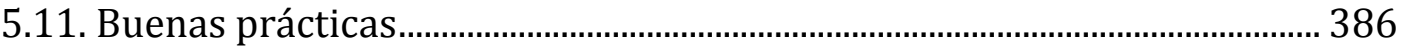

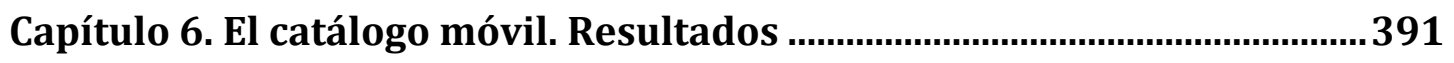

6.1. Catálogos móviles y herramientas de descubrimiento .................................... 394

6.2. Soluciones de movilidad .................................................................................... 395

6.3. Características de las herramientas de búsqueda para móviles ................. 400

6.4. Los catálogos móviles en aplicaciones nativas .................................................. 407 
Capítulo 7. La Biblioteca de la Universidad de Salamanca. Resultados.....411

7.1. Análisis del sitio web para móviles................................................................... 413

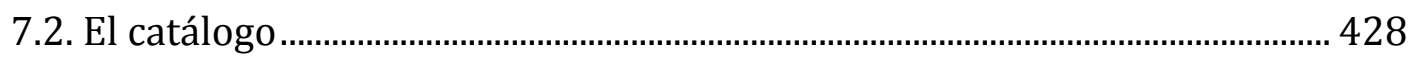

7.3. La aplicación Biblio USAL................................................................................ 432

Capítulo 8. Recomendaciones para bibliotecas ..............................................439

8.1. Pautas para sitios web y aplicaciones nativas............................................... 441

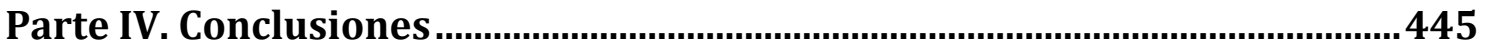

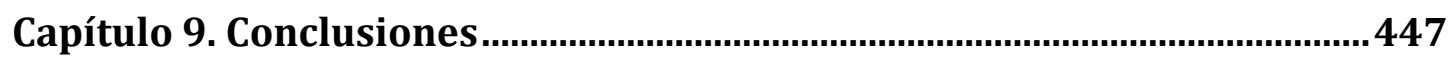

9.1. Sitios web para dispositivos móviles ............................................................... 449

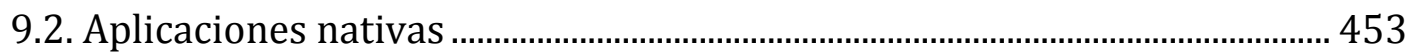

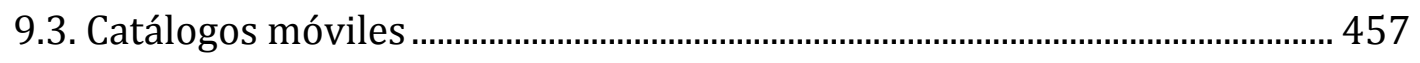

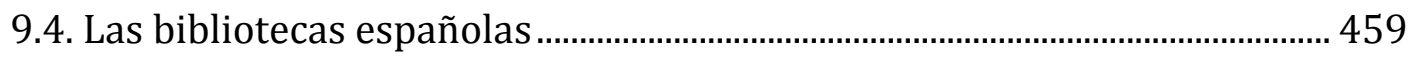

9.5. La Biblioteca de la Universidad de Salamanca ................................................. 460

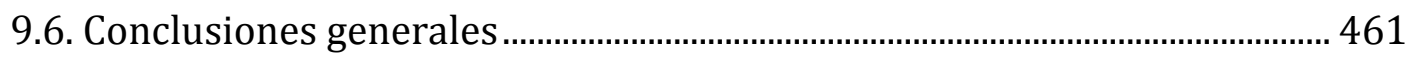

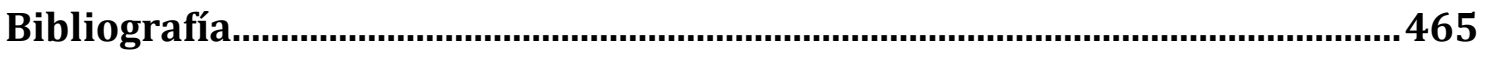

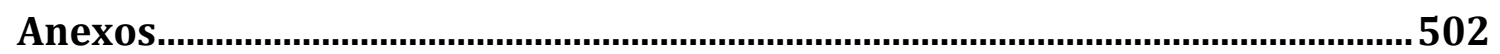

Anexo 1. Plantillas de diseño en sitios web para móviles ............................504

Anexo 2. Software móvil para herramientas de búsqueda ...........................507

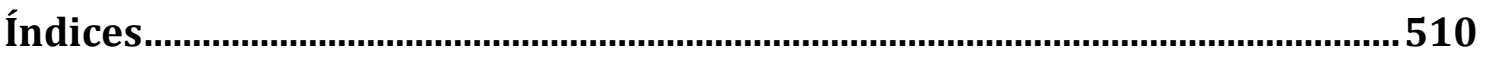

Índice de gráficos ........................................................................................512

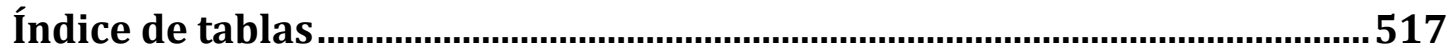

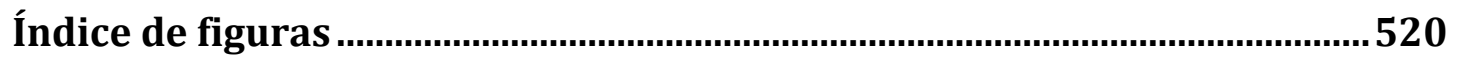



Parte I. Presentación 



\section{Capítulo 0. Contexto de la tesis doctoral}

En las siguientes páginas se proporciona un panorama general sobre los contenidos de la tesis doctoral que aquí se presenta. El objetivo es facilitar su lectura e introducir lo que se encontrará en los siguientes capítulos. Se avanzan en este capítulo el contexto y el planteamiento del trabajo de investigación, la metodología seguida y un breve resumen de cada uno de los capítulos.

Se expone también un análisis de la producción bibliográfica sobre dispositivos móviles en bibliotecas, como complemento al estado de la cuestión del segundo capítulo. Este análisis tiene el objetivo de mostrar a través de la bibliografía nacional e internacional cómo se ha desarrollado a lo largo del tiempo el tema de la tecnología móvil en bibliotecas, qué tipo de publicaciones son las más habituales y cuáles son los temas más tratados. 



\subsection{Contexto y planteamiento}

La aparición en el mercado de los primeros dispositivos móviles en los años noventa del pasado siglo trajo consigo los primeros servicios para usuarios de PDA en las bibliotecas. Se trataba de iniciativas puntuales para un grupo de personas con unas características y unas necesidades muy concretas. En 2007 se lanzó la primera versión del iPhone, que trajo consigo la gran popularidad de los smartphones que hoy conocemos. España es precisamente uno de los países en los que los smartphones están más presentes en el conjunto de la sociedad, hasta el punto de que el número de internautas que emplean un smartphone para acceder a internet ha superado al de quienes lo hacen desde un ordenador.

Pero la tecnología móvil no solo se refiere al smartphone, sin duda el dispositivo móvil más extendido. Hace unos años comenzó a configurarse un panorama multidispositivo en el que se encuentran también tabletas, phablets, videoconsolas portátiles, lectores de libros electrónicos, teléfonos móviles y relojes inteligentes. Todos ellos forman el grupo de dispositivos móviles, aparatos portátiles desde los que se puede acceder a internet y diseñados para ser utilizados en movimiento (Nkeze, Pearce y Womer, 2007).

En esta nueva etapa, protagonizada por los smartphones como principal dispositivo móvil, bibliotecas de todo tipo han comenzado a ofertar contenidos y servicios para smartphones y tabletas principalmente, sobre todo a través de sitios web y aplicaciones nativas. El acceso al catálogo se está planteando como uno de los servicios más importantes para los usuarios de este tipo de dispositivos.

Cómo son los sitios web, aplicaciones nativas y catálogos que las bibliotecas están construyendo para su uso a través de dispositivos móviles es la cuestión a la que quiere responder esta tesis doctoral. Esta cuestión, que a simple vista puede parecer sencilla, encierra una gran complejidad porque implica una gran diversidad de aspectos y tecnologías diferentes. Aunque la bibliografía sobre tecnología móvil en bibliotecas es extensa, se han detectado grandes lagunas en el conocimiento sobre las iniciativas en este sentido, especialmente en relación a los catálogos móviles y sobre las bibliotecas españolas, donde apenas se han realizado investigaciones al respecto.

La cuestión que se plantea en esta investigación tiene su punto de partida en el interés personal de la doctoranda. Su curiosidad sobre el empleo de la tecnología móvil en bibliotecas se ha plasmado en numerosas publicaciones que arrancan en 2009 y que pueden consultarse en la bibliografía. Dichas publicaciones y su 
experiencia profesional como formadora del personal bibliotecario sobre las posibilidades de los dispositivos móviles pusieron de manifiesto la necesidad de conocer a partir de datos reales las iniciativas llevadas a cabo por las bibliotecas para facilitar a los usuarios de smartphones y tabletas el acceso a sus contenidos y servicios.

Conocer lo que otros han hecho anteriormente constituye un ejercicio de benchmarking necesario para aquellas bibliotecas que ponen en marcha iniciativas de movilidad. El trabajo desarrollado en esta tesis doctoral analiza las experiencias de diversos tipos de bibliotecas, por lo que su valor práctico es considerable. Y no solo por eso, sino también porque pone de manifiesto los puntos críticos a tener en cuenta durante el proceso, así como las buenas y malas prácticas, si se quieren obtener mejores resultados.

El trabajo que se presenta en los siguientes capítulos constituye además un punto de partida en cuanto a la investigación sobre el empleo de la tecnología móvil en bibliotecas. No solo porque conocer el panorama general resulta esencial, sino también porque se identifican posibles líneas de investigación o aspectos críticos que requerirían una investigación más profunda. En este sentido, se espera que esta tesis doctoral sea un paso intermedio en la línea de trabajo de la doctoranda.

\subsection{Metodología y desarrollo de la investigación}

Para dar respuesta a la pregunta formulada - cómo son los sitios web, aplicaciones nativas y catálogos que las bibliotecas están construyendo para su uso a través de dispositivos móviles- se han concretado en cuatro objetivos:

- Dibujar un panorama completo y detallado sobre cómo las bibliotecas están construyendo sus sitios web, aplicaciones nativas y catálogos móviles.

- Identificar una serie de buenas prácticas que puedan servir como modelos para otras bibliotecas.

- Establecer una serie de pautas específicas para el desarrollo de sitios web y aplicaciones nativas para smartphones y tabletas en bibliotecas.

- Conocer los resultados de una experiencia concreta, la de la Biblioteca de la Universidad de Salamanca.

Para su consecución, la investigación se ha desarrollado en dos trabajos que se han planteado como complementarios. El primero consiste en un análisis de una 
muestra de sitios web, aplicaciones nativas y catálogos móviles de bibliotecas de todo tipo - públicas, universitarias y especializadas, fundamentalmente- . Sobre cada uno de ellos se han estudiado diferentes parámetros relacionados con los métodos de adaptación, el diseño, los contenidos, elementos de navegación, el aprovechamiento de las capacidades del dispositivo o el ajuste a sus características, entre otros.

En este primer trabajo se ha optado por una metodología de carácter descriptivo, basada en la observación, por ser la más adecuada dados los objetivos planteados. En este trabajo se ha construido una batería de variables de análisis a medida, partiendo de anteriores estudios. Estas variables se agrupan en los parámetros anteriormente mencionados.

El segundo trabajo consiste en el análisis del caso concreto de las Biblioteca de la Universidad de Salamanca. Para ello se han estudiado los datos de uso de su sitio web desde dispositivos móviles, de sus dos catálogos y de su aplicación nativa Biblio USAL. Los resultados obtenidos demuestran que este tipo de datos arrojan conclusiones significativas. El caso de la Biblioteca de la Universidad de Salamanca es de especial interés porque es una de las pioneras en cuando a iniciativas relacionadas con la tecnología móvil.

El trabajo que aquí se presenta ha sido realizado a lo largo de más de dos años. En octubre de 2012 se registró el proyecto de la presente tesis doctoral en la Universidad de Salamanca. Durante ese año y los primeros meses de 2013 se trabajó en la metodología para la recogida de datos de sitios web para dispositivos móviles, aplicaciones nativas y catálogos móviles, que entrañó una gran complejidad debido a la gran cantidad de variables observadas y al gran número de casos analizados, que hacen un total de 340. De ellos, 48 corresponden a bibliotecas españolas, lo que supone el $14,1 \%$ del total de la muestra. Este proceso se desarrolló fundamentalmente entre finales de abril y agosto de 2013, aunque se extendió posteriormente hasta diciembre de ese mismo año. La segunda fase de la investigación se llevó a cabo durante 2014. En ese mismo año se realizó el análisis y depuración de los datos, la redacción del trabajo de investigación y la actualización del estado de la cuestión.

Son varios los resultados que se exponen en esta tesis doctoral: una abundante cantidad de datos sobre cómo son los sitios web para dispositivos móviles, las aplicaciones nativas y los catálogos móviles de bibliotecas y el uso que se hace de las iniciativas llevadas a cabo por la Biblioteca de la Universidad de Salamanca. Ambos han permitido extraer conclusiones de interés para las bibliotecas y sobre las tendencias actuales y su evolución a lo largo del tiempo. 
Del análisis de sitios web, aplicaciones nativas y catálogos para dispositivos móviles se han podido escoger una serie de casos que constituyen las mejores prácticas. Se trata de ejemplos a seguir porque cumplen todas o casi todas las pautas que los expertos proponen o por su original planteamiento.

El trabajo de exploración previo al diseño de la investigación ha permitido recopilar una serie de pautas elementales para la creación de sitios web para dispositivos móviles y aplicaciones nativas en bibliotecas. Estas pautas se presentan en forma de chuleta en el octavo capítulo de esta tesis doctoral, de forma escueta, con la intención de que tengan una utilidad práctica para las bibliotecas que quieran consultarlas. Todas estas pautas tienen una razón de ser que se explica en los correspondientes capítulos dedicados a la metodología y a los resultados.

Por otra parte, los parámetros y variables definidos en el apartado de metodología constituyen una completa y original propuesta de marco conceptual para abordar posteriores estudios sobre los sitios web para dispositivos móviles, aplicaciones nativas y catálogos móviles de las bibliotecas.

Finalmente, el amplio estado de la cuestión sobre tecnología móvil en bibliotecas que se expone en el segundo capítulo puede considerarse uno de los resultados de esta tesis doctoral. No se conoce hasta el momento ningún estado de la cuestión más extenso, detallado y actualizado.

Los resultados y las conclusiones expuestos en esta tesis doctoral tienen interés nacional e internacional. Nacional porque los datos correspondientes a las bibliotecas españolas han sido tratados con especial cuidado. Por una parte, la selección de casos ha sido mucho más exhaustiva y se han incorporado todos los ejemplos conocidos, de manera que el número de casos de la muestra se acerca todo lo posible a la población. Por otra, en el análisis de los resultados y en la presentación de las conclusiones se dibuja un panorama específico para las bibliotecas españolas. La mayor parte de la muestra procede de bibliotecas de otros países, especialmente de Estados Unidos, pero también de Europa, Canadá, Latinoamérica, incluso hay algunos casos de Australia, Asia y África. 


\subsection{Contenidos}

La presente tesis doctoral se ha organizado en cuatro grandes apartados que se desarrollan en un total de nueve capítulos. La primera parte, que abarca al capítulo 0 , contiene un avance de lo que se encontrará después, a modo de resumen para facilitar la lectura. En la segunda parte (capítulos 1 y 2) se ha realizado un extenso análisis del estado de la cuestión, mientras que en la tercera se desarrollan la metodología y los resultados de la investigación (capítulos 3 a 8). Finalmente se presentan las conclusiones en la última parte, la cuarta. Bibliografía citada, anexos e índices cierran los contenidos de esta tesis doctoral. Se resumen a continuación brevemente cada uno de los capítulos.

Capítulo 0. Contexto y presentación de la tesis doctoral. Este capítulo constituye una presentación para facilitar una visión general sobre lo que encontrará en los siguientes párrafos. Se realiza además, en el último apartado, un análisis de la bibliografía publicada hasta el momento sobre tecnología móvil en bibliotecas, sobre cuáles son los temas que más interés están despertando y cuántas publicaciones ha habido hasta el momento.

Capítulo 1. La tecnología móvil. Introducción. Se ha querido plantear este capítulo como una introducción general a la tecnología móvil que sirva para contextualizar el trabajo de investigación que se presenta. Se abordan en él cuestiones como las características y funciones de los dispositivos móviles, el modelo de aplicaciones y la web móvil desde un punto de vista introductorio que sirva al lector para ponerse en situación.

Capítulo 2. Tecnología móvil en bibliotecas. Estado de la cuestión. Este capítulo constituye estado de la cuestión más exhaustivo sobre tecnología móvil en bibliotecas publicado hasta ahora. Proporciona una completa visión sobre este tema desde el punto de vista de la bibliografía publicada. Por eso no solo se abordan en él los aspectos más relacionados con el trabajo de investigación en esta tesis doctoral, sino que además se repasan códigos QR, realidad aumentada, NFC y Beacons.

Capítulo 3. Metodología del trabajo de investigación. Como su título promete, se expone de forma detallada la metodología para el desarrollo de la investigación desarrollada en esta tesis doctoral. El capítulo se divide en dos grandes apartados en los que se abordan las dos partes en que constituyen esta investigación: la primera consiste en el análisis de una muestra de sitios web para dispositivos móviles, aplicaciones nativas y catálogos móviles en bibliotecas y la segunda en el análisis concreto del caso de la Biblioteca de la Universidad de Salamanca. Para concluir se explica cuál es la aportación del trabajo y sus antecedentes. 
Capítulo 4. Sitios web para dispositivos móviles. Resultados. Se presentan en este capítulo los resultados del análisis de 196 sitios web para smartphones, tabletas y teléfonos móviles de bibliotecas de todo el mundo. Los apartados de este capítulo se corresponden con los parámetros de análisis y responden a las siguientes cuestiones: a qué dispositivos móviles están dirigidos estos sitios, los métodos de adaptación escogidos, facilidades para el acceso, cómo es su diseño, qué lenguajes de marcado, metadatos y herramientas de medición de analíticas emplean, qué elementos de navegación utilizan, de qué manera aprovechan las funciones del dispositivo, en qué formatos están sus contenidos, qué contenidos y servicios proporcionan y en qué manera se ajustan a las características del dispositivo. Para finalizar se destacan las mejores prácticas detectadas en el conjunto de la muestra.

Capítulo 5. Aplicaciones nativas en bibliotecas. Resultados. Se presentan en este capítulo los resultados del análisis de 73 aplicaciones nativas para smartphones, tabletas y teléfonos móviles de bibliotecas de todo el mundo. Los apartados de este capítulo se corresponden con los parámetros de análisis, que son diferentes de los aplicados al estudio de los sitios web, y responden a las siguientes cuestiones: a qué dispositivos móviles y sistemas operativos están dirigidos estos sitios, cómo se accede a la app, cómo es su diseño, qué elementos de navegación utilizan, de qué manera aprovechan las funciones del dispositivo, en qué formatos están sus contenidos, qué contenidos y servicios proporcionan y en qué medida se ajustan a las características del dispositivo. Finalmente se destacan las mejores prácticas detectadas en el conjunto de la muestra.

Capítulo 6. El catálogo móvil. Resultados. La adaptación del catálogo para su consulta desde dispositivos móviles es una de las prioridades de las bibliotecas con respecto a la movilidad. Por eso y por sus características únicas se les ha dedicado un capítulo aparte. En él se analiza qué soluciones de movilidad se están adoptando para su adaptación, qué funciones incorporan y cómo se están presentando a través de aplicaciones nativas.

Capítulo 7. La Biblioteca de la Universidad de Salamanca. Resultados. Los datos de uso del sitio web de la Biblioteca de la Universidad de Salamanca desde dispositivos móviles, de sus catálogos móviles y de su aplicación nativa Biblio USAL son la materia prima para analizar este caso concreto. Estos datos, que se exponen en este capítulo, proporcionan una visión única sobre cómo están acogiendo los usuarios las iniciativas de movilidad.

Capítulo 8. Recomendaciones para bibliotecas. Este capítulo recoge una serie de pautas para las bibliotecas que se enfrentan a la construcción de la versión para dispositivos móviles de su sitio web o de una aplicación nativa. Se han querido 
presentar estas pautas de manera escueta, a modo de chuleta que pueda ser utilizada de forma práctica por cualquier bibliotecario.

Capítulo 9. Conclusiones. Se exponen en este apartado las conclusiones que se extraen a partir de los resultados obtenidos del trabajo de investigación. Un total de 64 conclusiones sirven para conocer a partir de datos objetivos cómo se están construyendo bibliotecas de todo el mundo la versión para dispositivos móviles de sus sitios web, sus aplicaciones nativas y catálogos móviles, especialmente en España y qué se puede aprender del caso concreto de la Biblioteca de la Universidad de Salamanca.

\subsection{Análisis de la bibliografía sobre dispositivos móviles en bibliotecas}

El uso de dispositivos móviles en bibliotecas es un tema bien delimitado y diferenciado de otros, con entidad propia dada la cantidad de publicaciones en la bibliografía internacional. Sin embargo, para recuperarlo en las bases de datos se requieren búsquedas por diferentes descriptores, ya que son varias las tecnologías que abarca: m-libraries, smartphones, PDA, tablet, handheld, devices, QR codes, augmented reality, NFC, BYOD y responsive web design son algunos de ellos. Aunque la primera bibliografía sobre el tema data de comienzos de la década de los noventa, se le puede considerar una disciplina relativamente nueva, puesto que no es hasta finales de la primera década del segundo milenio cuando comienza a cobrar mayor importancia, como se aprecia en el gráfico 1.

Partiendo de la bibliografía revisada en este trabajo de doctorado se ha realizado un breve análisis de las publicaciones sobre el uso de dispositivos móviles en bibliotecas. Se han incluido en este análisis aquellas publicaciones que tratan como tema central el uso de dispositivos móviles y sus diferentes utilidades en bibliotecas, evitando las que lo abordan de manera tangencial. Las publicaciones en blogs o páginas web han sido excluidas, ya que sobre ellas no se puede garantizar la exhaustividad.

Se han contabilizado un total de 471 publicaciones entre 1995 y 2014. De todas ellas, menos de una décima parte (8,9\%) es anterior a 2007, fecha del lanzamiento del iPhone. Es en los años posteriores cuando este tema ha cobrado cierta relevancia, alcanzando el pico máximo de publicaciones en 2012, con 105. En 2013 
y 2014 vuelve a descender la producción bibliográfica, y aunque en este último año solo se ha recopilado lo publicado hasta el mes de octubre con cierta exhaustividad, cabe pensar que no se duplicará el número de publicaciones en tres meses.

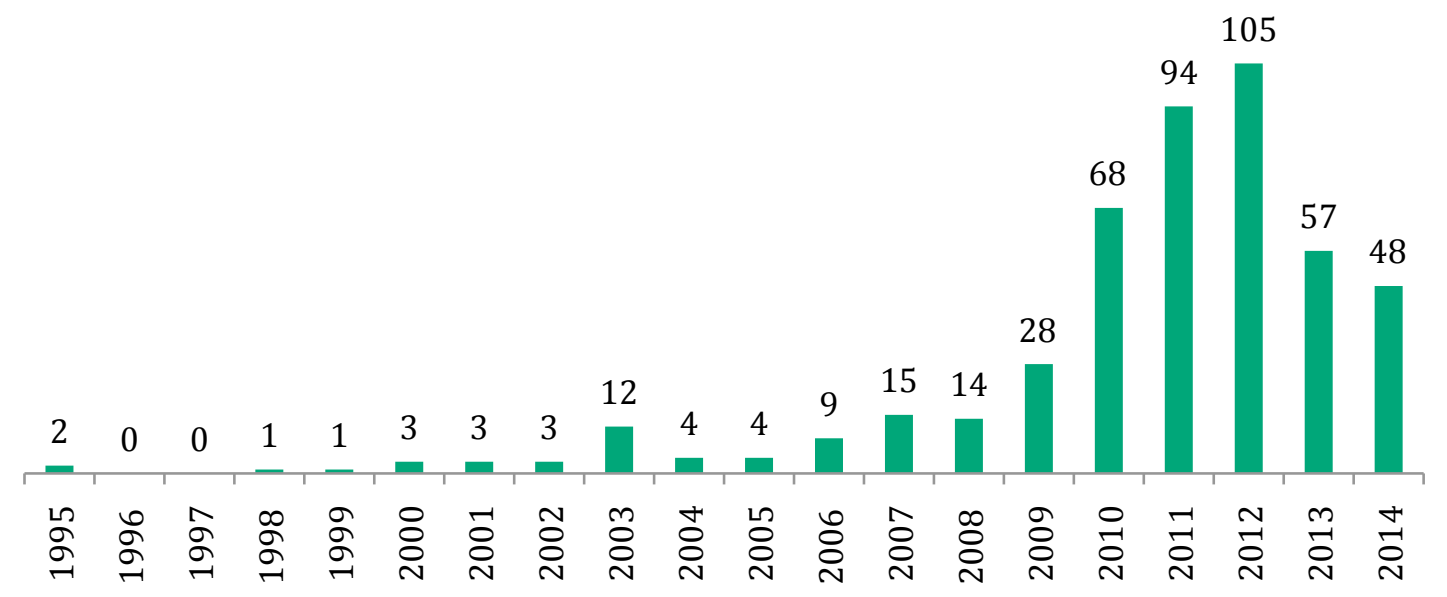

Gráfico 1. Publicaciones sobre el uso de dispositivos móviles en bibliotecas entre 1995 y 2014 en el ámbito internacional.

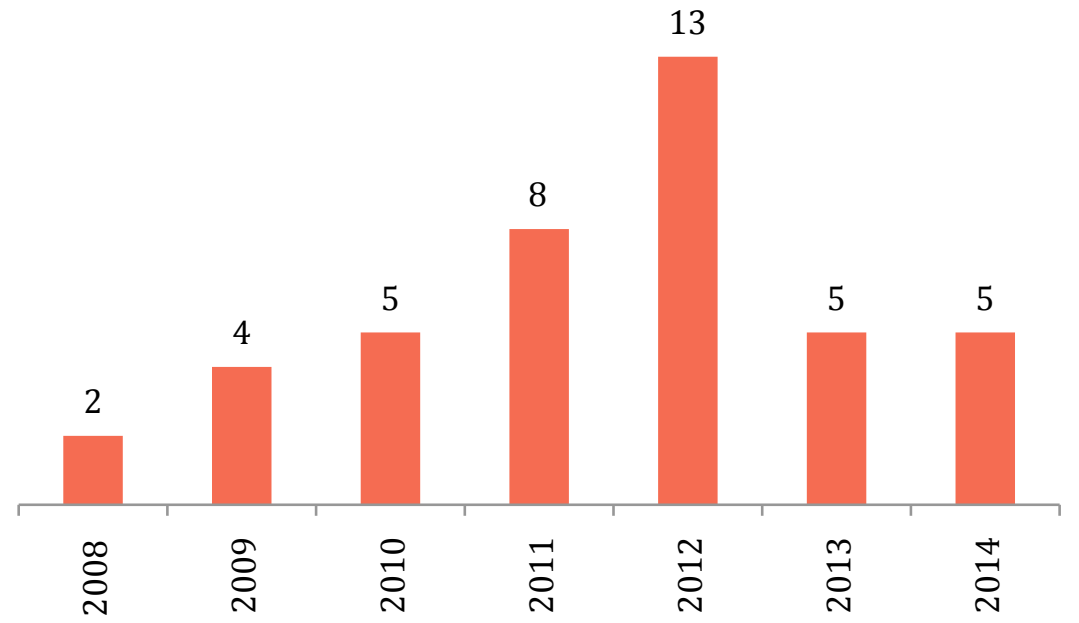

Gráfico 2. Publicaciones de autores españoles sobre el uso de dispositivos móviles en bibliotecas entre 2008 y 2014.

Se han recopilado un total de 43 referencias de autores españoles, en revistas y encuentros nacionales o internacionales. Estas referencias también se han contabilizado en el análisis de la bibliografía internacional. La producción 
bibliográfica sigue el mismo patrón que en el ámbito internacional, con un mayor número de publicaciones en los años posteriores al lanzamiento del iPhone que se moderan en los dos últimos años. En nuestro país el número de publicaciones supone el 9,1\% de todos los analizados, incluso a pesar de que se ha realizado una búsqueda más exhaustiva que en la bibliografía internacional, incluyendo publicaciones no indexadas en bases de datos.

Se han definido varias categorías para el estudio de la bibliografía: divulgación, experiencias, investigaciones, estados de la cuestión y selecciones.

- Divulgación. Son aquellos textos que explican técnicas para crear sitios web y aplicaciones nativas, implementar códigos QR u otras cuestiones. Tienen carácter informativo y su objetivo es mostrar a los bibliotecarios cómo enfrentarse a determinadas cuestiones.

- Experiencias. Son publicaciones que reflejan la experiencia de alguna biblioteca con respecto a una determinada acción. A menudo se solapan con trabajos de divulgación, en los que se explica cómo se ha puesto en marcha una acción en una biblioteca concreta desde un punto de vista más técnico. En el análisis de la bibliografía realizado en este trabajo se ha identificado a cada publicación con una sola de esas categorías, la que más se ajustara a sus objetivos y contenidos.

- Investigaciones. Son publicaciones que realizan algún tipo de investigación o que conllevan una técnica de investigación, incluyendo las más básicas, como entrevistas a los alumnos o recuentos de casos.

- Estados de la cuestión y revisiones bibliográficas, en los que se trata el estado de la movilidad en una determinada época y se analiza la bibliografía.

- Selecciones de aplicaciones nativas o de otros recursos para dispositivos móviles.

Como se aprecia en el gráfico 3, la gran mayoría de las publicaciones analizadas se inscriben en las categorías de divulgación $(43,3 \%)$ o experiencias $(39,9 \%)$. El resto de las categorías suman un 16,8\% del total. Hay muy poca investigación $(13,8 \%)$ y apenas se han encontrado estados de la cuestión $(0,8 \%)$. Se puede hablar, por lo tanto, de un tema joven, aún por madurar, que se está tratando preferentemente desde un punto de vista profesional, como demuestra el alto número de experiencias y textos divulgativos. El escaso número de investigaciones sobre el tema abren sin embargo la puerta a numerosas oportunidades.

Si se analiza la bibliografía internacional en función de temas concretos se puede observar que la mayor parte de las publicaciones tratan sobre temas generales relacionados con los dispositivos móviles en bibliotecas (gráfico 4). A este grupo se le ha etiquetado como m-libraries y se han encontrado un total de 106 textos 
(22,5\% del total). Hay que tener en cuenta que en este análisis son varias las publicaciones que han sido etiquetadas con más de un tema.

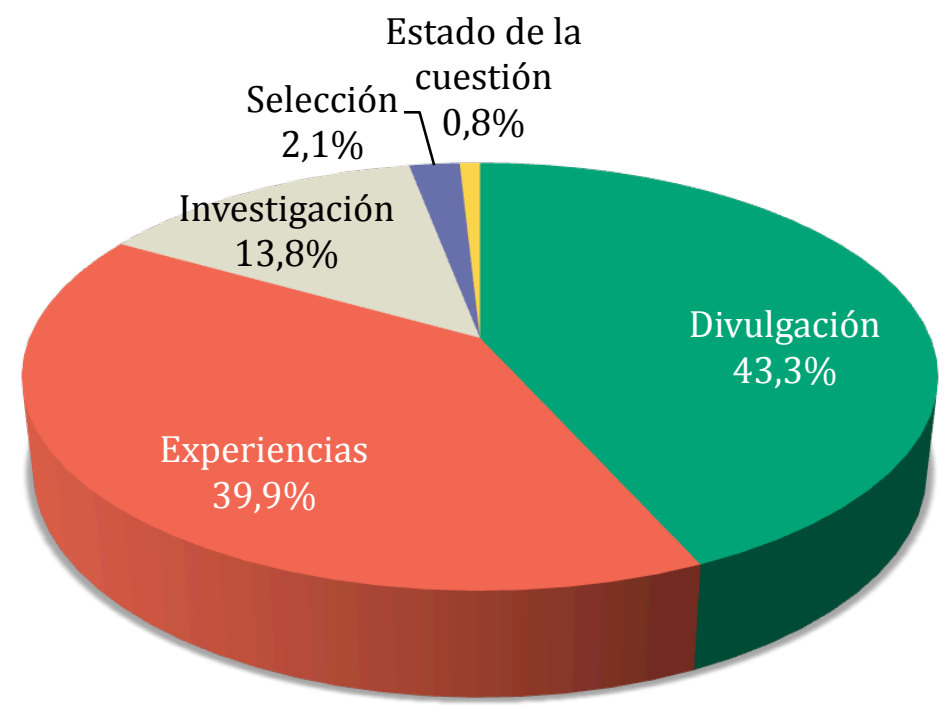

Gráfico 3. Publicaciones sobre el uso de dispositivos móviles en bibliotecas por tipo de publicación.

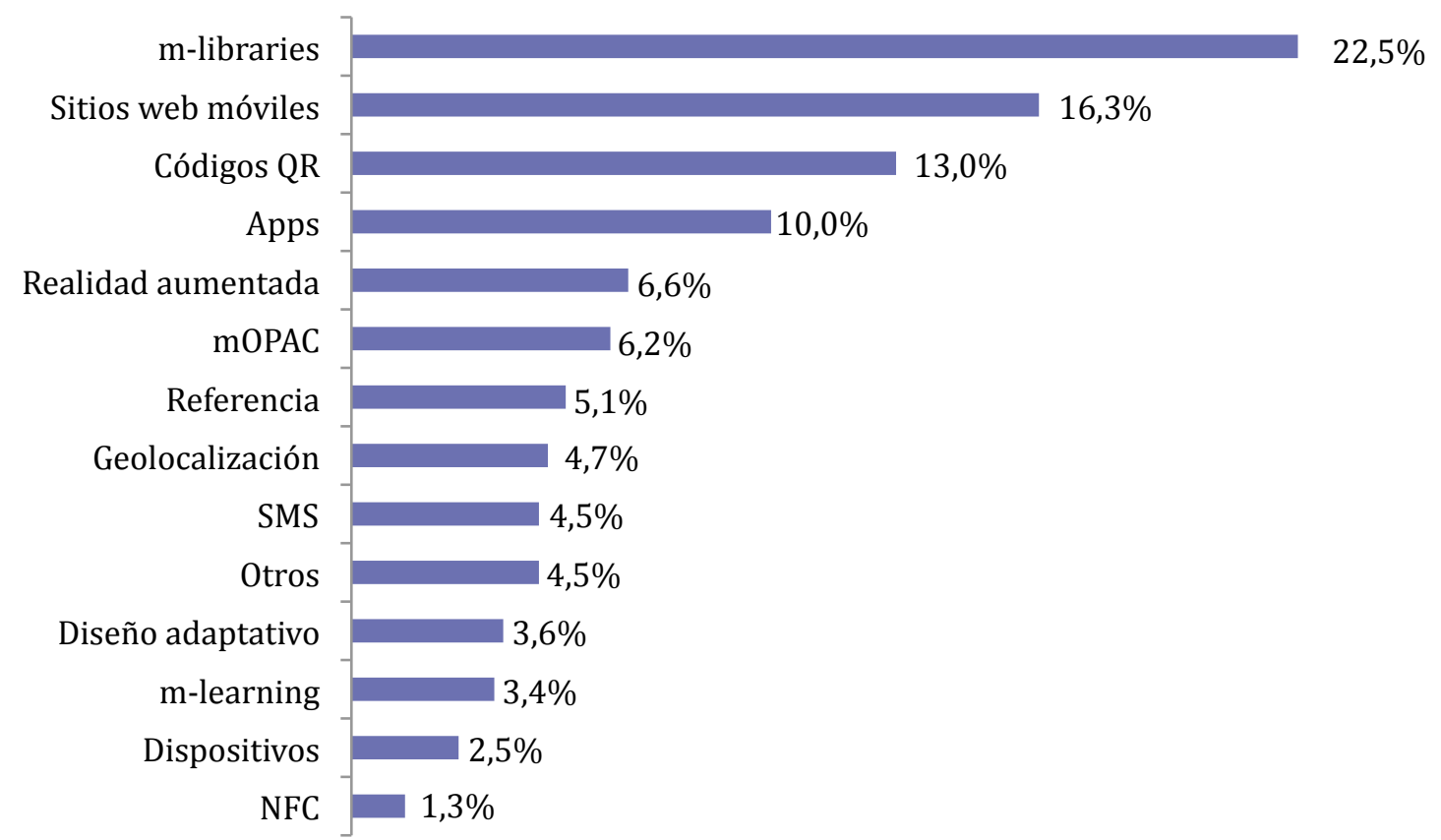

Gráfico 4. Publicaciones en la bibliografía internacional sobre el uso de dispositivos móviles en bibliotecas por tema. 
La creación de sitios web para móviles (16,3\% de las publicaciones), los códigos QR $(13,0 \%)$, las apps $(10,0 \%)$ son los temas estrella. Realidad aumentada $(6,6 \%)$, catálogos móviles $(6,2 \%)$, servicios de referencia $(5,1 \%)$ y geolocalización $(4,7 \%)$ son otros de los temas tratados. En el apartado de Otros (4,5\%) se han incluido temas menos habituales, como los ebooks, BYOD, audio y vídeo, cuestiones éticas o préstamo de dispositivos. Como tema con identidad propia dentro de las publicaciones sobre sitios web para móviles destaca el diseño web adaptativo, que supone el 3,6\% de todas las publicaciones (gráfico 4).

En España, como en la bibliografía internacional, se observan más publicaciones sobre temas generales (25,6\%), apps (20,9\%), sitios web para dispositivos móviles $(18,6 \%)$, códigos QR $(16,3 \%)$ y realidad aumentada $(14,0 \%)$, como se pude apreciar en el gráfico 5. En la bibliografía española aún no se han abordado temas como los catálogos móviles o los servicios de referencia.

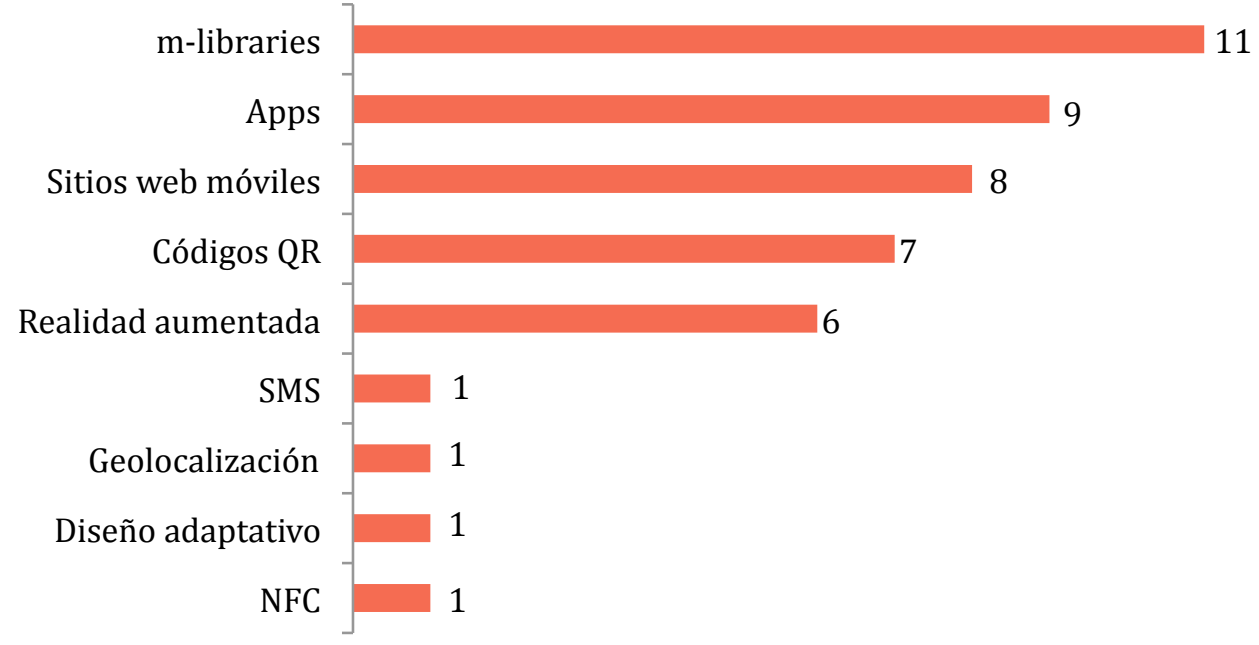

Gráfico 5. Publicaciones en la bibliografía española sobre el uso de dispositivos móviles en bibliotecas por tema.

En España la mayor parte de las publicaciones sobre el tema en el ámbito nacional o internacional son experiencias $(58,1 \%)$ o divulgación $(37,2 \%)$. Tan solo se ha encontrado una publicación que podría clasificarse como investigación y un estado de la cuestión. Esto lo convierte en un tema muy poco maduro, que ofrece grandes oportunidades y que previsiblemente se desarrollará en los próximos años. Al igual que en la bibliografía internacional, se hacen necesarias más investigaciones que den cuenta de los resultados obtenidos por las experiencias puestas en marcha. 
La primera publicación sobre dispositivos móviles en bibliotecas de la que se tiene noticia en España es la comunicación de Serrano-Muñoz (2000) sobre la puesta en marcha de una versión Wap del catálogo en la biblioteca de la Universitat Oberta de Catalunya. Más recientemente, el tema resurge en la bibliografía en 2008 con una nota ThinkEPI de Francisco Tosete sobre la web móvil, la comunicación de Pesquero Murillo (2008) en el IV Congreso Nacional de Bibliotecas Públicas, sobre la implementación de un servicio de alertas SMS, y en 2009 con el segundo número de la revista El profesional de la información, monográfico sobre Información y movilidad: la web móvil, con un artículo en referencia a las utilidades en bibliotecas (Arroyo-Vázquez, 2009). Ese mismo año, en los meses de abril y mayo, Pérez y Torn (2009) encuestan a las bibliotecas universitarias de Rebiun.

Son varias las monografías que se han publicado en el ámbito internacional. La primera fue la Cuddy (2005), un completo texto sobre las PDA y sus posibilidades en bibliotecas. Ellyssa Kroski (2008) inaugura la nueva etapa con un monográfico en la serie Library Technology Reports, que después publicaría otros títulos sobre el tema.

Con la popularidad de los smartphones llegan las monografías de Griffey (2010), que plantea los diferentes pasos para poner en marcha un proyecto de movilidad en bibliotecas; Greene, Roser y Ruane (2010) y Castledine, Eftos y Wheeler (2011), quienes abordan la creación de un sitio web para móviles; Clark (2012a) y LaCounte (2012), que se centran en la creación de aplicaciones nativas; Walsh (2012b), quien aborda la cuestión de la movilidad desde un punto de vista amplio; Murphy (2012), sobre códigos QR y geolocalización; Harmon y Messina (2013), quienes recogen varias experiencias; Peters y Bell (2013) coordinan una monografía sobre diferentes temas y experiencias relacionados con la movilidad; Nichols (2013) presenta varios programas para el uso del iPad en actividades con diferentes públicos; Reidsma (2014), sobre el diseño web adaptativo; y McHugh y Yarmey (2014), sobre NFC. En España solo se han publicado dos monografías: el Informe APEI sobre movilidad (2011a) e Información en el móvil (Arroyo-Vázquez, 2011b), ambos desde un punto de vista general, abarcan los diversos aspectos relacionados con el uso de dispositivos móviles en bibliotecas.

En el ámbito internacional se vienen celebrando de manera regular, cada uno o dos años, la conferencia m-Libraries. Se celebró por primera vez en 2007 y se han repetido nuevas ediciones en 2009, 2011, 2012 y 2014. Cada una de estas conferencias produce una monografía con los textos de las comunicaciones presentadas. En Estados Unidos se organiza la Handheld Librarian Online Conference, cuya última edición ha sido la novena, en febrero de 2014. La primera edición se celebró en 2009 de forma presencial. 
En España no se han organizado encuentros, foros o conferencias que tengan como tema central el uso de dispositivos móviles en bibliotecas, a excepción de dos actividades paralelas en el marco de las XII ${ }^{1}$ y XIII ${ }^{2}$ Jornadas Españolas de Documentación, en 2011 y 2013 respectivamente. Se trataba de mesas en las que diferentes participantes exponían una experiencia o un tema en un máximo de cinco minutos cada uno.

${ }^{1}$ http://www.fesabid.org/malaga2011/informacion-en-movimiento-la-web-movil-en-60-minutos

${ }^{2}$ http://www.fesabid.org/toledo2013/dispositivos-moviles-y-bibliotecas-experiencias-queconectan-lo-presencial-y-lo-digital 

Parte II. Bibliotecas y tecnología móvil 



\section{Capítulo 1. La tecnología móvil. Introducción}

Se realiza en este capítulo una introducción a la tecnología móvil con la intención de contextualizar el trabajo de investigación que se presenta en esta tesis doctoral. Con ese propósito se abordan en este primer capítulo los siguientes aspectos: evolución, tipos de tecnología móvil, características y funciones de los dispositivos móviles, el modelo de aplicaciones y la web móvil. Se explican con mayor detalle las peculiaridades del diseño web para móviles y las aplicaciones nativas, puesto que serán el tema central del trabajo de investigación.

Este capítulo fundamenta su estructura en dos trabajos previos de la doctoranda, el Informe APEI sobre movilidad (Arroyo-Vázquez, 2011a) y el libro Información en el móvil (Arroyo-Vázquez, 2011b). 



\subsection{Los dispositivos móviles}

Los dispositivos móviles y sus características y funcionalidades constituyen la base de la tecnología móvil. El World Wide Web Consortium define el término dispositivo móvil como «aquel aparato portátil con el que se puede acceder a la web y diseñado para ser usado en movimiento.» Por lo tanto, es el acceso a internet en movilidad lo que les diferencia de otros tipos de aparatos. Se trata de un subgrupo de los dispositivos inalámbricos, que incluyen también a los dispositivos fijos pero que, a diferencia de éstos, prescinden de conexiones físicas (Nkeze, Pearce y Womer, 2007).

Los orígenes de los dispositivos móviles que se utilizan en la actualidad se encuentran en la telefonía móvil, por una parte, y en el desarrollo de las PDA por otro. En los años noventa, con la llegada de la segunda generación de telefonía móvil (2G) y de aparatos cada vez más pequeños y asequibles, comenzaron a popularizarse los teléfonos móviles (Agar, 2005), y rápidamente se han convertido en una de las tecnologías más extendidas a nivel global. Según los datos publicados por la Unión Internacional de Telecomunicaciones, se estima que en 2014 había en todo el mundo 95,5 suscripciones de telefonía móvil por cada cien habitantes, mientras que en 2005 eran 33,9. A partir del año 2006 comenzó a haber más líneas de telefonía móvil que personas en España, y aunque ha descendido ligeramente el ratio en los últimos años, en el tercer trimestre de 2014 se registraron 109,8 líneas por cada cien habitantes, según datos de la Comisión Nacional de los Mercados y de la Competencia.

Las primeras PDA (acrónimo de la expresión Personal Digital Assistant) comenzaron a fabricarse en los años noventa. Eran pequeños ordenadores de mano enfocados en un principio a la organización de tareas y a la productividad personal, con funciones como agenda de contactos, calendario, calculadora y gestor de tareas. El lanzamiento de la Apple Newton en 1993 sentó las bases de las PDA posteriores, a pesar de que solo permaneció en el mercado durante cinco años. Tras ella fueron apareciendo modelos como la Palm Pilot, la Windows CE de Microsoft en 1996 - sustituida después por la Pocket PC 2002, a finales de 2001y la BlackBerry, en 1998. Estos se convirtieron precisamente en los terminales más populares en los primeros años del nuevo milenio (Cuddy, 2005).

Con la incorporación de nuevas funciones a los teléfonos móviles aparecieron los modelos híbridos, que concentraban las características de las PDA y la telefonía móvil simultáneamente, iniciando así el proceso de convergencia. En la actualidad el término PDA ha caído en desuso y se habla de teléfonos inteligentes o 
smartphones. En la calle parece que se mantiene el término teléfono móvil para referirse a los smartphones, aunque se trata de verdaderos ordenadores, muy diferentes de los primeros teléfonos móviles. Todas las funciones de las PDA han sido asumidas por los smartphones, pero siguen manteniéndose en ámbitos profesionales como en hostelería y servicios de mensajería o postales (ArroyoVázquez, 2011a).
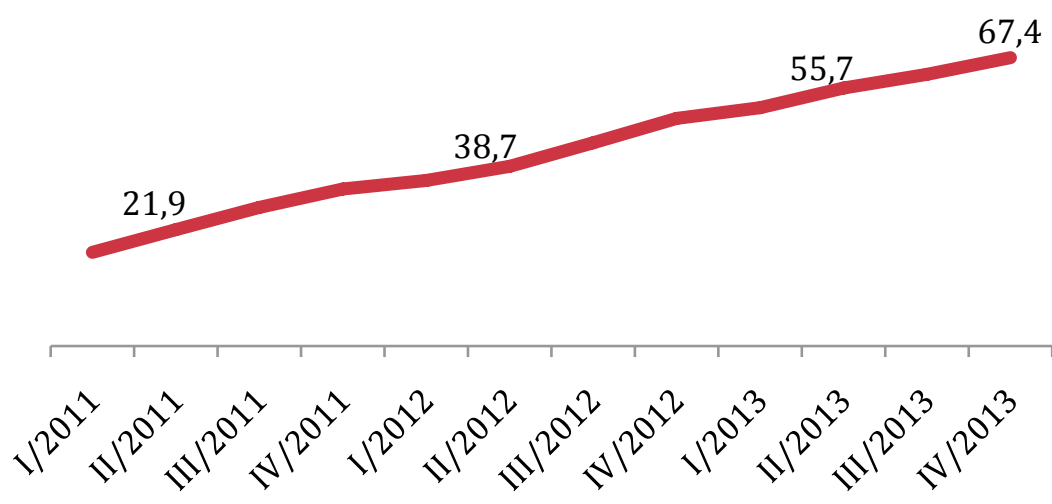

Gráfico 6. Penetración de la telefonía móvil (azul) y de la banda ancha (rojo) en España entre el primer trimestre de 2011 y el último de 2013. Elaboración propia a partir de los datos de la Comisión Nacional de los Mercados y de la Competencia.

Uno de los factores fundamentales en el éxito de los dispositivos móviles ha sido la evolución de las redes de datos y el abaratamiento de sus costes para los clientes, pero también la mejora de los dispositivos, que son más potentes, fáciles de manejar y asequibles. En 1999 aparecía en España el primer servicio de acceso a internet desde dispositivos móviles, la WAP (acrónimo de Wireless Access Protocol), de la mano de Telefónica, solo un año después de la primera versión de este estándar. La WAP constituía la primera promesa de acceso a datos desde dispositivos móviles (Pérez Yuste, 2002), pero no llegó a popularizarse en aquellos años, posiblemente porque el acceso a internet no se percibía como una necesidad entonces o porque la tecnología no estaba aún lo suficientemente madura como para que la experiencia de uso fuera satisfactoria (Arroyo-Vázquez, 2011a).

En este sentido, Ramsay y Nielsen (2000) ponen de manifiesto que los usuarios se sentían frustrados ante la WAP, con una pobre calidad de los datos y grandes 
dificultades para encontrar lo que buscaban. Las conexiones eran percibidas como muy lentas y no proporcionaban una experiencia de navegación cómoda. Pequeñas pantallas monocromas, terminales diseñados para hablar por teléfono, redes de comunicaciones $2 \mathrm{G}$ (con velocidades de entre $40 \mathrm{kbps}$ y $60 \mathrm{kbps}$ de bajada, y unos $30 \mathrm{kbps}$ de subida, mientras que las $3 \mathrm{G}$ alcanzan varios Mbps de bajada) y muy pocos contenidos adaptados.

Coincidiendo con el nacimiento de la WAP, la empresa NTT Docomo lanzó la tecnología iMode en Japón, que tuvo mayor fortuna. En 2002 se estrenó la segunda versión, la WAP 2.0, más cercana a los estándares actuales y que cerró la era de la denominada WAP, dando paso al concepto de web móvil (Firtman, 2013).

Los teléfonos móviles han ido incorporando con el tiempo nuevas funciones: envío de SMS, cámara de fotos y vídeo, reproducción de mp3, conectividad bluetooth, acceso a internet, sensores y GPS son algunos de ellos. En 2004 comenzaron a comercializarse en España los primeros terminales con tecnología 3G (UMTS)3 ${ }^{3}$ que luego evolucionarían hacia las actuales 3,5G (HSDPA) y 3,75G (HSUPA). En 2013 se comenzaron a extender las redes 4G (LTE), con velocidades muy superiores a las anteriores, y ya se encuentran a la venta terminales con esta tecnología. En el horizonte ya están las redes 5G, que aún tardaremos unos años en ver.

\subsubsection{La era de los smartphones}

La presentación del iPhone de Apple en $2007^{4}$ dio el pistoletazo de salida a la era de los smartphones y de las pantallas táctiles, pero no fue hasta julio de 2008 cuando estuvo disponible la versión 3G. También en 2007 Apple presentó el iPod Touch $^{5}$, un dispositivo similar al iPhone pero sin telefonía móvil. Un smartphone es, según la definición de la revista PC Magazine6, «un teléfono móvil que incluye aplicaciones y acceso a internet. Además de servicios digitales de voz, los

\footnotetext{
${ }^{3}$ Las licencias de UMTS podrían expirar antes de que las operadoras recuperen sus inversiones. En: El País, 15 noviembre 2004.

http://tecnologia.elpais.com/tecnologia/2004/11/15/actualidad/1100510881 850215.html
}

${ }^{4}$ Apple Reinvents the Phone with iPhone. En: Apple Press Releases. San Francisco, 9 enero 2007. https://www.apple.com/pr/library/2007/01/09Apple-Reinvents-the-Phone-with-iPhone.html

${ }^{5}$ Apple Unveils iPod touch. En: Apple Press Releases. San Francisco, 5 septiembre 2007. https://www.apple.com/pr/library/2007/09/05Apple-Unveils-iPod-touch.html

${ }^{6}$ Definition of smartphone. En: PC Magazine Encyclopedia.

http://www.pcmag.com/encyclopedia/term/51537/smartphone 
smartphones modernos ofrecen servicios de mensajería, correo electrónico, navegación web, cámara de fotos y vídeo, mp3, reproducción de vídeo y llamadas, entre otros. Además permiten instalar múltiples aplicaciones gratuitas y de pago que convierten un teléfono móvil en un ordenador personal.» Se diferencian de los teléfonos móviles en que tienen pantallas táctiles de al menos tres pulgadas y permiten la descarga de aplicaciones nativas desde una tienda en línea.

Bridges, Rempel y Griggs (2010) señalan las siguientes diferencias en los smartphones con respecto a los teléfonos móviles convencionales: pantallas más grandes, sincronización con un ordenador $-\mathrm{y}$ con otros dispositivos, se podría añadir-, teclado qwerty virtual o físico (los teléfonos suelen tener teclados numéricos), pantalla táctil, descarga de aplicaciones, navegador web, conectividad $3 \mathrm{G}$ y procesadores más potentes.

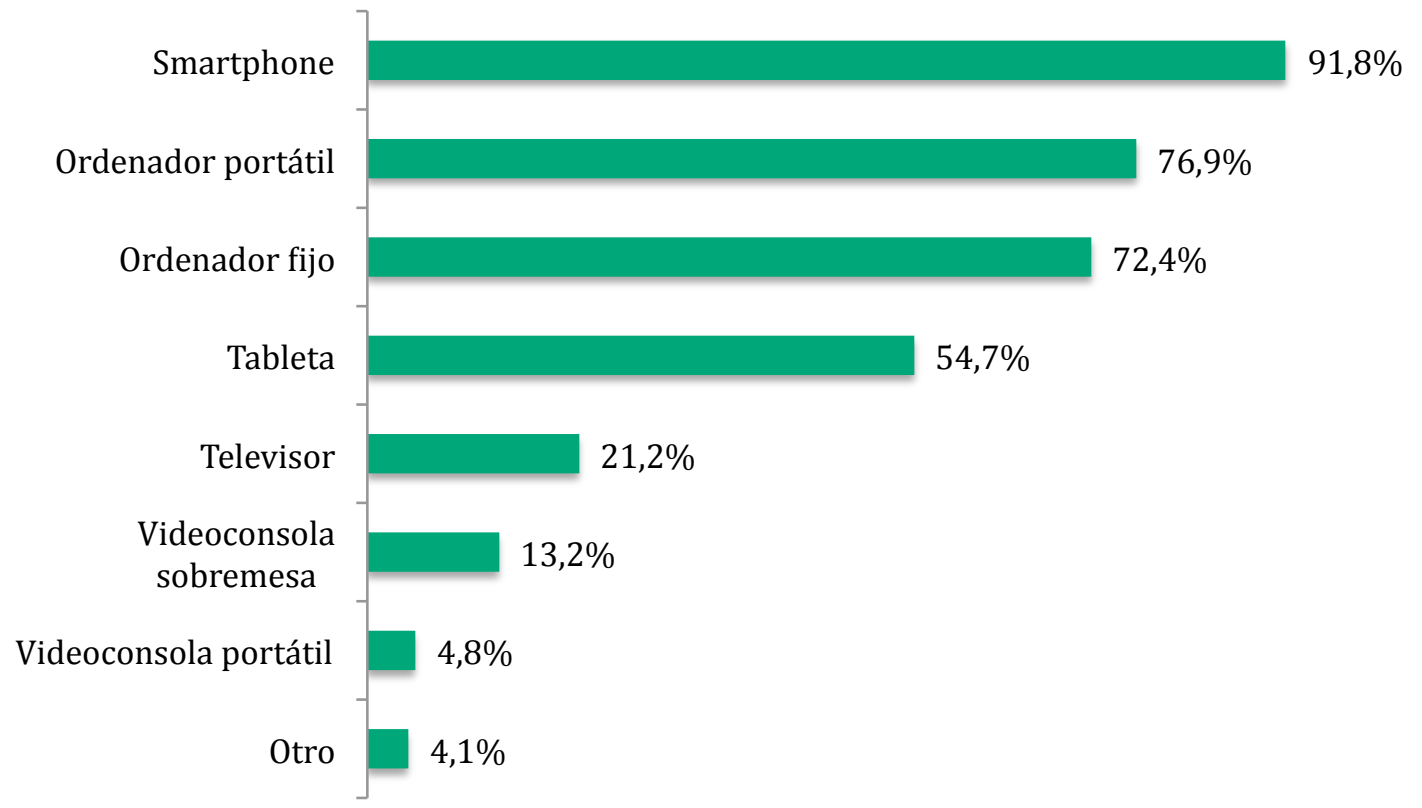

Gráfico 7. Equipos a través de los que se accede a internet. España, 2014. Elaboración propia a partir de los datos de Navegantes en la red. 17ª encuesta AIMC a usuarios de internet (2015).

Los primeros smartphones con sistema operativo Android, impulsado por Google, se pusieron a la venta en 2008. Gracias a Android los smartphones han dejado de ser de uso exclusivo para profesionales o personas con un alto poder adquisitivo y se han extendido hasta el punto de estar llamados a sustituir al teléfono móvil. Según los datos de la Comisión Nacional de los Mercados y de la Competencia, en el tercer trimestre de 2014 en España había 75,4 líneas de banda ancha móvil por 
cada cien habitantes, mientras que en el mismo trimestre del año anterior eran 63,5 . Por otra parte, el acceso a internet desde teléfonos móviles por los internautas superó por primera vez en 2013 al acceso desde el ordenador de sobremesa o portátil y en 2014 el 91,8\% de los internautas accede a internet desde el móvil (gráfico 7).

\subsubsection{La tableta, segundo dispositivo móvil más popular}

La segunda revolución en el mundo de los dispositivos móviles viene de la mano de las tabletas. El concepto de tableta surgió en 1972, con el prototipo Dynabook, de Alan Kay, que estaba dirigido al sector educativo. Posteriormente fueron apareciendo otras tabletas, como la LS800 — al nada asequible precio de 2.167 dólares ${ }^{7}$ - o la Microsoft Tablet PC (2001), pero ha sido el iPad de Apple la primera en alcanzar el éxito comercial tras su lanzamiento, en la primavera de 2010. Aunque no llegan a la popularidad de los smartphones, las tabletas son hoy el segundo dispositivo móvil más extendido en el acceso a internet (gráfico 7) y tienden a acabar con los ultraportátiles, pequeños ordenadores con pantallas de unas 10 pulgadas.

Las tabletas son «ordenadores compuestos de un solo panel que se caracterizan por su pantalla táctil como método de interacción.» ${ }^{8} \mathrm{Su}$ diseño y funcionamiento es idéntico al del smartphone, lo que las diferencia es el tamaño de su pantalla -a partir de siete pulgadas y que en los diferentes modelos de iPad están entre las 7,9 pulgadas del iPad Mini y las 9,7 del iPad Air-, y que no suelen contar con la función de telefonía móvil, aunque hay algunas excepciones, como el Asus Fonepad. Sony Xperia, Microsoft Surface, Asus MeMO Pad, Samsung Galaxy, la HP TouchPad, BlackBerry PlayBook, Kindle Fire y Nexus 7 son algunos de los modelos que pueden encontrarse actualmente en el mercado.

\subsubsection{Otros dispositivos móviles}

En 2010 comenzaron a comercializarse las llamadas phablets, smartphones con pantallas más grandes de lo habitual, entre 5 y 6,9 pulgadas, que les acercan a las

\footnotetext{
7 The History Of The Tablet, An Idea Steve Jobs Stole And Turned Into A Game-Changer. En: Business Insider, 2 junio 2013. http://www.businessinsider.com/history-of-the-tablet-2013-5

${ }^{8}$ Definition of tablet computer. En: PC Magazine Encyclopedia.

http://www.pcmag.com/encyclopedia/term/52520/tablet-computer
} 
tabletas. El propio término, una mezcla de phone y tablet, sugiere que están a caballo entre ambos dispositivos.

Videoconsolas portátiles como la PSP (PlayStation Portable) de Sony o la Nintendo DS y los lectores de libros electrónicos incluyen conexión a internet y navegador. Sin embargo, la experiencia de navegación en ellos es pobre, pues están diseñados para jugar y leer respectivamente y ni las pantallas de tinta electrónica en blanco y negro ni los sistemas de interacción por flechas de las videoconsolas proporcionan una experiencia óptima.

\subsubsection{Características de los dispositivos móviles}

Los dispositivos móviles actuales se caracterizan por sus pantallas táctiles y por el modelo de aplicaciones, sobre el que se hablará más adelante. Las pantallas monocromas de los primeros teléfonos móviles y PDA han dado paso al LCD (322 píxeles por pulgada y resolución de hasta 1.920 x 1.080 píxeles), AMOLED y super AMOLED (306 ppi y 1.280 x 720 píxeles) y retina (específica de Apple, con 326 ppi y 1.136 x 640 píxeles) de los smartphones y tabletas actuales.

Estas pantallas se han agrandado en los smartphones para facilitar el acceso a los contenidos, hasta alcanzar las 3,5 y 4 pulgadas en los smartphones y alrededor de 5 ó 6,9 pulgadas de las phablets, invirtiendo la tendencia a la miniaturización de los primeros teléfonos móviles.

Las pantallas multitáctiles y los teclados virtuales, que aparecen en la pantalla solo cuando son necesarios, han sustituido a los stylus - que tienen el aspecto de un lápiz y que se utilizan para seleccionar, algunas phablets actuales, como la Galaxy Note, lo incorporan-, el TrackBall — una bolita para mover el cursor en la pantalla que funciona a modo de ratón-, el TrackPad - una superficie que cumple la misma función que el TrackBall- y a los teclados. Así, la interacción es más sencilla e intuitiva y deja toda la superficie del dispositivo a la pantalla para una mejor visualización de los contenidos. La tecnología que está detrás de estas pantallas es capacitiva, y aunque es más cara de fabricar que la resistiva, no requiere que se ejerza tanta presión al seleccionar un objeto en la pantalla y detecta varias pulsaciones simultáneas, haciendo posible la combinación de gestos.

La tinta electrónica ha quedado para uso exclusivo de los dispositivos dedicados a la lectura, los lectores de libros electrónicos. Y aunque las tabletas también tienen esa utilidad, han optado por las pantallas LCD, a color y más vistosas. Solo de forma puntual han aparecido en el mercado otros dispositivos móviles con tinta 
electrónica, como el YotaPhone ${ }^{9}$, un modelo con dos pantallas, una LCD y otra de tinta electrónica.

La interacción a través de la voz se ha extendido gracias a los asistentes virtuales. Siri, Google Now y Cortana, los asistentes de Apple, Android y Windows Phone respectivamente, permiten solicitar al dispositivo que realice determinadas acciones, como enviar un correo electrónico, anotar una reunión en la agenda, reproducir una canción o recibir recordatorios.

Las pantallas multitáctiles permiten escribir directamente con el dedo sobre la pantalla. La versión web del buscador de Google para smartphones incluye esta utilidad: después de activarla en las opciones de configuración y seleccionar el botón que se activa a continuación, es posible escribir sobre la pantalla con el dedo para introducir los términos de búsqueda.

Los dispositivos móviles incorporan otras funciones, además de las ya mencionadas anteriormente. Firtman (2013) recoge las siguientes:

- Geolocalización, que se define como la capacidad para detectar la ubicación geográfica del usuario.

- Acelerómetro, un sensor que mide la aceleración en función de tres ejes y que se utiliza en juegos y para orientarse.

- Giroscopio, un sensor que mide la orientación y que se utiliza junto al acelerómetro.

- Magnetómetro, sensor que mide la dirección de los campos magnéticos y cumple la función de brújula digital.

- Otros sensores, como los de proximidad, luminosidad o de identidad de huella dactilar.

La conectividad es un elemento esencial para acceder a contenidos y comunicarse. Los smartphones incorporan conectividad WiFi y 3G. También las tabletas, aunque algunos modelos solo permiten la primera. La conectividad WiFi requiere un punto que emita la señal (un router) y un dispositivo con la tecnología necesaria para recibirla (un smartphones o una tableta, por ejemplo). Las redes WiFi están bastante extendidas en España y es frecuente encontrarlas en los hogares y en lugares públicos o negocios, que lo ofrecen como un servicio más.

Las operadoras de telefonía móvil proporcionan servicios de conectividad de datos. Las redes más frecuentes son las $3 G$ y superiores, que se consideran la primera banda ancha móvil, aportan comunicaciones más rápidas y permiten servicios como voz, fax e internet (Arroyo-Vázquez, 2011a). Como se explicó

${ }^{9}$ http://yotaphone.com 
anteriormente, comienzan a desarrollarse las redes de cuarta generación o 4G. Los servicios de datos hacen al dispositivo independiente de cualquier punto de acceso y permiten al usuario conectarse desde cualquier lugar con cobertura.

Bluetooth es una especificación para redes inalámbricas que hace posible la transmisión de datos en un radio de unos diez metros. Es una de las funciones más comunes en los teléfonos móviles y se emplea para el intercambio de información entre dispositivos cercanos, pero también para conectar periféricos. Los dispositivos móviles cuentan además con otros tipos de conectividad, como NFC o beacons, de los que se hablará en el apartado 2.8 en relación con sus utilidades en bibliotecas.

\subsubsection{Plataformas y sistemas operativos móviles}

En los últimos años el panorama de los sistemas operativos móviles ha cambiado completamente. Dos nuevos actores, Google y Apple, se han hecho con la mayor parte del mercado, mientras que otros que parecían consolidados han caído o se ven relegados a un pequeño nicho. Android, el sistema operativo impulsado por Google, se ha alzado con el primer puesto en número de ventas y estaba presente en el 78\% de los smartphones vendidos en 2013. Estos sistemas operativos forman el núcleo central de auténticas plataformas en las que vienen completados por todo un ecosistema de servicios, como la tienda de aplicaciones o los mapas, que constituyen prestaciones adicionales de la marca.

El sistema operativo Android, basado en Linux, fue creado por Google y la Open Handset Alliance y está presente en smartphones y tabletas de diferentes fabricantes - Acer, Asus, HTC, LG, Samsung y Sony son algunos de ellos-. Los primeros smartphones con Android estuvieron en el mercado en septiembre de 2008. Con la aparición de las tabletas se creó para ellas una versión específica de Android, la 3.0 (Honeycomb), pero a partir de la versión 4 funciona indistintamente en smartphones y tabletas. En los últimos años Android se está extendiendo a otros tipos de dispositivos: actualmente funciona en relojes inteligentes y televisores y se espera que próximamente funcione también en coches. La última versión es la 5.0, que recibe el sobrenombre de Lollipop -todas sus versiones llevan nombres de postres o golosinas-.

En 2013 se comenzó a observar una tendencia hacia la escisión en la plataforma Android. En mercados como China o India cada vez más fabricantes optan por instalar AOSP (Android Open Source Project), que no incluye los servicios de Google - aplicaciones nativas y servicios como Google Maps o Gmail, entre muchos otros-. Instalar la versión de Android con estos servicios requiere el pago de una 
licencia a Google por parte del fabricante (Pastor, 2014). Así, en el gráfico 8, con el número de dispositivos vendidos por sistema operativo, la porción con el título Android y AOSP corresponde un 25\% a AOSP y el 52\% restante a la versión de Android con los servicios de Google.

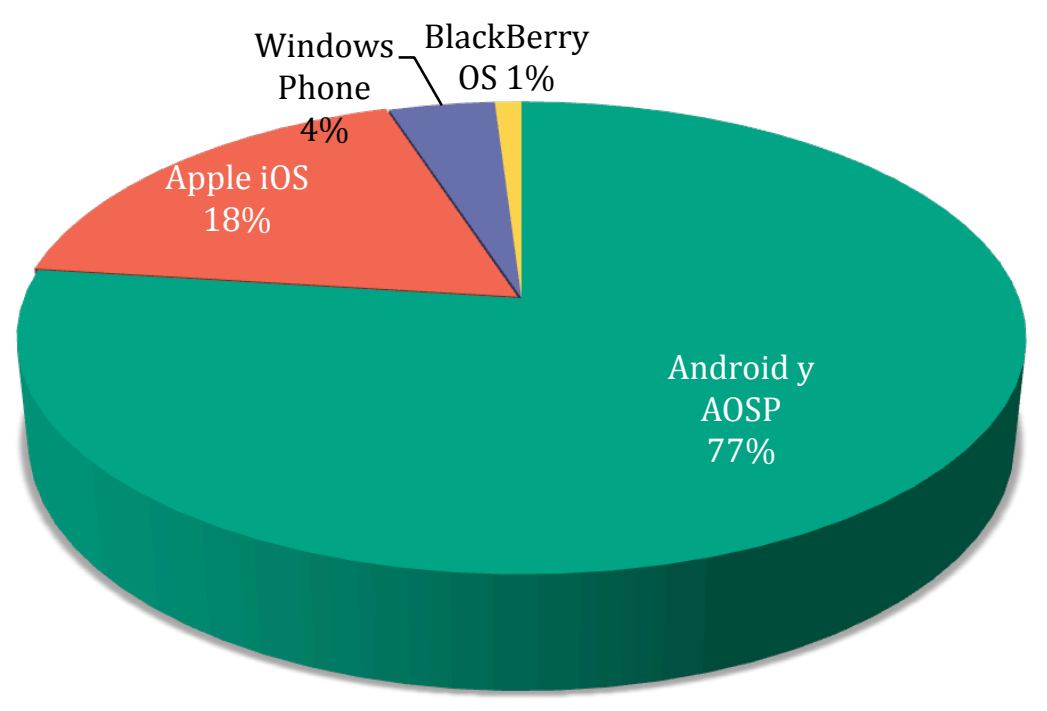

Gráfico 8. Smartphones vendidos por sistema operativo. Cuarto trimestre de 2013. Elaboración propia a partir de los datos de ABI Research ${ }^{10}$.

El segundo sistema operativo en ventas es el iOS de Apple. Deriva de Mac OS X y sólo funciona en los aparatos fabricados por Apple, en los que viene incorporado. La última versión disponible es la 8. Symbian, Windows Phone y BlackBerry han sido las más perjudicadas por la irrupción de Android y Apple en el mercado. Symbian, descendiente de una larga familia de software que se remonta a finales de los ochenta con EPOC, fue el sistema operativo para móviles mayoritario en Europa y en buena parte del mundo durante muchos años; estaba presente en los dispositivos de Sony Ericsson, Nokia, Motorola, Samsung y NTT Docomo, entre otros. Nokia, que finalmente se hizo con el control de Symbian, apostó por Windows Phone en 2011 y encargó a una empresa externa la actualización de Symbian. El Nokia 808 PureView, a la venta en 2012, fue el último dispositivo con este sistema operativo (Lunden, 2013).

${ }^{10}$ Q4 2013 Smartphone OS Results: Is Google Losing Control of the Android Ecosystem? En: $A B I$ Research, 29 enero 2014. https://www.abiresearch.com/press/q4-2013-smartphone-os-results-isgoogle-losing-con 
A diferencia de lo que sucede con los sistemas operativos para ordenadores de sobremesa y portátiles, donde Windows goza de una posición predominante, es el tercer sistema operativo con más ventas, aunque está muy lejos de Android y Apple. Los orígenes de Windows Phone arrancan en los años noventa con las primeras PDA. La última versión es la 8.1, que supone una convergencia entre los sistemas operativos para PC y móviles.

La primera BlackBerry fue lanzada por la compañía canadiense RIM en 1999. Sus dispositivos estaban muy bien considerados en el mercado, en parte por la garantía de privacidad y seguridad en el envío y recepción de información. Su sistema se basa en el uso de servidores intermedios por los que pasan los datos antes de ser recibidos por el cliente. Al igual que Apple, las BlackBerry tienen su propio sistema operativo, RIM OS, pero su cuota de mercado es mucho menor, del $1 \%$ en 2013.

El panorama de los dispositivos móviles ha evolucionado en los últimos años hacia una mayor homogeneidad, con dos tipos de dispositivos mayoritarios, dos sistemas operativos predominantes y características generales muy similares entre unos dispositivos y otros. Los teléfonos móviles convencionales están desapareciendo y determinados sistemas operativos han quedado prácticamente muertos o relegados a un pequeño nicho de mercado.

\subsection{La web móvil}

Se emplea el término web móvil para referirse al acceso a la web desde «dispositivos que pueden ser empleados en una situación de movilidad del usuario» (Arroyo-Vázquez, 2011b). Así, la cualidad de movilidad se atribuye al usuario, no al dispositivo (Ballard, 2007; Moll, 2008). Se trata de la misma web que se consulta desde el ordenador de sobremesa o el portátil, no de una web diferente ni de contenidos distintos. Eso es lo que significa el principio One web, que el World Wide Web Consortium define de la siguiente manera:

«One web means making, as far as is reasonable, the same information and services available to users irrespective of the device they are using. However, it does not mean that exactly the same information is available in exactly the same representation across all devices. The context of mobile use, device capability variations, bandwidth issues and mobile network capabilities all affect the representation. Furthermore, some services and 
information are more suitable for and targeted at particular user contexts» (Rabin y McCathieNevile, 2008).

Este principio supone un cambio de dirección con respecto a épocas anteriores, en las que se proponía crear una web específica para móviles, usando el dominio .mobi para esas páginas. La definición del principio One web identifica las dos cuestiones clave de la web móvil: la adaptación de diseño y de contenidos, sobre las que se hablará más adelante.

El término Web móvil 2.0 hace referencia al usuario como creador y consumidor de contenidos en el punto de inspiración (Jaokar y Fish, 2006). El dispositivo móvil se convierte por lo tanto en el instrumento para la inteligencia colectiva que propone la Web 2.0. El concepto de Mobile 2.0 va aún más allá, pues incorpora a los elementos característicos de los dispositivos móviles en la ecuación (Galindo, 2010).

\subsubsection{Los estándares de la web móvil}

Los estándares de la web móvil han evolucionado desde los años noventa en un proceso de convergencia que les ha unido a la web para ordenadores de sobremesa y portátiles en el lenguaje HTML5. Se enumeran en los siguientes puntos estos lenguajes, según se explican en el libro Información en el móvil (Arroyo-Vázquez, 2011b).

- HDML (Handheld Device Markup Language) fue el primer lenguaje para la web móvil. Propuesto en 1996 por Unwired Planet, se trataba de un subgrupo simplificado de SGML. Aunque nunca llegó a ser aceptado como estándar por el World Wide Web Consortium, abrió el camino a posteriores lenguajes.

- WML (Wireless Markup Language), heredero de XML, era el equivalente a HTML en las primeras versiones de WAP. Se trataba de un lenguaje de marcado sencillo y que permitía dividir un mismo documento en varias tarjetas.

- cHTML (Compact Hipertext Markup Languaje) era el lenguaje de marcado asociado al servicio iMode. Estaba basado en HTML y pensado para desempeñar las operaciones más básicas con la combinación de cuatro teclas. A diferencia de WML, iMode admitía la lectura de páginas HTML.

- WML 2.0, la segunda versión de este lenguaje de marcado, fue lanzada en 2001 con el objetivo de servir de puente hasta la creación de XHTML Basic y como resultado de la unión de XHTML-MP y WML. 
- A partir de XHTML (basado a su vez en HTML 4 y XML) surgió XHTML Basic en 2008, un conjunto de módulos imprescindibles pensando en clientes web que no soporten el conjunto completo de características de XHTML, como sucede con PDAs o teléfonos móviles.

- XHTML-MP (XHTML Mobile Profile) surgió como resultado de la colaboración entre NTT DoCoMo y el WAP Forum. En su construcción se tomó XHTML Basic como referencia y se agregaron características de cHTML y WML. XHTML-MP añadía WAP CSS y atributos de estilo, creando así páginas con más gráficos y mayor usabilidad.

\section{Evolution of Mobile Web-Related Markup Languages}

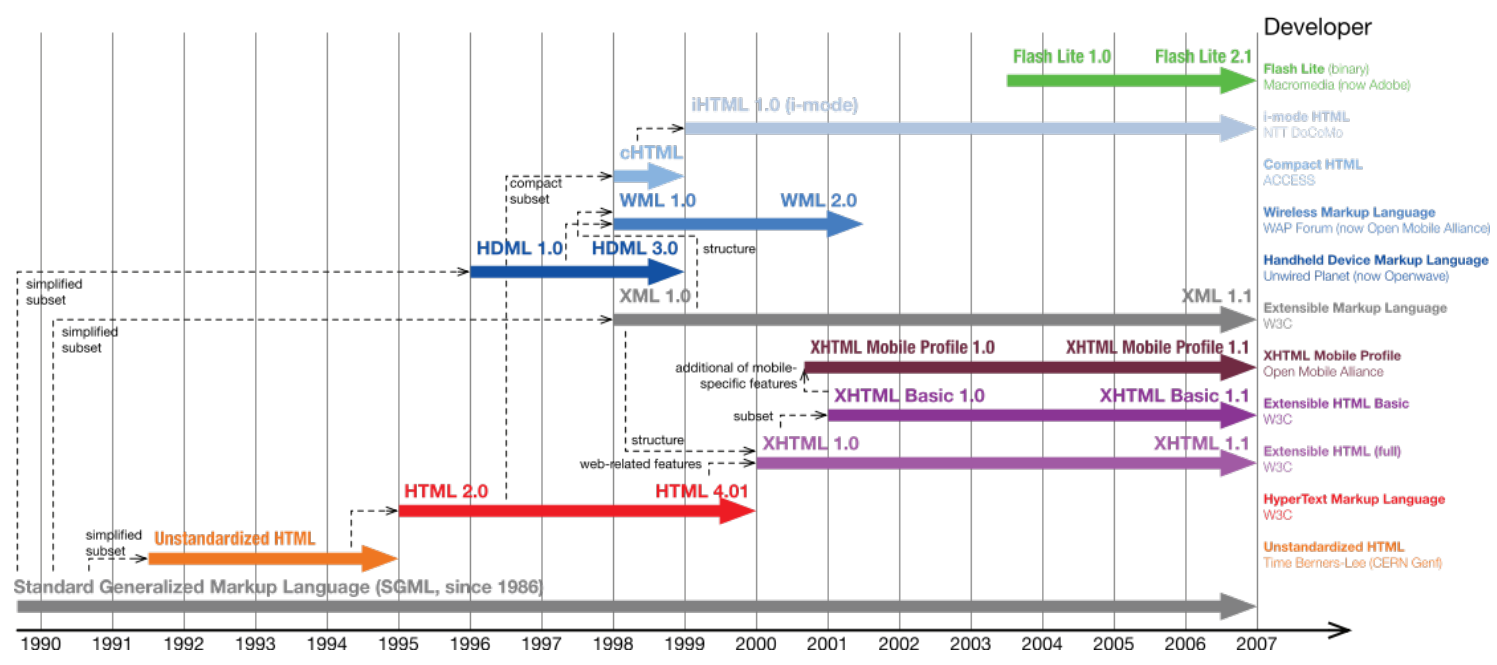

Figura 1. Evolución de los estándares de la web móvil. Imagen de Matthew Stuckwisch compartida bajo licencia CC BY 3.0 en la Wikipedia.

El World Wide Web Consortium publicó en octubre de 2014 la versión definitiva de HTML5 (Berjon, et al., 2014), que ya soportan los navegadores más actualizados. Aporta páginas web más ricas, que reducen las diferencias con respecto a las aplicaciones nativas, y supone la confluencia definitiva hacia un lenguaje independiente del dispositivo. Algunas de las novedades que introduce HTML5, recopiladas por Weyl (2014), son las siguientes:

- Soporta vídeo y audio de forma nativa, sin necesidad de plug-ins, con las etiquetas < video $>$ y $<$ audio $>$.

- Acceso offline. Gracias a una API asociada, es posible consultar un sitio web incluso cuando no hay cobertura, al igual que una app.

- Geolocalización, que permite identificar el lugar en que se encuentra el 
usuario, también a través de una API asociada.

- Nuevas etiquetas que definen grupos lógicos de etiquetas con el fin de dotar al documento de una estructura. Algunas de estas etiquetas son $<$ article $>$, <section $>$, < aside $>0<$ footer $>$.

- Etiquetas <svg> y <canvas>, que permiten dibujar en un lienzo, sin necesidad de incrustar imágenes.

- Otras APIs, como microdatos (un método para añadir metadatos legibles por ordenador) o Accessible Rich Internet Applications (ARIA), que mejora la accesibilidad.

\subsubsection{Adaptación de diseño y contenidos}

Smartphones y tabletas se han convertido en los dispositivos móviles más utilizados, hasta el punto de que el acceso a la web desde smartphones ha superado al acceso desde el ordenador. La segunda razón por la que se hace necesario adaptar los sitios web, especialmente en el caso de los smartphones, es la usabilidad, que mejora considerablemente en los sitios web adaptados, según los resultados publicados por Nielsen y Budiu (2013). Así, son los smartphones quienes requieren mayores ajustes, teniendo en cuenta que son el dispositivo más extendido y el que más diferencias presenta con respecto a los ordenadores, para los que están pensados la mayor parte de los sitios web actuales.

Las pantallas de los smartphones son el primer elemento a tener en cuenta a la hora de adaptar un sitio web porque, a menor tamaño, la usabilidad empeora. Nielsen y Budiu (2013) recomiendan descartar los teléfonos móviles convencionales, puesto que su usabilidad es «miserable» (y también porque están destinados a desaparecer). Por el contrario, en las pantallas de las tabletas la mayor parte de los sitios ofrecen una experiencia rica y cómoda. Nielsen y Budiu sí recomiendan crear una versión adaptada para las pantallas de las tabletas más pequeñas, de unas 7 pulgadas, como el Amazon Kindle Fire o el iPad Mini.

Como ya se avanzó en el apartado 1.1.4, las pantallas de los dispositivos móviles oscilan entre las 3,5 pulgadas de los smartphones - el iPhone 4 tiene 3,5-, las 5,5 y 6 en las phablets y entre 7 y 10 en las tabletas. Lejos de las 11 de los ultraportátiles y las 13 y 15 de los ordenadores portátiles. Pero además de la evidente diferencia en las pantallas, los smartphones y tabletas son también diferentes en otros aspectos. 
La interacción táctil sustituye al ratón -aunque algunos dispositivos, cada vez menos, utilizan otros sistemas, como se explicó en el apartado 1.1.4-. Esto implica, por un lado, que el área para hacer clic aumenta de tamaño, pues el dedo es más grueso que un puntero y se produce el llamado efecto fatfinger. Pero también que es posible interactuar mediante gestos, porque las pantallas son multitáctiles. Y además, no funcionarán elementos como el selector hover, que permite mostrar información cuando se pasa el cursor por encima de un enlace sin hacer clic (Nielsen y Budiu, 2013) o el orden de tabulación del control. Por otra parte, la entrada de datos se ve dificultada porque las dimensiones de los teclados virtuales y físicos son más pequeños.

Aunque las conexiones han mejorado considerablemente en velocidad con la generalización de las redes $3 \mathrm{G}$ y las tarifas de datos se han abaratado en los últimos años, no hay que menospreciar la velocidad de carga de las páginas. En las redes 3,5G la velocidad de descarga es de hasta 7,2 Mbps y la de subida de $5 \mathrm{Mbps}$, mientras que las redes 4G (LTE) se puede alcanzar hasta 150 de subida y 50 de bajada. Recordemos que el 2G (GPRS) solo permitía entre 40 kbps y 60 kbps de bajada, como se indicó en el apartado 1.1 .

Otra cuestión a tener en cuenta es la latencia, «el tiempo que tarda el primer byte de cada paquete de datos en llegar al dispositivo después de la petición de carga de una página» (Firtman, 2014). Esta latencia es cinco o diez veces mayor en las redes de telefonía móvil que en una red ADSL. Las capacidades de memoria y procesamiento de los dispositivos móviles, inferiores a las de los ordenadores portátiles y de sobremesa, también inciden en la velocidad de navegación. Por todo ello se hace necesario optimizar las páginas para que carguen lo más rápidamente posible.

No todos los formatos son soportados por todos los dispositivos, por lo que hay que prestar una especial atención a cuáles permiten y cuáles no. Uno de los casos que más han dado que hablar es el de Apple, que dejó de soportar Flash (Jobs, 2010).

Smartphones y tabletas incorporan funciones diferentes que enriquecen la experiencia del usuario y le hacen más fáciles algunas tareas. Algunos ejemplos son la posibilidad de colocar enlaces a números de teléfono para efectuar una llamada telefónica, enviar un SMS o añadir un número en la agenda de contactos con solo hacer un clic, correo electrónico para enviar un mensaje. Ciertas aplicaciones también pueden ser activadas desde un enlace, principalmente en el iPhone abrir la aplicación de mapas o realizar una llamada a través de Skype-, pero también en Android o Windows Phone (Firtman, 2013). Esto facilita la integración de las diferentes funciones del dispositivo. 
Así, todos estos elementos llevan a pensar que es necesario adaptar el diseño de los sitios web. En lo que no todos coinciden es en la adaptación de contenidos. El World Wide Web Consortium (W3C) define la adaptación de contenidos como el proceso de alteración del contenido para mejorar la experiencia de usuario en determinados dispositivos (Rabin y McCathieNevile, 2008). Se trata de que el usuario se encuentre cómodo visitando un sitio web y le sea de utilidad, de que su experiencia sea grata y obtenga la información que busca en el menor tiempo posible.

Nielsen y Budiu (2013) inciden también en la necesidad de ser concisos cuando se escribe para la web móvil, incluso más que cuando se escribe para grandes pantallas (ordenadores portátiles y de sobremesa). La razón es muy sencilla: la comprensión se reduce en las pantallas pequeñas, ya que los usuarios pueden ver menos contenidos al mismo tiempo y deben moverse más por la página, utilizando el scroll, por lo que el contenido debe ser fácil de leer. Esto supone todo un reto, pues la respuesta a una necesidad de información no debería variar en función del dispositivo. Firtman (2013) recuerda además la ley del 80/20: «el 80\% de tu sitio web para ordenadores de sobremesa y portátiles no será útil para los usuarios de smartphones. Por ello debes investigar cuál ese $20 \%$ en el que debes centrarte.» También señala la importancia de tener en cuenta otras funciones del dispositivo, además del tamaño de la pantalla (Firtman, 2014), lo que introducirá ciertas diferencias en la versión para smartphones de un sitio web frente a la versión de sobremesa.

La cuestión de la adaptación de contenidos es controvertida, pues hay quienes opinan que no deben variar los contenidos en la versión para móviles con respecto a la versión para grandes pantallas. Por un lado, argumentan, es arriesgado suponer qué contenidos son de utilidad para un grupo determinado de usuarios, si no se basa en datos objetivos, y los usuarios de dispositivos móviles pueden estar interesados en los mismos contenidos (McGrane, 2012). Por otro, que un usuario esté utilizando un smartphone no significa que esté en una situación de movilidad - podría estar en el sofá de su casa-, sino solo que utiliza un dispositivo con unas características determinadas. El contexto de movilidad en que se encuentra una persona que utiliza un dispositivo móvil queda también en entredicho.

Posiblemente la solución a esta discusión sea mucho más compleja y depende de cada sitio web y de sus contenidos, como apuntan Nielsen y Budiu (2013). Así, en un blog o un sitio web de prensa, dedicado a las noticias, la unidad de información, el post o la noticia, será la misma para quien accede desde un ordenador o desde un smartphone. Sin embargo, en el caso concreto del sitio web de una bibliotecas, siguiendo la regla del 80/20 de la que habla Firtman, sería recomendable plantear qué contenidos son más interesantes para los usuarios de dispositivos móviles. 


\subsubsection{Soluciones de movilidad para sitios web}

En este apartado se exponen las diferentes soluciones a la hora de adaptar un sitio web para smartphones, así como sus pros y sus contras. Estas soluciones son tres: la creación de páginas específicas, añadir una nueva hoja de estilo y el diseño web adaptativo. También se plantean otras aproximaciones más novedosas y complejas, como Mobile first, Progressive enhancement o Adaptive content.

La primera opción, como indica Moll (2008), es no hacer nada. Esta idea se fundamenta en que el número de visitas desde dispositivos móviles es mínimo y que quienes lo hacen pueden consultar los contenidos haciendo uso de herramientas como el zoom, para ver en detalle partes determinadas de la página, el scroll, que ayuda a moverse de arriba abajo y de izquierda a derecha, el cambio automático de pantalla en vertical a la postura horizontal o el «lector», que en el navegador Safari mantiene el texto de la página eliminando el formato.

El uso de transcoders o transcodificadores para adaptar el diseño de las páginas y enlazar el resultado como versión móvil ha dejado de utilizarse hace tiempo debido a sus pobres resultados, aunque hace unos años se consideraba una opción. Los transcoders son servicios web ${ }^{11}$ que adaptan durante el proceso de navegación y de forma automática los diferentes elementos de las páginas web a la pantalla de un smartphone, les dan un nuevo formato y los comprimen, de manera que se puedan consultar cómodamente mientras se navega.

\subsubsection{Sitios web con páginas diferenciadas para dispositivos móviles}

Una de las opciones de movilidad consiste en crear páginas diferenciadas específicas para smartphones o tabletas. De esta manera se pueden adaptar diseño y contenidos. Por el contrario, una de las desventajas de esta solución consiste que en la duplicidad de las páginas implica multiplicar los contenidos y también los esfuerzos en el mantenimiento del sitio, que debe actualizarse tantas veces como versiones se tenga. Aunque pueden crearse tantas versiones como tipos de dispositivos, si se quieren ahorrar esfuerzos lo más recomendable es crear solo dos, una para ordenadores y otra para smartphones, que son los terminales más empleados.

\footnotetext{
${ }^{11}$ Como el servicio de Google http://www.google.es/gwt/n
} 
Otro de los problemas que plantea este sistema está en el acceso. Si los usuarios conocen el URL de la versión de escritorio, ¿de qué manera acceden a la versión móvil? ¿Cómo llegan a ella? Existen dos formas: enlazar a la versión móvil desde la versión de escritorio o utilizar un sistema de detección de dispositivo. Cuando se opta por el enlace entre una versión y otra es necesario situarlo de manera que sea visible, previendo que quien acceda desde la pantalla de un smartphone deberá encontrarlo rápidamente.

Los sistemas de detección de dispositivo son capaces de reconocer el dispositivo o el navegador desde el que se accede a un sitio y de redireccionar a la versión correspondiente. Esta se considera mejor opción que la anterior, pues pasa completamente desapercibida para el usuario y le evita un paso, agilizando así la navegación.

\subsubsection{Hojas de estilo y diseño web adaptativo}

Las hojas de estilo aportan el formato a las páginas de un sitio web. Son ficheros individuales, con formato .css, en los que se indican todos los atributos de diseño de cada elemento del sitio. Una de las soluciones de movilidad pasa por añadir una hoja de estilo adicional en el sitio web, específica para determinados dispositivos. La página reconoce el dispositivo desde el que accede el visitante y cambia a la versión móvil gracias al atributo media:

<link href="mobile.css" rel="stylesheet" type="text/css" media="handheld"/>

Esta solución solo adapta el diseño del sitio, y no los contenidos, aunque existe la posibilidad de priorizar unos contenidos sobre otros. Esta solución parece superada en la actualidad por la siguiente, el diseño web adaptativo, aunque se mantienen sitios web que la utilizan.

El diseño web adaptativo fue propuesto por Ethan Marcotte (2010) y consiste en la adaptación del diseño de los sitos web a cualquier pantalla utilizando tres elementos: media queries, diseño fluido e imágenes flexibles. Se mantienen por lo tanto los mismos contenidos en las mismas páginas web, lo que cambia es el diseño, que se especifica en una única hoja de estilo y se adapta según el ancho de la página. Sin embargo, como señala Schade (2014), sí es posible priorizar contenidos y servicios, situándolos en lugares más visibles, y ocultar otros.

En el presente trabajo se sigue la recomendación de la Fundéu de traducir la expresión responsive web design como diseño web adaptativo ${ }^{12}$ frente a diseño

\footnotetext{
12 Diseño web adaptativo, traducción de responsive web design. En: Fundéu BBVA, 31 enero 2013. http://www.fundeu.es/recomendacion/diseno-web-adaptativo-traduccion-de-responsive-webdesign-1573/
} 
web adaptable o diseño web responsivo. Según explica Fundéu, adaptativo hace referencia a la capacidad de adaptación, mientras que adaptable implica la posibilidad de modificación por parte del usuario, eliminando el automatismo. El término responsivo tiene un sentido muy diferente, pues significa «perteneciente o relativo a la respuesta», según la definición de la RAE.

CSS3, la última versión del lenguaje de creación de hojas de estilo, permite diferenciar el estilo que se aplica a una página en función del ancho de la pantalla gracias a las media queries. A diferencia del sistema que se vale de hojas de estilo diferentes para cada versión, basado en el reconocimiento del dispositivo, el diseño web adaptativo se basa en la identificación del tamaño de la pantalla y emplea una sola hoja de estilo. Otra de las directrices del diseño adaptativo consiste en asignar a las imágenes y al diseño de cuadrícula (grid layout) valores relativos, y no absolutos, a la hora de especificar la anchura y altura que deben ocupar en la página. De esta manera, una imagen determinada ocupará un tamaño porcentual con respecto al ancho de la pantalla y variará el número de columnas en que se organizan los contenidos en la cuadrícula de la página.

Es fácil reconocer el diseño web adaptativo desde un navegador para ordenadores portátiles y de sobremesa, porque cambia el diseño al reducir o ampliar la ventana del navegador. El uso de hojas de estilo diferentes para cada versión, sin embargo, solo se aprecia al visitar el sitio desde un dispositivo móvil. El diseño web adaptativo se ha convertido en la opción de moda en los últimos años. Según un estudio realizado a comienzos de 2014, se estima que el 11 ó 12\% de los sitios web utilizan el diseño web adaptativo (Podjarny, 2014).

El diseño web adaptativo no está exento de inconvenientes. Los sitios que optan por esta solución no están optimizados para mejorar el rendimiento en smartphones y tabletas, por ejemplo reduciendo el tamaño de los recursos para que la carga de la página sea más rápida. Tampoco permite una solución óptima a la hora de aprovechar las capacidades del dispositivo. Esto implica que, por ejemplo, no se suelen enlazar los números de teléfono para realizar llamadas telefónicas haciendo clic y, en caso de que se haga, no funcionarían en la versión de escritorio. Y, finalmente, optar por el diseño web adaptativo implica embarcarse en la modificación del sitio web completo, por lo que solo se puede acometer si se va a emprender una reforma más profunda de la presencia web.

\subsubsection{Aproximaciones complementarias al diseño web adaptativo}

Con el fin de superar las limitaciones que el diseño web adaptativo plantea han surgido una serie de técnicas que lo complementan y mejoran, como Mobile first, Progressive enhancement, Adaptive content y RESS. La primera de esas propuestas, 
el denominado Mobile first, consiste en pensar en primer lugar en los usuarios de dispositivos móviles a la hora de diseñar un sitio, incluso por delante de los usuarios de ordenadores de sobremesa y portátiles. Esta técnica combina a la perfección con el diseño web adaptativo (Frost, 2011) y se justifica ante el aumento en el número de usuarios que consulta la web desde smartphones, que ya supera al uso desde ordenadores. Se basa también en la idea de que si un sitio web funciona en un smartphone, que es un contexto más restrictivo, funcionará en el resto de terminales.

Centrarse en el contenido y en las funcionalidades clave, como propone el Mobile first, conlleva un mejor rendimiento de las páginas cuando se consultan desde un smartphone (Wroblewski, 2011a), que es una de las limitaciones del diseño web adaptativo. Wroblewski también considera que simplificar el contenido y las funcionalidades de las páginas proporciona una experiencia de navegación más cómoda, incluso en entornos libres de distracciones. También tiene la ventaja de que permite optimizar para dispositivos móviles, aprovechando capacidades como la pantalla táctil y la geolocalización.

Aunque el Mobile first es más considerado con respecto a la web móvil, sigue teniendo la limitación de centrarse en un solo contexto, el móvil, mientras que los demás quedan supeditados a él. Por otra parte, no soluciona el problema de la adaptación de contenidos y requiere la remodelación completa de la web, como el diseño web adaptativo (Cremin, 2011).

Progressive enhancement (mejora progresiva) es otra técnica que consiste, en palabras de Cremin (2011), en servir una única página de base a cada dispositivo, mejorada con JavaScript. Este código JavaScript añadirá mejoras funcionales a la página cuando se acceda desde un ordenador de sobremesa o portátil o desde un smartphone. Esto hace posible crear una experiencia óptima para cada dispositivo. El truco está en que el navegador de cada dispositivo utiliza aquellas capas que es capaz de soportar e ignora el resto, pero presenta el inconveniente de que se puede ralentizar la carga de la página en determinados dispositivos con menos capacidades (Firtman, 2013). Aunque esta técnica fue creada por Steven Champeon en 2003 sin pensar en entornos móviles, se ha adaptado posteriormente como una posible solución ante el problema de la movilidad.

Una aproximación diferente es la del Adaptive content (contenido adaptado), que propone dotar de flexibilidad de los contenidos con el fin de que se puedan adaptar a diferentes tamaños de pantalla y presentarlos en diferentes formatos según el dispositivo desde el que se acceda (McGrane, 2012). Esta flexibilidad se consigue dotando de una estructura semántica al texto gracias a los metadatos. El contenido adaptado se basa en cinco elementos, según explica McGrane: 
- Contenido reutilizable, desarrollado para maximizar la reutilización en diferentes plataformas.

- Contenido estructurado, que permita combinarlo de diferentes maneras.

- Contenido independiente de la presentación, que no esté ligado a un formato o estilo determinado para ser visto de una manera concreta.

- Metadatos dotados de significado, que ayudan a las plataformas a decidir qué contenido mostrar en cada momento.

- Uso de gestores de contenidos (CMS) que permitan crear contenidos estructurados gracias a los metadatos, en lugar de escribir contenido para diferentes páginas.

Esta opción soluciona los problemas del diseño web adaptativo y de las páginas diferenciadas y facilita el mantenimiento de sitios web sin duplicidades.

Responsive Web Design + Server Side Components (RESS) es una solución propuesta por Luke Wroblewski (2011b) que combina el diseño web adaptativo y el uso de páginas diferenciadas. Mediante este sistema es posible crear contenidos y funciones diferentes para cada dispositivo pero realizando ajustes finales del lado del cliente, como puede ser la cabecera de la página, mantener una plantilla fluida o reaccionar a diferentes orientaciones (Firtman, 2013). El propio Wroblewski señala que este método sigue necesitando un sistema de detección del dispositivo, y estos sistemas no son completamente precisos. Por otra parte, es una técnica más compleja y tampoco resuelve definitivamente el mantenimiento de varias versiones para una misma página.

\subsubsection{El debate sobre las diferentes soluciones de movilidad}

Hasta el momento no parece haber un acuerdo entre los expertos a la hora de optar por una solución de movilidad u otra. Uno de los debates más importantes se centra en las ventajas e inconvenientes que plantean el diseño web adaptativo y la creación de páginas diferenciadas y cuál escoger en cada caso. En el centro del debate está la cuestión de la adaptación de los contenidos, sobre la que se habló en el apartado 1.2.2.

Nielsen y Budiu (2013) recomiendan crear páginas diferenciadas para smartphones siempre que sea posible. Basándose en estudios de usabilidad realizados previamente, aseguran que es la mejor solución desde el punto de vista de la experiencia de usuario. Valoran el diseño web adaptativo porque el coste de mantenimiento es menor y los beneficios pueden no ser suficientes como para justificar varios desarrollos y porque es la mejor solución para los usuarios que tienen el móvil como principal medio de acceso a internet, bien porque viajan o porque no tienen ordenador. Además, consideran, puede ser efectivo cuando las 
características y contenidos del sitio web sean los mismos para diferentes plataformas, como sucede con los sitios de noticias.

Sin embargo, exponen, no es bastante con modificar la plantilla, sino que debe conllevar diferentes interfaces de usuario para cada plataforma y debe prestarse atención a que los contenidos sean más concisos aún, por los motivos expuestos en el apartado 1.2.2. El diseño web adaptativo presenta peores resultados en cuanto a experiencia de usuario. Respecto a la filosofía Mobile first, consideran que los ordenadores no van a quedar relegados por la introducción de los dispositivos móviles, puesto que presentan grandes ventajas — pantalla más grande y mejores sistemas de interacción- y porque esta solución empobrece la experiencia de usuario desde un ordenador y, por el momento, en los sitios web suelen ser mucho menores las visitas procedentes de dispositivos móviles que las que proceden de ordenadores de sobremesa.

Firtman (2014) apoya la idea de que el diseño web adaptativo debe ser utilizado en combinación con otras técnicas. Desde su punto de vista, alcanzar este diseño no debe ser el objetivo final. Con él coincide Schade (2014), quien opina que el diseño web adaptativo no asegura la usabilidad y no es un remedio para todo, sino una herramienta.

Josh Clark (2012b), uno de los grandes aliados del diseño web adaptativo, señala que esta opción ahorra la creación y posterior mantenimiento de diferentes páginas para cada tipo de dispositivo. Por otra parte, que alguien visite una página desde una pantalla pequeña no significa que quiera menos contenidos o servicios, porque los usuarios no están siempre en movimiento. Este diseñador y desarrollador no es partícipe de diferenciar contenidos en función del tipo de dispositivo, sino que para él lo importante es que el diseño esté adaptado, y piensa que no se puede obligar a visitar páginas no adaptadas desde una pantalla pequeña, una experiencia muy frustrante. La misma opinión defiende McGrane (2012), quien anima a la paridad en los contenidos de todos los sitios web y para lo cual el diseño web adaptativo en combinación con Mobile first, Progressive enhancement u otras técnicas es una solución óptima. El diseño web adaptativo es también la opción recomendada por Google ${ }^{13}$.

Finalmente, a la hora de optar por una u otra versión, hay que evaluar si el coste que supone diseñar desde cero un sitio web es más rentable a largo plazo que afrontar la actualización de dos o más versiones simultáneamente. Ethan Marcotte (2011), el padre del diseño web adaptativo, explicó que esta técnica no pretende

\footnotetext{
13 Cómo crear sitios web optimizados para smartphones. En: Google Developers, 16 abril 2014. https://developers.google.com/webmasters/smartphone-sites/
} 
reemplazar los sitios web para móviles, sino que hay que evaluar las necesidades de cada proyecto. Quizás esa es la respuesta más sensata, pensar que no hay una solución única, sino que todo depende de cada caso, como ya se avanzó en el apartado 1.2.2.

\subsection{Aplicaciones nativas para móviles}

Son aplicaciones nativas aquellas que se descargan desde una tienda de aplicaciones o de otra fuente y se instalan en un dispositivo móvil, ampliando así sus funciones. No deben confundirse con las aplicaciones web, a las que se accede a través del navegador y que están alojadas en un servidor, o con las aplicaciones informáticas, que son los programas que se instalan en los ordenadores portátiles o de sobremesa. Para designar a las aplicaciones nativas para móviles se utilizan también los términos aplicaciones móviles y apps. Esta última es una contracción del inglés application y algunos medios la han castellanizado traduciéndola como «aplis». En este trabajo se utilizarán los términos app, aplicación móvil o aplicación nativa, por ser los que mejor las identifican.

Tras la inauguración de la App Store, la tienda de aplicaciones de Apple, el 10 de julio de 2008, cada plataforma ha desarrollado su propia tienda de aplicaciones. Los lenguajes para programar las apps son completamente diferentes en función del sistema operativo en el que vayan a funcionar: las apps para iPhone y iPad se programan en Objective $C$, mientras que para Android se deberá utilizar Java y en Windows Phone el lenguaje .NET. Así, las apps que se ofertan en la tienda de Apple solo se pueden instalar en un dispositivo con el sistema operativo iOS, y las que disponibles en Google Play, la tienda de Google, solo funcionan en sistema operativo Android.

Las tiendas de aplicaciones se han revelado como un lucrativo negocio. Su función consiste en actuar como intermediarias entre el desarrollador de apps y el usuario final: el primero encuentra en estas tiendas un escaparate para comercializar su trabajo y los segundos un espacio de confianza en el que buscar aplicaciones para realizar determinadas tareas. La tienda de aplicaciones obtiene a cambio un porcentaje de los beneficios obtenidos de la venta de las apps, en el caso de que sean de pago. En las dos principales tiendas, las de Apple y Google, este porcentaje es del 30\%. Se suma en algunas tiendas una tasa, que en el caso de Apple es de 99 dólares anuales para desarrolladores a título individual y en Google Play consiste 
en un solo pago de 25 dólares. BlackBerry, sin embargo, no cobra esa tasa para atraer así más aplicaciones nativas. La tienda de aplicaciones realiza un control sobre las apps para asegurar su calidad y seguridad, lo que supone una garantía para el usuario final.

Otras tiendas de aplicaciones son el Marketplace de Microsoft y la App World de BlackBerry. Esta última ha ideado un sistema para que las aplicaciones de Android puedan funcionar en una BlackBerry. También existen tiendas independientes del sistema operativo, como GetJar o la tienda de Amazon. Esta última contiene apps para Android enfocadas a sus propios dispositivos. Unos 75.000 millones de apps fueron descargadas de la tienda de aplicaciones de Apple hasta junio de 2014, mientras que en Google Play se han descargado apps 80.000 millones de veces (Yale, 2014). Esto significa que las descargas de la tienda de Google adelantaban en un $45 \%$ a las de Apple en el primer trimestre de 2014. Sin embargo, los datos publicados revelan que iOS aún genera un $85 \%$ más de beneficios que Google, aunque la diferencia se reduce (Parfitt, 2014).

\begin{tabular}{llr}
\multicolumn{1}{c}{ Tienda } & \multicolumn{1}{c}{ Propietario } & Número de apps \\
\hline App Store & Apple & 1.200 .000 \\
\hline Android Market & Android & 1.314 .746 \\
\hline Marketplace & Windows & 250.000 \\
\hline App World & BlackBerry & 234.500 \\
\hline
\end{tabular}

Tabla 1. Principales tiendas de aplicaciones móviles por número de apps. Elaboración propia a partir de diferentes fuentes ${ }^{14}$.

Las aplicaciones nativas constituyen por lo tanto un valor añadido a smartphones y tabletas y, según la amplitud de la oferta de la plataforma en la que funcione, sus usuarios tendrán acceso a más o menos contenidos. Así, las tiendas de Apple y Android son las más ricas (tabla 1), con más de un millón de apps cada una. Esto se debe a que los desarrolladores tienden a escoger estas dos plataformas por ser las que utilizan más dispositivos.

En los últimos años se ha desatado una especie de locura por las tiendas de aplicaciones. Cabe valorar si merece la pena el esfuerzo de desarrollar una app, que hay que programar varias veces, una por sistema operativo, y que funciona únicamente en la plataforma para la que ha sido programada, en un entorno restringido. Muchas de las apps existentes son meramente informativas, por lo que

14 Fuentes: Pérez (2014), Siegal (2014), AppBrain Stats (2014) y BlackBerry World (2014). 
podrían ser sustituidas por una aplicación web sin que se echara en falta ninguna funcionalidad. HTML5 promete aplicaciones web más potentes. Otra de las ventajas de las aplicaciones web es que es más sencillo hacer cualquier cambio en el futuro y se ahorra el trámite y la limitación que supone tener que pasar la aprobación de la tienda de apps.

Son tres las aportaciones de las aplicaciones nativas frente a los sitios web:

- El aprovechamiento de las funciones del dispositivo es uno de los motivos que justifican optar por las aplicaciones móviles. Solo a través de una app se puede hacer uso de determinadas funciones del dispositivo, como las notificaciones push, que hacen que se reciba una alerta cada vez que se produce un nuevo evento, la cámara de fotos, la agenda de contactos, la linterna o la navegación offline, por ejemplo.

- Las tiendas de aplicaciones se consideran escaparates. Sin embargo, hay que cuestionar si la visibilidad que puede alcanzar una aplicación concreta entre un millón merece la pena.

- Las apps presentan un mayor grado de usabilidad. Los estudios realizados demuestran que los usuarios encontraban mayor facilidad de uso en las apps (76\%) que en los sitios web (64\%) (Nielsen y Budiu, 2013). Estos autores recomiendan, en caso de que sea posible, optar por una app.

Para facilitar el desarrollo de apps han aparecido soluciones intermedias. Las aplicaciones híbridas son aquellas que funcionan a modo de navegador y en las que los contenidos son realmente páginas web en HTML o XHTML. El usuario final no nota la diferencia y el desarrollador utiliza un lenguaje estándar en su mayoría, lo que facilita la tarea (Wisniewski, 2011). Estas aplicaciones híbridas tienen las mismas ventajas, pues quedan a un clic en el escritorio del usuario, pero además se agiliza su actualización y su desarrollo es más sencillo.

Una herramienta que facilita la creación de apps son los frameworks, plataformas que proporcionan los elementos básicos para el desarrollo de software. PhoneGap, uno de estos frameworks, permite crear una app como si fuera una web, con conocimientos de HTML, CSS y JavaScript (Charland y LeRoux, 2011; La Counte, 2012). También han aparecido servicios web, como Mobincube, Nimbo o App Inventor, que permiten a cualquier persona sin conocimientos de programación crear una app desde un entorno gráfico intuitivo y sencillo. 


\section{Capítulo 2. Tecnología móvil en bibliotecas. Estado de la cuestión}

Este segundo capítulo recoge el estado de la cuestión en lo que a tecnología móvil en bibliotecas se refiere, a la luz de la bibliografía. El tema se ha abordado desde un punto de vista amplio, teniendo en cuenta no solo aquellos aspectos que se tratan en el trabajo de investigación que se presenta en esta tesis doctoral, que se afrontarán con especial detenimiento, sino todo aquello que tenga que ver con el uso de dispositivos móviles en bibliotecas, desde los orígenes a la actualidad.

Cada uno de los apartados de este capítulo se refiere a una tecnología o tecnologías concretas: la web móvil, aplicaciones nativas, localización, códigos QR, realidad aumentada, NFC y beacons-. La excepción está en el primero, con el que se quiere dar una visión general sobre el uso de dispositivos móviles en bibliotecas, y en el último, en el que se abarcan determinados servicios a los que atañen smartphones y tabletas y que no habían sido tratados de forma más detallada. 



\subsection{Introducción al uso de dispositivos móviles en bibliotecas}

Se introducen en este apartado cuestiones generales sobre el uso de dispositivos móviles en bibliotecas: los primeros años, previos a la explosión de los smartphones, los retos y barreras que se plantean, tanto para el personal como para los usuarios, y el porqué del interés de smartphones y tabletas para las bibliotecas. Se incluye también un análisis bibliográfico de las publicaciones sobre el tema con el fin de conocer cuáles son las áreas que más interés han suscitado y las que menos.

\subsubsection{Antecedentes y evolución de la tecnología móvil en bibliotecas}

Aunque pueda parecer una novedad, la preocupación por el acceso a la información en movilidad por parte de las bibliotecas no es reciente, sino que se remonta a comienzos de los años noventa en los bibliobuses, que necesitaban conectarse al catálogo (Longsdon, 1990). Unos pocos años después, en esa misma década, comenzaron a verse en el mercado las primeras PDA, con la Apple Newton inaugurando esta gama de dispositivos en 1993.

Teniendo en cuenta que no es objetivo de esta tesis doctoral analizar los orígenes de la tecnología móvil en bibliotecas, se darán en los siguientes párrafos algunas pinceladas que contribuyan a la comprensión de la situación en aquellos años, cuáles fueron las primeras iniciativas puestas en marcha por las bibliotecas, las barreras a las que se enfrentaban y que impidieron un mayor desarrollo de esta tecnología y, finalmente, las esperanzas de futuro.

El período que se aborda en este capítulo se inicia con la aparición de los primeros dispositivos móviles en el mercado y se cierra con el lanzamiento del iPhone, en 2007, y con el posterior desarrollo de Android, que supone la democratización de los smartphones.

\subsubsection{Primeros servicios de las bibliotecas}

Una de las primeras preocupaciones sobre los dispositivos móviles en bibliotecas consistió en averiguar si era posible acceder a los contenidos que se servían. El proyecto Library without a roof, llevado a cabo en noviembre de 1993 en la Universidad del Sur de Alabama (Estados Unidos), demostró que era posible 
investigar desde los espacios al aire libre del campus y consultar la información que la biblioteca proporciona a sus usuarios. Para ello se utilizó una EO 440, la única PDA con módem en aquellos años (Foster, 1995). Varios autores coinciden en señalar a este proyecto como el primero sobre el uso de dispositivos móviles en bibliotecas (Carney, Koufogiannakis y Ryan, 2004; Dresselhaus y Shrode, 2012).

Las bibliotecas del área de ciencias de la salud fueron pioneras en asimilar la introducción de los dispositivos móviles. Los profesionales de la medicina encontraron en ellos una gran utilidad para el seguimiento de los pacientes, pues les permitía sustituir el cuaderno de notas y obtener información en el momento en que la necesitaban, pero también para consultar la literatura científica, según señalan Shipman y Morton (2001). Para estos autores, el lanzamiento de la Palm Pilot 2000 en marzo de 1996 aceleró el uso de las PDA por parte de este colectivo y se crearon varios sitios web con información médica.

La Biblioteca de Ciencias de la Salud de la Universidad de Arizona (Estados Unidos) comenzó a proporcionar servicios de apoyo en 1993, tras la compra de varios ordenadores de bolsillo Hewlett-Packard 95LX palmtops ${ }^{15}$, que consistían en ofrecer bases para conectar estos dispositivos a los PC para el intercambio de datos y la conexión Telnet (Stoddard, 2001). En estos primeros años, los servicios de apoyo a los usuarios de dispositivos móviles fueron los primeros en ser ofertados por las bibliotecas en relación a las nuevas PDA. Consistían en la organización de grupos de usuarios de PDA, la creación de listas de discusión en línea y la celebración de charlas y conferencias. También se seleccionaban y proporcionaban recursos de interés a través de páginas web y se colocaban bases de sincronización para PDA en la biblioteca (Shipman y Morton, 2001). Estas bases de infrarrojos cumplían la función de transferir datos del ordenador a la PDA y viceversa, puesto que las primeras PDA no solían incluían conectividad a internet y dependían completamente del ordenador.

Son varias las bibliotecas de ciencias de la salud que coincidieron entonces en prestar estos mismos servicios, según recoge la bibliografía (Rios, 2004; Garrison, et al.; Stoddard, 2003). Algunas bibliotecas comenzaron también a invertir en la compra de PDAs como herramienta de productividad para el personal (Garrison, et al., 2003). Otras experiencias pioneras fueron las de las bibliotecas de las universidades de Alberta (Canadá) y Arizona o la Biblioteca del Centro Médico de la Universidad de Duke, en Estados Unidos. Esta última se interesó en 1999 por las PDA y exploró los potenciales usos para ofrecer recursos de información, según 
relatan Garrison, et al. (2003). En una entrevista llevada a cabo entre profesores, residentes y estudiantes de dicha universidad, estos autores concluyeron que el $48 \%$ de los encuestados utilizaban PDA y el 27\% planeaba adquirir una en el siguiente año, unos ratios muy altos para la época.

El acceso al catálogo fue uno de los primeros servicios en el punto de mira de las bibliotecas para ser consultados desde PDA (McCullough, 2003), y aún años después sigue siendo un reto. Las bibliotecas querían hacer sus catálogos accesibles a los usuarios de PDA, lo que les permitiría buscar desde cualquier lugar, acceder a la biblioteca sin visitarla físicamente, en cualquier momento y en tiempo real. Así, también los bibliotecarios se liberaban del mostrador y se podrían mover por cualquier parte.

El estudio de Jones, et al. (2000) pone de manifiesto el entusiasmo de los estudiantes de la Universidad de Cornell (Estados Unidos) ante el uso de la tecnología móvil en la biblioteca, especialmente en el acceso al catálogo, pero también es bien recibido el servicio de referencia a través de chat. Sin embargo, no se muestran tan dispuestos a pagar por esos servicios o ante la posibilidad de un incremento de las tasas para financiarlos. En la Universidad de Alberta (Canadá) el catálogo era también uno de los servicios más demandados (46\%), pero por detrás del acceso a bases de datos (76\%) (Carney, Koufogiannakis y Ryan, 2004).

Un original servicio que se propuso en la biblioteca de la Universidad de Cornell consistía en la digitalización de páginas de libros por parte de los usuarios para después imprimirlos o llevarlos en formato digital (Jones, et al., 2000). Otros servicios relacionados eran el desarrollo de colecciones, la catalogación de recursos para PDA (Cuddy; Koufogiannakis, Ryan y Dahl, 2005), el préstamo de PDA y de accesorios para ellos (Cuddy, 2005).

Tanto Larsson (2003) como Cuddy (2005) estudiaron las diferentes utilidades de productividad que las PDA permitían a los bibliotecarios y que recuerdan a las actuales: aplicaciones de ofimática, gestión de tareas y calendario, clientes de correo electrónico y mensajería instantánea, lectura de libros electrónicos son algunos. También empezó a surgir software dedicado a la circulación de la colección. Hay noticia de bibliotecas universitarias que utilizaban las PDA para el inventariado de la colección, haciendo uso del lector de códigos de barras. Otro uso que hacían los bibliotecarios de estos dispositivos es la recogida de datos (Cuddy, 2005).

Como se desprende de los anteriores párrafos, las bibliotecas universitarias también comenzaron a desarrollar en esta etapa iniciativas con respecto a las PDA. Según Koufogiannakis, Ryan y Dahl (2005), la realidad de los servicios que este 
tipo de bibliotecas prestan apenas queda reflejada en la bibliografía, pues es más robusta de lo que parece, pero no existen datos que lo constaten.

\subsubsection{Barreras para el uso de dispositivos móviles en bibliotecas}

Los dispositivos móviles estaban entonces muy poco extendidos en el conjunto de la sociedad si se comparan con el éxito que han alcanzado los actuales smartphones y tabletas. Este es uno de los motivos por las que las bibliotecas no dieron pasos más firmes en relación a la tecnología móvil. Y también podría ser la razón por la que la mayor parte de la bibliografía recolectada se refiere a bibliotecas en el área de ciencias de la salud y universitarias, y apenas a bibliotecas públicas.

El factor económico y la baja usabilidad pudieron ser los motivos para que estos dispositivos no llegaran a popularizarse. Se trataba de dispositivos que solo estaban al alcance de algunos bolsillos y a los que aún les faltaba mucho por mejorar. La Apple Newton y la EO 440 salieron al mercado a un precio de 700 y 2.000 dólares respectivamente en $1993^{16}$. Por otra parte, no eran fáciles de utilizar. La usabilidad era la principal barrera para el uso de estos dispositivos, según McFarland y Mussell (2006). Honeybourne, Sutton y Ward (2006) señalan las dificultades a las que se enfrentaban los propietarios de PDA, pues costaba poner a punto algunos productos para que funcionaran correctamente. Instalar el software adecuado con unas instrucciones pobres era un proceso para el que se requería mucho tiempo.

La mayoría de los primeros modelos no tenía conexión a internet y por lo tanto había que conectar el dispositivo a un ordenador para guardar los datos mediante un sistema de infrarrojos, como ya se ha explicado. Así, mediante este sistema se podían hacer búsquedas en el catálogo desde del ordenador y pasar los resultados a la PDA. Por lo tanto, este dispositivo se convertía en un complemento del ordenador (McCullough, 2003), y no era autónomo en absoluto.

Según Shipman y Morton (2001), para el personal médico, que fueron el primer grupo de usuarios al que se ofertó servicios relacionados con los dispositivos móviles en las bibliotecas, las barreras eran la seguridad en el tratamiento de los datos de los pacientes, el coste de las PDA y la confusión que producía la gran variedad de dispositivos en el mercado, cada uno con diferentes características, y la distracción que suponían, especialmente para el personal más mayor.

Por otro lado, las tareas de investigación se veían limitadas por las dificultades para acceder a los contenidos de la biblioteca desde la PDA. El formato

16 Datos procedentes de http://oldcomputers.net 
predominante ya era el pdf, y aunque existía software que permitía su lectura, la experiencia no era óptima (Deneen y Allert, 2003).

Por otra parte, apenas algunos distribuidores ofrecían versiones accesibles desde PDA de sus bases de datos, revistas científicas y libros electrónicos. Entonces los modelos de negocio no estaban aún maduros: mientras algunos distribuidores permitían el acceso a contenidos desde la PDA de forma gratuita siempre que una biblioteca se suscribía a un producto, otros obligaban al cliente a adquirir un complemento específico para PDA. Otros modelos requerían que la biblioteca suscribiera licencias específicas para estos dispositivos, en las que entraban en juego la cuestión de los límites de descargas (Koufogiannakis, Ryan y Dahl, 2005). Estos autores señalan otra opción para las bibliotecas: comprar títulos en tarjetas SD o similares de manera que pudieran tomarse en préstamo.

Los proveedores de software y contenidos para bibliotecas comenzaron entonces a desarrollar los primeros servicios para estos dispositivos. AirPac de Innovative Interfaces fue una de las primeras soluciones para los catálogos en línea. También VTLS Virtua tenía una versión XML para el acceso al OPAC (Cuddy, 2005). Incluso surgió algún sistema de circulación interna para PDA, como PocketCirc, de Sirsi, (Cuddy, 2005). Según McCullough (2003), en el que los proveedores tardaran tanto en ofrecer soluciones se debía a que aún la tecnología PDA no estaba muy extendida en la sociedad. Uno de los problemas a los que se enfrentaban los proveedores ante el desarrollo de soluciones era la falta de uniformidad de los dispositivos y que debían diseñar por lo tanto opciones que funcionaran en los principales tipos de PDA (McCullough, 2003).

Otro de los problemas surgía ante la escasez de contenidos adaptados para este tipo de dispositivos, pues muy pocos sitios web que estaban diseñados para ser vistos desde una PDA, lo que empobrecía considerablemente la experiencia de uso. Algunas bibliotecas comenzaban entonces a adaptar sus sitios web y se encuentran en esos años los primeros consejos en la bibliografía (Cao; Cuddy, 2006).

Pero esta no fue una de las preocupaciones iniciales para las bibliotecas respecto a los dispositivos móviles, sino que surgió después. En la literatura anterior a 2008, fecha del lanzamiento del iPhone, se habla de PDA y muy poco sobre el acceso a internet desde el móvil. Al buscar en las bases de datos especializadas son muy pocas las referencias a la WAP en bibliotecas que se encuentran.

\subsubsection{La movilidad como apuesta de futuro}

A pesar de que en este período se asistía a las primeras iniciativas, y teniendo en cuenta que a la tecnología móvil de esos años aún le quedaba mucho por mejorar, 
en la bibliografía se habla de la movilidad como una tendencia de futuro (Seadle, 2003). Estas esperanzas dibujaban bibliotecas en las que sería posible la descarga de contenidos a través de conexiones inalámbricas o infrarrojas, acceso a bases de datos y otros recursos electrónicos desde la PDA y consultas a través del chat que cambiarían el servicio de referencia por completo (Shipman y Morton, 2001) y verían un incremento de la comunicación con el usuario (Jones, et al., 2000). Una década después, este panorama no es aún una realidad extendida, aunque se acerca más.

Marshall, Golovchinsky y Price (2001) imaginaban una biblioteca en la que el personal pudiera independizarse del mostrador y ganara en movilidad (Cuddy, 2005) y que los dispositivos móviles facilitarían tareas internas como el inventariado (McCullough, 2003). Se esperaba poder consultar el catálogo desde cualquier lugar y en cualquier momento y la lectura de libros, artículos y otros contenidos. Para ello se necesitaban aún dispositivos más ligeros y con pantalla suficientemente grande (Marshall, Golovchinsky y Price, 2001). En este sentido, Bridges (2002) auguraba que se produciría una convergencia de varios dispositivos y que la tecnología móvil se adaptaría al estilo de vida de las personas, lo que supondría su adopción en masa, algo que posteriormente ha sucedido. Como ya se ha explicado, también los servicios que ofertaban los proveedores estaban por desarrollar (Koufogiannakis, Ryan y Dahl, 2005).

Este panorama parece coincidir exactamente con la situación actual, en la que los dispositivos y la conectividad han mejorado enormemente, haciendo la tecnología móvil ubicua y fácil de utilizar y permitiendo la sincronización de los mismos contenidos de forma automática gracias al cloud computing. Cierto es que la tecnología móvil aún está por generalizarse en las bibliotecas y que queda mucho por hacer.

\subsubsection{Los primeros años de la movilidad en España}

En esta etapa previa a la popularidad de los smartphones apenas se encuentran en la bibliografía referencias a los dispositivos móviles en las bibliotecas españolas. Las primeras referencias se encuentran en los años noventa en la revista Information World en español, - que después se convertiría en El profesional de la información-, haciendo referencia a las novedades tecnológicas en el mercado, como las PDA, pero sin relacionarlas con sus utilidades en bibliotecas (Baiget, 1993; Mahon, 1994).

Una de las primeras iniciativas de uso de la tecnología móvil en las bibliotecas españolas es la de la Universitat Oberta de Catalunya (UOC), que creó el primer catálogo móvil en 2000, por lo que se le puede considerar pionera de la movilidad 
en bibliotecas. En febrero de 2000 esta universidad también comenzó a ofrecer contenidos del campus virtual vía WAP (Serrano-Muñoz, 2001). A través de su sitio web para teléfonos móviles ofrecía la posibilidad de realizar gestiones con la secretaría, el calendario académico, información sobre centros de apoyo, buzón de correo, nuevas funciones del campus virtual y acceso al catálogo de la biblioteca, que utilizaba VTLS.

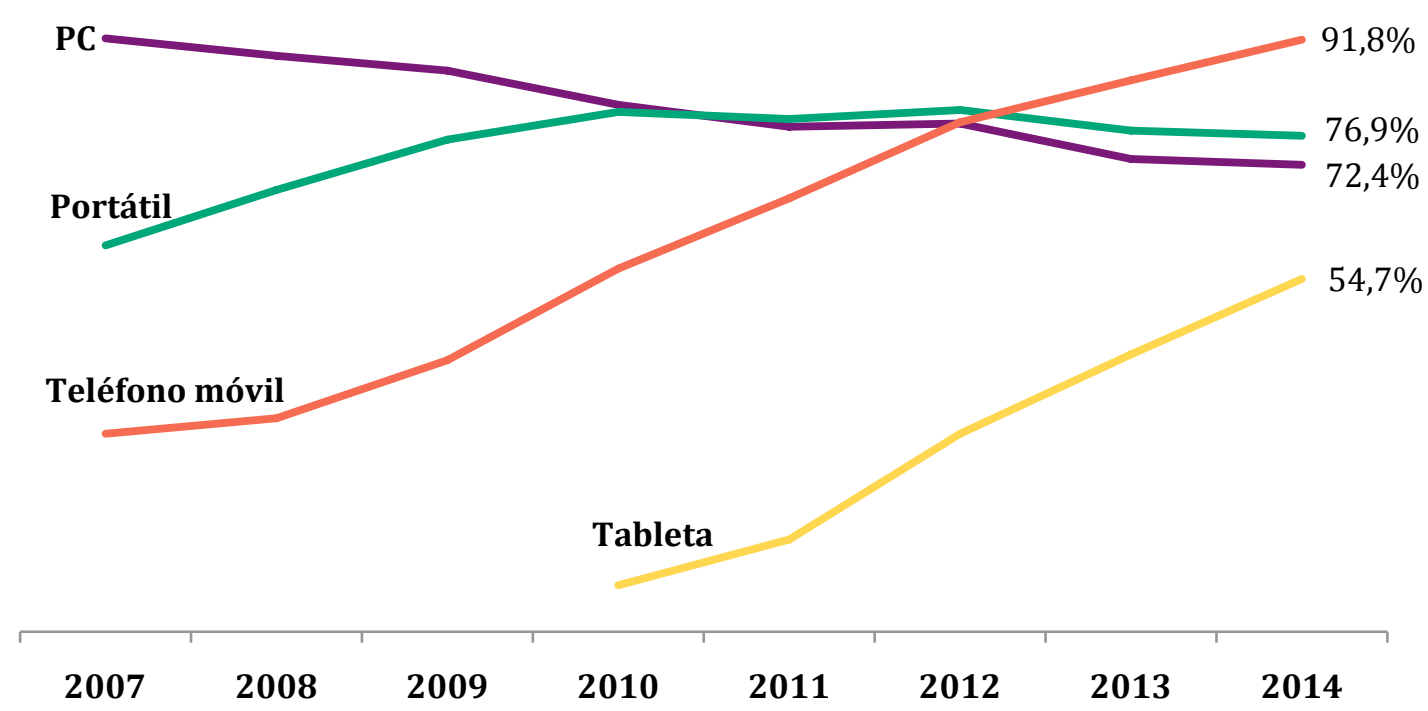

Gráfico 9. Evolución del acceso a internet desde los principales dispositivos en España, 2001-2014. Porcentaje de usuarios que acceden a internet desde diferentes dispositivos. Fuente: AIMC.

Según indica Seoane (2003), esta biblioteca siguió la estela de la Biblioteca de la Universidad de Castilla-La Mancha en cuanto al acceso al OPAC a través de WAP, aunque no se han encontrado otras referencias en la bibliografía sobre esta experiencia. También la Biblioteca Virtual Miguel de Cervantes introdujo determinados textos literarios para el móvil y se tiene noticia sobre su trabajo en información cartográfica y bases de datos territoriales, información jurídica y económica y diccionarios y enciclopedias (Universidad de Alicante, 2000).

Esta escasa apuesta por los dispositivos móviles en las bibliotecas españolas no hacía más que reflejar la poca confianza en la implantación de las PDA, sobre las cuales los expertos esperaban que comenzaran a utilizar los directivos en los próximos cinco años ( La sociedad..., 2000). El gráfico 9 muestra la enorme 
distancia entre el número de accesos a internet desde el ordenador y desde el teléfono móvil durante esos años. En el primer año sobre el que se dispone de datos, 2001, el 98,5\% de quienes consultaban internet lo hacían desde un ordenador, solo un 6,7\% lo hacían desde un teléfono móvil y el 1,7\% desde una PDA. El acceso desde PDA apenas llegó a superar el 10\% en 2007 y 2008 y luego cayeron en desuso, con la introducción de los smartphones. El teléfono móvil como vía de acceso a internet llegó al 20,3\% de los internautas en 2007 y después comenzó una amplia escalada, con la llegada de los smartphones a este segmento, hasta llegar al 91,8\% en 2014, año en que supera incluso al ordenador.

\subsubsection{Terminología}

En inglés se ha adoptado el prefijo $m$-para formar los términos $m$-libraries o $m$ librarians, que designan a las bibliotecas que ponen en marcha contenidos o servicios para los usuarios de dispositivos móviles y abarcaría por lo tanto a las diferentes tecnologías que incorporan estos dispositivos, como los códigos QR o la realidad aumentada. También se utiliza el término handheld librarian para designar a los bibliotecarios que emplean dispositivos móviles (Murphy, 2011).

Sin embargo, en español no existe ningún término comúnmente aceptado que describa este fenómeno. La tarea no es sencilla, puesto que emplear la palabra móvil, la que mejor identifica a esta tecnología, llevaría a confusión con el trabajo que desempeñan las bibliotecas móviles o bibliobuses, que llevan los servicios bibliotecarios a diferentes lugares no a través de las redes, sino sobre ruedas.

De manera un tanto informal, Arroyo-Vázquez (2013e) propuso el uso del término \#bibliomovilidad, que «define la aplicación de los dispositivos móviles y su tecnología en los servicios bibliotecarios, ya sea desde el punto de vista del usuario o del personal de la biblioteca.» Este término ha adoptado el formato de una etiqueta en Twitter en honor a su origen, pues se utiliza en este medio social para aglutinar los tuits con esa temática. En Facebook existe también un grupo con ese nombre ${ }^{17}$. Sin embargo, el uso de este término ha tenido poca difusión hasta el momento.

${ }^{17}$ http://www.facebook.com/groups/bibliomovilidad 


\subsubsection{La movilidad como tendencia}

El uso de dispositivos móviles en bibliotecas y otros aspectos relacionados con ellos ha sido considerado tendencia durante mucho tiempo. Ya en enero de 2003 un grupo de expertos de la Library and Information Technology Association (LITA), división de la American Library Association (ALA), señalaba como tendencia tecnológica las PDA y la portabilidad de los datos (LITA, 2003a). Ese mismo año, en el mes de junio, se volvía a identificar a los dispositivos móviles como tendencia en la Conferencia Anual de la ALA. Le acompañaban otros siete temas: la muerte del formato MARC, el cambio en las infraestructuras de banda ancha, sistemas integrados de bibliotecas en línea, filtros anti spam, seguridad, los blogs y las metabúsquedas o búsquedas federadas (LITA, 2003b).

Los Horizon Report, que identifican cada año las tendencias educativas, tienen a la movilidad en el punto de mira desde hace tiempo. En 2006 ya se hablaba de los teléfonos móviles como tendencia a medio plazo (dos o tres años). Entonces la popularidad que habían alcanzado estos dispositivos y el despliegue inicial de las redes 3G llevaban a considerarla una tecnología prometedora. Desde entonces, estos informes han destacado siempre algún aspecto relacionado con la movilidad: en 2007 fueron los teléfonos móviles y en 2008 la banda ancha móvil -la mejora de las interfaces y la visualización hacían pensar en el uso de internet desde el móvil- En la edición de 2009 se mencionaban las capacidades de información y las aplicaciones de la tienda de Apple, con el iPhone y los Android recién estrenados, y pasaban a tendencia a corto plazo (Johnson, Levine y Smith, 2009). En 2010 se incluyen en primera línea por la gran cantidad de actividades que se podían realizar desde ellos y en 2011 porque cada vez más gente los utiliza como primera opción para acceder a recursos en línea (Johnson, et al., 2011). En 2012 las aplicaciones para móviles y las tabletas emergían en primer lugar en educación superior (Johnson, Adams y Cummings, 2012) y en 2013 se ponía el énfasis en las tabletas una vez más (Johnson, et al., 2013).

A pesar de tantos años de trayectoria, la movilidad sigue siendo tendencia de una manera u otra: el informe de tendencias de la IFLA (2013), aunque no señala a la movilidad de forma directa, menciona el uso de dispositivos móviles varias veces: en relación con la privacidad, con la educación y los MOOC - a los que señala como facilitados por la tecnología móvil-, como principal medio de acceso a los contenidos.

En 2014 parece que los contenidos toman el protagonismo frente a los dispositivos, que habían acaparado la atención hasta ahora. Así, el ACRL Research Planning and Review Committee (ACRL, 2014) señala la importancia de los servicios digitales independientes del dispositivo en las bibliotecas académicas y 
apunta al diseño web adaptativo como una solución cada vez más popular. Coincide con la edición especial para bibliotecas de los Horizon Report en 2014 (Johnson, et al., 2014) sobre la necesidad de abogar por servicios adaptados a dispositivos móviles ante los proveedores. Este informe se centra en la necesidad de poder acceder desde el móvil a la variedad de contenidos que las bibliotecas ofrecen y señala a las apps como tecnología a desarrollar en el próximo año o dos. En esta misma línea, David Lee King pone en el punto de mira a la filosofía Mobile first en 2014 (LITA, 2014).

En España los profesionales coinciden en señalar la movilidad como una de las líneas de trabajo para las bibliotecas en los próximos años. El informe Prospectiva 2020 (Gallo León, 2013), del Grupo estratégico para el estudio de prospectiva sobre la biblioteca en el nuevo entorno informacional y social, prevé el desarrollo de servicios para dispositivos móviles en las bibliotecas en los próximos años y que «las bibliotecas adaptarán sus contenidos para ser usados desde todo tipo de dispositivos portátiles y móviles.» Por otra parte, se augura que la biblioteca dejará de invertir en equipamiento informático y se optará por fomentar el uso de los dispositivos de los usuarios en las bibliotecas. Este trabajo considera a los servicios a través de dispositivos móviles como servicios de futuro. También se entiende la movilidad como una oportunidad, ya que la conexión permanente favorece el uso de los servicios (Merlo-Vega, Gómez-Hernández y Hernández-Sánchez, 2011).

\subsubsection{Por qué utilizar dispositivos móviles en bibliotecas}

Cuando se introduce una nueva tecnología, los bibliotecarios buscan razones para abrazarla o rechazarla. Son muchos los textos sobre iniciativas relacionadas con el uso de dispositivos móviles en bibliotecas que comienzan exponiendo el creciente uso de smartphones y tabletas entre los ciudadanos, lo que lleva a pensar que el principal motivo de estas iniciativas es una respuesta a la expansión de una nueva tecnología en la sociedad.

Ante la evidencia de los datos, los bibliotecarios tienen la sensación de que los cambios tecnológicos deben reflejarse en los servicios bibliotecarios (Hahn, 2011) y se instala la idea de que los usuarios esperan que la biblioteca ofrezca servicios relacionados (Wong, 2013). También hay quienes asumen los dispositivos móviles como una apuesta de futuro (Kroski, 2008; Murphy, 2011). Con la vista puesta en el futuro, Jacobs (2009) se pregunta qué pasaría si las bibliotecas no se adaptaran a los dispositivos móviles. Se observa en los últimos años una especial preocupación por el futuro de las bibliotecas debido precisamente a los cambios que están 
afectando a las tecnologías de la información, entre las que se encuentran los dispositivos móviles (Gallo León, 2013).

Smartphones y tabletas se asocian especialmente con los más jóvenes, y esto tiene su fundamento, porque existe una estrecha relación entre la edad y la posesión de dispositivos móviles entre los ciudadanos. Así, la tecnología móvil se considera una oportunidad para atraer a los más jóvenes (Balas, 2007; Barnes y Brammer, 2014; Hu y Meier, 2010).

La accesibilidad de la biblioteca, abierta las 24 horas del día y los 7 días de la semana, es otra de las razones que se esgrimen a favor de los dispositivos móviles. El usuario lleva el smartphone siempre consigo y puede acceder a los contenidos y servicios de la biblioteca sin necesidad de que estén abiertas sus puertas (Choy, 2011; West, 2009). Pero también haría más accesibles a los bibliotecarios, que podrían moverse por diferentes zonas de la biblioteca y seguir atendiendo a los usuarios (Spires, 2008). El uso de PDA por los usuarios dentro de la biblioteca reduciría las colas de acceso al catálogo (Foster, 1995) y determinados servicios liberarían al bibliotecario de referencia de consultas más rutinarias. La accesibilidad también se refiere al usuario: una de las ventajas es que los discapacitados visuales pueden interactuar con el móvil por voz y aumentar el tamaño de las fuentes (West, 2009).

Arroyo-Vázquez (2013b) destaca la vertiente de los dispositivos móviles como tecnologías de la información y que, por lo tanto, conciernen plenamente a las bibliotecas, puesto que forman parte de sus funciones. Las bibliotecas, sin duda, deben conocer las tecnologías de la información del siglo XXI como conocen el libro impreso.

Inevitablemente también hay quienes esperan que las apps o los códigos QR proporcionen a la biblioteca una imagen de modernidad. Sin embargo, este no puede ser un fin en sí mismo, sino una consecuencia lógica derivada de la puesta en marcha de servicios útiles para los usuarios, que les faciliten sus tareas y se adapten a sus nuevos hábitos de lectura y de consumo de información.

Aunque no es un tema apenas tratado, en la bibliografía se constata la existencia de una parte de los profesionales que no cree que los dispositivos móviles sean de utilidad (Spires, 2008), quizás por desconocimiento de su funcionamiento y de sus posibles aplicaciones. 


\subsubsection{Los retos de la movilidad para las bibliotecas}

Las expectativas que despierta la tecnología móvil también traen consigo retos y cuestiones por resolver. El primero de ellos consiste en entender el funcionamiento de los dispositivos móviles y sus elementos diferenciales y en descubrir los posibles usos que se pueden dar a sus funciones. Esto supone ejercitar la imaginación y pensar cómo aprovechar la tecnología móvil. Se trata de integrar las nuevas tecnologías con los servicios tradicionales (Hahn, 2011), buscando la forma de mejorarlos, pero también descubriendo otros nuevos.

Resulta fundamental conocer las expectativas e intereses del usuario y su evolución en el tiempo para ofertar servicios de utilidad. Para Lippincott (2010) el reto de las bibliotecas académicas está en crear servicios de información irresistibles y hacer el contenido digital disponible, de manera que los usuarios no solo los encuentren aceptables, sino también ajustados a sus necesidades. En la bibliografía se pueden encontrar varios estudios que tienen este objetivo, conocer las expectativas de los usuarios respecto a los servicios de la biblioteca; sobre ellos se hablará más adelante. Sin embargo, se encuentran muy pocos ejemplos en la bibliografía de bibliotecas españolas que investigan los intereses del usuario.

Cuando se pone en marcha algún servicio enfocado a la Now Generation -aquellos que buscan información y la quieren en el momento- hay que tener en cuenta tres elementos clave, según Jacobs (2009): debe ser fácil, formar parte de una tecnología ubicua y ser relevante. Esto obliga a anticiparse a las necesidades del usuario, algo que resulta prácticamente imposible cuando no se está familiarizado con la tecnología en cuestión.

Parece evidente que se necesita contar con profesionales formados, capaces de entender las implicaciones de la tecnología móvil en el consumo de la información y de apropiarse de ella. Pero también en ocasiones será necesario contar con otras personas que tengan conocimientos especializados, como ingenieros informáticos, expone Hahn (2011). Esto supondrá buscar formas de colaboración o la integración de estos profesionales a las plantillas en las bibliotecas.

Ofrecer contenidos en formatos no solo legibles por móviles, sino que además se lean cómodamente, es uno de los retos a los que se enfrentan las bibliotecas. Los contenidos actuales se encuentran en formatos pensados para las grandes pantallas y queda mucho trabajo por hacer en cuanto a la adaptación al nuevo medio. Aquí entran en juego agentes externos, como los servicios de proveedores, y las bibliotecas no tienen el control sobre los formatos, que siguen muy ligados al papel y a las grandes pantallas.

La privacidad es uno de los asuntos más espinosos de los dispositivos móviles. Se han conocido varios casos en que las aplicaciones recogen datos sobre el uso que 
se hace de ellas, incluso datos personales como la localización, el número de teléfono o la agenda de contactos, y los transmiten a la empresa creadora y a terceros, como puso de manifiesto un estudio realizado por The Wall Street Journal ${ }^{18}$. Se ha sabido que el lector de pdf Adobe Digital Editions recoge información sobre la actividad del usuario - qué libros electrónicos se abren, qué páginas se leen y en qué orden- y se envían a sus servidores (Hoffelder, 2014). Este lector es recomendado por las bibliotecas, pues permite gestionar libros con DRM. La seguridad de las comunicaciones con el usuario a través de sistemas como el correo electrónico, el SMS, Facebook o WhatsApp también puede verse comprometida, advierte Vollmer (2010).

La localización es uno de los datos más susceptibles para la privacidad y la seguridad. Combinada con los medios sociales, en los que se comparte en ocasiones el lugar en que nos encontramos a través de smartphones y tabletas, se convierte en información que puede poner en posición vulnerable al usuario, como denunciaron Barry Borsboom, Boy van Amstel y Frank Groeneveld a través del sitio web Please rob me ${ }^{19}$.

Las bibliotecas siempre han garantizado al usuario que no se revelarán sus registros de uso y deben exigir también a sus proveedores digitales la certeza de que los datos de los usuarios no son utilizados. Sin embargo, no resulta sencillo saber si una app o un dispositivo recoge datos o no, pues aún no existe información suficiente. En cualquier caso, las bibliotecas debe intentar proteger la privacidad del usuario también en el entorno digital, evitar recomendar aplicaciones con vulnerabilidades conocidas y advertir sobre los peligros de la seguridad en los dispositivos móviles.

Las bibliotecas se enfrentan, por lo tanto, al reto de ser conscientes sobre los peligros para la privacidad y de integrar esta cuestión como elemento fundamental en sus políticas, garantizando que no se vulneren los derechos de los ciudadanos. Esto conlleva la necesidad de recopilar información sobre el tratamiento de la privacidad en diferentes dispositivos y apps y mantenerla actualizada, teniendo en cuenta que la tecnología cambia constantemente. Cyrus y Bagget (2012) señalan cuatro áreas que los bibliotecarios deben monitorizar: tendencias en tecnología móvil, la evolución en el uso de la tecnología, la legislación que concierne a la privacidad, la recogida de datos por parte de las corporaciones y las políticas de seguridad.

Por otra parte, es muy necesario que la sociedad sea consciente de los problemas

\footnotetext{
${ }^{18}$ http://blogs.wsj.com/wtk-mobile/

${ }^{19} \mathrm{http://pleaserobme.com}$
} 
que los dispositivos móviles presentan en lo relacionado con la privacidad, un tema que puede ser objeto de actividades formativas, en el marco de los programas de alfabetización informacional, sobre las precauciones a tener en cuenta. Cyrus y Baggett (2012) proponen además que las bibliotecas oferten servicios relacionados con la privacidad, como por ejemplo ofrecerse a cambiar los ajustes de privacidad en el móvil. Estos autores señalan además el reto para los bibliotecarios de convertirse en agentes sociales a favor de la privacidad en diferentes ámbitos.

Finalmente, el último reto para las bibliotecas está en situarse al mismo ritmo de la tecnología. Cada año aparecen nuevos dispositivos, nuevas funciones, nuevas apps y recursos, por lo que estar al día requiere una cierta dedicación. No es fácil, opina Jacobs (2009), porque es complejo conocer qué tecnologías van a triunfar y cuáles no.

\subsubsection{Barreras para el uso de la tecnología móvil}

Se identifican en este apartado los tipos de barreras que encuentran los usuarios y el propio personal de la biblioteca para el uso de dispositivos móviles. Conocer las barreras significa identificar las áreas de mejora que se pueden introducir y en las que trabajar, pero también conocer qué uso se hace de la tecnología para así orientar de forma más precisa los servicios ofertados por la biblioteca.

\subsubsection{Barreras para los usuarios}

Como se explicó en el apartado 2.1.1.2, en los primeros años de la tecnología móvil la principal barrera para el uso estaba en su alto coste, que impedía su popularidad, y en que aún necesitaba mejoras, pero también en la conectividad y la baja usabilidad. Con el tiempo los dispositivos móviles han mejorado significativamente, haciéndose más potentes, y sus diseños de interfaces son más sencillos de utilizar. La facilidad de uso es un importante factor a tener en cuenta, pues influye significativamente en la intención de utilizar la tecnología móvil (Aharony, 2013).

Sin embargo, en los siguientes años tras el lanzamiento del iPhone los usuarios de bibliotecas siguen indicando los costes de la conectividad como razones para no conectarse. En estos años la disponibilidad de teléfonos móviles y smartphones con acceso a internet creció de forma importante, pero los altos costes de las conexiones hacían que reservaran su uso para ocasiones que merecieran realmente la pena (Walsh, 2010b). En palabras de Hu y Meier (2011), que los 
usuarios tengan dispositivos móviles no significa que vayan a utilizar los recursos académicos. Por eso Wilson y McCarthy (2010) destacan que el acceso a internet vía WiFi es un servicio muy valorado por los usuarios de la biblioteca. El factor conectividad ha ido mejorando con el tiempo y si se preguntara hoy a los estudiantes, seguramente no lo percibirían como una barrera: el $3 G$ se ha extendido y las tarifas planas de datos lo hacen muy asequible. Por otra parte, la conectividad WiFi está muy extendida en hogares y lugares públicos.

Las pequeñas pantallas de los smartphones son otra de las barreras que indican los usuarios de forma recurrente (The M-Library Project..., 2011). En ellas no se hace fácil leer ni realizar anotaciones (Patterson y Low, 2011) y tampoco introducir contraseñas (The M-Library Project..., 2011), especialmente en el acceso a las bases de datos comerciales, que requieren sistemas complejos de autenticación que en ocasiones pasan por configurar previamente el navegador. En la actualidad, éste sigue siendo uno de los principales escollos en el acceso a las bases de datos científicas desde smartphones y tabletas, y debido a que las sesiones expiran pronto, los navegadores no recuerdan los datos de acceso.

Las pantallas de los smartphones dejan de ser un problema cuando el diseño, el contenido y los formatos están optimizados. El pdf constituye una barrera para la lectura de libros y artículos, pero también las páginas web no adaptadas. El estudio de Hu y Meier revela que una parte de los usuarios consideran que los smartphones no son aptos para determinadas tareas, como la investigación, por ser una tarea compleja, pero sí los utilizarían para consultar bases de datos, el catálogo y otros recursos. Y hay una pequeña parte que los emplea para leer libros electrónicos y artículos (The M-Library Project..., 2011).

El desconocimiento de los servicios para dispositivos móviles puestos en marcha por la biblioteca es otra de las barreras para que los usuarios los utilicen. Tras una encuesta a los estudiantes de la Ryerson University (Canadá), Wilson y McCarthy (2010) descubrieron que el 60\% no conocía los servicios móviles que ofrecía la biblioteca. Resultados menos esperanzadores reportan Hegarty y Wusteman (2011), quienes revelaron que, de los estudiantes de la Dublin Business School que participaron en un estudio de usabilidad, ninguno sabía que el acceso a la base de datos EBSCOhost estaba entre los servicios ofertados por la biblioteca. Por otra parte, es posible que se mantenga un porcentaje de población que no ve a los smartphones como dispositivos de acceso a la información, sino como teléfonos para hacer llamadas y enviar SMS (Mills, 2009). 


\subsubsection{Barreras para el personal bibliotecario}

El personal bibliotecario también encuentra ciertas barreras en la implementación de iniciativas relacionadas con el uso de dispositivos móviles. Escasez de presupuestos, las habilidades del personal, una cuestión de prioridades y la percepción de no ser necesarios fueron identificados como los principales motivos por los que algunas bibliotecas en Estados Unidos no han puesto en marcha ninguna iniciativa relacionada con los dispositivos móviles (Thomas, 2010). Cierto es que bibliotecas de diferentes países se han tenido que enfrentar en los últimos años a los recortes presupuestarios y de personal, lo que reduce el tiempo de trabajo. ¿Cómo enfrentarse a la revolución móvil en esas condiciones?, se pregunta Jacobs (2009). Quizás la forma de hacerlo sea establecer prioridades en los proyectos a emprender.

Cierta similitud guardan los resultados de un estudio realizado por la Universidad de Birmingham (Reino Unido) a bibliotecarios de todo el mundo entre noviembre de 2011 y enero de 2012, en el marco del proyecto M-Library Community Support Project (Alcock y Dalton; Dalton, et al., 2012), que reveló algunas de las principales dificultades. La mitad de los bibliotecarios señalaban como principal dificultad la falta de soporte técnico (52\%) y cuatro de cada diez el desconocimiento (41\%). Para algunas bibliotecas la movilidad no es una prioridad institucional (29\%) y hay quienes no están convencidas de que a los usuarios les pueda interesar (20\%). Finalmente, el coste (16\%), la falta de recursos (9\%) y las licencias (22\%) son otros motivos.

Son varios los trabajos que ponen de manifiesto que el coste de la implementación de los servicios móviles es una cuestión de percepción. Cierto es que determinados servicios pueden suponer una importante inversión para la biblioteca, especialmente si se externalizan, pero también es verdad que existen soluciones que no requieren apenas coste económico y que son sencillas de poner en marcha por el personal de la biblioteca. Murray (2011) compara el coste de varios servicios para crear sitios web para móviles y sus funciones. Travis (2011) propone un punto de vista edupunk en la puesta en práctica de servicios móviles, lo que implica hacer las cosas por uno mismo - la filosofía Do It Yourself- y recomienda varias soluciones sin coste alguno. Abarca Villoldo, et al. (2012) explican su experiencia en la creación de un sitio web a bajo coste.

Servicios como Mobincube, Nimbo o App Inventor reducen considerablemente el coste de crear una app (Carnerero y Bages, 2012). También existen servicios, como Ubik o el gestor de contenidos Joomla, para crear sitios web para móviles. Los códigos QR son realmente baratos de implementar y también existen aplicaciones de realidad aumentada gratuitas. La cosa se complica cuando se trata del catálogo, pero algunas bibliotecas han sido capaces de desarrollar sus propias interfaces, 
aunque para ello es necesario contar con personal especializado. Una solución barata para contar con personal especializado reduciendo coste es buscar la colaboración de alumnos de áreas como ingeniería del software. Es lo que proponen Connolly, Cosgrave y Krkoska (2011), quienes relatan la experiencia de la Biblioteca de la Cornell University (Estados Unidos) en el desarrollo de una app. Sin embargo, hay que contar con el inconveniente de que esta opción no asegura posteriormente el mantenimiento.

Reducir el coste implica en la mayor parte de las ocasiones que es el personal de la propia biblioteca quien debe encargarse de poner en marcha estos servicios, para lo cual es necesario que adquiera previamente unas habilidades básicas. Aquí entra en juego la formación, que implica unas limitaciones en función de los conocimientos previos del personal. Es decir, a alguien sin conocimientos de programación le resultaría muy costoso aprender a programar, pero sí para crear un sitio web con Ubik, un servicio web gratuito. Contar con personal amateur tiene el inconveniente de que los resultados pueden ser menos profesionales: cuando se contrata a una empresa para crear una app, por ejemplo, se cuenta con una experiencia previa sobre lo que funciona bien y lo que funciona mal. Por otra parte, estas empresas no solo se encargan de programar, sino que tienen en plantilla a especialistas en aspectos tan importantes en el resultado final como el diseño o usabilidad.

El ruido que producen los teléfonos móviles y los smartphones les han granjeado mala fama para los bibliotecarios y hay quienes los consideran una molestia en lugar de un dispositivo de lectura y acceso a la información (Ramos, 2011). Esta idea también se ha instalado entre los propios usuarios, algunos de los cuales buscan espacios de estudio en la biblioteca (Cummings, Merrill y Borrelli, 2010). Por eso las bibliotecas comenzaron a prohibir el uso del teléfono móvil en sus instalaciones. Sin embargo, teniendo en cuenta que se trata de dispositivos de lectura y acceso a la información, quizás bastaría con solicitar a los usuarios que restrinjan el sonido o que se reduzca su uso a determinadas zonas de la biblioteca, como propone Knecht (2003). Son varios los autores que defienden esta idea (Grupo Web Móvil UPV, 2012; Arroyo-Vázquez, 2012d).

\subsubsection{Uso de los servicios de la biblioteca desde el móvil}

El uso de la tecnología móvil hace que los usuarios de biblioteca esperen servicios similares basados en ella. Esta frase fue aplicada por Joe Murphy (2012) a Foursquare, pero bien podría extrapolarse al conjunto de la tecnología móvil. La movilidad es tendencia pero, ¿qué hay de su uso? No es sencillo conocer en qué 
medida utilizan los usuarios de dispositivos móviles los recursos de la biblioteca si no es teniendo acceso a los datos de uso, y estos suelen quedar en el ámbito privado. Se repasan en los siguientes párrafos algunos datos compartidos por bibliotecas de todo el mundo que, a modo de instantáneas, dan idea de un momento determinado en una biblioteca concreta. Al analizar estos datos hay que tener la precaución de evitar su comparación, puesto que se refieren a bibliotecas y momentos diferentes.

A partir de la bibliografía sí se puede afirmar que el número de accesos desde dispositivos móviles a los sitios web de la biblioteca ha ido en aumento, en consonancia con el mayor uso de dispositivos móviles, aunque aún representa un pequeño porcentaje. En los años posteriores a la aparición del iPhone y con la explosión de los smartphones y las tabletas, las bibliotecas registran un enorme crecimiento en los accesos a su sitio web desde dispositivos móviles. La biblioteca de la Cornell University (Estados Unidos) registró un incremento del 75\% en los accesos desde dispositivos móviles a la web de la biblioteca entre septiembre de 2008 y febrero de 2009. Si en el primer mes se contabilizaron 138 visitas desde un iPhone o iPod y 3 desde otros dispositivos, en el último se alcanzaron 5.844 desde esos mismos dispositivos y 4.676 más desde otros (Connolly, Cosgrave y Krkoska, 2011). Si bien estos datos muestran un crecimiento en el número de accesos, se desconoce qué porcentaje suponen con respecto al total de visitas. Por otro lado, esta tendencia al alza parece lógica en los primeros años de la expansión de los smartphones.

Menos del 1\% de visitas a la versión no móvil de la página principal de la biblioteca de la Ryerson University (Canadá) y al catálogo procedían desde dispositivos móviles en 2010. Pero las visitas al catálogo se duplicaron entre el otoño de 2008 y el de 2009. La página del servicio de reserva de salas de estudio, que tenía interfaz móvil, alcanzó un porcentaje del 5\%, según recogen Wilson y McCarthy (2010).

En 2010 el tráfico desde dispositivos móviles a la web de la biblioteca de la Grand Valley State University (Estados Unidos) era del 0,5\% y 18 meses más tarde era casi diez veces mayor: las visitas en los seis primeros meses de 2013 supusieron el $4,95 \%$ del total, lo que significa que uno de cada 20 visitantes accedió desde un dispositivo móvil (Reidsma, 2013).

La biblioteca del Hunter College, en Nueva York (Estados Unidos) recibió un 2,43\% de visitas procedentes de dispositivos móviles (un total de 11.116) entre el 1 de septiembre de 2011 y el 1 de enero de 2012. Un año más tarde, en ese mismo período, recibió un 4,78\% (22.185 visitas). En ese intervalo se incrementó además el número de páginas vistas por cada visita desde 2,56 a 2,67. Mayor fue aún el crecimiento de uso desde tabletas, que pasó de 2.961 entradas únicas en el primer período a 9.795 entradas en el segundo (Becker, Bonadie-Joseph y Cain, 2013). 
Los hábitos pueden variar enormemente entre unas regiones y otras del mundo. Así, la Biblioteca Pública de Hangzhou (China) observó también un importante aumento en las visitas desde dispositivos móviles entre 2011 y 2012, de 3.000 a 13.000 , lo que supone un $1,1 \%$ y un $4,1 \%$ del total en ambos períodos. Curiosamente esta biblioteca lanzó un servicio de acceso a los contenidos a través de la televisión por cable, ya que son más los ciudadanos con televisión por cable (93\%) que los que tienen ordenador en su hogar (63\%). El lanzamiento de estas plataformas implicó un importante incremento del uso del sitio web de la biblioteca, desde 344.900 visitas en 2009 a 1.197 .814 en 2011 (Clarke, Hui y Li, 2013).

Una encuesta realizada por Pew Internet en 2012 revelaba que el 13\% de los estadounidenses de 16 años o más habían accedido al sitio web de la biblioteca desde un móvil en alguna ocasión (Rainie, Zickuhr y Duggan, 2012). Un estudio anterior, realizado en 2009 por investigadores de la Universidad de Washington, halló que entonces el ratio era del 6\%, lo que implicaría que la proporción está creciendo, como es de esperar. El porcentaje de ciudadanos que accedía al sitio web de la biblioteca desde cualquier dispositivo en 2012 era del 39\% y una cuarta parte de la población lo hacía con cierta frecuencia.

En España apenas se dispone de datos de uso de los sitios web de las bibliotecas. Aunque la Subdirección General de Coordinación Bibliotecaria del Ministerio de Educación, Cultura y Deporte y la Red de Bibliotecas Universitarias (REBIUN) recogen datos estadísticos sobre el número de visitas a la web de la biblioteca, solo se dan datos totales. Nieves González (2013) presentó en abril de 2013 algunos datos sobre el porcentaje de accesos desde dispositivos móviles a los sitios web de once bibliotecas universitarias españolas cuyo nombre no se detalla, y que situó en una media del 5,47\%. Un año antes, en abril de 2012, ese porcentaje era del 3,26\%, por lo que el crecimiento en ese período ha sido del 67,8\%.

Bridges y Rempel (2014) dan datos de uso de la web que se pueden comparar con los publicados un año antes. La evolución muestra un incremento del tráfico hasta el 15\% desde smartphones y tabletas: los móviles suben un 43\%, mientras que las tabletas descienden un 19\%. El informe del Primary Research Group (2014b), en el que entrevista a unas sesenta bibliotecas públicas y universitarias, establece en el $14,5 \%$ el porcentaje medio de visitas desde dispositivos móviles a la web de la biblioteca, en un rango entre 0,5\% y 60\%, según ese informe. Las bibliotecas públicas $(17,7 \%)$ tienen un porcentaje ligeramente más alto que las especializadas $(16,9 \%)$ y significativamente mayor que las académicas, que se dividen en este estudio en niveles college (10,1\%) y de investigación (9,7\%).

De todo esto surge una cuestión: ¿por qué no se obtienen más visitas desde dispositivos móviles a los sitios web de las bibliotecas? ¿Tiene que ver con la 
biblioteca o sucede también en otros tipos de sitios web? ¿Se puede atraer un mayor tráfico? Los datos publicados por Clarke, Hui y Li (2013) llevan a plantear si la creación de una versión móvil de la web de la biblioteca produciría un incremento en las visitas desde dispositivos móviles.

Si poco se sabe sobre el uso de los sitios web desde el móvil, menos se sabe aún sobre el uso de las apps, cuyos datos quedan igualmente para uso interno. Johnstone (2011) comparte estadísticas del número de usuarios por tipo de dispositivo de la aplicación de la Bucks County Community College Library (Estados Unidos), creada con Boopsie, en marzo de 2011. Fueron 114 en total: el 38,6\% de iPhone, el 28,1\% de Android y el 22,8\% de BlackBerry. También dan datos de interrogaciones al catálogo: la mayor parte procedían de Android, seguido muy de cerca de iPhone.

McCarthy y Wilson (2011) reportan un mayor éxito de la versión para iPhone de la app de la biblioteca de la Ryerson University: entre octubre de 2010 y marzo de 2011 se descargó 4.180 veces desde la Apple Store. En un período similar, entre agosto de 2010 y marzo de 2011, se obtuvieron 343 descargas desde Android Market. Es difícil valorar estos datos cuando no se pueden comparar con otros ni contextualizar, pero cabe pensar que actualmente la tendencia está a favor de Android, teniendo en cuenta los datos del gráfico 8 (apartado 1.1.5), en los que queda claro que este es el sistema operativo más extendido a nivel global.

No es muy diferente el número de descargas de la app EconBiz, de la German National Library of Economics (Leibniz Information Centre for Economics, en Alemania) para la consulta en el catálogo, que son un total de 3.500 (Pianos, 2012), aunque no se especifica de forma exacta el intervalo de tiempo, tan solo desde su creación en marzo de 2011. Según señala esta autora, un estudio realizado por Pohla (2011) reporta entre 500 y 1.000 descargas durante las tres o cuatro primeras semanas para una selección de apps en bibliotecas. Pulgar y ManiegaLegarda (2014) reportan datos detallados sobre la app Liburutegiak durante su primer trimestre de vida: 1.007 usuarios únicos, 7.244 sesiones y 34.363 pantallas.

Diferentes estudios muestran que los usuarios son receptivos ante la creación de servicios para dispositivos móviles en las bibliotecas. Ya en 2006 los estudiantes de la International Islamic University (Malasia) se mostraban abiertos ante esa posibilidad, incluso aunque eran pocos quienes tenían acceso a internet desde el móvil (Karim, Darus y Hussin, 2006). También en las universidades inglesas de Edimburgo y Huddersfield los estudiantes están a favor de los servicios a través de dispositivos móviles (Paterson y Low; Walsh 2011). Sin embargo, la mitad de los estudiantes no intentaba acceder a la web de la biblioteca desde el móvil, aunque eran muchos quienes disponían de acceso a internet. Recordemos las palabras de $\mathrm{Hu}$ y Meier (2011) expuestas en el apartado 2.1.6.1: que los usuarios tengan 
dispositivos móviles no significa que vayan a utilizar los recursos académicos.

La predisposición a utilizar la tecnología móvil para acceder a los servicios de la biblioteca parece aumentar con los avances tecnológicos. En una encuesta realizada a los estudiantes de la Utah State University (Estados Unidos), el 70,2\% respondió que utilizaría los recursos de la biblioteca desde un smartphone y el 46,9\% desde un iPad, el 45,9\% desde un lector de libros electrónicos y el 63,2\% desde otros dispositivos. Se observa mucha diferencia entre el iPad y el smartphone, probablemente porque son pocos los que tienen una tableta (Dresselhaus y Shrode, 2012). Esto supone un avance con respecto a anteriores estudios, en los que el porcentaje era menor: por ejemplo, en la Washington State University Libraries (Estados Unidos), el 45,2\% de los estudiantes accederían al catálogo desde el móvil, independientemente de si poseían o no un dispositivo (Cummings, Merrill y Borrelli, 2010). Esta receptividad se debe a las ventajas que perciben, como poder acceder a la web de la biblioteca desde cualquier lugar y en cualquier momento, la multitarea o poder acceder mientras viajan (M-Library Project..., 2011). Y quizás también al atractivo de los smartphones (Hegarty y Wusteman, 2011).

Chang (2013) estudió los factores que influían en el uso de las apps de la biblioteca entre los estudiantes de las bibliotecas taiwanesas y descubrió que la percepción de que la app les ayudaría a desempeñar sus tareas era el factor más influyente en la intención de uso, seguido de la esperanza de esfuerzo, mientras que la influencia social (las recomendaciones de los contactos) no era tan relevante. Así, Chang recomienda que las bibliotecas se esfuercen en crear apps fáciles de usar y descargar.

En España poco se conoce sobre las expectativas de uso de los servicios móviles de la biblioteca. La encuesta realizada a los usuarios de las bibliotecas del País Vasco (Hernández Sánchez, 2014) revela que estos opinan que el préstamo de libros electrónicos y otros dispositivos móviles les ayudaría a hacer uso de los servicios de la biblioteca. Se concede gran importancia a la adaptación de los servicios virtuales para dispositivos móviles, algo que califican con un 7,1 sobre 10 . Es el cuarto servicio mejor valorado, después de la gestión de trámites a los usuarios, digitalizar y preservar la cultura vasca y formar en el uso de información. Incluso por encima de estar presentes en los medios sociales $(6,5)$. Los bibliotecarios consultados en este estudio también coincidieron en que hay que prestar servicios a través de dispositivos móviles. Entre los objetivos generales y específicos para las bibliotecas del País Vasco en el futuro, señalado por un panel de expertos en el marco del citado trabajo, están potenciar los servicios para la web móvil 8,6 - es uno de los más puntuados, el mejor en el apartado de tecnología- e incorporar dispositivos móviles como herramienta de trabajo $(8,2)$. 


\subsubsection{Uso de la tecnología móvil por los bibliotecarios}

Para prestar servicios adecuados, los bibliotecarios necesitan conocer la tecnología móvil de primera mano. Houghton (2012) aconseja que el personal bibliotecario conozca el uso de los dispositivos móviles: hay que enseñarles cómo se utilizan, comprar dispositivos para que los prueben, asegurarse de que puedan acceder desde el móvil al correo electrónico y al calendario y animarles a utilizar dispositivos móviles para realizar su trabajo cuando les sea posible.

Sobre las competencias y habilidades que los bibliotecarios necesitan adquirir para atender las necesidades de los usuarios de dispositivos móviles se ha escrito poco. Maloney y West (2012) definen una serie de competencias que el bibliotecario de referencia debería tener en el uso del iPad. Saravani y Haddow (2012) realizan un estudio en el que bibliotecarios de Australia y Nueva Zelanda identifican cuarenta tipos de habilidades y conocimientos. Las cinco categorías más citadas, y que constituyen aspectos muy generales, son: disponer de un dispositivo móvil en su puesto de trabajo para conocer su funcionamiento, el deseo de probar nuevas tecnologías, conocer el uso que los estudiantes hacen de la tecnología móvil y sus expectativas, habilidades para prestar servicios y el conocimiento para reconocer las oportunidades.

En cuanto a cuestiones más prácticas, emergen 39 categorías, de las cuales las más importantes son la experiencia práctica en el uso de varios dispositivos móviles, conocimiento del uso de los lectores de libros electrónicos, conocer las principales aplicaciones para dispositivos móviles, crear sitios web para móviles y la falta de planes de formación para el personal bibliotecario. Saravani y Haddow resumen estas en tres grandes grupos: conocimientos técnicos, prestación de servicios y competencias. La mayoría de los encuestados coincidió en la necesidad de ejercitar más las competencias que la prestación de servicios.

Por lo tanto, la formación para adquirir estas habilidades y conocimientos se hace necesaria. En las bibliotecas públicas el 53,4\% de los bibliotecarios encuestados por Ashford y Zeigen (2012a; 2012b) afirmó que no había recibido ninguna información o aprendizaje y en las bibliotecas universitarias un 59\%. Para Little (2011), son «los bibliotecarios, más que los usuarios, quienes necesitan las habilidades de entender y utilizar smartphones y nuevas tecnologías móviles, reconocer y analizar tendencias y dar respuestas estratégicas.»

Son pocos los trabajos que se han publicado sobre el uso que los propios bibliotecarios hacen de la tecnología móvil. La primera y mayor encuesta hasta el 
momento es la realizada por Todd Spires (2008) a 766 bibliotecarios estadounidenses sobre la percepción del uso de PDAs, smartphones y otros dispositivos móviles. El 19,4\% asegura utilizar dispositivos móviles, el 12,8\% del total lo hace en su trabajo. Este último grupo los utilizan para consultar el correo electrónico (58,7\%), el calendario, organizar tareas (35,9\%) y navegar $(27,2 \%)$. Otros mencionan además tareas como el acceso al catálogo y bases de datos de la biblioteca, leer documentos, consulta de blogs, realizar inventario, entre otras. Por lo tanto, el mayor uso que le dan son tareas relacionadas con la organización.

En este estudio se desvela la existencia de bibliotecarios que desconocen si su biblioteca presta servicios para dispositivos móviles: por ejemplo, una cuarta parte no sabe si su biblioteca tiene una versión móvil de su sitio web. Por otra parte, son muchos quienes piensan que los dispositivos móviles no están equipados para acceder a los contenidos de la biblioteca y algunos no consideran que estos dispositivos sean de utilidad, pero también otros están abiertos a utilizarlos. Es de esperar que con el tiempo estas percepciones hayan cambiado considerablemente. En consonancia con las tendencias sociales, sería previsible que el porcentaje de bibliotecarios que utiliza dispositivos móviles haya aumentado considerablemente y que el uso que hagan de ellos no se limite a tareas de organización, sino que sea más variado.

Una entrevista realizada por Aharony (2013) en el primer y segundo semestre de 2012 desvelaba significativas diferencias en el uso por parte de los profesionales y de los estudiantes israelíes en Biblioteconomía. Los estudiantes (52,2\%) utilizaban más los dispositivos móviles que los profesionales $(28,1 \%)$ y también percibían la tecnología móvil más fácil de utilizar y más útil que los bibliotecarios; además, eran más proclives a utilizarla en la biblioteca. Finalmente, aquellos que utilizaban dispositivos móviles eran más propensos a utilizarlos en la biblioteca.

Cummings, Merrill y Borrell (2010) identificaron diferencias en el uso que hacían de la tecnología estudiantes de diferentes especialidades. Esto lleva a pensar que los resultados de Aharony no pueden ser extrapolables a otros ámbitos. Sin embargo, sí se puede concluir que las nuevas generaciones de bibliotecarios estarán más dispuestas a poner en marcha servicios relacionados con dispositivos móviles. Los resultados de Aharony indican que la predisposición del personal, su percepción de la tecnología móvil y el uso que hacen de ella podría influir significativamente en la puesta en marcha de servicios móviles en la biblioteca.

No se conoce con certeza cómo están afectando los dispositivos móviles al trabajo de los bibliotecarios, pero se espera que les haga más accesibles, pudiendo estar en más lugares además del mostrador (Spires, 2008) y con los mismos recursos de información, lo que cambiaría las formas de organizar al personal. Por otra parte, la introducción de la tecnología móvil les obliga a estar preparados ante las 
posibles consultas de los usuarios y la puesta en marcha de servicios basados en movilidad en la biblioteca, por lo que influye en su formación.

Cuando el personal debe ausentarse de su puesto de trabajo por determinadas tareas, tener un dispositivo móvil permite estar siempre en contacto con otros miembros del personal. Sin embargo, hay quienes ven en ello una intromisión en su tiempo libre y que podría conllevar el estar siempre conectados. Por otra parte, aquellos bibliotecarios encargados del mantenimiento de los medios sociales podrán consultar y actualizar con mayor agilidad los perfiles de la biblioteca.

La tecnología móvil es capaz de facilitar determinadas tareas al personal bibliotecario. Tareas de circulación de la colección pueden agilizarse con la aparición de nuevas soluciones, como MobileCirc ${ }^{20}$, de la empresa Sirsi Dynix, que permite a los bibliotecarios efectuar préstamos, devoluciones, renovaciones y otras transacciones desde tabletas y smartphones a través de apps y la versión del sitio web para móviles. Conectando un escáner mediante bluetooth es posible realizar el inventariado de forma más rápida y sencilla. Gracias a soluciones de auto préstamo, como BookCheck ${ }^{21}$, de Boopsie, los usuarios podrán hacer préstamos a través de su propio dispositivo. Este tipo de funciones y otras descargaría al personal de la biblioteca para dedicarse a otras tareas. Libramatic $^{22}$ permite catalogar desde un smartphone: escaneando el código de barras se incorpora el documento al catálogo. En este sentido, aún queda mucho por avanzar, porque parece que la mayor parte de las iniciativas en bibliotecas están destinadas al usuario, y en menor medida al propio personal de la biblioteca. Estas apps aún no están generalizadas, pero posiblemente en los próximos se verán mejorar.

\subsubsection{Dispositivos móviles y espacios físicos}

Los servicios relacionados con dispositivos móviles son virtuales, pero desde luego dejan su impronta en los espacios físicos de la biblioteca, que necesitan ser adaptados a nuevas necesidades. Los enchufes para cargar la batería del smartphone o de la tableta son un servicio muy demandado por los usuarios. Por otra parte, cuando se prestan dispositivos hay que adecuar los mostradores para dar cabida a las estaciones de carga en serie que los mantengan siempre cargados,

\footnotetext{
${ }^{20}$ http://www.sirsidynix.com/products/mobilecirc

${ }^{21}$ http://www.boopsie.com/boopsie-launches-bookcheck-mobile-check-out-for-libraries/

22 http://libramatic.com/product/index.html
} 
como señala Lipincott (2008). También hay que tener en cuenta que los gastos en electricidad pueden aumentar. Para Peters (2013), las bibliotecas deben probar diferentes configuraciones de los espacios y propone observar el comportamiento de los usuarios. Quizás sería necesario habilitar espacios cómodos para la consulta o para hablar por teléfono.

La WiFi es un servicio básico que las bibliotecas deben prestar (Peters, 2013). En España, el 62,9\% de las bibliotecas públicas (a excepción de la Comunidad Autónoma de Cataluña) prestaba servicio de acceso a red WiFi en 2012, según los últimos datos del Ministerio de Educación, Cultura y Deporte ${ }^{23}$ disponibles. No se tienen datos sobre las universidades. Según los datos publicados por el INE, el $63,7 \%$ de las bibliotecas prestan servicio de WiFi (incluye la Nacional, centrales de comunidades autónomas, públicas, para grupos especiales de usuarios, de instituciones de educación superior y especializadas).

La localización es un elemento fundamental para los dispositivos móviles actuales, pues en función del lugar en el que se esté se tendrá acceso a unos contenidos y servicios. Aunque no cambia el espacio de forma visible, sí cambia la manera de moverse por ellos e influyen definitivamente en los contenidos y la información. El espacio físico es importante porque supone un punto de referencia para obtener contenidos y servicios determinados. Los dispositivos móviles ayudan a integrar lo digital en lo presencial gracias a los códigos QR, la geolocalización, la realidad aumentada o los beacons, como se verá en los siguientes apartados.

\subsection{La web móvil en las bibliotecas}

Definir una estrategia de movilidad en una biblioteca pasa por decidir en qué manera se presentarán los contenidos y servicios para dispositivos móviles: en un sitio web, en una app o en ambas. Existen numerosas razones, que se expondrán en el apartado 2.3.1, para escoger una u otra. Pero hay dos motivos por los que las bibliotecas ven inclinarse la balanza a favor de la web: los recursos humanos y económicos. No es habitual que las bibliotecas cuenten con personal que conozca los lenguajes de programación que emplean las apps (Cutshall, Blake y Bandy, 2011). Tampoco todas disponen de recursos económicos para contratar a un

\footnotetext{
${ }^{23}$ http://www.mecd.gob.es/cultura-mecd/areas-cultura/bibliotecas/mc/ebp/portada.html
} 
profesional especializado (Travis y Tay, 2011). En los siguientes apartados se abordará la primera de estas dos opciones, la creación de un sitio web para móviles, mientras que en el siguiente, el 2.3, se hablará de las aplicaciones nativas.

\subsubsection{Creación de un sitio web para móviles}

En la bibliografía profesional se pueden encontrar un gran número de artículos en los que se dan indicaciones sobre cómo crear un sitio web para smartphones y qué cuestiones hay que tener en cuenta. Este especial interés demuestra que adaptar el sitio web se considera una de las iniciativas prioritarias con respecto a los dispositivos móviles. Hay quienes abordan el proceso de crear un sitio web nuevo desde un punto de vista más amplio, como un nuevo proyecto que se emprende en la biblioteca, y recopilan las fases a contemplar (Ballard y Teague-Rector; Munro, et al., 2011) o simplemente indican algunos puntos a tener en cuenta, como realizar estudios de usabilidad, estar preparado para realizar modificaciones más adelante, aprovechar el código fuente de otros sitios o basar las decisiones en las necesidades del usuario y no en las suposiciones de las partes interesadas (Kim, 2012).

Otros trabajos tienen un punto de vista más técnico y contemplan aspectos como los lenguajes de programación, el ancho de la pantalla o los elementos de navegación y que se presentan en ocasiones como experiencias en una biblioteca concreta. Su carácter es divulgativo y su utilidad meramente práctica y podrían servir para cualquier otra institución que no fuera una biblioteca, pues apenas se encuentran elementos diferenciales, a excepción de los contenidos. Las publicaciones de Helsingor (2009), Griggs, Bridges y Rempel (2010), Chudnov (2010) y Jensen (2010) son algunas de ellas.

Con el tiempo se observa en la bibliografía un significativo cambio de tendencia en cuanto a las técnicas y se pasa de recomendar la creación de páginas diferenciadas a inclinarse decididamente por el diseño web adaptativo. Esto conlleva además un cambio de punto de vista con respecto a los contenidos que se abordará en los siguientes apartados.

Para Moll (2008), una de las opciones dentro de una estrategia de movilidad es no hacer nada. Esta opción, que parece ser la que más aceptación ha tenido hasta ahora en las bibliotecas españolas, se debe posiblemente en la mayor parte de los casos a que no se ha planteado la necesidad de una estrategia. Sin embargo, teniendo en cuenta el incremento de la navegación desde dispositivos móviles en 
los últimos años (ver apartado 1.1), no hacer nada es la elección menos consecuente con la realidad.

Hace algunos años el tráfico que llegaba a los sitios web de las bibliotecas desde dispositivos móviles era tan insignificante que se podía cuestionar la rentabilidad de crear una versión para smartphones. Así lo plantea Trainor (2010), quien reporta un $0,5 \%$ de tráfico desde navegadores móviles a la web de la biblioteca de la Eastern Kentucky University (Estados Unidos). Otras bibliotecas han registrado datos similares en esos años: Haefele (2011) cuenta que en su biblioteca suponía el 0,79\%. Trainor opina que a pesar de esos insignificantes porcentajes sí merece la pena y espera que crezca, como se ha demostrado después. Como se explicó en el apartado 2.1.7, este porcentaje parece incrementarse a la luz de los datos publicados por diferentes bibliotecas.

Las opciones para adaptar un sitio web van desde las más sencillas a las más complejas. A partir de una revisión de la bibliografía se pueden extraer los siguientes puntos a tener en cuenta a la hora de crear un sitio web para smartphones.

1. Planteamiento del sitio web.

2. Selección de los contenidos y servicios.

3. Creación del sitio web.

4. Testeo y prueba.

5. Promoción.

6. Mantenimiento y revisión.

La mayor parte de estos puntos son abordados en la bibliografía de una manera más ligera, mientras que los referentes a los contenidos y servicios que debe incluir un sitio web para smartphones y las técnicas para su creación cobran un mayor protagonismo. Se afrontan en los siguientes párrafos los primeros, mientras que los segundos se explicarán más detenidamente en el apartado 2.2.2. No se ha encontrado ningún texto que se refiera a la adaptación de sitios web para tabletas $\mathrm{u}$ otros dispositivos diferentes de los smartphones.

Como parte del planteamiento, y desde un punto de vista general, tanto Kroski (2008) como Bridges, Rempel y Griggs (2010) recomiendan abordar el proyecto de creación de un sitio web para móviles en varias fases, desde lo más simple a lo más complejo, comenzando por incluir unas cuantas funciones y ampliarlas con el tiempo. Kroski (2008) aconseja además definir perfiles de usuarios en función del tipo de dispositivos que utilizan y las necesidades que tienen.

Aunque son varios los autores que recomiendan poner en práctica técnicas de testeo, esta fase apenas se ve desarrollada, salvo por el trabajo de Travis y Tay (2011), quienes comparten un test heurístico de usabilidad en el que se incluyen 
elementos relacionados con el diseño de la interfaz, aspectos relacionados con el usuario - con los que se persigue comprobar que el sitio web es cómodo de utilizar - y contenidos. La propuesta de Travis y Tay presenta algunas debilidades si se emplea en la fase de testeo. La primera de ellas, y quizás la más evidente, es que incluye aspectos que no tienen que ver con la usabilidad, como son los contenidos, sobre los que cada biblioteca tiene libertad de decisión.

Pendell y Bowman (2012) explican cómo realizaron el estudio de usabilidad del sitio web móvil en su biblioteca, la de la Portland State University, en Estados Unidos. Emplearon para ello una técnica mixta que combina trabajo de campo y de laboratorio: los participantes deberían desempeñar cinco tareas y después se realizó una encuesta. Otra manera de abordar esta cuestión es a través de un focus group con la participación de los usuarios, como proponen Seeholzer y Salem (2011), para conocer sus opiniones.

Sin una promoción de la versión para smartphones es posible que el esfuerzo no se vea recompensado. Se trata de dar a conocer el nuevo sitio enlazando o redireccionando desde la versión de escritorio, pero también a través de pósters, newsletters, del blog de la biblioteca o de otros medios (Bridges, Rempel y Griggs, 2010; Haefele, 2011).

Una cuestión a prever es que el trabajo no finaliza una vez creado el sitio web, pues será necesario realizar tareas de mantenimiento. Por eso Haefele (2011) aconseja automatizar tantas tareas como sea posible para evitar incrementar la carga de trabajo. Así, a través de RSS se pueden mantener actualizadas las noticias de la biblioteca. En la Pollak Library (North Carolina State University, Fullerton) toman contenidos dinámicos a través de PHP. De esa manera, cuando se actualizan los horarios en la base de datos quedan actualizados en todas las versiones (DeMars, 2012).

Para DeMars (2012) las evidencias deben guiar la toma de decisiones en el proceso de creación de un sitio web para móviles. Esto significa que se deben recoger datos de las visitas que se reciben y analizarlos para obtener información sobre las preferencias de los usuarios. Un ejemplo de ello es la Ursula C. Schwerin Library (Estados Unidos), que optó por incluir un plugin para Drupal para adaptar su sitio web, basándose en el hecho de que entonces las visitas desde dispositivos móviles no alcanzaban el 1\% (Tidal, 2011).

A pesar de su importancia, la práctica de medir el uso de los recursos móviles no está tan extendida. Según una encuesta realizada por Ashford y Zeigen (2012a; 2012 b) a los bibliotecarios de los estados de Oregon, Washington y Idaho (Estados Unidos), menos de una quinta parte de las bibliotecas públicas $(17,1 \%)$ y la tercera parte de las universitarias no utilizaba ningún sistema de analíticas. Resulta 
significativo el porcentaje de profesionales que desconocían la respuesta: el 40,2\% en las públicas y el 35,9\% en las universitarias. Por otra parte, el estudio de Primary Research Group (2014b) revela que, dos años después, menos de la mitad de las bibliotecas encuestadas emplean Google Analytics para medir el uso de aplicaciones móviles (45,8\%).

\subsubsection{Contenidos en los sitios web para móviles de bibliotecas}

La bibliografía refleja una especial preocupación por los contenidos y servicios que se deben ofrecer a los usuarios de la biblioteca a través de dispositivos móviles. Para responder a esta cuestión se han empleado métodos como encuestas a los usuarios y el análisis de los contenidos que ofrecen otros sitios web para móviles. En este apartado se repasan estos dos tipos de trabajos. Sin embargo, no se han encontrado apenas referencias en la bibliografía sobre cuáles son las páginas a las que más acceden los usuarios cuando visitan la versión para móviles del sitio web de la biblioteca. Estos datos, que suelen quedar para uso propio, permitirían tomar decisiones a la hora de escoger qué contenidos y servicios ofrecer a los usuarios de dispositivos móviles (Chan, 2012), pero también adaptar la información ya existente a sus necesidades cambiantes basándose en la evidencia.

Aunque no se cuestiona la necesidad de adaptar el diseño de los sitios web para smartphones, en la bibliografía sobre bibliotecas se observan dos puntos de vista opuestos sobre la adaptación de contenidos. El primero, por ser el más antiguo, se muestra a favor, mientras que el segundo, más reciente, se muestra en contra. En los años posteriores a la aparición del iPhone se asumía la necesidad de adaptar los contenidos a las características del dispositivo, y por lo tanto había que seleccionar bien los contenidos (Wisniewski, 2011), pensando en los contenidos que tienen más sentido, como la localización (Bridges, Rempel y Griggs, 2010). Dada esa situación de movilidad, se recomienda ahorrar tiempo al usuario en la búsqueda de la información (Griggs, Bridges y Rempel, 2009) y evitar textos largos y profundos, que se asumen mejor desde el ordenador (Mairn, 2012).

En la bibliografía se observan varias aproximaciones a la hora de decidir qué contenidos y servicios incluir en un sitio web para móviles: preguntar a los usuarios directamente, analizar las visitas al sitio web completo desde dispositivos móviles (DeMars, 2012) e investigar qué contenidos ofrecen otras bibliotecas en sus sitios web móviles (DeMars, 2012). A ellas se puede añadir una cuarta opción, que consistiría en consultar la propia bibliografía sobre el tema. 
Con la llegada del diseño web adaptativo el punto de vista cambia: los usuarios de smartphones no tienen por qué estar en una situación de movilidad, sino que pueden querer otros contenidos que no está en la versión para móviles del sitio web que consultan. Para Cutshall, Blake y Bandy (2011) no se trata de hacer un sitio web en miniatura. Hay quienes cambian de opinión, como el equipo de la Oregon State University (Estados Unidos), que sustituyen su sitio web para móviles por una nueva versión con diseño web adaptativo (Rempel y Bridges, 2013). Pero también algunos mantienen la idea de que hay que recortar contenido, incluso cuando se trata de diseño web adaptativo (Kim, 2012; 2013). Sin embargo, este cambio de percepción no parece fundamentarse en datos concretos que avalen la idoneidad de los mismos contenidos para los usuarios de smartphones que los que tienen quienes acceden desde el sitio web completo.

La cuestión de los contenidos parece una de esas discusiones en las que hay dos posiciones enfrentadas en las que es probable acercar posiciones. Todo depende de la subjetiva cuestión sobre hasta cuándo se considera que hay que aligerar contenidos y funciones. Cuando Aldrich (2010) dice que los usuarios de móviles buscan contenidos como si estuvieran en el sitio web completo, se refiere al catálogo, al horario y acceso a bases de datos. Pero no se especifica la forma en que deben estar formateados estos contenidos, más ligeros (tómese el ejemplo de los catálogos, algunos están llenos de información de escasa utilidad). Por lo tanto, existe un reto en definir de manera más clara hasta dónde deben adaptarse los contenidos y funciones de un sitio web para móviles para que resulten óptimos.

\subsubsection{Contenidos y servicios de interés para el usuario}

Diferentes bibliotecas, sobre todo en el ámbito académico, han llevado a cabo estudios de usuarios para conocer cuáles serían los contenidos y servicios más útiles para quienes utilizan un smartphone, PDA u otros dispositivos móviles. Esta cuestión es fundamental para ofrecer unos servicios acordes a las expectativas y necesidades de los usuarios (Kim; Schmidt, 2013). Cabe pensar que el número de investigaciones de este tipo sea mayor, pero que los resultados se mantengan para uso interno, como se adivina puede suceder en la biblioteca de la Glasgow University (Munro, et al., 2011). Estos estudios tienen un interés local y sus resultados solo pueden aplicarse al ámbito en el que han sido tomados, sin que puedan ser extrapolados a otras bibliotecas - prueba de ello son las diferencias entre unos y otros-, pero recogen tendencias y opiniones, incluso presentan algunas coincidencias, y las metodologías empleadas sirven como base para otros estudios.

En la bibliografía se pueden encontrar varios artículos en esta línea, quizás una de 
las más productivos en el ámbito de dispositivos móviles en cuanto a número de trabajos publicados y con mayores implicaciones prácticas para las bibliotecas. En los últimos dos años, 2013 y 2014, este tipo de trabajos parece decaer, quizás debido a las nuevas corrientes que proponen mantener los mismos contenidos y servicios que los de la versión de escritorio. No se encuentran, sin embargo, este tipo de estudios referidos a las apps, aunque la mayor parte de ellas reproducen los mismos contenidos y servicios de los sitios web y, por lo tanto, serían pertinentes. Tampoco hay apenas referencias a las tabletas, bien porque su introducción es más tardía o porque se perciben como un dispositivo que apenas requiere adaptación (Nielsen y Budiu, 2013).

Algunos se centran en contenidos y servicios que ofrecer a través del sitio web (Mills, 2009), mientras que otros tienen una perspectiva más amplia e incluyen cualquier servicio que se pueda ofertar para los usuarios de dispositivos móviles, como notificaciones a través de SMS (Carney, Koufogiannakis y Ryan, 2004; Walsh, 2010b). También hay que diferenciar aquellas preguntas que van dirigidas a conocer qué servicios utilizarían y las que pretenden esclarecer cuáles son los que más se utilizan en la actualidad.

Las primeras publicaciones de este tipo se remontan a la era de la WAP y las PDA. La primera de la que se tiene noticia recoge los resultados de una encuesta realizada por Carney, Koufogiannakis y Ryan (2004) a los usuarios de la Biblioteca de la Universidad de Alberta (Canadá), una de las pioneras en ofrecer servicios a los usuarios de PDA. Estos autores concluyen que los servicios mejor considerados por estudiantes, profesores y personal de la biblioteca son las sesiones formativas sobre PDA (71\%), el sitio web con listas de recursos para PDA (70\%), realizar consultas sobre recursos para PDA (61\%), descarga de libros (53\%) y de los resultados de búsqueda en bases de datos (49\%).

Por otra parte, a los usuarios de la biblioteca les gustaría disponer de consulta a bases de datos (75\%) y al catálogo, (46\%), de guías de recursos del sitio web (36\%) y horarios de la biblioteca (17\%). Estos datos reflejan una realidad muy diferente a la actual: hoy nadie solicitaría poder descargar los resultados de búsqueda a una base de datos, sino el acceso a ella. Sin embargo, supone un punto de partida para los estudios que se han llevado a cabo más adelante y que utilizan una metodología similar, como se comprobará más adelante.

Karim, Darus y Hussin (2006) realizaron una encuesta a los estudiantes de la Universidad Internacional Islámica de Malasia, donde se habían implementado servicios a través de SMS en algunas bibliotecas, pero no existían aún servicios a través de internet. Al preguntar por la utilidad que otorgarían a posibles servicios de la biblioteca a través del móvil, asignándoles una puntuación de 1 a 5 , los servicios mejor valorados resultaron ser la renovación de préstamos (4,28 es la 
media), OPAC y bases de datos $(4,06)$, cuenta de usuario para consultar los documentos prestados $(4,06)$, alertas de devoluciones fuera de plazo $(3,98)$, información sobre sanciones $(3,80)$, recordatorios para devolver los documentos $(3,77)$ y referencia $(3,55)$. Estos resultados, al igual que los de Carney, Koufogiannakis y Ryan (2004) ya ponen de relieve servicios que serán en adelante muy valorados por los usuarios de dispositivos móviles, como el acceso al catálogo y a bases de datos y la información relacionada con los préstamos.

\section{Which resources and services would you find most useful to access on a mobile phone?}

$\square$ Cambridge University $\square$ The Open University

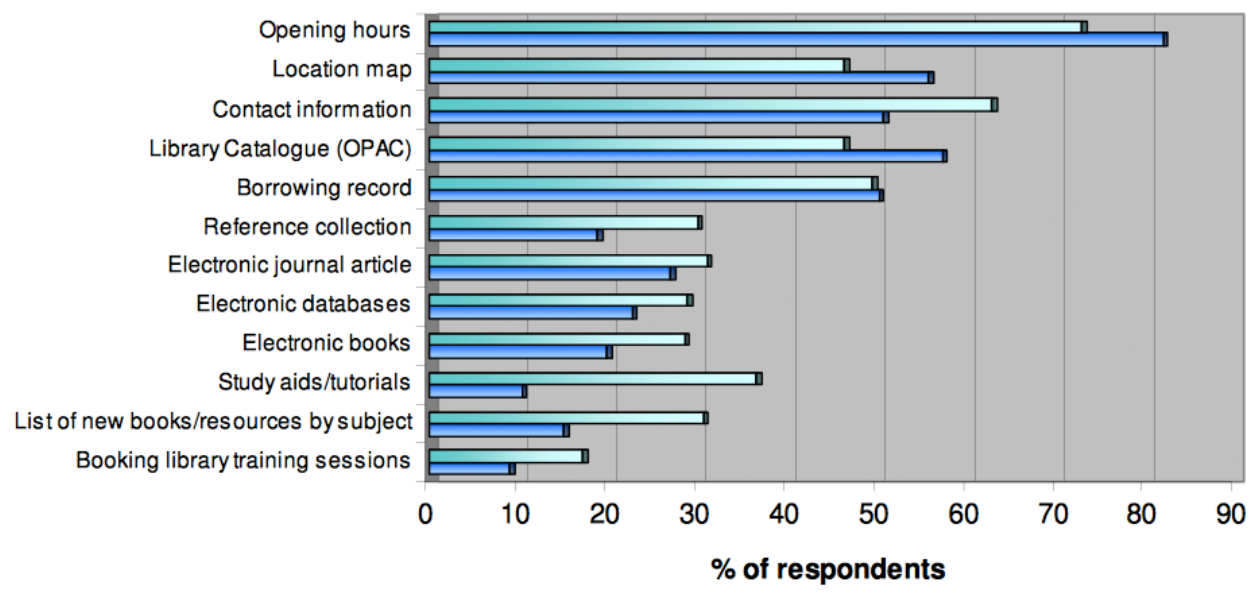

Figura 2. Servicios que consideran de utilidad desde el móvil los alumnos y el personal de la Universidad de Cambridge y la Universidad Abierta (Mills, 2009).

Los alumnos y el personal de la Cambridge University y la Open University (Reino Unido), en una encuesta realizada en el marco del Proyecto Arcadia (Mills, 2009), consideran útiles los horarios de apertura (alrededor del 75\%) ${ }^{24}$, la localización de las bibliotecas en el mapa (49\%), datos de contacto (55\%) y el acceso al catálogo (50\%), además de otros, como se aprecia en la figura 2. A diferencia de los usuarios de la Universidad de Alberta, los horarios de apertura de la biblioteca resultan más interesantes. Esta diferencia se entiende que viene dada por una mejora de las

\footnotetext{
${ }^{24}$ Los porcentajes son aproximados, ya que el trabajo de Mills (2009) solo los muestra en forma de gráfico, sin especificar el dato concreto.
} 
conexiones, pues algunos de los servicios mencionados en el trabajo de Carney, Koufogiannakis y Ryan (2004) funcionaban sin conexión.

Los usuarios de las bibliotecas de la Cambridge University y la Open University muestran interés en los servicios a través de SMS: al 21\% en Cambridge University y al 35\% en la Open University les gustaría recibir alertas de la biblioteca. El 27\% han utilizado servicio de referencia vía SMS. Sólo el 4\% no lo utilizaría. Este trabajo refleja además una práctica que sigue dándose hoy en día: el 50\% de los usuarios tomaban fotografías de los registros del catálogo para tener la información. Por el contrario, mostraban desinterés por la lectura de artículos y libros electrónicos desde el móvil, podcasts y audiolibros.

Muy similares son los resultados de Walsh (2010b), aunque la metodología que utiliza es la de focus group. Este trabajo, realizado en otoño de 2009 y 2010 en la University of Huddersfield (Reino Unido) está muy enfocado hacia los servicios a través de SMS y los resultados lo reflejan claramente, ya que hay varias preguntas al respecto. Los servicios mejor valorados, por este orden, son los siguientes: recordatorios a través de SMS, búsqueda desde el móvil, renovaciones del préstamo a través de SMS, páginas web adaptadas para móviles — que son percibidas como un servicio básico-, ayuda a través de SMS, recibir consejos a través de SMS, vodcasts, podcasts y códigos QR y bluetooth. Como se explicó en el apartado 2.1.6, durante estos años las barreras para el uso del teléfono móvil eran aún grandes, y como consecuencia los usuarios objeto del estudio afirmaron que no les gustaba consultar internet desde el móvil. Sin embargo, según el autor, se mostraron entusiasmados por algunos servicios.

En octubre de 2010 Paterson y Low (2011) combinaron el focus group y la encuesta para obtener información sobre servicios móviles de la biblioteca entre los estudiantes de la University of Edinburgh (Reino Unido). La disponibilidad de ordenadores, la consulta a las bases de datos y al catálogo, cuenta de usuario, reserva de documentos para el préstamo y localizar la signatura son la información y servicios más interesantes para ellos. Estos resultados coinciden tanto en el focus group como en la encuesta. Además, a través del focus group emergieron algunos servicios que serían de interés: las webcams - que situadas en la cafetería o las salas de estudio darían información en vivo sobre la ocupación-, Group Finder, disponibilidad de servicios y reserva. Valoran mucho este último servicio, la reserva de salas de estudio. Por el contrario, los contenidos menos interesantes para este grupo son las estadísticas de la biblioteca, las opciones sociales (comentarios de otros usuarios en los registros del catálogo, comentar y votar los registros o compartirlos), el localizador de amigos, el mapa para localizar la biblioteca más cercana, los mapas de las bibliotecas y recibir alertas. 
El 45,2\% de los estudiantes, profesores y personal de la Washington State University (Estados Unidos) utilizaría un móvil para acceder al catálogo, según los datos publicados por Cummings, Merrill y Borrelli (2010), pero el porcentaje aumenta al 58,4\% cuando se trata de usuarios de PDA (algo más de la mitad de los encuestados tiene una). El 36,4\% de los encuestados no lo utilizaría. Además, estos autores preguntan en qué circunstancias se utilizaría el catálogo desde el móvil. Los profesores accederían en su casa (67\%) y en el campus, fuera de la biblioteca $(60 \%)$. Los estudiantes graduados lo usarían viajando (50\%) y en el campus, fuera de la biblioteca (38\%). Los no graduados, viajando (46\%) y en el campus, fuera de la biblioteca (39\%).

Los usuarios de la Ryerson University (Canadá) aseguran que los servicios que más les gustaría tener disponibles desde dispositivos móviles son la búsqueda de artículos, la lectura de libros electrónicos y contactar con un bibliotecario para recibir ayuda para la investigación (Wilson y McCarthy, 2010). A la pregunta de qué servicios son los que más utilizan responden indicando los siguientes: la reserva de salas de estudio en primera posición (26\% aproximadamente), seguida de los horarios de apertura (22\%), el catálogo y reserva de libros (16\%), consultar las penalizaciones $(11 \%)$, disponibilidad de ordenadores $(10 \%)$ y signaturas para localizar los libros (7\%). Sin embargo, la mayor parte responde que desconoce estos servicios (casi un 60\%) o que no utiliza ninguno (más del 45\%). Todos estos datos son aproximados, pues no se mencionan las cifras exactas y han sido deducidas de un gráfico.

La única encuesta de este tipo que se conoce en España es la realizada por la Biblioteca Rector Gabriel Ferraté de la Universitat Politècnica de Catalunya (Benítez, et al., 2011) en julio de 2009. En ella los usuarios se muestran especialmente interesados en la reserva de salas de estudio (31\%), horarios de apertura $(21,7 \%)$ y reserva de ordenadores portátiles $(16,7 \%)$. Todos esos servicios se prestan en la actualidad desde su sitio web para móviles.

En el marco de The M-Library Project (2011), auspiciado por las universidades de Edimburgo, Napier, Queen Margaret y Highlands and Islands (en el Reino Unido) se realizó una investigación en noviembre de 2010, a través de una encuesta en línea cuyo objeto fueron los estudiantes. Los contenidos y servicios de la biblioteca a los que más accedían desde el móvil eran, en este mismo orden, la renovación del préstamo (35\%), la búsqueda en el catálogo (22\%), consultar la cuenta de usuario $(15 \%)$ y la búsqueda en bases de datos (12\%). Los porcentajes tan bajos parecen estar en consonancia con la percepción negativa de algunos usuarios al acceso a internet desde dispositivos móviles. Entre los servicios que les gustaría tener a través del móvil están la renovación del préstamo, consultar su cuenta de usuario y recibir recordatorios a través de SMS sobre la fecha de devolución de los 
préstamos (figura 3).

Las valoraciones recogidas en este proyecto coinciden en gran medida con las de los estudiantes de la Kent University (Reino Unido), quienes demandan servicios avanzados como el acceso a bases de datos, course reserves, acceso a la cuenta de usuario y al catálogo, así como funciones personalizadas (guardar resultados de búsqueda, por ejemplo). Sin embargo, perciben como básica la información del horario de apertura y los datos de contacto y localización. Estos resultados fueron recogidos por Seeholzer y Salem (2011) en cuatro focus group realizados durante la primavera de 2009, en los que se analizaron las impresiones de veinte participantes. Un dato curioso que revela este estudio y con el que no se ha encontrado parangón en otros, es la consideración de que cada página diseñada para teléfonos móviles o PDA debe contener un máximo de diez enlaces (se entiende que en un menú), incluso menos.

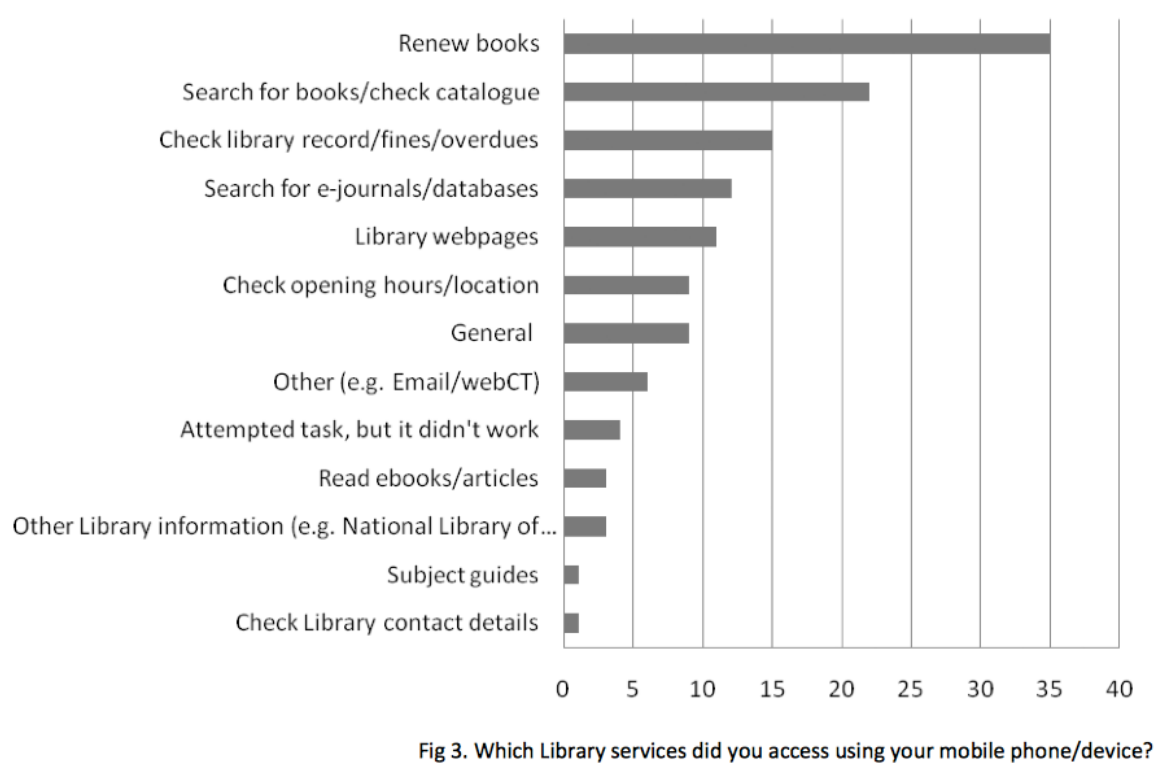

Figura 3. Servicios a los que acceden desde el móvil los estudiantes de las universidades de Highlands and Islands, Queen Margaret y Edinburgh Napier (The M-Library..., 2011).

Dresselhaus y Shrode (2012) preguntaron a los estudiantes de la Utah State University (Estados Unidos) en enero de 2011 qué servicios de la biblioteca utilizarían (figura 4). De las más de tres mil respuestas obtenidas, el 16\% emplearía el OPAC, el 11\% servicios móviles en general, el 10\% artículos, y el 9\% reserva de salas. A pesar de que el 70,2\% de los participantes afirmó que utilizaría los recursos de la biblioteca desde un smartphone y el 46,9\% desde un iPad, no se 
explica en el estudio por qué el porcentaje de respuestas sobre cada uno de los servicios es tan bajo.

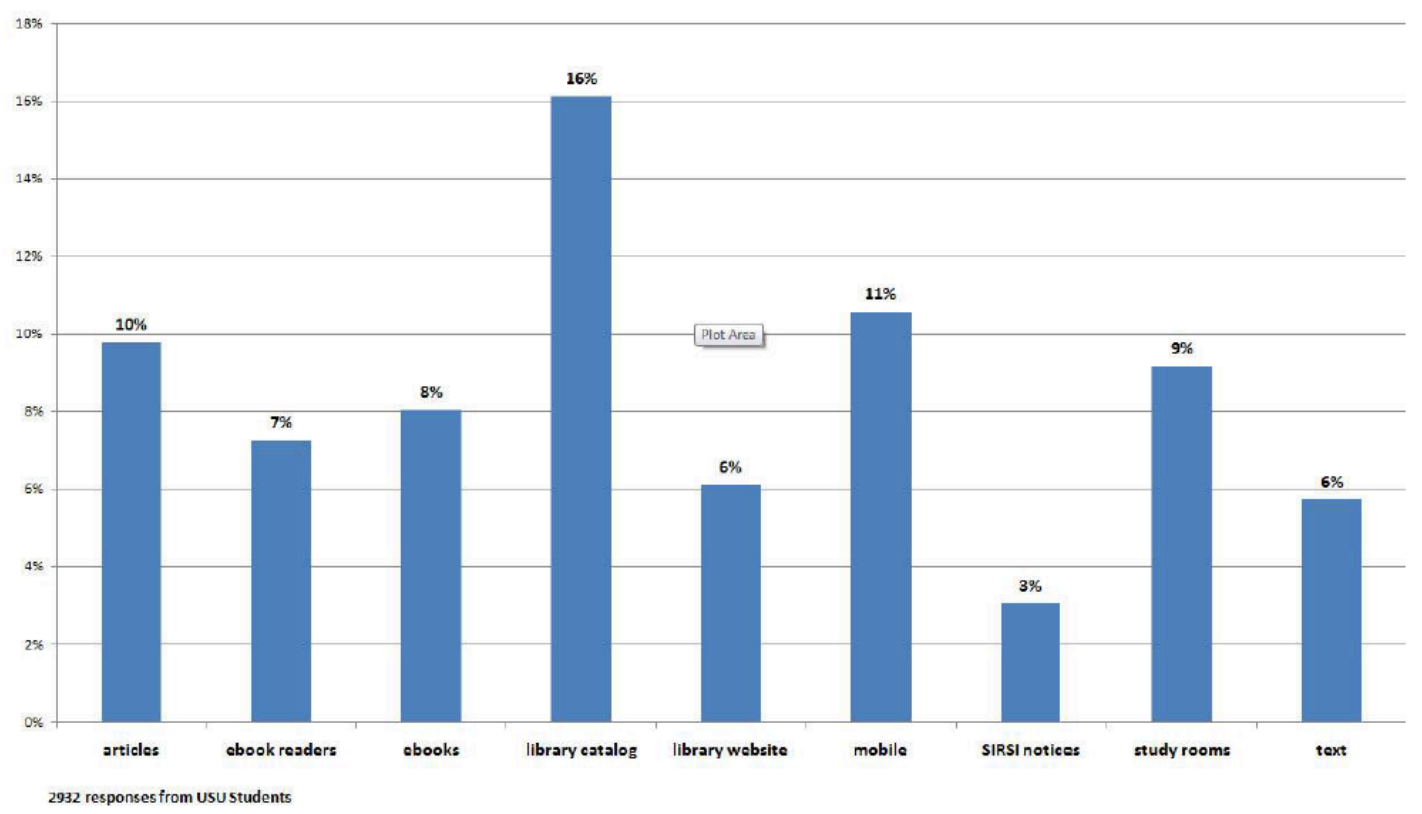

Figura 4. Servicios demandados por los estudiantes de la Utah State University. Fuente: Dresselhaus y Shrode (2012).

Becker, Bonadie-Joseph y Cain (2013) realizaron una encuesta en línea a los estudiantes en el Hunter College en Nueva York (Estados Unidos) entre septiembre de 2011 y enero de 2012. Las funciones que estos estudiantes desearían en el sitio web para móviles de la biblioteca son las bases de datos y el catálogo, reservar libros y el acceso a libros electrónicos. Los servicios a los que afirman acceder más desde el móvil son horarios (62,1\%), bases de datos $(52,3 \%)$ y catálogo $(50,3 \%)$. Además, el 58,2\% de estos estudiantes utilizarían en servicio de mensajería de texto para comunicarse con la biblioteca. Este estudio revela diferencias en el uso de dispositivos móviles entre personas procedentes de zonas rurales o las que viven en el campus y aquellas que utilizan el transporte público todos los días para llegar a la universidad.

Entre noviembre de 2012 y enero de 2013, en la biblioteca de la Oregon State University (Estados Unidos) se encuestó a quienes accedían a su sitio web desde dispositivos móviles (Rempel y Bridges, 2013). El 47\% de los 115 participantes escogió los horarios entre una lista de contenidos o servicios que buscarían en el sitio web. El 25\% indicó que buscaría un libro, el 21\% investigaría sobre un tema, el $13 \%$ reservaría salas de estudio, el $10 \%$ buscaría la disponibilidad de 
ordenadores y un $6 \%$ consultaría su cuenta de usuario. No se consideraron de interés el directorio de personal, webcams en la cafetería, course reserves, servicio de referencia, calendario académico y otras. En este caso, el 63,3\% de los participantes indicaron que era la primera vez que accedían al sitio web para móviles de la biblioteca.

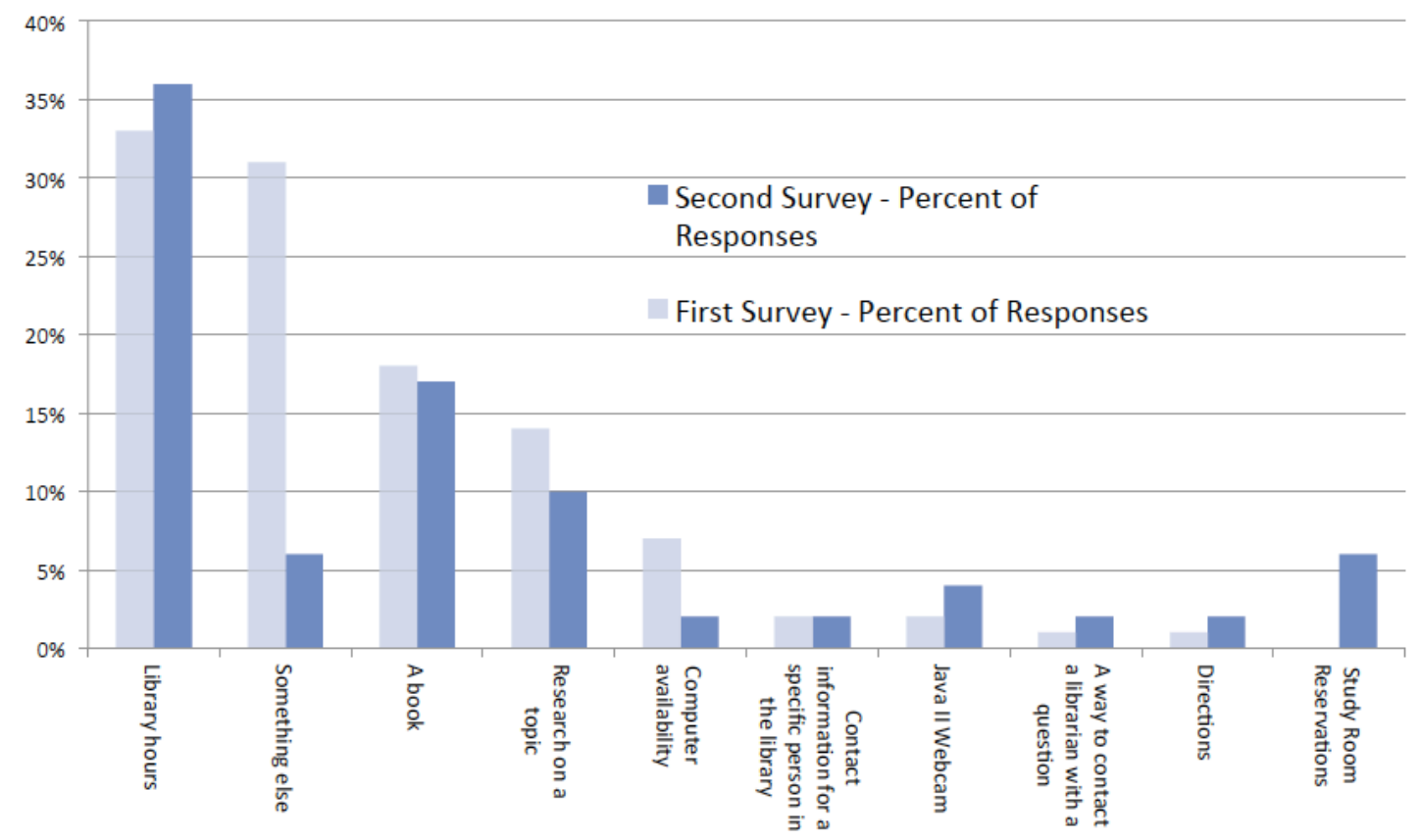

Figura 5. Contenidos y servicios que los estudiantes de la Oregon State University buscan en el sitio web móvil de la biblioteca. Comparación entre los resultados de la primera y segunda entrevista. Fuente: Rempel y Bridges (2014).

Un año más tarde, entre diciembre de 2013 y febrero de 2014, en esa misma biblioteca repitieron la encuesta con el objetivo de conocer cómo habían evolucionado los intereses de los usuarios (Bridges y Rempel, 2014). En líneas generales, los horarios de la biblioteca seguían siendo la página más consultada (más de 35\%, según declaraciones de los usuarios), seguido de la búsqueda en el catálogo (17\% aproximadamente), investigar sobre un tema (10\%) y la reserva de salas de estudio (más del 5\%). Estas autoras señalan el interés de los usuarios por realizar investigaciones en profundidad, y no solo por obtener información rápida y en movimiento, y ponen de relieve la importancia de valorar periódicamente los intereses de los usuarios para tenerlos en todo momento como centro del diseño del sitios web, pues cambian con el tiempo.

La biblioteca de la University of Leeds (Reino Unido) también realizó un trabajo para conocer los intereses de sus usuarios, según reporta Caperon (2014). A través 
de dos encuestas, realizadas en los meses de enero de 2012 y de 2013, se observa cómo se mantiene el interés por los datos básicos de la biblioteca, como el horario de apertura, la localización y el número de teléfono, mientras que en el resto de los parámetros desciende de forma paralela. Se valoraron especialmente la renovación del préstamo, el acceso a la cuenta de usuario, buscar libros en el catálogo y los datos básicos de la biblioteca. El servicio menos valorado fue el acceso a tutoriales o guías de investigación.

Un análisis riguroso de la bibliografía no permite comparar los resultados hasta ahora expuestos, pues el lugar y la fecha en que han sido recogidos y el tipo de participantes son muy diferentes. Sin embargo, la lectura cronológica revela algunos rasgos en la evolución que se ha producido en el consumo de información desde dispositivos móviles en los últimos años y sobre servicios que cobran especial importancia en un escenario determinado. Es el caso de los servicios a través de SMS, que cobraron un cierto protagonismo a mediados de la primera década del segundo milenio (Karim, Darus y Hussin, 2006; Mills, 2009; Walsh, 2010b), cuando el SMS alcanzó su máxima popularidad, y apenas son nombrados en los últimos trabajos.

En los primeros trabajos el uso de internet a través de dispositivos móviles era minoritario: Karim, Darus y Hussin (2006) reportan un 7,8\% de uso de WAP y el $8,7 \%$ de GPRS entre sus encuestados. Becker, Bonadie-Joseph y Cain (2013), hablan de un 39,9\% de entrevistados conectados a internet desde el smartphone y el 32,2\% desde un teléfono móvil. Entonces el iPhone era el dispositivo más popular, seguido de Android (30,1\%) y BlackBerry (17,1\%).

Los trabajos analizados revelan además una clara demanda por parte de los usuarios, con independencia del lugar y la fecha, de servicios relacionados con la investigación (búsqueda en el catálogo y bases de datos) y el préstamo (reservas y renovaciones, acceso a la cuenta de usuario). Otros servicios avanzados, como la disponibilidad de los recursos de la biblioteca, que requieren información actualizada en el momento, son también muy valorados. Como se puede apreciar en la tabla 2, sólo los usuarios de la Cambridge University, la Open University, Oregon State University y Leeds University (Mills, 2009; Rempel y Bridges, 2013; Caperon, 2014) señalan como elemento más importante el horario de apertura de la biblioteca y en las tres primeras universidades quedan en segunda y tercera posición la localización y los datos de contacto. En la Biblioteca Rector Gabriel Ferraté quedan los horarios en segunda posición (Benítez, et al., 2011).

Apenas hay demanda del acceso al documento completo, incluso algunos trabajos lo señalan como muy poco interesante (Mills, 2009). Sin embargo, en la Ryerson University se sitúa en segunda posición, solo por detrás de las bases de datos (Wilson y McCarthy, 2010). La aparición de esta categoría en los últimos años 
podría tener su razón de ser en la popularidad de dispositivos en los que la lectura se hace más cómoda. La aparición de servicios a través de SMS en los primeros puestos, a pesar del interés que se ha demostrado en algún otro estudio, parecen más influidos por una metodología que los favorecía.

\begin{tabular}{|c|c|c|c|c|}
\hline Trabajos & 1a posición & $2^{a}$ posición & 3a posición & 4ª posición \\
\hline Carney... 2004 & bases de datos & catálogo & recursos & horarios \\
\hline Karim ..., 2006 & renovar libros & catálogo & bases de datos & cuenta usuario \\
\hline Mills, 2009 & horarios & localización & contacto & catálogo \\
\hline Wilson..., 2010 & bases de datos & eBooks & ayuda & \\
\hline Benítez...., 2011 & reserva salas & horarios & reserva laptops & \\
\hline Walsh, 2010b & alertas SMS & búsqueda & renovación SMS & sitio web \\
\hline Paterson..., 2010 & PCs disponibles & bases de datos & catálogo & cuenta usuario \\
\hline M-Library..., 2011 & renovar libros & catálogo & cuenta usuario & bases de datos \\
\hline Seeholzer ..., 2011 & bases de datos & course reserves & cuenta usuario & guía edificio \\
\hline Dresselhaus..., 2012 & catálogo & servicios móvil & artículos & reserva salas \\
\hline Becker..., 2013 & bases de datos & catálogo & renovar libros & eBooks \\
\hline Rempel..., 2013 & horarios & catálogo & investigar & reserva salas \\
\hline Bridges..., 2013 & horarios & catálogo & investigar & reserva salas \\
\hline Caperon, 2014 & horarios & renovar libros & cuenta usuario & catálogo \\
\hline
\end{tabular}

Tabla 2. Contenidos y servicios más demandados por los usuarios de dispositivos móviles tal y como se recogen en la bibliografía.

En cinco de los catorce trabajos analizados no se indica ningún contenido meramente informativo en los cuatro primeros puestos, sino que todos están relacionados con la investigación (bases de datos y acceso al catálogo), gestiones de la biblioteca, como reservas o acceso a la cuenta de usuario (Karim, Darus y Hussin, 2006; Paterson y Low, 2010; The M-Library Project, 2011; Dresselhaus y Shrode, 2012; Becker, Bonadie-Joseph y Cain, 2013) o acceso al documento completo (Wilson y McCarthy, 2011).

Una encuesta realizada por Pew Internet (Rainie, Zickuhr y Duggan, 2012) halló que el 39\% de los estadounidenses de 16 años o más había visitado alguna vez el sitio web de una biblioteca - no necesariamente desde un dispositivo móvil- y que el $25 \%$ lo hizo en el último año. De este $25 \%$, la mayor parte entra en busca de la consulta del catálogo (82\%), información básica sobre horarios, localización e indicaciones sobre cómo llegar (72\%), reserva de libros (62\%), renovación de préstamos (51\%) o bases de datos en línea (51\%). Además, también buscaron 
información sobre programas y eventos (48\%), investigaron o entraron para hacer deberes en casa (44\%), leer revisiones de libros o recomendaciones (30\%), comprobar si tenían multas por retraso en las devoluciones (30\%), se suscribían para recibir información sobre programas y eventos (27\%), tomaban libros electrónicos en préstamo (22\%) o reservaban salas de reuniones (6\%). Estos datos coinciden de forma bastante precisa con la información y servicios que los usuarios demandan desde dispositivos móviles, lo que lleva a pensar que se utilizan los mismos contenidos que desde el ordenador.

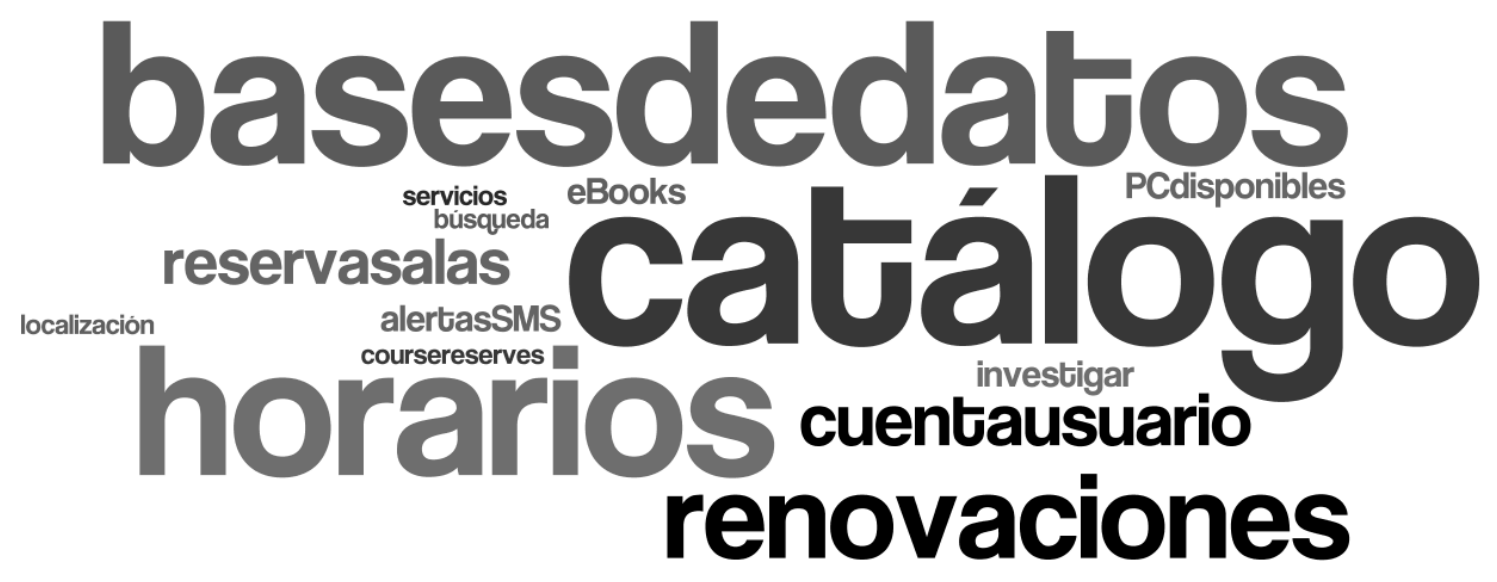

Figura 6. Servicios de la biblioteca más demandados por los usuarios de dispositivos móviles según la bibliografía. Elaboración propia.

En opinión de Aaron Schmidt (2013), la cuestión sobre qué contenidos y servicios interesan a los usuarios no está aún resuelta y sigue siendo clave, pues ayudaría al desarrollo de los sitios web para móviles y también a tomar decisiones sobre el diseño, otra de las cuestiones controvertidas.

\subsubsection{Contenidos y servicios en los sitios web para móviles de las bibliotecas}

Otro grupo de estudios sobre dispositivos móviles en bibliotecas lo forman aquellos que analizan qué contenidos y servicios se ofrecen en los sitios web diseñados para dispositivos móviles de las bibliotecas. A diferencia del anterior grupo, cuyos datos se obtenían a través de entrevistas, focus group u otros 
métodos para conocer la opinión de los usuarios y pretendían averiguar qué contenidos y servicios serían de interés para ellos, estos análisis parten de la observación directa y su objetivo es conocer la realidad.

La primera investigación conocida en esta línea es la de Alan Aldrich (2010), que examinó 25 sitios web para móviles de las universidades de Estados Unidos y Canadá en busca de los servicios que ofrecían y los comparó con una serie de trabajos previos de diferentes autores que identificaban los contenidos y servicios más valorados por los usuarios. Aldrich subrayó en este estudio el poco trabajo que se había realizado hasta el momento en ese sentido y aportó resultados sobre la frecuencia de aparición de diferentes contenidos y servicios en los sitios web diseñados para dispositivos móviles.

Aldrich halló los siguientes contenidos y servicios: horarios (75\%), directorio de bibliotecas (67\%), catálogo (67\%), contacto (50\%), enlace al sitio web principal (42\%), bases de datos (67\%), referencia (25\%), noticias y eventos (25\%), directorio de personal (21\%), cuenta de usuario (21\%), disponibilidad de ordenadores $(8 \%)$, mapas de planta $(8 \%)$ y otros cuantos que encontró en un único caso, como el acceso al servidor Proxy, enlace a Google Scholar, períodos de préstamo, reserva de salas de estudio, buscador de artículos a texto completo, novedades, webcam y podcast.

Aaron Tay (2010a) analizó el diseño, contenidos y servicios de 40 sitios web para smartphones de bibliotecas de todo tipo. Como resultado identificó los siguientes contenidos: horarios de apertura, contacto y directorios, mapas y direcciones, catálogo y opciones de préstamo, perfiles en redes sociales, bases de datos y recursos académicos, extras (webcams, disponibilidad de ordenadores o reserva de salas de trabajo en grupo) y noticias, FAQ y podcast. A diferencia de Aldrich, Tay no midió la frecuencia de aparición de estos contenidos. También estudió qué estilos presentaban estos sitios web e identificó cuatro plantillas diferentes que serán analizadas más adelante, en el apartado 4.5. Aunque posteriormente realizó un análisis de 24 aplicaciones nativas de bibliotecas (Tay, 2010b), no desgranó los contenidos presentes en cada una de ellas.

Dos años más tarde y partiendo del trabajo de Tay (2010a), Kim (2012) analizó la evolución de los sitios web para móviles de las bibliotecas. Detectó las siguientes tendencias:

- En estos sitios web hay más contenidos, además de los horarios, localización y contacto. Ese tipo de información solía ser la prioritaria con anterioridad, pero en 2012 las opciones de búsqueda e investigación y los recursos de la biblioteca (bases de datos, LibGuides, artículos, course reserves, libros o artículos) se situaban en primer lugar. 
- Las casillas de búsqueda comienzan a aparecer en los sitios web para móviles.

- Se añaden nuevos servicios para realizar transacciones, como reservas para cursos, renovaciones de préstamo u otras a través de la cuenta de usuario.

- Reservas de salas y de ordenadores se añaden en algunos sitios web.

\begin{tabular}{lr}
\multicolumn{1}{c}{ Contenidos y servicios } & Frecuencia (\%) \\
\hline Library catalogue & 100,0 \\
\hline Library hours & 81,8 \\
\hline Contact information & 81,8 \\
\hline Account access & 81,8 \\
\hline Library location & 72,7 \\
\hline Library news & 54,5 \\
\hline Main library web site link & 45,4 \\
\hline Reference/ask a librarian & 36,3 \\
\hline Computer availability & 27,2 \\
\hline Study rooms & 27,2 \\
\hline Feedback & 27,2 \\
\hline E-databases & 18,2 \\
\hline Bibliographic management software & 18,2 \\
\hline Workshops & 18,2 \\
\hline Course reserves & 9,1 \\
\hline Full-text article finder & 9,1 \\
\hline Social networking & 9,1 \\
\hline FAQs & 9,1 \\
\hline
\end{tabular}

Tabla 3. Contenidos y servicios en los sitios web para móviles de las bibliotecas de la AUCC. Elaboración propia a partir de los datos publicados por Canuel y Crichton (2011).

El panorama que dibuja Kim concuerda de manera bastante aproximada con los resultados de las encuestas señaladas en el anterior apartado de este mismo trabajo (apartado 2.2.2.1), donde precisamente servicios como el acceso a bases de datos y al catálogo, la posibilidad de reservar salas y ordenadores y el acceso a la cuenta de usuario, para consultar el estado de los préstamos o realizar reservas o renovaciones, eran los más valorados por los usuarios.

Los sitios web para móviles de las 95 bibliotecas académicas canadienses miembros de la Association of Universities and Colleges of Canada (AUCC) son el objeto de estudio de Canuel y Crichton (2011), quienes examinaron los once sitios 
web para móviles encontrados en este grupo en busca de 22 categorías de contenidos y servicios. Esta lista de categorías fue elaborada basándose en una revisión de la literatura y en un análisis de los sitios web móviles. Como se puede observar en la tabla 3, el catálogo estaba presente en todas las bibliotecas y muchas ofrecían además información sobre el horario de apertura, datos de contacto y localización, acceso a la cuenta de usuario y noticias.

\begin{tabular}{lr}
\multicolumn{1}{c}{ Contenidos y servicios } & Frecuencia (\%) \\
\hline Search Link & 86 \\
\hline Hours & 80 \\
\hline Location / maps & 59 \\
\hline Contact information & 53 \\
\hline Ask a librarian & 47 \\
\hline News / events & 32 \\
\hline Personal account / renew & 28 \\
\hline Search box & 25 \\
\hline Research Guide & 24 \\
\hline Computer availability & 18 \\
\hline Study room reservation & 11 \\
\hline Feedback & 11 \\
\hline Social Network & 7 \\
\hline FAQ / Help & 7 \\
\hline Staff Directory & 7 \\
\hline About Us & 5 \\
\hline Course reserves & 4 \\
\hline
\end{tabular}

Tabla 4. Contenidos y servicios en los sitios web para móviles de las bibliotecas universitarias. Elaboración propia a partir de los datos publicados por Han y Jeong (2012).

Han y Jeong (2012) analizaron 76 sitios web para móviles de bibliotecas universitarias en busca de los contenidos y servicios más frecuentes. A diferencia de otros estudios, Han y Jeong solo analizan la primera página del sitio web, sin hacer scroll, lo que significa que solo toman los primeros resultados que ve el usuario al acceder al sitio (tabla 4).

Estos autores compararon además los resultados de Aldrich (2010) y Canuel y Crichton (2011) y concluyeron que existen diferencias entre lo que los usuarios dicen manifestar y los contenidos de los sitios web de las bibliotecas. Sin embargo, para ello se basaron en un único estudio anterior, el de Wilson y McCarthy (2010), 
cuando ya se habían publicado otros, como el de Mills (2009), cuyos primeros resultados coincidían exactamente con los de Han y Jeong (2012). A pesar de ello, tienen razón en el sentido de que la mayor parte de los sitios contienen especialmente información (horarios, datos de contacto y localización, noticias), más que servicios para la investigación, como la búsqueda en el catálogo o en bases de datos.

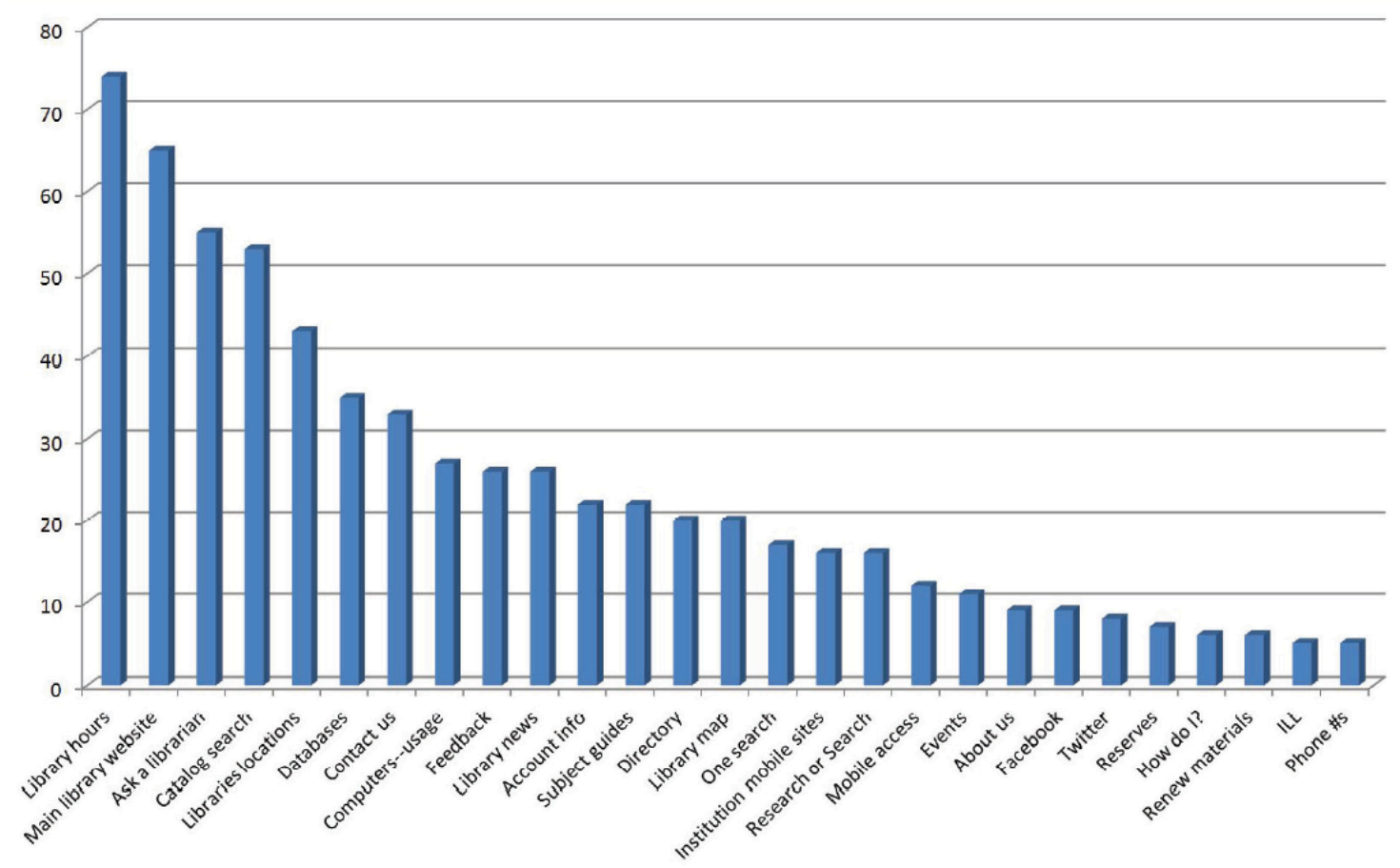

Figura 7. Contenidos y servicios en los sitios web diseñados para dispositivos móviles en las bibliotecas universitarias de Estados Unidos. Fuente: Jackson (2013).

En la ya mencionada encuesta realizada a 126 bibliotecarios de 80 bibliotecas públicas de los estados de Oregon, Washington e Idaho (Estados Unidos), Ashford y Zeigen (2012a) preguntaban también qué tipo de información se incluían en sus sitios web para móviles. Los más frecuentes en las respuestas de los bibliotecarios fueron el catálogo $(52,9 \%)$, cuenta de usuario $(44,1 \%)$, horario de apertura $(39,7 \%)$, localización y/o mapa $(38,2 \%)$ y referencia $(29,4 \%)$. Otros tipos de información que a veces se incluían: enlaces a bases de datos $(22,1 \%)$, enlaces a la versión completa del sitio $(25,0 \%)$, libros electrónicos, enlaces a los perfiles de la biblioteca en medios sociales, información sobre programas y eventos, y reserva de salas $(2,9 \%)$.

En la encuesta paralela a los bibliotecarios de las universidades en esos mismos estados, Ashford y Zeigen (2012b) obtuvieron el siguiente listado de contenidos y 
servicios habituales: el catálogo $(70,9 \%)$, servicio de referencia $(61,8 \%)$, enlaces a bases de datos $(63,6 \%)$, horarios $(63,6 \%)$ y otra información como la cuenta de usuario $(38,2 \%)$, enlace a la versión completa del sitio web $(47,3 \%)$, vídeos formativos (10,9\%), localización y/o mapas (45,5\%) y reservas de salas (3,6\%).

La comparación de ambos estudios pone de manifiesto las diferencias entre estos dos tipos de bibliotecas. Sin embargo, cabe ser precavidos en la interpretación de los datos: al obtener esta información de los propios bibliotecarios se corre el riesgo de conseguir datos poco precisos y basados en criterios dispares. Por otro lado, y como ya se advirtió con anterioridad, al ser mayor el número de bibliotecarios que de bibliotecas se puede adivinar que los contenidos de una misma biblioteca podrían estar recogidos más de una vez.

De las 99 primeras bibliotecas académicas de Estados Unidos, 83 contaban con una versión móvil de su sitio web en 2012, según los datos publicados por Rebecca Jackson (2013). Los resultados se muestran en la figura 7, donde se observa cómo los horarios de apertura, el enlace a la versión para ordenador de sobremesa o portátil, el servicio de referencia, la búsqueda del catálogo y la localización de las bibliotecas en el mapa son los más presentes, en más de la mitad de los casos.

Estos estudios suelen quedarse en el listado de contenidos, sin aclarar otra información relevante para el análisis. Sería de interés conocer si se están analizando los enlaces, que pueden ir a páginas externas o no, o los contenidos reales del sitio, pues los resultados variarían notablemente. A pesar de sus limitaciones, se refleja en estos estudios una cierta proximidad entre lo que los usuarios demandan - como se ha visto en el anterior apartado- y los contenidos y servicios que las bibliotecas ofertan en las versiones para dispositivos móviles de sus sitios web.

\subsubsection{Sitios web con páginas diferenciadas}

La cuestión sobre cómo crear un sitio web para dispositivos móviles es una de las que más interés ha suscitado, tal y como refleja la bibliografía. Se pueden encontrar numerosos artículos con instrucciones y recomendaciones, ya sea desde una experiencia práctica o con simple intención divulgativa. Entre ellos destaca el de Griggs, Bridges y Rempel (2009) por ser de los más completos y sistematizados. Arroyo-Vázquez (2010) recopiló varios de esos consejos, partiendo de las recomendaciones del World Wide Web Consortium (Rabin y McCathieNevile, 2008), y los agrupó en función de las limitaciones que presentan los smartphones. Se recogen a continuación, actualizados y completados. 
1. Diversidad de dispositivos.

- Diseñar una página para que pueda ser vista desde dispositivos con diferentes sistemas operativos. En la actualidad los navegadores de los sistemas operativos más comunes, iOS y Android, se basan en WebKit, por lo que son muy similares (Wisniewski, 2010).

- Escoger para qué tipo o tipos de dispositivos diseñar nuestras páginas. Es posible realizar tantas versiones como se considere oportuno.

- Consultar las características de los dispositivos a los que se dirige el sitio web. Para ello se puede emplear herramientas como DeviceAtlas.

2. Pantallas pequeñas, aunque desde hace unos años parecen estar triunfando las phablets, con pantallas algo mayores.

- Evitar elementos que no puedan verse en la página desde un dispositivo con pantalla pequeña, como imágenes grandes, textos demasiado largos o marcos.

- Evitar el scroll horizontal y vertical simultáneamente.

- Evitar que las páginas sean demasiado largas.

- Facilitar la lectura de los elementos de la pantalla, evitando imágenes de fondo o poco contraste entre fondo y forma.

- Utilizar la metaetiqueta Viewport para que el sitio se ajuste a la pantalla más pequeña, escalándose (Griggs, Bridges y Rempel, 2009; Spitzer, 2012).

- Incluir los contenidos justos y necesarios, evitando texto claro y conciso.

3. Limitaciones en la entrada de datos y la interacción ante la ausencia de teclados qwerty en algunos dispositivos, que cuando existen son de reducidas dimensiones. Esto hace complicado teclear URLs largos o introducir textos extensos. El ratón no existe y la navegación se realiza desde teclas de posición u otros elementos. Las pantallas táctiles y los lápices-puntero o stylus facilitan esta labor.

- Escoger URLs cortos y fáciles de escribir, evitando caracteres no alfanuméricos (Griggs, Bridges y Rempel, 2009).

- Evitar la entrada de texto libre, estableciendo valores preseleccionados siempre que sea posible.

- Marcar el orden de tabulación de los enlaces disponibles.

- Evitar que el usuario tenga que hacer clic más de tres veces para llegar al contenido que busca (Griggs, Bridges y Rempel, 2009).

- Utilizar botones en lugar de enlaces para evitar el efecto fatfinger. 
4. Algunos dispositivos no soportan determinados formatos como JavaScript o Flash, o ciertos formatos de vídeo, por lo que es recomendable evitarlos. Prescindir también de aquellos elementos no compatibles o que pueden dar problemas potencialmente, como objetos o scripts incrustados, ventanas emergentes o tablas.

5. Limitaciones en las conexiones, como un menor ancho de banda y una mayor latencia.

- Diseñar páginas ligeras, manteniendo un peso limitado y evitando elementos pesados como imágenes grandes y todo aquello que sea superfluo.

- Evitar la actualización automática periódica de las páginas sin informar al usuario.

- Si la página se hace larga, da opción para subir al comienzo de forma rápida (Kim, 2013).

6. Menor capacidad de memoria.

- Evaluar el uso que los dispositivos a los que nos dirigimos hacen de cookies y de caché.

- Asegurarse de que el tamaño total de la página sea apropiado teniendo en cuenta las limitaciones de memoria del dispositivo.

7. Uso en distintos contextos. El usuario puede encontrarse en una situación de movilidad y con prisas, pero también en casa o en otras situaciones. Por ello el W3C recomienda dar más flexibilidad y permitirle decidir (Connors y Sullivan, 2010), pero sin olvidar a aquellos que se encuentran en una situación de movilidad.

- Permitir que la aplicación web recuerde los datos de acceso de forma automática.

- Enlazar con la versión completa del sitio web.

- Pensar qué información y servicios pueden ser relevantes y adecuados para un usuario en una situación de movilidad y prescindir del resto.

- Facilitar la navegación, identificando claramente qué se encontrará tras cada enlace y creando una estructura lógica, asignando títulos claros a las páginas y teclas de acceso rápido en los menús. En este sentido, Cutshall, Blake y Bandy (2011) aconsejan mostrar en la página de inicio todos los contenidos y recursos del sitio para que se pueda acceder a un clic y Ryan (2011) propone reducir el número de páginas que uno tiene que visitar para consultar la información que el usuario busca. DeMars (2012) recomienda situar los recursos más demandados en primer lugar, para que se encuentren rápidamente. 
- Evitar enlazar a páginas web no adaptadas para móviles, y si se hace, indicarlo con un icono representativo (Griggs, Bridges y Rempel, 2009).

- Aprovechar las capacidades del dispositivo (Connors y Sullivan, 2010), como la geolocalización, el almacenamiento offline o los enlaces a números de teléfono.

Todos estas recomendaciones bien podrían aplicarse a cualquier sitio web para móviles, no solo a los de bibliotecas. La bibliografía recoge consejos generales, sin diferenciar lo que funciona bien en una biblioteca u otros sitios. Son los contenidos y servicios específicos los que hacen que estos textos estén dirigidos a bibliotecarios.

Ante la variedad de situaciones, Seeholder y Salem (2011) proponen incluir en el sitio web para móviles opciones que permitan al usuario personalizar su experiencia, como seleccionar las bases de datos favoritas y los enlaces que más va a visitar el usuario. Estos sistemas, sin embargo, son más sofisticados y complejos de desarrollar, por lo que encarecen el producto.

En el extremo contrario se pueden encontrar soluciones para facilitar el desarrollo del sitio web. Una de las más recomendadas es el uso de frameworks, mencionados en el apartado 1.3 en referencia a las aplicaciones nativas. Son «plantillas de código construidas para manejar aspectos básicos de la interfaz de usuario, como botones, fondos y enlaces de navegación» (Haefele, 2013). Gracias a estos frameworks, se puede aprovechar el trabajo anterior de otros y modificar el diseño, los contenidos y otras opciones precisas para personalizar el sitio. Algunos de los frameworks más conocidos son iWebkit, jQuery Mobile, JQTouch, XUI, o IUI (Kim, 2012).

Sin duda la opción más barata y fácil de poner en práctica para poner en marcha un sitio web para smartphones es el uso de un transcodificador. Es una opción que se contempla en la bibliografía (Kroski, 2008) y que ha sido empleada por algunas bibliotecas (Connolly, Cosgrave y Krkoska, 2011) pero que ha dejado de recomendarse en los últimos años por los pobres resultados que ofrece. Otra solución asequible es optar por uno de los servicios de creación y mantenimiento de sitios web para smartphones, como Ubik (Román-Molina, 2010), incluso gestores de contenidos generales con WordPress (Travis y Tay, 2011).

\subsubsection{Hojas de estilo}

La literatura especializada en bibliotecas contempla también la opción de adaptar solo el diseño del sitio web mediante hojas de estilo, aunque es menor el número 
de publicaciones sobre este tema. Para Ryan (2011), las hojas de estilo constituyen una buena solución cuando el número de visitas desde el móvil no justifica el esfuerzo de crear un nuevo sitio web. Ya en 2005 lo recomendaba Stormer (2005). Helsingor (2009) lo propuso como una solución cuando los contenidos del sitio son tantos que crear un nuevo sitio web supondría un gran esfuerzo, sin tener en cuenta las recomendaciones sobre la adaptación de contenidos. Sus propuestas son eminentemente técnicas, muy centradas en el código fuente, y aborda aspectos como el lenguaje y qué etiquetas funcionan y cuáles no. Las hojas de estilo es la opción que suelen incluir gestores de contenidos como Joomla, Drupal o WordPress, que tienen la ventaja de facilitar enormemente el trabajo: basta con añadir un plugin para ver el diseño adaptado.

\subsubsection{Diseño web adaptativo}

El diseño web adaptativo está de moda en las bibliotecas, especialmente en Estados Unidos, donde el ACRL Research Planning and Review Committee (2014) lo señaló entre las tendencias para 2014 en las bibliotecas académicas. También David Lee King lo identificó como tendencia para este mismo año, solo por detrás de la filosofía Mobile first, íntimamente relacionada con él (LITA, 2014). En este país, Estados Unidos, el diseño web adaptativo se ha convertido en uno de los temas estrella en encuentros, conferencias y reuniones profesionales (Schofield, 2014) y se habla sobre él en blogs y medios especializados cada vez con mayor frecuencia a partir de 2012. El primer tuit ${ }^{25}$ que lo asocia a las bibliotecas es el de la bibliotecaria inglesa Damyanti Patel, en el que difunde el enlace a una presentación en SlideShare sobre el tema.

También en talleres virtuales (hangouts) o presenciales es un tema estrella. Los trabajos que se encuentran hasta ahora en la bibliografía profesional siguen dos líneas: una buena parte de ellos tienen carácter divulgativo y explican en qué consiste, así como consejos para ponerlo en práctica. Otros relatan experiencias de creación de sitios web en bibliotecas con esta técnica. No se ha encontrado hasta el momento ninguna publicación con investigaciones sobre este tema.

Cada vez son más las bibliotecas en Estados Unidos y en otros países que optan por esta solución. Eric Rumsey (2012) mantiene una lista con bibliotecas universitarias cuyos sitios web utilizan diseño web adaptativo, lista que en la actualización de julio de 2014 incluía 39 sitios web de bibliotecas académicas estadounidenses -

25 https://twitter.com/damyantipatel/status/199970487407886337 
incluidas una en el Reino Unido y dos en Canadá- y dos bibliotecas públicas. La Bibliopedia francesa ${ }^{26}$ también recoge un listado de bibliotecas que han optado por el diseño web adaptativo.

Las bibliotecas públicas estadounidenses también lo están adoptando, con una incidencia de entre el 5\%, en las bibliotecas de municipios de 10.000 a 29.999 habitantes, hasta el $1 \%$ en las de municipios mayores de 100.000 habitantes (Wanucha y Hofschire, 2013). Es significativo que en bibliotecas que sirven a poblaciones de menor tamaño la incidencia es mayor, al contrario de lo que sucede con otros aspectos tecnológicos. Por otra parte, el trabajo de investigación llevado a cabo en el marco de esta tesis doctoral, que se presenta en la tercera parte, también permite deducir el creciente interés por ese tipo diseño.

En España el diseño adaptativo no parece haber llegado a las bibliotecas, pues no se conoce ninguna que haya optado por esta solución. Además de algunas menciones en comunicaciones sobre el tema de la movilidad en bibliotecas (Arroyo-Vázquez, 2013c; González-Fernández-Villavicencio, 2014), sólo se ha encontrado un artículo dedicado exclusivamente a este tema (González y Marcos, 2013).

\subsubsection{Los bibliotecarios, convencidos del diseño adaptativo}

La bibliografía profesional y académica del ámbito bibliotecario se muestra convencida de las virtudes del diseño web adaptativo, pero apenas recoge los inconvenientes que presenta. Los beneficios son prácticamente los mismos que recoge la bibliografía general (apartado 1.2.3.2.):

- Se evita duplicar el esfuerzo que conlleva crear y mantener varios sitios web diferenciados para cada pantalla (Fox, 2012; Kim, 2013).

- Permite tener el mismo contenido en una sola página web (Fox, 2012; Borg; González y Marcos, 2013) y por lo tanto hay un solo URL de acceso (Reidsma; Kim; González y Marcos, 2013).

- No se debe presuponer cuáles son los contenidos que necesitan los usuarios (Reidsma; Kim, 2013),

- Mejoran la usabilidad (Snell, 2013) y la experiencia de usuario (Frederick; González y Marcos, 2013).

- Un sitio web adaptativo es mucho más fácil de navegar para los usuarios que uno de escritorio no adaptativo (Kim, 2013).

\footnotetext{
${ }^{26}$ http://www.bibliopedia.fr/wiki/Responsive Web_Design
} 
- Hay que desterrar la idea de que los usuarios están en movimiento (Borg, 2013).

- Hay que aprovechar las ventajas de los nuevos dispositivos sin cerrar las puertas a los nuevos (Reidsma, 2013).

- La diferencia de sitios web produce un enfoque artificial en los dispositivos en lugar de los contenidos: hay que olvidarse de si estamos accediendo desde un móvil o desde un ordenador, de esa forma se sitúa al usuario en primer lugar (Fox, 2012).

- Se conoce como the fold a la parte de un periódico que queda visible cuando se pliega. Los contenidos que se sitúan en ese espacio son aquellos a los que se quiere dar una especial relevancia, porque son los primeros que se ven. Esta idea se ha llevado al diseño web pensando que la parte de una página web que se ve sin hacer scroll es la más importante. Sin embargo, internet no es como el medio impreso y no debería estar limitado a esas restricciones (Reidsma, 2012; Fox; Kim, 2013). El diseño adaptativo suele extender los mismos contenidos del sitio web para grandes pantallas en vertical, alargando la página, al contrario que los sitios web con páginas diferenciadas para dispositivos móviles, que suelen ocupar la página principal con un menú de navegación.

- El diseño adaptativo permite construir sitios agnósticos del dispositivo (Fox, 2013).

- Google lo recomienda (González y Marcos, 2013).

En la mayor parte de los trabajos citados hasta el momento no se recogen los inconvenientes del diseño web adaptativo (Borg; Fox; Frederick; González y Marcos; Snell, 2013), a pesar de que han sido reconocidos por el padre de la idea (Marcotte, 2011) y debatidos ampliamente (Nielsen y Budiu, 2013; Firtman; Schade, 2014). Estas aproximaciones que solo aportan los pros y se olvidan de los contras no son beneficiosas para los profesionales, pues se corre el riesgo de que se establezca la idea preconcebida de que el diseño web adaptativo es la solución a todos los problemas sin identificar aspectos que necesitan mejoras.

Solo unos pocos trabajos ofrecen una perspectiva más amplia, con sus ventajas e inconvenientes, y dan lugar a soluciones alternativas. Uno de ellos es el de Boyun Kim (2013), en el que concreta los siguientes inconvenientes:

- El diseño web adaptativo no garantiza por sí solo una buena experiencia de usuario: los sitios con un mal diseño siguen siendo igual de engorrosos e incómodos de navegar.

- No hay opción para volver al diseño completo.

- Las páginas con diseño adaptativo tardan más en cargar, lo que podría causar problemas serios de accesibilidad. 
La conclusión de esta autora es que cada biblioteca debe considerar si el diseño web adaptativo es la mejor opción para su biblioteca y para sus usuarios.

Siguiendo con los puntos de vista críticos, o al menos en parte, Aaron Schmidt (2013) opina que el diseño web adaptativo no constituye la solución al problema clave de proveer servicios bibliotecarios en un contexto de movilidad, pues una de sus limitaciones está en que los enlaces a otros sitios web y servicios externos a la biblioteca (las bases de datos o el catálogo, por ejemplo) no tienen por qué estar adaptados y produce frustración en el usuario. Sobre ello también advierten Reidsma (2013) y Rempel y Bridges (2013).

Un inconveniente específico con que se encuentran las bibliotecas está en que no todos los proveedores ofrecen servicios adaptados o contratarlos conlleva un esfuerzo económico adicional. Catálogos, bases de datos, cuenta de usuario y otros servicios no adaptados romperían la experiencia de navegación del usuario y la estética del sitio web de la biblioteca al enlazarlos desde el sitio web adaptativo.

Para Reidsma (2014), crear un sitio web con páginas diferenciadas puede tener sentido cuando la experiencia que se busca desde un dispositivo móvil es claramente diferente de lo que se pretende desde un ordenador. Si el propósito para una biblioteca es ofrecer los mismos servicios que desde la versión para grandes pantallas, el diseño adaptativo será la mejor solución.

Wisniewski (2013) indica que el diseño adaptativo conlleva concretar una estrategia de contenidos prácticamente desde el principio, ya que «escribir para la web es escribir para dispositivos móviles hoy en día.» Kim (2013) apunta dos posibles soluciones al problema de los contenidos. La primera consiste en incluir opciones de personalización en el sitio web, de manera que el usuario pueda decidir qué contenidos verá en los menús cada vez que acceda a la página. Sin embargo, como ya se indicó anteriormente, este tipo de desarrollos son más complejos e implican un mayor grado de dificultad, por lo que requieren mayores conocimientos y podrían ser más costosos. Otra solución pasa por mantener páginas diferenciadas y el diseño web adaptativo simultáneamente, explica Boyun Kim, como en el caso de la Penn State University (Estados Unidos).

\subsubsection{Experiencias en bibliotecas}

Aún son pocas, pero en la bibliografía ya se encuentran algunas experiencias sobre el uso del diseño adaptativo en los sitios web de bibliotecas. Mathew Reidsma, una de las primeras voces sobre este tema, cuenta la experiencia de cómo transformó el sitio web de las Bibliotecas de la Grand Valley State University, en Estados Unidos, con este sistema (Reidsma, 2013). Según explica, modificar las hojas de 
estilo le llevó apenas una semana, teniendo en cuenta que habían sido bien documentadas previamente. Como otros autores, Reidsma adopta además la filosofía Mobile first, pensando primero en las pantallas más pequeñas (no hace referencia a otros elementos). Previamente, en agosto de 2011, había modificado los contenidos del sitio web, retirando el 70\% y, según explica, nadie los echó en falta (Reidsma, 2012).

La biblioteca de la Oregon State University sustituyó su anterior sitio web para móviles por el diseño web adaptativo (Rempel y Bridges, 2013). Su elección se basa en el cambio de hábitos de los usuarios, que «quieren acceder a la misma información que desde el ordenador». Para ello utilizan los módulos y los temas de Drupal, una solución sencilla. Una de las decisiones derivadas de este cambio fue la retirada de una política previamente establecida que obligaba a enlazar únicamente a sitios web adaptados para dispositivos móviles.

Gayhart, Khalid y Belray (2014) explican la experiencia al convertir el catálogo de las Bibliotecas de la Universidad de Toronto con diseño web adaptativo. Sus datos están almacenados en Endeca y se envían al sistema integrado de gestión de la biblioteca, Unicorn; gracias a la API de Sirsi Dynix se obtuvieron los datos. Sin embargo, explican que renunciaron a la filosofía Mobile first porque la mayor parte de sus usuarios (93\%) visitaban el catálogo desde un ordenador.

\subsubsection{Valoración}

El diseño web adaptativo apenas ha cumplido dos años de vida en las bibliotecas y su juventud se nota. Una vez que el entusiasmo inicial quede superado, es necesario abordar sin tapujos los inconvenientes de este sistema y la forma de solucionarlos, conociendo qué es exactamente. Se abre un interesante campo de experimentación a posibles mejoras que solucionen las limitaciones.

Por otra parte, se consideran necesarios estudios de usuarios que analicen si esta solución cumple con sus expectativas o no y en qué situaciones y que vuelvan a poner el foco en el contenido sobre el diseño. A través del repaso por la bibliografía se observa una disparidad a la hora de entender determinados conceptos, como señala Firtman (2014). ¿Qué es el diseño web adaptativo exactamente? ¿Qué implicaciones tiene el Mobile first? ¿Solo pensar en la pantalla primero o también hay que pensar en otras peculiaridades del dispositivo?

Finalmente, cabe preguntarse si las bibliotecas están entendiendo los elementos diferenciales que implica la movilidad y teniendo en cuenta las características únicas de los dispositivos móviles. 


\subsubsection{El catálogo}

La preocupación por el acceso al catálogo desde dispositivos móviles no es nueva. En noviembre de 1993 la Biblioteca de la Universidad del Sur de Alabama (Estados Unidos) inició el proyecto The Library Without a Roof, con el que pretendía demostrar que era posible acceder al catálogo en línea y a otros recursos de la biblioteca desde una PDA a través de una conexión de datos móvil (Foster, 1995). La consulta al catálogo es precisamente una de las funciones más solicitadas por los usuarios de dispositivos móviles, según demuestran varios de los estudios mencionados en el apartado 2.2.2.1.

El catálogo móvil u OPAC móvil se define como aquel cuya interfaz ha sido adaptada para los usuarios de dispositivos móviles mediante alguna de las diferentes técnicas existentes. En la bibliografía es habitual encontrar el término mOPAC, por Mobile OPAC, para referirse al catálogo móvil.

La adaptación del catálogo implica un mayor esfuerzo que la adaptación de cualquier sitio web con contenidos meramente informativos. La tarea es más compleja técnicamente, ya que la interfaz debe ser integrada en una base de datos. Las soluciones de movilidad que ofertan los proveedores de software para bibliotecas suelen tener un coste adicional, aunque no todas. Son tres las soluciones de movilidad que las bibliotecas tienen para el catálogo: interfaces ligadas a un software concreto, ya sea software comercial o libre, soluciones de terceros compatibles con varios productos y desarrollos propios, hechos a medida.

Es necesario establecer dos niveles en los catálogos móviles. Por un lado están aquellos que presentan interfaces adaptadas para la consulta en dispositivos móviles. Estas interfaces se adaptan a la pantalla siguiendo las mismas técnicas empleadas en cualquier otro sitio web - páginas diferenciadas para la versión móvil, hojas de estilo y diseño adaptativo-, e incluso ven reducidas las funciones y la información, en una versión más simple. Se les podría denominar catálogos adaptados para móviles. Por otro lado, algunos catálogos están aprovechando las capacidades del dispositivo para mejorar las funciones tradicionales. Así, utilizan la geolocalización para mostrar la ruta hasta la biblioteca más cercana o la cámara de fotos para realizar búsquedas con solo leer el código de barras. En esta caso se podría hablar de catálogos nativos móviles.

Se abordan en los siguientes apartados diferentes aspectos relacionados con los catálogos móviles: soluciones de movilidad, sus funciones y características y líneas de investigación en este ámbito. Se aborda también el asunto de las herramienta de descubrimiento. 


\subsubsection{Productos comerciales}

Las soluciones comerciales para adaptar el catálogo a los dispositivos móviles, especialmente a smartphones, se han ido ampliando con el tiempo. Esto se debe, según Breeding (2011), a que el aumento del uso de dispositivos móviles por parte de la población motiva a los proveedores de software. Este tipo de soluciones se presentan como complemento al software contratado previamente y están íntimamente ligados a él, con pocas opciones de personalización y/o modificación, por lo que es más restrictivo. Tienen la ventaja de que suponen un ahorro de trabajo para el personal de la biblioteca, pero a cambio conllevan un desembolso económico adicional.

En los siguientes párrafos se repasan algunos de los productos comerciales en el mercado, con especial atención a aquellos que han sido detectados en las bibliotecas analizadas durante el trabajo de investigación realizado en el marco de esta tesis doctoral.

AirPac, de Innovative Interfaces, es el módulo que complementa el sistema integrado para bibliotecas Millenium y uno de los primeros productos comerciales de los que se tiene noticia, pues su lanzamiento fue anunciado en 200127. Esta primera versión para teléfonos móviles y smartphones, con una interfaz sencilla, permitía buscar en el catálogo. Más tarde apareció una versión más sofisticada, que incluía además el acceso a la cuenta de usuario y la opción de reservar documentos.

BicatWISE, el sistema integrado de bibliotecas de la empresa holandesa Huijsmans en Kuijpers Automatisering BV (HKA), presente en el más de la mitad de las bibliotecas holandesas, lanzó en abril de 2012 un módulo que se combina con versiones 6.2.0 y superiores. BicatWISE fue adquirido por la OCLC en 2013.

DDElibra MoBiblio es el módulo móvil de Axiell, una empresa de automatización con sede en Suecia y que opera en los países nórdicos y Reino Unido, principalmente. Este módulo se lanzó en enero de 2008.

Mopac es un módulo creado por la empresa española Baratz, que funciona con su software AbsysNet 2.0. Fue lanzado en marzo de 2012 y se caracteriza porque incorpora opciones sociales, algo nada habitual en las versiones móviles del catálogo.

\footnotetext{
${ }^{27}$ Innovative Interfaces (2001). Innovative rolls out new products at ALA Annual Meeting. En: Library Technology Guides, 16 junio. http://librarytechnology.org/diglibfulldisplay.pl?SID $=20140820193359375 \& \mathrm{RC}=9206 \&$ code $=$ pr $\&$ Row $=31$
} 
Polaris MobilePAC (MPAC) es un módulo que se añade al sistema integrado para bibliotecas Polaris para dotarlo de una interfaz móvil. Este software, antes perteneciente a Polaris Library Systems, proveedora de software para las bibliotecas de Estados Unidos, ha pasado a pertenecer a Innovative Interfaces en abril de 2014 .
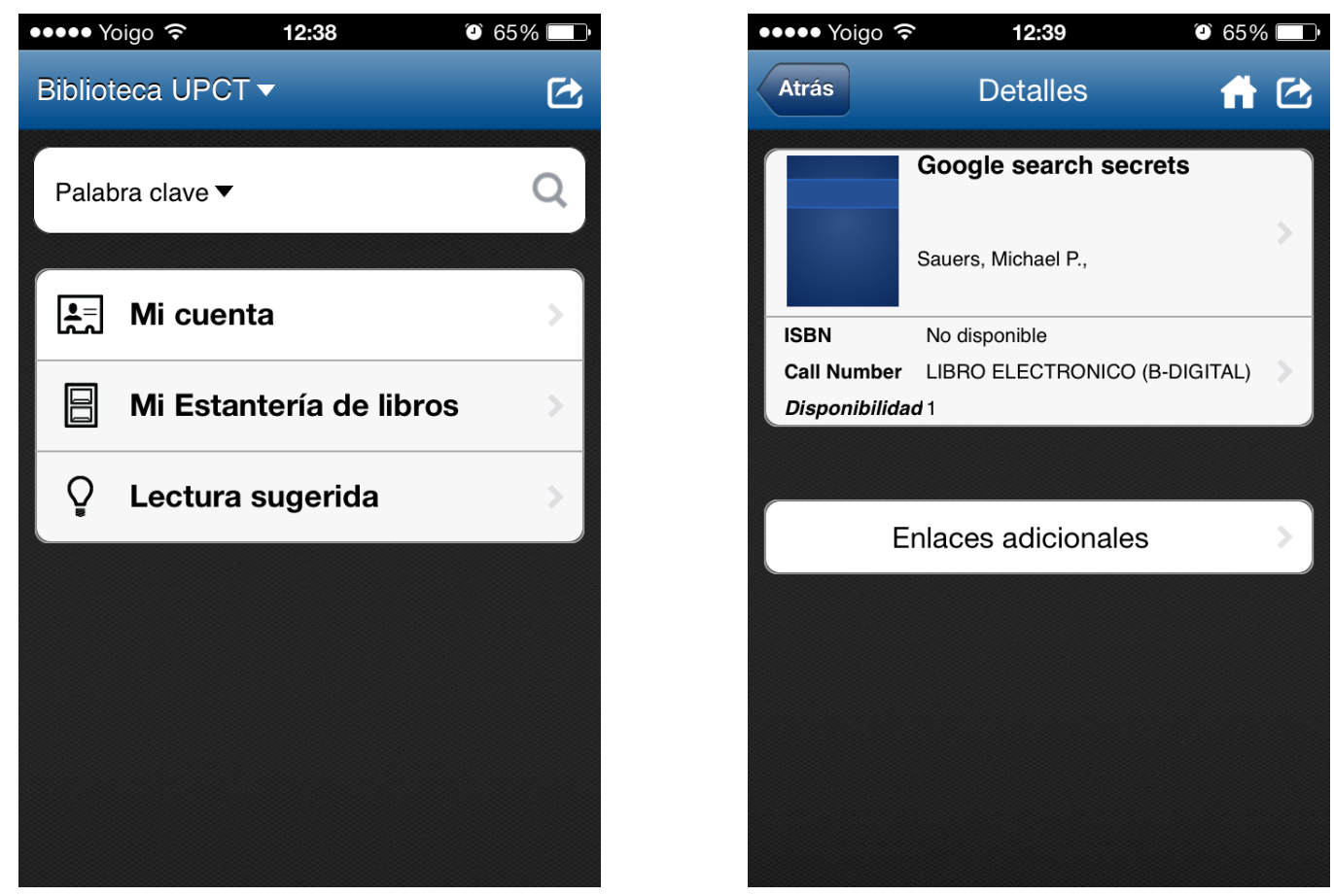

Figura 8. Catálogo de la Biblioteca de la Universidad Politécnica de Cartagena en la aplicación nativa BookMyne.

BookMyne, de la empresa SirsiDynix, se oferta exclusivamente en forma de aplicación nativa, por lo que no puede ser consultada vía web. Según Wong (2013), la aplicación nativa BookMyne no supone un coste añadido para las bibliotecas que contratan SirsiDynix. Esta app de consulta al catálogo permite además reservar libros y renovar préstamos, enviar por correo los registros, acceder a la cuenta de la biblioteca, crear una lista personalizada de libros, escanear el códigos de barras para comprobar la disponibilidad y ver listas sugeridas. En España la Biblioteca de la Universidad Politécnica de Cartagena, que utiliza actualmente el software Symphony, permite el acceso al catálogo desde la aplicación nativa BookMyne.

Library Anywhere se comercializa en forma de aplicación web y nativa desde octubre de 2010 y no sólo transforma la interfaz del catálogo para dispositivos móviles, sino que además permite incluir algunas páginas con información sobre la 
biblioteca. Se trata de un servicio de la empresa LibraryThing que funciona en el $90 \%$ de los catálogos comerciales, según se asegura en su publicidad.

La empresa Boopsie, especializada en el desarrollo de apps para bibliotecas, también genera una versión móvil del catálogo y, al igual que Library Anywhere, se considera un producto de terceros. Incorpora una utilidad, Smart Prefix, que muestra los resultados de búsqueda en tiempo real mientras se van introduciendo los caracteres en la búsqueda, como las search suggest de Google. De esta manera, el usuario no tiene que introducir los términos completos, lo que facilita la interacción con el catálogo. Según se anuncian en su sitio web, el resultado es que los usuarios realizan 2,4 búsquedas más en el catálogo. Además, Smart Prefix permite buscar en múltiples campos simultáneamente desde una única casilla de búsqueda (Boopsie, 2013).

Breeding (2014) anunció nuevas interfaces móviles en varios productos comerciales en 2013. Destiny Library Manager, especializado en bibliotecas escolares, ha incorporado una $a p p^{28}$, Destiny Quest mobile app, para la consulta del catálogo a través de dispositivos iOS y Android y la lectura de libros electrónicos. Verso ILS, de la empresa Auto-Graphics, incluye un desarrollo en HTML5 para el acceso desde cualquier tipo de dispositivo.

\subsubsection{Software libre}

Los principales productos para bibliotecas que se distribuyen bajo licencias de software libre también han desarrollado versiones móviles. Para que un software se considere libre se debe poder estudiar y modificar el programa, así como mejorarlo, según estipulan las libertades establecidas por Stallman. Por lo tanto, el software libre presenta la ventaja de que es más sencillo crear interfaces móviles y que éstas puedan ser personalizadas.

Koha, desarrollado en Nueva Zelanda en 1999, tiene el honor de ser el primer software libre y de código abierto de automatización en bibliotecas. En la documentación disponible en el sitio web de la Comunidad Koha ${ }^{29}$ se puede encontrar información para personalizar la interfaz y desarrollar una versión móvil modificando las hojas de estilo. Una gran parte de las bibliotecas que utilizan este software lo hacen contratando los servicios técnicos de una empresa como LibLime o ByWater Solutions (Breeding, 2009). Ambas ofrecen una interfaz para móviles. LibLime lo incorporó en septiembre de 2012, a partir del desarrollo de la

\footnotetext{
${ }^{28}$ http://www.follettsoftware.com/ezform.cfm?ezid=281\&urlRef=destinyquestmobile

${ }^{29}$ http://koha-community.org
} 
Hartford University ${ }^{30}$ (Estados Unidos). Koha-Kobli, la distribución que mantiene el Grupo de Trabajo de las Bibliotecas de la Administración General del Estado, dispone de una interfaz móvil que funciona como diseño adaptativo desde la versión 1.12.431.
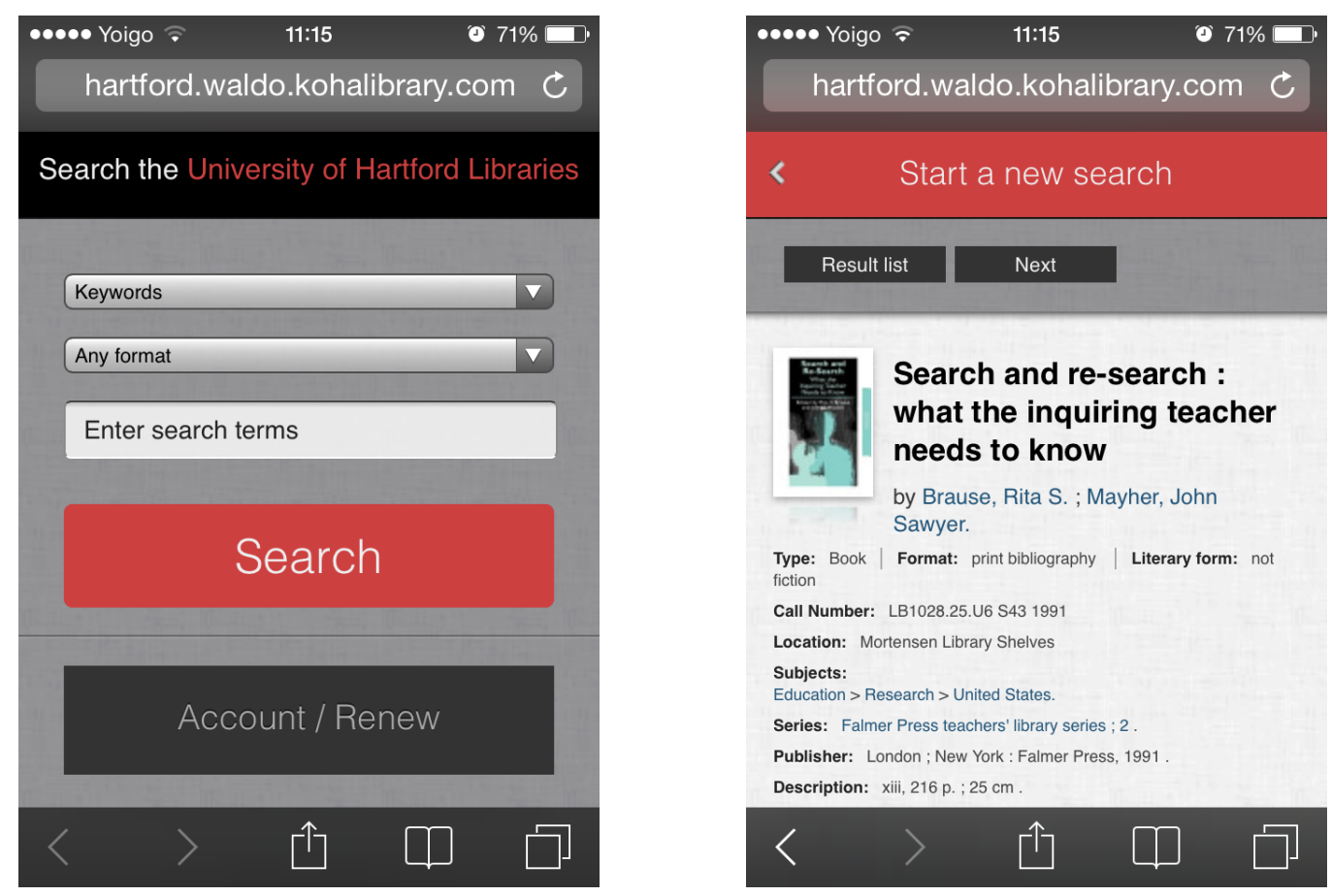

Figura 9. Catálogo de las bibliotecas de la Universidad de Hartford 32 , que funciona con Koha.

Evergreen es un sistema integrado de gestión bibliotecaria que también utilizan las bibliotecas como interfaz del catálogo. El Proyecto Evergreen fue iniciado por el Sistema de Bibliotecas Públicas de Georgia (Estados Unidos) en 2006 para más de 275 bibliotecas públicas. En 2010 Sitka y el Sistema de Bibliotecas del Condado de King desarrollaron una interfaz móvil para el catálogo con funciones para la consulta de la cuenta de usuario y en ese mismo año se lanzó la versión beta. El código de la última versión, la segunda, se comparte bajo licencia del MIT³.

\footnotetext{
${ }^{30}$ http://www.liblime.com/liblime-academic-koha-50-now-available-from-mobile-devices

${ }^{31}$ Bibliotecas de la Administración Gerneral del Estado (2013). Disponible Kobli 1.12.4. En: Sitio web de Kobli, 7 noviembre. http://kobli.bage.es/disponible-kobli-1-12-4/

32 http://hartford.waldo.kohalibrary.com/cgi-bin/koha/opac/opac-main.pl

${ }^{33}$ http://code.google.com/p/evergreen-mobile-opac
} 


\subsubsection{Herramientas de descubrimiento}

Desde su irrupción en el mercado, alrededor de 2009, las herramientas de descubrimiento están tomando fuerza (Breeding, 2014). Las Discovery Tools, herramientas de descubrimiento o discoveries, como se les conoce coloquialmente, son definidas por Fagan, et al. (2012) como un «software web que busca metadatos de artículos de revista y del catálogo en un índice unificado y presenta los resultados en una única interfaz. Esto difiere del software de búsqueda federada, que busca en múltiples bases de datos y agrega los resultados.» Se recogen a continuación las soluciones de movilidad que ofertan las herramientas de descubrimiento.

Aquabrowser es un software de la empresa ProQuest que se describe a sí misma como una capa de descubrimiento. En palabras de Breeding, traducidas por el Grupo ThinkEPI (2014), «muchas de las bibliotecas en los Estados Unidos que previamente implementaron interfaces de descubrimiento, especialmente AquaBrowser, han migrado a utilizar el catálogo en línea que les fue proporcionado con sus ILS. AquaBrowser sigue siendo popular en los Países Bajos y países vecinos.»

BiblioCommons es una empresa con sede en Canadá cuyo software de descubrimiento se está convirtiendo en la principal opción adoptada por las bibliotecas públicas (Breeding, 2014). Ofrece el servicio BiblioMobile como complemento de BiblioCore, que se contrata aparte y se compone de una app con versiones para Android y iPhone y una interfaz para smartphones que permiten la consulta del catálogo.

Ebsco Discovery Services es la herramienta de descubrimiento más extendida, con 5.612 suscripciones de bibliotecas, según los datos publicados por Breeding (2014). Entre sus prestaciones incluye una interfaz diseñada para smartphones, sin que sea necesario contratarla aparte.

Encore es un producto de la empresa Innovative Interfaces que representa el esfuerzo por producir un catálogo de nueva generación, en palabras de Marshall Breeding (2007). Fue lanzado a mediados de 2007 e incluía sindicación de contenidos, etiquetado social, servicios web y técnicas de redes sociales. Incorpora una solución de movilidad propia.

Primo, de la empresa Ex libris, es una de las herramientas de descubrimiento más extendidas, con 1.407 licencias vendidas a bibliotecas (Breeding, 2014). Dispone de una solución de movilidad Primo Mobile. 
Summon, el software de ProQuest, es uno de los productos más populares del mercado, pues funciona en 673 bibliotecas. Desde 2009 cuenta con una interfaz móvil.

VuFind es un software de código abierto desarrollado y mantenido por la Biblioteca Memorial, en la Universidad Vilanova (Estados Unidos). En la versión 1.2, lanzada en enero de 2011, incorpora la primera interfaz para móviles, que ha ido mejorando con el tiempo. La última versión es la 2.2, lanzada en enero de 2014. La interfaz móvil de este software admite personalización.

WorldCat Local es la herramienta de descubrimiento de la OCLC, con 1.717 bibliotecas suscritas. En junio de 2011 lanzó su versión móvil, que ofrece como un servicio más. En abril de 2014 se anunció el que será el sustituto de WorldCat Local, WorldCat Library Services.

\subsubsection{Desarrollos propios}

Algunas bibliotecas prefieren desarrollar sus propias interfaces para dispositivos móviles en lugar de contratar este servicio. Las razones que esgrimen son el ahorro económico y las opciones de personalización que el software comercial no suele contemplar. Para que esto sea posible es imprescindible tener acceso a los datos del catálogo en formatos legibles por ordenador. Hay tres formas de acceder a estos datos a través de la interfaz móvil, según explica Haefele (2013): a través de una API (siempre y cuando el software lo permita), mediante la técnica del screen scraping o a través de los feeds de sindicación. Una opción más es PHPYAZ ${ }^{34}$, un producto que puede poner los datos en un formato usable desde un Z39.50 (Haefele, 2011).

Una API (Application Programming Interface) es «un conjunto de funciones que un programa informático pone a disposición de otros programas para que puedan comunicarse directamente.» (Yee, 2008). Las API permiten acceder a los datos y funciones de los sistemas de automatización, haciendo más independiente a la biblioteca del proveedor. Ex libris, Innovative Interfaces, SirsiDynix, VTLS, Polaris, Koha y Evergreen son algunos de los sistemas integrados de bibliotecas que ofrecen API (Breeding, 2009). Programas como WorldCat, Symphony, Sierra o el japonés Kariru han registrado sus APIs en la lista de Programmable Web ${ }^{35}$.

\footnotetext{
${ }^{34}$ http://www.indexdata.com/phpyaz

35 http://www.programmableweb.com/news/49-library-apis-librarything-worldcat-search-andbookshare/2012/11/06
} 
Disponer de una API facilita enormemente el trabajo, puesto implica contar con documentación detallada.

El uso de la API es el sistema empleado por la Universidad Rice (Galvin y Sun, 2011). Gracias a los web services que Symphony lanzó en 2010 crearon una interfaz móvil utilizando SOAP, un protocolo http para el intercambio de información entre servicios web. Esta interfaz no solo permite la consulta del catálogo, sino también el acceso a la cuenta de usuario para realizar renovaciones y otras gestiones del préstamo.

En el marco del proyecto MACON (Mobilising Academic Content Online) del JISC, en colaboración con EBSCO, se desarrolló una interfaz móvil personalizado para la herramienta de descubrimiento de esta empresa gracias a su API (Mills, 2012).
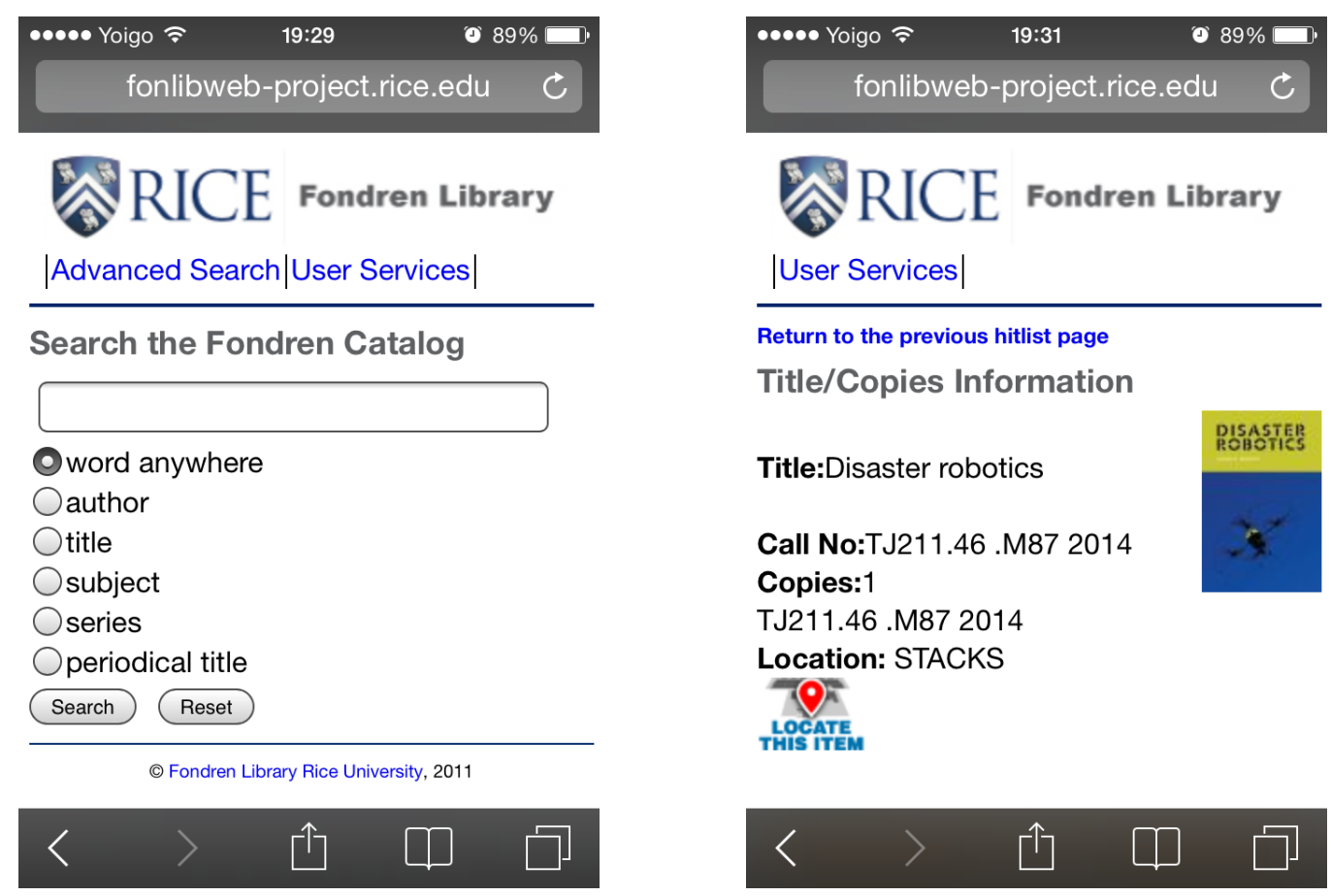

Figura 10. Catálogo de la Biblioteca Fondren, Rice University (Estados Unidos).

Las técnicas de screen scraping permiten capturar datos de sitios web. Es la solución adoptada por las bibliotecas de la Universidad de Texas (Broussard, Zhou y Lease, 2010) y de la Universitat Politècnica de Catalunya. Según explican Benítez, et al. (2011), el contenido del catálogo, que funciona gracias al software Millennium de Innovative Interfaces, es extraído diariamente mediante técnicas de minería de datos y se vuelca a una base de datos MySQL. Es a esta base de datos a la que interrogan los usuarios del catálogo móvil. 
Ejemplo de uso de feeds de sindicación es Endeca, una capa de descubrimiento que funciona sobre el software del catálogo, que produce feeds en formato XML con los resultados del catálogo y pueden servir como base para una nueva interfaz. Este es el sistema que han utilizado las bibliotecas de la Universidad de Toronto (Gayhart, Khalid y Belray, 2014) y la North Carolina State University.

Esta última, la North Carolina State University, desarrolló en 2007 la plataforma CatalogWS ${ }^{36}$ (Sierra, Ryan y Wust, 2007) con el fin de facilitar la creación de nuevas interfaces del catálogo. Funcionaba sobre el índice de la capa de Endeca y fue implementado como una API REST. Las peticiones se procesaban a través del protocolo HTTP GET y las respuestas se devuelven como en formato XML o en RSS. Como resultado se obtuvo MobiLib, un catálogo básico que permite la búsqueda por título, autor, palabra clave e ISBN. Este catálogo ha sido posteriormente renovado con una interfaz más moderna.

La app para iPhone desarrollada para la Biblioteca de la Universidad de Cornell (Estados Unidos) coincide con el lanzamiento de la API de Voyager 7, que viene en forma de servicios web XML, por lo que lo aprovechan para incluir la consulta en el catálogo desde la app (Connolly, Cosgrave y Krkoska, 2011).

Algunos desarrolladores de interfaces móviles comparten su trabajo bajo licencias de código abierto para que otras bibliotecas puedan utilizarlo. Algunos de los resultados son:

- MobileCat, una interfaz desarrollada por el consorcio Tri-College Libraries (que incluye a los colleges de Bryn Mawr, Haverford y Swarthmore) para los catálogos web de Innovative Interfaces. Está escrito en PHP y se distribuye bajo licencia GNU GPL v3.

- Tom Pasley, del Universal College of Learning in New Zealand, desarrolló en 2010 una interfaz que adapta el catálogo WebVoyage, el modulo OPAC web de Voyager. Está escrito en Perl y se distribuye bajo licencia BSD.

- Mango/Endeca es una interfaz para el catálogo Endeca que utilizan las 11 bibliotecas de la Florida State University. El catálogo es producido por una combinación del software comercial Endeca y una aplicación web llamada Mango, que desarrolló el Florida Center for Library Automation. Incluye una versión para móviles.

- Xerxes es una aplicación para una interfaz de usuario que permite personalizar herramientas como Metalib, Solr, Summon, Primo Central, Ebsco Discovery y Worldcat. Fue desarrollado por David Walker, de la

\footnotetext{
${ }^{36}$ La API de CatalogWS está registrada en Programmable Web http://www.programmableweb.com/api/catalogws
} 
California State University, y Johnathan Rochkind, de la John Hopkins University. Lo utilizan unas cuarenta instituciones en todo el mundo. La última versión, la 2.0, se encuentra compartida bajo licencia GNU GPL v3.

\subsubsection{Funciones del catálogo móvil}

Los contenidos y funciones que deben ofrecer los sitios web para dispositivos móviles han sido discutidos ampliamente en la bibliografía, como ya se explicó en el apartado 2.2.2. Sin embargo, las funciones y contenidos que debe incluir el catálogo móvil no parecen despertar el mismo interés, pues no se ha encontrado ningún trabajo que las analice.

Un vistazo rápido a diferentes catálogos móviles permite afirmar que las funciones que incorporan pueden ser muy variadas. Los más sencillos ofrecen la búsqueda, algunos incluso con opciones avanzadas y limitadores; otros además permiten acceder a la cuenta de usuario para consultar los libros en préstamo, realizar reservas, consultar las multas o renovar préstamos. El proceso de búsqueda se despliega normalmente en tres pasos: casilla de búsqueda, listado de resultados y vista de cada registro (Hegarty y Wusteman, 2011). Entre las opciones que se incluyen están la búsqueda avanzada, la localización de los registros (a través de la signatura, la biblioteca en que se encuentra o incluso en un mapa de planta), compartirlos a través de medios sociales, por correo electrónico o de otras formas y guardar los resultados en un espacio personalizado. Estas opciones serán analizadas en detalle en la investigación que se aborda en la tercera parte de la presente tesis doctoral.

En un ejercicio de benchmarking como paso previo a la creación del catálogo móvil de la Universidad de Texas, Broussard, Zhou y Lease (2010) analizaron diez apps de catálogos de otras bibliotecas. Los parámetros que observaron son: casilla y botón de búsqueda (que incluían todos los catálogos analizados), opciones de tipo de búsqueda ( 8 de 10), autor y título (todos), imagen de portada (3 de 10), estado del libro (9 de cada 10), signatura y localización (todos) y escaneado (uno de diez).

Chickering y Yang (2014) analizaron las herramientas de descubrimiento de varias bibliotecas en Estados Unidos para conocer las características más utilizadas: AquaBrowser, Axiell Arena, BiblioCommons, EBSCO Discovery Service, Encore, Endeca, Primo, Summon, Visualizer, VuFind, Worldcat Local, Blacklight, SirsiDynix Enterprise y eXtensible Catalog. Tan solo las tres últimas herramientas no incluían interfaz móvil separada (se entiende que se refieren a una versión móvil con páginas diferenciadas). Eso no implica, según los autores, que algunas de las bibliotecas analizadas en el experimento tuvieran una interfaz móvil. A título personal, se ha accedido a los catálogos de las bibliotecas analizadas por 
Chickering y Yang y se ha hallado que solo cuatro de las siete que utilizan Blacklight tiene una interfaz móvil. El ratio desciende a una de cinco con eXtensible Catalog (la demo y otro enlace no funcionan) y a cero en Enterprise.

Desde luego, el estudio de estos autores resulta confuso, especialmente por la diferencia que establecen entre «interfaz móvil», que definen como una versión simplificada de la herramienta optimizada para su uso en teléfonos móviles, y «compatible con móviles», que implica que un sitio web puede ser visto y usado en un dispositivo móvil.

Especial interés cobran aquellos catálogos que hacen uso de las características únicas de los dispositivos móviles, como la cámara o la geolocalización. Para ello las apps son una vía más potente que la web, pues permiten aprovechar estas funciones. Una solución que están adoptando cada vez más catálogos móviles es la posibilidad de buscar un libro escaneando un código de barras. Esta función puede tener interés para los usuarios que están en una librería, por ejemplo, y quieren comprobar si el libro que acaban de encontrar está disponible en su biblioteca.

El escaneado de códigos de barras se incluye en la app para Android de la Biblioteca de la Universidad de Texas (Broussard, Zhou y Lease, 2010). Estos autores señalan la necesidad de averiguar en futuras investigaciones si merece la pena desarrollar estas funciones o no. Sin embargo, McCarthy y Wilson (2011) consideran difícil medir el éxito de este tipo de utilidades a partir de las estadísticas de las tiendas de aplicaciones, que sólo indican el número de veces que una app ha sido instalada y desinstalada, pero no cuántas veces ha sido instalada. Una solución, que funciona en el caso de aplicaciones híbridas, está en medir las estadísticas de uso de las páginas web que se visitan, pero esto no diferencia las visitas web de las visitas que se realizan a través de la app y no incluiría el uso de la función de escaneado.

McCarthy y Wilson explican además con todo detalle cómo implementar esta utilidad en una aplicación nativa a partir de su experiencia con la aplicación nativa de la Biblioteca y Archivos de la Ryerson University, además de un lector de códigos QR como complemento. Otras utilidades de la lectura de códigos de barras podrían ser las auto-devoluciones (Broussard, Zhou y Lease, 2010) o la introducción del carné de usuario, que ahorraría tener que teclear un código de varios dígitos. Biblio USAL, la app de la biblioteca de la Universidad de Salamanca, incluye esta función (Merlo-Vega, 2012).

La función de lectura de códigos ha sido implementada también en el sitio web móvil de la University of North Carolina at Chapel Hill (Haefele, 2013). Sin embargo, como desde la web no se puede hacer uso directamente de la cámara de fotos del dispositivo, se ha implementado un paso adicional. Así, cuando alguien 
activa la opción de lectura de código de barras desde el sitio web, se llama a una app de escaneado - como pic2shop o Barcode Scanner-, que debe estar previamente instalada en el dispositivo. La página web obtiene automáticamente el código del libro tras el escaneado y devuelve el resultado de la búsqueda en la base de datos. Este proceso resulta un tanto engorroso para una función cuyo principal interés está en la rapidez.
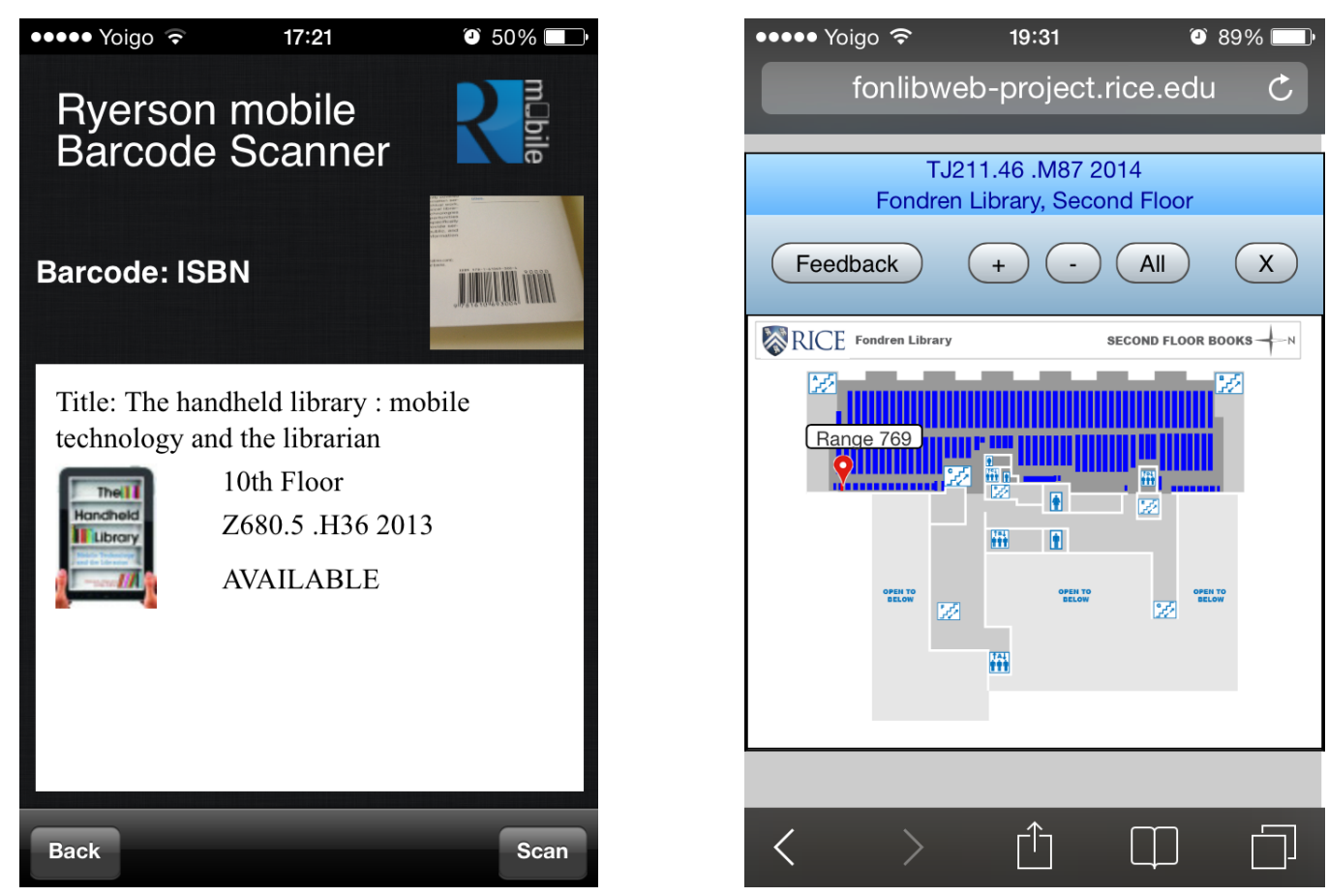

Figura 11. Resultado del escaneado del código de barras en un libro en la aplicación nativa de la Ryerson University (izquierda) y localización de los registros de la biblioteca de la Rice University en el mapa (derecha).

Algunas aplicaciones relacionadas con los libros ya utilizan el escaneado de códigos de barras. Las redes sociales de recomendación de lecturas Anobii y GoodReads lo utilizan en sus apps para obtener las opiniones de otros sobre un libro concreto, un dato que puede ser de gran utilidad en el momento de compra. Aplicaciones de compra como ShopSavvy permiten comparar los precios de un producto, que puede ser un libro o cualquier otro artículo a la venta, en varias tiendas en línea.

La geolocalización cobra un sentido especial en el catálogo, pues permite ofrecer información sobre cuál es la biblioteca más cercana en la que encuentra un documento concreto, incluso obteniendo la ruta hasta el lugar. Catálogos móviles 
como el de la Biblioteca de la Universidad de Oxford (Reino Unido), que puede consultarse a través de la web, ya la incorporan.

La localización de un libro dentro del espacio de la biblioteca constituye todo un reto, puesto que las técnicas de geolocalización en interiores no están aún avanzadas. La solución a este problema se ha encontrado por el momento indicando la localización en un mapa de planta en la biblioteca en cada uno de los registros del catálogo. Son varias las bibliotecas que incorporan esta función. Una de ellas es la biblioteca de la Rice University (figura 11). La Biblioteca de la Universitat Politècnica de Catalunya desarrolló una aplicación para mostrar la ubicación de cada documento en el catálogo en un plano de la biblioteca (SerranoMuñoz, et al., 2010). Esta aplicación ha sido aprovechada para la versión móvil, desde donde también se puede visualizar ese mapa.

Teniendo en cuenta estas funciones, se adivinan grandes posibilidades para las bibliotecas en lo que se ha dado en llamar SoLoMo (social, local y móvil). Una combinación de los datos del catálogo de las bibliotecas de una zona con los catálogos de librerías permitiría al usuario disponer de información rápida para localizar un libro determinado. El escaneado de códigos de barras contribuiría a hacer más rápida la búsqueda y la geolocalización permitiría averiguar cuál es el lugar más cercano donde encontrarlo (local). El componente social vendría dado por las opiniones de los usuarios.

\subsubsection{Líneas de investigación sobre catálogos móviles}

Muy poco se ha investigado sobre el uso del catálogo móvil, a pesar de la necesidad de conocer el comportamiento de los usuarios al consultarlo para mejorar el servicio. ¿Qué buscan los usuarios? ¿Cómo formulan las búsquedas? ¿En qué se diferencian del catálogo para grandes pantallas? (Song, et al., 2013). Estas preguntas bien podrían trasladarse al catálogo móvil.

Murakami y Kanata (2008) analizaron los ficheros log -que contienen las estadísticas de uso- del catálogo móvil de la Universidad de la Ciudad de Osaka (Japón) en 2005 para conocer qué tipo de búsquedas realizan sus usuarios desde el móvil y encontraron que la media de términos que se introducen en cada búsqueda era de 1,4 (el 92,2\% de las búsquedas solo utilizan un término). El número de términos introducidos se asemejaba al de otras búsquedas web y motores de búsqueda móviles. La media de caracteres introducidos en cada interrogación era de 6,5 con espacios y 6,1 sin espacios, siendo la búsqueda más larga en japonés de 22 caracteres y de 32 en otros idiomas. Las búsquedas más cortas fueron de un solo carácter. Hay que tener en cuenta que este estudio se realizó con el japonés como idioma principal y que se sus caracteres son silábicos, a diferencia del inglés 
o el español, donde cada carácter representa a una letra.

Como paso previo al desarrollo de una app que funcione a modo de interfaz de descubrimiento, la Biblioteca Regional Yellowhead (Canadá) analizó el uso que se hacía de su catálogo (Zylstra, 2011). A partir de esos datos concluyeron que la búsqueda avanzada se utilizaba muy poco, en el $4 \%$ de las búsquedas, mientras que la sencilla se utilizaba en el $96 \%$ restante de los casos. La cuenta de usuario era muy popular. Aquellas opciones que no tenían relación con la búsqueda o la cuenta de usuario apenas se utilizaban, por lo que se puede decir que los usuarios buscaban cosas muy concretas.

A falta de más información sobre cómo buscan los usuarios en el catálogo se pueden obtener algunas pistas a través de los estudios sobre los motores de búsqueda, salvando las diferencias. Al contrario de lo que se podría pensar teniendo en cuenta las limitaciones de entrada de datos de los dispositivos móviles, estudios recientes aseguran que los usuarios de motores de búsqueda utilizan más términos y letras desde el móvil y desde la tableta que desde el ordenador de sobremesa (Song, et al., 2013), como se puede apreciar en la tabla 5. Estos resultados, similares a los de estudios anteriores, rebaten la idea de que la entrada de datos es costosa al usuario.

\begin{tabular}{lrrr} 
& Móvil (iPhone) & Tableta (iPad) & Ordenador \\
\hline $\mathrm{N}^{\circ}$ de palabras & 3,05 & 2,88 & 2,73 \\
\hline $\mathrm{N}^{\circ}$ de caracteres & 18,93 & 18,02 & 17,44 \\
\hline
\end{tabular}

Tabla 5. Longitud de las búsquedas desde smartphones, tabletas y ordenador. Fuente: Song, et al. (2013).

Las búsquedas desde el ordenador se realizaron especialmente entre las 8:00 de la mañana y las 17:00 horas, mientras que el pico desde el móvil era entre las 18:00 y las 22:00 horas. Quienes buscaban desde el smartphone eran más susceptibles de hacerlo fuera de sus localidades de origen que quienes utilizaban una tableta: el $43 \%$ de los usuarios de móviles buscaban desde su lugar de origen, mientras que el ratio era del $79 \%$ en las tabletas. Los autores revelaron además que los patrones de búsqueda desde dispositivos móviles evolucionan con el tiempo. Sobre las búsquedas desde móviles, pero desde el punto de vista de la alfabetización informacional, se volverá en el apartado 2.9.4.

Otra línea de investigación sobre el catálogo móvil está en los estudios de usabilidad. Samuel Liston (2009) realizó un sencillo experimento en el que analizaba cómo se veían tres catálogos de proveedores diferentes (SirsiDynix, 
Innovative Interfaces y Aquabrowser) en tres dispositivos diferentes (Windows Mobile, BlackBerry y iPhone). El que mejores resultados dio fue el catálogo de SirsiDynix, mientras que el Aquabrowser no funcionaba correctamente en dispositivos Windows ni BlackBerry. En cuanto a dispositivos, los mejores resultados se obtuvieron desde el iPhone, los peores desde BlackBerry. Este tipo de estudios ha quedado superado porque los actuales smartphones están optimizados para la navegación.

Desde la biblioteca de la University of Illinois at Urbana-Champaign, Josh Bishoff realizó un test de usabilidad para comprobar el funcionamiento de la versión móvil de la web de la biblioteca desde un iPod Touch. Uno de los resultados que obtuvo es que los títulos en la lista de resultados deberían tener un mayor espacio alrededor para evitar el efecto fatfinger (Guajardo, 2011). El mismo problema fue señalado por Hegarty y Wusteman (2011).

Los estudios sobre el comportamiento de los usuarios ante el catálogo, señala Pianos (2012), indican que estos quieren una interfaz de búsqueda fácil de utilizar que haga sugerencias y tolere los errores tipográficos en las búsquedas; lo que quieren es una respuesta satisfactoria y el acceso fácil al documento. Quizás el futuro de los catálogos pase, como sugiere Jingru (2013), por búsquedas por voz y limitación de los resultados basándose en la localización. Esta última opción permitiría al usuario obtener los resultados relacionados con el lugar en el que se encuentra, como se ha investigado en la app de la Biblioteca Nacional de Noruega para Android, en la que se probó a incorporar un botón con esta función (Jingru, 2013).

En definitiva, la investigación sobre catálogos móviles es escasa, a pesar de que es necesario conocer más sobre lo que los usuarios necesitan y su comportamiento. Esto se vuelve imprescindible para las bibliotecas a la hora de valorar una solución de movilidad para el catálogo.

\subsubsection{Otros contenidos y servicios de la biblioteca}

El catálogo no es el único recurso de información que ofrece la biblioteca. El ecosistema se completa con bases de datos y revistas electrónicas, repositorios plataformas de préstamo de libros electrónicos y otros espacios. ¿Cómo se ven los contenidos que la biblioteca oferta a través de estos espacios desde diferentes dispositivos móviles? ¿Están adaptados para quienes acceden desde un smartphone o una tableta? 
En lo referente al acceso desde dispositivos móviles a los documentos que la biblioteca sirve, entran en juego por lo tanto varias cuestiones: el acceso a la plataforma para descargar el documento, que el formato sea compatible con el dispositivo y que el documento sea legible de forma fácil y cómoda.

\subsubsection{Las interfaces}

Son varias las bases de datos de proveedores que incluyen una interfaz específica para dispositivos móviles: EBSCOhost, IEEEXplore, PubMed, Scopus, Science Direct, JSTOR, arXiv. Algunas bibliotecas incluyen en sus sitios web listados de bases de datos para smartphones. Spires (2008) denunció que la mayor parte de las bibliotecas (68\%) no adquirirían bases de datos específicas para móviles, tan solo el 18\% aseguraba comprar contenidos específicos, mientras que un 14\% no lo sabía. Posiblemente la situación haya cambiado desde entonces, pues cada vez son más los proveedores que ofrecen soluciones móviles.

Tay (2011) realizó, desde un punto de vista crítico, una comparación de las interfaces para smartphones de varias bases de datos. De su descripción se desprenden algunas limitaciones, quizás derivadas del recorte de funciones. La mayor parte de estas bases de datos ofrecen una única casilla de búsqueda por palabras clave o por varios campos. No suelen ofrecer la posibilidad de ordenar los resultados, sino que utilizan una opción por defecto. Tampoco suelen ofertar opciones para refinar la búsqueda ni para expandirla. EBSCOhost permite hacer clic en cada materia, autor o fuente del registro y recuperar los resultados que lo incluyen.

La base de datos de Emerald es un buen ejemplo de cómo superar estas limitaciones. En un menú lateral incluye varias opciones de búsqueda y descubrimiento, incluida la posibilidad de limitar una búsqueda realizada. Además es posible personalizar la página de inicio con contenidos específicos.

Una utilidad fundamental desde un dispositivo móvil, señala Tay, es el envío de un registro a través del correo electrónico o de otro sistema para acceder después desde el ordenador. Algunas bases de datos, como Scopus o Nature, permiten además compartirlos en medios sociales, incluso en redes sociales académicas o agregarlos a gestores de referencias.

Una cuestión peliaguda, según Tay, es si las bases de datos deben presentarse en forma de app o a través de la web. Las apps tienen la ventaja de que permiten enviar alertas a través de notificaciones push y que disponen de espacios personalizados para que el usuario guarde registros o búsquedas sin necesidad de introducir sus datos de acceso. Algunos proveedores optan por las aplicaciones 
nativas para la consulta de sus bases de datos, mientras que otros permiten la consulta solo desde la web. También hay quienes ofrecen las dos opciones.

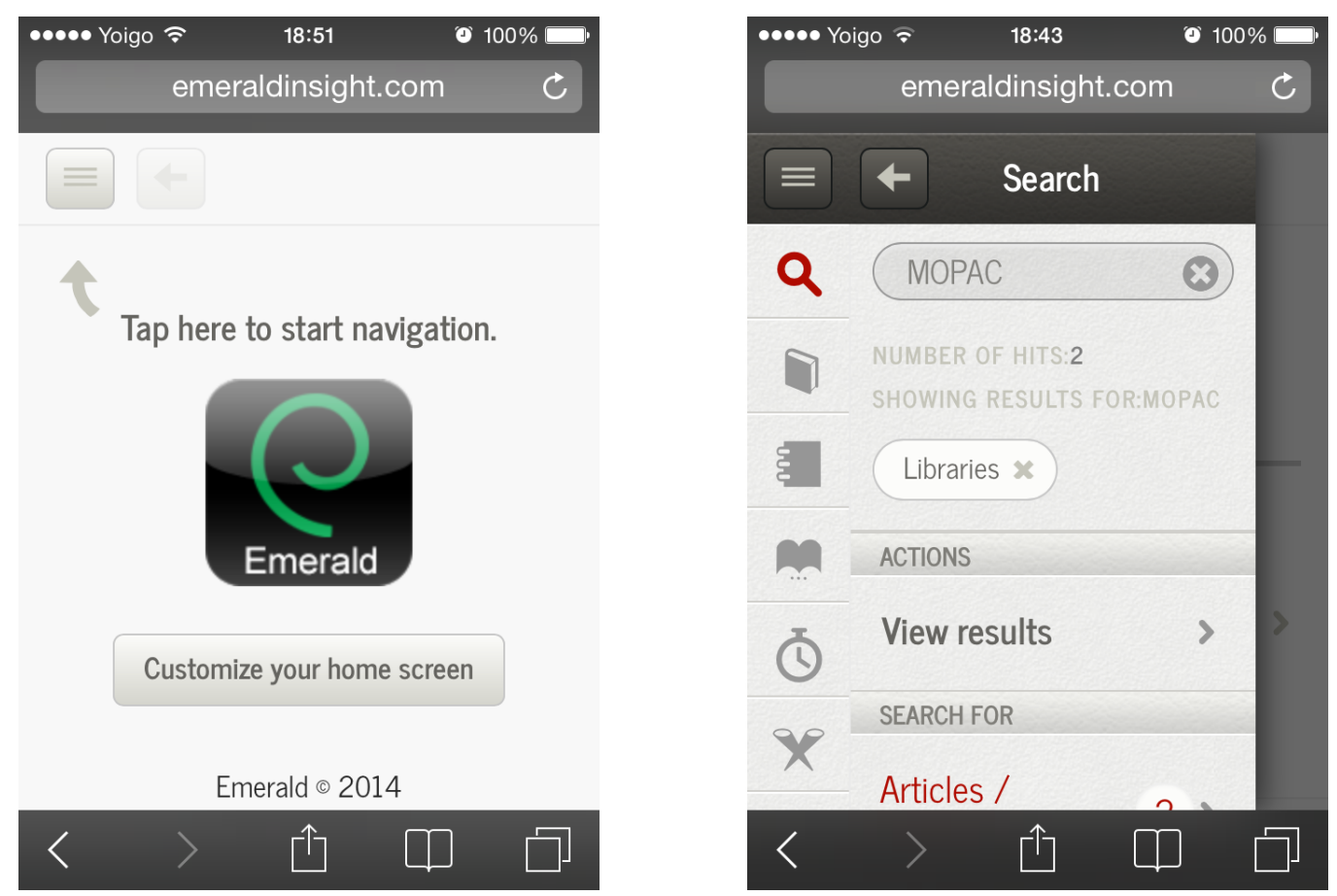

Figura 12. Opciones de personalización y búsqueda en la base de datos de Emerald.

Francoeur (2011) expresa su preferencia por la web en lo que a bases de datos comerciales se refiere por varios motivos: las apps necesitan ser descargadas previamente y no funcionan en todos los sistemas operativos, por lo que algunos usuarios no tendrán acceso. Por otra parte, la identificación puede ser engorrosa.

Uno de los problemas que plantean estas bases de datos, que se agravan desde el móvil, es el acceso. Los sistemas que utilizan los proveedores pueden resultar complicados para el usuario incluso desde un ordenador, pues en ocasiones es necesario haber configurado previamente el proxy y hay que introducir los datos de acceso cada vez que la sesión expira. Esto puede conducir a desistir desde un smartphone.

Con este problema se encontraron en el desarrollo de la app de la biblioteca de la Cornell University. El sistema de autenticación, CUWebAuth, no estaba disponible un formulario en versión móvil para introducir los datos ni era posible almacenar los datos de acceso del usuario en las opciones de configuración de la app, según explican Connolly, Cosgrave y Krkoska (2011). Para evitar que el usuario tuviera que introducir los datos de acceso cada vez que entrara, se utilizó un sistema para 
identificar al usuario la primera vez y la recordara en las siguientes. Sin embargo, este sistema no resultó satisfactorio.

Hegarty y Wusteman (2011) realizaron un estudio de usabilidad sobre la base de datos EBSCOhost Mobile. A pesar del buen funcionamiento que demostraba en cuestiones de facilidad de aprendizaje, navegación y de ser bien puntuada en cuanto a su estética, algunas funciones, como el envío de registros por correo electrónico, no eran tan intuitivas para el usuario, lo que conllevaba un mayor tiempo de dedicación. Esto podría solucionarse con un mejor diseño de la interfaz. Sin embargo, las bibliotecas no tienen apenas control sobre el diseño de las bases de datos comerciales y se hace prácticamente imposible integrarlas dentro de la estética de los recursos de la biblioteca.

Muy diferente es el caso de los repositorios. Benítez, et al. (2011) explican cómo diseñaron la versión para móviles del Repositorio UPC Commons de la Biblioteca de la Universitat Politécnica de Catalunya, basado en el software DSpace. Los datos son importados a través del protocolo OAI-PMH.

\subsubsection{Formatos y acceso a los contenidos}

¿Cómo se ven los contenidos que oferta la biblioteca desde diferentes dispositivos móviles? ¿Cómo se ven los libros electrónicos, los artículos que se descargan desde los servicios a los que se suscribe la biblioteca o los documentos que se publican en el sitio web? ¿Existen limitaciones técnicas o de legibilidad?

Lippincott ya señalaba en 2008 la necesidad de ofrecer formatos accesibles para móviles (ePub o mp3, por ejemplo). Algunos estudios han analizado las restricciones a la hora de consultar los contenidos de las bibliotecas desde dispositivos móviles. La investigación llevada a cabo por Lisa C. Thomas (2009) concluyó que al $84 \%$ de la colección de libros electrónicos de la Yale University (Estados Unidos), con aproximadamente un millón, se podía acceder al menos desde un dispositivo móvil, el iPod Touch. Sin embargo, solo el 24\% de la colección era accesible a través de lectores de libros electrónicos (Amazon Kindle 2.0, Sony Reader PRS-500 y iRex iLiad), aunque requerían métodos adicionales o pasos intermedios, como incorporarlo al dispositivo a través del ordenador. Para el estudio seleccionó los cuatro dispositivos citados y una lista de proveedores de contenidos científicos, para después probar su uso en cada dispositivo, anotó si se podía acceder o no (formato y accesibilidad de la plataforma) y, en caso afirmativo, si se podía leer correctamente (usabilidad).

En un estudio realizado en la biblioteca de la University of Birmingham, Anderson y Andrews (2011) demostraron que los contenidos de la biblioteca no se veían 
correctamente desde algunos dispositivos. Coincidiendo con los resultados de Thomas (2009), el iPod Touch demostró ser el dispositivo más adecuado para el acceso a los contenidos de la biblioteca, gracias a la aplicación iBooks, junto con el netbook, que realmente es un ordenador de menor tamaño. Sin embargo, el Kindle presentaba varios problemas con los pdf: no permitía ampliar el tamaño de letra y la pantalla era demasiado pequeña.

Además, desde los lectores de libros electrónicos resultaba imposible descargar directamente los artículos científicos porque no tenían navegador para acceder a la plataforma, era necesario descargarlos a un ordenador primero y pasarlos al lector después. Finalmente, el acceso desde el smartphone Palm Treo era frustrante al navegar por la plataforma debido a la pantalla pequeña y la conexión lenta. Estos autores señalaron la importancia de poder descargar directamente el documento desde el dispositivo y la necesidad de unirse para solicitar a los proveedores contenidos más flexibles.

El proyecto MACON (Mobilising Academic Content Online) del JISC, en funcionamiento entre el 1 de noviembre de 2011 y el 1 de agosto de 2012, puso de manifiesto las dificultades con las que se encuentran las bibliotecas para ofrecer contenidos académicos de calidad a los usuarios de dispositivos móviles. La mayor parte de las revistas ofertan sus artículos en formato pdf, un formato que está diseñado para pantallas grandes o para ser impreso $\mathrm{y}$, aunque no presenta incompatibilidades técnicas, resulta incómodo para la lectura en una pantalla pequeña. Sin embargo, algunos editores comienzan a publicar en formato ePub, que se adapta a cualquier pantalla y es óptimo para ser leído desde cualquier dispositivo, como complemento al pdf (Polanka, 2014). Otro de los resultados de este proyecto es un conjunto de herramientas ${ }^{37}$ para fomentar las buenas prácticas, en el que se incluye información sobre los formatos para dispositivos móviles, sobre usabilidad y otros recursos.

Las bibliotecas están tomando consciencia de la importancia de contar con servicios y contenidos móviles. El Horizon Report 2014 Library Edition señala esta prioridad como una de las tendencias a corto plazo (uno o dos años) para las bibliotecas académicas (Johnson, et al., 2014). Pero no todo el peso debe recaer sobre los fabricantes de dispositivos o de los proveedores, sino que hay que tener también en cuenta si los documentos que se producen desde la propia biblioteca están disponibles en formatos que, como el ePub, se adaptan a la pantalla de cualquier dispositivo (Arroyo-Vázquez, 2013b).

${ }^{37}$ http://www.open.ac.uk/blogs/macon/toolkit/ 
Las bibliotecas públicas se enfrentan a una cuestión diferente: las restricciones que el mercado está imponiendo a los contenidos digitales. Muchos de los contenidos que prestan en papel no están disponibles en formato digital. En ocasiones los editores incluyen un período de embargo, por lo que los usuarios no pueden tomar en préstamo las novedades en formato digital, aunque sí en papel. Los DRM son otra de las limitaciones que se impone a los formatos digitales.

\subsubsection{El avance de los sitios web para móviles en bibliotecas}

¿Cuántas bibliotecas han desarrollado alguna iniciativa relacionada con la movilidad? ¿Qué porcentaje tiene una versión de su sitio web para smartphones o tabletas o ha creado una app? Estas cuestiones se han abordado en varios trabajos de investigación, dirigidos a ámbitos y áreas geográficas determinadas, con resultados difícilmente comparables entre sí, puesto que no hay consenso en cuanto al tipo de servicios móviles de la biblioteca, pero también porque miden realidades diferentes: bibliotecas públicas, especializadas o de otro tipo en áreas geográficas distintas.

El primer trabajo conocido que intenta dar solución a esta pregunta es el de Spires (2008), en el que el 59\% de los entrevistados afirmaban que el sitio web de su biblioteca no contaba con una versión específica para dispositivos móviles. El 15\% respondió de manera afirmativa y un porcentaje significativo, el $26 \%$, respondió que lo desconocía. De las respuestas afirmativas, tres se referían al catálogo y siete al sitio web. La mayor parte de las bibliotecas en las que declaraban tener usuarios de dispositivos móviles no se adquirían bases de datos específicas para móviles (68\%). Sólo el 18\% aseguraba adquirir contenidos específicos para móviles y el $14 \%$ afirmaba no saberlo.

La encuesta realizada por Spires fue respondida por 776 bibliotecarios estadounidenses, sobre todo procedentes de bibliotecas universitarias, pero también de públicas y otros tipos, en el verano de 2007. Teniendo en cuenta que la unidad de respuesta era el bibliotecario, y no cada una de las bibliotecas, no se pueden utilizar para explicar la realidad de forma precisa. Esto implica, como señalan Ashford y Zeigen (2012b), que podría haber más de una respuesta por cada biblioteca.

Esta misma limitación presenta el trabajo de Dalton, et al. (2012). En el marco del proyecto del Joint Information Systems Committee (JISC), M-Library Community Support Project, se distribuyeron dos encuestas, la primera entre noviembre de 2011 y enero de 2012 y la segunda entre julio y agosto de 2012. De ellas se 
obtuvieron 188 respuestas en la primera ronda, procedentes de bibliotecarios de todo tipo y de diferentes países, aunque la mayoría procedían del Reino Unido y trabajaban en bibliotecas universitarias.

En esta primera ronda el 63\% de los bibliotecarios entrevistados afirmaban llevar a cabo alguna iniciativa relacionada con la movilidad, entendiéndose como tales un amplio abanico: catálogo móvil, sitio web móvil, códigos QR, apoyo a los usuarios en el uso de sitios web y apps, aplicación nativa de la biblioteca, app institucional, uso de dispositivos móviles para el personal de la biblioteca, préstamo de dispositivos móviles y comunicación vía SMS con el usuario. Desgraciadamente, ni este trabajo ni el de Alcock y Dalton (2012), que publican los mismos resultados, ofrecen datos sobre el número de usos de cada uno de estos servicios. Sí queda patente la intención de poner en marcha proyectos relacionados con la movilidad (90,4\% de las respuestas).

Aldrich (2010) examinó en 2010 los sitios web de las 111 bibliotecas en Norte América que formaban entonces parte de la Association of Research Libraries (ARL) y detectó que el 21,6\% tenían un sitio web diseñado para móviles. Además de ellas, el 13,5\% de las universidades tenían un sitio web para móviles.

Un estudio similar realizaron Canuel y Crichton (2011) sobre las bibliotecas de Canadá. En él descubrieron que, de las 95 bibliotecas miembros de la Association of Universities and Colleges of Canada (AUCC), 13 tenían presencia específica para móviles $(13,7 \%)$. Resultados más detallados identifican 8 bibliotecas con sitio web para móviles (8,3\%), 2 bibliotecas con app $(2,1 \%)$ y 3 con web y app $(3,2 \%)$.

En esa misma línea, Rebecca Jackson (2013) analizó 99 bibliotecas académicas en Estados Unidos con el objetivo de identificar cuántas tenían un sitio web diseñado para smartphones y los contenidos que presentaban. Según sus datos, el $84 \%$ de las bibliotecas analizadas tenían una versión para smartphones de su sitio web en 2012 (no se especifica el mes). Si se comparan estos datos con los de estudios anteriores se deduce que se ha producido un claro crecimiento en las iniciativas relacionadas con la movilidad en las bibliotecas universitarias estadounidenses entre los años 2011 y 2012.

Yee (2012) entrevistó en 2010 a los 39 miembros del Council of Australian University Librarians (CAUL), con el fin de determinar qué iniciativas de movilidad se están desarrollando en las bibliotecas universitarias australianas y de Nueva Zelanda. Las 23 respuestas recibidas (58,97\%) reportan un 43,5\% de catálogos móviles y la intención por parte del resto de implementar este servicio en los próximos 5 años. Tres universidades permitían la reserva de salas desde el móvil y eran $15(65,2 \%)$ las que anunciaban no tener intención de ofrecer este servicio en el futuro. Además, una universidad permitía reservar ordenadores desde el móvil y 
8 bibliotecas $(34,8 \%)$ planeaban introducir servicio de referencia a través del móvil. No se informa en este trabajo sobre la existencia de sitios web diseñados para dispositivos móviles.

De forma general, se han encontrado más trabajos sobre bibliotecas universitarias que sobre públicas. En este ámbito se circunscribe la ya mencionada encuesta de Ashford y Zeigen (2012a), realizada a 126 bibliotecarios de 80 bibliotecas públicas de los estados de Oregon, Washington e Idaho en enero 2012. Los resultados obtenidos son los siguientes: el 40,9\% aseguraba ofrecer versión móvil del catálogo, el 32,3\% sitio web móvil, el 25,8\% servicio de referencia a través de mensajería o SMS, y el 18,3\% otros servicios (libros electrónicos, mensajería de texto para informar sobre los límites del préstamo, enlaces a bases de datos con interfaces móviles). El 39\% no ofrecía ningún servicio móvil.

En un estudio paralelo a los bibliotecarios universitarios en esos tres estados, los mismos autores encontraron que el $52,7 \%$ ofrecía una versión móvil del sitio web, el 48,6\% del catálogo, el 37,8\% asistencia a través de SMS o mensajería de texto, el $17,6 \%$ otros servicios (enlaces a bases de datos, por ejemplo). El 31,1\% no ofrecía ningún servicio móvil, un porcentaje menor que en las bibliotecas públicas de la misma zona geográfica (Ashford y Zeigen, 2012b).

Kim (2013) señala que la lista que recopila el Wiki Library Success ${ }^{38}$, con sitios web e interfaces de catálogos diseñados para dispositivos móviles en bibliotecas, pasó de los 40 en 2010, que contabilizó Tay (2010a), a 130 en 2013. Aunque este listado no es exhaustivo, estos datos son un claro indicador en el número de iniciativas durante estos años.

\begin{tabular}{lrrrr} 
& $\begin{array}{c}\text { Algún } \\
\text { servicio }\end{array}$ & \multicolumn{1}{c}{ Sitio web } & \multicolumn{1}{c}{$\begin{array}{c}\text { Aplicación } \\
\text { nativa }\end{array}$} & $\begin{array}{c}\text { Diseño } \\
\text { adaptativo }\end{array}$ \\
\hline 500.000 o más & $75 \%$ & $41 \%$ & $60 \%$ & $1 \%$ \\
\hline De 100.000 a 499.999 & $62 \%$ & $23 \%$ & $52 \%$ & $0 \%$ \\
\hline De 25.000 a 99.999 & $59 \%$ & $25 \%$ & $48 \%$ & $3 \%$ \\
\hline De 10.000 a 24.999 & $33 \%$ & $20 \%$ & $19 \%$ & $5 \%$ \\
\hline Menos de 10.000 & $17 \%$ & $14 \%$ & $2 \%$ & $2 \%$ \\
\hline
\end{tabular}

Tabla 6. Porcentaje de bibliotecas públicas con algún servicio para dispositivos móviles por tramos de población. Elaboración propia a partir de los datos de Wanucha y Hofschire (2013).

${ }^{38}$ http://www.libsuccess.org/index.php?title=M-Libraries 
Wanucha y Hofschire (2013) realizaron en 2012 una encuesta a una muestra de bibliotecas públicas en municipios de 499.999 habitantes o menos, a las que se suman las 83 bibliotecas en municipios de 500.000 habitantes o más en Estados Unidos. Los datos publicados muestran las diferencias entre bibliotecas más pequeñas y más grandes en la adopción de la tecnología móvil. Como se observa en la tabla 6, entre el 17\% y el 75\% de las bibliotecas públicas estadounidenses, según el tramo de población, tenían en 2012 una versión para móviles de su sitio web, una app o incorporaban diseño adaptativo. Estos datos ha crecido considerablemente con respecto a 2010.

El último estudio de este tipo del que se tiene noticia es Survey of Policies to Assure Mobile Device Access to the Library Website, publicado por Primary Research Group en 2014. Consiste en una encuesta a 60 bibliotecas públicas, universitarias y especializadas en Estados Unidos y otros países sobre las iniciativas relacionadas con la movilidad que han llevado a cabo. De sus respuestas se desprende que una cuarta parte $(25,4 \%)$ ha desarrollado diferentes versiones de su sitio web para dispositivos móviles. En el caso de las bibliotecas universitarias $(38,5 \%)$ este ratio es ligeramente mayor que en las públicas (25,8\%). Y también parece más habitual en las bibliotecas grandes que en las más pequeñas: el 42,1\% de las bibliotecas con más de treinta empleados dispone de versión móvil, mientras que en las de entre 7 y 30 empleados se reduce al 25,0\% y en las de menos de siete al 10,0\%. Son aún menos las bibliotecas que han creado una aplicación nativa, el 11,9\%.

En España, Pérez y Torn (2009) encuestaron a las bibliotecas integradas en la Red de Bibliotecas Universitarias (REBIUN) durante los meses de abril y mayo de 2009. De las 71 bibliotecas que formaban entonces parte de la Red se obtuvo respuesta de 63. De ellas, 18 ofrecían algún servicio accesible desde dispositivos móviles: servicios relacionados con el préstamo, como renovaciones o reservas $(22,2 \%)$, servicios de información (15,9\%), acceso al OPAC $(9,5 \%)$ o textos electrónicos accesibles $(1,6 \%)$. Además, otras 18 bibliotecas se estaban planteando nuevas iniciativas $(28,6 \%)$.

Serrano-Muñoz (2013) avanzó los resultados de una encuesta realizada entre diciembre de 2012 y abril de 2013 en el marco de la línea 3 de REBIUN, que trabaja para potenciar el desarrollo y el uso de la Biblioteca digital 2.0, internet y las redes sociales. De las bibliotecas universitarias que enviaron respuesta (51,39\%), 15 habían desarrollado alguna iniciativa relacionada con la movilidad (el 40,5\% de las que han respondido), lo que significa que tenían una versión para móviles del sitio web (13) o una app. Los servicios que proporcionaban a través de los sitios web eran información (todas), acceso al OPAC (84,6\%), a bases de datos (92,3\%), o realizar algún tipo de interacción o trámite $(69,2 \%)$. Los altos porcentajes que se 
obtuvieron en este trabajo llevan a pensar que quienes no respondieron lo hicieron porque no disponían de ningún servicio relacionado con la movilidad.

Los datos de Serrano-Muñoz y Pérez y Torn recogen aspectos diferentes y su representatividad también difiere, por lo que hay que ser cautelosos a la hora de comparar los resultados. Son los únicos trabajos de este tipo de los que se tiene noticia en España, por lo que se puede afirmar que existe un gran desconocimiento del panorama de la movilidad en este país, especialmente en el ámbito de las bibliotecas públicas. Por ello es necesario realizar nuevos estudios, más actuales y que cubran diferentes ámbitos, que lleven a conocer el estado de nuestro país y de otros en cuanto al uso de dispositivos móviles en las bibliotecas. Se hace también necesario un consenso a la hora de realizar este tipo de estudios, de manera que se midan los mismos parámetros y variables con el fin de que sean comparables.

\subsection{Aplicaciones nativas}

El uso de dispositivos móviles en bibliotecas no es reciente, pero sí lo es el interés por las aplicaciones nativas, que se originó tras el lanzamiento de la tienda de aplicaciones de Apple y la posterior popularidad del modelo de aplicaciones. Las apps se han consolidado como un canal más para ofertar contenidos y servicios desde las bibliotecas, pero también como una herramienta para los bibliotecarios. A pesar de que antes de las tiendas de apps también existía la posibilidad de crear aplicaciones para dispositivos móviles, no se conoce ninguna desarrollada entonces por bibliotecas, por lo que se puede afirmar que el factor de difusión de las tiendas de aplicaciones ha sido el detonante de esta relación. La primera app de bibliotecas fue District of Columbia Public Library (Estados Unidos), cuya primera versión data del 8 de enero de 2009 y que sirve para la consulta del catálogo (Bridges, Rempel y Griggs, 2010).

El Horizon Report 2014, Library Edition, señala a las apps como uno de los desarrollos más importantes en el ámbito tecnológico a corto plazo, en uno o dos años (Johnson, et al., 2014). Lo cierto es que el número de apps de bibliotecas ha crecido en los últimos años: según recoge Pianos (2012), en junio de 2010 HansBodo Pohla contabilizó 36 apps de bibliotecas para iPhone, una para BlackBerry y 11 para Android. Solo diez meses más tarde, en abril de 2011, encontró unas 100 apps. Como se explicará en el trabajo de investigación en el marco de la presente tesis doctoral, hoy son muchas más. 
A diferencia de países como Estados Unidos, donde las apps en bibliotecas están ampliamente extendidas, en España son aún una novedad. Tras una exhaustiva búsqueda, se han localizado las siguientes apps creadas exclusivamente por y para bibliotecas en España. Sobre ellas se hablará con más detalle en la tercera parte de esta tesis doctoral, correspondiente al trabajo de investigación.

1. Siete apps de bibliotecas universitarias, en las universidades de Salamanca, Burgos, Cádiz, de A Coruña, UNED, Autónoma de Barcelona y Valladolid. Esta última es de reciente creación, está en la App Store desde junio de 2014.

2. Otras siete en bibliotecas públicas: DeCuentos, del Centro Internacional del Libro Infantil y Juvenil, Biblioteques del Maresme, Xarxa de Biblioteques Municipals de Barcelona, Biblioteca Comarcal Jaume Vila de Mollerussa, Liburutegiak, de la Red de Lectura Pública de Euskadi y Bibliotecas de Navarra.

3. Otros tipos de bibliotecas: BNE 300 años, de la Biblioteca Nacional, y Biblioteca FM, de la Fundación Mapfre.

La bibliografía profesional internacional no ha quedado indiferente a las aplicaciones nativas, ya sea para compartir experiencias de desarrollo de apps desde la biblioteca (Connolly, Cosgrave y Krkoska; McCarthy y Wilson; Morris y Davis, 2011; Merlo-Vega, 2012), seleccionar apps para algún colectivo o con una utilidad concreta (Besara, 2012), reflexionar sobre su oportunidad (Kraft, 2010; Benítez, et al., 2011; Wong, 2012) o ayudar a enfrentarse a ellas (La Counte; Clark, 2012a). Al igual que sucedía en el campo de la web móvil en bibliotecas, este grupo de publicaciones tiene hasta el momento un marcado carácter divulgativo, con varios artículos en los que se explican los pros y los contras de la creación de apps y cómo abordar ese proceso. También se pueden encontrar numerosos textos con experiencias, que se irán mencionando en los siguiente párrafos. Apenas hay trabajos de investigación que valoren cómo están funcionando las apps en bibliotecas, si están teniendo éxito y qué uso hacen de ellas sus destinatarios. Los datos que se comparten hasta el momento sobre los resultados obtenidos por las apps en bibliotecas son escasos y se producen a título individual.

¿Qué uso están haciendo las bibliotecas de las aplicaciones nativas? Son varias las dimensiones a explorar para responder a esta cuestión: creación, selección y utilización. La primera hace referencia a las aplicaciones creadas por bibliotecas, la segunda a la recomendación de aplicaciones nativas para los usuarios y la tercera al uso para fines profesionales por parte del personal bibliotecario. En los siguientes apartados se explorarán estas tres orientaciones. 


\subsubsection{Aplicaciones nativas versus aplicaciones web}

Al igual que en el entorno de los desarrolladores web y de apps, en bibliotecas una de las cuestiones más recurrentes en la bibliografía es si crear un sitio web o una app como medio para mostrar contenidos y servicios en las bibliotecas. Sin embargo, solo se han tratado los pros y los contras desde un punto de vista externo, reproduciendo los mismos motivos que se esgrimen en el entorno del desarrollo web, pero nunca preguntando al usuario o analizando los datos de uso. Se recogen en este apartado los pros y los contras para escoger una u otra solución según refleja la bibliografía en el ámbito bibliotecario.

El carácter universal de la web, que se puede consultar desde el navegador de cualquier dispositivo, el uso de un lenguaje conocido por los bibliotecarios, una actualización más fácil de los contenidos - que no requiere el beneplácito de la tienda de aplicaciones y que por lo tanto se agiliza la introducción de posteriores mejoras- son las razones de peso para decantarse por la web. Además, optar por crear un sitio web tiene la ventaja de que se puede testar su usabilidad más fácilmente, incluso desde un ordenador (Wisniewski, 2011). Uno de los motivos con mayor peso es que los sitios web son indexados por los motores de búsqueda, y por lo tanto si un usuario busca información sobre la biblioteca en Google u otro buscador desde el móvil llegará a la web de la biblioteca, y no a la app.

Lo restringido de las apps, que funcionan en una única plataforma, es una cuestión de importancia en bibliotecas, que deben prestar acceso universal a la información (Clark, 2012a). Además, la cosa se complica con los diferentes kits de desarrollo de software que emplea cada plataforma (Charland y Leroux, 2011). Por otra parte, las apps tienen la ventaja de que se integran mejor con el entorno del dispositivo móvil y por lo tanto se gana en usabilidad, según han demostrado Nielsen y Budiu (2013). Para Wisniewski (2011), el usuario debe acordarse del URL, abrir el navegador, teclearlo y esperar a que cargue la página, y todo esto es ajeno al desarrollador, mientras que en una app solo hay que hacer clic. Sin embargo, Wisniewski olvida que la app debe haber sido instalada previamente, lo que también requiere una acción por parte del usuario.

Determinadas funciones del dispositivo solo pueden ser empleadas desde una aplicación nativa, y no desde una página web, como las notificaciones push o la cámara de fotos, por ejemplo. También permiten el uso de bases de bases datos locales, como la agenda de contactos. Al contrario, el desarrollo de apps es más costoso, requieren lenguajes de programación con los que los bibliotecarios están menos familiarizados y funcionan en sistemas operativos concretos, dejando a un lado a un sector de los usuarios. 
Una de las ventajas de las apps es que se sitúan directamente en un acceso directo desde el escritorio, haciendo que el proceso de abrirlas para utilizarlas sea más rápido. Para paliar esta limitación, algunos sitios web para móviles de bibliotecas invitan al usuario a que añada un enlace directo, como hace la biblioteca de la Rice University, que explica en una página de su sitio web móvil cómo hacerlo ${ }^{39}$.

A la luz de la bibliografía, dos son los motivos que están seduciendo a los bibliotecarios para crear apps: que están de moda y que las tiendas de aplicaciones actúan como escaparate (Iglesias y Meesangnil; Wisniewski; Wong, 2011). Además, tienen la ventaja de que hay montones para escoger y que son poco costosas (Johnson, et al., 2014). «Los usuarios de la biblioteca se podrían sentir emocionados cuando les digas que pueden descargar una app de la biblioteca desde la App Store», algo que no sucedería con acceder al sitio web de la biblioteca, sugieren Iglesias y Meesangnil (2011).

Es difícil creer en el efecto escaparate de las tiendas de aplicaciones cuando en ellas hay más de un millón de apps. Wong (2011) constata el poder de promoción que ejerce la App Store, pues durante el siguiente mes al lanzamiento de la aplicación HKBUtube, creada por la biblioteca de la Hong Kong Baptist University, consiguió casi el mismo número de visitas que su sitio web. Incluso durante unos días las visitas desde la app fueron más, y piensan que se debe a que durante esos días la app estaba en algunos de los listados generados por la App Store, como Release Date o Top Free, algo que es fácil al principio. El número de visitas descendió cuando la aplicación dejó de estar en esos listados.

Así, el efecto marketing no se genera solo por estar en la tienda, sino por estar en las listas, y es muy difícil mantener a una app durante más tiempo en estos listados, ante la gran cantidad de aplicaciones nuevas y la feroz competencia. Incluso en los listados por categorías las tiendas de aplicaciones solo muestran las 200 primeras apps de cada categoría. Esto supone que solo si alguien busca esa app concretamente la recuperará. Por lo tanto el efecto marketing no es tal e incluso el descubrimiento de una app concreta es difícil. De ahí que la promoción por parte de la biblioteca sea esencial.

Una de las cuestiones a tener en cuenta por las bibliotecas es la integración de apps o sitios web para móviles con otros desarrollos. Las bibliotecas suelen prestar servicios a través de diferentes plataformas de distintos proveedores. Esto genera una gran dispersión de los recursos y servicios que presta la biblioteca. Así, una cuestión a tener en cuenta en los dispositivos móviles es la de presentar los diferentes recursos de una manera unificada, integrando a unos con otros. En la

${ }^{39} \underline{\text { http://m.library.rice.edu }}$ 
web esto se soluciona de forma sencilla mediante enlaces, pero en el entorno móvil no es sencillo enlazar desde un sitio web a una app, porque debe ser previamente instalada. Con este problema se encontraron en la biblioteca del National Institute of Education (NIE), en Hong Kong, donde debieron abandonar la idea de desarrollar un sitio web para móviles porque no se integraba con la aplicación BookMyne, que se configuraba como la mejor solución de movilidad para el catálogo (Wong, 2013).

Kraft (2010) recomienda evitar caer en la «locura» desatada por las apps. La cuestión está en qué aportan estas aplicaciones frente a la web. ¿Merece la pena la inversión que supone una app si lo mismo se puede hacer desde una página web? Haefele (2013) se muestra a favor de las aplicaciones web, especialmente para el catálogo, porque no requiere uso de hardware especial. Es una solución más «realista y útil». También Serrano-Muñoz (2014) se muestra a favor de la web, por su carácter universal.

Posiblemente la solución a la discusión sobre si escoger apps o web se resuelva encontrando un espacio para cada una. La cuestión no es si poner los contenidos en una $a p p$ o en un sitio web, sino qué quiero hacer y cuál es la mejor tecnología para ello. 0 incluso a qué público me quiero dirigir. El debate sobre si crear un sitio web adaptado para móviles y/o una app desde la biblioteca, suficientemente debatido en la bibliografía, debe plantearse desde un nuevo punto de vista: ¿para qué crear una aplicación? ¿Qué funciones de los dispositivos móviles pueden ser explotadas desde las bibliotecas para facilitar el trabajo a bibliotecarios y usuarios? En este texto se han presentado aplicaciones exploradas hasta el momento, como el escaneado de códigos de barras o la publicación de fondos patrimoniales no solo textuales. El reto ahora está en encontrar nuevos usos.

\subsubsection{Creación de aplicaciones nativas en bibliotecas}

Si hace unos años se planteaba la cuestión sobre para qué plataformas crear apps desde la biblioteca - Chudnov (2010) se pregunta si para Apple o Android y si no sería una pérdida de tiempo desarrollar para una única plataforma-, hoy parece evidente que al menos hay que realizar una versión para Android y otra para Apple por ser las más extendidas, con diferencia. Hay que tener en cuenta que cada plataforma adicional encarecerá el proyecto, por lo que es preciso valorar si servirá a un gran número de personas.

La mayor parte de los autores aporta ayuda técnica sobre cómo abordar la creación de una app, de un sitio web para móviles o adaptar el catálogo. Sin 
embargo, pocos son los que establecen el proceso a seguir a la hora de poner en marcha un proyecto de movilidad. Clark (2012a) establece varias etapas:

- Definir la audiencia e investigar el mercado. En primer lugar hay que conocer quiénes serán los usuarios de la $a p p$, y una vez conocida la audiencia hay que investigar sus necesidades a través de conversaciones informales, encuestas, tests de usabilidad, análisis de las estadísticas u otros métodos.

- Definir la principal razón del proyecto. Esto servirá para comunicarle al personal de la biblioteca por qué este proyecto merece la pena.

- Establecer el principal objetivo del proyecto, definiendo su alcance y sus límites. Se trata de responder a la cuestión de para qué va a servir la app o sitio web.

- Hacer un esquema de los requerimientos del proyecto y de las entregas. Con ello se pretende definir cuál será el resultado final, de la manera más precisa posible. Entre los requerimientos se debe especificar los requisitos técnicos (qué lenguajes de programación utilizará y a qué plataformas móviles estará dirigido), requisitos de marca, rutinas de mantenimiento y actualización y reuniones para hacer un seguimiento del trabajo durante la marcha del proyecto.

- Definir un grupo de trabajo que se encargue de ponerlo en marcha, especificando los diferentes roles de cada persona.

- Establecer fechas para el desarrollo de las tareas, definiendo lo que hay que hacer y las estimaciones de tiempo que conllevarán.

«En el caso de los servicios de información, la app debe ser la extensión de estos servicios, que sirva como instrumento para la gestión de demandas de información $\mathrm{y}$, a su vez, sea una herramienta para resolver las necesidades de los usuarios a través de tecnología móvil.» Estas palabras de Lara-Navarra, Serradell y Maniega (2014) dejan clara su visión sobre cómo debe ser la aplicación de una biblioteca, pero también puntualizan que se debe evitar incluir en ellas todos los contenidos y servicios de la biblioteca, seleccionando solo aquellos que tengan un «alto valor añadido para el usuario».

La creación de apps supone un paso extra para las bibliotecas (La Counte, 2012). Lo específico de los lenguajes de desarrollo requiere personal especializado, un perfil poco común en nuestras bibliotecas. Por eso abordar la creación de una app puede ser un proceso más costoso y son muchas las bibliotecas que optan por contratarlo a una empresa externa.

Las apps han demostrado además su capacidad para generar un modelo de negocio, y eso también se ha trasladado al ámbito bibliotecario, con la aparición de nuevas empresas o áreas de ellas dedicadas a la creación de aplicaciones para 
bibliotecas. En Estados Unidos la empresa Boopsie se ha especializado en la creación de apps para bibliotecas y es una de las soluciones más populares, con unas 2.500 aplicaciones creadas hasta el momento, según señalan Johnson, et al. (2014). Si bien las opciones de personalización que oferta esta empresa son limitadas, puesto que se facilita una serie de plantillas entre las que escoger, supone un ahorro de esfuerzo para la biblioteca y el coste se considera moderado (Johnstone, 2011).

El proceso de crear una app con Boopsie, según explica Johnstone (2011), es el siguiente: la empresa proporciona una serie de plantillas y la biblioteca se encarga de detallar el contenido y la navegación de la app. A partir de ellos, la empresa crea la aplicación y envía una previsualización a la biblioteca, para que pueda ver los resultados y realizar las modificaciones que considere oportunas. Finalmente, la biblioteca debe también encargarse de proporcionar las imágenes y los contenidos para la descripción de la app en la tienda de aplicaciones. Además de los contenidos, es posible incluir la consulta al catálogo, con la posibilidad de consultarlo escaneando un código de barras, el uso de las opciones de geolocalización para detectar la biblioteca más cercana y opciones para compartir en medios sociales. El proceso de integración del catálogo es la parte más compleja, pues la biblioteca debe proporcionar a la empresa un fichero MARC con los datos planos del catálogo y un data set que Boopsie indexa para la búsqueda, según explica Johnstone.

La ventaja de contratar a una empresa es que se cuenta con personal especializado y con experiencia y los resultados serán más profesionales, además del considerable ahorro de tiempo. Por el contrario, el coste se encarecerá. No se encuentran en la bibliografía referencias al gasto que conlleva poner en marcha una app, a excepción de Forsyth (2011), quien indica que pueden ser de entre 10.000 y 60.000 dólares por app. Esta cantidad puede variar en función del país, de la empresa a la que se encargue y de la complejidad que entrañe la propia app. A ella habrá que sumar los costes de mantenimiento y las posteriores actualizaciones.

En España son dos las empresas que especializadas en desarrollo de apps para bibliotecas que se conocen: Swets e ICAlia Solutions. Swets se ha aliado $^{40}$ con Obture CODE - la empresa desarrolladora de la app BiblioUSAL de la Biblioteca de la Universidad de Salamanca y posteriormente de la app Biblio UVAL, de la Universidad de Valladolid-para ofertar el servicio Swets Apps Service. Tras la

${ }^{40} \underline{\text { http://obturecode.com/es/blog/swets-apps-service-powered-by-obture-code/ }}$ 
noticia de la bancarrota de Swets ${ }^{41}$ se desconoce si este servicio sigue prestándose. ICAlia Solutions ofrece Librantia ${ }^{42}$, una plataforma para la creación de apps, utilizada en el desarrollo de Liburutegiak, de la Red de Lectura del País Vasco.

Otra opción para abordar la creación de una aplicación nativa es contar con estudiantes. Las bibliotecas de universidades con titulaciones relacionadas con la informática pueden ofrecer a los estudiantes la posibilidad de desarrollar prácticas o trabajos de clase cuya finalidad sea la creación de una app para la biblioteca. En este sentido cabe reseñar la experiencia de la biblioteca de la Cornell University, que contó con los alumnos de la asignatura de ingeniería del software para crear una app de la biblioteca para iPhone/iPod Touch. Los estudiantes debían desarrollar al final del semestre un proyecto y se ofreció a algunos que consistiera en la creación de esta app (Connolly, Cosgrave y Krkoska, 2011). En la Burritt Library en la Connecticut State University también optaron por esta solución (Iglesias y Meesangnil, 2011).

La ventaja de esta solución está en que el gasto se reduce considerablemente, pero por el contrario queda desatendido el posterior mantenimiento de la app, ya que los estudiantes, una vez finalizado el proyecto, no tienen motivos para seguir actualizándolo. Y hacer que se encargue una persona nueva, que no ha participado previamente, puede suponer un problema si el proyecto no ha sido bien documentado. Si lo ha sido, la nueva persona dedicaría mucho tiempo a entender cómo funciona, explican Connolly, Cosgrave y Krkoska (2011). La solución que se dio en la Cornell University fue contratar después a uno de los estudiantes que había participado en el desarrollo de la app para que se encargara del mantenimiento.

Otra forma de colaboración con los estudiantes es a través de competiciones. La biblioteca de la University of Illinois at Urbana-Champaign ${ }^{43}$ ha utilizado este sistema, además de contar con alumnos de clases específicas, en la creación de su aplicación Minrva. El diseño modular de esta app permite ampliar nuevos módulos para sumar nuevas funciones sin modificar los anteriores (Hahn y Ryckman, 2012). Esto permite que se trate de un proyecto colaborativo. Los concursos son una buena solución para obtener ideas, mientras que las becas o los convenios con estudiantes de determinadas asignaturas facilitan el desarrollo de las tareas, opinan Hahn y Ward (2013).

\footnotetext{
${ }^{41}$ https://twitter.com/SwetsGlobal/status/525604527186407424

42 http://www.librantia.com

${ }^{43}$ http://www.library.illinois.edu/nlg student apps
} 
Una opción poco frecuente es la colaboración con empresas externas. Esta fue la vía para el desarrollo de la aplicación de la British Library 19th Century Collection. Un convenio con Microsoft, que se encargó de la digitalización de los fondos, y con BiblioLabs, que corrió con los costes de desarrollo, marketing y mantenimiento, supuso un gran ahorro para la biblioteca, que no necesitó invertir presupuesto ni recursos técnicos al proyecto y tuvo la oportunidad de participar en el diseño (Morris y Davis, 2011).

Desde luego, la opción ideal es contar con personal en la biblioteca que pueda encargarse del desarrollo de la app. Sin embargo, no es habitual que el personal de la biblioteca tenga conocimientos de desarrollo de apps. Los servicios web para la creación de apps hacen posible que el propio personal de la biblioteca pueda abordar esta tarea sin necesidad de conocimientos especializados de programación. Estos servicios tienen siempre algún coste, aunque suele ser bastante menor que el de contratar a una empresa. Por una lado, presentan la ventaja de que el control del desarrollo queda de parte del equipo de la biblioteca, así como las futuras actualizaciones, sin necesidad de intermediarios. Además del evidente ahorro económico que suponen.

Por el contrario, una de sus desventajas de estos servicios reside en la personalización, como señalan Carnerero y Bages (2012), puesto que en ocasiones las opciones son muy limitadas. El tiempo que se debe dedicar es mayor, ya que requiere una etapa de selección de la herramienta - algunas de ellas son App Inventor, Mobincube, Nimbo y Apps Bar-, probando diferentes opciones antes de tomar una decisión. Por otra parte, no se dispone de profesionales que asesoren en cuestiones de diseño y usabilidad, por lo que a menudo los resultados son menos profesionales. A pesar de las evidentes limitaciones de esta opción, puede ser adecuada si se desean resultados sencillos. En España destaca la app de las Bibliotecas de Navarra como exponente de esta solución.

\subsubsection{Utilidades de las aplicaciones nativas en bibliotecas}

¿Para qué sirven las apps en bibliotecas? ¿Cuáles son las funciones que se están incluyendo? Son muchas las que reproducen los contenidos y funciones del sitio web, con información básica sobre horarios, datos de contacto y localización, noticias, sobre los servicios que presta la biblioteca o la consulta al catálogo, entre otros. Se trata de apps gratuitas pero que, en algunos casos, tienen utilidades exclusivas para los usuarios de la biblioteca a las que se accede con contraseña, como la gestión del préstamo (renovaciones, reservas, etc.) o la consulta de los datos de usuario. 
A diferencia de lo que sucede con los sitios web para móviles, sobre los que las bibliotecas han realizado varios estudios para averiguar qué contenidos y servicios pueden ser de utilidad para los usuarios, no existen apenas trabajos publicados sobre apps. ¿Se asume quizás que los mismos contenidos del sitio web para móviles pueden ser trasladados a la app? ¿Esperan lo mismo los usuarios de las apps que de los sitios web?

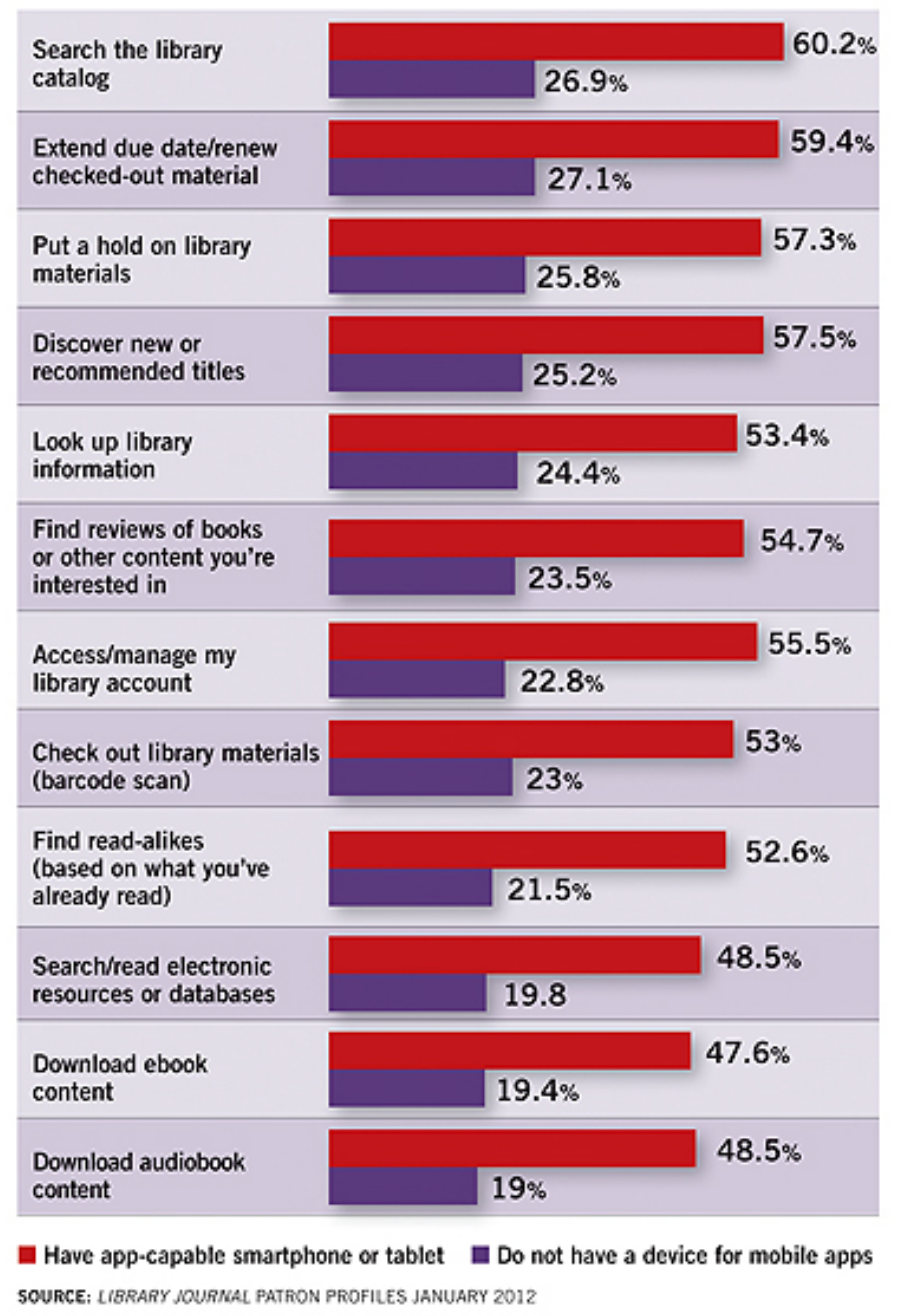

Figura 13. Expectativas de los usuarios para las aplicaciones nativas de las bibliotecas. Fuente: Library Journal Patron Profiles (Rapp, 2012).

Los resultados de una encuesta llevada a cabo por Library Journal a más de 2.000 usuarios de bibliotecas en Estados Unidos identifican las siguientes preferencias en las apps de la biblioteca entre los propietarios de smartphones: la búsqueda en el catálogo $(60,2 \%)$, renovaciones $(59,4 \%)$, reservas $(59,4 \%)$, nuevos títulos $(57,5 \%)$, buscar información de la biblioteca $(53,4 \%)$, encontrar revisiones de 
libros $(54,7 \%)$ y acceder a la cuenta de la biblioteca (55,5\%), entre otros (Rapp, 2012). Como se puede comprobar, los contenidos y servicios son muy similares a los de los sitios web de la biblioteca. Quizás buscar los materiales de la biblioteca escaneando del código de barras y las sugerencias de lectura, al estilo de Amazon, son las utilidades que marcan la diferencia. El citado trabajo revela que, aunque los deseos de aquellos usuarios que no poseen un smartphone son muy similares, sus expectativas son inferiores a las de quienes sí lo poseen.

Se especifican en los siguientes apartados otros tipos de aplicaciones nativas que se pueden encontrar en bibliotecas, a la luz de la bibliografía y haciendo hincapié en algunas de las más significativas por su originalidad.

\subsubsection{El catálogo}

La búsqueda en el catálogo es una de las funciones que se ha trasladado a las aplicaciones nativas. Algunas, como las apps de Boopsie, la integran junto con otras funciones como el sitio web de la biblioteca. Otras, como la de la Biblioteca Nacional de Australia, están dedicadas exclusivamente a la consulta del catálogo. Estos catálogos son muy similares a los que se presentan como aplicaciones web, puesto que son bases de datos con la información bibliográfica básica que pueda necesitar alguien en una situación de movilidad.

Una de las primeras apps para la consulta del catálogo fue la desarrollada por Boopsie para WorldCat en 2009. Hace uso del GPS y mapas para conectar a los usuarios con la biblioteca más cercana al lugar en que se encuentran (Hadro, 2009) y opciones de redes sociales (Johnstone, 2011).

La Yellowhead Regional Library planteó la creación de una app para iPad como solución ante el problema de la dispersión de los espacios virtuales de la biblioteca (Zylstra, 2011). A través de ella se ofrece una interfaz de descubrimiento que realiza búsquedas en las diferentes herramientas de la biblioteca gracias a la API. Como resultado, se vieron incrementados los préstamos en los jóvenes entre 12 y 15 años.

La descarga del documento completo es una de las utilidades más demandadas por los usuarios. La aplicación MobileRead ha sido diseñada para la lectura de documentos electrónicos. El acceso a algunos de esos documentos requiere introducir el número de carné de usuario, pero otros no. El préstamo de libros electrónicos se realiza a través de aplicaciones como Overdrive Media Console desde los dispositivos móviles, pero no es frecuente que sea la propia biblioteca quien introduzca la descarga de contenidos como una utilidad de sus aplicaciones. 
EconBiz constituye otro ejemplo de interfaz de búsqueda a través de dispositivos móviles. En este caso se trata de una base de datos especializada en un área concreta - ciencias empresariales y económicas-, que accede directamente al buscador Lucene/sorl gracias a la API disponible en el verano de 2012. Además de la búsqueda se incluye un mapa con bibliotecas que tienen colecciones sobre el tema y permite la descarga en pdf de los documentos a texto completo (Pianos, 2014).

Una de las ventajas de especial interés para el catálogo que presentan las apps es la posibilidad de crear un espacio personalizado para el usuario sin necesidad de tener una cuenta de la biblioteca. En este espacio se pueden guardar búsquedas o registros concretos que después se pueden recuperar. Según explica Vatter (2011), la aplicación EDsync ${ }^{44}$, creada por Martin Kim Dung-Pham, recuerda al usuario cuándo deben realizar las devoluciones, permite visualizar el estado de los préstamos y se puede ver en un mapa la ubicación de la biblioteca en la que se ha realizado el préstamo. Los préstamos se pueden ampliar con una sola pulsación de un botón. Utiliza un sistema de VoiceOver para que la gente con discapacidad pueda escuchar. También se pueden ver los cargos por los préstamos retrasados.

\subsubsection{Aplicaciones de utilidad patrimonial}

Mostrar documentos que forman parte de las colecciones bibliotecarias bajo un hilo conductor es otra de las utilidades para las apps que han explorado las bibliotecas. Para Morris y Davis (2011), la habilidad de compartir colecciones seleccionadas de materiales originales no necesariamente textuales (imágenes, sonidos y otros medios) y que hace unos años no se podían distribuir fácilmente es una clara oportunidad para las bibliotecas. Estos autores explican brevemente la experiencia de desarrollo de la app 19th Century Collection, de la British Library. Supuso un importante esfuerzo de curación de contenidos y permite mostrar fondos que no se pueden consultar de otra manera en línea. Además, ofrece un servicio de curación de fondos in app (dentro de la aplicación). Aunque hay algunos ejemplares de prueba, el acceso completo a los 60.000 títulos de la colección implica el pago una tasa de 79,99 euros in app, que van destinadas al mantenimiento del servicio, según se indica en la propia aplicación (figura 14).

Espectaculares son las aplicaciones para iPad de la New York Public Library, en esta misma línea. Biblion: World's Fair realiza un recorrido por la colección sobre la Exposición Internacional de 1939 en Nueva York y Biblion: Frankenstein contiene una recopilación de documentación sobre ese personaje. Con un inmenso volumen

\footnotetext{
${ }^{44}$ https://itunes.apple.com/de/app/edsync/id383008918?mt=8
} 
de material fotográfico, carteles, grabados, manuscritos, notas de prensa, telegramas o informes, entre otros. Estas apps constituyen un buen ejemplo de cómo aprovechar las capacidades del dispositivo.

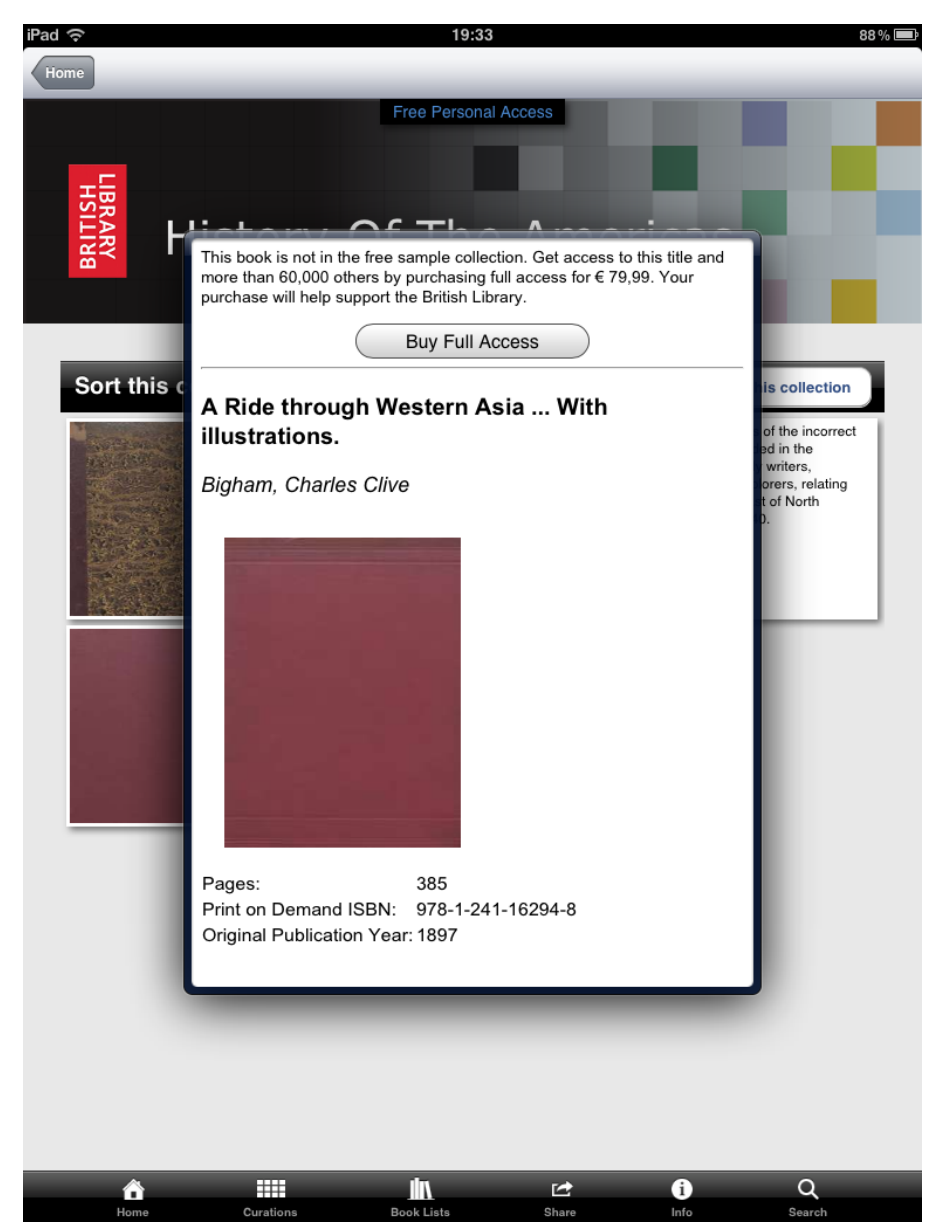

Figura 14. Opciones de pago en la app 19th Century Collection, de la British Library.

La Biblioteca Nacional de España publicó a finales de 2011 una aplicación para iPhone y Android en la que se muestran 50 obras emblemáticas de la exposición Biblioteca Nacional de España: 300 años haciendo historia, junto con comentarios, bibliografía y localización. Además, BNE 300 Años —así se llama la aplicaciónincluye información de utilidad práctica para visitar la exposición (plano, fechas y horarios, localización y varios enlaces a otros recursos de su web sobre la exposición) y una selección de fotografías históricas del edificio de la Biblioteca Nacional. 


\subsubsection{Geolocalización y escaneado de códigos de barras}

Washburn (2011) señala la importancia de tener en cuenta el contexto de movilidad a la hora de desarrollar aplicaciones nativas para bibliotecas, preguntarse si las apps tienen sentido en ese contexto móvil; eso puede clarificar su características. Arroyo-Vázquez (2012c) y Lara-Navarra, Serradell y Maniega (2014) coinciden en que no basta con trasladar los contenidos de la web, sino que las bibliotecas deben aprovechar las funciones únicas de los dispositivos móviles. Espacios personalizados, uso de la geolocalización y escaneado de códigos de barras se alían para mejorar los servicios tradicionales de las bibliotecas.

La ubicación de bibliotecas en el mapa, con el fin de facilitar información de contacto y localización de las más cercanas a la posición del usuario, es una de las utilidades más evidentes. Puede encontrarse sola, que es lo más habitual, o en combinación con otras funciones. Es el caso de Local Books, la aplicación de LibraryThing que permite encontrar bibliotecas, pero también otros equipamientos como librerías y ferias del libro. Además de publicar fondos fotográficos patrimoniales, la aplicación WolfWalk, desarrollada por la Biblioteca de la North Carolina State University, hace uso de la geolocalización para situar en un mapa del campus fotografías históricas, dotándolas así de un contexto (Sierra y Casden, 2011).

Ya se ha mencionado con anterioridad la capacidad de escaneado de los dispositivos móviles para realizar búsquedas en el catálogo y otras funciones. Así, gracias a la aplicación RedLaser es posible capturar el código de barras de un libro y obtener información sobre su precio en varias tiendas en línea y otras físicas que se encuentran más cerca al lugar en que nos encontremos, detalles y opiniones sobre la obra. La aplicación LibAnywhere, creada por LibraryThing en versiones para iPhone y Android, que sirve para dar soporte al catálogo y sitio web para móviles, incluye la función de escaneado de código de barras. En ella el resultado de la búsqueda es la información bibliográfica del libro y la identificación de los documentos en las bibliotecas más cercanas y en una tienda online. Bibliotecas como la de la Ryerson University (Canadá) también están incorporando en el catálogo esta opción de escaneado (McCarthy y Wilson, 2011).

Pero el escaneado tiene muchas más funciones. M-biblio es una aplicación en versión beta que nace de la colaboración de la división de investigación y desarrollo y la biblioteca de la Bristol University con la intención de permitir almacenar y organizar referencias bibliográficas. Escaneando el código de barras de un libro es posible almacenar la referencia bibliográfica, hacer listas y enviarlas por correo electrónico en diferentes estilos de citas (Jones, et al., 2011). 


\subsubsection{Gamificación en apps de bibliotecas}

La gamificación consiste, según la definición de Deterding, et al. (2011), en «el uso de elementos de diseño de juegos en otros contextos diferentes». Algunas aplicaciones creadas por bibliotecas son juegos para que los usuarios realicen tareas de una manera más lúdica o simplemente con propósitos de ocio. Un buen ejemplo es Library Quest, una aplicación de la Grand Valley State University Library cuya finalidad es orientar a los estudiantes en los servicios y colecciones de la biblioteca. Mientras van realizando tareas obtienen puntos y recompensas (Johnson, et al., 2014). Del mismo tipo es la aplicación Kent Libraries Augmented Treasures $^{45}$, solo para usuarios de la biblioteca, que incluye experiencias de realidad aumentada.

Find the future ${ }^{46}$ es un juego desarrollado por la New York Public Library en 2011. Cien códigos QR escondidos en la biblioteca conectaban con sus correspondientes libros, todos ellos con un gran valor histórico. A través de un cuaderno virtual se podían ir anotando lo que esos libros inspiraban a cada uno de los participantes. Para jugar cada usuario debía acceder a la app con un nombre de usuario y contraseña.

La app Liburutegiak, de la Red de Lectura Pública de Euskadi, ha incluido un sistema de reputación mediante el cual, cada vez que se comentan o valoran los contenidos o cuando se hace check-in en una de las bibliotecas, se obtienen puntos que mejoran su reputación (Pulgar y Maniega-Legarda, 2014).

Todos estos son solo ejemplos de cómo la gamificación se está introduciendo en las apps bibliotecarias de diferentes maneras, ya sea con fines educativos o como un mero incentivo.

\subsubsection{Utilidad profesional}

Los usuarios son los principales destinatarios de las apps, pero no los únicos. Existe un grupo de aplicaciones nativas enfocadas a los profesionales con diferentes finalidades. Quizás el grupo más habitual de aplicaciones de este tipo son las dedicadas a los eventos profesionales. En algunos encuentros o congresos se han creado apps específicas con el programa, los horarios, localización e incluso las ponencias, a modo de guía, para que los asistentes tengan toda la información de utilidad sobre el evento, conectando con lo que se dice en los medios sociales e incluso permitiendo crear una agenda propia. En España, los asistentes al Sexto

\footnotetext{
${ }^{45}$ http://sol.us/libtreasures/

${ }^{46}$ http://www.nypl.org/blog/2011/04/01/iane-mcgonigal-and-nypl-present-find-future-game
} 
Congreso de Bibliotecas Móviles contaron con una app. La cuestión que emerge sobre estas aplicaciones es si merece la pena el esfuerzo, pues su coste puede ser alto y la utilidad en el tiempo se ve muy reducida.

Otro enfoque, también profesional, es el de la app New LIS Books de la biblioteca de la University of Illinois at Urbana-Champaign (Estados Unidos), con información para bibliotecarios y estudiantes de Biblioteconomía sobre las últimas publicaciones profesionales. Paralelamente han desarrollado otras dos apps con las novedades en las áreas de Francés y Alemán.

Aplicaciones de gran originalidad son Suma, ShelvAR o Ugl4eva. La primera de ellas, Suma es una aplicación para iPad que aún se encuentra en fase piloto. Desarrollada por el equipo bibliotecario de la North Carolina State University (Estados Unidos), tiene el objetivo de facilitar la recogida de datos sobre el uso de espacio y servicios. Además, permite su análisis en tiempo real y simplifica las tareas de recuento (Casden y Chapman, 2011).

Ingeniosa es ShelvAR, capaz de localizar en una estantería cuáles son los libros que están desordenados y señalar el lugar correcto en que deberían estar colocados. Funciona con el sistema de realidad aumentada y previamente hay que pegar en el lomo del libro un tejuelo diseñado para tal fin. Se está aplicando en la Biblioteca Wertz de Arte y Arquitectura de la Universidad de Miami.

Kelley, Kaugars y Garrison (2011) proponen una aplicación para la localización del personal dentro de la biblioteca. Encontrar a los bibliotecarios itinerantes o que tienen necesidades de movilidad concretas dentro del espacio de trabajo cuando hay que comunicarse con ellos es uno de los problemas con los que se encontraban y a la que dieron solución a través de una app para Android. El personal puede hacer check-in en un lugar de la biblioteca (el mostrador de préstamo o la sala de investigación, por ejemplo) y a través de una aplicación web se puede consultar dónde está cada persona. La WiFi es el sistema para la localización.

\subsubsection{Descubrimiento, selección y recomendación de apps}

Teniendo en cuenta que existen más de un millón de aplicaciones en cada una de las principales tiendas y que el número sigue subiendo, un problema al que se enfrentan los usuarios de dispositivos móviles es el descubrimiento de apps. Por eso, recomendar aplicaciones a los usuarios sobre temas determinados puede ser un servicio de interés, de la misma manera que se recomiendan lecturas, música, películas $\mathrm{u}$ otros tipos de contenido. Selecciones de aplicaciones dirigidas a investigadores - recomendando gestores bibliográficos, bases de datos o lectores 
de artículos-,para niños cuyos padres quieren asegurarse de que sus hijos utilizan aplicaciones con valor educativo o para lectores - con aplicaciones dedicadas a la lectura- pueden ser buenos ejemplos.

A través de LibGuides, el servicio de la empresa Springshare para publicar guías de recursos, algunas bibliotecas están publicando selecciones de recursos móviles, incluidas apps. Un ejemplo entre los muchos existentes es la Library of Sciences de la University of Washington ${ }^{47}$, que recomienda apps relacionadas con la salud y para médicos. En España hay algunos ejemplos de recomendación de aplicaciones en bibliotecas públicas: la guía de lectura Lo más 201248, elaborada por el Centro Internacional del Libro Infantil y Juvenil, incluía aplicaciones junto a libros, música o películas para niños y jóvenes. Recientemente la Biblioteca Pública de Ciudad Real ha incluido una selección de apps para lectores en su sitio web ${ }^{49}$.

Dada la diversidad de usuarios y de bibliotecas, las posibilidades son enormes. Muestra de ello es la selección de apps contra el estrés de Finley (2014), que procede de una biblioteca médica. En ámbitos como el de la educación o la salud, donde la fiabilidad de la información juega un importante papel por cuestiones obvias, las recomendaciones procedentes de fuentes fidedignas son aún más relevantes. Por ello han aparecido portales con la garantía de un organismo, como la Health Apps Library50 del Servicio Nacional de Salud inglés, y sistemas de distintivos que garantizan al usuario la calidad, como AppSaludable ${ }^{51}$, de la Junta de Andalucía, en España.

Ante la realización de selecciones de aplicaciones para los usuarios surge la pregunta de qué pautas hay que tener en cuenta. Arroyo-Vázquez (2014a) recopila una serie de recomendaciones a tener en cuenta a la hora de elaborar una selección de apps, pero también pautas para descubrir aplicaciones y seleccionarlas. Según esta autora, los elementos que debe incluir una selección de apps son los siguientes:

- Nombre de la app, tal y como aparece en la tienda de aplicaciones.

- Enlace a la página de descarga en la tienda, para facilitar su instalación. Si la selección se publicara en formato impreso es recomendable acortar el

\footnotetext{
${ }^{47}$ http://libguides.hsl.washington.edu/mobile

${ }^{48}$ http://recursos.fgsr.es/lomas/

${ }^{49} \mathrm{http}$ ://reddebibliotecas.jccm.es/intrabibl/index.php/ebiblioteca/recursos-digitales/appslectores

${ }^{50}$ http://apps.nhs.uk

51 http://www.juntadeandalucia.es/agenciadecalidadsanitaria/calidadappsalud/
} 
URL mediante algún servicio web como Bitly o recogerlo en un código QR, de forma que se evite teclear los largos URL a las tiendas de aplicaciones y se facilite el acceso desde un dispositivo móvil.

- Breve descripción, de un párrafo, que explique sus principales funcionalidades. El mejor valor que puede aportar la recomendación, además de la propia selección, es un comentario conciso y personalizado, con información de utilidad sobre lo que la aplicación aporta.

- Características básicas, como el coste de la descarga, el idioma (especialmente si pueden entrañar alguna dificultad para el usuario), el tipo de dispositivo y el sistema operativo en los que funciona la app.

Se trata de ofrecer al usuario la suficiente información para que pueda decidir rápidamente si le interesa o no descargar la $a p p$, pero sin extenderse demasiado. Además, se recomienda incluir algún elemento gráfico que identifique a la app, como el icono en la tienda de aplicaciones. Arroyo-Vázquez (2014a) señala también varias fuentes de información para el descubrimiento de aplicaciones nativas para móviles, un proceso previo a la publicación de la selección. En primer lugar, explica, hay que definir un sector de usuarios y escoger un tema de interés para ellos. La tienda de aplicaciones se convierte en la fuente de información primaria, puesto que los sistemas de búsqueda y descubrimiento que incorporan -buscador, organización por categorías, rankings de aplicaciones (las más populares o las mejor valoradas), selecciones temáticas de la propia tienda- son de utilidad en el proceso. Además, existen otras fuentes de información de utilidad para la selección, como los sitios web y aplicaciones de descubrimiento o selecciones y revisiones realizadas por terceros.

Sobre los criterios a tener en cuenta en el proceso de selección, Arroyo-Vázquez señala los siguientes:

- Se deben escoger apps procedentes de una fuente fiable, tanto por el desarrollador como por el lugar desde el que se efectúa de la descarga. Las tiendas de aplicaciones, que revisan las apps, son fuentes fiables, pero existen otras.

- Los contenidos deben estar actualizados recientemente.

- Hay que tener en cuenta criterios como el coste y la calidad de los contenidos, así como la utilidad del servicio que proporcionan para el público al que se dirige la selección.

Información de utilidad en el proceso de selección son los datos sobre la app que aparecen en su correspondiente ficha en la tienda de aplicaciones y que incluyen una descripción, información sobre el desarrollador y comentarios y valoraciones de los usuarios. Se recomienda además descargar la aplicación y probarla. Kendall, 
Nino y Stewart (2010) señalan varios criterios a tener en cuenta a la hora de evaluar aplicaciones de uso general para su uso en la biblioteca:

- El coste, si la aplicación es gratuita o si existe una versión lite.

- Revisiones publicadas previamente en blogs o revistas profesionales.

- Versión: si es la más reciente o ha sido sustituida por una nueva.

- Tamaño de la app: cuánto ocupa en la memoria del dispositivo al instalarla.

- Autoría: quién ha desarrollado la app y cuál es su reputación.

- Si para todas las funciones de la app es necesario ser usuario de la biblioteca.

- Si mantiene la privacidad de los datos del usuario.

- Interfaz web: si los contenidos también están disponibles a través de un sitio web.

\subsubsection{Las aplicaciones nativas en el trabajo del bibliotecario}

Aunque la bibliografía se ha centrado especialmente en la creación de aplicaciones nativas desde la biblioteca, también algunos autores han señalado el uso que los bibliotecarios pueden hacer de ellas. En la bibliografía profesional se pueden encontrar listados de aplicaciones nativas de utilidad para los bibliotecarios. Kendall, Nino y Stewart (2010) seleccionan aplicaciones con utilidades de productividad, marketing (centrándose en los medios sociales) y de apoyo a los servicios de referencia itinerantes -mapas, legislación, bases de datos o el catálogo, por ejemplo-. En este sentido, las aplicaciones pueden ser de gran utilidad por la rapidez con que se inician los dispositivos y las propias aplicaciones. La selección de Polanka (2012) va dirigida a este mismo grupo de bibliotecarios e incluye apps de proveedores de información como DK, Oxford University Press, Wiley, Enciclopedia Británica, Elsevier y Gale.

Rachel Besara (2012) propone una selección de apps para recoger datos cuantitativos y cualitativos en la biblioteca. Incluye cámara de vídeo, fotos y grabador de audio; apps para dibujar. Entre las aplicaciones cuantitativas se encuentran contadores, mediciones ambientales (luz y sonido) y encuestas. Brown (2012) realiza una selección de apps para bibliotecarios, organizadas en varias categorías: productividad, negocios y noticias, comunicación, estilo de vida, localización y apps poco usuales y divertidas. En ella se encuentran apps de carácter general que podrían ser de utilidad para cualquier otro ciudadano, para buscar un servicio próximo o un restaurante para comer o el localizador del coche, por ejemplo. 
Alonso Arévalo (2014) propone varias apps de lectura e investigación que pueden servir tanto para bibliotecarios como para el público general. En los blogs se pueden encontrar numerosas selecciones de apps para bibliotecarios, de carácter general, como la de Tay ${ }^{52}$ o específico. Una de las más citadas es la selección de Ellysa Kroski 30 iPhone apps, que no se encuentra ya disponible en la web.

\subsection{Localización}

La capacidad de los dispositivos móviles de detectar la posición geográfica en que se encuentran en un momento determinado les convierte en instrumentos idóneos para obtener información sobre los lugares a su alrededor y datos basados en el contexto. La conjugación de lo social, lo local y lo móvil (SoLoMo), como se explicó en el apartado 2.2.6.5, está fomentando la participación de la gente para enriquecer los servicios basados en localización facilitados por los dispositivos móviles. El uso de la geolocalización se materializa en los dispositivos móviles a través de aplicaciones nativas y de sitios web, que constituyen la base fundamental para otros servicios móviles.

El contexto en que se encuentra el usuario es un factor crucial en la recuperación de la información de diferentes tipos, especialmente cuando se trata de contenidos locales. La información a menudo se refiere a lugares y describiéndola en función de unas coordenadas de latitud y longitud es posible recuperarla cuando guarda relación con el lugar en que se encuentra el usuario (Mountain, Myrhaug y Göker, 2009). El uso de la información desde dispositivos móviles, que cambian de lugar rápidamente cuando su propietario se mueve, supone un nuevo reto para los sistemas de información cuando la localización es el factor diferencial (Goker, Myrhaug y Bierig, 2009). Los buscadores han entendido muy bien este concepto y tienen en cuenta la localización del usuario a la hora de mostrar los resultados.

Se define el término geolocalización como la descripción de un objeto en función de unas coordenadas de latitud y longitud (Arroyo-Vázquez, 2011a). Cada vez es más habitual encontrar objetos geolocalizados en la web: fotografías, entradas en la Wikipedia, las publicaciones en Facebook y Twitter y otros recursos tienen asociadas unas coordenadas en el mapa. La aparición de herramientas gratuitas y

\footnotetext{
52 http://musingsaboutlibrarianship.blogspot.com/2010/02/iphone-apps-for-librarians.html
} 
sencillas de utilizar en la web, como Google Maps, democratizó el uso de los mapas hace años. Es por ello que han proliferado los mashups basados en datos geoetiquetados: según datos de Programmable $\mathrm{Web}^{53}$, las API relacionadas con los mapas son la cuarta categoría más habitual.

El valor de la geolocalización ha sido reconocida en el ámbito de las humanidades digitales con el surgimiento de una disciplina conocida como Geohumanidades o Humanidades espaciales, que se define como «la creciente zona de interacción creativa entre la geografía y las humanidades.» (Richardson, et al., 2011). Reunir información relacionada con un mismo lugar permite obtener patrones de conocimiento y una nueva forma de visualización (Bodenhamer, Corrigan y Harris, 2010). Se trata de un campo interdisciplinar que afecta a la historia, el arte, la literatura y otras disciplinas y en el que se habla de un «giro espacial», es decir, de una nueva perspectiva.

\subsubsection{Funcionamiento de los sistemas de localización}

Las formas de detectar la posición geográfica que utilizan los dispositivos móviles actuales, según recoge Arroyo-Vázquez (2011b) son las siguientes:

- Sistema de Posicionamiento Global (GPS), que se basa en los satélites espaciales.

- Redes de los operadores de telefonía móvil. Este sistema se basa en la detección de la torre de telefonía móvil más cercana, de la que toma la señal el dispositivo en cuestión. Si un dispositivo se encuentra en un lugar con varias torres alrededor, el cálculo de la posición será más precisa.

- El sistema de posicionamiento WiFi (WPS), que permite detectar la posición a partir de los routers WiFi más cercanos.

- Detectando la dirección IP del cliente y comprobando su situación en una de las bases de datos públicas existentes. Este sistema presenta un bajo nivel de exactitud, pues solo es capaz de identificar la ciudad o región.

- Preguntando al usuario para que introduzca datos de localización, como el código postal o el nombre de la ciudad en que se encuentra.

El problema de la localización es más amplio aún, si se tiene en cuenta la posición de un dispositivo en el interior de un edificio. Estos sistemas no han sido tan

\footnotetext{
53 Programmable Web (2014). Fastest Growing Web API Categories Since 2009. http://www.slideshare.net/programmableweb/fastest-growing-web-api-categories-since-2009
} 
populares, pero se espera que en los próximos años crezcan. Existen varias formas de deducir la localización en interiores:

- Identificar la localización dentro de un edificio a partir de los hotspots de la red WiFi.

- Los iBeacons desarrollados por Apple en 2013, de los que se hablará en el apartado 2.8, son dispositivos fijos que emiten señales de baja intensidad, capaces de comunicarse con un dispositivo móvil.

- Mediante campos magnéticos, como sugieren Raab, et al. (1979). Este sistema requeriría una mayor infraestructura y su puesta en marcha es más complejo (Walsh, 2012b).

La localización en interiores permitiría, por ejemplo, crear aplicaciones para facilitar la búsqueda de un determinado punto dentro de un edificio, pero también para obtener información relacionada con un lugar concreto. En el ámbito de la publicidad esta última utilidad ha despertado especial interés, pues permitiría enviar a los clientes de un centro comercial ofertas y publicidad para cada sección. Un paso adelante para la localización en interiores son los mapas interiores de Google ${ }^{54}$, que permiten compartir de forma voluntaria mapas de planta de un edificio.

El uso más común de la geolocalización en bibliotecas consiste en situar en el sitio web un mapa indicando dónde está la biblioteca, como indicaba Margaix (2008). Pero son muchas otras las utilidades que las bibliotecas han dado hasta el momento a las tecnologías de localización. Se profundiza más en ellas en los siguientes apartados.

\subsubsection{Geolocalización en bibliotecas}

Localizar un lugar y trazar la ruta hasta llegar a él es un servicio básico en varias aplicaciones web y nativas para móviles en bibliotecas, como ya se ha indicado previamente. En ocasiones el objetivo de la búsqueda no es un lugar determinado, sino un recurso o un servicio. Es la idea que subyace en la aplicación Computer Finder $^{55}$ de la McGill University (Canadá), que trata de ayudar a encontrar los ordenadores disponibles en la biblioteca más cercana (West, 2010). Otro ejemplo es la aplicación web no oficial para encontrar la sede de la biblioteca más cercana

\footnotetext{
54 https://www.google.com/maps/about/partners/indoormaps/

55 http://apps.library.mcgill.ca/library/services/computers/computer-finder
} 
en la que se encuentra cualquier libro del catálogo de la Toronto Public Library (Canadá), desarrollada por Suhonos (2010).

Aún quedan utilidades de la geolocalización que podrían aplicarse en las bibliotecas. Una de ellas es la ordenación de los resultados de búsqueda en función del lugar en que se encuentra el usuario (O'Donoghue, 2014). En esta misma categoría estaría el experimento mencionado en el apartado 2.2.6.6., sobre la creación de un botón de búsqueda en la app de la Biblioteca Nacional de Noruega para mostrar los recursos de la colección relacionados con un lugar (Jingru, 2013).

Si se amplía la mirada más allá de los muros de la biblioteca, se verá que el problema para el usuario está realmente en la localización de un libro, ya sea en una de las bibliotecas cercanas o en una librería física o en línea. Desde este punto de vista, las bibliotecas tienen la oportunidad de permitir que los datos de sus catálogos sean reutilizados por terceros para mezclarlos con otros y mejorar los servicios existentes.

Visualizar imágenes históricas en el lugar puede ayudar a los estudiantes a aprender sobre la historia de una ciudad o a un arquitecto a examinar los detalles de un edificio. Verlos en su lugar les dota de contexto, lo que refuerza las conexiones entre el pasado y el presente, es una forma de ver cómo ha cambiado un lugar (Boyer, 2011). Estar en un lugar físico incrementa el interés y comprensión de los hechos históricos, según desvelaron los resultados de la investigación llevada a cabo por Cocciolo y Rabina (2013). Los participantes en el experimento se sintieron más entusiasmados al recibir nueva información en entornos físicos que les eran familiares y se mostraron predispuestos a utilizar aplicaciones móviles para aprender sobre la historia local en otros sitios.

Basándose en esta idea y en la de situar fotografías u otros contenidos históricos en su contexto, permitiendo así su consulta, son varias las aplicaciones que se han creado. Uno de los ejemplos más conocidos es PhillyHistory.org, la aplicación web de Filadelfia con más de un millón de fotografías antiguas de la ciudad. Nacida para ordenadores de sobremesa, en 2007 se lanzó la versión móvil, gracias a la cual es posible visualizar estas fotografías en su contexto y comparar cómo han evolucionado diferentes lugares (Boyer, 2011). El público puede contribuir reportando errores, dejando comentarios o añadiendo etiquetas de sus fotos favoritas. Con el tiempo el número de fotografías ha ido en aumento. En 2009 se lanzó la app para Android e iOS, que se ha completado con una capa de realidad aumentada en Layar, como se explicará en el apartado 2.6.

Wolfwalk $^{56}$ es una aplicación de las bibliotecas de la North Carolina State

${ }^{56}$ http://www.lib.ncsu.edu/wolfwalk/ 
University (Estados Unidos) que sitúa fotografías antiguas de su campus en el mapa (Sierra y Casden, 2011). De esa manera, quien vaya visitando el campus encontrará en contexto estas fotografías. Funciona desde un sitio web y desde una app. La visita guiada de las bibliotecas de la Oregon State University (Estados Unidos), Beaver Tracks ${ }^{57}$, está inspirada en WolfWalk. Permite encontrar el lugar en que uno se encuentra y trazar la ruta hasta el lugar del campus al que se quiere llegar. Esta aplicación web está enfocada a lugares históricos, incluye 22 lugares cuya historia se relata y se pueden buscar en el catálogo imágenes históricas.

\subsubsection{Redes sociales basadas en localización}

La geolocalización también ha dado lugar a una nueva generación de redes sociales en las que la posición geográfica del usuario juega un papel fundamental. Es por ello que a menudo se relaciona la geolocalización con las redes sociales en las bibliotecas (Murphy, 2012). La red social basada en geolocalización más conocida es Foursquare, un juego en el que se obtienen recompensas por compartir el lugar en que te encuentras y recomendar restaurantes, hoteles u otros negocios locales. Pero también es una gran base de datos en la que buscar información local (Arroyo-Vázquez, 2012a).

La presencia de las bibliotecas en este tipo de medios sociales no está muy extendida. Margaix Arnal (2013) encontró que solo dos de las 75 bibliotecas universitarias españolas estaban presentes en Foursquare, frente a las 46 presentes en Facebook o las 42 en Twitter. La presencia en Foursquare y otros medios sociales basados en localización es necesaria para monitorizar la reputación online de la biblioteca. Se configura además como una forma de conectar en el entorno digital con aquellos usuarios que nos visitan. En su contra se puede argumentar que aún este tipo de redes sociales no está tan extendido en algunos lugares.

Un ejemplo paradigmático es el de la New York Public Library (Estados Unidos), quien además de controlar todas sus sedes ha creado una página en la que publica curiosidades sobre ellas y sugerencias de cosas que hacer. También lanza promociones, como descuentos especiales en su tienda para los usuarios de Foursquare. Con motivo de su centenario lanzó un badge o insignia ${ }^{58}$ que se

\footnotetext{
57 http://tour.library.oregonstate.edu/beavertracks

${ }^{58}$ http://www.nypl.org/press/press-release/2011/05/01/earn-nypl-foursquare-badge
} 
concede a los usuarios de Foursquare cuando hacen check-in un número determinado de veces en sus sedes, a modo de incentivo.

\subsubsection{Localización en interiores}

Localizar un libro en la biblioteca es un reto al que se enfrentan los usuarios, que deben aprender el funcionamiento del sistema de clasificación y conocer las signaturas. La tarea, por lo tanto, puede resultar complicada para los nuevos usuarios, que necesitan asistencia del personal. Para facilitar el proceso, algunas bibliotecas sitúan en cada registro del catálogo un mapa de sus espacios indicando en qué estantería se encuentra el libro (Gallagher; Serrano-Muñoz, et al., 2010; Bauer, Friscia y Matheson, 2012). En el caso de la Biblioteca Sterling Memorial (Yale University, Estados Unidos), este sistema supuso una reducción del 20,6\% de las consultas al personal sobre signaturas (Bauer, Friscia y Matheson, 2012). Jones, et al. (2000) propusieron un sistema en la biblioteca de la Cornell University para localizar en un mapa los libros a través del catálogo móvil. En su estudio concluyen que es más adecuado en bibliotecas grandes.

La función de geolocalización puede mejorar incluso este tipo de aplicaciones. La idea no es nueva: en 1995, mucho antes de los sofisticados smartphones y tabletas actuales, Nagao y Rekimoto propusieron un dispositivo de fabricación propia, denominado Ubiquitous Talker, que hacía uso de la realidad aumentada para mostrar el camino a seguir para localizar un documento en la biblioteca. Ubiquitous Talker consistía en una pantalla LCD, una cámara y un micrófono como sistema de interacción. Cuando un usuario quería llegar a una zona determinada de la biblioteca se lo hacía saber al sistema, que le indicaba en un mapa la ruta a seguir. Cuando llegaba a esa zona, el sistema le decía que había llegado y le preguntaba qué tipo de libro estaba buscando. Cuando cogía un libro, la pantalla mostraba una descripción sobre él. El usuario podía pedir más información sobre el autor, por ejemplo, y el sistema se la mostraba.

Basándose en la realidad aumentada, Reitmayr y Schmalstieg (2003) presentaron $A R L i b$, una aplicación de búsqueda y recuperación que ayudaba a los visitantes de la biblioteca a localizar un libro deseado y después el lugar asignado en las estanterías, para su devolución. El funcionamiento era el siguiente: a través de una interfaz se buscaba un libro. Cuando el usuario escogía uno de la lista de resultados, se mostraba su localización en la estantería con un marco. Para devolver el libro, ARLib detectaba los marcadores colocados previamente en el libro y que contenían la información sobre el lugar que debía ocupar en la estantería. 
Ambos sistemas se servían de dispositivos de fabricación propia. ARLib, bastante aparatoso, constaba de un casco, sobre el que se montaba la cámara y un sensor, una mochila con un ordenador portátil a las espaldas y guantes con marcadores especiales. En la actualidad estos sistemas han sido superados gracias a los dispositivos móviles, que integran las tecnologías necesarias para el funcionamiento de estos sistemas en terminales ligeros y pensados para ser utilizados en movimiento. Son varias las bibliotecas que hacen uso de la geolocalización combinada con la realidad aumentada. Se hablará de ellas en el apartado 2.6 de este trabajo.

La primera aplicación que se conoce capaz de valerse de la localización en interiores desde un smartphone es SmartLibrary, desarrollada por la Universidad de Oulu (Finlandia). Al buscar un libro en el catálogo móvil de esta universidad, OULA-pda ${ }^{59}$, y tras hacer clic en el enlace «locate», se detecta la posición de la PDA desde la que se consulta. Esta información se muestra en la pantalla al usuario, que puede ver el punto en el que está y la estantería donde se encuentra el libro (Aittola, Ryhänen y Ojala, 2003). Todo ello funciona a través de una aplicación web. SmartLibrary, concluyen estos autores tras un estudio de usuarios, es más sencillo para el usuario que localizar el libro desde el catálogo a través de la signatura.

SmartLibrary ha servido posteriormente de inspiración para otras aplicaciones en bibliotecas. Library Helper ${ }^{60}$, la aplicación nativa de la University of Illinois at Urbana-Champaign (Estados Unidos), es una de ellas. Desarrollada por Jim Hahn y Dennis Matthews en 2010, funciona introduciendo la signatura de un libro en la $a p p$, tras lo cual se obtiene un mapa de la biblioteca con la localización del libro en cuestión. Además, calcula la posición en la biblioteca en función de las WiFi e indica la localización del dispositivo dentro del edificio y se recalcula el mapa en función de la posición (Hahn y Morales, 2011).

A diferencia de SmartLibrary, Library Helper funciona como aplicación nativa, mientras que la primera es una aplicación web. Por otra parte, la integración de la función de localización en el catálogo ahorraría al usuario el paso de abrir una nueva aplicación e introducir la signatura que ha tomado del catálogo. Al igual que SmartLibrary, la app de la University of Illinois at Urbana-Champaign es valorada positivamente por los usuarios, que la consideran más eficiente que el sitio web, donde encuentran demasiada información (Hahn y Morales, 2011).

Una aplicación original es la de la Biblioteca de la Nanyang Technological University Library (Singapur). Esta app guía al usuario a las diferentes secciones

\footnotetext{
${ }^{59}$ http://www.kirjasto.oulu.fi/oulapda/

${ }^{60} \underline{\text { https://play.google.com/store/apps/details?id=uiuc.library.helper }}$
} 
de la biblioteca utilizando la realidad virtual en 3D (Chia, 2014). La aplicación está disponible en las tiendas de Apple ${ }^{61}$ y Android, pero solo pueden utilizarla los estudiantes y el personal de la Universidad Politécnica de Nanyang, pues está protegida por contraseña.

La localización en interiores también es útil para conocer recomendaciones lectoras basadas en la posición del usuario. Así lo proponen Chen y Yang (2010), quienes desarrollaron un sistema de recomendación de libros basado en la localización desde tabletas o miniportátiles EeePC con un mapa de guía. Este sistema comprende varias funciones: la localización del usuario dentro de la biblioteca, que le ayuda a no perderse, y una interfaz de búsqueda. En los resultados se muestran los libros más cercanos a la posición del usuario y que se ajustan a los términos de búsqueda. Además, los mostraba en un mapa de la biblioteca en el que se señala la localización del usuario.

El funcionamiento es el siguiente: los usuarios pueden buscar un libro a través de esta interfaz. El sistema de recomendaciones determina la posición del usuario correctamente, si los libros están en la estantería, cuáles se encuentran más cerca del usuario y cuáles están más relacionados con la búsqueda realizada. Esta información se muestra basada en un ranking de similaridad. Al igual que las investigaciones de Aittola, Ryhänen y Ojala (2003) y Hahn y Morales (2011), este sistema funciona mejor que el catálogo en la búsqueda de libros y se acorta además el tiempo de búsqueda de un libro.

La biblioteca de la University of Illinois at Urbana-Champaign también ha desarrollado un prototipo para la recomendación de lecturas basado en la posición, que cobra forma en un sitio web ${ }^{62}$ para smartphones (Hahn, 2011). Las secciones temáticas de la biblioteca son divididas en áreas en función de los puntos de acceso a la WiFi. Una vez que el dispositivo identifica la sección de la biblioteca en que se encuentra el usuario, permite seleccionar entre recursos digitales o impresos.

Una última función de la localización en interiores podría ser la localización del personal itinerante. En este sentido cabe recordar la aplicación para Android sobre la que informan Kelley, Kaugars y Garrison (2011) y de la que se habló en el apartado 2.3.3.5.

Todos los sistemas mencionados hasta ahora utilizan el sistema de localización en interiores mediante puntos de acceso WiFi. Un nuevo reto para la este tipo de

\footnotetext{
${ }^{61}$ https://itunes.apple.com/es/app/nyp-library-map/id688712486?mt=8

${ }^{62}$ http://sif.grainger.uiuc.edu/uglbot/
} 
función son los beacons, pero aún están apareciendo las primeras experiencias de uso en bibliotecas. Aunque ya se les adivinan utilidades: se podrían emplear como sustitutos de la localización WiFi en cualquiera de las aplicaciones hasta ahora citadas, pero también se pueden combinar con otros servicios, como el carné de la biblioteca, para enviar notificaciones con sugerencias, avisos u otros tipos de información, como propone Arroyo-Vázquez (2014b).

¿Cuáles son las implicaciones de este tipo de aplicaciones en el trabajo del bibliotecario? Hahn (2011) las resume de la siguiente manera: en primer lugar, descargan al personal de resolver cuestiones básicas, de manera que puede centrarse en otras. En el caso de las aplicaciones de recomendación de lecturas, es necesario contar con la implicación de los bibliotecarios en la tarea de dibujar las asociaciones entre unas lecturas y otras. Por otra parte, se plantea la necesidad de examinar de nuevo la dicotomía entre la colección impresa y la digital, un problema que se convertirá en anticuado. Finalmente, demuestran que es posible mejorar los servicios de alfabetización informacional e integrar las nuevas tecnologías con los servicios tradicionales. Además, algo que no señala este autor es que proporcionan seguridad e independencia al usuario en su manejo de la biblioteca.

En definitiva, la geolocalización tiene varias utilidades prácticas en la biblioteca y además parece contar con el interés de una parte significativa de los usuarios. Una encuesta realizada por Pew Internet en 2012 entre el público estadounidense concluyó que el 34\% de los ciudadanos de 16 años o más en ese país utilizarían muy probablemente apps de navegación GPS para localizar el material dentro de la biblioteca. El 28\% dijo que las utilizaría probablemente. (Zickuhr, Rainie y Purcell, 2013).

\subsection{Códigos QR}

Los códigos bidimensionales, cuya utilidad está en la codificación de la información, son una evolución de los códigos de barras, aunque a diferencia de estos últimos, los bidimensionales aprovechan dos dimensiones, ancho y alto, de manera que son capaces de almacenar más cantidad de información. A los códigos bidimensionales se les conoce también como códigos 2D, códigos de matriz o códigos bidi (Arroyo-Vázquez, 2011a).

Existen varios tipos de códigos bidimensionales: Datamatrix, Aztek, Maxicode, 
ShotCode, Semacode, BeeTag y HCCD son algunos de ellos, fácilmente reconocibles por su apariencia. El tipo más extendido son los códigos QR (acrónimo de quick response, respuesta rápida), creados por la empresa japonesa Denso Wave en 1994, en reacción a las limitaciones de los códigos de barras, y con capacidad para casi 4.300 caracteres alfanuméricos y más de 7.000 numéricos. Aunque otros códigos bidimensionales son capaces de almacenar mayor cantidad de información incluso, los QR tienen la ventaja de que se leen diez veces más rápido, según se explica en la página web de la empresa ${ }^{63}$.

La popularidad de los QR frente a otros tipos de códigos se debe probablemente a su carácter abierto: la empresa propietaria de la patente ha decidido no ejercer sus derechos y se ha publicado un estándar ISO/IEC 18004:2006 que define las características de la simbología, los métodos de codificación, los formatos de los símbolos y otros aspectos. Otra de las ventajas de los QR es que están preparados para ser leídos aunque se pierda una parte del código. Esto garantiza su funcionamiento a pesar del deterioro que puedan sufrir y permite introducir elementos de diseño modificando una parte del código, con lo que se obtienen diseños más vistosos y de apariencia original.

A pesar de que los QR aparecieron en los noventa, ha sido la popularidad de los smartphones el factor que les ha sacado del entorno industrial y ahora se ven en todas partes. ¿Qué pueden contener? Textos, URL, ubicaciones geográficas, números de teléfono, correos electrónicos, tarjetas de visita vCard o los datos de acceso a una red WiFi, por ejemplo.

Para decodificar un código $\mathrm{QR}$ es necesario instalar previamente una app adecuada para ello en una tableta o un smartphone. Tras abrir esa aplicación, se activa la cámara de fotos, que lee el código. En el siguiente paso, la app muestra el contenido del código. En caso de que el código contenga un URL o un número de teléfono, la aplicación dirigiría después a la página en cuestión o realizar una llamada a un número de teléfono (Arroyo-Vázquez, 2011a). Generar un QR es una tarea sencilla que cualquiera puede realizar en unos segundos. Existen numerosos servicios generadores en la web: basta con introducir los datos que se quieren codificar y hacer clic en el botón para obtener una imagen con el código.

A menudo se confunde en la bibliografía a los códigos QR con una forma de realidad aumentada (Pence, 2011; Accart; Fernández, 2014). A la luz de la definición de Azuma (1997), esta asociación es completamente errónea, pues la realidad aumentada consiste en la superposición de objetos digitales sobre la realidad, como se explicará más adelante, mientras que en los códigos QR la

63 http://www.qrcode.com/en/history/ 
información se muestra de manera secuencial: primero se escanea el código QR y después se muestra la información, en ningún momento se superponen.

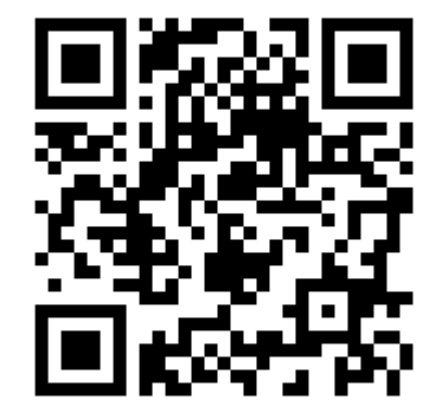

Figura 15. Aspecto de un código QR.

\subsubsection{Códigos QR en bibliotecas}

Es en 2008 cuando se encuentran los primeros indicios del interés de las bibliotecas por los códigos QR, a excepción de Japón, donde ya eran muy populares. Ramsdem y Jordan (2009) informan sobre una encuesta llevada a cabo en la biblioteca de la University of Bath (Reino Unido) a sus estudiantes preguntándoles sobre su conocimiento de los QR. En ese año, que coincide con la aparición del iPhone en el mercado, solo seis de los catorce teléfonos móviles más populares permitían instalar un lector de códigos QR, entre ellos el iPhone. El primer manual sobre el uso de dispositivos móviles en bibliotecas tras el lanzamiento del iPhone solo los menciona de pasada en un capítulo sobre sitios web diseñados para dispositivos móviles (Kroski, 2008). Tay (2010c) reconoce que la presentación de Bonnie Roalsen ${ }^{64}$ sobre este tema en 2008 fue adelantada a su tiempo.

Desde entonces se han publicado una gran cantidad de artículos, comunicaciones y entradas en blogs, mucho mayor que sobre otras utilidades de los dispositivos móviles en bibliotecas, como la realidad aumentada, la geolocalización o el NFC, por ejemplo. Esta abundancia bibliográfica, abultada especialmente por las experiencias de uso, es indicativa de la popularidad de los códigos QR en bibliotecas. El principal motivo de este especial interés puede atribuirse a la

\footnotetext{
${ }^{64}$ http://www.slideshare.net/wizardhere/talking-walls-hidden-clues-qrcodes-in-the-wildpresentation
} 
facilidad de creación de los códigos QR y los pocos recursos que requieren. También se asocian a los jóvenes (Schultz, 2013) y se consideran una manera de conectar con este tipo de público. Las bibliotecas esperan que su imagen despierte curiosidad en el usuario y que estos códigos les den un aire de modernidad.

En la encuesta a 110 bibliotecarios de 68 universidades en los estados de Oregon, Washington y Idaho, realizada por Ashford y Zeigen (2012b), el 40\% respondió que en su biblioteca se utilizan códigos QR para publicidad o para ampliar la información en materiales impresos o sitios web. Una encuesta paralela fue realizada al personal de bibliotecas públicas (Ashford y Zeigen, 2012a), donde el $32 \%$ respondió que en su biblioteca se utilizan estos códigos.

Son varios los autores que destacan la capacidad de los códigos QR para enlazar lo físico con lo digital (Wisniewski; Pulliam y Landry, 2010; Hicks y Sinkinson, 2011). Con ello se espera que aumente el retorno de la inversión de los recursos digitales (Wisniewski, 2010). Pero además, los QR evitan teclear (Sekyere, 2012) y permiten acceder de manera más rápida a una página web. Un estudio llevado a cabo por Lo, Coleman y Theiss (2013) concluyó que el tiempo medio para escanear un código QR y descargar la página a la que enlaza es de 8 segundos. En cambio, teclear un URL acortado y ver la página supone 24 segundos. Si hay que teclear un URL largo y descargar la página son 82,5 segundos.

Otras ventajas que se les han encontrado a estos códigos es que son gratuitos (Pulliam y Landry, 2010), no son invasivos y la información que contienen puede ser almacenada para un uso posterior (Hicks y Sinkinson, 2011), son dinámicos en el sentido de que, al dirigir a un URL desde un QR, los contenidos de esa página web pueden variar sin necesidad de cambiar el URL o el código (Pulliam y Landry, 2010; Juárez-Urquijo, 2013) y ofrecen flexibilidad para llegar a los usuarios en cualquier parte de la biblioteca o del campus, sin que haya un bibliotecario. Esto permite, por ejemplo, colocar varios códigos QR con instrucciones o ayuda en cualquier lugar (Hicks y Sinkinson, 2011).

Aunque no son muchas las voces críticas hacia los códigos QR, las hay. Aaron Schmidt recomienda no perder el tiempo con ellos y dedicarlo a otras tareas más productivas $^{65}$. El poco uso que se hace en la práctica de estos códigos puede ser uno de sus mayores inconvenientes, como señala Dans (2012). Este bloguero español indica además que no son suficientemente intuitivos, que requieren la descarga previa de una app -y por lo tanto una acción previa por parte del usuario-, que implican demasiado esfuerzo en relación al resultado obtenido y

${ }^{65} \underline{\mathrm{http}}$ ///implementingqrcodesinlibraries.org 
que hay alternativas que les han comido el terreno, como NFC, RFID o la realidad aumentada.

\subsubsection{Utilidades de los códigos $Q R$ en bibliotecas}

Es numerosa la bibliografía en la que se habla de los posibles usos de los QR en bibliotecas, ya sea compartiendo una experiencia o en textos divulgativos. Teniendo en cuenta que en muchos casos estas experiencias no aportan innovación con respecto a otras iniciativas anteriores y que no es este el tema objeto de esta tesis doctoral, se abordarán de manera superficial en los siguientes párrafos.

Estos usos de los códigos QR en bibliotecas se pueden agrupar, según el resultado final, de la siguiente manera: enlazar con información digital desde un soporte físico, guardar contenidos para su uso posterior - por ejemplo, la signatura del catálogo o un mapa para guiarse en la biblioteca o los datos de acceso a la WiFi- y como facilitadores de la comunicación, al enlazar a datos de contacto o redes sociales. De forma más concreta, y sin intentar ser exhaustivos, podemos encontrar los siguientes usos:

1. Enlazar con información digital desde un soporte físico codificando un URL. Esto puede plasmarse en varias utilidades:

- En el material promocional de la biblioteca, como folletos o carteles, para enlazar a un URL con más información sobre la biblioteca, sobre un servicio concreto o un listado de recursos, por ejemplo (Ohigashi Oasay; Pulliam y Landry; Walsh, 2011).

- Enlazar a la versión digital de un libro o de un documento impreso publicado por la biblioteca (Schultz, 2013).

- Para anunciar los servicios digitales de la biblioteca cuando tienen versión móvil (Pons, et al., 2011).

- En libros, DVD, CD u otros materiales de la biblioteca, para dar más información sobre la obra o su autor.

- En pósters en los autobuses urbanos, para descargar audiolibros (MacKinnon y Sanford, 2010; Hicks y Sinkinson, 2011).

- En la entrada a la biblioteca, para descargar una audioguía, como en la Ryerson University (Schultz, 2013) y la Harold B. Lee Library en la Brigham Young University, Estados Unidos (Whitchurch, 2012).

- En las estanterías, con enlaces a listados de recursos por materias, a selecciones de lecturas u otros recursos relacionados ( $Q R$ codes, s. d.) o a la versión electrónica de algunos libros, como propone Green 
(2013), que sugiere colocar en las estanterías un soporte que emula el lomo de un libro y en el que se coloca un código QR que enlaza a recursos electrónicos que no tienen versión en papel. Es una manera de hacer visibles los recursos electrónicos.

- En la señalización de los espacios físicos, para enlazar con sitios web con más información, reservar salas (Alcock; Whitchurch, 2012) o también incluyendo mapas de planta o de la zona de estanterías (Pons, et al., 2011).

- Para dar más información sobre las obras expuestas en sus espacios: vídeos o enlaces, por ejemplo (Baker, et al., 2012).

- Para enlazar con vídeos instruccionales. Por ejemplo, sobre cómo utilizar la fotocopiadora (Walsh, 2010a).

2. Guardar contenidos para su uso posterior. En los registros del catálogo, indicando la signatura que ayude al usuario a encontrar el libro en la estantería y le evite tener que anotarla, como en la University of Bath (Robinson, 2010), donde integran Google Chart API en el catálogo para generar dinámicamente los códigos. También utilizan QR en el catálogo en la biblioteca de la University of Huddersfield (Walsh, 2010). MacDonald (2012) señala que este proceso es inverso al que usualmente se hace de los QR, pues enlaza lo digital con lo físico.

3. Como facilitadores de comunicación.

- En tarjetas de visita, para guardar los datos de contacto de la biblioteca (Ramsden y Jordan, 2009; Wisniewski, 2010).

- Enlazando con los perfiles en medios sociales de la biblioteca para facilitar el acceso o publicar un mensaje directamente (Schultz, 2013). Pueden situarse en folletos, carteles u otros soportes.

- Indicando un número de teléfono para recibir ayuda sobre cómo utilizar el equipamiento de la biblioteca.

4. Juegos como la búsqueda del tesoro, que consisten en situar en diferentes lugares de la biblioteca códigos QR detrás de los que se encuentran pistas (Alcock; Cerny y Holcomb, 2012).

Una de las cuestiones en la investigación sobre el uso de los códigos QR en bibliotecas son las expectativas de los usuarios acerca de ellos. ¿Qué les gustaría encontrar? ¿Cómo prefieren que sean implementados? Lo, Coleman y Theiss (2013), en un focus group con 16 estudiantes de la Kansas State University (Estados Unidos) en octubre de 2011, obtuvo algunas respuestas en este sentido. La mitad de los participantes preferían que el QR fuera acompañado del URL acortado y de indicaciones sobre su contenido, el 25\% que el URL fuera el original, para asegurarse de que era de confianza. El 18,75\% escogería el código con URL corto y el 6,25\% restante, el QR solo, sin URL ni indicaciones. Sobre el tamaño, los 
participantes opinaron que dependía de dos factores: el contexto y de en qué medida lo que hay alrededor compite en atención con el código.

De las propuestas de la biblioteca, todos los participantes en dicho estudio consideraron que serían muy útiles los códigos QR para ver una lista de libros relacionados con un título determinado, obtener un mapa para llegar a un lugar desde un punto determinado o para acceder a un blog. También se consideraron de utilidad enlazando a instrucciones en vídeo para usar el equipamiento de la biblioteca (9 de 13 participantes) y en los DVD con trailers de las películas (10 de 14). Casi nadie consideró útil enlazar con los datos de contacto de la biblioteca (1 de 13).

\subsubsection{Uso por los usuarios de bibliotecas}

Aunque son muchas las experiencias que se han compartido, son pocas las que publican los resultados obtenidos de la implantación de estos códigos. A pesar de referirse a realidades completamente diferentes, lo que no les hace comparables, estos estudios coinciden en varios puntos. Varios autores creen en la necesidad de medir cuántas veces se escanean. En este sentido, Sekyere (2012) propone un método para hacer seguimiento del uso de los QR que consiste en crear un URL intermedio que redireccione, mediante un script, a la página final con los contenidos. Este URL intermedio permitiría discernir qué visitas vienen de los códigos QR y capturar los datos de uso en una base de datos MYSQL. Pons, et al. (2011) explican que también puede realizarse esto con un acortador de URL o con un gestor de contenidos como Joomla.

La necesidad de contabilizar el uso es más necesaria aún ante una de las críticas más frecuentes a estos códigos: su bajo índice de uso. Los datos recogidos hasta ahora en diferentes bibliotecas confirman este temor. Schultz (2013) señala que de los usuarios observados durante el estudio que llevó a cabo en la biblioteca de la Ryerson University y el Museum of Inuit Art de Toronto (Canadá), solo uno fue visto escaneando un QR. Wilson (2012) obtuvo datos decepcionantes, según sus propias palabras, sobre el uso de QR en la Eda Kuhn Loeb Music Library, del Harvard College (Estados Unidos), durante el semestre de otoño en el curso académico 2011-2012. Ninguno de los tres recursos en línea (research guides o guías de investigación temáticos) fueron visitados desde QR más de cinco veces durante el semestre.

Los datos publicados por Walsh (2010) en la biblioteca de la University of Huddersfield (Reino Unido) coinciden en esos bajos índices de uso: teniendo en 
cuenta que esta universidad tiene unos 23.000 estudiantes, las 125 veces que fueron escaneados los códigos en el catálogo entre septiembre y diciembre de 2009 resultan insignificantes. También lo son las 140 vistas del vídeo con instrucciones sobre el uso de la fotocopiadora, el más popular de todos -otros se escanearon solo 29 y 21 veces en total-, y mucho más de las 16 y 22 veces que fueron visitados los libros y revistas electrónicas enlazadas desde otros QR respectivamente. Una de las limitaciones que señalan estos autores es la imposibilidad de medir el uso de un QR cuando detrás se esconde un correo electrónico o un número de teléfono.

En esta misma línea están los resultados de Hicks y Sinkinson (2011), quienes en otoño de 2010 llevaron a cabo un estudio piloto en las bibliotecas de la University of Colorado Boulder (Estados Unidos). Los 56 códigos fueron escaneados 226 veces durante cuatro meses, lo que hace una media aproximada de cuatro usos por cada código. Los más utilizados fueron el mapa de las estanterías de la biblioteca, 35 veces, y los mapas que dirigen desde la estantería al mostrador de circulación, 12 veces. Además se escanearon 18 veces los que sirven para realizar una llamada telefónica a la biblioteca, 14 veces los de acceso al chat y 12 los que envían los datos de contacto de la biblioteca. Según los datos publicados por esta universidad, cuentan con unos 30.000 estudiantes ${ }^{66}$.

La Biblioteca Rector Gabriel Ferraté de la Universitat Politècnica de Catalunya (España) llevó a cabo una encuesta en línea a sus usuarios en abril de 2011. De ellos, el 40,7\% no sabía qué eran los códigos QR. Estaban familiarizados el 30,9\% y no lo estaban el 28,4\% (Benítez, et al. 2011). Resultados similares se obtuvieron en la biblioteca de la Kansas State University (Estados Unidos). Tras colocar cuarenta copias de un mismo cartel con tres códigos cada uno -el primero para ver un mapa del edificio, el segundo con una guía de las estanterías y el tercero con datos de contacto de la biblioteca-, se contabilizaron 91 escaneos, de los cuales la mayor parte correspondía al primer código (64,8\%), el 26,4\% al segundo y 8,8\% al tercero (Lo, Coleman y Theiss, 2013). Según los autores del estudio, la mayor preferencia por el primero no es significativa y podría deberse simplemente a que está situado el primero y la gente tiende más a probarlo por eso.

En ninguno de los casos expuestos hasta aquí se puede hablar de éxito en la implementación de códigos QR en la biblioteca, a pesar de que estos códigos son muy fáciles de descifrar, sino más bien lo contrario. Emerge por lo tanto una cuestión: ¿merece la pena implementar códigos QR en la biblioteca? Wilson (2012) opina que, aún con bajos resultados, el bajo coste en términos de esfuerzo, gasto

\footnotetext{
${ }^{66}$ http://www.colorado.edu/sites/default/files/attached-files/JusttheFacts2014_opt2.pdf
} 
económico y tiempo hacen que merezca la pena implementarlos. Sin embargo, se trata de una cuestión muy discutible que merecería profundizar en los motivos por los que no se utilizan más.

\subsubsection{Barreras y razones para no usar los códigos QR}

El desconocimiento de estos códigos podría ser una de las razones por las que no se usan más. Varios estudios confirman la existencia de una franja de usuarios que no los conoce. En la University of Bath, Ramsdem y Jordan (2009) identificaron a un 15,26\% de los estudiantes conocedores de los códigos QR. En la Ryerson University, el 44\% de los usuarios no conocían los códigos QR (Schultz, 2013). La promoción podría ser una solución a este problema: en la University of Huddersfield (Reino Unido) el 8\% de los encuestados por Walsh (2010a) conocían los códigos QR en mayo de 2009, mientras que en el mes de enero de 2010, tras promocionarlos, este ratio ascendió al $12 \%$.

Sin embargo, los datos llevan a pensar que el conocimiento de estos códigos no conlleva un mayor uso. El estudio de Ramsden y Jordan (2009) ya mostraba esa brecha entre el conocimiento y el uso: a pesar de que el 15,26\% de los estudiantes de la University of Bath conocen los QR, como ya se ha explicado, sólo el 2,82\% accedió a ellos. Los datos de Schultz (2013) reflejan un mayor conocimiento que estudios anteriores de otras universidades, pero también un bajo uso. Por otra parte, los ya mencionados datos de IAB Spain (2012) ilustran también la amplia brecha entre el conocimiento y el uso: la mitad de los ciudadanos españoles (52\%) los conocen pero no los han utilizado. Estos datos apuntan, por lo tanto, a que las razones del bajo uso pueden ser otras.

La ausencia de tecnología apropiada (Ramsden y Jordan, 2009) y el coste del acceso a internet (Walsh, 2010a) han sido algunas de las razones mencionadas. Sin embargo, en los últimos años el panorama ha cambiado: el uso de smartphones se ha extendido rápidamente en todo el mundo -y muy especialmente en los países de las universidades mencionadas y entre la población más joven-, las tarifas de datos se han abaratado considerablemente y son muchas las bibliotecas que ofrecen acceso gratuito a la WiFi. Así, aunque siga existiendo una parte de la población que no dispone de dispositivos móviles, no parece que esta sea una razón de peso. Para llegar también a esa parte de la población que no dispone de un smartphone o una tableta, Schultz (2013) plantea como posible solución prestar dispositivos para que descifren los códigos QR. Ramsden y Jordan (2009) proponen que se añada un texto con los contenidos debajo del código. 
Aunque los estudios analizados no aportan datos concluyentes, se apuntan otros posibles motivos: que no se tenga instalada una app para descifrarlos - aunque también hay quienes llevan una aplicación para la lectura de QR pero nunca la utilizan (Green, 2013) - , antipatía ante los códigos QR porque no funcionan a veces o la información que albergan no es útil, desconfianza ante la posibilidad de encontrar URLs maliciosos (Wilson, 2012), timidez de los usuarios —si los pones delante del mostrador de referencia, les dará vergüenza escanearlo delante del personal de la biblioteca, opinan Hicks y Sinkinson (2011) - y falta de interés (Walsh, 2010a; Wilson, 2012).

El factor localización es relevante en los códigos QR. El código está situado en un lugar determinado, con un contexto, lo que probablemente lleve al usuario a formarse una idea sobre su contenido. Este sería un factor a tener en cuenta en las expectativas de los usuarios ante lo que pueden encontrar detrás de un QR. Por ejemplo, si el QR está situado junto a una pieza de un museo se esperará que diga algo más sobre esa pieza. Según el estudio de IAB Spain (2012), la curiosidad juega un importante papel: el 13\% afirmó utilizarlos para ver cómo funcionan. La cuestión es qué sucederá cuando el usuario ya los conozca, ¿los seguirán utilizando cuando se ha saciado la curiosidad o simplemente se olvidarán?

Schultz (2013) destaca la necesidad de realizar estudios sobre la implementación de los QR, sobre qué esperan encontrar los usuarios y cuáles son sus verdaderas expectativas y percepciones. En este sentido, el estudio de Lo, Coleman y Theiss (2013) demuestra el interés de los estudiantes en los códigos QR por su habilidad de ayudarles a llevar a cabo tareas valiosas para ellos de forma rápida. Para ellos, los QR que no resuelven alguna necesidad no merecen la pena ser escaneados. Es una de las buenas prácticas que indica Arroyo-Vázquez (2013d), que los códigos tengan alguna utilidad, pero también ponerse en la situación de quien lo descifra.

Lo cierto es que hacen falta más investigaciones para conocer realmente cuáles son las motivaciones de los usuarios para usar y no usar los códigos QR. Todos los estudios señalados hasta ahora no dejan de ser sectoriales, pues representan a una situación concreta en una ciudad concreta, y han sido llevados a cabo en bibliotecas universitarias, donde el público es joven y se encuentra en el momento de realizar sus estudios. Pero no se conocen las motivaciones de otros tipos de usuarios. Como señala Schultz (2013), cuando hay ausencia de evaluación formal, las asunciones comunes se propagan sin evidencias que apoyen las iniciativas que sugieren.

En España, concretamente, la ausencia de estudios es más notable aún, pues a excepción de los datos publicados por Benítez, et al. (2011) no se conocen más. Son varias las experiencias que se han compartido, algunas de ellas son las de la Biblioteca de la Universidad Politécnica de Valencia (Pons, et al., 2011), la 
Biblioteca Pública de Muskiz (Juárez-Urquijo, 2013), los Bibliobuses de León (Soto, 2013), el Servicio Municipal de Bibliotecas de Níjar (Villegas Lirola, 2013) y las Bibliotecas Públicas de Barcelona (Bröll, Cabré y Gándara, 2014). En este momento sobran artículos de divulgación y faltan investigaciones que nos ayuden a conocer mejor el uso de estos códigos.

\subsection{Realidad aumentada}

La realidad aumentada consiste en la superposición de objetos digitales sobre la realidad, lo que genera una versión enriquecida de ésta. En palabras de Azuma (1997), «la realidad aumentada permite al usuario ver el mundo real con objetos virtuales superpuestos o mezclados con él. Por lo tanto, la realidad aumentada complementa la realidad en lugar de reemplazarla.» Son tres las características descritas por Azuma: combina lo real y lo virtual, es interactiva en tiempo real gracias a enlaces a la web-y en 3D.

La realidad aumentada es parte del continuo realidad-virtualidad delimitado por Milgram, et al. (1994), en el que realidad y virtualidad están en los dos extremos. Entre ellos se encuentra la realidad mezclada (mixed reality), que a su vez comprende la realidad aumentada, más cercana a la realidad, y la virtualidad aumentada, próxima a la virtualidad. Así, en la realidad aumentada la parte de realidad es mayor que en la realidad virtual.

En los años noventa Tom Claudell y David Mizell acuñaron el término realidad aumentada y comenzaron a aparecer las primeras publicaciones científicas y a celebrarse los primeros congresos sobre el tema. Si bien los usos en ámbitos como la cirugía, la aviación o el militar ya existían, el detonante para la popularidad de la realidad aumentada fue la aparición de los smartphones (Arroyo-Vázquez, 2011b). La cámara del dispositivo capta la realidad y se visualiza la mezcla a través de la pantalla. Los datos virtuales superpuestos llegan desde la conexión a internet.

También puede hacerse efectiva a través de dispositivos que se montan en la cabeza del usuario (head-mounted display), como cascos o lentes que proyectan imágenes sobre la retina del ojo humano o en superficies reflectivas, valiéndose de proyectores. El dispositivo más popular en esta categoría son las Google Glass, unas gafas desarrolladas por Google que se están distribuyendo en modo beta. Un último tipo de realidad aumentada, conocida como spatial augmented reality, es posible gracias a la proyección de imágenes en una superficie. 
El funcionamiento de la realidad aumentada, en líneas generales, es el siguiente: se captura la realidad a través de la cámara del dispositivo y, en función de unas referencias determinadas, se mostrará una información u otra sobre la imagen de la realidad. Lo que varía son precisamente estas referencias, y por ello se puede hablar de cuatro tipos de realidad aumentada:

- Basada en la localización, cuando el punto de referencia viene determinado por las coordenadas geográficas. Así, en función del lugar y dirección en que nos encontremos la información que se visualizará en la pantalla del dispositivo será una u otra.

- Basada en el reconocimiento de imágenes, donde el punto de referencia es una imagen, que puede ser un logotipo, la portada de un libro, una fotografía, un dibujo o cualquier otra.

- Basada en marcadores. En este caso, el dispositivo toma como punto de referencia unos códigos 2D similares a los códigos QR, pero no iguales.

- Sin puntos de referencia, lo que permite situar un objeto digital en cualquier lugar. Un ejemplo de uso es ver cómo quedaría un mueble en un rincón de una habitación.

Para que la realidad aumentada funcione en una tableta o en un smartphone debe tener previamente instalada una aplicación para ello. En los últimos años han surgido los llamados navegadores de realidad aumentada, un tipo de aplicaciones nativas que facilitan a terceros la inclusión de capas. Así, se pueden crear capas de datos geolocalizados, que pueden ser, por ejemplo, farmacias, restaurantes, monumentos o bibliotecas (Arroyo-Vázquez, 2011a). El usuario final selecciona cuál es la capa que quiere consultar en un momento dado en función de sus necesidades. Wikitude, Layar, Junaio y Acrossair son los navegadores de realidad aumentada más conocidos. Cada uno de ellos ofrece contenidos diferentes, lo que significa que para que una capa funcione debe ser agregada a cada uno de ellos.

Los datos geolocalizados también pueden ser visualizados en una lista o en un mapa. Lo que aporta la realidad aumentada es una forma de visualización diferente, integrada en el contexto de la realidad, y por lo tanto con puntos de referencia visuales. Cuando buscamos algo en un mapa tenemos que hacer el esfuerzo mental de extrapolar nuestro conocimiento de la realidad y adaptarlo a la representación del mapa.

Navegadores de realidad aumentada como Layar, Wikitude o Junaio han incorporado más tarde el reconocimiento de imágenes. Así, además de agregar capas de datos geolocalizados también permiten asociar determinados objetos digitales a una imagen. El usuario final solo tendría que enfocar desde la cámara y con la aplicación adecuada esa imagen para visualizar la mezcla. 
Las utilidades de la realidad aumentada son innumerables y pueden abarcar a prácticamente cualquier ámbito en el que se requiera la visualización de datos. Juegos como EyePet ${ }^{67}$, de Sony, para PS3 y PSP, o Invizimals ${ }^{68}$ hacen uso de la realidad aumentada. En noviembre de 2012 se lanzó al mercado Wonderbook ${ }^{69}$, el libro de los hechizos, basado en la historia de Harry Potter. Se trata de un libro que incluye marcadores con contenidos aumentados que se visualizan a través de la PlayStation 3 de Sony.

En el ámbito educativo se espera que la realidad aumentada ayude a los estudiantes a entender las explicaciones al completar los textos con vídeos e imágenes, incluso en 3D, más cercanos a la realidad. Por otra parte, hace posible la integración del mundo real y los recursos digitales de aprendizaje (Wu, et al., 2013) y se muestra potencialmente útil en el aprendizaje de tareas que requieren experimentación, habilidades espaciales y colaboración, entre otros (Di Serio, Ibáñez y Delgado Kloos, 2013).

Ya se encuentran en el mercado varios libros con experiencias de realidad aumentada, sobre los que se pueden ver imágenes en $3 \mathrm{D}$ y en movimiento que recrean las capas de tierra, mapas, dinosaurios y otros objetos con fines educativos, normalmente con ayuda de un ordenador con webcam. En España, la empresa AR-Books se ha especializado en este tipo de libros. La edición de 2014 del Libro Guiness de los Records viene acompañado de una app para smartphones con la que ver sus contenidos de una manera diferente.

Son varias las aplicaciones de la realidad aumentada en diferentes aspectos relacionados con el patrimonio cultural: turismo cultural, creación artística y espacios expositivos y patrimoniales son algunos de los ámbitos que explora Ruiz Torres (2013). Miradores turísticos con información digital superpuesta, exposiciones enriquecidas con contenidos digitales, visualizar el estado anterior de una obra o de edificios desaparecidos son solo algunas de sus utilidades. El ámbito cultural está muy relacionado con el trabajo que se realiza desde las bibliotecas, por lo que puede servir de inspiración para posibles utilidades, como se verá en el siguiente apartado.

\footnotetext{
${ }^{67}$ http://www.eyepet.com

${ }^{68} \mathrm{http}$ ///invizimals.eu.playstation.com/es ES/home

${ }^{69} \mathrm{http}$ ://es.playstation.com/bookofspells
} 


\subsubsection{Realidad aumentada en bibliotecas}

En 2010 el Informe Horizon señalaba la realidad aumentada como una de las tecnologías que se implantarían en educación en los próximos dos o tres años (Johnson, et al., 2010). Al igual que otras utilidades de los dispositivos móviles, los casos de uso de realidad aumentada en bibliotecas aún hoy son incipientes, pero ya se pueden adivinar las posibles aplicaciones y hasta conocer algunos casos de uso, aunque se encuentran en fase de desarrollo e investigación, como afirma Hahn (2012).

Hasta el momento la bibliografía profesional se ha ocupado especialmente de relatar esos casos y de divulgar información básica sobre qué es la realidad aumentada y sus posibles utilidades para las bibliotecas. De forma general, la realidad aumentada es percibida a través de la bibliografía como un nuevo campo lleno de posibilidades para las bibliotecas y su uso se complementa con otras tecnologías como QR, NFC o la geolocalización (Fernandez, 2014).

Uno de los dilemas que se plantean a la hora de crear una experiencia de realidad aumentada es si optar por un navegador de realidad aumentada o desarrollar una app propia desde el principio (Azavea, 2011; Hahn, 2012). Desde luego, todo depende de para qué y de cuál sea el objetivo. Si la única intención es superponer contenidos digitales a una imagen, se podrá utilizar una aplicación como Layar Creator. Una tarea también sencilla de acometer es crear una capa de datos geolocalizados en Layar, Junaio o Wikitude: con intermediarios como Hoppala Augmentation se evita programar la capa y se facilita enormemente el proceso (Arroyo-Vázquez, 2011c).

Pero si se desean resultados más personalizados o, simplemente, diferentes, habrá que pensar en crear una app propia, una solución sin duda más costosa y para la que habrá que contar con programadores especializados. En definitiva, algunas formas de realidad aumentada son asequibles para cualquier biblioteca, mientras que otras están al alcance de solo unas pocas. En cualquier caso, requiere un esfuerzo considerable, como asegura Ekart (2011).

Una cuestión que no se ha tratado apenas en la bibliografía es el uso que se está haciendo de la realidad aumentada por parte de los usuarios: ¿en qué medida les interesa? Es difícil anticipar la difusión que tendrá (Fernandez, 2014), y tampoco resulta sencillo medirla en algunos casos. Layar Creator y otras herramientas muestran las estadísticas de uso. ¿Pero cómo medir el uso que se hace cuando se trata de una app propia y la realidad aumentada es solo una parte de ella?

Dada la escasez de investigaciones en el ámbito bibliotecario hay que acudir al educativo, donde se han llevado a cabo varios estudios sobre el impacto de la realidad aumentada en los procesos de aprendizaje. Di Serio, Ibáñez y Delgado 
Kloos (2013) han demostrado el impacto positivo de este tipo de visualización de la información en la motivación de los estudiantes de secundaria. Sumadio, Dwistratanti y Rambli (2010) ya habían concluido anteriormente que la realidad aumentada puede generar una experiencia natural, incrementar la efectividad de la enseñanza y atraer la atención de los estudiantes, haciendo los temas más atractivos. Chen y Tsai (2012) recuerdan el valor del contexto en los procesos de aprendizaje, pues contribuye a mejorar el interés en el aprendizaje y su eficiencia, y concluyen que interactuar con el mundo real activamente favorece la aplicación del conocimiento.

Uno de los desafíos a los que se enfrentan las bibliotecas ante la realidad aumentada es que no es muy conocida y no es fácil de utilizar por todo el mundo. Una encuesta realizada por IAB Spain (2012) a ciudadanos españoles de entre 18 y 55 años reveló que solo el 12\% había utilizado la realidad aumentada en ese año y algo más de la mitad (51\%) no la conocía. El 37\% restante la conocía pero no la había utilizado. En cambio, el 38\% de los encuestados había utilizado los códigos QR y solo el $10 \%$ no los conocía.

Un estudio realizado por Cocciolo y Rabina (2013) en el Pratt Institute School of Information and Library Science de Nueva York reveló que la realidad aumentada no es fácil de utilizar para todo el mundo. Algunas personas que no la habían utilizado previamente se encontraron con dificultades de usabilidad y no fueron capaces de aprovechar una capa en Layar con datos geolocalizados, incluso a pesar de que recibieron instrucciones previas. Esa misma investigación reveló que la realidad aumentada no contribuía a un mejor entendimiento de la información o a un mayor compromiso por parte del usuario.

La realidad aumentada, como otras utilidades de las tecnologías más novedosas, promete dar un aire de modernidad a la biblioteca. Boyer (2011) recomienda que no se abrace la tecnología por sí misma, sino porque tenga algún beneficio. Aún queda mucho por investigar en ese sentido.

Se recogen en los siguientes apartados varias experiencias puestas en marcha en bibliotecas, agrupadas por su utilidad. Además de ellas, se adivinan muchas otras: demostraciones en vídeo, ayuda superpuesta en los servicios basados en pantallas - por ejemplo, se podría acompañar al catálogo en línea con flechas y notas explicativas-, asistente de personal o recordados y localizador de libros son algunas de las que señala Humphries (2012). Una gran limitación que se ha encontrado a la hora de analizar estos casos de uso es que solo se pueden consultar los datos cuando alguien se encuentra en el lugar determinado. 


\subsubsection{Fondos patrimoniales y visitas guiadas}

Mostrar los fondos patrimoniales o hechos históricos en su contexto es una de las utilidades de la realidad aumentada más explotadas por las bibliotecas. En palabras de Boyer (2011), "puede ayudar a las colecciones bibliotecarias a encontrar una nueva audiencia, crear nuevas oportunidades de acceso y redibujar sus propios límites.» Si a través de la movilidad los usuarios pueden llevar la información a cualquier parte, con la realidad aumentada esos contenidos se pueden ver exactamente en su contexto, lo que ayuda a conectar con el pasado y constituye una forma de ver cómo ha cambiado un lugar (Boyer, 2011).

El portal PhillyHistory.org, que contiene más de un millón de fotografías antiguas de la ciudad de Filadelfia y sobre el que se habló en el apartado 2.4.2, ha sido uno de los primeros en poner en contexto los fondos patrimoniales a través de la realidad aumentada. En 2011 lanzaron una capa de realidad aumentada con más de 90.000 imágenes que funciona en Layar (Azavea, 2011). Las limitaciones de Layar, según reportan, son los fallos en la plataforma derivados de su versión beta y las restricciones en las opciones de personalización. Aún así, esta capa se inicia con una página personalizada.

Muy similares son los proyectos GeoStoryteller ${ }^{70}$ y Scan José. El primero de ellos fue desarrollado por la Pratt Institute School of Information and Library Science y los bibliotecarios del Goethe-Institut (Cocciolo y Rabina, 2013). Coincide en el objetivo y en la forma con PhillyHistory.org, pero en el caso de GeoStoryteller el objetivo es mostrar los lugares relacionados con la cultura alemana en la ciudad de Nueva York. Estas fotos, que se muestran en una capa en Layar, revelan cambios en el sitio a lo largo del tiempo, y no solo responden a una moda. La movilidad sirve también para que cualquier persona pueda compartir sus historias en la plataforma. Scan José ${ }^{71}$, desarrollado por la ciudad de San José (Estados Unidos), cuenta con un sitio web para móviles y una capa de realidad aumentada en Layar. En este caso cada una de las tres rutas sugeridas se pueden descargar también en un pdf antes de la visita cuando la conexión es lenta (Hill, 2011).

En lugar de la evolución de un lugar en el tiempo, la capa de realidad aumentada en Layar de la Biblioteca de Muskiz (España) muestra los hechos históricos acaecidos. La batalla de Somorrostro 1874 sitúa en el mapa documentación histórica relacionada con la Batalla de Somorrostro, que tuvo como escenario la localidad de Muskiz durante las guerras carlistas (Riancho y Juárez-Urquijo, 2011; JuárezUrquijo, 2012).

\footnotetext{
${ }^{70} \underline{\mathrm{http}}$ ///library.gc.cuny.edu/geo/index.php

${ }^{71}$ http://www.scanjose.org
} 
En todos los proyectos mencionados hasta ahora se ha optado por herramientas de terceros. A diferencia de ellos, la Biblioteca del Estado de Baviera (Alemania), en colaboración con el Departamento de Palacios, Jardines y Lagos del Estado, creó con motivo del 125 aniversario de la muerte de Luis II de Baviera, en 2011, la aplicación Ludwig II - Walking in the Footsteps of a Fairytale King. Esta app localiza diferentes lugares relevantes en la vida del príncipe bávaro y se vale de la realidad aumentada de tres maneras, según explica Ceynowa (2013):

- Para ver cuáles son los lugares cercanos relacionados con el personaje de Luis II de Baviera. Se incluyen 140 lugares, 80 de ellos con información más detallada, por ser más significativos. Para cada lugar se muestran el nombre, la distancia y una breve información. Se incluye un botón para ver más información.

- Visualizar espacios ya desaparecidos, como el invernadero de Luis II, que fue demolido tras su muerte. Al enfocar al lugar en que estuvo situado, los visitantes pueden ver una simulación en 3D realizada gracias a la tecnología de la empresa Metaio.

- Los visitantes del Castillo Neuschwanstein, cuando apuntan al ticket de visita con el smartphone, aparece un modelo del castillo en 3D. La miniatura se guarda en el álbum de regalos de la app y puede ser visualizado después sin el ticket.

Estas capas son además capaces de ejercer como guías turísticas en la ciudad. Es el caso de los Paseos literarios por Burgos de las Bibliotecas Municipales de Burgos (España), que se acompañan de ficheros de audio con pasajes literarios relacionados con diferentes lugares de la ciudad de Burgos. Para acompañar al proyecto, y como otra manera de seguirlo, se crea una capa de realidad aumentada en Layar en la que se sitúan estos mismos lugares (Ibáñez-Hernández, 2012). Así, estos paseos literarios se convierten en una manera diferente de pasear por la ciudad.

Todas estas iniciativas conllevan un importante trabajo de documentación y curación de contenidos que ha requerido la colaboración de especialistas en las diferentes materias. Es por lo tanto una oportunidad para que las bibliotecas saquen a la luz fondos patrimoniales, pero también supone un reto la necesidad de contar con la colaboración de diferentes especialistas.

La geolocalización juega un papel fundamental en todos los casos, es quien dota de contexto a la información. Pero a la vez supone una limitación en el acceso a los fondos, puesto que no se puede acceder a los contenidos geolocalizados si no es desde un lugar cercano. Esta limitación pone de relieve la necesidad de que esos fondos no estén exclusivamente publicados en una capa de realidad aumentada si se quiere garantizar el acceso universal, uno de los principios básicos de las 
bibliotecas. Por ello en los ejemplos vistos hasta ahora la realidad aumentada es un complemento a otras formas de visualización de la información.

Todos ellos son proyectos exploratorios, que apenas cumplen el objetivo de desarrollar una capa y no se analiza el impacto que está teniendo o cómo lo están utilizando. A excepción del mencionado trabajo de Cocciolo y Rabina (2013), que incluye una pequeña investigación, ninguno analiza los resultados de la puesta en marcha de estas experiencias - o no al menos de forma pública-, algo que se hace necesario para mejorar las futuras experiencias.

La realidad aumentada consigue que algo más serio, como pueden ser los fondos de la biblioteca, bien contextualizados, se conviertan en información divulgativa, incluso sirvan para una guía turística y hagan disfrutar a los ciudadanos que visitan una ciudad. Se trata de que esos fondos lleguen al lugar en el que sirven mejor a la ciudadanía, en las calles.

Aunque también dentro del enfoque patrimonial, es diferente la aproximación del proyecto SCARLET. Financiado por el JISC (Reino Unido), este proyecto es coordinado por Mimas (parte de la División de Recursos Digitales de JISC en colaboración con la University of Manchester, el Manchester Museum, la John Rylands Library de esta misma ciudad, la University of Sussex y el Craft Study Centre de la University for the Creative Arts. Su razón de ser está en salvar los obstáculos en el uso de colecciones especiales por parte de los estudiantes, quienes habitualmente encuentran grandes dificultades para la consulta de libros raros, manuscritos o archivos. Este material está aislado por cuestiones de conservación y su interpretación requiere en ocasiones conocimientos adicionales.

Así, en el marco de este proyecto y de su ampliación SCARLET +, se han creado capas de realidad aumentada basadas en el reconocimiento de imágenes que pretenden mejorar la experiencia de uso con información adicional y recursos relacionados (Skilton, et al., 2013). En la segunda fase del proyecto (junio de 2012 a abril de 2013) se creó la capa Voices In Your Pocket en Junaio, con dos vídeos y tres códigos sobre los que se puede hacer clic para descubrir información adicional. Similar es el resultado de la colaboración con la Universidad de Artes creativas, que tiene implicaciones educativas.

Una línea similar a la del proyecto SCARLET sigue el sistema de modelado de libros raros de la National Library of Malaysia, conocido como AR Rare BM (Parhizkar y Zaman, 2009). El objetivo de esta iniciativa, según indican los mencionados autores, está en evitar el deterioro de las colecciones especiales y permitir a la vez su consulta en el contexto original: los usuarios pueden pasear por las estanterías de la sección de libros raros y manuscritos y ver las categorías y las listas de los libros. Además, pueden consultar los libros pasando las páginas en la mesa, pero 
para acceder al contenido completo deben identificarse antes como usuarios. La realidad aumentada les permite además algo que no podrían hacer: poner marcadores en el libro. Estas páginas señaladas se pueden además imprimir.

\subsubsection{Exposiciones}

La dinamización de exposiciones es una de las utilidades que han encontrado los museos a la realidad aumentada. Son tres las aplicaciones de la realidad aumentada en este tipo de espacios, según Ruiz Torres (2013): guías personales a través de smartphones y tabletas, basadas en el uso de marcas y reconstrucciones virtuales aumentadas, que consisten en escenas virtuales generadas en el espacio en cuestión gracias a pantallas fijas.

Las bibliotecas, como instituciones organizadoras de exposiciones, también están explorando esta vía. La exposición Lecturas de cabecera, exhibida en el Centro de Desarrollo Sociocultural de la Fundación Germán Sánchez Ruipérez en Peñaranda de Bracamonte (España) entre el 7 y el 31 de octubre de 2013, contenía información adicional solo visible desde un smartphone o una tableta gracias a la realidad aumentada: al abrir algunas de las mesillas se encontraban imágenes y vídeos con booktrailers o presentaciones gracias a Layar y Aurasma (Redondo, 2014).

Situada en frente de la biblioteca de la University of Bath (Reino Unido) se encuentra una imprenta de 1839 donada a la universidad para acompañar a la Colección Pitman, así denominada en honor de un famoso impresor de la ciudad. Gracias a la realidad aumentada, los usuarios de smartphones pueden encontrar más información sobre la historia de la imprenta y su funcionamiento (Augmented..., 2013).

En este tipo de situaciones es necesario hacer saber al visitante que al escanear una imagen de su entorno encontrará información adicional desde un dispositivo móvil, puesto que la realidad aumentada no se ve a simple vista, como sí sucede con los códigos QR.

\subsubsection{Geolocalización}

Hasta ahora se han recogido algunas experiencias que hacen uso de la geolocalización con alguna finalidad. Pero la localización puede ser un objetivo por sí mismo en la realidad aumentada. En España la primera experiencia conocida de 
realidad aumentada en bibliotecas fue la capa que la Subdirección General de Coordinación Bibliotecaria del entonces Ministerio de Cultura puso en marcha con los principales lugares del V Congreso Nacional de Bibliotecas Públicas, celebrado en Gijón en 2010: hoteles, restaurantes y la sala de convenciones se podían ubicar gracias a esta iniciativa que actualmente no está en funcionamiento (ArroyoVázquez, 2011a). Un año después la misma Subdirección publicó una capa ${ }^{72}$ con la ubicación de más de 8.000 bibliotecas situadas por todo el país. Así, cualquier persona que desee encontrar una biblioteca cercana al lugar al que se encuentra podrá hacerlo a través de Layar y obtendrá además el nombre de la biblioteca, su dirección, número de teléfono y el correo electrónico (Subdirección General de Coordinación Bibliotecaria, 2011). Otras capas similares en nuestro país son las de Archivos Estatales y Biblioteques $\mathrm{BCN}^{73}$, con las bibliotecas de la ciudad de Barcelona (Molina y Ribera, 2012).

\subsubsection{Marketing}

Relacionar los contenidos de lo físico con lo digital es una de las utilidades de la realidad aumentada. Si se tiene como base el reconocimiento de imágenes, pueden agregarse contenidos en libros, folletos o carteles o cualquier otra superficie con una imagen reconocible. La Biblioteca de Muskiz también ha experimentado con la realidad aumentada basada en el reconocimiento de imágenes enriqueciendo los contenidos de su folleto (Juárez-Urquijo, 2013). Con Layar Creator se han asociado varios botones a la parte delantera y trasera del tríptico, enlazando a la cuenta del Twitter, al número de teléfono de la biblioteca y a un vídeo. Esta misma utilidad, la de enriquecer los contenidos impresos, ha sido aplicada por la biblioteca con vídeos de usuarios recomendando determinadas lecturas que se superponen a la portada de ese libro mediante Aurasma. Juárez-Urquijo (2013) destaca la implicación de los usuarios en este proceso.

Meredith (2014) propone esta misma utilidad para el público infantil, de manera que la realidad aumentada sirva como vía para descubrir lecturas similares a la que el usuario tiene en las manos. Una forma de hacerlo es enlazando a listas previamente seleccionadas desde un botón que anuncie lecturas relacionadas. Pero también puede servir a este tipo de público añadir información relacionada en las portadas de los libros.

\footnotetext{
72 https://www.layar.com/layers/bibliotecas2011

${ }^{73}$ https://www.layar.com/layers/provabiblioteca
} 


\subsubsection{Integración de contenidos digitales en los espacios físicos}

La dicotomía entre lo físico y lo virtual, entre los contenidos y servicios presenciales y los digitales, podría ser salvable gracias a la realidad aumentada, que hace posible la integración de contenidos digitales en los espacios físicos (Barnes y Brammer, 2013). La señalización de espacios y la agregación de datos procedentes de bases de datos son dos de los aspectos en los que se materializa esta integración.

Ya en 1995 Nagao y Rekimoto pensaban en la necesidad que plantearía la integración de los recursos impresos y los digitales y propusieron Ubiquitous Library, un sistema de realidad aumentada a través del que los contenidos digitales quedan representados en un espacio físico. A esta composición le llaman biblioteca aumentada (augmented library).

La biblioteca de la University of Illinois at Urbana-Champaign ha añadido información digital a su colección física, procedente de sus bases de datos. Así, la aplicación resultante sirve para identificar áreas temáticas en las estanterías. Además, el software superpone varios contenidos digitales: de cada libro, el usuario puede ver a través de la pantalla de su smartphone información sobre el número de veces que se ha tomado en préstamo el libro y llegar a recomendaciones relacionadas con ese libro al tocar los botones que aparecen en cada libro (Hahn, 2012).

Esta misma biblioteca ha investigado además en otros aspectos recogidos por Hahn (2012):

- El desarrollo de una app que dirija al usuario, como en un «embudo», hacia las características más relevantes en las estanterías mientras caminan para conseguir un libro en la biblioteca.

- Reconocimiento óptico de caracteres (OCR) aplicado para que los estudiantes puedan encontrar otros recursos de la biblioteca relacionados con el que están escaneando. Así, a partir de una página de un libro, de una cita de la bibliografía o de una determinada sección de la colección se obtendrían otros recursos similares que se podrían enviar después a través del correo electrónico o compartir en redes sociales.

- El reconocimiento de textos podría ayudar a los estudiantes a entender lo leído, a aprender idiomas o facilitar la lectura a quienes tienen deficiencias visuales. 
- Los sistemas de reconocimiento facial tendrían una gran utilidad en la identificación de los usuarios en la biblioteca.

La señalización de los espacios físicos serviría para localizar la biblioteca dentro del campus o a encontrar determinadas secciones dentro de un edificio. Meredith (2014) propone estas indicaciones dirigidas al público infantil. Barnes y Bramer (2013) documentan el uso de la ya desaparecida aplicación de realidad aumentada Stiktu en la biblioteca de la Florida State University para marcar las materias de cada sección. Otro buen ejemplo, aunque en un ámbito más amplio que el meramente bibliotecario, es la app de la Universidad de Salamanca Umbrella $\mathrm{USAL}^{74}$, una guía para descubrir los diferentes espacios de la universidad mediante la realidad aumentada.

\subsubsection{Alfabetización informacional y gamificación}

Mostrar el funcionamiento de la biblioteca a los usuarios es una de las utilidades que se le ha dado a la realidad aumentada. Chen y Tsai (2012) presentan un sistema de instrucción de usuarios denominado ARLIS que explica el funcionamiento del sistema de clasificación chino a los estudiantes utilizando tecnología interactiva 3D. En una investigación realizada por estos autores se demuestra que este sistema produce resultados muy similares al sistema de instrucción personal, a través de un bibliotecario. Además, la realidad aumentada tiene la ventaja de que permite liberar recursos humanos.

Convertir el aprendizaje en un juego es el objetivo de las siguientes aplicaciones. El efecto misterioso de la realidad aumentada es especialmente idóneo en dinámicas del tipo búsqueda del tesoro, que han sido adaptadas en varias bibliotecas para aprender su funcionamiento y descubrir sus recursos y servicios de una manera lúdica. La búsqueda del tesoro organizada por la Openbare Bibliotheek Deventer (biblioteca pública de Deventer, en Holanda) tuvo como objetivo enseñar a los estudiantes sobre su ciudad y convertir a la biblioteca como centro de información de referencia. A través de una capa de realidad aumentada en Layar dos grupos de estudiantes tuvieron que encontrar pistas para completar diferentes tareas y ganar puntos, según explica Cameron (2010).

Una de las bibliotecas de la Stetson University College of Law (Estados Unidos) utilizó la ya desaparecida app Stiktu, antes mencionada, en una búsqueda del tesoro que tiene como objetivo final promocionar la biblioteca y los servicios

${ }^{74}$ http://www.usal.es/webusal/node/39314 
tecnológicos que ofrece, como el préstamo de iPads (Barnes y Brammer, 2013). Según explican estos autores, al escanear determinados recursos informativos de la biblioteca el jugador iba completando un puzle que le llevaba al resultado final. En este juego se han diseñado dos aproximaciones: en la primera, con una intención educativa, el graffiti virtual resultante daría pistas para encontrar el siguiente recurso. En la segunda se intenta que el jugador conozca la biblioteca, y para ello se colocan diferentes símbolos en diferentes lugares. Al unirlos todos se obtiene una frase completa.

\subsubsection{Utilidades profesionales}

Una de las aplicaciones más originales que hacen uso de la realidad aumentada es ShelvAR75 (Brinkman y Brinkman, 2013). Desarrollada por el Miami University Augmented Research Group (MUARG), su finalidad es detectar los libros mal colocados en las estanterías de la biblioteca, como ya se indicó en el apartado 2.3.3.5. Para que ShelvAR sea capaz de reconocer esos libros, previamente se coloca un tejuelo con un código especial en cada libro. Al escanear el libro con la app, se identifican los que están mal colocados con un aspa en color rojo y los que están bien con una $\mathrm{V}$ en verde. Además, se muestra una flecha indicando la posición que deberían ocupar de los mal colocados. Según explican Brinkman y Brinkman, se trabaja en mejoras en el proceso de inventariado, generando listas de libros perdidos, identificar secciones con mayor actividad y mejorar la eficiencia del personal indicando cuáles son las áreas que más se revisan y cuáles las que menos.

Ayudar en la gestión de la colección es el objetivo de la aplicación Libagent, presentada por Shatte, Holdsworth y Lee (2014) y aún en fase de experimentación. Muy similar a ShelvAR, Libagent es capaz de ordenar una sección de libros indicando el orden que debe ocupar cada uno. Comparando los datos con los del catálogo se puede extraer información sobre los libros perdidos o en préstamo. Finalmente, se puede buscar un libro para que aparezca marcado en la estantería y sea más fácil localizarlo.

La ventaja de este tipo de aplicaciones está en que se minimizan los errores, según indican Shatte, Holdsworth y Lee (2014), aunque estos autores no han encontrado pruebas concluyentes de que se tarde menos tiempo que con un método tradicional. Lo que sí se indica es que la app tarda menos de un segundo en mostrar los resultados. Sin embargo ShelvAR sí promete más rapidez en su sitio

${ }^{75}$ http://www.shelvar.com 
web y también mayor precisión. En el momento de escribir estas líneas, ShelvAR puede descargarse de las tiendas de aplicaciones de Apple y Android y aquellas bibliotecas interesadas en utilizarla pueden solicitarlo, mientras que Libagent es aún un prototipo.

ShelvAR y Libagent son buenos ejemplos de cómo los dispositivos móviles y sus utilidades pueden facilitar los procesos de trabajo, un área aún poco explorada, puesto que la mayor parte de las iniciativas se dirigen a los usuarios.

\subsubsection{Google Glass}

Las Google Glass, las gafas de Google están aún en fase de pruebas, pero ya han despertado el interés de las bibliotecas, posiblemente debido a su potencial para la investigación y el descubrimiento de información, como señalan Booth y Brecher (2014). Se trata de un dispositivo de visualización de la realidad aumentada con el que se interactúa a través de la voz humana. Los objetos digitales, la información, se muestran proyectados sobre la retina del portador. De esta manera es posible visualizar el mundo real y los datos relacionados con él mezclados.

El primer uso que se les está dando a estas gafas en bibliotecas de Estados Unidos es prestarlas a los usuarios. Teniendo en cuenta que no es fácil conseguirlas hasta el momento solo se venden en Estados Unidos por el precio de unos 1.500 dólares-, este servicio está despertando el interés de los usuarios, como explican Booth y Brecher (2014). El siguiente paso consistiría en desarrollar aplicaciones específicas para estas gafas.

Aún es pronto para conocer las posibles utilidades que pueden tener en bibliotecas, pero ya se adivina que pueden ser muy similares a las de otros dispositivos de realidad aumentada, aunque la experiencia de llevar puestas las gafas en lugar de llevar el smartphone o tableta en la mano sea diferente. Visitas guiadas, recibir información adicional al visitar una exposición, obtener datos sobre los lugares más cercanos a nuestra posición, superponen contenidos digitales sobre los impresos, señalización de espacios físicos, instrucción sobre los recursos de la biblioteca y utilidades profesionales como ShelvAR entrarían dentro de las posibilidades de estas gafas, aunque habría que adaptarlas a sus peculiaridades, como la interacción por voz. Verma (2013) señala además otras utilidades: grabación de eventos y de videotutoriales, radiodifusión en tiempo real, traducción textual, ayuda a la lectura para los discapacitados y recibir sugerencias de lectura. En los próximos años seguramente se vean nuevas iniciativas. 


\subsection{Near Field Communication (NFC)}

Los dispositivos móviles incluyen otras tecnologías menos extendidas pero que en un tiempo podrían popularizarse y que además hacen intuir varias utilidades para las bibliotecas. Se trata del NFC, una conectividad de corto alcance que permite el intercambio de datos, los beacons, unos sensores que emiten señales a los dispositivos que se encuentran a unos metros, y las aplicaciones como PassBook, que centraliza las tarjetas de fidelización, cupones y entradas y que serviría también para llevar el carnet de la biblioteca en el móvil.

Near Field Communication (NFC), según la definición de McHugh y Yarmey (2014), es un «conjunto de especificaciones técnicas y estándares para transferir información entre dos objetos próximos a través de campos de radio frecuencia a 13,56 MHz». El NFC se construye sobre la tecnología RFID (Radio-Frequency Identification), que se utiliza en las bibliotecas desde hace tiempo para el seguimiento de los documentos en operaciones como el préstamo, las devoluciones o el inventariado, también para el autopréstamo y auto-devoluciones, y además funciona como sistema antirrobo. La primera biblioteca pública que utilizó RFID fue la Farmington Community Library en Michigan, en 1999 (GómezGómez, Ena-Rodríguez y Priore, 2007). El año anterior lo había implementado la Library of Rockefeller University, en Estados Unidos (Moreno, et al., 2014).

El funcionamiento del NFC es similar al de RFID: requiere un dispositivo iniciador o lector y un target o transpondedor. El iniciador emite una señal de radio desde una antena, señal que el target recibe y a la que responde. En el caso de NFC, el target debe estar situado a unos tres o cinco centímetros del iniciador para que se pueda establecer la comunicación, mientras que RFID tiene un rango más amplio. La comunicación en RFID puede ser pasiva, cuando la etiqueta recibe la energía necesaria del iniciador, o activa, cuando la etiqueta tiene su propia fuente de energía y se puede establecer una comunicación en ambas direcciones. Sin embargo, NFC permite hasta tres modos de comunicación, según recogen Igoe, Coleman y Jepson (2014):

- Las etiquetas de lectura y escritura permitirían la conexión directa a un sitio web, enviar SMS sin escribir u obtener cupones de descuento, solo acercando el dispositivo a la etiqueta a no más de cinco centímetros. 
- En modo peer-to-peer un lector-escritor se puede comunicar con otro lector-escritor para intercambiar datos. Por ejemplo, dos smartphones podrían intercambiar las tarjetas de visita de sus propietarios.

- En un dispositivo en modo de tarjeta de emulación el NFC actúa como una tarjeta inteligente para realizar pagos, controlar el acceso a determinados espacios o comprar entradas.

El NFC conecta con el concepto de internet de las cosas, ya que dota de conectividad y datos adicionales a los objetos a través de etiquetas.

\subsubsection{Tecnología NFC en bibliotecas}

En este momento las posibilidades de uso de la tecnología NFC en bibliotecas responden más a un ejercicio de imaginación que a una realidad, pues son muy pocos los casos que se han puesto en práctica. También son escasas las publicaciones al respecto, siendo la ya citada monografía de McHugh y Yarmey (2014) el punto de referencia en este momento. Tampoco se encuentran apenas textos en blogs u otros contenidos sobre el tema, por lo que se adivina que apenas ha despertado el interés de los bibliotecarios, como sí ha sucedido con los códigos QR.

El uso más extendido de la tecnología NFC es el pago a través del móvil. Google Wallet, el sistema de Android, ha sido una de las primeras apuestas. Apple anunció en septiembre de 2014 su nuevo sistema de pagos desde el móvil, Apple Pay, que se basa en la tecnología NFC. Esto podría suponer un espaldarazo definitivo a esta tecnología, y a que está demostrado que los usuarios de Apple están más dispuestos a pagar, al menos así se desprende de los datos de las tiendas de aplicaciones.

En España La Caixa ha implementado el NFC para el pago mediante tarjetas contactless $^{76}$. De esta manera solo es necesario acercar la tarjeta al lector para realizar un pago o consultar el saldo en el cajero automático. También BBVA permite el pago desde el móvil mediante NFC desde mediados de 201477. El Corte Inglés ${ }^{78}$ ya permite este tipo de pagos mediante un sistema que funciona desde

\footnotetext{
${ }^{76}$ https://portal.lacaixa.es/tarjetas/contactless/quecomo es.html

77 ¡Ahora, BBVA Wallet permite pago móvil NFC!. En: BBVA Web Site, 30 junio 2014. http://www.blogbbva.es/bbva-wallet-nfc-2/

${ }^{78} \mathrm{El}$ Corte Inglés da su primer paso hacia el pago móvil. En: TicBeat, 28 enero 2014. http://www.ticbeat.com/tecnologias/el-corte-ingles-da-su-primer-paso-hacia-el-pago-movil/
} 
comienzos de 2014. El pago en el transporte público es otra de las posibles utilidades, ya son varias las ciudades españolas que cuentan con este sistema. McHugh y Yarmey sugieren el uso de NFC para que la biblioteca acepte pagos mediante NFC - por multas o fotocopias, por ejemplo- y Mies (2014) recoge una serie de puntos por los que comenzar.

Sustituir las llaves y tarjetas de identificación o el acceso a espacios restringidos es otra de las posibilidades de los smartphones gracias a la tecnología NFC. Una utilidad evidente que señalan McHugh y Yarmey es el uso por parte del personal de las bibliotecas. El pago NFC podría emplearse en las bibliotecas que cobran algún servicio a sus usuarios, señalan estos autores. Ejemplos reales que aportan son la máquina de autopréstamo Bibliotheca, que desde septiembre de 2013 se vale del NFC para el pago ${ }^{79}$, y los quioscos de autopréstamo D-Tech RFID AIR SelfCheck ${ }^{80}$, que permiten acceder a la cuenta de usuario para realizar gestiones a través de NFC. Ambas máquinas incorporan RFID para el préstamo.

El autopréstamo desde el dispositivo móvil del propio usuario, o incluso del personal de la biblioteca, podría ser otra de las utilidades del NFC, como ya anunciaba el prototipo de Bibliotheca (NXP, 2011). Aquellas que ya han implementado RFID podrían aprovechar estas etiquetas y tendrían la ventaja de eliminar las colas en los puestos de autopréstamo y el personal no tendría que encontrarse en un mostrador de préstamo necesariamente.

Otra opción es utilizad las etiquetas NFC para enviar información al usuario, de forma similar a los códigos QR pero con ciertas diferencias, como se explicará más adelante. En bibliotecas se pueden encontrar más ejemplos de este tipo que de ningún otro, porque quizás es el más evidente:

- En la Biblioteca Pública de Hanno, en Japón, ha colocado etiquetas NFC en las estanterías para ofrecer información adicional sobre algunas secciones (Arroyo-Vázquez, 2013a).

- En la Renison University College Library (Canadá) los usuarios pueden recibir desde una etiqueta NFC un listado de los servicios de la biblioteca (Tin, McMilliam y McNeil, 2014).

- Esta misma biblioteca ha dotado de interactividad a un libro añadiendo una etiqueta NFC para poder descargarlo en formatos pdf, mp3 y ePub. En

\footnotetext{
${ }^{79} \mathrm{http}$ ://www.bibliotheca.com/1/index.php/our-products/self-service-kiosks/smartserve1000

${ }^{80}$ http://www.d-techdirect.com/products/rfid-products/d-tech-self-service/
} 
el sector editorial se encuentran varios ejemplos de libros interactivos con información adicional ${ }^{81}$.

- Un grupo de estudiantes propuso la descarga de libros electrónicos de la New York Public Library (Estados Unidos) desde un panel en el metro de la ciudad. Este proyecto nunca llegó a ponerse en práctica.

- En las Bibliotecas Públicas de Barcelona el NFC sirve para acceder a información básica sobre las bibliotecas: cuál es la más cercana, horarios de apertura, vídeos o actividades (Bröll, Cabré y Gándara, 2014).

Además, NFC también puede interactuar, permitiendo una comunicación bidireccional, por ejemplo para comprar tickets, guardar cupones o registrarse en un evento, explican McHugh y Yarmey. Estos autores señalan otros usos, como enlazar con los medios sociales, de manera que tocando la etiqueta con el móvil se marque con un «me gusta» el perfil de Facebook o se comparta un tuit, o un libro en Twitter u otras redes sociales.

Algunos juegos y apps basadas en la gamificación emplean NFC para facilitar el trabajo a sus usuarios o para regalarles extras ligados a determinados espacios físicos. Foursquare permite hacer check-in rápidamente desde sus apps para Android y BlackBerry tocando una etiqueta situada en el lugar en el que nos encontramos. Se pone un URL en una etiqueta NFC y cuando el usuario la toca con su dispositivo móvil se envía a ese lugar específico dentro de la app ${ }^{82}$. También el célebre juego Angry Birds proporciona más información y recompensas a sus jugadores en sus Magic Places a través de NFC.

La Luvia Municipal Library (Finlandia) presentó en la 80a Conferencia y Asamblea General de la IFLA el juego Literature Race, que motiva a los niños de 11 a 15 años a buscar información en equipos para solucionar determinados retos, con el objetivo de que se familiarizaran con la biblioteca. Según explican Koivisto, Ketamo y Hammais (2014), el NFC sirve aquí para escanear los libros que irán dando pistas para resolver las cuestiones y pasar a la siguiente fase del juego. Ha sido desarrollado por un equipo de profesores y estudiantes de la Satakunta University of Applied Sciences (Finlandia) en cooperación con la biblioteca.

Una posibilidad del NFC para las bibliotecas, que no se ha encontrado documentada en la bibliografía, es la configuración de acciones en los dispositivos móviles de los usuarios. Por ejemplo, se podría colocar una etiqueta NFC en el

\footnotetext{
81 Van Nuenen, Pieter (2012). Could NFC redefine how we interact with books in the future?. En: NXP Blog, 15 octubre. http://blog.nxp.com/could-nfc-redefine-how-we-interact-with-books-in-thefuture/
}

${ }^{82}$ https://developer.foursquare.com/resources/client 
cartel que pide silencio en las salas de estudio, de manera que al tocarla se silencie el teléfono, o para configurar automáticamente la WiFi. Aplicaciones nativas como Trigger $^{83}$ (para Android) permiten programar estas acciones en una etiqueta NFC de forma sencilla.

La Biblioteca LG Sangnam (Corea del Sur) proponía en 2007 el uso de la tecnología NFC para salvar barreras de accesibilidad (Bae, et al., 2007). Así, explica la puesta en marcha de un sistema de identificación mediante NFC que se completa con la transferencia vía bluetooth de audiolibros digitales para quienes no pueden acceder al material escrito debido a una discapacidad visual, física, perceptiva, de desarrollo, cognitiva o de aprendizaje. Esta identificación sirve para acceder a internet y para descargar audiolibros al móvil. El usuario solo tiene que acercar el móvil al ordenador.

\subsubsection{NFC y códigos QR}

Algunas de las funciones de NFC podrían ser desempeñadas por los códigos QR, pues sirven igualmente para conectar lo físico con lo digital. Esto pone sobre la mesa dos cuestiones: las diferencias entre ambos y las ventajas e inconvenientes de cada uno. La primera diferencia es física: las etiquetas NFC se adquieren por un precio menor de un euro cada unidad y deben ser programadas para que transmitan la información deseada, mientras que los códigos QR se generan fácilmente desde un servicio web y se imprimen en cualquier tipo de superficie (papel, tela u otras). También hay diferencias en la forma de lectura: los QR se leen capturando el código de la cámara, la distancia depende del tamaño del código, de manera que si fuera suficientemente grande podría leerse desde metros. Sin embargo, para conectarse a una etiqueta NFC hay que situar el dispositivo a unos centímetros de la etiqueta, casi tocarla.

Por otra parte, la lectura de códigos QR se realiza desde una app instalada previamente. En cualquier tienda de aplicaciones se pueden encontrar aplicaciones de lectura de códigos QR como RedLaser. Lo único que se requiere, por lo tanto, es un dispositivo que permita la instalación de este tipo de apps. Sin embargo, para que un dispositivo sea capaz de comunicarse con una etiqueta NFC el primero debe tener esta función incorporada al comprarlo, y no todos los smartphones y tabletas en el mercado vienen equipados con esta tecnología. Una notable ausencia hasta hace poco fueron los dispositivos de Apple, que solo a partir del iPhone 6 incluye

\footnotetext{
${ }^{83}$ https://play.google.com/store/apps/details?id=com.jwsoft.nfcactionlauncher
} 
tecnología NFC. Una diferencia más está en la capacidad de almacenaje, que en las etiquetas NFC es de hasta un Mb, más de lo que permite un código QR (McHugh y Yarmey, 2014).

En cuanto a las ventajas y desventajas de códigos QR y NFC cabe analizar factores como los costes, facilidad a la hora de ponerlos en funcionamiento, el conocimiento por parte del público y la función que cumplirán. Aunque el coste de una etiqueta NFC es barato, lo es aún más generar un código QR, que basta con imprimir y es muy sencillo generar.

Un factor determinante es la función, qué es lo que queremos que ese código o esa conectividad hagan. Los códigos QR permiten almacenar información: un URL, un texto, un número de teléfono o unas coordenadas de localización, por ejemplo, que luego se pueden enlazar. Las etiquetas NFC también almacenan información, pero además se pueden utilizar para otras funciones, como realizar pagos automáticamente, configurar el dispositivo para que se silencie, cambie el brillo o se conecte a una WiFi, o para hacer check-in en Foursquare. Así, si la función que queremos cumplir es dirigir al usuario a una página web, sería más sencillo optar por los QR, pero si queremos que el dispositivo se silencie, solo podremos hacerlo con NFC.

La última cuestión está relacionada con el conocimiento de la tecnología por parte de los usuarios y con la comodidad de uso para ellos. Poner en marcha un servicio basado en una tecnología que los usuarios no conocen puede suponer un fracaso si no va acompañado de formación adicional. Una encuesta en línea realizada en 2013 por IAB y The Cocktail Analysis a internautas españoles de entre 18 y 55 años concluía que el $67 \%$ no conocía el NFC. Solo un 6\% lo conocía y lo utilizaba, mientras que el 27\% restante lo conocía pero no lo utilizaba. En cambio, el 59\% había utilizado en alguna ocasión un código QR y el 14\% lo usaba habitualmente. Se entiende que el 36\% restante no lo había utilizado (Clarke, 2013).

El escaso uso de NFC puede deberse, según McHugh y Yarmey, a que no todos los dispositivos móviles lo incluyen. Los datos publicados por IHS (2014) revelan que el 18,2\% de los teléfonos móviles vendidos en 2013 en todo el mundo incorporaban NFC. Por otra parte, poner en marcha servicios como el pago móvil implica poner de acuerdo a demasiados agentes, lo que puede ser una causa de que se haya ralentizado. La mayor facilidad de uso podría ser sin embargo una baza a favor de NFC frente a los códigos QR. Un estudio piloto de Kraft demostró que los usuarios se comprometían doce veces más con el sistema NFC que con los códigos QR (Tode, 2012). 


\subsubsection{Problemática y discusión}

El principal problema al que se enfrenta la tecnología NFC en bibliotecas es que utiliza la misma frecuencia que el sistema RFID. Esto implica que desde un teléfono móvil lector con una aplicación gratuita para programar etiquetas NFC se podrían leer y modificar las etiquetas RFID que se implementan en la biblioteca. El NFC Working Group de Book Industry Communication (2014) identifica varios posibles problemas para las bibliotecas en este sentido. Si se sobrescriben las etiquetas RFID en los documentos de la biblioteca podrían hacerse irreconocibles para el sistema de gestión. También se podrían reprogramar los bits que controlan el paso por los arcos de seguridad para robar los libros impunemente.

Sin embargo, los riesgos quedan mitigados por varios factores, según este grupo de trabajo sobre NFC. El esfuerzo que requiere manipular intencionadamente estos códigos es tanto que sería más fácil encontrar otras formas de dañar la colección o los sistemas de la biblioteca, como eliminar las etiquetas de los libros directamente. Por otra parte, la tecnología NFC es de corto alcance, por lo que modificar una etiqueta RFID desde un dispositivo con NFC requeriría cogerlo de la estantería y ponerlo lo suficientemente cerca del dispositivo para modificarlo. Por otra parte, la información que se almacena en las etiquetas no es confidencial, por lo que no hay riesgo para la privacidad.

La tecnología NFC es aún una desconocida para las bibliotecas, puesto que apenas se encuentran casos de uso. Tampoco hay apenas bibliografía al respecto y aún es poco conocida por nuestros usuarios, muchos de los cuales no disponen de dispositivos con esta conectividad. Sin embargo, la obra de McHugh y Yarmey ya permite adivinar interesantes posibilidades. Se hacen necesarias en este momento investigaciones que exploren si el NFC resulta atractivo y útil para nuestros usuarios y si estarían dispuestos a utilizarlo.

\subsection{Beacons}

iBeacon es una tecnología presentada por Apple en la Apple Worldwide Developers Conference 2013 y disponible a partir de iOS 7. Viene a solucionar el problema de la localización en interiores, por lo que también se habla de micro-localización, colocando dispositivos fijos denominados beacons. Estos beacons se colocan en un espacio físico - por ejemplo, en una superficie comercial o en una sala de la 
biblioteca - y emiten una señal unidireccional Bluetooth Low Energy (BLE) en una frecuencia de 2,4GHz. Aunque es un sistema desarrollado por Apple, los iBeacons también funcionan en los dispositivos con sistema operativo Android.

Cuando un smartphone se acerca a un beacon, las aplicaciones que tengan habilitada esta tecnología desencadenan alguna acción, como puede ser mostrar una notificación. Para que todo funcione el usuario debe tener instalada la aplicación correspondiente y haber activado la geolocalización, el bluetooth y las notificaciones en su dispositivo. Esto les convierte en un sistema poco invasivo, ya que el usuario puede decidir prescindir de él. Cada beacon se identifican utilizando tres valores, según explica Apple (Getting started..., 2014):

- UUID de proximidad, un identificador de 16 bytes, que identificaría a la biblioteca como marca.

- Mayor, de 2 bytes, que identificaría a una sede concreta de la biblioteca.

- Menor, de 2 bytes, que identifica a un lugar concreto, como podría ser el mostrador de préstamo o la sección de referencia.

También existe un identificador interno para referencia propia. Las señales de los iBeacons tienen tres rangos: inmediato (justamente al lado), cerca (entre 1 y 3 metros), lejano (hasta 30 o 50 metros, en función de varios factores) y desconocido, cuando no se puede determinar. Hay que tener en cuenta que las señales pueden ser interferidas por el cuerpo humano, muros y puertas: ante ellos la señal se atenúa o se apaga, de ahí que las distancias puedan variar en cada caso. Esto, que en principio puede parecer una desventaja, puede ser una baza en edificios no diáfanos, pues permitiría diferenciar las acciones a ejecutar.

Las primeras utilidades de los iBeacons se han dado en superficies comerciales y en aeropuertos. En las tiendas de Apple los usuarios que han descargado la app de la Apple Store reciben mensajes cuando se encuentran en una de las tiendas físicas que han habilitado este sistema. Es conocido el caso de la aerolínea Virgin Atlantics, cuyos usuarios de clase superior reciben una notificación para abrir la tarjeta de embarque al llegar a los arcos de seguridad y reciben ofertas especiales, como el cambio de divisas sin comisiones en el aeropuerto de Heathrow, según se informa en el blog de la compañía (Maxine, 2014).

En el ámbito editorial, Exact Editions propone utilizarlos para promocionar apps de revistas, de manera que se pueda acceder a determinados contenidos a través de estas apps en lugares determinados (Hodgkin, 2013). Los museos también parecen estar pensando en cómo aprovechar estos beacons en sus espacios: la Casa de Rubens, en Amberes (Bélgica), ofrece «información adicional sobre lo que están viendo, como las historias detrás de algunas pinturas, imágenes en rayos X de las obras, así como juegos interactivos.» (Vázquez, 2014). 
En bibliotecas no se han encontrado apenas referencias. Nurse (2014) propone utilizarlo para dirigir hacia los PC de uso público, para anunciar al entrar en la biblioteca que el libro reservado ya está disponible o para recordar las devoluciones pendientes. También para llamar la atención sobre los nuevos recursos en las diferentes secciones de la biblioteca o para informar sobre nuevos eventos.

Estas acciones deberían realizarse a través de la app de la biblioteca, pero también podrían programarse a través de PassBook, PassWallet u otras apps similares para llevar el carné de la biblioteca en el móvil, como sugiere Arroyo-Vázquez (2014b). Así, un usuario que ha solicitado un carné de usuario digital a la biblioteca y lo lleva en una app tipo PassBook podría recibir notificaciones a través de esta aplicación.

La implantación de esta tecnología no supone un desembolso económico grande: los beacons de Estimote tienen un coste de unos 33 dólares cada unidad, pero también hay otros más baratos. El mayor coste vendría a la hora de desarrollar la app que reaccionaría a los beacons, un perfil profesional que no se suele encontrar en nuestras bibliotecas y para lo cual las bibliotecas suelen acudir a empresas externas.

Aunque el usuario puede escoger habilitar o no las notificaciones emitidas por los beacons, una tecnología invisible como esta debería ser anunciada convenientemente, puesto que en caso contrario se corre el riesgo de que pase desapercibida. También se adivina la posibilidad de que si se programan demasiados beacons por toda la biblioteca el usuario se sienta abrumado y llegue a considerarlo una molestia, por lo que se recomienda usarlo con cautela.

En noviembre de 2014 se ha sabido que dos empresas, Capira Technologies y BluuBeam, facilitan a las bibliotecas el servicio de beacons y que algunas bibliotecas en Estados Unidos están comenzarlo a experimentar con el envío de notificaciones a través de este sistema (Enis, 2014).

\subsection{Otros servicios basados en dispositivos móviles}

Además de los mencionados en los apartados anteriores, la tecnología móvil está incidiendo en otros servicios bibliotecarios que se repasan a continuación: la 
comunicación con el usuario, la lectura digital, el préstamo de dispositivos móviles, la alfabetización informacional y el carné de la biblioteca en el móvil.

\subsubsection{Servicios de referencia y comunicación con el usuario}

En los primeros años de la telefonía móvil la comunicación a través de mensajes de texto (SMS) con el usuario es una de las utilidades que las bibliotecas comienzan a considerar, especialmente teniendo en cuenta el gran éxito de este servicio. Los primeros teléfonos móviles con SMS aparecen en 1993, pero no es hasta finales de los noventa cuando comienzan a alcanzar su máxima popularidad.

En 2004 y 2005 aparecen los primeros servicios de referencia vía SMS en bibliotecas. La biblioteca de la Curtin University of Technology, en Australia, es la primera de la que se tiene noticia (Giles y Grey-Smith, 2005). Poco después ponen en marcha este servicio las bibliotecas Sims Memorial en la Southeastern Louisiana University, en Estados Unidos (Hill, Hill y Sherman, 2007) y del Southbank Institute of Technology, en Australia. Las dos primeras utilizan Altarama, un software para PC de una compañía australiana, y la última MessageNet. Estos programas proporcionan un número al que los usuarios pueden enviar sus SMS, que el personal recibe en una cuenta de correo electrónico y los responde desde esa misma cuenta, aunque el usuario los recibe como un SMS.

Los servicios de referencia vía SMS se ven limitados por la longitud máxima de 160 caracteres, lo que atrae preguntas de respuesta corta (Hill, Hill y Sherman, 2007) y más superficiales (Jensen, 2010). Debido a esta limitación el personal bibliotecario se ve obligado a utilizar abreviaturas, enviar la respuesta en varios mensajes o no incluir la fuente de la información, explica Jensen (2010). Por otra parte, se trata de un servicio que tiene un coste para la biblioteca y para el propio usuario, pues por cada mensaje las compañías aplican una tarifa de unos veinte céntimos de euro, actualmente.

Pearce, Collard y Whatley (2010) desmitifican algunas de las afirmaciones sobre los servicios de referencia a través de SMS a partir de su propia experiencia. Los datos de uso de este servicio en la biblioteca de la New York University entre los meses de junio de 2008 y mayo de 2009 dicen que la comunicación no siempre es rápida, sino que en ocasiones se convierte en asíncrona, tardando un máximo de 2,9 días en completar una transacción. Y se trata de un hecho que los propios usuarios toleran. Por otra parte, no solo se reciben cuestiones sencillas o direccionales, sino que también se atienden cuestiones más complejas que requieren el intercambio de varios mensajes con el usuario. 
La bibliografía en este ámbito tiende a compartir experiencias que también incluyen cifras sobre el tipo de consultas recibidas (Giles y Grey-Smith, 2005; Pearce, Collard y Whatley, 2010). En la Sims Library se produjo un significativo incremento en las consultas recibidas vía SMS durante el curso 2009-2010, con más de 500, que incluso superaban a las atendidas a través del correo electrónico (Stahr, 2011).

Aunque el servicio de referencia vía SMS se puede atender desde un teléfono móvil cualquiera, las bibliotecas utilizan software específico que funciona en el ordenador, como el ya mencionado Altarama, Text a librarian, de Mosio, ${ }^{84} \mathrm{o}$ Twilio. Un caso especial es el del servicio consorciado MyInfoQuest ${ }^{85}$, en el que participaban 70 bibliotecas públicas afiliadas en 2010 (Jensen, 2010) y que probablemente ahora sean más.

Los mensajes de texto también se han empleado para el envío de información al usuario. Varios trabajos, a los que se ha hecho referencia en el apartado 2.2.2.1, señalan el interés de los usuarios por estos servicios: Karim, Darus y Hussin (2006) afirman que el $94 \%$ de los estudiantes de la International Islamic University, en Malasia, estarían dispuestos a recibir SMS con información de la biblioteca en su teléfono móvil. En la Cambridge University y la Open University, en el Reino Unido, los porcentajes son menores, de un $21 \%$ en la primera y del $35 \%$ en la segunda (Mills, 2009), lo que revela diferencias en función del tipo de usuarios. Pero solo el 4\% declara que no utilizaría este servicio. Por otra parte, Seeholzer y Salem (2011) también identifican el interés de los alumnos de la Kent University en recibir alertas. Los usuarios parecen dispuestos a recibir información, pero cuando se trata de publicidad surgen serias reticencias, como señala Dowd (2011).

Estos servicios de alertas se han empleado para recibir información sobre programas y actividades organizadas por las bibliotecas, como en el caso de las Bibliotecas Municipales de A Coruña, que utilizan el servicio SMS\&Mobility (Pesquero-Murillo, 2008). Se trata de un servicio de alertas que constaba en sus inicios de cuatro canales -Actividades infantiles, Actividades juveniles, Cursos de formación y Conferencias, recitales - que han variado con el tiempo. En otras instituciones se están empleando los SMS para enviar información de otro tipo, como el número de ordenadores disponibles en un momento dado o el horario de apertura de la biblioteca (Beccaria, 2011).

\footnotetext{
${ }^{84}$ http://www.textalibrarian.com

85 http://www.myinfoquest.info
} 
En la actualidad el SMS se está viendo desplazado por WhatsApp, un servicio de mensajería de texto a través de internet que apareció en 2009 y no tiene coste alguno, a excepción de la tarifa de datos. Otra de las ventajas de WhatsApp frente al SMS es que no existe limitación de caracteres. Aunque hay constancia de que son varias las bibliotecas que ofertan esta vía de comunicación con el usuario, se han encontrado escasas referencias en la bibliografía. Caplan y Lan (2014) explican cómo a través de este servicio se han recibido el 6,8\% de las consultas en la biblioteca de la Hong Kong University of Science \& Technology, incluso más que a través del correo electrónico $(2,6 \%)$ y muy cerca de las llamadas telefónicas (8\%) entre el 4 de febrero y el 29 de abril de 2014.

Los dispositivos móviles también están siendo empleados en los servicios de referencia como herramienta principal o secundaria de acceso a la información por parte del personal bibliotecario. Los servicios de referencia itinerantes encuentran en las tabletas un aliado perfecto: pesan poco y se transportan cómodamente y la batería dura bastante tiempo. Sin embargo, hay a quienes les resulta incómodo para escribir y como sistema de almacenamiento (Lotts y Graves, 2011). Las tabletas en general, y el iPad en particular - puesto que es la tableta sobre la que más referencias se encuentran en la bibliografía-, resultan atractivas para los usuarios debido al efecto que produce la nueva tecnología, por lo que puede hacer más interesante el servicio de referencia (Smith y Pietraszewski, 2004).

La experiencia de la Warwick University pone de manifiesto que las tabletas proporcionan mejores resultados que los smartphones, debido a su pequeña pantalla y las dificultades para navegar con ella, especialmente en las consultas complejas. Sin embargo, el smartphone permite ponerse en contacto con otros miembros de la plantilla para solucionar algunas cuestiones (Widdows, 2011). En la primavera de 2003 las bibliotecas de la Texas A\&M University pusieron en marcha el primer servicio de referencia itinerante con tablet PC del que se tiene noticia (Smith y Pietraszewski, 2004). Las dificultades técnicas entonces eran un serio inconveniente.

En la University of the Pacific (Estados Unidos) se utilizan las tabletas como herramienta de apoyo en el mostrador de referencia, para aquellos casos en que el usuario tiene prisa y puede hacer uso de ellas para resolver alguna cuestión, de manera que mejoraría su experiencia de uso (Maloney y Wells, 2012). Estas autoras han elaborado además un listado de competencias básicas que el personal bibliotecario debería adquirir para el uso del iPad como herramienta en un servicio de referencia. 


\subsubsection{Lectura en dispositivos móviles}

El lanzamiento del Kindle de Amazon en 2007 fue el detonante para la explosión del libro electrónico, cuyas ventas crecieron desde entonces. Esta popularidad se ha producido paralela a la de los smartphones, que han incorporado funciones para la lectura de prensa y de libros electrónicos, entre otras, convirtiéndose en el dispositivo de lectura más extendido. Las tabletas ocupan la segunda posición y parecen destinadas a desbancar a los lectores de libros electrónicos o e-readers como dispositivo lector más extendido. A pesar de las evidentes ventajas que estos presentan para la lectura, como la tinta electrónica, que fatiga menos la vista, y una menor distracción, las tabletas incorporan un mayor número de funciones.

Por primera vez, en 2014 los libros que se tomaron en préstamo en las bibliotecas estadounidenses se descargaron con mayor frecuencia en una tableta (84\%) que en un e-reader (78\%). El smartphone, a pesar de su pequeña pantalla, es el tercer dispositivo de lectura (48\%), incluso por delante del ordenador (28\%) (Ebook usage..., 2014).

De las personas que leen libros electrónicos en Estados Unidos, el 32\% lee en el móvil, el $55 \%$ en tableta, el $57 \%$ en e-reader y el $29 \%$ en ordenador. Este último es el único cuyo uso para la lectura desciende (en 2011 el 41\% leía en ordenador), mientras que los demás aumentan. Los datos publicados por Pew Internet (Zickuhr y Rainie, 2014) sitúan casi a la par la lectura de libros en e-readers (el $57 \%$ de lectores de libros electrónicos lee en uno) y tabletas (55\%) entre los ciudadanos estadounidenses mayores de dieciocho años. Es interesante que un 32\% declara leer en su teléfono móvil.

Las pequeñas pantallas de los smartphones no inducen a pensar en ellos como dispositivos adecuados para la lectura de libros. Sin embargo, estudios en diferentes países revelan que existe un porcentaje de lectores que utilizan este dispositivo para leer no solo noticias cortas, sino también libros. En España, un $4,6 \%$ declaraba leer libros en su smartphone, frente al 6,3\% que lo hacía en un $e$ reader (Hábitos..., 2013).

Un estudio de la Unesco para conocer a los lectores en teléfonos móviles en países en vías de desarrollo (West y Chew, 2014) revela que este dispositivo puede abrir caminos para la alfabetización en grupos marginales. A pesar de lo que podría parecer, la conveniencia - siempre se lleva consigo- es el principal motivo por el que se lee en el móvil (67\%), mientras que solo el $9 \%$ alega que no tiene otro modo de acceso a los libros. Otros motivos son el menor coste de los libros (13\%) y el que se prefiera leer en el móvil (9\%). El 62\% de los encuestados afirmó que el móvil les hace leer más. 
En España, la segunda pantalla en la que más se lee es la del smartphone, después del ordenador, según los últimos datos disponibles (Hábitos..., 2013). Según este estudio, el $12,9 \%$ de los españoles lee en su smartphone, mientras que el 55,8\% lo hace en el ordenador y el 6,6\% en un e-reader. La lectura electrónica en su sentido más amplio -incluyendo libros, revistas, periódicos, cómics y sitios web, blogs y foros - ha crecido en los últimos años hasta alcanzar al 58,0\% de los ciudadanos españoles de catorce años o más, aunque aún le queda para llegar al 92,0\% de la lectura en papel. Siguiendo la tendencia, cabe esperar que estos porcentajes hayan aumentado en los últimos dos años. En ese año, el 11,7\% leía libros digitales, frente al 63,0\% que leía libros en papel.

La lectura parece ser hasta el momento la característica de los dispositivos móviles más interesante para las bibliotecas públicas españolas, teniendo en cuenta que los primeros y más importantes esfuerzos han estado relacionadas con la lectura. En 2014 las bibliotecas públicas españolas han comenzado a prestar libros electrónicos gracias al proyecto puesto en marcha por el Ministerio de Educación, Cultura y Deporte. Entre sus prestaciones, este proyecto pone a disposición de los usuarios de bibliotecas públicas una app para la lectura en smartphones y tabletas. Este proyecto se convierte en la primera iniciativa relacionada con los dispositivos móviles para la gran mayoría de las bibliotecas públicas de nuestro país.

La lectura digital es un nuevo fenómeno, complejo y en evolución, que aún no se conoce en profundidad y en el que intervienen varios factores. A diferencia del papel, se ha demostrado que la lectura en pantallas reduce la comprensión debido al contraste, la resolución y la menor experiencia, y producen una mayor fatiga visual (Jeong, 2012). La lectura se hace más lenta y propensa a errores (Nielsen y Budiu, 2013). Por el contrario, en un dispositivo ligero se puede almacenar una gran cantidad de libros y lo digital facilita la búsqueda de contenidos. Los smartphones y tabletas añaden además otras funciones, que si bien pueden ser una oportunidad para ofrecer contenidos enriquecidos, también pueden ser un elemento de distracción.

En España el proyecto Territorio eBook, impulsado por la Fundación Germán Sánchez Ruipérez (Ebook -18..., 2012; Ebook +18 -40..., 2013), ha estudiado el cambio de hábitos que supone la lectura en dispositivos móviles para diferentes grupos de edad. Entre sus conclusiones cabe destacar una excelente acogida de las tabletas (iPad) como dispositivo lector entre los más jóvenes, de nueve a dieciocho años, que destacan su facilidad de uso y las funciones adicionales. A los jóvenes entre 18 y 40 años les atraen más las tabletas que los e-readers. La mediación y la animación emergen en este estudio como elementos fundamentales para una mejor experiencia de lectura. 
Las bibliotecas, como mediadoras de la lectura, necesitan conocer los hábitos de lectura de sus usuarios para ofrecerles servicios relacionados, asesorarles y abrirles camino. También necesitan conocer las tecnologías de la lectura del siglo XXI: los dispositivos, las aplicaciones y su funcionamiento, porque resultan fundamentales para una buena experiencia. El otro reto pendiente es el de los contenidos, que deben estar disponibles en formatos como ePub o html, adecuados para la lectura desde cualquier pantalla. En este sentido las bibliotecas deben tener en cuenta este factor en su papel como editoras de contenidos.

\subsubsection{Préstamo de dispositivos móviles}

Las bibliotecas han actuado como facilitadoras de las tecnologías de la información para los ciudadanos desde hace mucho tiempo. Primero sucedió con los ordenadores y el acceso a internet, con los que se pretende mitigar la brecha digital y ofrecer igualdad de condiciones en el acceso a la información, y después se ha extendido a todo tipo de equipamiento: ordenadores portátiles, videocámaras, cámaras digitales y muchos otros. El préstamo de dispositivos parece ser una de las primeras acciones que se adoptan con respecto a las tecnologías de la información en bibliotecas de todo tipo.

En los primeros años de las PDA algunas bibliotecas comenzaron a prestarlas y a poner a disposición de los usuarios estaciones de sincronización (Cuddy, 2005). Pero quizás uno de los mejores ejemplos sean los primeros pasos con respecto a la introducción del libro electrónico en las bibliotecas españolas. En la actualidad algunas bibliotecas universitarias estadounidenses prestan las gafas de Google a sus usuarios, como se indicó en el apartado 2.6.9.

Antes que prestar contenidos en un mercado poco maduro, se comenzaron a facilitar lectores de libros electrónicos, como una forma de dar a conocer a los usuarios la tecnología. En 2010 el Ministerio de Educación, Cultura y Deporte propició el préstamo de 677 e-readers en 15 Bibliotecas Públicas del Estado. La mayor parte de los usuarios de este servicio fueron personas que nunca antes habían utilizado este dispositivos (96\%). En 2012 este proyecto se amplió a otras 36 Bibliotecas Públicas del Estado con la adquisición de 1.361 nuevos dispositivos (El préstamo..., 2012).

La mayoría de la literatura sobre el préstamo de dispositivos móviles se refiere a ordenadores portátiles, como señalan Chapman y Woodbury (2012) y a lectores de libros electrónicos, pero se pueden encontrar algunas experiencias concretas sobre 
el préstamo de tabletas, especialmente iPads, como las que se mencionan en los siguientes párrafos.

Los dispositivos móviles actuales, tabletas y smartphones, están diseñados para el uso individual, lo que plantea cierta problemática en lo referente al préstamo. Los smartphones nunca se han considerado un dispositivo susceptible de ser prestado en bibliotecas por esa razón, pero sí los iPod Touch, muy similares pero sin las funciones de telefonía. Por otra parte, las tabletas son difíciles de gestionar para el uso institucional (Revelle y Polanka, 2013) y su puesta a punto conlleva un trabajo previo de configuración. En primer lugar, hay que prestar atención a las cuentas de usuario necesarias para que el dispositivo funcione y que en ocasiones requieren introducir el número de una tarjeta de crédito en la que cargar las posibles compras de aplicaciones, explican Revelle y Polanka. Para ello Nichols (2013) recomienda utilizar tarjetas de regalo en lugar de una tarjeta de crédito y el uso de funciones como el control parental, que pueden ser útiles a la hora impedir la descarga de apps de pago.

Por otra parte, hay que tener en cuenta cuestiones relacionadas con la privacidad de los propios usuarios, que debe ser preservada cuando se presta un dispositivo a un usuario después de haber sido utilizado por otro. Por ello se hace necesario borrar sus datos personales, como fotografías y vídeos que haya podido tomar o el historial de navegación y los datos que hayan podido quedar almacenados en las aplicaciones y en servicios en la nube.

Nichols (2013) aconseja deshabilitar la tienda de aplicaciones en las opciones de privacidad, no utilizar las cuentas personales en aplicaciones como Twitter, Facebook o el correo electrónico, familiarizarse con los dispositivos y poner nombres a cada iPad. Cuando se prestan estos dispositivos, por lo tanto, el usuario debe tener contenidos cargados previamente: apps, libros electrónicos, audiolibros u otros (Eichenlaub, et al., 2011). Otra opción consiste en permitir la instalación de apps a los usuarios con su propia cuenta (Tomlin, 2012); de esta manera el dispositivo tendrá más posibilidades. Revelle y Polanka (2013) recomiendan adquirir estaciones de sincronización cuando se tienen varias tabletas en préstamo, para que siempre tengan la batería cargada.

La mayor barrera para el préstamo de estos dispositivos es sin duda económica: su coste es alto y pronto quedan superados por nuevos terminales con tecnologías más avanzadas. Debido a este alto coste, Yelton (2012) aconseja poner establecer políticas que contemplen la posibilidad de pérdida y daños en el dispositivo y explica que en la L. E. Phillips Memorial Public Library, en Eau Claire (Wisconsin, Estados Unidos), los prestatarios tienen que firmar un contrato en el que aseguran que devolverán el iPad en buen estado. 
Según Yelton, esta fue la primera biblioteca en prestar iPads, iPod Touch y otras tabletas. Aunque la literatura es escasa, se han encontrado noticias de otras experiencias. Así, la North State Carolina University (Chapman y Woodbury, 2012) explica cómo los iPads estaban entre los dispositivos más demandados de los que prestaban, con tiempos de espera de hasta 17 días en el curso 2010-2011, también debido a que el número de dispositivos era bajo. El iPod Touch, que también prestaban, tenía tiempos de espera de 4 días.

Una encuesta realizada por Smith (2013) concluye que el 47,9\% de las 307 bibliotecas que respondieron prestaban tabletas y e-readers, mientras que el préstamo de ordenadores portátiles alcanzaba el 68,7\%. La inmensa mayoría de las bibliotecas que respondieron eran académicas, algunas públicas y solo unas cuantas de otros tipos.

En los últimos años se ha acuñado el término BYOD, acrónimo de la expresión en inglés Bring Your Own Device, para referirse a la tendencia que se observa en las empresas de que los empleados utilicen sus propios dispositivos en lugar de los de la compañía. Para las bibliotecas este concepto puede tener dos implicaciones: en el propio personal de la biblioteca y en los usuarios, quienes pueden emplear sus portátiles, tabletas o smartphones para conectarse a las redes de la biblioteca.

Poner en marcha un programa BYOD supone un gran ahorro en dispositivos para la biblioteca, pero implica mucho más que permitir que personal y usuarios utilicen el móvil. Johnson (2013) propone facilitar la infraestructura necesaria, como enchufes para la carga de baterías y red WiFi, soporte para resolver dudas y problemas en la conexión por parte del personal y ofertar contenidos para dispositivos móviles. Y también poner en marcha políticas sobre lo que es aceptable y lo que no, como cuáles son los espacios donde está permitido el uso de dispositivos móviles o si hay usos no permitidos para el personal, como los juegos durante el horario laboral (Lyttle y Walsh, 2013).

Además del ahorro económico, el sistema BYOD tiene la ventaja de que los usuarios conocen sus dispositivos y están familiarizados con ellos, como indica Walsh (2012b), quien también advierte de las desventajas: es posible que algunos usuarios no dispongan de dispositivos móviles y pueden tener una gama muy amplia de dispositivos, con funciones diferentes, por lo que se corre el riesgo de que algunos de los servicios no funcionen.

\subsubsection{Alfabetización informacional y mobile learning}

La biblioteca cumple una doble función educativa proporcionando recursos de 
información para la formación y, de forma más directa, a través de los programas de alfabetización informacional y sobre el uso de los recursos de la propia biblioteca. Si se entiende la biblioteca como una institución educativa, los diferentes recursos que proporciona en sus versiones para móviles, sobre los que se ha hablado hasta ahora, podrían entenderse como mobile learning. Por eso nos centraremos en este apartado en la alfabetización informacional y la formación en el uso de la biblioteca.

En ambas dimensiones los dispositivos móviles tienen algo que aportar y en las dos es aplicable el concepto de mobile learning, que Canuel y Crichton (2011) definen de una forma sencilla como la intersección entre el aprendizaje y los dispositivos móviles. Para Farkas (2013) este concepto va mucho más allá del mero uso de un dispositivo móvil para acceder a los contenidos educativos, se trata también de aprovechar las capacidades únicas de los dispositivos móviles para mejorar la educación.

Así, según explica Farkas (2013), smartphones, tabletas y otros dispositivos móviles aportan la posibilidad de acceder a la información en contexto, lo que le da más sentido, combinan el aprendizaje formal y el informal, permiten mayor autonomía a los alumnos y conectan con información adicional. Cuando las bibliotecas trabajan para ofertar información y recursos para los usuarios de dispositivos móviles están entrando en la intersección con el concepto de mobile learning, pero también cuando preparan material para informar sobre el uso de la biblioteca o con la práctica de la alfabetización informacional.

La tecnología móvil proporciona información para todos, subraya Ally (2012) y conlleva una gran responsabilidad para los bibliotecarios en el sentido de que deben trabajar para hacer accesibles los contenidos y servicios de la biblioteca desde dispositivos móviles. El CILIP (2004) entiende que «la alfabetización informacional es saber cuándo y por qué necesitas información, dónde encontrarla y cómo evaluarla, usarla y comunicarla de una forma ética.» Para Gómez Hernández y Benito Morales (2001) este es uno de los dos sentidos en los que se entiende el término alfabetización informacional (ALFIN), y que hace referencia al punto de vista del usuario. En bibliotecas y otras instituciones educativas, la ALFIN hace referencia a los servicios puestos en marcha "para lograr la enseñanzaaprendizaje de los conceptos, procedimientos y actitudes relativos al acceso y uso de la información.»

El CILIP también define una serie de habilidades requeridas para hablar de una persona alfabetizada informacionalmente: comprender la necesidad de información, los recursos disponibles para acometerla, cómo encontrar la información, la necesidad de evaluar los resultados, cómo trabajar o explotar los resultados, la ética y responsabilidad de uso, cómo comunicar o compartir los 
resultados y cómo gestionar esos resultados. Los dispositivos móviles, como herramienta de información, intervendrían en la mayor parte de estas habilidades. ¿Conocen nuestros usuarios cómo utilizarlos en los procesos de información?

Desde el primero de estos puntos de vista, el del usuario, Andrew Walsh (2012a) señala cuatro áreas en las que la ALFIN varía desde dispositivos móviles con respecto al ordenador: dónde, qué, cómo y durante cuánto tiempo se producen las búsquedas. Cuando se busca desde un smartphone, el dispositivo móvil más extendido, se intenta obtener información rápida, a menudo relacionada con el contexto o la localización, que llega a través de búsquedas más cortas en las que se buscan datos concretos y que suele consultarse desde pequeñas apps o sitios especializados, en lugar desde la web en general. Además, la búsqueda puede producirse en cualquier lugar y desde cualquier dispositivo. Cuando la herramienta de búsqueda es el ordenador, queda ligada a un lugar específico, el rango de herramientas es mayor y abarca además a motores de búsqueda generales y el tiempo varía desde accesos largos a otros más cortos. Cuando se trata de información para uso académico, la gente pasa largos periodos buscando, organizando y extrayendo la información, en palabras de Walsh.

Walsh aborda el proceso de búsqueda, pero no otros que también tienen que ver en la alfabetización informacional. ¿Qué diferencias hay entre acometer los procesos de explotación, comunicación y gestión de los resultados desde un dispositivo móvil o desde un ordenador? ¿Existen diferentes aspectos en cuanto a la ética y responsabilidad de uso?

Desde el segundo de los enfoques antes mencionados, el de la biblioteca y otras instituciones educativas, Havelka y Verbovetskaya (2012) proponen integrar los dispositivos móviles en las funciones de alfabetización informacional, y especialmente las apps, que deben ser recomendadas también a los usuarios. Estas autoras señalan varias acciones que deben acometer los bibliotecarios: identificar las apps más importantes, pedir a los proveedores que oferten alguna opción para consultar su base de datos desde un smartphone, hacer una lista de sitios web para dispositivos móviles y publicarla en la web de la biblioteca, indicar a los usuarios la versión móvil de las bases de datos y mantenerse al día. Desde su punto de vista, no importa de dónde obtienen la información los usuarios. Bolorizadeh, et al. (2012) recomiendan pensar en qué dispositivos utilizan los usuarios, qué necesitan aprender y cómo debe ser adaptado el contenido, preferiblemente en piezas pequeñas.

Cuestión abordada por algunos autores son las utilidades y herramientas de los dispositivos móviles que pueden ser aprovechadas en las actividades de alfabetización informacional. Godwin (2009) señala las siguientes: sitios web móviles, visitas guiadas, referencia, screencasting, podcasting y vodcasting, personal 
response systems (PRS) - que permiten enviar encuestas o preguntas a los estudiantes y que las respondan para conocer su opinión-, Twitter y códigos QR. También menciona YouTube para tutoriales cortos. Pero también la realidad aumentada, la geolocalización y muchas otras funciones podrían ser empleadas.

Apenas existen datos sobre en qué grado las bibliotecas están incorporando los dispositivos móviles en los programas de formación. Dos de cada tres bibliotecarios de los estados de Oregon, Idaho y Washington (Estados Unidos) encuestados por Ashford y Zeigen (2012a) afirman que las bibliotecas públicas en las que trabajan no ofertan formación a los usuarios sobre cómo utilizar las aplicaciones móviles de sus proveedores (66,3\%). El 18,0\% oferta formación y unas pocas proporcionan instrucción individualizada sobre herramientas populares como OverDrive o Library2Go a aquellos que lo solicitan. Los datos son muy similares en las bibliotecas universitarias, con un 63,2\% que no proporcionan formación y un 19,1\% que sí (Ashford y Zeigen, 2012b). El principal motivo para esta falta de formación podría ser que el personal bibliotecario no ha sido previamente formado, un paso imprescindible.

En el apartado de instrucción en el uso de la biblioteca, Farkas (2013) añade dos nuevas posibilidades: los sistemas para facilitar la orientación dentro del edificio de la biblioteca — como los mencionados en el apartado 2.4.4- y búsqueda del tesoro con códigos QR u otros sistemas. Los tutoriales en vídeo, que también menciona Farkas, se están empleando para explicar a los usuarios diferentes aspectos relacionados con el uso de la biblioteca y sus recursos de información. Carles-Pomar, Castellano López y Guerrero Rebollo (2013) explican la experiencia de la Biblioteca de Medicina de la Universidad Autónoma de Barcelona con el software Polimedia ${ }^{86}$, desarrollado por la Universidad Politécnica de Valencia. Sin embargo, no se dispone de datos sobre sus resultados o el uso.

A lo largo de los anteriores apartados se han expuesto algunas experiencias de uso de los dispositivos móviles en bibliotecas muy relacionados con la alfabetización informacional, como pueden ser las selecciones de aplicaciones nativas. A ellas se pueden sumar algunas más. Johnston y Marsh (2014) explican la puesta en marcha de un programa de ALFIN embebido en el currículum de los alumnos de la asignatura de inglés como segunda lengua en los Higher Colleges of Technology (HCT), institución de enseñaza superior en Emiratos Árabes. El programa ha sido fruto de la colaboración entre profesores y bibliotecarios, explican, y en él se hace uso de iBooks y otras aplicaciones nativas para iPad. Algunas de las actividades que los alumnos deben completar en el marco de este programa son el escaneado

${ }^{86} \underline{\text { http://polimedia.uab.cat }}$ 
de códigos QR, el uso de libros electrónicos y la definición de palabras clave, la identificación de detalles bibliográficos en un libro, como autor, título o editor.

Con actividades como ésta se transmite a los usuarios la idea de que la información bibliográfica y para la investigación también puede ser gestionada desde un iPad u otros dispositivos móviles y cómo utilizarlos para este tipo de usos. Además, las bibliotecas podrían poner en marcha actividades formativas en las que explicar a determinados grupos de usuarios cómo utilizar los dispositivos móviles para otros usos - como la lectura en los más pequeños-, cómo salvaguardar la privacidad o hacer un buen uso en adolescentes o cómo utilizar las funciones básicas de un dispositivo móvil para los más mayores.

Con la incorporación de los dispositivos móviles al panorama informativo se hacen necesarios programas que orienten a los usuarios en su utilización. Se ha detectado una importante necesidad de información por parte de los usuarios en cuestiones relacionadas con la privacidad y la seguridad (Cushon, 2013), pero también con las buenas prácticas y la etiqueta. Hahn (2008) señala que en algunos programas son los adolescentes quienes enseñan a los mayores. En España la bibliografía no recoge hasta el momento ninguna experiencia ni otro tipo de publicaciones sobre actividades de formación de usuarios en el uso de los dispositivos móviles, a pesar de la constancia de que se están celebrando. Las Bibliotecas Municipales de Pinto han celebrado algunas sesiones de formación con usuarios sobre el uso de los teléfonos móviles, según explican en su página en Facebook $^{87}$.

\subsubsection{El carné de la biblioteca en el móvil}

Algunas bibliotecas han comenzado a ofrecer a sus usuarios la posibilidad de llevar el carné de la biblioteca en el smartphone. Este dispositivo siempre se lleva a mano, evita la pérdida u olvido de la tarjeta, conlleva un ahorro de espacio en la cartera y ofrece servicios añadidos, como se verá más adelante. Se explican a continuación las tres soluciones recopiladas por Arroyo-Vázquez (2014b).

La solución más sencilla para sustituir las tarjetas son las aplicaciones como RedLaser, CardStar o KeyRing, con las que el usuario puede realizar un duplicado del código de barras de su carné y llevarlo así en su smartphone. Esta opción tiene

87

https://www.facebook.com/424285120968091/photos/a.556462537750348.1073741832.42428 5120968091/639838692746065/? 
la ventaja de que es sencilla para el usuario, para quien apenas supone un pequeño esfuerzo, y para la biblioteca, que solo debe estar atenta a que sus escáneres puedan leer el código en una pantalla con brillo -y sustituirlos por escáners CCD, como explica Herzog (2011)—, además de advertir al personal de atención al público de esta posibilidad. Varias bibliotecas estadounidenses recomiendan a sus usuarios esta opción y lo explican en su sitio web $^{88}$.

La segunda opción para llevar el carné de la biblioteca en el móvil son aplicaciones como PassBook, que permiten gestionar auténticos carnés en formato digital con extensión .pkpass. La aplicación PassBook fue desarrollada por Apple con la intención de convertir al teléfono móvil en una cartera y gestionar cupones, tarjetas de fidelidad, tickets de viaje o entradas para eventos. En este caso la biblioteca tendría que realizar un considerable esfuerzo generando los carnés digitales, pero como contrapartida se podría proporcionar un valor añadido al usuario: cuando éste se aproxime al lugar en que se encuentra la biblioteca, verá aparecer en la pantalla de su smartphone el carné para utilizarlo inmediatamente. Combinado con los beacons, las apps como PassBook permiten enviar notificaciones al usuario al acarcarse a un punto concreto de la biblioteca.

Una tercera solución es la tecnología NFC, cuya utilidad más conocida es el pago, pero que también puede utilizarse para la identificación, como proponen Livergood (2011) y McHugh y Yarmey (2014). La Biblioteca LG Sangnam, en Corea del Sur, proponía el uso de NFC como modo de identificación para conectarse a la banda ancha y descargar audiolibros digitales (Bae, et al., 2007). También las máquinas de autopréstamo D-Tech RFID AIR SelfCheck emplean NFC como método de identificación para realizar gestiones desde el smartphone.

${ }^{88}$ https://delicious.com/glauka/carnet-móvil 

Parte III. Sitios web, aplicaciones nativas y catálogos móviles 



\section{Capítulo 3. Metodología del trabajo de investigación}

Se presentan en este capítulo los objetivos y la metodología seguidos en las dos partes del trabajo de investigación realizados en el marco de esta tesis doctoral. La primera parte describe de forma detallada el método diseñado para el estudio de una muestra de sitios web, aplicaciones nativas y catálogos para dispositivos móviles. La segunda, las líneas principales para el análisis del caso concreto de la Biblioteca de la Universidad de Salamanca. En cada una de esas dos partes se explican las limitaciones y la problemática detectadas, así como cada uno de los datos recogidos, entre muchos otros aspectos.

Además, se proporciona en este apartado el contexto en el que se desarrolla la presente tesis doctoral y se exponen sus antecedentes y su aportación al campo en el que se circunscribe. 



\subsection{Contexto y objetivos de la investigación}

A la luz de la bibliografía, una de las cuestiones que más ha preocupado a los profesionales de las bibliotecas es cómo construir sitios web y aplicaciones nativas para dispositivos móviles, ya sea desde un enfoque técnico o analizando los contenidos y servicios que deberían ofertar. Esta preocupación tiene además importantes implicaciones prácticas para las bibliotecas. Es en este contexto en el que se va a desarrollar el trabajo de investigación que aquí se presenta.

Se han encontrado en la bibliografía diferentes tipos de publicaciones para abordan algunos aspectos de este problema:

- Trabajos teóricos sobre qué pautas seguir a la hora de crear sitios web o aplicaciones nativas para móviles en bibliotecas, que se expusieron en el apartado 2.2.1. El carácter de estos textos es más bien divulgativo y ofrecen información básica desde diferentes puntos de vista.

- Experiencias de creación de sitios web y aplicaciones nativas para dispositivos móviles en bibliotecas, donde se comparte información sobre cómo se desarrolló el proceso de creación (apartado 2.2.1).

- Encuestas a usuarios de bibliotecas con el propósito de conocer qué contenidos y servicios les serían de utilidad desde un dispositivo móvil, recogidas en el apartado 2.2.2.1. Este grupo es el más numeroso, pues son varias las bibliotecas que han publicado resultados de este tipo. Las diferencias entre los resultados de unos trabajos y otros demuestra que su validez no es universal, sino que se circunscribe al ámbito de los encuestados.

- Análisis de los sitios web y aplicaciones nativas para dispositivos móviles en bibliotecas desde el punto de vista de los contenidos, el diseño y la usabilidad (apartado 2.2.2.2).

- Evaluación de aplicaciones nativas para su recomendación en bibliotecas.

Esta cuestión ha sido tratada desde diferentes puntos de vista, pero siempre de forma parcial, con poca atención a las aplicaciones nativas y a los catálogos y con muestras reducidas. En España las lagunas son aún mayores, puesto que no se ha realizado hasta el momento ningún trabajo que tenga como objeto un análisis más profundo sobre las iniciativas puestas en marcha en las bibliotecas españolas y que fuera más allá de un mero recuento de iniciativas o la transmisión de experiencias.

Se parte, por lo tanto, de un conocimiento fragmentario de la realidad, por cuanto refleja situaciones, etapas y casos muy concretos, y presenta varias áreas aún por 
estudiar. También se caracteriza por una escasez de investigaciones, como se ha comprobado en el análisis de la bibliografía y de un insuficiente conocimiento de las iniciativas en España.

Por eso se ha querido plantear un trabajo de investigación que proporcione un conocimiento exhaustivo y profundo sobre cómo son los sitios web, aplicaciones nativas y catálogos que las bibliotecas están construyendo para su uso a través de dispositivos móviles. Para ello se han escogido tres unidades de análisis: sitios web, aplicaciones nativas y catálogos diseñados para smartphones y tabletas.

El objetivo de la presente investigación se puede detallar en otros cuatro más concretos:

1. Dibujar un panorama completo y detallado sobre cómo son los sitios web, aplicaciones nativas y catálogos móviles de las bibliotecas, las tendencias actuales y su evolución a lo largo del tiempo, especialmente en España.

2. Identificar una serie de buenas prácticas que puedan servir como modelos para otras bibliotecas. Estos casos ejemplares serán aquellos que destaquen por cumplir en mayor medida las recomendaciones.

3. Establecer una serie de pautas específicas para el desarrollo de sitios web y aplicaciones nativas para smartphones y tabletas en bibliotecas, que sirva también para su evaluación.

4. Conocer los resultados de una experiencia concreta, la de la Biblioteca de la Universidad de Salamanca, que resulta significativa por ser pionera en España.

Se han planteado dos trabajos de investigación que se detallarán en los apartados 3.2 y 3.3. El primero consiste en un análisis de diferentes sitios web, aplicaciones nativas y catálogos diseñados para dispositivos móviles. Sobre cada uno de ellos se estudiarán diferentes parámetros relacionados con los métodos de adaptación, el diseño, los contenidos, elementos de navegación, el aprovechamiento de las capacidades del dispositivo o el ajuste a sus características, entre otros. El segundo trabajo consiste en el análisis del caso de la Biblioteca de la Universidad de Salamanca, con especial atención a los resultados que se están obteniendo.

Se parte en ambos trabajos de dos formas, los sitios web para dispositivos móviles y las aplicaciones nativas, como unidades esenciales de proporcionar contenidos y servicios al usuario de biblioteca. Es preciso aclarar que los catálogos serán una sub-unidad de los sitios web para móviles o de las aplicaciones nativas, ya que realmente son las dos formas en que se presentan. Se ha querido analizar en un apartado adicional los catálogos móviles por ser uno de los servicios más importantes y característicos de las bibliotecas y porque plantean una problemática especial. 
Se han excluido de este estudio otras iniciativas relacionadas con los dispositivos móviles en bibliotecas para centrarse en las principales formas de ofertar contenidos y servicios. El uso de códigos QR no se ha abordado como iniciativa de movilidad en su conjunto porque no se están empleando como una forma de proporcionar contenidos, sino el acceso a los mismos. Sin embargo, sí han sido tenidos en cuenta cuando se emplean como medio de acceso a la versión móvil del sitio web o a la app de la biblioteca desde un sitio web. Tampoco se han estudiado experiencias de realidad aumentada o de uso de la geolocalización que no estuvieran incluidas en sitios web para dispositivos móviles y aplicaciones nativas, por ser muy minoritarios hasta el momento y porque requerirían un tipo de análisis muy diferente dadas sus originales características, pero también por la necesidad de acotar los límites del trabajo de investigación de manera que fuera abarcable.

\subsection{Análisis de sitios web, aplicaciones nativas y catálogos móviles en bibliotecas: metodología}

El objetivo de conocer cómo son los desarrollos para dispositivos móviles en bibliotecas ha llevado a optar por una metodología de investigación de tipo descriptivo. Pardo Merino (2014) define este tipo de investigaciones como aquellas mediante las que «se intenta obtener conocimiento sobre algo desconocido, identificar problemas de investigación y generar ideas (posibles soluciones a los problemas) para ser estudiados a otros niveles.» Desde este punto de vista se ha realizado una recogida de datos basada en un diseño observacional, que se basa en la observación de una selección de casos en un momento determinado.

Se especifican en los siguientes apartados los detalles sobre el diseño la investigación: la selección de la muestra, los parámetros y variables de análisis, el proceso de recogida de datos y el alcance y aportación de la investigación.

\subsubsection{Selección de la muestra}

Teniendo en cuenta el objetivo de esta investigación, la población objeto de análisis son todos los sitios web, aplicaciones nativas y catálogos para dispositivos 
móviles de las bibliotecas. De forma intencionada no se ha querido acotar la población a un tipo de biblioteca o a una zona geográfica concretas con el fin de obtener un panorama lo más amplio y variado posible, teniendo también en cuenta el carácter exploratorio de esta investigación.

Explorar todas las bibliotecas en busca de sitios web, aplicaciones nativas y catálogos para dispositivos móviles resultaría un trabajo ingente. Por lo tanto, el punto de partida a la hora de seleccionar la muestra fue el listado recogido en el Wiki Library Success ${ }^{89}$, tal y como se mostraba el día 16 de septiembre de 2013. Algunos de los sitios web y aplicaciones nativas no funcionaban en el momento del análisis o no cumplían con los requisitos del análisis —que se explicarán más adelante-, por lo que fueron retirados. Esta muestra se ha ampliado con otros casos procedentes de:

- Bibliografía. Se han añadido los casos sobre los que se ha tenido noticia a través de artículos, conferencias u otras publicaciones.

- Búsquedas en las app stores o tiendas de aplicaciones. Se han realizado diferentes búsquedas por la palabra «biblioteca» en varios idiomas en las principales tiendas de aplicaciones, Google Play para Android y App Store de Apple.

- En el caso de España, a través de los foros profesionales, como listas de distribución, encuentros o redes sociales.

- Descubrimiento casual. Durante la recogida de datos o al visitar los sitios web de las bibliotecas se han ido descubriendo nuevos ítems que se han incorporado a la muestra.

Como se ha explicado previamente, las unidades de análisis son dos: la sede web y la aplicación nativa para móviles. Se define la sede web como una «página web, o conjunto de páginas web ligadas jerárquicamente a una página principal, identificable por un URL y que forma una unidad documental reconocible e independiente de otras bien por su temática, bien por su autoría, o por su representatividad institucional.» (Arroyo y Pareja, 2003).

Por otra parte, recordemos que las aplicaciones nativas son aquellas que se descargan desde una tienda de aplicaciones o de otra fuente y se instalan en un dispositivo móvil, ampliando así sus funciones, tal y como se explicó en el apartado 1.3 de esta misma tesis doctoral.

Se han querido analizar de forma diferenciada los catálogos móviles, que pueden presentarse en forma de sede web o de aplicación nativa. Por eso se ha

\footnotetext{
${ }^{89} \underline{\mathrm{http}} \mathrm{/} / /$ www.libsuccess.org/index.php?title=M-Libraries
} 
considerado al catálogo, a efectos de este trabajo, como una sub-unidad de análisis dentro de las unidades sede web y aplicación.

Todos los sitios web o aplicaciones nativas que forman parte de la muestra han sido creados y son mantenidos por una biblioteca o por una institución que la representa y tienen una utilidad para la propia biblioteca o para sus usuarios. Esto no impide, sin embargo, que del desarrollo se hayan encargado empresas u otros agentes externos a petición de la biblioteca.

En el caso de las aplicaciones nativas, sólo se han analizado aquellas que han sido creadas por completo con fines bibliotecarios. En las universidades es común que la biblioteca ocupe un espacio dentro de la app de la universidad, no teniendo presencia propia. Este tipo de apps ha sido excluido de la muestra, con el fin de constituir una unidad de análisis coherente, ya que el objetivo de esta investigación es conocer las iniciativas puramente bibliotecarias. Sí que se han analizado algunas subsedes de sitios web para móviles dedicados a la biblioteca, puesto que constituyen una unidad documental diferenciada (Arroyo y Pareja, 2003).

Existen empresas que ofrecen servicios de creación de aplicaciones nativas, como Boopsie, que opera fundamentalmente en Estados Unidos. Aunque se ha encontrado una multitud de aplicaciones de bibliotecas creadas por esta empresa y por otras similares, sólo se ha incorporado a la muestra una o dos aplicaciones de cada desarrollador, a modo representativo, ya que las demás son muy similares y el análisis de cada una no aportaría nada añadido al tema del que nos ocupa. En total se detectaron en las tiendas de aplicaciones, en abril de 2014, siete empresas especializadas en el desarrollo de apps para bibliotecas con más de una aplicación nativa: Boopsie, BiblioCommons, BiblioLabs, LibraryThing, Solus UK, CG Soluzioni Informatiche SRL y VTLS. Entre todas suman 368 apps de bibliotecas, de las cuales 115 están en la tienda de aplicaciones de Apple y 359 en la de Android. En España aún no se han generalizado las aplicaciones nativas $\mathrm{y}$, aunque existen empresas especializadas en la creación de apps para bibliotecas, sus desarrollos son aún unos pocos.

Dadas las características de la fuente principal para la selección de la muestra de sitios web y aplicaciones nativas para móviles, se puede deducir un claro sesgo hacia ejemplos procedentes del ámbito anglosajón, y en especial de Estados Unidos. Este sesgo queda además reforzado por las limitaciones lingüísticas: el inglés se ha convertido en el idioma universal en internet y los contenidos que están en otros idiomas se vuelven menos accesibles para quienes no están familiarizadas con su lenguaje. 
Por otra parte, se adivinan áreas geográficas que no quedan cubiertas por este trabajo. A modo de ejemplo, es de esperar que en países asiáticos como Japón, donde el uso de internet desde el móvil está ampliamente extendido desde hace varios años, sean muchos más los ejemplos de sitios web y aplicaciones nativas para móviles desarrollados desde las bibliotecas.

Teniendo en cuenta las limitaciones de la muestra, ésta no pretende ser exhaustiva ni representativa de todas las bibliotecas con sitios web, aplicaciones o catálogos para dispositivos móviles. Pero sí se pretende recoger una muestra suficiente que proporcione una idea de cómo se están construyendo los sitios web y apps para móviles en las bibliotecas. Por otra parte, no es objetivo de este trabajo averiguar cuántas son las bibliotecas que tienen alguna versión para dispositivos móviles de su sitio web, una aplicación nativa o un catálogo móvil.

En el caso de las bibliotecas en España se ha procurado intencionadamente que la muestra se acerque en la mayor medida posible a la población, al menos en el ámbitos de bibliotecas públicas y universitarias. Por ello se han incluido todos los sitios web y aplicaciones nativas conocidos. Sin embargo, no se descarta la posibilidad de que exista algún caso del que no se tiene noticia.

Los datos de REBIUN indican que en España existen 75 bibliotecas universitarias y se han encontrado 15 bibliotecas con al menos un sitio web para móviles o aplicación nativa, lo que supone que el $20,0 \%$ ha desarrollado alguna. En lo referente a bibliotecas públicas, en el último año con datos disponibles, 2012, el INE contabilizó 4.211 bibliotecas públicas (unidades administrativas), de las cuales aproximadamente un 19,0\% quedaría representado por alguna aplicación nativa o sitio web para móviles, si se tiene en cuenta que algunos de ellos - los de Bibliotecas de Castilla y León, Bibliotecas de Navarra, Xarxa de Biblioteques Municipals de la Diputació de Barcelona, Biblioteques de Barcelona y la Red de Lectura Pública del País Vasco - representan a la mayor parte de las bibliotecas municipales de sus regiones.

Sin embargo, si solo se tienen en cuenta los desarrollos propios de cada biblioteca, solo se contabilizan cuatro bibliotecas públicas españolas con alguna iniciativa relacionada con la movilidad en 2013 (0,1\%). Poniendo este dato en perspectiva, según los datos publicados por la Subdirección General de Coordinación Bibliotecaria ${ }^{90}$, correspondientes a 2012, algo más de la cuarta parte de las bibliotecas públicas disponía de sitio web $(28,2 \%)$. Este porcentaje no incluye a

\footnotetext{
90 Bibliotecas públicas españolas en cifras. Ministerio de Educación Cultura y Deporte. http://www.mecd.gob.es/cultura-mecd/areas-cultura/bibliotecas/mc/ebp/portada.html
} 
Cataluña, sobre la que no se dispone de datos. Esto es un claro indicativo de la escasa presencia de las bibliotecas públicas en la web.

El país con más casos en el conjunto de la muestra es Estados Unidos. La ausencia de datos sobre el número exacto de iniciativas relacionadas con los dispositivos móviles hace imposible conocer el grado de representatividad de la muestra en este país. Sí se puede afirmar con certeza que las 114 bibliotecas analizadas, de las cuales 86 son bibliotecas universitarias, constituyen una de las muestras más amplias sobre este país estudiadas hasta el momento, si se compara con las publicaciones recogidas en el capítulo 2 .

Durante el proceso de recogida de datos se han encontrado algunos problemas que han limitado la información disponible. El primero de ellos está en los espacios protegidos por contraseña, como los que permiten la gestión del préstamo por parte de los usuarios, a los que no se puede acceder y que, por lo tanto, no ha sido posible describir. Estas áreas quedan dentro de lo que se conoce como internet invisible.

La obtención de la fecha de creación de sitios web y aplicaciones ha sido especialmente dificultosa. Este dato solo se puede conocer en los sitios web si se incluye en los metadatos o en el propio sitio web, algo muy poco frecuente, o a través de la bibliografía o de noticias en el sitio web. En los ejemplos en que ha sido imposible obtenerlo por estas vías se han utilizado otros métodos:

- Infiriéndolo de la fecha del copyright, siempre y cuando pareciera razonable. Por ejemplo, cuando esta fecha coincide con la del año en curso, no se ha tomado por su baja fiabilidad.

- Internet Archive ${ }^{91}$ es una gran base de datos que guarda copias de los sitios web a lo largo del tiempo. Rastreando la primera versión del sitio web en Internet Archive se ha podido obtener una fecha orientativa. Sin embargo, Internet Archive también tiene sus limitaciones y no guarda copia de todos los sitios, bien porque no los ha localizado o porque el sitio web en cuestión incluye algún sistema de exclusión de robots.

- Preguntando a la biblioteca directamente, en aquellos casos en que no ha sido posible recabar la información por otras vías.

En el caso de las aplicaciones, la tienda de aplicaciones de Apple ofrece el dato de la fecha de creación y de las versiones posteriores. Sin embargo, la tienda de Android solo recoge la fecha de la última actualización, que en algunos casos coincide con la fecha de creación, pero no siempre es así.

\footnotetext{
${ }^{91}$ http://archive.org
} 
El análisis de aplicaciones nativas para móviles se ha limitado a aquellas que están disponibles para smartphones y tabletas con sistemas operativos Android y Apple, que son los más extendidos. Se ha prescindido por lo tanto de las apps para Windows, BlackBerry y otros, que representan un pequeño porcentaje.

En las aplicaciones nativas para Android no se especifica si están diseñadas para tableta o para smartphone. Se han analizado siete apps de bibliotecas con versión exclusiva para Android. Teniendo en cuenta que la versión de Android para smartphones y tabletas es la misma desde el lanzamiento a finales de 2011 de Ice Cream Sandwich, la versión 4.0 de este sistema operativo, se ha entendido que tienen versión para tableta también las siguientes aplicaciones: BibliotequesXBM, Biblioteca UCS, Catàleg de biblioteques UAB, Colección Libro al Viento y Biblioteca Móvil de la UCA, UDC Biblio y UNED Biblioteca. Se ha excluido de la muestra la aplicación de la Biblioteca de la Universidad de Burgos, BUBUApp, debido a los problemas encontrados durante su instalación. Esta aplicación requiere para su funcionamiento la instalación previa de Adobe Air, programa que solo está disponible en determinados modelos de smartphones y no funciona en las versiones Android 4.0 y posteriores. Por otra parte, la app ha sido creada para Android 2.2 y posteriores. Estos factores limitan enormemente su instalación.

Ha resultado dificultoso averiguar qué software está por detrás de los catálogos y herramientas de descubrimiento de las bibliotecas, por lo que ha sido necesario, en algunos casos, interrogar directamente a la biblioteca.

\begin{tabular}{lrrr} 
& Sitios web & Aplicaciones & \multicolumn{2}{c}{ Catálogos } \\
\hline Estados Unidos & 131 & 20 & 32 \\
\hline España & 25 & 14 & 9 \\
\hline Otros países & 40 & 39 & 30 \\
\hline Total & 196 & 73 & 71 \\
\hline
\end{tabular}

Tabla 7. Número de casos de la muestra por unidad de análisis y país.

Se enumeran en los siguientes apartados los sitios web para móviles, aplicaciones nativas y catálogos que se han analizado en este trabajo de investigación. Se ordenan por estas tres categorías y, dentro de ellas, por el país de la biblioteca a la que pertenecen. 


\subsubsection{Listado de sitios web para dispositivos móviles}

De cada uno de los siguientes sitios web para móviles se incluye, en este mismo orden, el nombre del sitio tal y como aparece en él, la biblioteca que lo ha creado, a qué tipo de biblioteca corresponde (pública, universitaria, especializada o escolar), el dispositivo para el que ha sido diseñado, sistema de adaptación empleado, utilidad, año de creación y URL.

\section{Alemania}

Bayerische Staatsbibliothek, München. Bayerische Staatsbibliothek. Biblioteca pública. Dispositivo: smartphone. Nuevo sitio. Sitio web de la biblioteca. Año de creación: 2011.

http://m.bsb-muenchen.de

UB Heildelberg. Heidelberg University Library. Biblioteca universitaria. Dispositivo: smartphone. Nuevo sitio. Sitio web de la biblioteca. Año de creación: 2010.

http://m.ub.uni-heidelberg.de

KIT Bibliothek. KIT Bibliothek (Kalsruher Institut für Technologie). Biblioteca universitaria. Dispositivo: smartphone. Nuevo sitio. Sitio web de la biblioteca. Año de creación: 2012.

http://m.bibliothek.kit.edu

ulb ZB Medizin. ulb ZB Medizin (Westfälische Wilhelms-Universität Müster). Biblioteca universitaria. Dispositivo: smartphone. Nuevo sitio. Sitio web de la biblioteca. Año de creación: 2009.

http://www.uni-muenster.de/ZBMed/m

\section{Australia}

National Library of Australia. National Library of Australia. Biblioteca nacional. Dispositivo: smartphone. Diseño adaptativo. Sitio web de la biblioteca. Año de creación: 2012.

\section{http://www.nla.gov.au}

UTS Library. University of Technology Sidney Library. Biblioteca universitaria. Dispositivo: smartphone. Hoja de estilo. Sitio web de la biblioteca. Año de creación: 2009.

\section{http://www.lib.uts.edu.au}

\section{Canadá}

CAIJ | mobile. Centre d'accès à l'information juridique (CAIJ). Biblioteca especializada (derecho). Dispositivo: smartphone. Nuevo sitio. Sitio web de la biblioteca. Año de creación: 2009.

\section{http://m.caij.qc.ca}

McGill University Libraries. McGill University Libraries. Biblioteca universitaria. Dispositivo: smartphone. Nuevo sitio. Sitio web de la biblioteca. Año de creación: 2011.

http://m.library.mcgill.ca 
RULA Library \& Archives. Ryerson University Library. Biblioteca universitaria. Dispositivo: smartphone. Nuevo sitio. Sitio web de la biblioteca. Año de creación: 2008.

http://library.ryerson.ca/m

Ryerson University Library and Archives (OPAC). Ryerson University Library. Biblioteca universitaria. Dispositivo: smartphone. Diseño adaptativo. OPAC. Año de creación: 2013.

http://apps.library.ryerson.ca/bookfinder

The John Richard Allison Library. The John Richard Allison Library (Regent College). Biblioteca universitaria. Dispositivo: smartphone. Diseño adaptativo. Sitio web de la biblioteca. Año de creación: 2012.

http://allisonlibrary.regent-college.edu

University of Alberta Libraries mobile. University of Alberta Library. Biblioteca universitaria. Dispositivo: smartphone. Nuevo sitio. Sitio web de la biblioteca. Año de creación: 2009.

http://m.library.ualberta.ca

University of Alberta Libraries. University of Alberta Library. Biblioteca universitaria. Dispositivo: smartphone y tableta. Diseño adaptativo. Sitio web de la biblioteca. Año de creación: 2012.

http://www.library.ualberta.ca

Library. University of British Columbia Library. Biblioteca universitaria. Dispositivo: smartphone. Nuevo sitio. Sitio web de la biblioteca. Año de creación: 2013.

http://m.ubc.ca/libraries

Library Mobile. University of British Columbia Library. Biblioteca universitaria. Dispositivo: smartphone. Nuevo sitio. Sitio web de la biblioteca. Año de creación desconocido.

http://moobile.library.ubc.ca

University of Lethbridge Library. University of Lethbridge Library. Biblioteca universitaria. Dispositivo: smartphone. Nuevo sitio. Sitio web de la biblioteca. Año de creación: 2009.

http://www.uleth.ca/lib/mobile

University of Toronto Libraries. University of Toronto Libraries. Biblioteca universitaria. Dispositivo: smartphone. Nuevo sitio. Sitio web de la biblioteca. Año de creación: 2009.

http://m.library.utoronto.ca

\section{Chile}

Sistema de Bibliotecas DuocUC Chile. Sistema de Bibliotecas DuocUC. Biblioteca universitaria. Dispositivo: smartphone. Nuevo sitio. Sitio web de la biblioteca. Año de creación: 2010.

http://mbiblioteca.auroralabs.no 


\section{Dinamarca}

Aalborg Libraries, Denmark. Aalborg Libraries. Aalborg Libraries. Biblioteca pública. Dispositivo: teléfono. Nuevo sitio. Sitio web de la biblioteca. Año de creación: 2007.

http://www.mobib.nu

\section{Estados Unidos}

The Grotto Library. The Grotto Library (Cortiva Institute). Biblioteca especializada. Dispositivo: smartphone. Nuevo sitio. Sitio web de la biblioteca. Año de creación: 2010.

http://winksite.mobi/xhtml/ms consent?susid=32991

Yale University's Cushing/Whitney Medical Library. Cushing/Whitney Medical Library (Yale University). Biblioteca especializada (salud). Dispositivo: smartphone. Nuevo sitio. Sitio web de la biblioteca. Año de creación: 2011.

\section{http://doc.med.yale.edu/m}

MD Anderson Cancer Center Research Medical Library. MD Anderson Center Research Medical Library. Biblioteca especializada (salud). Dispositivo: smartphone. Nuevo sitio. Sitio web de la biblioteca. Año de creación desconocido.

http://www3.mdanderson.org/library/mobile

MD Anderson Cancer Center. MD Anderson Center Research Medical Library. Biblioteca especializada (salud). Dispositivo: tableta. Nuevo sitio. Sitio web de la biblioteca. Año de creación: 2012.

\section{http://www3.mdanderson.org/library/tablet}

MIT Libraries. Massachusetts Institute of Technology Library. Massachusetts Institute of Technology. Biblioteca especializada (tecnología). Dispositivo: smartphone. Nuevo sitio. Sitio web de la biblioteca. Año de creación: 2011.

\section{http://m.mit.edu/libraries}

Boise Public Library. Boise Public Library. Biblioteca pública. Dispositivo: smartphone. Nuevo sitio. Sitio web de la biblioteca. Año de creación: 2011.

http://www.boisepubliclibrary.org/mobile

Bklyn Public Library. Brooklyn Public Library. Biblioteca pública. Dispositivo: smartphone. Nuevo sitio. Sitio web de la biblioteca. Año de creación: 2011.

http://m.brooklynpubliclibrary.org

Canton Public Library. Canton Public Library. Biblioteca pública. Dispositivo: smartphone. Diseño adaptativo. Sitio web de la biblioteca. Año de creación: 2012.

\section{http://www.cantonpl.org}

Chelmsford Public Library. Chelmsford Public Library. Biblioteca pública. Dispositivo: smartphone. Nuevo sitio. Sitio web de la biblioteca. Año de creación: 2010.

http://www.chelmsfordlibrary.org/mobile

Contra Costa County Library. Contra Costa County Library. Biblioteca pública. Dispositivo: smartphone. Nuevo sitio. Sitio web de la biblioteca. Año de creación: 2010.

https://snapngo.ccclib.org 
CRRL Pocket Library. Crowley Ridge Regional Library System. Biblioteca pública. Dispositivo: smartphone. Nuevo sitio. Sitio web de la biblioteca. Año de creación: 2011.

http://m.libraryinjonesboro.org

DeKalb County Public Library Mobile. DeKalb County Public Library. Biblioteca pública. Dispositivo: smartphone. Nuevo sitio. Sitio web de la biblioteca. Año de creación: 2011.

http://m.dekalblibrary.org

Enoch Pratt Free Library. Enoch Pratt Free Library. Biblioteca pública. Dispositivo: smartphone. Nuevo sitio. Sitio web de la biblioteca. Año de creación: 2011.

\section{http://prattlibrary.mobi}

Iowa City Public Library. Iowa City Public Library. Biblioteca pública. Dispositivo: smartphone. Nuevo sitio. Sitio web de la biblioteca. Año de creación desconocido.

\section{http://www.icpl.org/m}

Mount Prospect Public Library. Mount Prospect Public Library. Biblioteca pública. Dispositivo: smartphone. Nuevo sitio. Sitio web de la biblioteca. Año de creación: 2012.

\section{http://mppl.org/mobile/index.php}

askALibrarian.org. Museums and Library Services. Biblioteca pública. Dispositivo: smartphone. Nuevo sitio. Servicio de referencia. Año de creación: 2012.

\section{http://askalibrarian.org/m}

New York Public Library Website. New York Public Library. Biblioteca pública. Dispositivo: smartphone. Nuevo sitio. Sitio web de la biblioteca. Año de creación: 2009.

\section{http://m.nypl.org}

Onondaga County Public Library, New York. Onondaga County Public Library. Biblioteca pública. Dispositivo: smartphone. Nuevo sitio. Sitio web de la biblioteca. Año de creación: 2011.

\section{http://m.onlib.org}

Orange County Library System (FL). Orange County Library System. Biblioteca pública. Dispositivo: smartphone. Nuevo sitio. Sitio web de la biblioteca. Año de creación: 2011.

\section{http://m.ocls.info}

Kids connect. Orange County Library System. Biblioteca pública. Dispositivo: smartphone. Nuevo sitio. Sitio web de la biblioteca. Año de creación: 2012.

\section{http://kids.ocls.info/Default.asp?mobile=true}

Rochester Hills Public Library (Michigan). Rochester Hills Public Library. Biblioteca pública. Dispositivo: smartphone y teléfono. Nuevo sitio. Sitio web de la biblioteca. Año de creación: 2010.

\section{http://www.rhpl.org/m}

Sacramento Public Library. Sacramento Public Library. Biblioteca pública. Dispositivo: smartphone y tableta. Diseño adaptativo. Sitio web de la biblioteca. Año de creación: 2012.

\section{http://www.saclibrary.org}


San Francisco Public Library. San Francisco Public Library. Biblioteca pública. Dispositivo: smartphone. Nuevo sitio. Sitio web de la biblioteca. Año de creación: 2011.

http://sfpl.org/mobile.xhtml.php

Gimme!. Scottsdale Public Library. Scottsdale Public Library. Biblioteca pública. Dispositivo: smartphone. Nuevo sitio. Recomendaciones. Año de creación: 2011.

http://gimme.scottsdalelibrary.org

Tulsa City-County Library. Tulsa City-County Library. Biblioteca pública. Dispositivo: smartphone. Nuevo sitio. Sitio web de la biblioteca. Año de creación: 2010.

\section{http://m.tulsalibrary.org}

Worthington Libraries. Worthington Libraries. Biblioteca pública. Dispositivo: smartphone. Nuevo sitio. Sitio web de la biblioteca. Año de creación: 2009.

\section{http://m.worthingtonlibraries.org}

Albertsons Library. Albertsons Library (Boise State University). Biblioteca universitaria. Dispositivo: smartphone. Hoja de estilo. Sitio web de la biblioteca. Año de creación: 2013.

http://library.boisestate.edu/?display=mobile

Albertsons Library. Albertsons Library (Boise State University). Biblioteca universitaria. Dispositivo: smartphone y tableta. Diseño adaptativo. Sitio web de la biblioteca. Año de creación: 2012.

\section{http://library.boisestate.edu}

Alvin Sherman Library. Alvin Sherman Library (Nova Southeastern University). Biblioteca universitaria. Dispositivo: smartphone. Nuevo sitio. Sitio web de la biblioteca. Año de creación: 2011.

\section{http://sherman.library.nova.edu/m}

Alvin Sherman Library. Alvin Sherman Library (Nova Southeastern University). Biblioteca universitaria. Dispositivo: smartphone y tableta. Diseño adaptativo. Sitio web de la biblioteca. Año de creación desconocido.

http://www.nova.edu/library/main

Geek the library. Alvin Sherman Library (Nova Southeastern University). Biblioteca universitaria. Dispositivo: smartphone y tableta. Diseño adaptativo. Sitio web de la biblioteca. Año de creación: 2013.

http://sherman.library.nova.edu/geek

American University Library. American University Library. Biblioteca universitaria. Dispositivo: smartphone. Nuevo sitio. Sitio web de la biblioteca. Año de creación: 2010.

http://www.library.american.edu/mobile

Auburn University Libraries. Auburn University Libraries. Biblioteca universitaria. Dispositivo: smartphone. Nuevo sitio. Sitio web de la biblioteca. Año de creación: 2010.

http://m.lib.auburn.edu 
Ball State Libraries. Ball State University Libraries. Biblioteca universitaria. Dispositivo: smartphone. Nuevo sitio. Sitio web de la biblioteca. Año de creación: 2012.

\section{http://www.bsu.edu/libraries/mobile}

Berkeley Library. Berkeley Library. Biblioteca universitaria. Dispositivo: smartphone. Nuevo sitio. Sitio web de la biblioteca. Año de creación: 2011.

http://mobile.lib.berkeley.edu

Binghamton University Libraries. Binghamton University Libraries. Biblioteca universitaria. Dispositivo: smartphone. Nuevo sitio. Sitio web de la biblioteca. Año de creación: 2010.

\section{http://library.binghamton.edu/m}

Black Hills State University. Library catalog. Black Hills State University Library. Biblioteca universitaria. Dispositivo: smartphone y tableta. Diseño adaptativo. Sitio web de la biblioteca. Año de creación: 2013.

http://iis.bhsu.edu/lis

Boston College Libraries. Boston College Libraries. Biblioteca universitaria. Dispositivo: smartphone. Nuevo sitio. Sitio web de la biblioteca. Año de creación: 2011.

http://www.bc.edu/sites/libraries/m

Boston University Medical Center Mobile Library. Boston University Medical Center Library. Medical Center. Biblioteca universitaria. Dispositivo: smartphone. Nuevo sitio. Sitio web de la biblioteca. Año de creación: 2007.

http://med-libwww.bu.edu/mobile

Cal Poly Pomona University Library Mobile. Cal Poly Pomona University Library (California State University, Fullerton). Biblioteca universitaria. Dispositivo: smartphone. Nuevo sitio. Sitio web de la biblioteca. Año de creación desconocido.

\section{http://www.csupomona.edu/ library/m}

CSUMB Library. California State University, Monterey Bay, Library. Biblioteca universitaria. Dispositivo: smartphone. Nuevo sitio. Sitio web de la biblioteca. Año de creación: 2010.

http://library2.csumb.edu/m

LibrarySearch. Cambridge University Library. Biblioteca universitaria. Dispositivo: smartphone. Nuevo sitio. OPAC. Año de creación: 2011.

\section{http://www.lib.cam.ac.uk/mob}

Cape Fear Community College Learning Resource Center. Cape Fear Community College Learning Resource Center. Biblioteca universitaria. Dispositivo: smartphone. Nuevo sitio. Sitio web de la biblioteca. Año de creación: 2010.

\section{http://cfcc.edu/lrc/m}

Chambers Library. Chambers Library (University of Central Oklahoma). Biblioteca universitaria. Dispositivo: smartphone. Nuevo sitio. Sitio web de la biblioteca. Año de creación: 2010.

$\underline{\text { http://library.uco.edu/m }}$ 
LRC Mobile. Chesapeake College Library (Chesapeake College). Biblioteca universitaria. Dispositivo: smartphone. Nuevo sitio. Sitio web de la biblioteca. Año de creación: 2012.

http://info.chesapeake.edu/lrc/m

Claire T. Carney Library UMass Dartmouth. Claire T. Carney Library UMass Dartmouth (University of Massachusetts Dartmouth). Biblioteca universitaria. Dispositivo: smartphone. Nuevo sitio. Sitio web de la biblioteca. Año de creación: 2010.

http://m.lib.umassd.edu

Clemens \& Alcuin Libraries. Clemens \& Alcuin Libraries (St. John's University). Biblioteca universitaria. Dispositivo: smartphone. Hoja de estilo. Sitio web de la biblioteca. Año de creación desconocido.

http://www.csbsju.edu/Libraries.htm?mobile=true

C.O.D. Library. College of DuPage Library. Biblioteca universitaria. Dispositivo: smartphone. Nuevo sitio. Sitio web de la biblioteca. Año de creación: 2010.

\section{http://m.codlibrary.org}

DiMenna-Nyselius Library. DiMenna-Nyselius Library (Fairfield Univerity). Biblioteca universitaria. Dispositivo: smartphone. Nuevo sitio. Sitio web de la biblioteca. Año de creación: 2011.

http://mlib.fairfield.edu

Dowling College Library. Dowling College Library. Biblioteca universitaria. Dispositivo: smartphone. Nuevo sitio. Sitio web de la biblioteca. Año de creación: 2010.

\section{http://www.dowling.edu/library/m/index.html}

Duke Libraries. Mobile Library Home. Duke University Libraries. Biblioteca universitaria. Dispositivo: smartphone. Nuevo sitio. Sitio web de la biblioteca. Año de creación: 2008.

\section{http://library.duke.edu/mobile}

Duke Libraries. Mobile Library Home. Duke University Libraries. Biblioteca universitaria. Dispositivo: smartphone y tableta. Diseño adaptativo. Sitio web de la biblioteca. Año de creación desconocido.

http://library.duke.edu

Durham University Library. Durham University Library. Biblioteca universitaria. Dispositivo: smartphone. Diseño adaptativo. Sitio web de la biblioteca. Año de creación: 2012.

\section{http://www.dur.ac.uk/library}

FIU Medical Library. FIU Medical Library (Florida International University). Biblioteca universitaria. Dispositivo: smartphone. Nuevo sitio. Sitio web de la biblioteca. Año de creación: 2011.

\section{http://medlib.fiu.edu/m}

RICE Fondren Library. Fondren University Library. Biblioteca universitaria. Dispositivo: smartphone. Nuevo sitio. Sitio web de la biblioteca. Año de creación: 2009.

http://m.library.rice.edu 
George Mason University Libraries. George Mason University Libraries. Biblioteca universitaria. Dispositivo: smartphone. Nuevo sitio. Sitio web de la biblioteca. Año de creación: 2010.

http://m.gmu.edu

Georgetown University Library. Georgetown University Library. Biblioteca universitaria. Dispositivo: smartphone. Nuevo sitio. Sitio web de la biblioteca. Año de creación: 2009.

http://www.library.georgetown.edu/mobile

Georgia Stare University Library. Georgia State University Library. Biblioteca universitaria. Dispositivo: smartphone. Nuevo sitio. Sitio web de la biblioteca. Año de creación: 2011.

\section{http://m.library.gsu.edu}

Grand Valley State University. University Libraries. Grand Valley State University Library. Biblioteca universitaria. Dispositivo: smartphone y tableta. Diseño adaptativo. Sitio web de la biblioteca. Año de creación: 2012.

http://www.gvsu.edu/library

GHSU Greenblatt Mobile Library. Greenblatt Library (Georgia Health Science University). Biblioteca universitaria. Dispositivo: smartphone. Nuevo sitio. Sitio web de la biblioteca. Año de creación: 2012.

http://lib.georgiahealth.edu/m

Hanover College, Duggan Library. Duggan Library (Hanover College). Biblioteca universitaria. Dispositivo: smartphone. Diseño adaptativo. Sitio web de la biblioteca. Año de creación: 2012.

http://library.hanover.edu

Harold B. Lee Library. Harold B. Lee Library (Brigham Young University). Biblioteca universitaria. Dispositivo: smartphone. Nuevo sitio. Sitio web de la biblioteca. Año de creación: 2009.

http://www.lib.byu.edu/m

Harvard College Library. Harvard College Library. Biblioteca universitaria. Dispositivo: teléfono. Nuevo sitio. Sitio web de la biblioteca. Año de creación: 2007.

http://hcl.harvard.edu/mobile

Library. Harvard College Library. Biblioteca universitaria. Dispositivo: smartphone. Nuevo sitio. Sitio web de la biblioteca. Año de creación: 2011.

http://m.harvard.edu/libraries

HimmelfarbMOBILE. Himmelfarb Health Sciences Library. Biblioteca universitaria. Dispositivo: smartphone. Nuevo sitio. Sitio web de la biblioteca. Año de creación: 2010.

\section{http://www.gwumc.edu/library/mobile}

IC Library. Ithaca College Library. Biblioteca universitaria. Dispositivo: smartphone. Diseño adaptativo. Sitio web de la biblioteca. Año de creación: 2013. 
Michigan Tech. J. R. Van Pelt and Opie Library. J. R. Van Pelt and Opie Library (Michigan Technological University). Biblioteca universitaria. Dispositivo: smartphone. Nuevo sitio. Sitio web de la biblioteca. Año de creación: 2010.

http://www.lib.mtu.edu/m

Van Pelt and Opie Library. J. R. Van Pelt and Opie Library (Michigan Technological University). Biblioteca universitaria. Dispositivo: smartphone. Nuevo sitio. Sitio web de la biblioteca. Año de creación: 2013.

http://m.lib.mtu.edu

Walker library. James E. Walker Library. Biblioteca universitaria. Dispositivo: smartphone. Nuevo sitio. Sitio web de la biblioteca. Año de creación: 2011.

http://library.mtsu.edu/m

DSU Dakota State. Karl E. Mundt Library (Dakota State University). Biblioteca universitaria. Dispositivo: smartphone y tableta. Diseño adaptativo. Sitio web de la biblioteca. Año de creación: 2012.

http://www.dsu.edu/library

Lane Library Mobile. Lane Community College Library. Biblioteca universitaria. Dispositivo: smartphone. Nuevo sitio. Sitio web de la biblioteca.

http://www.lanecc.edu/library/mobile/index.htm

Langsdale on the Go!. Langsdale Library. Biblioteca universitaria. Dispositivo: smartphone. Nuevo sitio. Sitio web de la biblioteca. Año de creación: 2012.

http://langsdale.ubalt.edu/m

Law Library. Law Library (George Mason University). Biblioteca universitaria. Dispositivo: smartphone. Diseño adaptativo. Sitio web de la biblioteca. Año de creación: 2012.

\section{http://www.law.gmu.edu/library}

University of Hawaii - Leeward Community College Library. Leeward Community College Library (University of Hawaii). Biblioteca universitaria. Dispositivo: smartphone. Nuevo sitio. Sitio web de la biblioteca. Año de creación: 2011.

http://www.leeward.hawaii.edu/lib/m

McCain Library - Agnes Scott College. McCain Library (Agnes Scott College). Biblioteca universitaria. Dispositivo: smartphone. Nuevo sitio. Sitio web de la biblioteca. Año de creación: 2011.

http://library.agnesscott.edu/m

Mendik Mobile. Mendik Library. Biblioteca universitaria. Dispositivo: smartphone. Nuevo sitio. Sitio web de la biblioteca. Año de creación: 2011.

\section{https://nyls.boopsie.bredir.com/m}

Miami University Libraries. Miami University Libraries (Ohio). Biblioteca universitaria. Dispositivo: smartphone. Nuevo sitio. Sitio web de la biblioteca. Año de creación: 2010.

http://www.lib.muohio.edu/m 
Mississippi State University Libraries. Mississippi State University Libraries. Biblioteca universitaria. Dispositivo: smartphone. Nuevo sitio. Sitio web de la biblioteca. Año de creación: 2010.

http://library.msstate.edu/m

Molloy Mobile Library. Molloy College Library. Biblioteca universitaria. Dispositivo: smartphone. Nuevo sitio. Sitio web de la biblioteca. Año de creación: 2010.

http://molloycollegelibrary.com/m/index.html

MSU Library (mobile). Montana State University Library. Biblioteca universitaria. Dispositivo: smartphone. Nuevo sitio. Sitio web de la biblioteca. Año de creación: 2011.

http://www.lib.montana.edu/m

Musselman Library. Musselman Library. Gettysburg College. Biblioteca universitaria. Dispositivo: smartphone. Nuevo sitio. Sitio web de la biblioteca. Año de creación: 2009.

\section{http://www.gettysburg.edu/library/m}

NCSU Libraries. North Carolina State University Library. Biblioteca universitaria. Dispositivo: smartphone. Nuevo sitio. Sitio web de la biblioteca. Año de creación desconocido.

http://m.lib.ncsu.edu

WolfWalk. North Carolina State University Library. Biblioteca universitaria. Dispositivo: smartphone. Nuevo sitio. Patrimonial. Año de creación desconocido.

http://m.lib.ncsu.edu/wolfwalk

My \#HuntLibrary. North Carolina State University Library. Biblioteca universitaria. Dispositivo: smartphone y tableta. Diseño adaptativo. Utilidades. Año de creación: 2013.

http://d.lib.ncsu.edu/myhuntlibrary

Northwestern University Library. Northwestern University Library. Biblioteca universitaria. Dispositivo: smartphone. Nuevo sitio. Sitio web de la biblioteca. Año de creación: 2012.

\section{http://m.library.northwestern.edu}

Hendrix. Olin C. Bailey Library. Olin C. Bailey Library. Biblioteca universitaria. Dispositivo: smartphone. Diseño adaptativo. Sitio web de la biblioteca. Año de creación: 2012.

\section{http://www.hendrix.edu/baileylibrary}

Oregon State University Libraries. Oregon State University Libraries. Biblioteca universitaria. Dispositivo: smartphone. Nuevo sitio. Sitio web de la biblioteca. Año de creación: 2011.

\section{http://m.library.oregonstate.edu}

Book Genie. Oregon State University Libraries. Biblioteca universitaria. Dispositivo: tableta. Nuevo sitio. Recomendaciones. Año de creación: 2011.

http://genie.library.oregonstate.edu 
BeaverTracks. Oregon State University Libraries. Biblioteca universitaria. Dispositivo: smartphone. Nuevo sitio. Tour. Año de creación: 2010.

http://tour.library.oregonstate.edu

Pappas Law Library Mobile. Pappas Law Library (Boston University). Biblioteca universitaria. Dispositivo: smartphone. Nuevo sitio. Sitio web de la biblioteca. Año de creación: 2013.

http://www.bu.edu/lawlibrary/mobile

Penn State University Libraries. Penn State University Libraries. Biblioteca universitaria. Dispositivo: smartphone. Nuevo sitio. Sitio web de la biblioteca. Año de creación: 2011.

http://m.libraries.psu.edu

University of Denver (Penrose Library). Penrose Library (University of Denver). Biblioteca universitaria. Dispositivo: smartphone. Nuevo sitio. Sitio web de la biblioteca. Año de creación: 2010.

\section{http://mysite.du.edu/ jokraus/test/m.html}

Penrose Library. Penrose Library (University of Denver). Biblioteca universitaria. Dispositivo: smartphone. Nuevo sitio. Sitio web de la biblioteca. Año de creación: 2013.

http://m.library.du.edu

Pollak Library. Pollak Library (California State University). Biblioteca universitaria. Dispositivo: smartphone. Nuevo sitio. Sitio web de la biblioteca. Año de creación: 2010.

http://www.library.fullerton.edu/mobile/MobileDefault.php

River Campus Libraries. River Campus Libraries (University of Rochester). Biblioteca universitaria. Dispositivo: smartphone. Nuevo sitio. Sitio web de la biblioteca. Año de creación: 2009.

\section{http://www.lib.rochester.edu/m}

SDSU Mobile Library. San Diego State University Library. Biblioteca universitaria. Dispositivo: smartphone. Nuevo sitio. Sitio web de la biblioteca. Año de creación: 2012.

http://m.library.sdsu.edu

Simmons Library. Simmons College Library. Biblioteca universitaria. Dispositivo: smartphone. Nuevo sitio. Sitio web de la biblioteca. Año de creación: 2011.

http://www.simmons.edu/library/m

Sonoma State University. Library Home. Sonoma State University Library. Biblioteca universitaria. Dispositivo: smartphone. Nuevo sitio. Sitio web de la biblioteca. Año de creación: 2011.

http://library.sonoma.edu/m

TCU Library. Texas Christian University Library. Biblioteca universitaria. Dispositivo: smartphone. Nuevo sitio. Sitio web de la biblioteca. Año de creación: 2009.

$\underline{\text { http://lib.tcu.edu/m }}$ 
Thomas G. Carpenter Library. Thomas G. Carpenter Library. Biblioteca universitaria. Dispositivo: smartphone. Nuevo sitio. Sitio web de la biblioteca. Año de creación desconocido.

\section{http://www.unf.edu/library/mobile.aspx}

University of Arkansas for Medical Sciences Library. University of Arkansas for Medical Sciences Library. Biblioteca universitaria. Dispositivo: smartphone. Nuevo sitio. Sitio web de la biblioteca. Año de creación: 2011.

http://www.library.uams.edu/m

University of California, Irvine. University of California Library. Biblioteca universitaria. Dispositivo: smartphone. Nuevo sitio. Sitio web de la biblioteca. Año de creación desconocido.

http://m.lib.uci.edu

University of California, Grunigen. University of California Library. Biblioteca universitaria. Dispositivo: smartphone. Nuevo sitio. Sitio web de la biblioteca. Año de creación: 2011.

http://m.lib.uci.edu/gml

The Library. University of California San Diego Library. Biblioteca universitaria. Dispositivo: smartphone. Nuevo sitio. Sitio web de la biblioteca. Año de creación: 2011.

http://libraries.ucsd.edu/m

UCSF Mobile. Library. University of California San Diego Library. Biblioteca universitaria. Dispositivo: smartphone. Nuevo sitio. Sitio web de la biblioteca. Año de creación: 2010.

\section{http://m.ucsf.edu/library}

University of Illinois at Urbana-Champaign Library. University of Illinois at UrbanaChampaign Library. Biblioteca universitaria. Dispositivo: smartphone. Nuevo sitio. Sitio web de la biblioteca. Año de creación: 2009.

http://m.library.illinois.edu

Infopoint. University of Illinois at Urbana-Champaign Library. Biblioteca universitaria. Dispositivo: smartphone. Nuevo sitio. Tour. Año de creación: 2012.

http://sif.grainger.uiuc.edu/tour

UI Libraries Mobile. University of Iowa Libraries. Biblioteca universitaria. Dispositivo: smartphone. Nuevo sitio. Sitio web de la biblioteca. Año de creación: 2010.

http://www.lib.uiowa.edu/m

The University of Iowa Libraries. University of Iowa Libraries. Biblioteca universitaria. Dispositivo: smartphone. Diseño adaptativo. Sitio web de la biblioteca. Año de creación: 2012.

\section{http://www.lib.uiowa.edu}

University of Michigan Library. University of Michigan Library. Biblioteca universitaria. Dispositivo: smartphone. Nuevo sitio. Sitio web de la biblioteca. Año de creación: 2011.

$\underline{\text { http://m.lib.umich.edu }}$ 
M Libraries. University of Minnesota Library. Biblioteca universitaria. Dispositivo: smartphone. Nuevo sitio. Sitio web de la biblioteca. Año de creación: 2010.

http://www.lib.umn.edu/mobile

University of Missouri - Columbia. University of Missouri - Columbia Libraries. Biblioteca universitaria. Dispositivo: smartphone. Nuevo sitio. Sitio web de la biblioteca. Año de creación desconocido.

http://mulibraries.missouri.edu/mobile

Mansfield Library. University of Montana Library. Biblioteca universitaria. Dispositivo: smartphone. Nuevo sitio. Sitio web de la biblioteca. Año de creación: 2011.

http://m.lib.umt.edu

UNL Libraries (Mobile). University of Nebraska-Lincoln Libraries. Biblioteca universitaria. Dispositivo: smartphone. Nuevo sitio. Sitio web de la biblioteca. Año de creación: 2012.

http://libraries.unl.edu/m

UNL Libraries (Mobile). University of Nebraska-Lincoln Libraries. Biblioteca universitaria. Dispositivo: smartphone y tableta. Diseño adaptativo. Sitio web de la biblioteca. Año de creación desconocido.

http://libraries.unl.edu

University of North Carolina at Chapel Hill. University of North Carolina at Chapel Hill Libraries. Biblioteca universitaria. Dispositivo: smartphone. Nuevo sitio. Sitio web de la biblioteca. Año de creación: 2009.

http://www.lib.unc.edu/m

University of Pennsylvania. University of Pennsylvania Libraries. Biblioteca universitaria. Dispositivo: smartphone. Nuevo sitio. Sitio web de la biblioteca. Año de creación: 2009.

http://www.library.upenn.edu/m

University of Richmond (Boatwright Memorial Library). University of Richmond Library. Biblioteca universitaria. Dispositivo: smartphone. Hoja de estilo. Sitio web de la biblioteca. Año de creación desconocido.

http://library.richmond.edu

UTHSC Library Mobile. University of Tennessee Health Science Center Library. Health Science Center. Biblioteca universitaria. Dispositivo: smartphone. Nuevo sitio. Sitio web de la biblioteca. Año de creación: 2010.

http://library.uthsc.edu/mobile

The Libraries UT Health Science Center. University of Texas Health Science Center at San Antonio Libraries. Biblioteca universitaria. Dispositivo: smartphone. Nuevo sitio. Sitio web de la biblioteca. Año de creación: 2010.

http://uthscsa.mobi/library 
The Libraries UT Health Science Center. University of Texas Health Science Center at San Antonio Libraries. Biblioteca universitaria. Dispositivo: smartphone. Hoja de estilo. Sitio web de la biblioteca. Año de creación desconocido. Año de creación desconocido.

http://library.uthscsa.edu/mobile

University of Virginia Library. University of Virginia Library. Biblioteca universitaria. Dispositivo: teléfono. Nuevo sitio. Sitio web de la biblioteca. Año de creación: 2007.

http://mobile.virginia.edu/library.php

University of Virginia Library. University of Virginia Library. Biblioteca universitaria. Dispositivo: smartphone. Nuevo sitio. Sitio web de la biblioteca. Año de creación desconocido.

http://m.library.virginia.edu

University of Virginia Library. University of Virginia Library. Biblioteca universitaria. Dispositivo: smartphone y tableta. Diseño adaptativo. Sitio web de la biblioteca. Año de creación: 2012.

http://www.library.virginia.edu

Ursula C. Schwerin Library. Ursula C. Schwerin Library (New York College of Technology). Biblioteca universitaria. Dispositivo: smartphone. Nuevo sitio. Sitio web de la biblioteca. Año de creación: 2013.

http://m.library.citytech.cuny.edu

Virginia Commonwealth University Libraries. Virginia Commonwealth University Libraries. Biblioteca universitaria. Dispositivo: smartphone y tableta. Nuevo sitio. Sitio web de la biblioteca. Año de creación: 2010.

http://m.library.vcu.edu

Aladin Mobile. Washington Research Library Consortium. Biblioteca universitaria. Dispositivo: smartphone. Nuevo sitio. OPAC. Año de creación: 2011.

\section{http://m.wrlc.org}

Washington Research Library Consortium. Washington Research Library Consortium. Biblioteca universitaria. Dispositivo: smartphone y tableta. Diseño adaptativo. Sitio web de la biblioteca. Año de creación: 2013.

http://www.wrlc.org

WSULS Mobile Web. Wayne State University Libraries. Biblioteca universitaria. Dispositivo: smartphone. Nuevo sitio. Sitio web de la biblioteca. Año de creación desconocido.

\section{http://m.lib.wayne.edu/home}

WVU Libraries. West Virginia University Libraries. Biblioteca universitaria. Dispositivo: smartphone. Nuevo sitio. Sitio web de la biblioteca. Año de creación: 2010.

\section{http://m.lib.wvu.edu}

Yale University Library. Yale University Library. Biblioteca universitaria. Dispositivo: smartphone. Nuevo sitio. Sitio web de la biblioteca. Año de creación: 2009.

http://www.library.yale.edu/m 


\section{España}

CSIC. Red de Bibliotecas y Archivos del CSIC. Consejo Superior de Investigaciones Científicas. Biblioteca especializada. Dispositivo: smartphone. Nuevo sitio. Sitio web de la biblioteca. Año de creación: 2009.

\section{http://bibliotecascsic.ubik.net}

Bibliosaúde móvil. Biblioteca Virtual del Sistema Sanitario Público Gallego. Biblioteca especializada (salud). Dispositivo: smartphone. Nuevo sitio. Sitio web de la biblioteca. Año de creación: 2010.

http://bibliosaude.sergas.es/movil

Biblioteca Virtual del Sistema Sanitario Público de Andalucía. Biblioteca Virtual del Sistema Sanitario Público de Andalucía. Biblioteca especializada (salud). Dispositivo: smartphone. Hoja de estilo. Sitio web de la biblioteca. Año de creación: 2010.

http://www.bvsspa.es/profesionales

Saludteca. Biblioteca Virtual del Sistema Sanitario Público de Extremadura. Biblioteca especializada (salud). Dispositivo: smartphone. Nuevo sitio. Sitio web de la biblioteca. Año de creación: 2012.

http://movil.saludteca.gobex.es

Biblioteca Escolar Colegio San Gabriel. Biblioteca Escolar Colegio San Gabriel. Biblioteca especializadas. Dispositivo: smartphone. Nuevo sitio. Sitio web de la biblioteca. Año de creación desconocido.

http://www.alisesprofesor.es/biblioteca1/phone/index.m.htm

Bibliotecas de Castilla y León. Bibliotecas de Castilla y León. Biblioteca pública. Dispositivo: smartphone. Hoja de estilo. Sitio web de la biblioteca. Año de creación: 2012.

\section{http://www.bibliotecas.jcyl.es}

Bibliotecas Públicas de Navarra. Bibliotecas Públicas de Navarra. Biblioteca pública. Dispositivo: smartphone. Hoja de estilo. Sitio web de la biblioteca. Año de creación desconocido.

\section{http://www.navarra.es/home es/Temas/Turismo+ocio+y+cultura/Bibliotecas}

Biblioteques públiques de Terrassa. Biblioteques públiques de Terrassa. Biblioteca pública. Dispositivo: smartphone. Nuevo sitio. Sitio web de la biblioteca. Año de creación: 2013.

https://sites.google.com/site/bctxarxamobil

Biblioteca UNED móvil. Biblioteca de la UNED. Biblioteca universitaria. Dispositivo: smartphone. Nuevo sitio. Sitio web de la biblioteca. Año de creación: 2012.

http://bibliotecauned.wirenode.mobi

Biblioteca de la Universidad de Alicante. Biblioteca de la Universidad de Alicante. Biblioteca universitaria. Dispositivo: smartphone. Nuevo sitio. Sitio web de la biblioteca. Año de creación: 2010.

$\underline{\text { http://m.biblioteca.ua.es }}$ 
Universidad de Cádiz. Área de Biblioteca y Archivo. Biblioteca de la Universidad de Cádiz. Biblioteca universitaria. Dispositivo: smartphone. Nuevo sitio. Sitio web de la biblioteca. Año de creación: 2012.

http://bibmovil.uca.es

Biblioteca i TIC mòbil. Biblioteca de la Universidad Pompeu Fabra. Biblioteca universitaria. Dispositivo: smartphone. Nuevo sitio. Sitio web de la biblioteca. Año de creación: 2012.

http://www.upf.edu/bibtic/m

Biblioteca del Campus de Fuenlabrada de la Universidad Rey Juan Carlos. Biblioteca del Campus de Fuenlabrada (Universidad Rey Juan Carlos). Biblioteca universitaria. Dispositivo: smartphone. Nuevo sitio. Sitio web de la biblioteca. Año de creación: 2013.

http://bibliotecafuenlabradaurjc.wordpress.com

Biblioteca i Documentació Científica. Universitat Politècnica de València. Biblioteca i Documentació Científica (Universitat Politècnica de València). Biblioteca universitaria. Dispositivo: smartphone. Nuevo sitio. Sitio web de la biblioteca. Año de creación: 2010.

http://bibmobil.upv.es

IE Library. Biblioteca IE. Biblioteca universitaria. Dispositivo: smartphone. Nuevo sitio. Sitio web de la biblioteca. Año de creación: 2011.

http://library.ie.edu/mobile/server/mobile.php?lang=sp\# search

Biblioteca UC. Biblioteca Universidad de Cantabria. Biblioteca universitaria. Dispositivo: tableta. Nuevo sitio. Sitio web de la biblioteca. Año de creación: 2012.

http://www.buc.unican.es/mobile

Bibliotecas Universidad de Salamanca. Biblioteca Universidad de Salamanca. Biblioteca universitaria. Dispositivo: smartphone. Hoja de estilo. Sitio web de la biblioteca. Año de creación: 2013.

http://bibliotecas.usal.es/?q=inicio\&amp;mobile switch=mobile

CRAI. Centre de Recursos per a l'Aprenentatge i la Investigació (CRAI). Biblioteca universitaria (Universidad de Barcelona). Dispositivo: smartphone. Nuevo sitio. Sitio web de la biblioteca. Año de creación: 2011.

http://www.bib.ub.edu/m/

Universidad de A Coruña. Escuela Técnica Superior de Ingenieros de Caminos, Canales y Puertos. Escuela Técnica Superior de Ingenieros de Caminos, Canales y Puertos (Universidad de A Coruña). Biblioteca universitaria. Dispositivo: smartphone. Nuevo sitio. Sitio web de la biblioteca. Año de creación: 2008.

http://bibliocaminos-udc.ubik.net

Universidad de Navarra. Biblioteca (Universidad de Navarra). Biblioteca universitaria. Dispositivo: smartphone. Nuevo sitio. Sitio web de la biblioteca. Año de creación: 2012.

http://www.unav.es/biblioteca/m 
Universidad de Gerona. Universitat de Girona. Biblioteca (Universitat de Girona). Biblioteca universitaria. Dispositivo: smartphone. Nuevo sitio. Sitio web de la biblioteca. Año de creación: 2012.

http://m.udg.edu/Biblioteca

UPC Commons. Universitat Politècnica de Catalunya. Bibliotecas (Universidad Politécnica de Cataluña). Biblioteca universitaria. Dispositivo: smartphone. Nuevo sitio. Repositorio institucional. Año de creación: 2010.

http://m.bibliotecnica.upc.edu/upcommons

UWIN. Universitat Politècnica de Catalunya. Bibliotecas (Universidad Politécnica de Cataluña). Biblioteca universitaria. Dispositivo: smartphone. Nuevo sitio. Utilidades. Año de creación: 2009.

http://flas.upc.edu/uwin/m

Ooohweb!. Universitat Politècnica de Catalunya. Bibliotecas (Universidad Politécnica de Cataluña). Biblioteca universitaria. Dispositivo: smartphone. Nuevo sitio. Utilidades. Año de creación: 2010.

http://bibliotecnica.upc.edu/ooohweb/m

Bibliotécnica. Universitat Politècnica de Catalunya. Bibliotecas (Universidad Politécnica de Cataluña). Biblioteca universitaria. Dispositivo: smartphone. Nuevo sitio. Sitio web de la biblioteca. Año de creación: 2012.

http://m.bibliotecnica.upc.edu

\section{Francia}

Ros@lis mobile. Bibliothèque de Toulouse. Bibliothèque de Toulouse. Biblioteca pública. Dispositivo: smartphone. Nuevo sitio. Patrimonial. Año de creación: 2012.

http://m.numerique.bibliotheque.toulouse.fr

\section{Holanda}

Koninklijke Bibliotheek, National Library of the Netherlands. Biblioteca Nacional de Holanda. Biblioteca nacional. Dispositivo: smartphone. Diseño adaptativo. Sitio web de la biblioteca. Año de creación: 2013.

http://www.kb.nl

de Bibliotheek. Bibliotheek Maasland. Basisbibliotheek Maasland. Biblioteca pública. Dispositivo: smartphone. Nuevo sitio. Sitio web de la biblioteca. Año de creación desconocido.

http://bicat.bibliotheekmaasland.nl/cgi-bin/bx.pl?sid=8a49403b-cb4b-4e34-b8f73c459f75acbc;vestnr $=4199 ;$ prt=INTERNET; cdef $=002 ;$ taal $=1 ; \mathrm{sn}=10 ; \mathrm{var}=\mathrm{mob}$

UBLeiden. Biblioteca de la Universidad de Leiden. Biblioteca universitaria. Dispositivo: smartphone. Nuevo sitio. Sitio web de la biblioteca. Año de creación desconocido.

http://m.ubl.leiden.edu

MobileCMB.nl. MobileCMB.nl. University of Groningen. Biblioteca universitaria. Dispositivo: smartphone. Nuevo sitio. Sitio web de la biblioteca. Año de creación: 2011.

$\underline{\text { http://mobilecmb.nl }}$ 
University of Amsterdam. University of Amsterdam Library. Biblioteca universitaria. Dispositivo: smartphone. Diseño adaptativo. Sitio web de la biblioteca. Año de creación: 2013.

\section{http://uba.uva.nl}

Utrecht University Library. Utrecht University Library. Biblioteca universitaria. Dispositivo: smartphone. Nuevo sitio. Sitio web de la biblioteca. Año de creación: 2010.

http://m.library.uu.nl/index.php

\section{México}

Biblioteca Campus Monterrey. Biblioteca del Tecnológico de Monterrey. Biblioteca universitaria. Dispositivo: smartphone. Diseño adaptativo. Sitio web de la biblioteca. Año de creación: 2013.

http://biblioteca.mty.itesm.mx

\section{Noruega}

National Library of Norway. National Library of Norway. Biblioteca nacional. Dispositivo: smartphone. Diseño adaptativo. Sitio web de la biblioteca. Año de creación: 2012.

\section{http://www.nb.no}

Norwegian Business School Library. Norwegian Business School Library. Biblioteca universitaria. Dispositivo: smartphone. Diseño adaptativo. Sitio web de la biblioteca. Año de creación desconocido.

http://www.bi.edu/library

\section{Puerto Rico}

Centro de Información y Tecnologías. Biblioteca Néstor Rodríguez Rivera (University of Puerto Rico). Biblioteca universitaria. Dispositivo: smartphone. Nuevo sitio. Sitio web de la biblioteca. Año de creación: 2010.

http://citec.mobify.me

\section{Reino Unido}

Bodleian Libraries. Bodleian Libraries (Oxford University). Biblioteca universitaria. Dispositivo: smartphone y tableta. Diseño adaptativo. Sitio web de la biblioteca. Año de creación: 2013.

http://www.bodleian.ox.ac.uk

Library@Brunel. Brunel Library. Biblioteca universitaria. Dispositivo: smartphone. Nuevo sitio. Sitio web de la biblioteca. Año de creación desconocido.

http://libguides.brunel.ac.uk/mobile/4219

Open University Library, United Kingdom. Open University Library. Biblioteca universitaria. Dispositivo: smartphone. Nuevo sitio. Sitio web de la biblioteca. Año de creación: 2007.

http://www.open.ac.uk/libraryservices/m 
Open University Library, United Kingdom. Open University Library. Biblioteca universitaria. Dispositivo: smartphone. Diseño adaptativo. Sitio web de la biblioteca. Año de creación: 2013.

http://www.open.ac.uk/library

Mobile Oxford. Oxford University Libraries. Biblioteca universitaria. Dispositivo: smartphone. Nuevo sitio. OPAC. Año de creación: 2010.

http://m.ox.ac.uk/library

UCP Marjon (University College Plymouth) (UK). UCP Marjon Library (University College Plymouth). Biblioteca universitaria. Dispositivo: smartphone. Nuevo sitio. Sitio web de la biblioteca. Año de creación: 2011.

http://www.marjon.ac.uk/mobile/facilities/library

\section{Singapur}

National Library Board Singapore. National Library Board Singapore. Biblioteca pública. Dispositivo: smartphone. Nuevo sitio. Sitio web de la biblioteca. Año de creación desconocido.

http://m.nlb.gov.sg

Nanyang Technological University Library. Nanyang Technological University Library. Biblioteca universitaria. Dispositivo: smartphone. Nuevo sitio. Sitio web de la biblioteca. Año de creación: 2012.

http://blogs.ntu.edu.sg/mlibrary

\section{Sudáfrica}

University of Pretoria, South Africa. University of Pretoria, South Africa. Biblioteca universitaria. Dispositivo: teléfono. Nuevo sitio. Sitio web de la biblioteca. Año de creación: 2010.

http://www.library.up.ac.za/mobi

\section{Suiza}

ETH-Bibliotek. ETH-Bibliotek (Swiss Federal Institute of technology Zurich). Biblioteca universitaria. Dispositivo: smartphone. Nuevo sitio. Sitio web de la biblioteca. Año de creación: 2012.

http://www.library.ethz.ch/mobile

\subsubsection{Listado de aplicaciones nativas}

De cada una de la aplicaciones nativas de la siguiente lista se incluye, en este mismo orden, el nombre de la app tal y como aparece en la tienda de aplicaciones, la biblioteca que la ha creado, el tipo de biblioteca que es (pública, universitaria, especializada o escolar), el sistema operativo y dispositivo en el que funciona, su utilidad, año de creación y URL para la descarga en la tienda de aplicaciones. 


\section{Alemania}

EconBiz. German National Library of Economics (Leibniz Information Centre for Economics). Biblioteca especializada. Sistema operativo: iOS y Android. Dispositivo: smartphone y tableta. Utilidad: catálogo. Año de creación: 2011

https://itunes.apple.com/es/app/econbiz/id419108453?mt=8

Famous books - Treasures of the Babarian State Library. Bayerische Staatsbibliothek. Biblioteca pública. Sistema operativo: iOS. Dispositivo: smartphone y tableta. Utilidad: patrimonial. Año de creación: 2010.

\section{http://itunes.apple.com/app/id380668385}

Oriental Books. Bayerische Staatsbibliothek. Biblioteca pública. Sistema operativo: iOS. Dispositivo: smartphone y tableta. Utilidad: patrimonial. Año de creación: 2011.

\section{https://itunes.apple.com/en/app/oriental-books/id434831284}

Ludwig II - Walking in the Footsteps of a Fairytale King. Bayerische Staatsbibliothek. Biblioteca pública. Sistema operativo: iOS. Dispositivo: smartphone. Utilidad: patrimonial (biografía). Año de creación: 2011.

https://itunes.apple.com/us/app/ludwig-ii-walking-infootsteps/id463331755? $\mathrm{mt}=8$

Pracht auf pergament. Bayerische Staatsbibliothek. Biblioteca pública. Sistema operativo: iOS y Android. Dispositivo: smartphone. Utilidad: patrimonial (exposición). Año de creación: 2012.

\section{https://itunes.apple.com/en/app/pracht/id564228189?mt=8}

Bayern in historischen Karten. Bayerische Staatsbibliothek. Biblioteca pública. Sistema operativo: iOS. Dispositivo: smartphone y tableta. Utilidad: patrimonial. Año de creación: 2013.

https://itunes.apple.com/us/app/bayern-in-historischenkarten/id615552739? $\mathrm{mt}=8$

Dichterwege. Auf den Spuren von Jean Paul. Bayerische Staatsbibliothek. Biblioteca pública. Sistema operativo: iOS y Android. Dispositivo: smartphone y tableta. Utilidad: patrimonial (biografía). Año de creación: 2013.

https://itunes.apple.com/en/app/dichterwege.-auf-den-

spuren/id669682084? $\mathrm{mt}=8$ \&ign-mpt=uo\%3D2

\section{Australia}

National Library of Australia Mobile Catalogue. National Library of Australia. Biblioteca nacional. Sistema operativo: iOS y Android. Dispositivo: smartphone. Utilidad: catálogo. Año de creación: 2011.

\section{http://itunes.apple.com/au/app/national-library-australia/id454084627?mt=8}

National Library of Australia Treasures Gallery. National Library of Australia. Biblioteca nacional. Sistema operativo: iOS y Android. Dispositivo: smartphone. Utilidad: patrimonial (exposición - tour). Año de creación: 2011.

https://itunes.apple.com/us/app/national-library-australia/id459734024?mt=8 
Forte. National Library of Australia. Biblioteca nacional. Sistema operativo: iOS. Dispositivo: tableta. Utilidad: patrimonial. Año de creación: 2013.

https://itunes.apple.com/us/app/forte/id598850264?mt=8

\section{Bélgica}

UB Gent. Ghent University Library. Biblioteca universitaria Sistema operativo: iOS y Android. Dispositivo: smartphone. Utilidad: sitio web de la biblioteca. Año de creación: 2010.

http://itunes.apple.com/es/app/ub-gent/id362022518?mt=8

\section{Brasil}

Biblioteca UCS. Universidade de Caxias do Sul, Biblioteca. Biblioteca universitaria. Sistema operativo: Android. Dispositivo: smartphone y tableta. Utilidad: noticias. Año de creación: 2012.

https://play.google.com/store/apps/details?id=com.appmakr.app458257\&hl=en

\section{Canadá}

OPL Mobile. Ottawa Public Library. Biblioteca pública. Sistema operativo: iOS y Android. Dispositivo: smartphone. Utilidad: sitio web de la biblioteca. Año de creación: 2011.

https://itunes.apple.com/us/app/opl-mobile/id417445178?mt=8

YourLibraryCa. Richmond Public Library. Biblioteca pública. Sistema operativo: iOS y Android. Dispositivo: smartphone. Utilidad: sitio web de la biblioteca. Año de creación: 2012.

https://itunes.apple.com/es/app/yourlibraryca/id584421596?ign-mpt=uo\%3D5

TRACpac. The Regional Automation Consortium. Biblioteca pública. Sistema operativo: iOS y Android. Dispositivo: smartphone. Utilidad: catálogo. Año de creación desconocido.

\section{https://play.google.com/store/apps/details?id=com.hybridforge.tracpac}

\section{Chile}

Visita virtual - Biblioteca Nacional de Chile. Biblioteca Nacional de Chile. Biblioteca nacional. Sistema operativo: iOS. Dispositivo: smartphone y tableta. Utilidad: visita virtual. Año de creación: 2013.

https://itunes.apple.com/hk/app/visita-virtual-biblioteca/id687930326?mt=8

\section{Colombia}

Biblioteca Nacional de Colombia: selección Samper Ortega de literatura colombiana. Biblioteca Nacional de Colombia. Biblioteca nacional. Sistema operativo: iOS. Dispositivo: tableta. Utilidad: patrimonial. Año de creación: 2012.

https://itunes.apple.com/us/app/biblioteca-nacionalcolombia/id567550644?mt=8

Ediciones Biblioteca Nacional. Biblioteca Nacional de Colombia. Biblioteca nacional. Sistema operativo: iOS y Android. Dispositivo: tableta. Utilidad: lectura. Año de creación: 2013. 
https://itunes.apple.com/es/app/ebooks-bnc/id640154249?mt=8

Colección Libro al Viento. Biblioteca Nacional de Colombia. Biblioteca nacional. Sistema operativo: Android. Dispositivo: smartphone y tableta. Utilidad: lectura. Año de creación: 2013.

https://play.google.com/store/apps/details?id=com.ColeccionLibroAlViento.LibroA $\underline{\text { lViento\&hl=es } 419}$

Exhibiciones Virtuales. Red de bibliotecas de Medellín Área Metropolitana. Biblioteca pública. Sistema operativo: iOS y Android. Dispositivo: smartphone y tableta. Utilidad: patrimonial (exposición). Año de creación: 2013.

https://itunes.apple.com/es/app/id589612762?mt=8

Uniandes - Sistema bibliotecas. Biblioteca de la Universidad de los Andes. Biblioteca universitaria. Sistema operativo: iOS y Android. Dispositivo: smartphone. Utilidad: sitio web de la biblioteca. Año de creación: 2013.

https://itunes.apple.com/es/app/uniandes-sistema-

bibliotecas/id604843050? $\mathrm{mt}=8$

\section{Dinamarca}

Gladsaxe Public Libraries. Gladsaxe Public Library. Biblioteca pública. Sistema operativo: iOS y Android. Dispositivo: smartphone.Utilidad: catálogo. Año de creación: 2010 .

https://itunes.apple.com/es/app/gladsaxe-public-

libraries $/ \mathrm{id} 369889251$ ? $\mathrm{l}=\mathrm{en} \& \mathrm{mt}=8$

\section{Estados Unidos}

DCPL. District of Columbia Public Library. Biblioteca pública. Sistema operativo: iOS y Android. Dispositivo: smartphone. Utilidad: sitio web de la biblioteca. Año de creación: 2009.

http://itunes.apple.com/WebObjects/MZStore.woa/wa/viewSoftware?id=3010778 $\underline{50 \& m t=8}$

READometer. King County Library System. Biblioteca pública. Sistema operativo: iOS. Dispositivo: smartphone. Utilidad: medir tiempo de lectura. Año de creación: 2013.

https://itunes.apple.com/us/app/readometer/id658819682?mt=8

AskALibrarian.org. Museums and Library Services (Florida Department of State's Division of Library and Information Services). Biblioteca pública. Sistema operativo: iOS y Android. Dispositivo: smartphone y tableta. Utilidad: referencia. Año de creación: 2013.

https://itunes.apple.com/us/app/ask-fla-ask-a-librarian/id615534104?mt=8

NYPL Mobile. New York Public Library. Biblioteca pública. Sistema operativo: iOS y Android. Dispositivo: smartphone. Utilidad: sitio web de la biblioteca. Año de creación: 2011.

\section{http://itunes.apple.com/es/app/nypl-mobile/id441537393?mt=8}

NYPL Biblion: World's Fair. New York Public Library. Biblioteca pública. Sistema operativo: iOS. Dispositivo: tableta. Utilidad: patrimonial. Año de creación: 2011. 
http://itunes.apple.com/es/app/nypl-biblion-worlds-fair/id433418206?mt=8

Find the Future at NYPL: The Game. New York Public Library. Biblioteca pública. Sistema operativo: iOS. Dispositivo: smartphone. Utilidad: juegos. Año de creación: 2011.

http://itunes.apple.com/es/app/find-future-at-nypl-game/id435613260?mt=8

NYPL Biblion: Frankenstein. New York Public Library. Biblioteca pública. Sistema operativo: iOS. Dispositivo: tableta. Utilidad: patrimonial (exposición). Año de creación: 2012.

https://itunes.apple.com/es/app/nypl-biblion-frankenstein/id521833980?mt=8

OCLS Shake It!. Orange County Library System. Biblioteca pública. Sistema operativo: iOS y Android. Dispositivo: smartphone. Utilidad: recomendación de libros. Año de creación: 2010.

https://itunes.apple.com/us/app/ocls-shake-it!/id380507093?mt=8

SPL Mobile. Seattle Public Library. Biblioteca pública. Sistema operativo: iOS y Android. Dispositivo: smartphone y tableta. Utilidad: sitio web de la biblioteca. Año de creación: 2010.

http://itunes.apple.com/us/app/spl-mobile/id364019201?mt=8

TCLibToGo. Tulare County Library. Biblioteca pública. Sistema operativo: iOS y Android. Dispositivo: smartphone y tableta. Utilidad: sitio web de la biblioteca. Año de creación: 2012.

https://itunes.apple.com/us/app/tclibtogo/id509237585?mt=8

Worthington Libraries. Worthington Libraries. Biblioteca pública. Sistema operativo: iOS y Android. Dispositivo: smartphone y tableta. Utilidad: sitio web de la biblioteca. Año de creación: 2012.

https://itunes.apple.com/es/app/worthington-libraries/id499501417?mt=8

CCSU Elihu Burrit Library. Elihu Burritt Library (Central Connecticut State University). Biblioteca universitaria. Sistema operativo: iOS y Android. Dispositivo: smartphone. Utilidad: sitio web de la biblioteca. Año de creación: 2012.

\section{http://itunes.apple.com/es/app/ccsu-elihu-burritt-library/id500205696?mt=8}

ShelvAR: Miami University Libraries (Ohio). Biblioteca universitaria. Sistema operativo: iOS y Android. Dispositivo: smartphone y tableta. Utilidad: ordenar libros. Año de creación: 2013.

https://itunes.apple.com/us/app/shelvar/id694851251

WolfWalk. North Carolina State University Library. Biblioteca universitaria. Sistema operativo: iOS. Dispositivo: smartphone y tableta. Utilidad: patrimonial, geolocalización. Año de creación: 2010.

http://itunes.apple.com/es/app/wolfwalk/id377191481?mt=8

NU Library. Northwestern University Library. Biblioteca universitaria. Sistema operativo: iOS. Dispositivo: smartphone y tableta. Utilidad: sitio web de la biblioteca. Año de creación: 2012.

https://itunes.apple.com/us/app/nu-library/id520234215?mt=8 
New Germanic Books. University of Illinois at Urbana-Champaign Library. Biblioteca universitaria. Sistema operativo: iOS. Dispositivo: smartphone y tableta. Utilidad: novedades bibliográficas. Año de creación: 2010.

http://itunes.apple.com/es/app/new-germanic-books/id371890453?mt=8

New LIS books. University of Illinois at Urbana-Champaign Library. Biblioteca universitaria. Sistema operativo: iOS. Dispositivo: smartphone. Utilidad: novedades bibliográficas. Año de creación: 2010.

http://itunes.apple.com/us/app/new-lis-books/id352102769?mt=8

ugl4eva. University of Illinois at Urbana-Champaign Library. Biblioteca universitaria. Sistema operativo: iOS. Dispositivo: smartphone. Utilidad: visita virtual. Año de creación: 2010.

http://itunes.apple.com/es/app/ugl4eva/id352224134?mt=8

Minrva. University of Illinois at Urbana-Champaign Library. Biblioteca universitaria. Sistema operativo: iOS y Android. Dispositivo: smartphone y tableta. Utilidad: catálogo. Año de creación: 2012.

https://itunes.apple.com/us/app/minrva/id572981792?mt=8\&ign-mpt=uo\%3D4

New French Books. University of Illinois at Urbana-Champaign Library. Biblioteca universitaria. Sistema operativo: iOS. Dispositivo: smartphone. Utilidad: novedades bibliográficas. Año de creación: 2010.

https://itunes.apple.com/us/app/new-french-books/id372987259?mt=8

\section{España}

Biblioteca FM. Centro de Documentación Fundación Mapfre. Biblioteca especializada. Sistema operativo: iOS y Android. Dispositivo: smartphone y tableta.Utilidad: catálogo. Año de creación: 2013.

https://itunes.apple.com/es/app/biblioteca-fm/id663896475?mt=8

BNE 300 Años. Biblioteca Nacional de España. Biblioteca nacional. Sistema operativo: iOS y Android. Dispositivo: smartphone. Utilidad: patrimonial. Exposición. Año de creación: 2011.

http://itunes.apple.com/es/app/bne-300-anos/id484584222?mt=8

Biblioteca de Mollerussa. Biblioteca de Mollerussa. Biblioteca pública. Sistema operativo: iOS y Android. Dispositivo: smartphone. Utilidad: sitio web de la biblioteca. Año de creación: 2013.

https://itunes.apple.com/es/app/biblioteca-de-mollerussa/id695526728?mt=8

Bibliotecas de Navarra. Bibliotecas Públicas de Navarra. Biblioteca pública. Sistema operativo: iOS y Android. Dispositivo: smartphone y tableta. Utilidad: sitio web de la biblioteca. Año de creación: 2013.

https://itunes.apple.com/es/app/bibliotecas-de-navarra/id777591714?mt=8

BibliosBCN. Biblioteques de Barcelona. Biblioteca pública. Sistema operativo: iOS y Android. Dispositivo: smartphone. Utilidad: agenda. Año de creación: 2013.

https://itunes.apple.com/es/app/bibliosbcn/id638704165?mt=8 
BiblioMaresme. Biblioteques del Maresme. Biblioteca pública. Sistema operativo: iOS y Android. Dispositivo: smartphone y tableta. Utilidad: sitio web de la biblioteca. Año de creación: 2013.

https://play.google.com/store/apps/details?id=com.dortoka.BiblioMaresme\&hl=en

DeCuentos. Centro Internacional del Libro Infantil y Juvenil (Fundación Germán Sánchez Ruipérez). Biblioteca pública. Sistema operativo: iOS y Android. Dispositivo: smartphone y tableta. Utilidad: videocuentos. Año de creación: 2013.

https://itunes.apple.com/us/app/decuentos/id643623155?mt=8

Liburutegiak. Red de Lectura Pública de Euskadi. Red de Lectura Pública de Euskadi. Biblioteca pública. Sistema operativo: iOS y Android. Dispositivo: smartphone y tableta. Utilidad: sitio web de la biblioteca. Año de creación: 2013.

https://itunes.apple.com/es/app/liburutegiak/id740627974?mt=8

BibliotequesXBM. Xarxa de Biblioteques Municipals (Diputació de Barcelona). Biblioteca pública. Sistema operativo: Android. Dispositivo: smartphone y tableta. Utilidad: sitio web de la biblioteca. Año de creación: 2013.

https://play.google.com/store/apps/details?id=com.diba.bibliotequesxbm\&hl=en

UNED Biblioteca. Biblioteca de la Universidad Nacional de Educación a Distancia (UNED). Biblioteca universitaria. Sistema operativo: Android. Dispositivo: smartphone y tableta. Utilidad: sitio web de la biblioteca. Año de creación: 2012.

https://play.google.com/store/apps/details?id=com.app.bibliouned

Biblioteca Móvil de la UCA. Biblioteca de la Universidad de Cádiz. Biblioteca universitaria. Sistema operativo: Android. Dispositivo: smartphone y tableta. Utilidad: sitio web de la biblioteca. Año de creación: 2012.

https://play.google.com/store/apps/details?id=es.uca.biblioteca.bibliotecauca\&feat

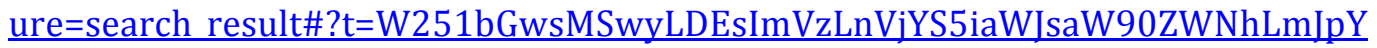
mxpb3RIY2F1Y2EiXQ

Catàleg de biblioteques UAB. Biblioteca de la Universitat Autonoma de Barcelona. Biblioteca universitaria. Sistema operativo: Android. Dispositivo: smartphone y tableta. Utilidad: Catálogo. Año de creación: 2013.

https://play.google.com/store/apps/details?id=com.uab\&hl=en

Bibliotecas USAL. Biblioteca Universidad de Salamanca. Biblioteca universitaria. Sistema operativo: iOS y Android. Dispositivo: smartphone y tableta. Utilidad: sitio web de la biblioteca. Año de creación: 2011.

http://itunes.apple.com/es/app/bibliotecas-usal/id477970535?mt=8

UDC Biblio. Universidad de A Coruña, Biblioteca. Universidad de A Coruña. Biblioteca universitaria. Sistema operativo: Android. Dispositivo: smartphone. Utilidad: catálogo. Año de creación: 2012.

https://play.google.com/store/apps/details?id=org.GalIO.Biblio\&hl=en

\section{Francia}

Bpi mobile. Bibliothèque Centre Pompidou. Biblioteca especializada. Sistema operativo: iOS. Dispositivo: smartphone. Utilidad: sitio web de la biblioteca. Año de creación: 2013. 
https://itunes.apple.com/es/app/bpi-mobile/id604197794?mt=8\&ign$\underline{\mathrm{mpt}=\mathrm{uo} \% 3 \mathrm{D} 4}$

Miniatures flamandes de la cour de Bourgogne. Bibliothèque Nationale de France. Biblioteca nacional. Sistema operativo: iOS. Dispositivo: tableta. Utilidad: patrimonial. Exposición. Año de creación: 2012.

http://itunes.apple.com/es/app/enluminures-flamandes-lacour/id501800441?mt=8

Gallica. Bibliothèque Nationale de France. Bibliothèque Nationale de France. Biblioteca nacional. Sistema operativo: iOS y Android. Dispositivo: smartphone y tableta. Utilidad: patrimonial. Año de creación: 2012.

https://itunes.apple.com/es/app/gallica/id561943007?mt=8

L'Âge d'or des cartes marines. Bibliothèque Nationale de France. Biblioteca nacional. Sistema operativo: iOS. Dispositivo: tableta. Utilidad: patrimonial (exposición). Año de creación: 2012.

https://itunes.apple.com/fr/app/lage-dor-des-cartes-marines/id573961409?mt=8

Bibliothèque publique Toulouse. Bibliothèque de Toulouse. Biblioteca pública. Sistema operativo: iOS. Dispositivo: smartphone. Utilidad: sitio web de la biblioteca. Año de creación: 2011.

http://itunes.apple.com/es/app/id419585406

\section{Hong Kong}

HKBUtube. Hong Kong Baptist University Library. Biblioteca universitaria. Sistema operativo: iOS. Dispositivo: smartphone. Utilidad: vídeo. Año de creación: 2011.

https://itunes.apple.com/us/app/hkbutube-on-the-go/id427735080?mt=8

\section{Italia}

Biblioteche Venezia. Sistema Bibliotecario Urbano Ciudad de Venecia. Biblioteca pública. Sistema operativo: iOS y Android. Dispositivo: smartphone. Utilidad: sitio web de la biblioteca. Año de creación: 2013.

https://itunes.apple.com/es/app/biblioteche-venezia/id608203433?mt=8

\section{Puerto Rico}

UneBib. Biblioteca Universidad del Este. Biblioteca universitaria. Sistema operativo: iOS y Android. Dispositivo: smartphone y tableta. Utilidad: sitio web de la biblioteca. Año de creación: 2012.

https://itunes.apple.com/es/app/unebib/id574297755?mt=8

\section{Reino Unido}

British Library 19th Century Collection. British Library. Biblioteca nacional. Sistema operativo: iOS. Dispositivo: tableta. Utilidad: patrimonial (lectura). Año de creación: 2012.

http://itunes.apple.com/es/app/british-library-19th-century/id438196905?mt=8

Victorian Christmas. British Library. Biblioteca nacional. Sistema operativo: iOS. Dispositivo: tableta. Utilidad: patrimonial. Año de creación: 2011. 
https://itunes.apple.com/es/app/victorian-christmas/id475329730?mt=8

Explore the John Murray Archive. National Library of Scotland. Biblioteca nacional. Sistema operativo: iOS. Dispositivo: smartphone. Utilidad: patrimonial (tour). Año de creación: 2010.

http://itunes.apple.com/es/app/explore-john-murray-archive/id368209244?mt=8

Manchester Libraries. Manchester Libraries. Biblioteca pública. Sistema operativo: iOS y Android. Dispositivo: smartphone y tableta. Utilidad: sitio web de la biblioteca. Año de creación: 2013.

https://itunes.apple.com/gb/app/id588973651?mt=8\&affld=1860684

\section{Singapur}

NIE Library. National Institute of Education (NIE). Biblioteca especializada. Sistema operativo: iOS y Android. Dispositivo: smartphone y tableta. Utilidad: sitio web de la biblioteca. Año de creación: 2012.

https://itunes.apple.com/us/app/nie-library/id513175751?mt=8

MobileRead. National Library Board Singapore. Biblioteca pública. Sistema operativo: iOS y Android. Dispositivo: smartphone y tableta. Utilidad: lectura. Año de creación: 2011.

$\underline{\text { http://itunes.apple.com/sg/app/mobileread/id411883163?mt=8 }}$

SG Memory. National Library Board Singapore. Biblioteca pública. Sistema operativo: iOS. Dispositivo: smartphone. Utilidad: compartir fotografías. Año de creación: 2012.

https://itunes.apple.com/es/app/sg-memory/id519007795?mt=8

\section{Suecia}

Bibli - Uppsala. Bibliotecas de Uppsala. Biblioteca pública. Sistema operativo: iOS y Android. Dispositivo: smartphone.Utilidad: catálogo. Año de creación: 2012.

https://itunes.apple.com/es/app/bibli-uppsala/id538689198?l=en\&mt=8

\section{Varios países}

Europeana Open Culture. Europeana. Biblioteca digital. Sistema operativo: iOS. Dispositivo: tableta. Utilidad: patrimonial. Año de creación: 2013.

https://itunes.apple.com/nl/app/europeana/id646414251?l=en\&amp;mt=8

\subsubsection{Listado de catálogos y herramientas de descubrimiento}

Se enumeran a continuación los catálogos y herramientas de descubrimiento analizados, ya sea en formato de aplicación nativa o de sitio web para móviles. Sobre cada uno de ellos se incluye, en este mismo orden, su nombre tal y como aparece en el sitio web, la biblioteca que lo ha creado, el tipo de biblioteca que es (pública, universitaria, especializada o escolar), el sistema de adaptación que emplea, para qué gama de dispositivos ha sido diseñado, sistema de adaptación (nuevo sitio web, diseño adaptativo u hojas de estilo), año de creación, solución adoptada (desarrollo propio o software comercial) y URL de acceso. 


\section{Alemania}

Bayerische Staatsbibliothek. Bayerische Staatsbibliothek. Biblioteca pública. Dispositivo: Smartphone. Sistema de adaptación: nuevo sitio web. Desarrollo propio. https://m.opacplus.bsb-muenchen.de

EconBiz. German National Library of Economics. Biblioteca especializada. Sistema de adaptación: aplicación nativa. https://itunes.apple.com/es/app/econbiz/id419108453?mt=8

UB Heildelberg. Heidelberg University Library. Biblioteca universitaria. Dispositivo: Smartphone. Sistema de adaptación: nuevo sitio web (detección). Desarrollo propio.

http://katalog.ub.uni-heidelberg.de

Universitaetsbibliothek Koeln. Universitaetsbibliothek Koeln. Biblioteca universitaria. Dispositivo: Smartphone. Sistema de adaptación: nuevo sitio web. Desarrollo propio.

http://mobil.ub.uni-koeln.de

\section{Australia}

National Library of Australia Mobile Catalogue. National Library of Australia. Biblioteca nacional. Sistema de adaptación: aplicación nativa.

http://itunes.apple.com/au/app/national-library-australia/id454084627?mt=8

UTS Library. University of Technology Sidney Library. Biblioteca universitaria. Dispositivo: smartphone. Sistema de adaptación: hoja de estilo. Desarrollo propio.

http://www.lib.uts.edu.au

\section{Bélgica}

Meercat - Mobile. Ghent University Library. Biblioteca universitaria. Dispositivo: smartphone. Sistema de adaptación: nuevo sitio web. Desarrollo propio.

http://search.ugent.be/meercat/x/mobile

\section{Canadá}

CAIJ | mobile. Centre d'accès à l'information juridique (CAIJ). Biblioteca especializada. Dispositivo: smartphone. Sistema de adaptación: nuevo sitio web. Desarrollo propio.

http://m.caij.qc.ca

McGill University Libraries. McGill University Libraries. Biblioteca universitaria. Dispositivo: smartphone y teléfono móvil. Sistema de adaptación: nuevo sitio web. Desarrollo propio.

http://m.library.mcgill.ca/touch/catalogue

OPL Mobile. Ottawa Public Library. Biblioteca pública. Sistema de adaptación: aplicación nativa.

https://itunes.apple.com/us/app/opl-mobile/id417445178?mt=8

RULA Library \& Archives. Ryerson University Library. Biblioteca universitaria. Dispositivo: smartphone. Sistema de adaptación: nuevo sitio web. Desarrollo propio. 
http://apps.library.ryerson.ca/bookfinder/search

YourLibraryCa. Richmond Public Library. Biblioteca pública. Sistema de adaptación: aplicación nativa.

https://itunes.apple.com/es/app/yourlibraryca/id584421596?ign-mpt=uo\%3D5

\section{Dinamarca}

Gladsaxe Bibliotek. Gladsaxe Public Library. Biblioteca pública. Dispositivo: smartphone. Sistema de adaptación: nuevo sitio web. Software comercial (DDElibra MoBiblio).

http://www.ghlbib.dk/sites/GMOBILE/mobile/menu.html;jsessionid=0185836834 66D87BA65C6AE848C46519

Gladsaxe Public Libraries. Gladsaxe Public Library. Biblioteca pública. Sistema de adaptación: aplicación nativa.

https://itunes.apple.com/es/app/gladsaxe-public-

libraries/id369889251?l=en\&mt=8

\section{Estados Unidos}

Aladin Mobile. Washington Research Library Consortium. Biblioteca universitaria. Dispositivo: smartphone. Sistema de adaptación: nuevo sitio web. Desarrollo propio.

http://m.wrlc.org/catalog/index.php

Canton Public Library. Canton Public Library. Biblioteca pública. Dispositivo: smartphone. Sistema de adaptación: diseño adaptativo. Desarrollo propio.

\section{http://catalog.cantonpl.org}

Contra Costa County Library. Contra Costa County Library. Biblioteca pública. Dispositivo: smartphone. Sistema de adaptación: nuevo sitio web. Desarrollo propio.

https://snapngo.ccclib.org/?pg=item

DCPL. District of Columbia Public Library. Biblioteca pública. Sistema de adaptación: aplicación nativa.

http://itunes.apple.com/WebObjects/MZStore.woa/wa/viewSoftware?id=3010778 $\underline{50 \& \mathrm{mt}=8}$

Fullerton OPAC. Cal Poly Pomona University Library. Biblioteca universitaria. Dispositivo: smartphone. Sistema de adaptación: nuevo sitio web. Software comercial (Xerxes).

\section{http://xerxes.calstate.edu/fullerton/books?is mobile $=1$}

Georgetown University Library. Georgetown University Library. Biblioteca universitaria. Dispositivo: smartphone. Sistema de adaptación: nuevo sitio web. Desarrollo propio.

http://www.library.georgetown.edu/mobile/library-catalog

Georgia Stare University Library. Georgia State University Library. Biblioteca universitaria. Dispositivo: smartphone. Sistema de adaptación: hoja de estilo. Software comercial (VuFind).

http://gilfind.gsu.edu 
KCLS mobile. King County Library System. Biblioteca pública. Dispositivo: smartphone. Sistema de adaptación: nuevo sitio web. Desarrollo propio.

\section{http://catalog.kcls.org/opac/extras/mobile/}

Lane Library Mobile. Lane Library. Biblioteca universitaria. Dispositivo: smartphone. Sistema de adaptación: nuevo sitio web. Desarrollo propio. Año de creación desconocido.

http://www.lanecc.edu/library/mobile/search books.php

Langsdale on the Go!. Langsdale Library. Biblioteca universitaria. Dispositivo: smartphone. Sistema de adaptación: nuevo sitio web. Desarrollo propio.

http://langsdale.ubalt.edu/m/book-search.cfm

Library. Harvard College Library. Biblioteca universitaria. Dispositivo: smartphone. Sistema de adaptación: nuevo sitio web. Desarrollo propio.

http://m.harvard.edu/libraries/

LibrarySearch. Cambridge University Library. Biblioteca universitaria. Dispositivo: smartphone. Sistema de adaptación: nuevo sitio web. Desarrollo propio.

http://www.lib.cam.ac.uk/mob/

Mansfield Library. University of Montana Library. Biblioteca universitaria. Dispositivo: smartphone. Sistema de adaptación: nuevo sitio web. Desarrollo propio.

http://catalog.lib.umt.edu/vwebv/searchBasic?sk=mobile um

Mendik Mobile. Mendik Library. Biblioteca universitaria. Dispositivo: smartphone. Sistema de adaptación: nuevo sitio web. Desarrollo propio.

https://nyls.boopsie.bredir.com/m/\#2!nyls holdings/

Miami University Libraries. Miami University Libraries (Ohio) . Biblioteca universitaria. Dispositivo: smartphone. Sistema de adaptación: nuevo sitio web. Desarrollo propio.

http://www.lib.muohio.edu/m/multifacet

Mirlyn Mobile. University of Michigan Library. Biblioteca universitaria. Dispositivo: smartphone. Sistema de adaptación: nuevo sitio web. Desarrollo propio.

http://m.mirlyn.lib.umich.edu

MIT Mobile. Massachusetts Institute of Technology Library. Biblioteca especializada. Sistema de adaptación: aplicación nativa.

http://itunes.apple.com/us/app/mit-mobile/id353590319

Molloy Mobile Catalog. Molloy College Library. Biblioteca universitaria. Dispositivo: smartphone. Sistema de adaptación: nuevo sitio web. Desarrollo propio.

http://endeavor.molloy.edu/vwebv/searchBasic?sk=mobile

Mount Prospect Public Library. Mount Prospect Public Library. Biblioteca pública. Dispositivo: smartphone. Sistema de adaptación: nuevo sitio web. Desarrollo propio.

http://mppl.org/mobile/index.php

NCSU Libraries. North Carolina State University Library. Biblioteca universitaria. Dispositivo: smartphone. Sistema de adaptación: nuevo sitio web. Desarrollo propio. 


\section{http://m.lib.ncsu.edu/catalog/}

NU Library. Northwestern University Library. Biblioteca universitaria. Sistema de adaptación: aplicación nativa.

https://itunes.apple.com/us/app/nu-library/id520234215?mt=8

NYPL Mobile. New York Public Library. Biblioteca pública. Sistema de adaptación: aplicación nativa.

http://itunes.apple.com/es/app/nypl-mobile/id441537393?mt=8

Onondaga County Public Library. Onondaga County Public Library. Biblioteca pública. Dispositivo: smartphone. Sistema de adaptación: nuevo sitio web. Software comercial (Polaris Mobile PAC).

http://catalog.onlib.org/mobile

Oregon State University Libraries. Oregon State University Libraries. Biblioteca universitaria. Dispositivo: smartphone. Sistema de adaptación: nuevo sitio web. Desarrollo propio.

http://m.library.oregonstate.edu/search/

RICE Fondren Library. Fondren Library. Biblioteca universitaria. Dispositivo: smartphone. Sistema de adaptación: nuevo sitio web. Desarrollo propio.

http://fonlibweb-project.rice.edu:8080/mobilecat3 live/

TCLibToGo. Tulare County Library. Biblioteca pública. Sistema de adaptación: aplicación nativa.

https://itunes.apple.com/us/app/tclibtogo/id509237585?mt=8

TCU Library. Texas Christian University Library. Biblioteca universitaria. Dispositivo: smartphone. Sistema de adaptación: nuevo sitio web. Desarrollo propio.

http://libweb.lib.tcu.edu/F?func=find-b\&local base $=t c u 01 \mathrm{~m}$

Tripod Mobile. Tripod Mobile. Biblioteca universitaria. Dispositivo: smartphone. Sistema de adaptación: nuevo sitio web. Desarrollo propio.

http://m.tripod.brynmawr.edu

University of Illinois at Urbana-Champaign Library. University of Illinois at UrbanaChampaign Library. Biblioteca universitaria. Dispositivo: smartphone. Sistema de adaptación: nuevo sitio web. Desarrollo propio.

http://m.library.illinois.edu/vu1112.asp

University of North Carolina at Chapel Hill. University of North Carolina at Chapel Hill Libraries. Biblioteca universitaria. Dispositivo: smartphone. Sistema de adaptación: nuevo sitio web. Desarrollo propio.

http://www.lib.unc.edu/m/\# catalog

University of Virginia Library. University of Virginia Library. Biblioteca universitaria. Dispositivo: smartphone. Sistema de adaptación: nuevo sitio web. Desarrollo propio.

http://m.library.virginia.edu 
Worthington Libraries. Worthington Libraries. Biblioteca pública. Sistema de adaptación: aplicación nativa.

https://itunes.apple.com/es/app/worthington-libraries/id499501417?mt=8

\section{España}

Biblioteca de la Universidad de Cádiz. Biblioteca de la Universidad de Cádiz. Biblioteca universitaria. Dispositivo: smartphone. Sistema de adaptación: nuevo sitio web. Software comercial (AirPac).

http://diana.uca.es/airpac/

Biblioteca de la Universidad de Cádiz. Biblioteca de la Universidad de Cádiz. Biblioteca universitaria. Dispositivo: smartphone. Sistema de adaptación: nuevo sitio web. Software comercial (AirPac).

\section{http://bibm.uca.es}

Biblioteca FM. Centro de Documentación Fundación Mapfre. Biblioteca especializada. Sistema de adaptación: aplicación nativa.

https://itunes.apple.com/es/app/biblioteca-fm/id663896475?mt=8

Biblioteca i TIC mòbil. Biblioteca de la Universidad Pompeu Fabra. Biblioteca universitaria. Dispositivo: smartphone. Sistema de adaptación: nuevo sitio web. Producto de terceros (Library Anywhere).

http://www.libanywhere.com/m/517

Bibliotecas Universidad de Salamanca. Biblioteca Universidad de Salamanca. Biblioteca universitaria. Dispositivo: smartphone. Sistema de adaptación: nuevo sitio web. Software comercial (WorldCat).

\section{http://usal.worldcat.org/m/}

Bibliotecas USAL. Biblioteca Universidad de Salamanca. Biblioteca universitaria. Sistema de adaptación: aplicación nativa.

$$
\text { http://itunes.apple.com/es/app/bibliotecas-usal/id477970535?mt=8 }
$$

Catàleg de biblioteques UAB. Biblioteca de la Universitat Autonoma de Barcelona. Biblioteca universitaria. Sistema de adaptación: aplicación nativa.

https://play.google.com/store/apps/details?id=com.uab\&hl=en

Catàleg de les Biblioteques UPC (BETA). Universitat Politècnica de Catalunya. Bibliotecas. Biblioteca universitaria. Dispositivo: smartphone. Sistema de adaptación: nuevo sitio web. Desarrollo propio.

http://m.cataleg.upc.edu

Catálogo de la Red de Bibliotecas de Navarra. Bibliotecas Públicas de Navarra. Biblioteca pública. Dispositivo: smartphone. Sistema de adaptación: nuevo sitio web. Software comercial (Mopac).

\section{http://www.navarra.es/Appsext/Mopac/}

\section{Finlandia}

Terkko Navigator. National Library of Health Sciences. Biblioteca especializada. Dispositivo: smartphone. Sistema de adaptación: diseño adaptativo. Desarrollo propio. 
http://www.terkko.helsinki.fi/english/helka/

\section{Francia}

Bibliothèque publique Toulouse. Bibliothèque de Toulouse. Biblioteca pública. Sistema de adaptación: aplicación nativa.

http://itunes.apple.com/es/app/id419585406

Bpi mobile. Bibliothèque Centre Pompidou. Biblioteca especializada. Sistema de adaptación: aplicación nativa.

https://itunes.apple.com/es/app/bpi-mobile/id604197794?mt=8\&ign$\underline{\mathrm{mpt}=\mathrm{uo} \% 3 \mathrm{D} 4}$

Catalogue SUDOC. Agencia Bibliográfica de Enseñanza Superior. Biblioteca universitaria. Dispositivo: smartphone. Sistema de adaptación: nuevo sitio web. Desarrollo propio.

\section{http://m.sudoc.fr}

Ros@lis mobile. Bibliothèque de Toulouse. Biblioteca pública. Dispositivo: smartphone. Sistema de adaptación: nuevo sitio web. Desarrollo propio.

http://catalogues.toulouse.fr/web2/tramp2.exe/log in?setting key=BMTM

\section{Holanda}

de Bibliotheek. Bibliotheek Maasland. Biblioteca pública. Dispositivo: smartphone. Sistema de adaptación: hoja de estilo. Software comercial (bicatWISE).

http://bicat.bibliotheekmaasland.nl/cgi-bin/bx.pl?sid=49841d9c-599e-4ce8-b3b1bdb723fee7a2;vestnr=4199;prt=INTERNET; cdef $=002 ;$ taal=1;sn=10;var=portal

\section{Italia}

Biblioteche Venezia. Sistema Bibliotecario Urbano Ciudad de Venecia. Biblioteca pública. Sistema de adaptación: aplicación nativa.

https://itunes.apple.com/es/app/biblioteche-venezia/id608203433?mt=8

Catalogo Italiano Periodici. Area Sistemi Dipartamentali e Documentali. Biblioteca universitaria. Dispositivo: smartphone. Sistema de adaptación: nuevo sitio web. Desarrollo propio.

http://acnp.unibo.it/cgi-ser/start/it/ipod/cnr/index.html

Centro Inter-Bibliotecario Universitá di Bologna. Area Sistemi Dipartamentali e Documentali. Biblioteca universitaria. Dispositivo: teléfono móvil. Sistema de adaptación: nuevo sitio web. Desarrollo propio.

http://acnp.unibo.it/cgi-ser/start/it/mobile/cnr/fp.tcl

\section{Luxemburgo}

Bibnet. Red de Bibliotecas de Luxemburgo. Biblioteca pública. Dispositivo: smartphone. Sistema de adaptación: nuevo sitio web. Desarrollo propio.

http://m.catalog.bibnet.lu 


\section{Reino Unido}

Manchester Libraries. Manchester Libraries. Biblioteca pública. Sistema de adaptación: aplicación nativa.

https://itunes.apple.com/gb/app/id588973651?mt=8\&affId=1860684

MMU Library. MMU Library. Biblioteca universitaria. Dispositivo: smartphone. Sistema de adaptación: nuevo sitio web. Software comercial (Prism).

http://prism.talis.com/mmu/

Mobile Oxford. Oxford University Libraries. Biblioteca universitaria. Dispositivo: smartphone. Sistema de adaptación: nuevo sitio web. Desarrollo propio.

http://m.ox.ac.uk/library/

\section{Singapur}

National Library Board Singapore. National Library Board Singapore . Biblioteca pública. Dispositivo: smartphone. Sistema de adaptación: nuevo sitio web. Desarrollo propio.

http://m.nlb.gov.sg/searches/search

\section{Suecia}

Bibli - Uppsala. Bibliotecas de Uppsala. Biblioteca pública. Sistema de adaptación: aplicación nativa.

https://itunes.apple.com/es/app/bibli-uppsala/id538689198?l=en\&mt=8

\section{Suiza}

ETH-Bibliotek. ETH-Bibliotek. Biblioteca universitaria. Dispositivo: smartphone. Sistema de adaptación: nuevo sitio web. Desarrollo propio.

http://www.library.ethz.ch/mobile en

\subsubsection{Parámetros y variables de análisis}

En el estudio de los sitios web y aplicaciones nativas diseñados para dispositivos móviles se han tenido en cuenta varios puntos de vista:

- El de la usabilidad, que es definida por Jakob Nielsen (1999) como «el atributo que evalúa la facilidad de uso de las interfaces.» Aunque también se utiliza para referirse a «los métodos para mejorar la facilidad de uso durante el proceso de diseño», en este trabajo se adoptará la primera acepción. Este punto de vista permitirá identificar buenas y malas prácticas a partir de algunos elementos extraídos de la bibliografía.

- El diseño, que proporcionará una visión sobre cómo es el aspecto de los sitios web y aplicaciones nativas para móviles creados por y para las bibliotecas. 
- Los contenidos, con el objetivo de conocer qué información y servicios se están prestando desde los sitios web y apps diseñados para smartphones y tabletas.

- El aprovechamiento de las capacidades del dispositivo y la adaptación a sus características. Smartphones y tabletas incluyen funciones que les diferencian de los ordenadores de sobremesa y portátiles, como la telefonía móvil, el envío de SMS o la cámara de fotos. Su aprovechamiento puede ofrecer nuevos servicios y facilitar determinadas tareas a los usuarios. Por otra parte, una pantalla pequeña obliga a considerar varios factores.

Para el análisis de sitios web para dispositivos móviles y aplicaciones nativas se han establecido varios parámetros, que se definen a efectos de este trabajo como agrupaciones de variables en función de aspectos concretos. Un punto de partida importante en la elaboración de estos listados de variables han sido los estudios sobre usabilidad móvil de Nielsen y Budiu (2013), cuyas recomendaciones para obtener unos resultados óptimos han sido incorporadas en gran medida en la definición de las variables. También las recomendaciones del World Wide Web Consortium (Rabin y McCathieNevile, 2008) y los trabajos de Tay (2010a, 2010b) sobre interfaces y sobre los contenidos y servicios que incluyen los sitios web y aplicaciones web para móviles. Se ha preferido justificar más adelante, en los capítulos referentes a los resultados, el porqué de cada uno de estos parámetros con el fin de facilitar su lectura.

Teniendo en cuenta las diferencias entre los sitios web y las aplicaciones nativas ha sido necesario elaborar dos listados de parámetros y variables, uno para apps y otro para sitios web. Ambos listados comparten la mayor parte de las categorías y los datos, pero también se han añadido o retirado otros, en función de las peculiaridades del objeto de análisis. Así, las apps presentan una serie de características propias:

- Están ligadas a un sistema operativo y este elemento determina diferentes variables.

- No se accede a ellas desde un URL, sino al descargarlas desde la tienda de aplicaciones.

- La tienda de aplicaciones ofrece una serie de información sobre cada aplicación, como el tamaño que ocupa al instalarla o el número de descargas, entre otros datos.

- Permiten utilizar determinadas funciones del dispositivo de las que no se puede hacer uso desde una aplicación web, como la cámara de fotos o las notificaciones push. 
En el estudio de catálogos y herramientas de descubrimiento se han tenido en cuenta parámetros completamente diferentes de los sitios web para móviles y las aplicaciones, prestando especial atención a la solución adoptada por cada biblioteca a la hora de adaptar el catálogo - software comercial asociado al catálogo, software de terceros o desarrollos propios- y las funciones que incorporan.

Los parámetros han sido concretados en una batería de variables que se especifican en los siguientes apartados en relación a su correspondiente parámetro. Cabe señalar que los listados iniciales con las variables de análisis han ido moldeándose sobre la marcha, de forma que ha sido necesario añadir o eliminar apartados durante el proceso de recogida de datos para adaptarse así a la realidad una vez constatada.

Se incluyen en los siguientes apartados tres listados con los parámetros y variables analizadas en cada uno de los sitios web y aplicaciones nativas para dispositivos móviles, así como para los catálogos.

\subsubsection{Parámetros y variables de análisis para los sitios web para móviles}

Se establecen en los siguientes párrafos cuáles son los parámetros de análisis para sitios web diseñados para dispositivos móviles y las variables que se analizarán para cada uno de ellos. En el capítulo 4 se explicarán de manera más detallada y justificando el porqué de su elección.

1. Datos identificativos, que servirán para identificar a cada uno de los registros. Se trata de datos como el nombre y URL del sitio web analizado, la biblioteca a la que pertenece, el país en que se encuentra o el idioma de los contenidos.

- Código de identificación del registro. Se trata de un número correlativo que se asigna a cada registro para su control en la base de datos.

- Título. Nombre del sitio web, tal y como aparece en él.

- URL de acceso al sitio web.

- Nombre de la biblioteca que mantiene el sitio web.

- Nombre de la institución a la que pertenece la biblioteca.

- País en que se encuentra la biblioteca.

- URL del sitio web analizado en su versión para grandes pantallas, si la tuviera.

- URL del sitio web de la biblioteca, en su versión para grandes pantallas. Puede coincidir con el URL del sitio web analizado o no. 
- Tipo de biblioteca: si se trata de una biblioteca pública, universitaria, especializada, nacional o escolar.

- Tipo de institución: si se trata de una biblioteca a título individual, de una red de bibliotecas, bibliotecas virtuales o consorcios.

- Año de creación del sitio web para dispositivos móviles.

- Idioma o idiomas en que están los contenidos del sitio web para dispositivos móviles.

- Utilidad del sitio web. Es la función que cumple y podría encontrarse en las siguientes categorías: representar al sitio web de la biblioteca, el acceso al catálogo, sacar a la luz fondos patrimoniales, servicio de referencia, recomendar lecturas, visitas guiadas y otras.

- Fecha de recogida de datos: fecha en que han sido recogidos los datos del registro.

2. Dispositivos para los que está optimizado el sitio. Estos datos servirán para conocer hacia qué dispositivos están enfocando las bibliotecas sus esfuerzos.

- Tipo de dispositivo para el que está optimizado el sitio web: teléfono móvil, smartphone o tableta.

3. Métodos de adaptación. Se trata de definir en este apartado cuál es la solución adoptada en la construcción de la versión para móviles: crear un nuevo sitio web con páginas diferenciadas de la versión para grandes pantallas, emplear hojas de estilo u optar por el diseño web adaptativo.

- Solución adoptada para adaptar el sitio web: páginas diferenciadas, hojas de estilo o diseño web adaptativo. Aunque se había contemplado en un principio, no se ha encontrado ningún caso de uso de transcodificador.

- CMS. Si se ha empleado un gestor de contenidos (CMS) en la construcción de la versión móvil.

4. Acceso a la versión móvil desde la versión para grandes pantallas. Se analiza en este apartado si se hace uso de elementos que faciliten el acceso a la versión móvil desde el sitio web, como enlaces o códigos QR, y la longitud del URL.

- Detección de dispositivo. Si el sitio web objeto de estudio incorpora este sistema o no.

- Enlace desde la versión del sitio web para grandes pantallas. Si el sitio web objeto de estudio lo incorpora o no.

- Visibilidad del enlace. Si el enlace de la variable anterior se sitúa en un lugar visible de la página.

- Códigos QR. Si se emplea este medio de acceso a la versión móvil en la versión para grandes pantallas. 
- Longitud del URL. Es el número de caracteres que hay que teclear para acceder a la página principal del sitio. No se incluyen los caracteres innecesarios, como http:// al principio, sin los cuales el navegador es llegar al sitio.

- Ir a la versión para grandes pantallas desde la versión móvil.

5. Diseño de la interfaz. Se estudia el diseño de las interfaces en función de dos aspectos: la plantilla de diseño de la página principal y los elementos de interacción táctil.

a. Plantilla de diseño. Se identifica el tipo de diseño de la página principal del sitio web para móviles analizado. Para ello se ha realizado la siguiente clasificación de plantillas de diseño. Cada una de ellas constituye una variable cuyo valor puede ser «sí»o «no».

- Menú vertical, bien sea en formato textual o como botones, con iconos o sin ellos.

- Retícula de iconos, que imita la disposición de los iconos en los dispositivos móviles actuales.

- Módulos. Esta plantilla está formada por recuadros de contenidos dispuestos verticalmente, unos debajo de otros.

- Textual. Se trata de un diseño en el que no hay apartados o menús, sino que el texto es el protagonista.

- Casilla de búsqueda, cuando la búsqueda en el catálogo u otras bases de datos juegan el papel principal.

- Otros diseños menos habituales, como los de banner, cuadro desplegable y recuadros de imágenes.

b. Táctil. Se indica si el sitio web incluye algún tipo de botón que facilite la interacción táctil o no. Cada sitio web se clasifica en uno de estos apartados:

- Nivel 0, cuando no se utiliza ningún botón.

- Nivel 1, si utiliza botones de forma muy puntual. Por ejemplo, solo en la página principal.

- Nivel 2, si utiliza botones en los menús y en la página principal.

- Nivel 3, si todos o casi todos los enlaces son un botón.

6. Lenguajes de marcado, metadatos y analíticas. Se identifica en este apartado qué lenguajes de marcado emplean los sitios web diseñados para dispositivos móviles por las bibliotecas y si utilizan metadatos y algún tipo de servicio de analíticas, como Google Analytics.

- Lenguajes de marcado. Se indica qué lenguaje y versión se emplea en la construcción del sitio (HTML, xhtml...).

- Metadatos: si el sitio web incluye metadatos y qué lenguaje utiliza para ello. 
- Analíticas web. Se consigna si el sitio web emplea Google Analytics como sistema de analíticas web.

7. Elementos de navegación. Se analizan en este apartado cuáles son los elementos de navegación que se utilizan en los sitios web para móviles de las bibliotecas. Los elementos que se contemplan, y que constituyen cada una de las variables de este parámetro, tomando valores «sí» o «no», son:

- Menú en la página principal.

- Menú horizontal superior.

- Menú horizontal inferior.

- Menú desplegable.

- Casilla de búsqueda, como vía para acceder a los contenidos del sitio, y no para la interrogación de bases de datos.

- Sistemas contextuales.

- Ir al la página principal.

- Volver a la página anterior.

- Subir al comienzo de la página, una opción que se utiliza en páginas que se alargan verticalmente.

- Migas de pan localizadoras.

- Mapa del sitio.

- Banners con formato de diapositivas.

8. Aprovechamiento de las funciones del dispositivo, como la telefonía, el envío de SMS o correos electrónicos o la geolocalización, entre otros. En este apartado se pretende responder a la cuestión sobre cuáles de estas funciones únicas de los dispositivos móviles se están utilizando. Los elementos que se contemplan, y que constituyen cada una de las variables de este parámetro, tomando valores «sí» o «no», son:

- Enlace a los números de teléfono cuando se indican.

- Envío de SMS, enlazando los números de teléfono.

- Envío de correos electrónicos, enlazando este dato.

- Agenda de contactos, enlazando los datos de contacto de alguien para que automáticamente se puedan añadir en la agenda.

- Geolocalización, solicitando la posición del usuario para mostrar información relacionada.

- Añadir eventos al calendario del dispositivo.

9. Formato de los contenidos, donde se concreta si se incluyen formatos de audio, vídeo, documentos o sindicación de contenidos, además de los contenidos textuales e imágenes. Los elementos que se contemplan, y que constituyen cada una de las variables de este parámetro, tomando valores «sí» o «no», son precisamente esas cuatro:

- Audio. 
- Vídeo.

- Documentos, como pdf, documentos de texto o ePub.

- Ficheros de sindicación de contenidos en formato RSS u otros equivalentes.

10. Contenidos y servicios. Se ha identificado una lista de 35 contenidos y servicios que aparecen en los sitios web diseñados para dispositivos móviles. Se estudia detenidamente en este apartado cuáles son los más habituales. Las variables de estudio, cada una de las cuales tomará valores «Sí» o «no», se enumeran a continuación. En el apartado 4.10 se explica en qué consiste cada uno de ellos, por lo que aquí solo se exponen brevemente.

- Datos de contacto.

- Datos de localización.

- Mapa con la situación de la biblioteca o de los puntos de servicio de la red.

- Cómo llegar.

- Mapa de planta.

- Mapa de signatura.

- Horario de apertura.

- Directorio de bibliotecas.

- Directorio de personal.

- Servicios que presta la biblioteca.

- Noticias.

- Eventos.

- Recomendación de lecturas y otros contenidos.

- Selección de novedades.

- Enlaces de interés sobre temas determinados.

- Guías de investigación o LibGuides.

- Disponibilidad de los recursos de la biblioteca.

- Reserva de recursos.

- Enlaces a los perfiles en redes sociales de la biblioteca.

- Acceso al catálogo.

- Herramienta de descubrimiento.

- Revistas electrónicas.

- Acceso a bases de datos.

- Préstamo de libros electrónicos.

- Colección digital.

- Cuenta de usuario.

- Servicio de referencia.

- Visitas guiadas y tutoriales.

- Juegos. 
- Recomendación de aplicaciones nativas para móviles.

- Descarga de aplicaciones de la biblioteca.

- Feedback.

- Preguntas frecuentes o FAQ.

- About.

- Ayuda.

11. Ajuste a las características del dispositivo, teniendo en cuenta sus limitaciones, especialmente en el caso de teléfonos móviles y smartphones. Dentro de este parámetro se han analizado las siguientes variables, cuyos posibles valores serán «sí» 0 «no»:

- Extensión del texto: si es corto o extenso.

- Información concreta y directa: si la información cumple estas características o no.

- Enlaces a páginas web no adaptadas para dispositivos móviles: si los hay o no.

- Si los enlaces que dirigen a páginas no adaptadas se identifican con algún tipo de señal.

\subsubsection{Parámetros y variables de análisis para las aplicaciones nativas}

Se identifican en los siguientes párrafos cuáles son los parámetros de análisis para las aplicaciones nativas. En el capítulo 5 se explicarán de manera más detallada y justificando el porqué de su elección.

1. Datos identificativos, que servirán para identificar a cada uno de los registros. Se trata de datos como el nombre y URL para su descarga desde la tienda de aplicaciones, la biblioteca a la que pertenece, el país en que se encuentra o el idioma de los contenidos.

- Código de identificación del registro. Se trata de un número correlativo que se asigna a cada registro para su control en la base de datos.

- Título: nombre de la aplicación, tal y como aparece en la tienda de aplicaciones.

- URL de acceso a la app en la tienda de aplicaciones.

- Nombre de la biblioteca que mantiene la app.

- Nombre de la institución a la que pertenece la biblioteca.

- País en que se encuentra la biblioteca.

- URL de la web de la biblioteca.

- Tipo de biblioteca: si se trata de una biblioteca pública, universitaria, especializada, nacional o escolar. 
- Tipo de institución: si se trata de una biblioteca a título individual, de una red de bibliotecas, bibliotecas virtuales o consorcios.

- Año de creación de la app.

- Idioma o idiomas en que están los contenidos de la app.

- Utilidad de la app. Es la función que cumple y podría encontrarse en las siguientes categorías: reproducir los contenidos del sitio web de la biblioteca, acceso al catálogo, sacar a la luz fondos patrimoniales, servicio de referencia u otras utilidades.

- Fecha de recogida de datos: fecha en que han sido recogidos los datos del registro.

2. Dispositivos y sistemas operativos. Además del tipo de dispositivo (smartphones o tableta), se analiza también en este apartado el sistema operativo en el que funcionan las aplicaciones nativas.

- Tipo de dispositivo para el que está optimizada la app. Los valores que puede adoptar esta variable son smartphones o tableta.

- Sistema operativo en el que funciona la app, Android o iOS.

3. Información de la tienda de aplicaciones. Este grupo de variables incluye información muy variada sobre cada aplicación. El denominador común es que ha sido proporcionada por la tienda de aplicaciones.

- Coste: qué cantidad debe pagar el usuario por descargar la aplicación.

- Categoría temática en la que el desarrollador ha clasificado la app dentro de la tienda de aplicaciones.

- Clasificación por edades. Las tiendas de aplicaciones establecen esta clasificación para la protección de los menores.

- Fecha de la primera versión de la app.

- Fecha de la última actualización.

- Última versión de la app.

- Tamaño que ocupa la aplicación al instalarla en el dispositivo.

- Nombre del desarrollador, según aparece en la tienda de aplicaciones.

- Número de descargas. Este dato solo se puede obtener de la tienda de aplicaciones de Android, puesto que en la tienda de Apple no se facilita. Se proporciona en forma de intervalo.

- Número de valoraciones de los usuarios.

- Valoración media de los usuarios.

4. Acceso a las aplicaciones. Se mide en este parámetro si existen enlaces en el sitio web de la biblioteca, especialmente en su versión móvil, que conduzcan a la página de la aplicación en la tienda de apps para facilitar su descarga. También se analiza si estos enlaces son visibles y si se emplean 
códigos QR para facilitar el acceso. Las variables de análisis, que pueden tomar valores «sí» o «no», son los siguientes:

- Enlace desde la web principal en su versión para grandes pantallas.

- Enlace desde la versión móvil del sitio web, si lo tuviera.

- Visibilidad del enlace. Si el enlace de la variable anterior se sitúa en un lugar visible.

- Códigos QR. Si se emplea este medio como forma de acceso a la aplicación desde el sitio web.

- Acceso con contraseña, en caso de que sea necesario disponer de una cuenta de usuario para acceder a los contenidos.

5. Diseño de la interfaz. Al igual que en el caso de los sitios web para dispositivos móviles, se estudia el diseño de las interfaces en función de la plantilla de diseño de la página inicial. En este caso ha sido más efectivo construir las variables de análisis en función no de plantillas, sino de los posibles elementos que pueden incluir:

- Cortinilla inicial, que es una pantalla que se visualiza durante unos segundos al arrancar la aplicación y que funciona a modo de presentación.

- Menú horizontal inferior con iconos, que sirve como elemento de navegación constante y es característico de las apps.

- Contenido central. Esta variable puede tomar como valores las siguientes categorías: menú vertical, retícula de iconos, contenidos -cuando se muestran directamente los contenidos de la aplicación, sin necesidad de un menú en la página inicial—, portada visual con enlaces, iconos cuadrados, imágenes tipo Pinterest, línea del tiempo, mapa, login y portada visual.

6. Elementos de navegación. Se analizan en este apartado cuáles son los elementos de navegación que se utilizan en las aplicaciones nativas de las bibliotecas. Las elementos que se contemplan, y que constituyen cada una de las variables de este parámetro, tomando valores «sí»o «no», son:

- Menú inferior o menú iPhone.

- Menú en la página principal.

- Menú desplegable.

- Enlace al sitio web.

- Casilla de búsqueda.

- Ir al la página principal.

- Volver a la página anterior.

- Pasar a la siguiente página.

- Línea del tiempo. 
- Otros. Esta variable toma valores diferentes, como menú gestual, cronológico o numérico. Al ser muy poco frecuentes se ha preferido agruparlos.

7. Aprovechamiento de las funciones del dispositivo, como la telefonía, el envío de SMS o correos electrónicos o la geolocalización, entre otros. En este apartado se pretende responder a la cuestión sobre cuáles de estas funciones únicas de los dispositivos móviles se están utilizando. Los elementos que se contemplan, y que constituyen cada una de las variables de este parámetro, tomando valores «sí» o «no», son:

- Enlaces para realizar llamadas telefónicas.

- Envío de SMS, enlazando los números de teléfono.

- Envío de correos electrónicos, enlazando este dato.

- Geolocalización, solicitando la posición del usuario para mostrar información relacionada.

- Notificaciones push, que son las alertas que se reciben cuando se produce un nuevo evento (por ejemplo, cuando llega un nuevo correo electrónico o un SMS).

- Rotación de pantalla, lo que permite una visualización diferente.

- Escaneado de códigos, gracias al uso de la cámara de fotos.

- Linterna.

8. Formato de los contenidos, donde se concreta si se incluyen formatos de audio, vídeo, documentos o sindicación de contenidos, además de texto o imágenes. Los elementos que se contemplan, y que constituyen cada una de las variables de este parámetro, tomando valores «sí» o «no», son precisamente esas cuatro:

- Audio.

- Vídeo.

- Documentos, como pdf, documentos de texto o ePub.

- Ficheros de sindicación de contenidos en formato RSS u otros equivalentes.

9. Contenidos y servicios. Se ha identificado una lista de contenidos y servicios que aparecen en las aplicaciones nativas de las bibliotecas. Se estudia detenidamente en este apartado cuáles son los más habituales. Las variables de estudio, cada una de las cuales tomará valores «sí» 0 «no», son las siguientes:

- Datos de contacto, como el número de teléfono o el correo electrónico.

- Datos de localización, referido a la dirección en formato texto (no en un mapa). 
- Mapa con la situación de la biblioteca o de los puntos de servicio de la red.

- Cómo llegar.

- Mapa de planta.

- Mapa de signatura.

- Horario de apertura de la biblioteca.

- Directorio de bibliotecas.

- Directorio de personal.

- Información sobre los servicios que presta la biblioteca.

- Noticias sobre la biblioteca u otros aspectos relacionados con sus ámbitos de trabajo.

- Eventos que organiza la biblioteca.

- Recomendación de lecturas, música, películas u otros materiales.

- Selección de novedades.

- Selección de enlaces de interés.

- Guías de investigación o LibGuides.

- Disponibilidad de salas en grupo, ordenadores de uso público u otros servicios y recursos de la biblioteca.

- Reserva de salas en grupo, de ordenadores o de material específico para algunos cursos.

- Enlaces a los perfiles de la biblioteca en las redes sociales.

- Acceso al catálogo de la biblioteca.

- Herramienta de descubrimiento.

- Revistas electrónicas.

- Acceso a bases de datos.

- Préstamo de libros electrónicos.

- Colección digital.

- Cuenta de usuario.

- Servicio de referencia.

- Visitas guiadas y tutoriales.

- Juegos.

- Recomendación de aplicaciones nativas para móviles.

- Descarga de aplicaciones de la biblioteca.

- Compartir en medios sociales.

- Guardar en favoritos.

- Configuración de opciones.

- Escaneado de código de barras.

- Feedback.

- Preguntas frecuentes o FAQ.

- About. 
- Ayuda.

10. Ajuste a las características del dispositivo, teniendo en cuenta sus limitaciones, especialmente en el caso de teléfonos móviles y smartphones. Dentro de este parámetro se han valorado tres variables, cuyos posibles valores serán «sí» 0 «no»:

- Extensión del texto: si es corta o extensa.

- Información concreta y directa: si la información cumple estas características o no.

- Enlaces a páginas web no adaptadas para dispositivos móviles: si los hay o no.

- Si se indica que los enlaces envían a páginas no adaptadas.

\subsubsection{Variables de análisis para herramientas de búsqueda}

En el caso de los catálogos y herramientas de descubrimiento se ha estudiado qué software hace posible la versión móvil y cuáles son las funciones que incluyen. Así, las variables de análisis son:

- Tipo de software empleado en la versión móvil del catálogo o herramienta de descubrimiento.

- Nombre del software empleado.

- Búsqueda sencilla o con limitadores.

- Búsqueda avanzada.

- Acotar búsquedas una vez obtenidos los resultados.

- Búsquedas recientes.

- Guardar búsquedas.

- Guardar registros en el espacio personal.

- Crear alertas de búsqueda.

- Ordenar los registros.

- Número de pasos para la consulta del registro completo.

- Descripción del documento breve o larga.

- Datos para la localización del documento, como la signatura.

- Disponibilidad del documento para el préstamo.

- Cuenta de usuario.

- Envío de registros por e-mail o SMS.

- Compartir registros en redes sociales.

- Comentar y valorar los documentos en una escala de cinco estrellas.

- Exportar los registros a diferentes formatos bibliográficos. 


\subsubsection{Recogida de datos}

La recogida de los datos correspondientes a los sitios web y aplicaciones nativas que componen la muestra se ha realizado de forma manual, tras un examen detallado y completando los valores correspondientes a las variables descritas anteriormente. El examen de los sitios web y de las aplicaciones nativas se ha realizado desde los siguientes dispositivos:

- iPhone 4S, smartphone con la entonces última versión del sistema operativo iOS, la 6.1.3 y el navegador Safari incluido en esa versión.

- HTC Wildfire, smartphone con sistema operativo Android 2.2.1 y navegador WebKit 3.1.

- iPad 1 con sistema operativo iOS 5.1.1. Este dispositivo no soporta la actualización a la versión 6 de iOS, de manera que para analizar las aplicaciones nativas que sólo funcionan en esa versión se ha utilizado un iPad 2 con iOS 6.1.3.

- $\quad$ Nevir Tab 7 S1, tableta con sistema operativo Android 4.1.

Todos los sitios web han sido analizados desde dispositivos con sistema operativo iOS. En el caso de las aplicaciones nativas, se ha preferido también ese sistema operativo cuando existía una versión para él. Los dispositivos con sistema operativo Android han sido utilizados exclusivamente en los casos en que la única versión de la app funcionaba en ese sistema operativo.

El análisis de la muestra se realizó entre el 29 de abril y el 23 de agosto de 2013. En diciembre de 2013 se incorporaron además algunos casos a la muestra por ser especialmente significativos para las bibliotecas españolas: las aplicaciones Bibliotecas de Navarra, Liburutegiak y Biblioteca de Mollerussa, así como la Visita virtual - Biblioteca Nacional de Chile, READometer y ShelvAR, todas ellas creadas entre septiembre y diciembre de ese mismo año, 2013. Con estas excepciones se ha querido ofrecer una visión más actualizada del panorama.

Entre octubre de 2012 y abril de 2013 se realizó un análisis previo con el objetivo de detectar posibles problemas y ajustar los datos a extraer en función de la realidad constatada. En este sentido, algunos datos fueron incluidos durante esta fase, tras la observación de las características de los sitios web y aplicaciones de la muestra y de sus contenidos. Se ha considerado importante que el intervalo de tiempo dedicado al análisis de la muestra fuera lo más corto posible con el fin de asegurar la coherencia de los datos y de obtener una descripción de la realidad correspondiente a un momento determinado.

Durante y después de la fase de recogida de datos se realizaron también algunos ajustes en las variables de análisis, incorporando algunas nuevas y prescindiendo de otras para ajustarlas a la realidad observada. 
Los datos resultantes del análisis se recogieron directamente en formato digital, en una base de datos creada a medida y para este fin con el programa FileMaker Pro Advanced 10.0v1. En septiembre y octubre de 2013 se realizó una depuración de los datos, intentando detectar y subsanar posibles errores.

Con el objetivo de obtener algunos datos que no se habían podido recabar de otra forma se efectuaron consultas puntuales a algunas bibliotecas. Así, en enero de 2014 se enviaron correos electrónicos a un total de 56 bibliotecas, en los que se les preguntaba por el software que utilizan para sus catálogos o herramientas de descubrimiento, la vía por que los han adaptado (desarrollo propio, contratando un módulo adicional o a través de un software específico) y la fecha de creación de su sitio web para móviles. Se obtuvieron un total de 36 respuestas.

Teniendo en cuenta los cambios a los que se enfrenta la información en la web, se han recogido copias de las páginas principales (homepage) de todos los sitios web analizados. De esta forma ha sido posible resolver a posteriori algunas dudas y errores en la recogida de datos, especialmente en el caso de los sitios web que han desaparecido o han sido modificados posteriormente. Internet $\operatorname{Archive}^{92}$ ha servido también como apoyo con este mismo objetivo. A través del programa Microsoft Site Analyst se ha realizado una copia de cada sitio web analizado siempre que ha sido técnicamente posible, ya que algunos sitios han presentado problemas. En el caso de las apps para iOS, se han realizado copias de cada una de ellas en formato .ipa.

\subsection{Biblioteca de la Universidad de Salamanca: metodología}

La segunda parte de la investigación que se plantea en esta tesis doctoral consiste en un análisis de casos, el de la Biblioteca de la Universidad de Salamanca. Gracias a la indispensable colaboración del Servicio de Bibliotecas de esta universidad se ha podido disponer de las analíticas del sitio web, de los catálogos y de la aplicación BiblioUSAL, que servirán como base para estudiar el uso que se está haciendo de ellos.

La Biblioteca de la Universidad de Salamanca utiliza Google Analytics para obtener los datos de uso del sitio web. Los datos disponibles parten del día 18 de julio de

\footnotetext{
${ }^{92}$ https://archive.org
} 
2011, fecha en que comenzó a utilizarse esta herramienta. Los periodos establecidos para el presente estudio se han hecho coincidir con el curso universitario, de manera que cada período abarca desde el 1 de septiembre al 31 de agosto del año siguiente. Así, se obtienen tres períodos de análisis, que corresponden a los cursos 2011-2012, 2012-2013 y 2013-2014.

A efectos de análisis se ha dividido el curso en dos semestres por una cuestión práctica: cuando se solicita a Google Analytics datos de un período de tiempo largo, como puede ser un año, proporciona datos de una muestra93, y no del total. En algunos casos se ha preferido contar con el total de los datos y no con una muestra, por lo que se suministra la información en períodos de seis meses (del 1 de septiembre al 28 de febrero y del 1 de marzo al 31 de agosto). En los siguientes párrafos se indicará cuándo los datos hacen referencia a una muestra.

La principal limitación en este apartado consiste en que no se dispone de información del uso de la versión móvil de la web de la biblioteca, ya que las páginas web son las mismas, lo que cambia es el diseño, y las herramientas de analíticas web solo miden el acceso a cada página. Por ello se ha asumido que desde la fecha del lanzamiento de la versión móvil, el 18 de febrero de 2013, quienes visitan la versión móvil lo hacen también desde un dispositivo móvil, aunque no sea siempre así. Esto implica que se pierde información sobre quién prefiere la versión completa desde un móvil.

Los datos que se han extraído de Google Analitics tanto para el sitio web como para la aplicación nativa son los siguientes:

- Sesiones o visitas, que Google Analytics define como «un conjunto de interacciones que tienen lugar en su sitio web en un periodo determinado. Por ejemplo, una única visita puede contener páginas vistas, eventos, interacciones sociales, variables personalizadas y transacciones de comercio electrónico [...]. Se puede decir que una visita es el elemento que engloba las acciones del visitante en su sitio.» ${ }^{94}$ El término sesión es equivalente al de visita. Según Kaushik (2010), las visitas reflejan que alguien ha accedido a un sitio web y ha pasado un tiempo en él.

- Páginas vistas por sesión. Es el número de páginas que un usuario ve durante una visita al sitio web.

- Duración media de una sesión. Es el tiempo que pasa desde que una persona inicia una sesión hasta que la finaliza.

\footnotetext{
${ }^{93}$ https://support.google.com/analytics/answer/2637192?hl=es

${ }^{94}$ Las definiciones procedentes de Google Analytics han sido extraídas de la ayuda: https://support.google.com/analytics/
} 
- Porcentaje de rebote (bounce rate), según se explica en Google Analytics, es el porcentaje de visitas en las que solo se consulta una página del sitio web antes de salir de él.

- Nuevas sesiones son las visitas realizadas por primera vez por un usuario.

Google Analytics permite desglosar los datos anteriores por el tipo de dispositivo desde el que se accede -ordenador, teléfono o smartphone y tableta-, lo que ayuda a conocer el comportamiento de los usuarios en un sitio web. Además, es posible diferenciar por sistemas operativos, incluso por marcas y modelos. También se puede averiguar cuáles son las páginas más visitadas desde diferentes tipos de dispositivos, lo que permitirá conocer los contenidos más demandados. Se analizan también los accesos desde dispositivos móviles al catálogo brumario.usal.es, pero de forma menos detallada, puesto que no dispone de versión móvil. Finalmente, se estudian los datos de uso del catálogo WorldCat.

La aplicación Biblio USAL es una app híbrida, lo que significa que sus contenidos están alojados en páginas web y, por lo tanto, se puede emplear Google Analytics para extraer las métricas de uso. Se ha podido tener acceso exclusivo al número de descargas totales de la aplicación desde que fue creada. Una de las limitaciones que se han encontrado es que Google Analytics solo registra las visitas a la app procedentes de dispositivos con sistemas operativos iOS, aunque también existe una versión para sistemas operativos Android. Por lo tanto hay que tener en cuenta que los datos disponibles son parciales y solo representan a un porcentaje del total.

\subsection{Antecedentes y aportación de la investigación}

El amplio punto de vista del trabajo de investigación que se presenta en esta tesis doctoral es el motivo por el que se puedan considerar como antecedentes directos diversos tipos de trabajos, que ya han sido mencionados en el capítulo 2 . En primer lugar, cabe señalar a aquellos que analizan el contenido y el diseño de los sitios web para móviles y apps, que se mencionan en el apartado 2.2.2.2. Los trabajos de Aldrich (2010), Tay (2010a; 2010b; 2011), Canuel y Crichton (2011), Tay y Travis (2011), Kim (2012), Ashford y Zeigen (2012a; 2012b) y Jackson (2013) se pueden considerar claros antecedentes en lo referente a contenidos y servicios. A ellos habría que añadir alguno más, como el de Cutshall, Blake y Bandy (2011), que realizan un pequeño análisis sobre qué contenidos y servicios incluir en su sitio 
web comparando los de siete sitios web. También DeMars (2012) investiga sitios web móviles de otras bibliotecas para tomarlas como modelo a la hora de crear su sitio web (benchmarking).

En la bibliografía sobre bibliotecas se refleja una evidente preocupación por las cuestiones técnicas a tener en cuenta a la hora de crear sitios web para móviles y apps en bibliotecas. Estos estudios contemplan aspectos como lenguajes de programación y recomendaciones de carácter técnico para la construcción del sitio y se resumen en el apartado 2.2.3. Sobre ellas se investiga también en el presente trabajo, pero más bien sobre si se cumplen o no, una cuestión que pocas veces se ha tratado. Si bien ellas han servido como punto de partida en la elaboración del listado de aspectos a valorar en sitios web para móviles, aplicaciones nativas y catálogos, ha sido el trabajo de Nielsen y Budiu (2013) el que ha proporcionado las respuestas sobre por qué cada uno de los elementos analizados era importante.

El test de usabilidad realizado por Tay y Travis (2011), mencionado en el apartado 2.2.1, emplea la misma metodología que se ha escogido en el presente trabajo, que consiste en la elaboración de un listado heurístico. Sin embargo, aunque existen coincidencias en algunos de los aspectos analizados, el listado aquí empleado es más amplio y la muestra abarca un mayor número de casos, incluyendo también a apps y catálogos, y no solo a sitios web para móviles. El objetivo de ambos trabajos también difiere: si bien Travis y Tay buscan analizar la usabilidad de los sitios web para móviles, mientras que aquí se trata de conocer cómo se está construyendo la presencia de las bibliotecas.

La mayor parte de las investigaciones sobre cómo es la presencia de las bibliotecas en dispositivos móviles está dirigida a los sitios web para móviles, mientras que las aplicaciones nativas y los catálogos han sido poco tratados. A las investigaciones recogidas en apartado 2.2.6.6 hay que añadir el análisis de Aaron Tay (2011) sobre los mOPAC o catálogos móviles, en función de los siguientes parámetros:

1. Al comparar la versión web para dispositivos móviles y apps con la creada para grandes pantallas:

- ¿Cuáles son las opciones por defecto?

- ¿Qué limitadores están disponibles para la versión móvil?

- ¿Qué opciones no lo están?

- ¿Qué opciones para compartir están disponibles?

2. En relación a la versión para apps nativas:

- Si hay una versión para web móvil además de la app, ¿cuáles son las diferencias?

- ¿Qué uso se hace de las funciones nativas?

- ¿Cómo se realiza la autenticación? 
Sobre el catálogo, Broussard, Zhou y Lease (2010) analizaron 10 apps de catálogos de otras bibliotecas como paso previo a la elaboración del suyo, en la Biblioteca de la Universidad de Texas. Los parámetros que tuvieron en cuenta fueron: casilla y botón de búsqueda (que incluyen todas), opciones de tipo de búsqueda (8 de 10), autor y título (todas), estado del libro (todas), signatura y localización (todas) y escaneado (una de diez).

Con respecto a la evaluación de apps, Kendall (2010) señala varios criterios a tener en cuenta a la hora de evaluar aplicaciones de uso general para su uso en la biblioteca: el coste, revisiones publicadas, versión, tamaño, autoría, privacidad de los datos del usuario y si es necesario ser usuario de la biblioteca para acceder.

El trabajo que aquí se presenta aporta un conocimiento sobre cómo se están construyendo los sitios web para smartphones y tabletas, las aplicaciones nativas y los catálogos móviles en bibliotecas. Se inspira en varios de los citados en el apartado anterior, especialmente en los de Aldrich (2010) y Tay (2010a, 2010b, 2011), pero amplía y actualiza los resultados obtenidos anteriormente, permitiendo extraer nuevas conclusiones y observar la evolución en el tiempo de algunas variables. Hasta ahora no se había realizado un estudio con una muestra tan amplia ni que analizara tal cantidad de variables y de casos. Por otra parte, hasta el momento no se ha tratado la presencia de las bibliotecas como un todo, incluyendo a sitios web, aplicaciones móviles y catálogos y las relaciones entre ellos.

Por otra parte, se puede afirmar que este es el primer estudio que proporciona una panorámica sobre cómo están construyendo las bibliotecas españolas sus sitios web para móviles y sus aplicaciones nativas y sobre las experiencias existentes. Además, se establece una comparación con experiencias de otros países, especialmente de Estados Unidos, que proporciona puntos de referencia para poner en perspectiva la situación. Finalmente, la experiencia de la Universidad de Salamanca aporta los primeros datos detallados en España sobre los resultados obtenidos tras la creación de un sitio web para móviles y una app en bibliotecas.

Los catálogos móviles son uno de los aspectos menos estudiados en la bibliografía sobre dispositivos móviles. El análisis sobre sus características aporta datos sobre cómo se están construyendo y las funciones que incluyen, tanto en el software comercial como en las interfaces creadas a medida por las propias bibliotecas.

Uno de los resultados más originales de este trabajo es la identificación de buenas prácticas que permitan disponer de modelos a seguir. Y también se propone una serie de pautas para la evaluación de sitios web, aplicaciones nativas para dispositivos móviles, que se espera tenga una utilidad práctica para aquellas 
bibliotecas que están pensando en poner en marcha alguna iniciativa como las aquí analizadas.

Las variables analizadas en sitios web para dispositivos móviles, aplicaciones nativas y catálogos móviles proprocionan un completo marco conceptual para posteriores estudios sobre las soluciones de movilidad adoptadas por las bibliotecas. En el apartado 3.2 .2 se recogen los parámetros y variables de análisis que construyen este marco conceptual.

Este trabajo aporta también una importante revisión bibliográfica sobre el tema (capítulo 2), lo que ha permitido dibujar un estado de la cuestión actualizado e identificar las áreas que más interés han suscitado entre los profesionales y posibles ámbitos de investigación. 



\section{Capítulo 4. Sitios web para dispositivos móviles. Resultados}

En este apartado se describen los resultados obtenidos del análisis de 196 sitios web de bibliotecas diseñados para dispositivos móviles. Se comenzará describiendo la muestra en función del tipo de bibliotecas, su procedencia geográfica, idioma, fecha de creación y utilidad del sitio web para después estudiar diferentes aspectos sobre su diseño, los métodos de adaptación, forma de acceso, lenguajes de programación, navegación, formato de los contenidos, aprovechamiento de las funciones del dispositivo, contenidos y servicios que ofrecen y el ajuste a las características del smartphone o tableta.

Todo ello desde el prisma de tres variables fundamentalmente: la procedencia geográfica, con especial atención a dos países, Estados Unidos y España, el año de creación de los sitios web, el tipo de bibliotecas y el método de adaptación, pues configuran grupos diferenciados dentro de los que es posible definir pautas comunes. 



\subsection{Descripción de la muestra}

En el presente trabajo se han analizado un total de 196 sitios web adaptados para dispositivos móviles de 167 bibliotecas diferentes en todo el mundo en este momento, adaptar su sitio web. La mayor parte de las bibliotecas analizadas $(86,2 \%)$ tienen un solo sitio web con versión para móviles, que suele ser el sitio web de la biblioteca. Este dato demuestra que esa es la prioridad para las bibliotecas de todo el mundo. El 13,8\% restante corresponde a 23 bibliotecas en las que conviven dos, tres o más sitios web adaptados. Solo en una biblioteca, la Biblioteca de la Universitat Politècnica de Catalunya, se han detectado más de 3 sitios web, además del catálogo, que no se contabiliza en estas cifras.

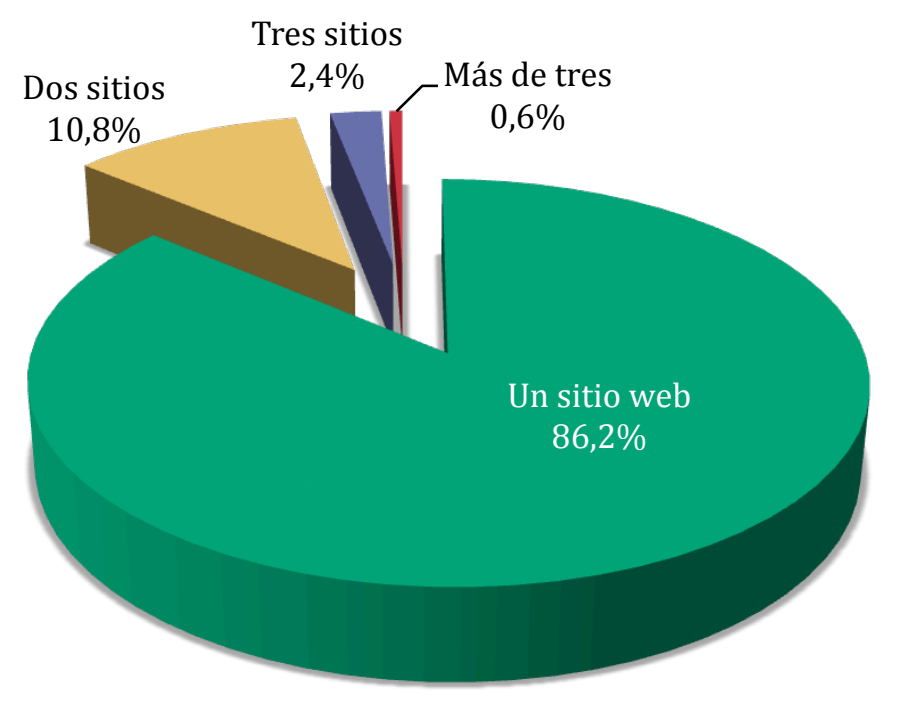

Gráfico 10. Bibliotecas por número de sitios web para dispositivos móviles en la muestra ( $n=167$ bibliotecas).

Se han detectado cuatro motivos por los que una biblioteca mantiene más de un sitio web para móviles (tabla 8):

1. Funciones diferentes. Algunas bibliotecas han adaptado varios de sus sitios web, y no solo el que representa a la biblioteca. Este caso se ha hallado en seis bibliotecas y quizás el mejor exponente sea la Universitat Politècnica de Catalunya, que ha adaptado su repositorio y mantiene 
también un sitio sobre videojuegos y otro con recomendaciones de enlaces, además del sitio web de la biblioteca.

2. Simultaneidad de la versión antigua y la nueva de un mismo sitio web. Esta es la situación más habitual, se da en 14 de los 23 casos analizados, e indica una evolución en el desarrollo de sitios web para móviles.

\begin{tabular}{|c|c|c|}
\hline Motivo & Biblioteca & País \\
\hline \multirow{2}{*}{$\begin{array}{l}\text { Diferentes sedes de } \\
\text { la biblioteca }\end{array}$} & University of California Library & EE. UU. \\
\hline & University of California San Diego Library & EE. UU. \\
\hline \multirow{14}{*}{$\begin{array}{l}\text { Evolución del sitio } \\
\text { web }\end{array}$} & Penrose Library & EE. UU. \\
\hline & University of Alberta Library & Canadá \\
\hline & University of British Columbia Library & Canadá \\
\hline & Albertsons Library & EE. UU. \\
\hline & Duke Libraries & EE. UU. \\
\hline & Harvard College Library & EE. UU. \\
\hline & J. R. Van Pelt and Opie Library & EE. UU. \\
\hline & University of Iowa Libraries & EE. UU. \\
\hline & University of Nebraska-Lincoln Libraries & EE. UU. \\
\hline & University of Texas Health Science Center at San Antonio & EE. UU. \\
\hline & University of Virginia Library & EE. UU. \\
\hline & Washington Research Library Consortium & EE. UU. \\
\hline & Open University Library & Reino Unido \\
\hline & Alvin Sherman Library & EE. UU. \\
\hline \multirow{7}{*}{ Varios desarrollos } & Alvin Sherman Library & EE. UU. \\
\hline & Ryerson University Library & Canadá \\
\hline & North Carolina State University Library & EE. UU. \\
\hline & Orange County Library System & EE. UU. \\
\hline & Oregon State University Libraries & EE. UU. \\
\hline & University of Illinois at Urbana-Champaign Library & EE. UU. \\
\hline & Universitat Politècnica de Catalunya. Bibliotecas & España \\
\hline Varios dispositivos & MD Anderson Center Research Medical Library & EE. UU. \\
\hline
\end{tabular}

Tabla 8. Bibliotecas con más de un sitio web analizado.

3. Diferentes sedes de la biblioteca. Esto sucede en bibliotecas con más de un punto de servicio y se registra en solo dos casos.

4. Versiones para distintos tipos de dispositivos. Así ocurre en la MD Anderson Center Research Medical Library - único caso de este tipo 
detectado-, que ha desarrollado dos versiones de su sitio, una para smartphones y otra para tabletas.

\subsection{1. Área geográfica e idioma}

La mayor parte de los sitios web analizados proceden de bibliotecas estadounidenses $(66,8 \%$ de la muestra). El segundo grupo más numeroso es el de las bibliotecas españolas $(12,8 \%)$ y le siguen las canadienses $(5,6 \%)$. La suma de estos tres grupos supone el 85,2\% del total. El 14,8\% restante está compuesto por sitios web de bibliotecas de otros países en todo el mundo, especialmente de Europa (10,7\% del total, sin España), aunque también hay algunos casos puntuales de Sudamérica (3), Australia (2), Asia (2) y Sudáfrica (1). Así, a efectos del análisis se configuran cuatro áreas geográficas: Estados Unidos, España, resto de Europa y otros países.

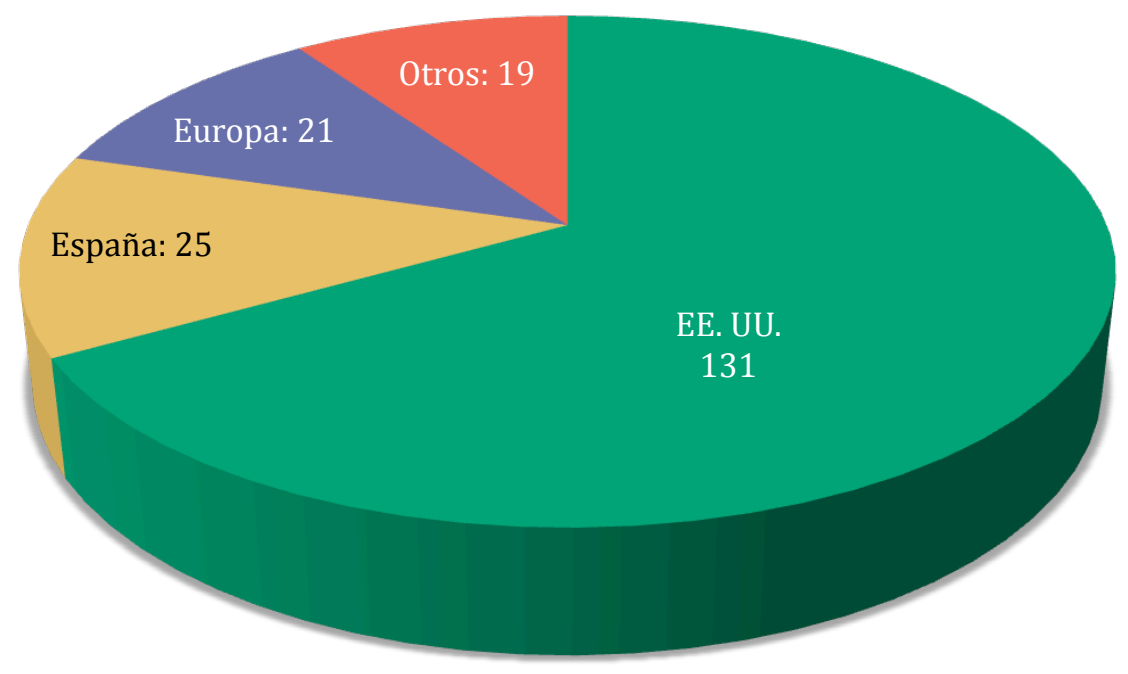

Gráfico 11. Sitios web por área geográfica ( $n=196$ sitios web).

Como era de esperar teniendo en cuenta el gran peso de las bibliotecas estadounidenses en la muestra y que el inglés es el lenguaje internacional por excelencia, ese es el idioma más común en los sitios web analizados, está presente en el $85,2 \%$ de ellos. Téngase en cuenta que hay sitios web cuya información se ofrece en dos idiomas $(7,7 \%$ de la muestra) y hasta tres $(1,5 \%)$. El siguiente idioma más común es el español (en el 10,2\% de los sitios web analizados). También hay 
algunos sitios en holandés (6), francés (4), alemán (5), noruego (2), danés (1) y japonés (1).

En el caso de España es patente el bilingüismo de algunas zonas y el enfoque internacional de algunas universidades. Así, aunque la gran mayoría están en un solo idioma (español, catalán o gallego), hay un $20 \%$ de los sitios en dos (siempre español e inglés) o tres idiomas.

\subsubsection{Tipos de bibliotecas}

Aunque hasta ahora se ha hablado exclusivamente de bibliotecas al referirse a la muestra, ya que constituyen el grupo más importante, los sitios web analizados no solo las representan a ellas, sino también a otros grupos menores:

- Bibliotecas públicas o universitarias: 153 instituciones (91,6\% del total). Se incluyen en este grupo unidades administrativas - cuando existe una versión para móviles del sitio web de la red-y puntos de servicio cuando la única sede existente con versión para móviles representa a una sola biblioteca-.

- Redes de bibliotecas de nivel superior al municipal: 9 instituciones $(5,4 \%)$. Se incluyen en este apartado las redes regionales.

- Bibliotecas virtuales. Este apartado lo constituyen tres bibliotecas españolas especializadas del área sanitaria (1,8\%).

- Consorcios o servicios consorciados: 2 instituciones (1,2\%).

Por otra parte, la muestra incluye sitios web de diferentes ámbitos: bibliotecas universitarias, públicas, especializadas, bibliotecas nacionales y una biblioteca escolar. El grupo mayor, con diferencia, es el de las bibliotecas universitarias, que representan al 78,1\% de la muestra, seguidas de las bibliotecas públicas $(14,8 \%)$. El 7,1\% restante está formado por una biblioteca escolar, 3 bibliotecas nacionales (Holanda, Noruega y Australia) y 10 bibliotecas especializadas.

En el grupo de sitios web de bibliotecas estadounidenses la distribución es muy similar, aunque no están representadas las bibliotecas nacionales ni escolares y es algo mayor el peso de las bibliotecas universitarias $(80,2 \%)$ y públicas $(16,0 \%)$. También se han incluido 5 bibliotecas especializadas $(3,8 \%)$.

En España se han analizado 25 sitios web, de los cuales la mayor parte son del ámbito universitario $(68,0 \%)$, de bibliotecas especializadas $(16,0 \%)$ y públicas $(12,0 \%)$. Además se ha analizado una biblioteca escolar, la única de la muestra. 


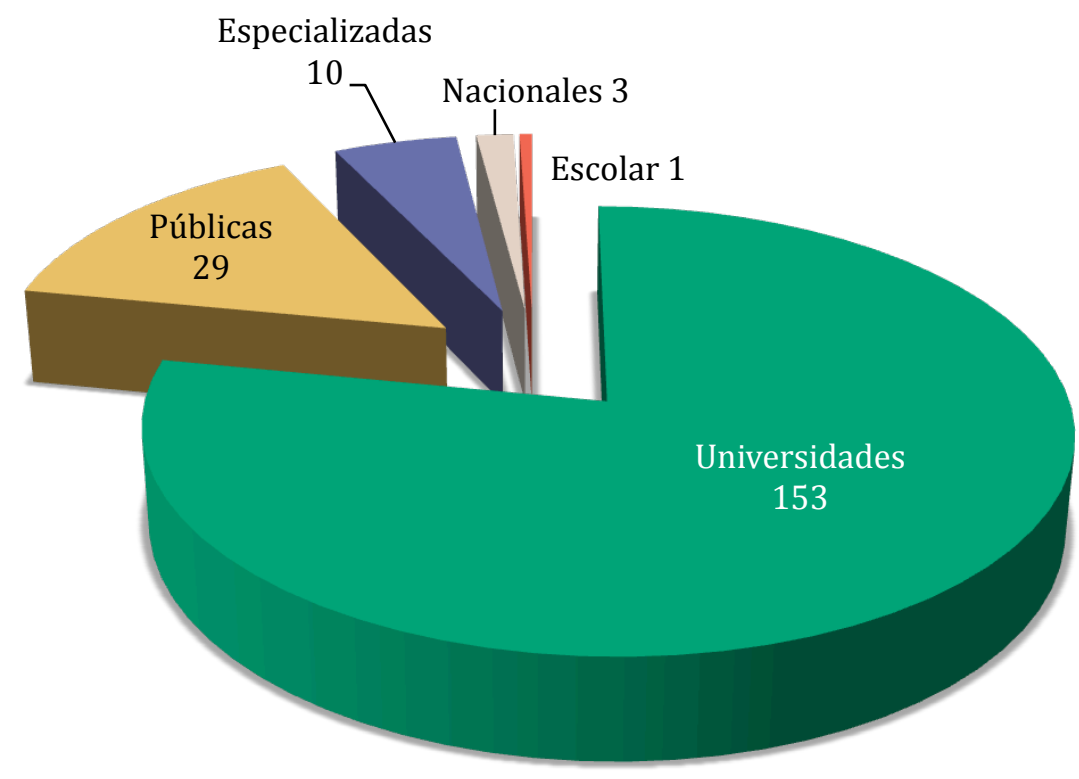

Gráfico 12. Sitios web por tipo de biblioteca ( $n=196$ sitios web).

EE. UU.

España

Otros

\begin{tabular}{lrrrrrr}
\hline & Sitios web & \% & Sitios web & \% & Sitios web & \% \\
\hline Universidad & 105 & $80,2 \%$ & 17 & $68,0 \%$ & 31 & $77,5 \%$ \\
\hline Públicas & 21 & $16,0 \%$ & 3 & $12,0 \%$ & 5 & $12,5 \%$ \\
\hline Especializadas & 5 & $3,8 \%$ & 4 & $16,0 \%$ & 1 & $2,5 \%$ \\
\hline Nacionales & 0 & $0,0 \%$ & 0 & $0,0 \%$ & 3 & $7,5 \%$ \\
\hline Escolares & 0 & $0,0 \%$ & 1 & $4,0 \%$ & 0 & $0,0 \%$ \\
\hline Total & 131 & & 25 & & 40 & \\
\hline
\end{tabular}

Tabla 9. Sitios web por tipo de biblioteca y país ( $n=196$ sitios web).

El resto de los países está representado por un total de 40 sitios, de los cuales más de las tres cuartas partes corresponden a bibliotecas universitarias, el 12,5\% a bibliotecas públicas, tres son bibliotecas nacionales y una especializada (tabla 9).

Prácticamente todas las bibliotecas analizadas están presentes en los medios sociales $(96,4 \%)$. Sólo se han encontrado seis que no tienen presencia propia: Bibliotecas de Castilla y León, Bibliotecas Públicas de Navarra (España), Boston University Medical Center Library (Estados Unidos), Centre d'accès à l'information juridique (Canadá), Harvard College Library (Estados Unidos) y Museums and 
Library Services (Florida Department of State's Division of Library and Information Services, Estados Unidos).

Ante la falta de estudios, es difícil saber en qué medida esto se corresponde con la realidad del conjunto de las bibliotecas. En el grupo de las bibliotecas universitarias españolas, de las que sí se dispone de datos, el 68,0\% tenía presencia propia en los medios sociales (Margaix, 2013).

\subsubsection{Año de creación}

Tal y como se explicó en el apartado de metodología, no ha sido posible conocer el año de creación de todos los sitios web analizados, pero sí de la gran mayoría $(87,2 \%)$. La mayor parte de los sitios para los que se dispone de ese dato fue creado entre 2010 y 2012. Los primeros sitios aparecieron en 2007 y 2008 recordemos que 2007 fue el año del lanzamiento del primer iPhone, que supuso el punto de inflexión en la popularidad de los smartphones- Los sitios web de esta época son casi todos estadounidenses y procedentes de bibliotecas universitarias. Solo las bibliotecas públicas de Aalborg (Dinamarca) y una biblioteca de la Universidad de A Coruña (España) no proceden de ese país. Los casos analizados de esos dos años son muy pocos, 8 en total, pero tienen el valor de ser pioneros. Las bibliotecas comenzaron a adaptar sus sitios web para móviles de forma más significativa en 2009, año en que aparecen 20 de las sedes analizadas (gráfico 13).

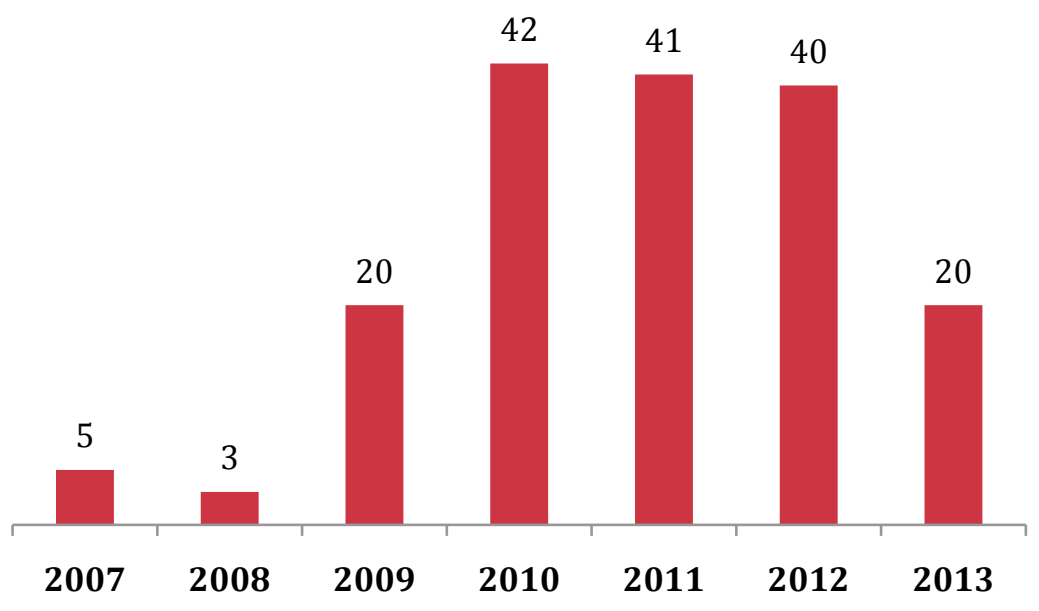

Gráfico 13. Sitios web por año de creación ( $n=171$ sitios web). 
El descenso en el número de sitios web analizados en 2013 no significa necesariamente que se haya perdido el interés en la adaptación a los dispositivos móviles, sino que, simplemente, la fuente empleada para la detección de los casos, el Wiki Library Success, ha registrado un menor número de ejemplos creados ese año.

En España los primeros sitios web para smartphones aparecen un año después, en 2008. Al igual que en Estados Unidos, también son pioneras las bibliotecas universitarias: la E.T.S. de Ingenieros de Caminos, Canales y Puertos de la Universidad de A Coruña es la primera de la que se tiene constancia. Al año siguiente se incorporan al grupo las Bibliotecas del CSIC y la Biblioteca Rector Gabriel Ferraté, que creó en 2009 su primer sitio web móvil —actualizado en 2012- y adaptó el sitio sobre videojuegos Uwin.

En España los datos no dibujan una línea de tendencia creciente a lo largo de los años, como sucede en Estados Unidos (gráfico 14), sino que más bien se observan datos aislados año tras año.
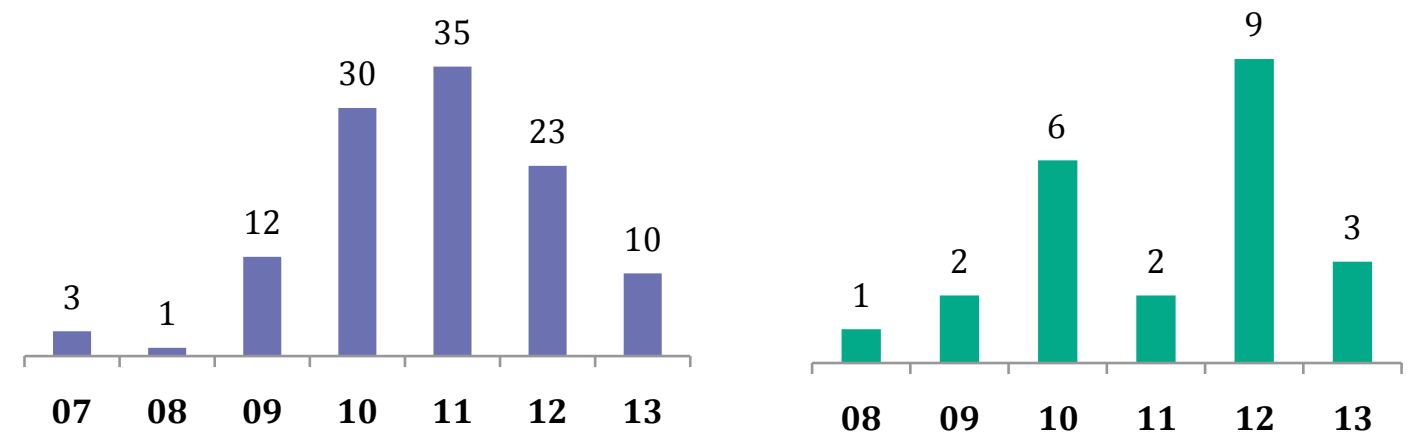

Gráfico 14. Sitios web por fecha de creación en Estados Unidos (izquierda) y España (derecha) ( $n_{1}=114$ sitios web y $n_{2}=23$ sitios web).

\subsubsection{Utilidad de los sitios web}

Adaptar el sitio web de la biblioteca para su consulta desde dispositivos móviles es la prioridad. El 92,3\% de los sitios analizados son precisamente adaptaciones del sitio web de la biblioteca, pero se han estudiado también otros que tienen como principal utilidad el acceso al catálogo (2,0\%). En esta ocasión sólo se han incluido los catálogos «no puros», que incluyen también alguna información adicional sobre la biblioteca, como los horarios de apertura o los datos de contacto. 


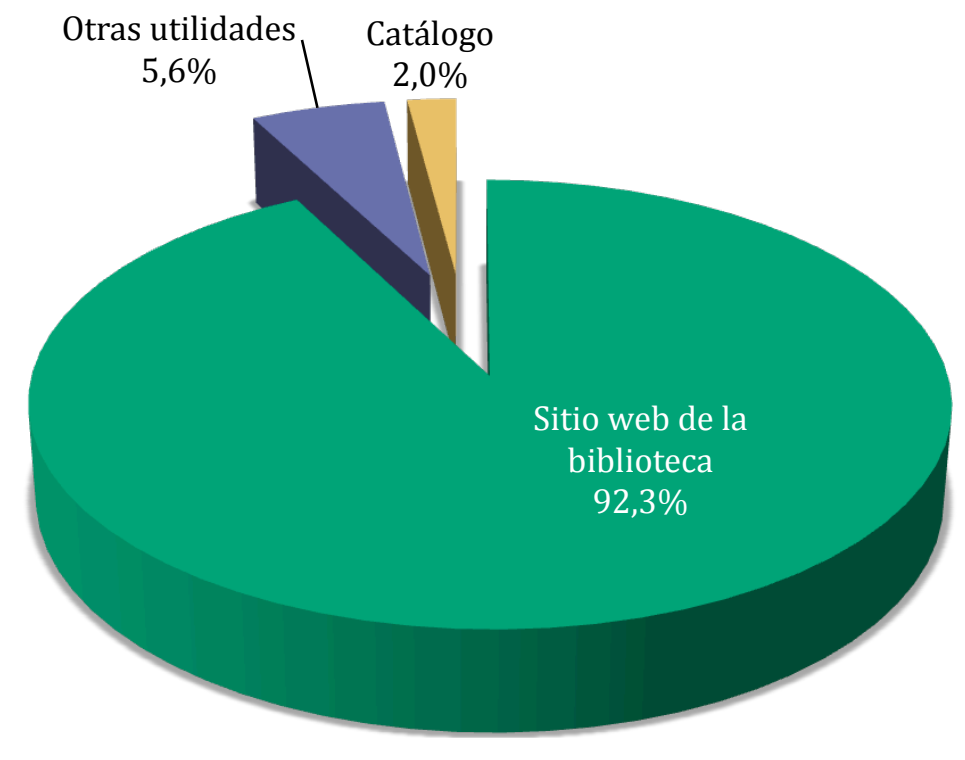

Gráfico 15. Sitios web en función de su utilidad ( $n=196$ sitios web).

Comienzan a verse además desarrollos con otras funcionalidades: recomendar lecturas, visitas guiadas, sacar a la luz fondos patrimoniales o hacer accesibles otros contenidos o servicios de la biblioteca, como el repositorio institucional o el servicio de referencia. Otras utilidades originales que se han encontrado son juegos, recopilación de enlaces o depósito de fotografías. Esto lleva a pensar que es posible que en los próximos años se podrían diversificar los sitios web para móviles de las bibliotecas en función de su utilidad, aunque esta práctica es aún muy puntual.

En España destaca el caso de la Biblioteca de la Universitat Politècnica de Catalunya, que además de su sitio web ha adaptado el catálogo, el repositorio institucional y otros dos sitios web dedicados a la recopilación de enlaces y a los videojuegos respectivamente, como ya se explicó en el apartado 4.1.

En el caso de los 11 sitios web que presentan utilidades diferentes del OPAC y del sitio web $^{95}$, normalmente se trata de portales de bibliotecas que ya tienen

\footnotetext{
95 No se ha contabilizado el servicio de referencia AskALibrarian, que no representa a una biblioteca, sino a un servicio de referencia, por lo que se puede considerar que representa a la institución.
} 
disponible una versión para smartphones de su sitio web. Es el caso de UPC Commons, Uwin y Ooohweb!, de la Biblioteca de la Universitat Politècnica de Catalunya; Genie y BeaverTracks, de la Oregon State University Libraries (Estados Unidos); WolfWalk y \#MyHuntLibrary, de la North Carolina State University Library (Estados Unidos); y de Infopoint, de la University of Illinois at UrbanaChampaign (Estados Unidos). Sólo en el caso de la Scottsdale Public Library (Estados Unidos) y de la Bibliothèque de Toulouse (Francia) el sitio web de la biblioteca no tiene versión para móviles.

\begin{tabular}{lrrrrrr} 
& EE.UU. & \multicolumn{2}{c}{ España } & Otros \\
\hline & Sitios web & \multicolumn{1}{c}{$\%$} & Sitios web & \% & Sitios web & \% \\
\hline Sitio web biblioteca & 122 & $93,1 \%$ & 22 & $88,0 \%$ & 37 & $92,5 \%$ \\
\hline OPAC & 2 & $1,5 \%$ & 0 & $0,0 \%$ & 2 & $5,0 \%$ \\
\hline Utilidades & 1 & $0,8 \%$ & 2 & $8,0 \%$ & 0 & $0,0 \%$ \\
\hline Tour & 2 & $1,5 \%$ & 0 & $0,0 \%$ & 0 & $0,0 \%$ \\
\hline Recomendaciones & 2 & $1,5 \%$ & 0 & $0,0 \%$ & 0 & $0,0 \%$ \\
\hline Patrimonial & 1 & $0,8 \%$ & 0 & $0,0 \%$ & 1 & $2,5 \%$ \\
\hline Servicio de referencia & 1 & $0,8 \%$ & 0 & $0,0 \%$ & 0 & $0,0 \%$ \\
\hline Repositorio & 0 & $0,0 \%$ & 1 & $4,0 \%$ & 0 & $0,0 \%$ \\
\hline Total & 131 & & 25 & & 40 & \\
\hline
\end{tabular}

Tabla 10. Sitios web en función de su utilidad y país ( $n=196$ sitios web).

Por lo tanto, se puede decir que las bibliotecas que crean sitios web adaptados para móviles con utilidades originales suelen haber adaptado previamente el sitio web de la biblioteca. Suelen ser bibliotecas pioneras en cuanto a movilidad, como es el caso de la North Carolina State University, Oregon State University Library y la Universitat Politècnica de Catalunya, una de las primeras en España.

\subsection{Dispositivos}

La mayor parte de los sitios web analizados han sido diseñados para smartphones (96,4\%), mientras que sólo 18 sitios han sido diseñados pensado en tabletas y 5 para teléfonos móviles. Como se puede observar, se produce un cierto solapamiento, y es que hay algunos sitios web diseñados para varios dispositivos: 15 sitios web han sido adaptados pensando tanto en smartphones como tabletas. 
La mayor parte de ellos (14) ha empleado un diseño web adaptativo; tan solo el sitio de la Virginia Commonwealth University Libraries (Estados Unidos) ha creado páginas diferenciadas para smartphones y tabletas. Además, se han encontrado un sitio web diseñado para smartphones y teléfonos móviles, con versiones para ambos: el de la Rochester Hills Public Library (Estados Unidos).

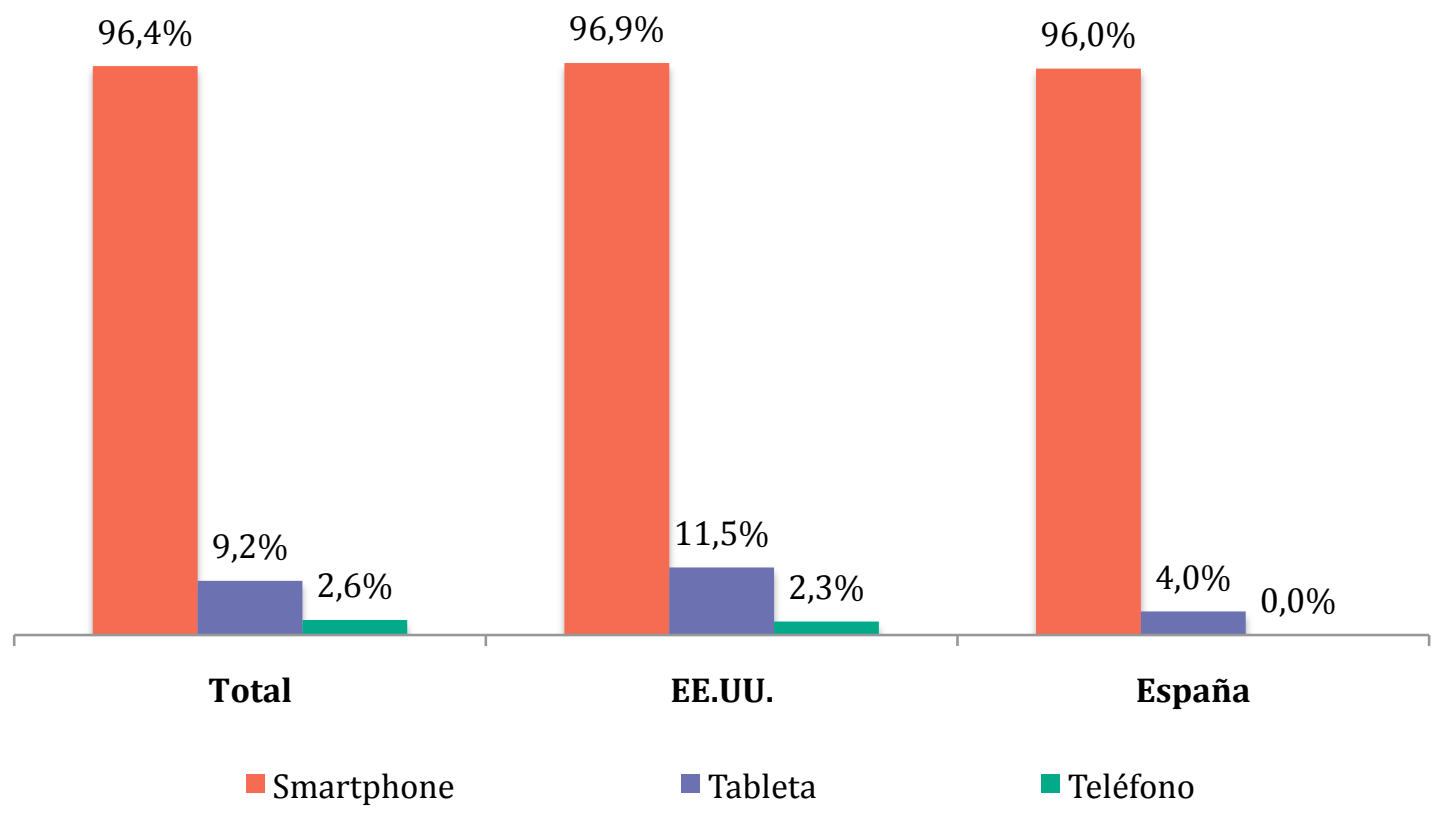

Gráfico 16. Sitios web por tipo de dispositivo ( $n=196$ sitios web).

Eso significa que tan solo 3 sitios web han sido diseñados exclusivamente para tabletas y 4 para teléfonos móviles (no smartphones). Esos tres sitios web diseñados para tabletas son:

- MD Anderson Cancer Center, con información sobre investigación médica.

- BookGenie, un sitio web de recomendación de lecturas de la Oregon State University Library (Estados Unidos).

- El sitio web de la Biblioteca de la Universidad de Cantabria. Aunque se anuncia como «para dispositivos móviles», su pantalla es tan ancha que se ha optado por clasificarlo en el apartado de tabletas.

Los sitios web diseñados para teléfonos móviles están en peligro de extinción en las bibliotecas, aunque aún quedan vestigios. En la muestra analizada, tres fueron creados en 2007, año en que los smartphones hacían su aparición, y uno en 2010, el correspondiente a la Universidad de Pretoria (Sudáfrica), donde el panorama de 
uso de dispositivos móviles podría ser diferente. Teniendo en cuenta los grandes cambios en el mercado de los dispositivos móviles en los últimos años es sorprendente que pervivan estas versiones para teléfonos móviles, aunque se aprecian cambios en ellos:

- Las Bibliotecas de Aalborg (Dinamarca) ha actualizado recientemente su sitio web para móviles con un diseño web adaptativo, haciendo desaparecer el anterior.

- Los sitios de la University of Virginia y Harvard College Library (Estados Unidos) han creado nuevas versiones, pero mantienen aún las antiguas, diseñadas para teléfonos móviles.

- Se mantiene sin actualización la web de la Universidad de Pretoria (Sudáfrica). También la Rochester Hills Public Library (Estados Unidos) mantiene una versión para móviles, simultánea a la versión para smartphones.

Todo apunta a que los sitios web para teléfonos móviles tenderán a desaparecer completamente en los próximos años.

\subsection{Métodos de adaptación}

Hasta el momento las bibliotecas han optado en su mayoría por crear páginas diferenciadas para la versión móvil, pero esa tendencia está cambiando. Los sitios web con páginas diferenciadas representan el $80,1 \%$ de los casos analizados. Sin embargo, se observa cómo va cobrando fuerza con el tiempo el diseño web adaptativo, que ya representa el 15,3\% de los casos estudiados. El uso de hojas de estilo es una opción bastante poco extendida, con solo 9 casos (4,6\%), de los cuales 4 se presentan en España (gráfico 17).

En los dos últimos años del análisis, 2012 y 2013, el 43,3\% de sitios web de nueva creación ha optado por el diseño web adaptativo. La mayor parte de ellos se dan en Estados Unidos (63,3\% de los sitios con diseño adaptativo), lo que en el conjunto del país supuso casi la mitad de los nuevos sitios creados en esos dos años $(48,5 \%$, teniendo solo en cuenta a los 33 sitios de los que se conoce el año de creación).

También se han analizado ejemplos de diseño web adaptativo en Australia (1), Canadá (3), Holanda (2), México (1), Noruega (2) y Reino Unido (2). En España no se ha encontrado ningún sitio web que utilice esta técnica en el ámbito 
bibliotecario durante la fase de análisis, aunque sí posteriormente. Se trata del sitio de Bibliosaúde, la Biblioteca Virtual do Sistema Público de Saúde de Galicia ${ }^{96}$, que a finales de 2013 sustituyó su anterior sitio web por un diseño adaptativo. Esto se puede interpretar como un indicativo de una lenta adaptación a las últimas tendencias las bibliotecas españolas en cuestión de movilidad.

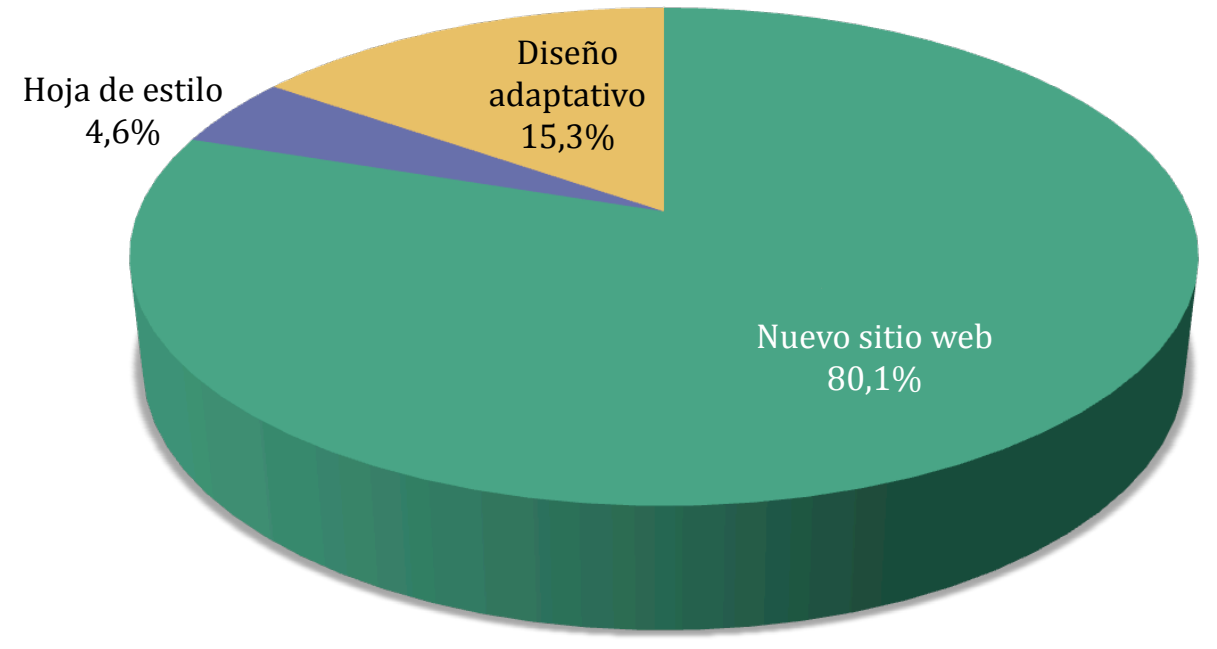

Gráfico 17. Sitios web por métodos de adaptación a los dispositivos móviles ( $n=196$ sitios web).

Se ha detectado una tendencia creciente hacia el diseño web adaptativo en bibliotecas. En los meses después del análisis realizado para este trabajo se han observado 13 sitios web, de los incluidos en la muestra, que han cambiado a un diseño web adaptativo. En la mayor parte de los casos (12) desapareció la versión anterior, mientras que solo en uno se mantuvo de forma paralela.

Algunos de los sitios web analizados $(16,8 \%)$ han sido creados gracias a un gestor de contenidos (CMS). Esta última es una buena opción para bibliotecas con pocos recursos y/o conocimientos de programación, pues permite ahorrar el mantenimiento de servidores y la programación de software y las interfaces son asequibles para cualquier persona que utilice internet a nivel de usuario. En el caso de España, el uso de CMS es habitual: 9 sitios web de 25. Algunos utilizan CMS genéricos, como Joomla!, Drupal, WordPress o Google Sites (5 sitios web) o CMS

96 http://bibliosaude.sergas.es 
propios (1). Otros han escogido un CMS específicos para móviles, como Ubik (2) o Wirenode (1).

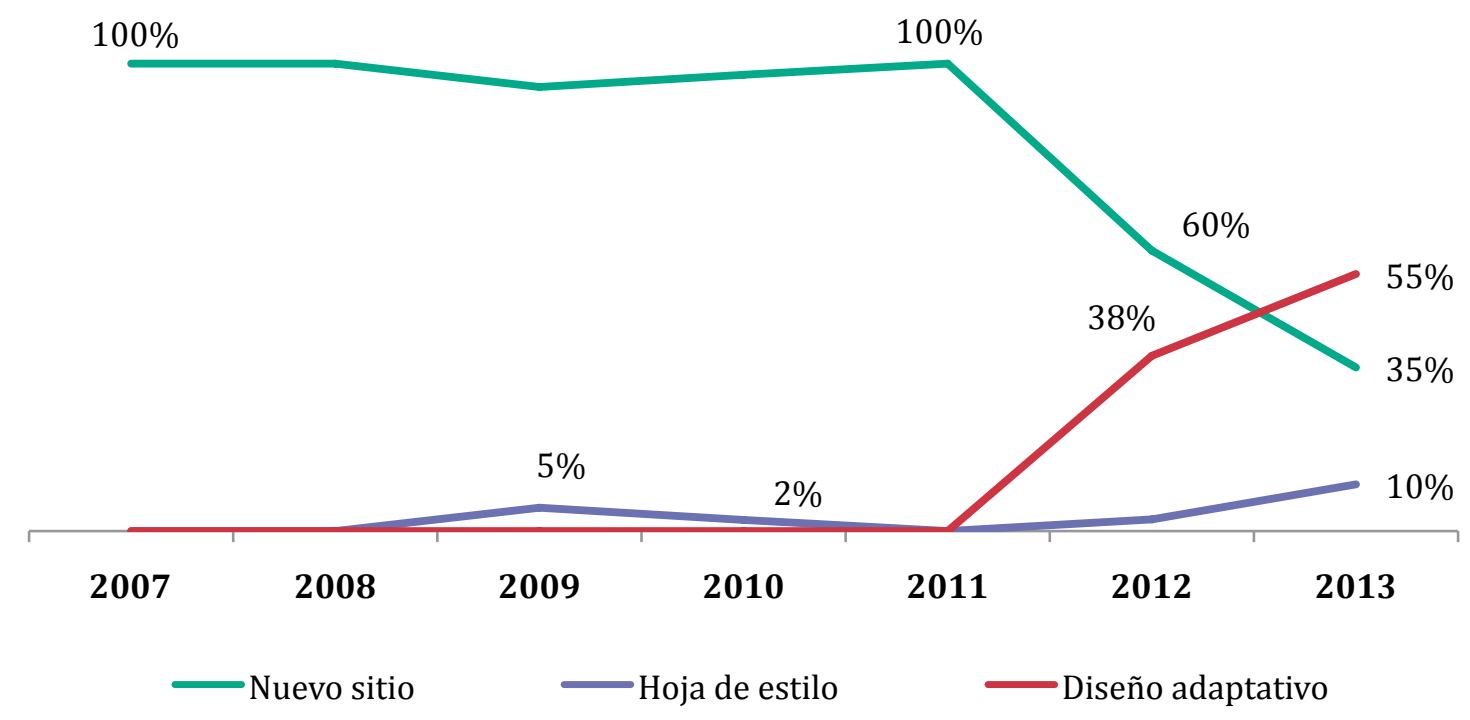

Gráfico 18. Evolución de los sitios web en función de la solución de movilidad que emplean ( $n=171$ sitios web).

\begin{tabular}{lrrrrrr} 
& \multicolumn{2}{c}{ EE.UU. } & \multicolumn{2}{c}{ España } & \multicolumn{2}{c}{ Otros } \\
\hline & Sitios web & \multicolumn{1}{c}{$\%$} & Sitios web & \% & Sitios web & \% \\
\hline Nuevo sitio & 108 & $82,4 \%$ & 21 & $84,0 \%$ & 28 & $70,0 \%$ \\
\hline Hoja de estilo & 4 & $3,1 \%$ & 4 & $16,0 \%$ & 1 & $2,5 \%$ \\
\hline Adaptativo & 19 & $14,5 \%$ & 0 & $0,0 \%$ & 11 & $27,5 \%$ \\
\hline Total & 131 & \multicolumn{3}{c}{25} & & 40 \\
\hline
\end{tabular}

Tabla 11. Sitios web por soluciones de movilidad y por países $(n=196)$.

Los CMS utilizados en Estados Unidos son diferentes de los que utilizan las bibliotecas españolas y no son tan frecuentes en la muestra analizada, solo representan el 8,4\% de los casos). Así, se han analizado en este país dos sitios que utilizan Drupal, cuatro WordPress y uno Percussion. En el apartado de CMS específicos para dispositivos móviles se han detectado Kurogo (2), Winksite (1) y Boopsie (1). Además, cinco sitios más han sido creados con el framework iWebKit, todos ellos en Estados Unidos. 


\subsection{Acceso a la versión móvil}

En este apartado se analizarán las facilidades que los usuarios encuentran a la hora de acceder a la versión móvil del sitio web de la biblioteca, ya sea desde la versión completa o tecleando la URL.

Jakob Nielsen y Raluca Budiu (2013) recomiendan dirigir directamente a la versión para móviles a quienes acceden desde este tipo de dispositivos, ya que los usuarios que llegan desde un buscador no acceden a la versión móvil directamente. Además aconsejan también poner un enlace a la versión móvil en el sitio web para grandes pantallas y asegurarse que ese enlace vaya directamente a la versión móvil y no a una página intermedia. Es una cuestión de promoción del sitio web que muchas bibliotecas pasan por alto (Kim, 2013), a pesar de que no resulta costosa de poner en práctica.

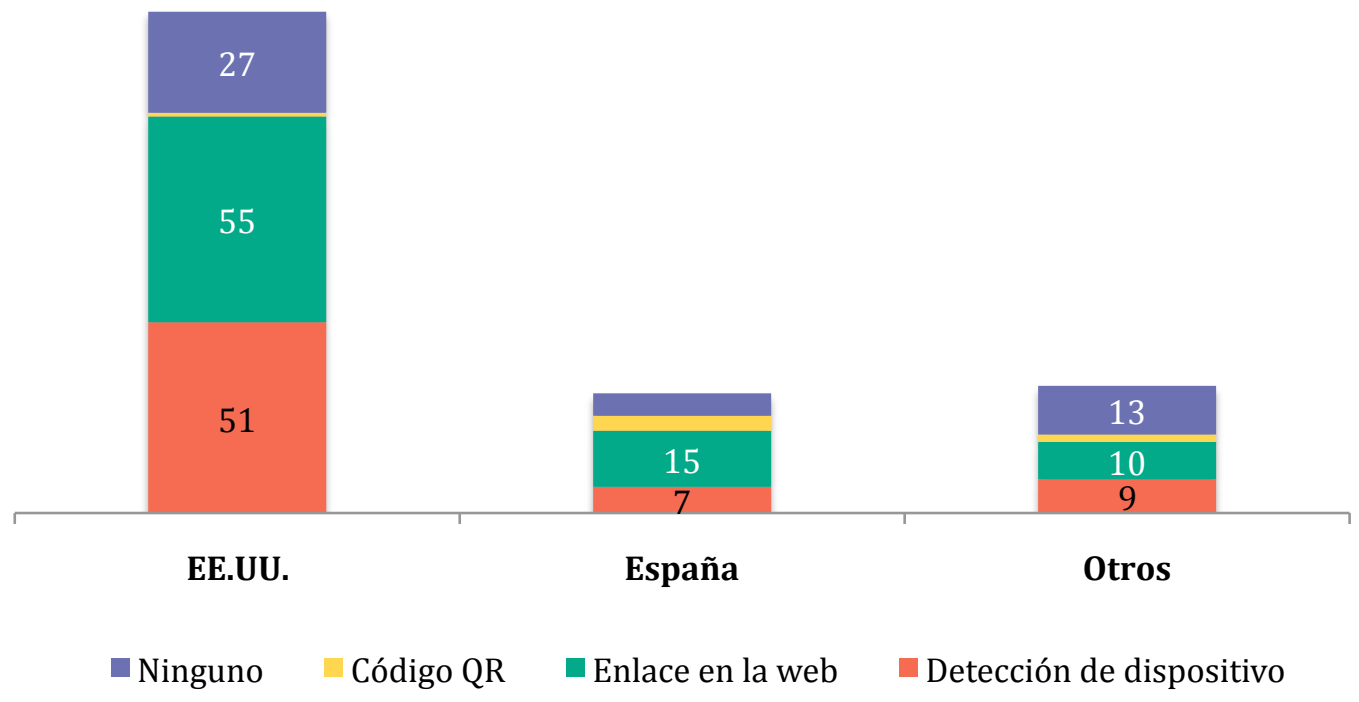

Gráfico 19. Sitios web con páginas diferenciadas para dispositivos móviles por sistema de acceso desde la versión completa y por país ( $n=157$ sitios web).

Lo más probable es que quienes acceden a un sitio web desde dispositivos móviles lo hagan desde un buscador o a través del URL que ya conocen. Por eso lo óptimo es facilitar el acceso a la versión móvil desde la web para grandes pantallas, como ya se avanzó en el apartado 1.2.3.1. En el caso de los sitios web con diseño 
adaptativo u hojas de estilo el acceso es automático, pero cuando la versión móvil se presenta en un sitio web con páginas diferenciadas es necesario establecer algunas medidas para facilitar el acceso.

En este último caso, el sistema más cómodo para el usuario es la detección de dispositivo, que dirige automáticamente a la versión móvil cuando se accede a la web completa desde un dispositivo móvil, sin que el visitante tenga que realizar ninguna acción. Pero también se puede incorporar un enlace entre una versión y otra, en cuyo caso habrá que situarlo en un lugar visible para que el usuario de dispositivo móvil, cuando accede desde una pantalla más pequeña, lo localice fácilmente entre la gran cantidad de contenidos del sitio para grandes pantallas.

En algunos casos se ha observado que se utilizan códigos QR para enlazar desde una versión a otra. En ese caso, se solventa el acceso cuando el usuario tiene delante un ordenador y quiere visitar la web desde el smartphone, pero no es una vía de acceso desde el móvil, en cuyo caso el código QR deberá ir además acompañado de un enlace a la versión móvil.

Total

EE.UU.

España

\begin{tabular}{|c|c|c|c|c|c|c|}
\hline & Sitios web & $\%$ & Sitios web & $\%$ & Sitios web & $\%$ \\
\hline Solo detección & 30 & $19,1 \%$ & 25 & $23,1 \%$ & 0 & $0,0 \%$ \\
\hline Solo enlace & 39 & $24,8 \%$ & 28 & $25,9 \%$ & 6 & $28,6 \%$ \\
\hline Solo QR & 0 & $0,0 \%$ & 0 & $0,0 \%$ & 0 & $0,0 \%$ \\
\hline Detección + enlace & 34 & $21,7 \%$ & 26 & $24,1 \%$ & 5 & $23,8 \%$ \\
\hline Enlace + QR & 4 & $2,5 \%$ & 1 & $0,9 \%$ & 2 & $9,5 \%$ \\
\hline Detección + enlace + QR & 3 & $1,9 \%$ & 0 & $0,0 \%$ & 2 & $9,5 \%$ \\
\hline Ninguno & 46 & $29,3 \%$ & 27 & $25,0 \%$ & 6 & $28,6 \%$ \\
\hline $\mathrm{NS} / \mathrm{NC}$ & 1 & $0,6 \%$ & 1 & $0,9 \%$ & 0 & $0,0 \%$ \\
\hline Total & 157 & & 108 & & 21 & \\
\hline
\end{tabular}

Tabla 12. Sitios web con páginas diferenciadas para dispositivos móviles según el sistema de acceso de la versión completa y por país ( $n=157$ sitios web).

El sistema más popular para acceder a la versión móvil es a través de un enlace (presente en el 51,0\% de los sitios web para móviles con páginas diferentes de la versión para grandes pantallas). En España ese porcentaje es aún mayor y asciende al 71,4\%, mientras que los sistemas de detección de dispositivo bajan al 33,3\%. En Estados Unidos estos sistemas han sido utilizados en el 47,2\% de los sitios web analizados, por lo que se convierte en el segundo sistema más empleado, tanto en ese país como en el conjunto de la muestra. 
El uso de códigos QR es minoritario, sólo aparece en el 4,5\% de los casos. En España es más habitual que en el conjunto de la muestra $(19,0 \%)$, mientras que en Estados Unidos tan solo se ha encontrado en una ocasión.

Más de una cuarta parte de los sitios web $(26,1 \%)$ presenta varias de estas opciones simultáneamente. Así, los sistemas de detección de dispositivo se presentan en la mitad de los casos combinados con un enlace a la versión móvil y los códigos QR siempre van acompañados de enlaces. En tres casos puntuales los sistemas de detección se han encontrado combinados con todos los sistemas. En España lo más habitual es enlazar al sitio web (el 28,6\% lo utiliza como único sistema) y combinar el enlace con un sistema de detección de dispositivo $(23,8 \%)$.

En casi una tercera parte de los sitios web analizados $(29,3 \%)$ no se ha encontrado ninguna forma de acceso al sitio web para móviles, lo que complica llegar a él. Este porcentaje es algo menor en Estados Unidos $(25,0 \%)$ y muy similar en España $(28,6 \%)$. No enlazar la versión móvil es, por lo tanto, uno de los puntos que se suelen pasar por alto, pero no el único: en ocasiones los enlaces no se sitúan en un lugar visible de la página para grandes pantallas.

Para valorar la visibilidad se han analizado los siguientes parámetros:

- Si está enlazado desde un texto o desde un icono reconocible.

- Si el enlace aparece en un lugar destacado de la página.

- El tamaño del texto o del icono que contiene el enlace.

La situación idónea es un lugar superior, con un enlace y en un tamaño grande. Sin embargo, en un tercio de los sitios web analizados $(33,8 \%)$ los enlaces no estaban lo suficientemente visibles. En el caso de España ese ratio asciende al 40,0\%. Se trata de un pequeño gesto que facilita el acceso al usuario.

En el caso de los sitios web con páginas diferenciadas Jakob Nielsen y Raluca Budiu (2013) recomiendan ofrecer «un enlace claro desde la versión para móviles a la versión para grandes pantallas para aquellos (pocos) usuarios que necesiten características especiales que sólo se encuentran en la versión completa.» Las dos terceras partes de los sitios web con páginas específicas para móviles $(79,0 \%)$ incluyen este tipo de enlace. En Estados Unidos este ratio es mayor, alcanza el $85,2 \%$, mientras que en España y otros países desciende de forma considerable (71,4\% y $60,7 \%$ respectivamente).

Esta práctica se está perdiendo con el tiempo en los sitios web para móviles. Fue creciendo hasta 2009, año en que se registró el mayor ratio de sitios web con páginas diferenciadas con esta opción $(85,0 \%)$, para después descender hasta el 30,0\% en los sitios creados en 2013 (gráfico 21). Aunque menos habitual, el enlace a la versión completa de la página también se ha encontrado en prácticamente la 
mitad de los sitios web analizados con hoja de estilo $[55,6 \%)$ y en un solo sitio web con diseño adaptativo, el de la Universidad de Amsterdam. Este sitio no sólo adapta el diseño, sino también los contenidos.

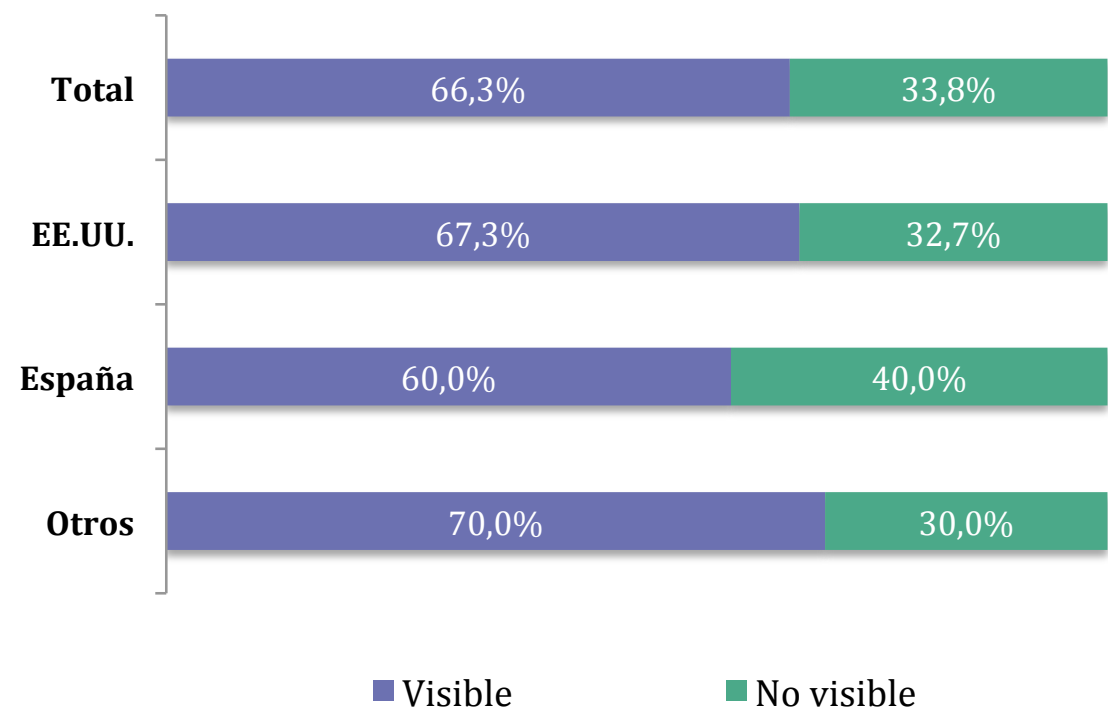

Gráfico 20. Sitios web para dispositivos móviles enlazados desde la versión completa según la visibilidad de los enlaces y país ( $n=80$ sitios web).

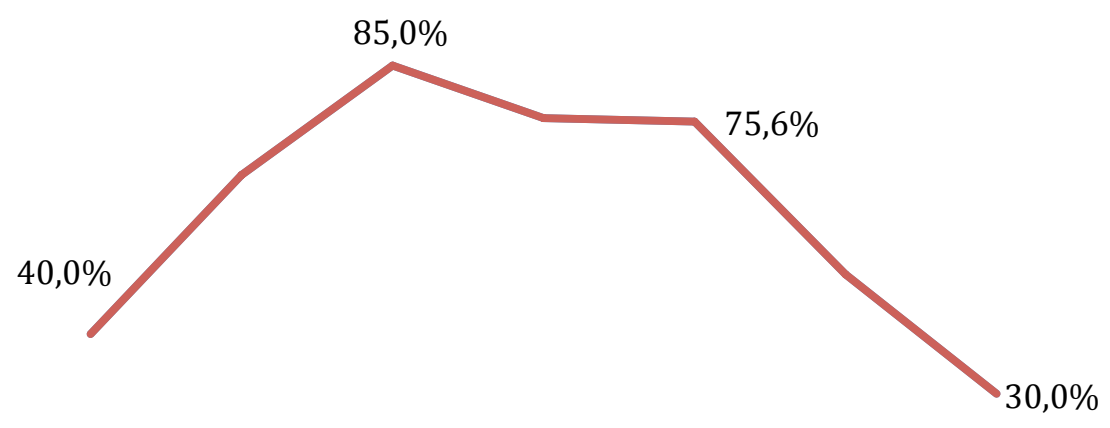

$\begin{array}{lllllll}2007 & 2008 & 2009 & 2010 & 2011 & 2012 & 2013\end{array}$

Gráfico 21. Sitios web con páginas diferenciadas para dispositivos móviles con la opción «Ir al sitio completo», por años. 
Una última cuestión que tiene que ver con el acceso es la longitud de los URL. Los usuarios de dispositivos móviles odian tener que teclear, explican Nielsen y Badiu (2013), por dos razones: tienen que estar atentos a la pantalla mientras escriben, puesto que no conocen la situación exacta de las teclas y porque tienen que asegurarse de que han sido lo suficientemente precisos al teclear. Por ello recomiendan facilitar a los usuarios de dispositivos móviles la entrada de datos. El World Wide Web Consortium (Rabin y McCathieNevile, 2008) también se manifiesta en este sentido y aconseja «que los URLs sean cortos». Una de las formas de facilitar la entrada de datos es creando URLs sencillos de teclear. Un URL largo puede llegar a ser un elemento disuasorio para visitar un sitio web.

Coleman y Theiss (2013) ilustraron mediante un experimento, citado en el apartado 2.5.1, el importante ahorro de tiempo que supone teclear un URL corto. Concluyeron que el tiempo medio para teclear un URL acortado y descargar la página supone 24 segundos, mientras que con un URL largo son 82,5 segundos.

Con el objetivo de conocer si los URL de los sitios web para móviles de las bibliotecas son fáciles de teclear desde un dispositivo móvil se ha realizado un recuento del número de caracteres de estos URL. Para ello se ha prescindido de los sitios diseñados para tabletas exclusivamente - un total de tres-, porque la experiencia de teclear desde una tableta es diferente. Para el recuento del número de caracteres de los URL se ha excluido el http:// — que no es necesario teclear para acceder al sitio desde el navegador-y aquellas partes sin las cuales se puede cargar el sitio web, por ejemplo el /index.html en algunos casos. No se han tenido en cuenta otras variables, como la facilidad de identificar su sintaxis - que sin duda facilita a la hora de teclearla-, debido a su subjetividad.

Para abordar la cuestión, se han establecido cuatro intervalos que definen a un URL. Los intervalos en la mayor parte de estas categorías se han establecido de una manera completamente aleatoria, teniendo en cuenta que no se han encontrado en la bibliografía puntos de referencia que establezcan qué número de caracteres debe tener un URL para que a los usuarios les resulte más fácil de teclear.

- Corto, cuando tiene hasta 15 caracteres. Para definir esta cifra se ha tenido en cuenta la longitud de los URL acortados por servicios como Bitly, que está en unos 12 ó 13 caracteres, aproximadamente. Se considera que los URL de este grupo facilitan el acceso a los sitios a los que representan.

- Medio, si tiene entre 16 y 25 caracteres. Esta categoría, al igual que las dos siguientes, se han establecido de forma aproximada, dada la ausencia de puntos de referencia. Aún es factible teclear los URL de este grupo, aunque el usuario tiene que realizar un esfuerzo mayor.

- Largo, si tiene entre 26 y 30 caracteres. Se considera que los URL de este grupo son costosos de teclear en un smartphone. 
- Muy largo, si supera los 30 caracteres. Se considera que la longitud de los URL de este grupo es un elemento disuasorio a la hora de acceder al sitio desde un smartphone.

Son pocas las bibliotecas que han realizado un esfuerzo para facilitar el acceso a la versión móvil de su sitio web desde un smartphone o un teléfono: solo el 14,0\% de los URL analizados no superan los 15 caracteres. Más de la mitad de la muestra se sitúa en un grupo intermedio (57,5\%), aquel en el que aún es factible teclear el URL para acceder al sitio. Un $14,0 \%$ son costosos de teclear y el $14,5 \%$ restante disuade de visitar el sitio, como muestra la tabla 13.

\begin{tabular}{lrrrrrr} 
& \multicolumn{2}{c}{ Total } & \multicolumn{2}{c}{ EE.UU. } & \multicolumn{2}{c}{ España } \\
\hline & Sitios web & \% & Sitios web & \% & Sitios web & \% \\
\hline Corto & 27 & $14,0 \%$ & 16 & $12,4 \%$ & 2 & $8,3 \%$ \\
\hline Medio & 111 & $57,5 \%$ & 77 & $59,7 \%$ & 12 & $50,0 \%$ \\
\hline Largo & 27 & $14,0 \%$ & 22 & $17,1 \%$ & 3 & $12,5 \%$ \\
\hline Muy largo & 28 & $14,5 \%$ & 14 & $10,9 \%$ & 7 & $29,2 \%$ \\
\hline Total & 193 & \multicolumn{1}{c}{129} & & 24 & \\
\hline
\end{tabular}

Tabla 13. Sitios web para smartphones y teléfonos móviles por longitud del URL y país ( $n=193$ sitios web).

El sistema de adaptación de contenidos en el que se encuentran más sitios con URL largos o muy largos son las hojas de estilo. Esto se debe a que en ocasiones las versiones móviles son generadas de forma dinámica y añaden sintaxis de este tipo después del dominio: /?display=mobile. Son los sitios con diseño web adaptativo los que menos utilizan URL largos o muy largos, con una incidencia de solo el $16,7 \%$ en ese grupo, mientras que en el conjunto de la muestra es del $29,2 \%$. Se han detectado además dos URL que contienen el símbolo de la virgulilla $(\sim)$, difícil de encontrar en los teclados de los dispositivos móviles.

\subsection{Diseño de la interfaz}

En este apartado se estudia el diseño de las interfaces en función de dos aspectos: la plantilla de diseño de la página principal y los elementos de interacción táctil. Siguiendo el trabajo de otros autores, la plantilla de diseño se refiere únicamente a 
la página principal, sin tener en cuenta el resto de las páginas del sitio. Muy poco se ha escrito sobre este tema hasta el momento, salvo los trabajos de Tay (2010a) y Kim (2012; 2013). El primero de estos autores identificó las siguientes plantillas de diseño:

- Menú vertical, u Horizontal lines to create rows. Se caracteriza por mostrar las opciones dispuestas en vertical. En los sitios web analizados se han encontrado tres variantes: con iconos o sin ellos y en botones.

- Retícula de iconos, que Tay denomina Mimic iPhone app layouts. En 2010 era el estilo más novedoso, según explica Tay y simula los iconos del iPhone en su página principal. En algunos casos los iconos recuerdan completamente a los del iPhone, mientras que en otros el diseño es diferente. Una variante son los recuadros de imágenes.

- Menú vertical basado en texto, que Tay denomina Text based layouts. Se trata de una variante del menú vertical en el cuál las opciones son textos breves numerados. Como indica Tay, es quizás el menos sofisticado, pues deriva claramente de los diseños para teléfonos móviles.

- Casilla de búsqueda o Search box, que es habitual en los catálogos y en otros sitios cuya principal utilidad está relacionada con la búsqueda. Es original el caso del Tecnológico de Monterrey, donde prima una casilla de búsqueda en toda la página.

En el presente trabajo se han identificado además otros diseños:

- Módulos. Se trata de recuadros ordenados de forma vertical que ejercen como separación de los diferentes contenidos. Estos módulos pueden incluir banners, casillas de búsqueda, textos o imágenes, menús u otras opciones. Este diseño se asemeja más a los sitios web para grandes pantallas, pero dispone las cajas de contenidos en vertical para ajustarlas a la pantalla. El primer diseño de módulos registrado en la muestra data de 2007 y corresponde a un sitio web adaptado con hoja de estilo.

- Cuadro desplegable. Se trata de un menú con opciones únicas que se utiliza en un tipo muy concreto de sitios web, los que sirven para recomendar lecturas. El usuario selecciona una de las opciones y se devuelven varias opciones.

- Texto. La página principal no está organizada en un menú —o lo hace de forma poco perceptible-, sino que es completamente textual. Se trata de un diseño poco habitual.

- Recuadros de imágenes. Este diseño se utiliza en casos concretos, cuando la imagen o la fotografía juega un papel importante en el sitio, como en las recopilaciones o en las colecciones de fondos patrimoniales. 
- Banner. Se trata de un diseño hallado en un sitio web específico que no representa al sitio web de la biblioteca, sino a un sitio web informativo de un proyecto concreto, Geek the Library. El diseño sin duda es más sofisticado y no parece en nada a los tradicionales.

Se analizan en este apartado los 175 sitios para smartphones que representan al sitio web de la biblioteca. Se han excluido los sitios con otras utilidades (catálogo y otros) porque sus funciones son diferentes y podrían variar mucho más sus diseños. Téngase en cuenta que es el grupo mayor y abarca al 89,3\% de los casos analizados.

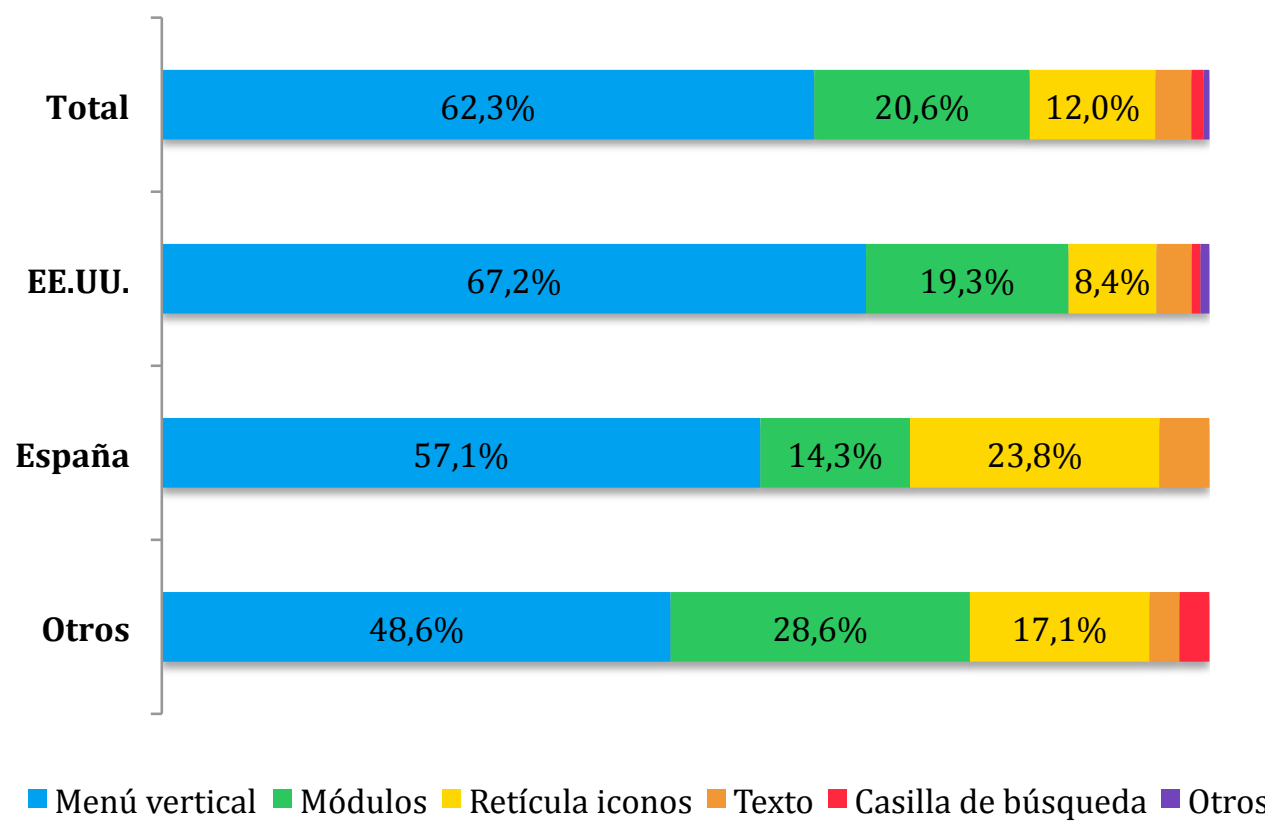

Gráfico 22. Sitios web para smartphones por plantilla de diseño y país ( $n=175$ sitios web).

El diseño más habitual en los sitios web para smartphones es el de menú vertical, presente en un $62,3 \%$ de los sitios web (gráfico 22). Su gran peso viene de la popularidad en Estados Unidos (67,2\% de los sitios). Le sigue el diseño de módulos $(20,6 \%)$, que es especialmente característico de los sitios web con diseño adaptativo - el 76,7\% de los sitios web con diseño adaptativo y que representan al sitio web de la biblioteca tienen un diseño de módulos- y el más frecuente en sitios adaptados mediante hojas de estilo, se da en 6 de los 9 casos.

Han y Jeong (2012), tras analizar 76 sitios web para móviles de bibliotecas universitarias estadounidenses, revelaron que el 62\% tenía un diseño de menús 
textuales, sin imágenes ni iconos, el 13\% utilizaban iconos con un breve texto debajo y el 25\% tenían iconos seguidos. Estos autores recomiendan el menú de retícula de iconos y señalan que solo una cuarta parte tienen casilla de búsqueda en la principal.

En los años 2012 y 2013 esta tendencia se invierte y es el diseño de módulos quien gana peso gracias a la entrada en escena del diseño web adaptativo. De los 24 sitios web con diseño de módulos creados en 2012 y 2013 en el conjunto de la muestra, sólo cinco no son de diseño web adaptativo.

En España es bastante frecuente encontrar plantillas con forma de retícula de iconos (23,8\%), aunque no exactamente con formato iPhone. Si bien en 2010 apuntaba Tay que este diseño era sofisticado, parece que nunca ha llegado a popularizarse: suponen el 12,0\% de la muestra, algo menos en Estados Unidos, el 8,4\%. Debido al poco calado del diseño web adaptativo, en España las plantillas de módulos son excepcionales, se dan en tres casos, de los cuales dos utilizan hojas de estilo. El resto de las plantillas (casilla de búsqueda, texto y otros diseños) se dan de forma puntual $(5,1 \%$ del total $)$ en el total de la muestra.

\subsubsection{Diseño táctil}

Las pantallas táctiles son el sistema de interacción más habitual en los dispositivos móviles. Por lo tanto, resulta lógico integrar elementos de interacción en consecuencia. Y no sólo por cuestiones de usabilidad, sino también aprovechando los gestos que el dispositivo permite. Según Nielsen y Badiu (2013), el hecho de que el ratón y las pantallas táctiles presenten fuertes diferencias es una de las razones para diseñar diferentes interfaces de usuario para sitios web para grandes pantallas y para dispositivos móviles. Así, la interacción táctil es menos precisa. Por ello se aconseja agrandar los elementos de la interfaz para eliminar el efecto fat finger.

En este sentido, el World Wide Web Consortium (Connors y Sullivan, 2010) recomienda:

- Los elementos seleccionables deben tener espacio suficiente, de manera que el usuario pueda seleccionarlos directamente.

- Los elementos seleccionables deben ser lo suficientemente grandes para ser fácilmente seleccionables. Por ejemplo, los ítems de una lista deben tener un espacio de al menos un centímetro alrededor.

- Los elementos con información adicional, como los mouseover, no funcionan 
en pantallas táctiles.

Para conocer en qué medida los sitios web de la muestra tienen en consideración las pantallas táctiles se ha analizado si emplean botones para los elementos seleccionables y enlaces o no. Debido a la complejidad que entrañaría analizar el espacio entre enlaces, se ha tomado el uso de botones como indicador de la preocupación por facilitar la interacción. Sin embargo, hay que tener en cuenta que no es la única estrategia posible y por lo tanto los resultados también deben ser analizados con cautela. No se ha encontrado ningún caso de uso de los gestos más allá de los que permite el propio navegador.

Así, se ha establecido una clasificación por niveles que miden el grado de interacción táctil, siendo los sitios web clasificados en el nivel 0 los que menos grado de interacción presentan (ninguna) y el nivel 3 los que mayor grado.

- Nivel 0. No se utiliza ningún botón.

- Nivel 1. Se utilizan botones de forma muy puntual. Por ejemplo, solo en la página principal.

- Nivel 2. Se utilizan botones en los menús y en la página principal.

- Nivel 3. Todos o casi todos los enlaces están bajo botones.

En el análisis del diseño táctil se ha prescindido de los sitios web específicos para teléfonos móviles, que no suelen tener pantallas táctiles.

\begin{tabular}{lrrrrrrrr} 
& \multicolumn{2}{c}{ Total } & \multicolumn{2}{c}{ EE.UU. } & \multicolumn{2}{c}{ España } & \multicolumn{2}{c}{ Otros países } \\
\hline & Sitios web & \% & Sitios web & \% & Sitios web & \% & Sitios web & \% \\
\hline Nivel 0 & 52 & $27,1 \%$ & 35 & $27,1 \%$ & 10 & $40,0 \%$ & 7 & $18,9 \%$ \\
\hline Nivel 1 & 57 & $29,6 \%$ & 32 & $24,8 \%$ & 8 & $32,0 \%$ & 17 & $44,7 \%$ \\
\hline Nivel 2 & 47 & $24,5 \%$ & 39 & $30,2 \%$ & 4 & $16,0 \%$ & 5 & $13,2 \%$ \\
\hline Nivel 3 & 35 & $17,9 \%$ & 23 & $17,8 \%$ & 3 & $12,0 \%$ & 9 & $23,7 \%$ \\
\hline Total & 192 & & 129 & & 25 & 38 & \\
\hline
\end{tabular}

Tabla 14. Sitios web para smartphones y tabletas por nivel de diseño táctil y país $(n=192$ sitios web).

Más de la mitad de los sitios web analizados $(56,7 \%)$ no presentan ningún uso de botones o lo hacen a un nivel muy básico. Los diseños que mayor uso hacen de este elemento de interacción (nivel 3) aparecen por primera vez en 2009 y se observa una clara evolución en el tiempo en su favor. Sin embargo, esta tendencia decae claramente en 2012, con la introducción del diseño web adaptativo (Gráfico 23). 


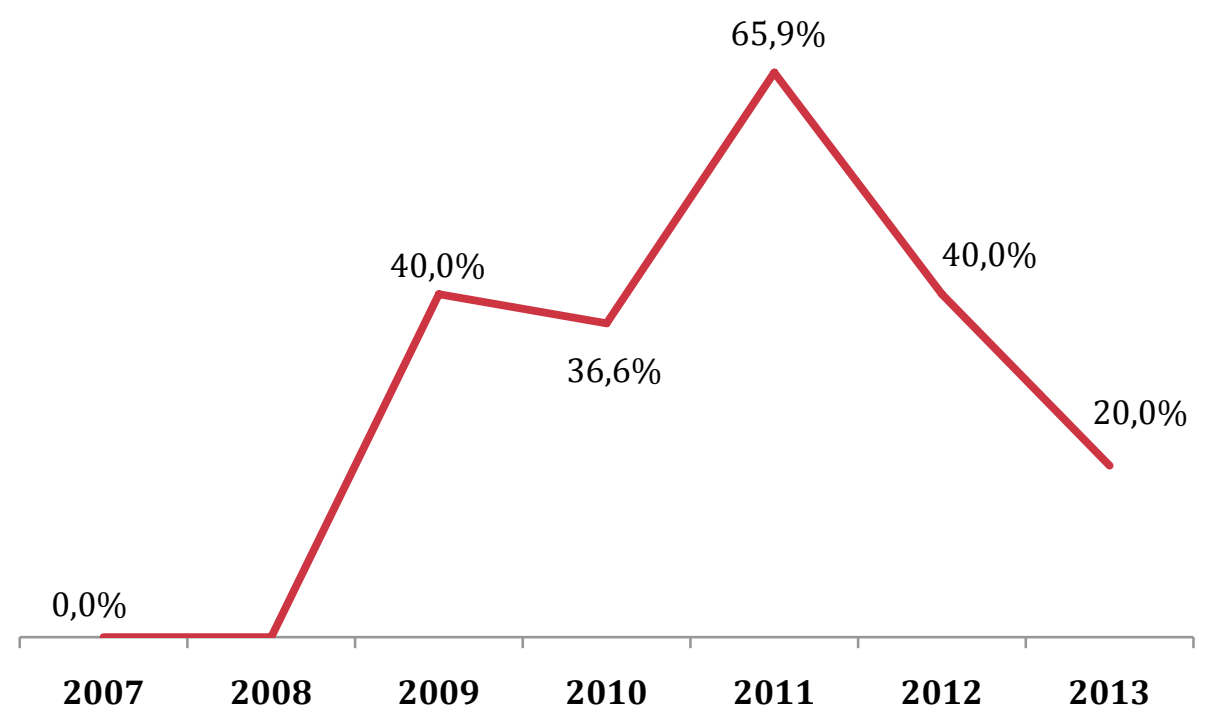

Gráfico 23. Evolución de los sitios web para smartphones y tabletas con botones para enlaces y elementos seleccionables (niveles 2 y 3$)(n=70)$.

El diseño web adaptativo tiende a prescindir del uso de botones, la mayor parte de los sitios que lo incorporan se sitúan en los niveles 0 y 1 (90,0\% de los casos). El $43,3 \%$ de estos sitios no presenta ningún elemento de diseño táctil. Sólo un sitio web presenta un nivel máximo, pero no se trata de un sitio web de biblioteca, sino del grupo de «utilidades».

En España los elementos táctiles son poco frecuentes: el 72,0\% de los sitios se encuentra en los niveles 0 y 1 . Sólo tres sitios web de los 25 analizados están en el nivel 3 de interacción táctil y cuatro en el nivel 2. Son las universidades donde se observa un mayor nivel de interacción táctil en nuestro país: Universidad de Girona, el repositorio UPC Commons y la Pompeu Fabra. En el nivel 2 también son casi todos sitios web de universidades, además del sitio de las Bibliotecas de Castilla y León. Si atendemos a su evolución en el tiempo, los sitios web con mayores niveles de interacción táctil en este país se han creado a partir de 2010 y, curiosamente, en 2013 desaparecen completamente. En este año, los tres casos encontrados se sitúan en el nivel 0 ó 1 . De los tres sitios web creados en este año, dos han sido construidos por la propia biblioteca. 


\subsection{Lenguajes de marcado, metadatos y analíticas}

Este apartado comprende tres aspectos relacionados con la construcción del sitio web: los lenguajes de marcado, el uso de Google Analytics u otras herramientas de analíticas web y el empleo de metadatos. En este apartado se reducirá la muestra a aquellos sitios web con páginas diferenciadas para smartphones u otros dispositivos, lo que excluye a aquellos que han sido adaptados mediante hojas de estilo o diseño adaptativo. Así, el universo se reduce a 157 sitios web, 108 correspondientes a bibliotecas en Estados Unidos, 21 en España y 28 en otros países.

\subsubsection{Lenguajes de marcado}

Los sitios web para móviles analizados con páginas diferenciadas suelen estar creados con lenguajes de marcado no específicos para móviles. Esto se observa de forma general en toda la muestra (75,8\% de los casos), con HTML y XHTML como únicos lenguajes. El porcentaje es aún mayor en el caso de Estados Unidos (76,9\%) y España, donde abarca al 90,5\%. En el resto de los países es bastante menor $(60,7 \%)$.

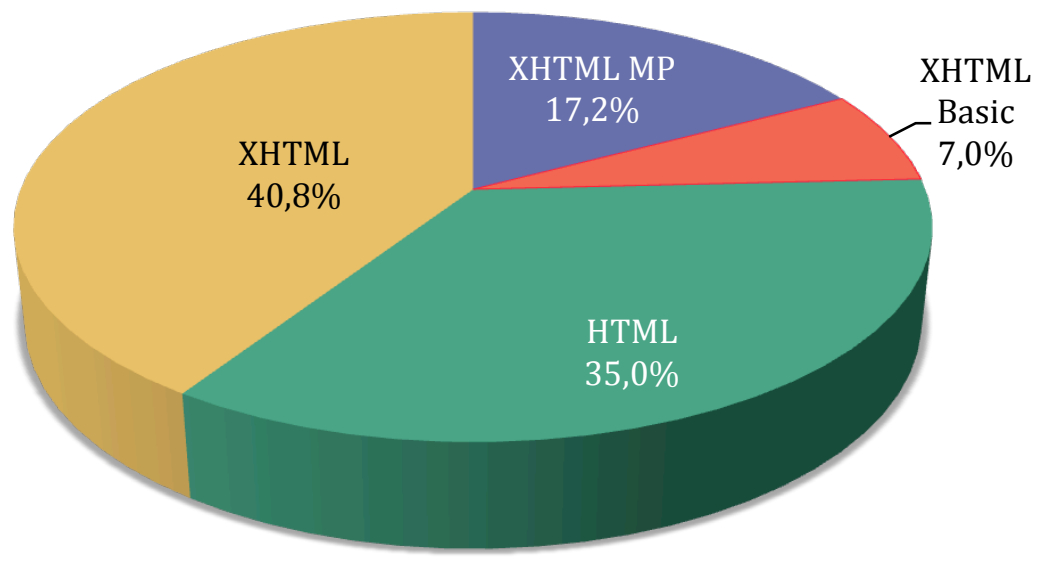

Gráfico 24. Porcentaje de sitios web con páginas diferenciadas para dispositivos móviles por lenguajes de marcado ( $n=157$ sitios web). 
Los lenguajes específicos para dispositivos móviles que se han hallado son XHTML Mobile Profile y XHTML Basic, presentes en un 17,2\% y 7,0\% de los casos respectivamente. XHTML-MP deriva de XHTML Basic 1.0 y fue definido como el lenguaje de marcado de la WAP 2.0. En julio de 2008 XHTML Basic 1.1 se convirtió en recomendación, superando así a XHTML-MP.

EE.UU.

España

Otros

\begin{tabular}{lrrrrrr}
\hline & Sitios web & \multicolumn{1}{c}{$\%$} & Sitios web & \% & Sitios web & \% \\
\hline Móvil & 25 & $23,1 \%$ & 2 & $9,5 \%$ & 11 & $39,3 \%$ \\
\hline XHTML MP & 17 & $15,7 \%$ & 2 & $9,5 \%$ & 8 & $28,6 \%$ \\
\hline XHTML Basic & 8 & $7,4 \%$ & 0 & $0,0 \%$ & 3 & $10,7 \%$ \\
\hline No móvil & 84 & $76,9 \%$ & 19 & $90,5 \%$ & 17 & $60,7 \%$ \\
\hline HTML & 33 & $30,6 \%$ & 11 & $52,4 \%$ & 11 & $39,3 \%$ \\
\hline XHTML & 50 & $46,3 \%$ & 8 & $38,1 \%$ & 6 & $21,4 \%$ \\
\hline Total & 108 & & 21 & & 28 &
\end{tabular}

Tabla 15. Sitios web con páginas diferenciadas para dispositivos móviles por lenguajes de marcado y país ( $n=157$ sitios web).

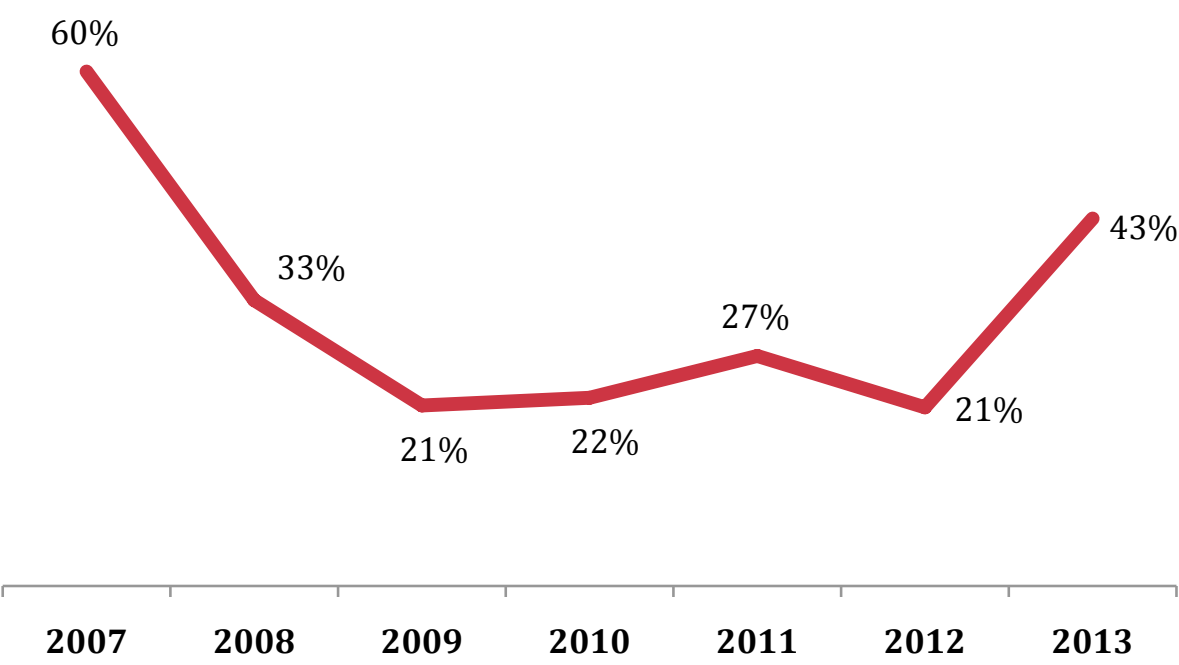

Gráfico 25. Evolución de los lenguajes de marcado móviles (XHTML MP y XHTML Basic) en los sitios web de bibliotecas con páginas diferenciadas para dispositivos móviles $(n=38$ sitios web).

En los sitios web para dispositivos móviles de las bibliotecas se observa una tendencia a lo largo del tiempo hacia un menor uso de los lenguajes específicos 
para dispositivos móviles (gráfico 25). Los dispositivos móviles actuales no discriminan contenidos en función del lenguaje de marcado, sino que son capaces de mostrar cualquier sitio web. Por otra parte, HTML y XHTML son lenguajes más extendidos. Y, finalmente, la evolución de la web conduce hacia una convergencia en los lenguajes que se manifiesta en HTML 5, que desde 2012 fue recomendación candidata del World Wide Web Consortium y se convirtió en recomendación en octubre de 2014. Sin embargo, en ninguno de los casos analizados se ha encontrado indicios de HTML 5.

\subsubsection{Metadatos}

El uso de metadatos que describan los contenidos incide directamente en la recuperación de la información. Con el fin de estudiar el uso que se hace en ellos de los metadatos, los sitios web para móviles de las bibliotecas han sido clasificados en tres apartados:

1. Sin ningún tipo de metadatos o con etiquetas <meta > básicas. Son los sitios en los que no se han encontrado metadatos o que las tienen, pero se trata de etiquetas HTML que no implican ningún tipo de descripción de los contenidos y que generan automáticamente los gestores de contenidos o los programas de desarrollo web, como Content-type.

2. Etiquetas meta descriptivas. Se trata de las etiquetas de descripción que permite HTML bajo la etiqueta <meta>, como autor o palabras clave, por ejemplo.

3. Uso de otros esquemas de metadatos, diferentes de HTML, como Dublin Core y Open Graph (OG). El uso de este tipo de metadatos y del anterior grupo requiere un esfuerzo de descripción del sitio por parte de sus desarrolladores.

No es habitual el uso de metadatos que describan los contenidos (puntos 2 y 3 ) en los sitios web de bibliotecas, se han hallado en el 23,5\% de la muestra (gráfico 26). En la mayor parte de los casos se trata de etiquetas HTML <meta $>$ (21,0\%), tan solo el 2,5\% utiliza algún otro esquema (Open Graph o Dublin Core). Téngase en cuenta que este ratio excluye a los sitios web adaptados mediante hojas de estilo o diseño web adaptativo (157 sitios web).

En Estados Unidos el porcentaje de sitios con metadatos para la descripción de los contenidos es algo más bajo (19,4\%). En España el uso de metadatos es más habitual, se da en el $42,9 \%$ de los casos y se observa cómo los sitios web que incluyen metadatos más elaborados son los de bibliotecas universitarias. 


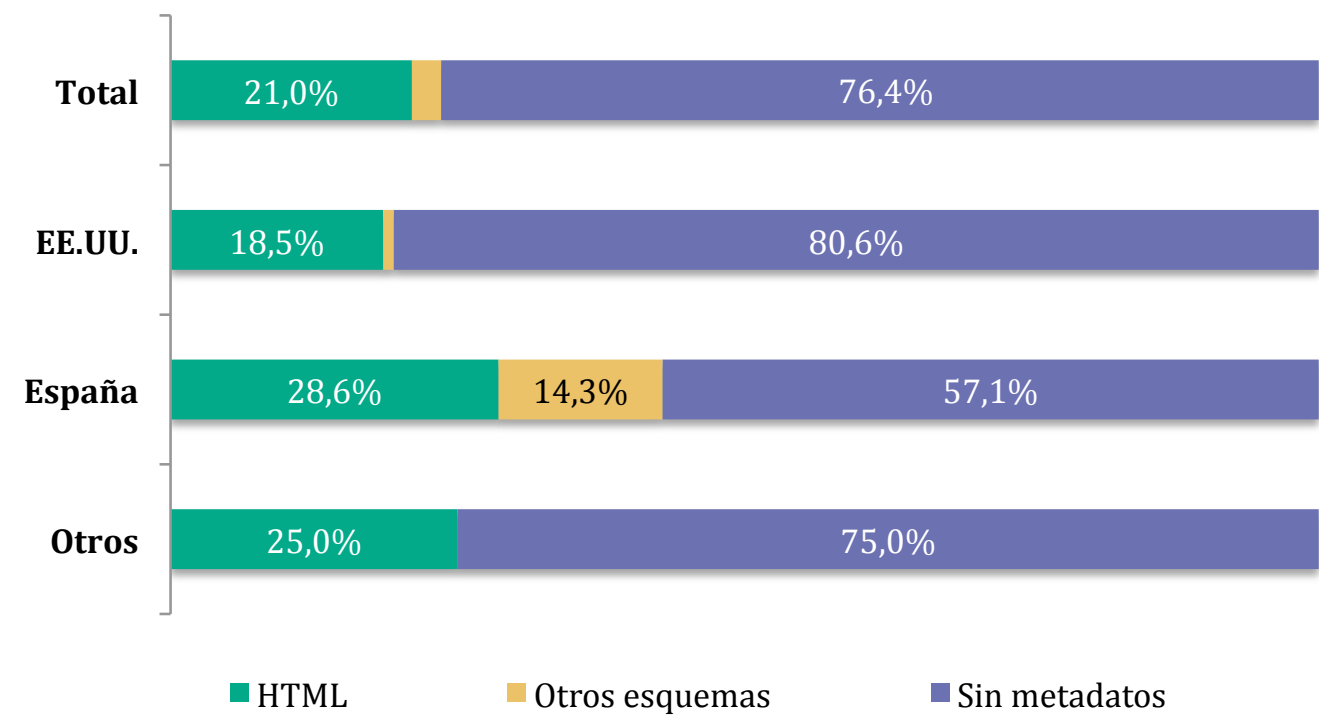

Gráfico 26. Sitios web con páginas diferenciadas para dispositivos móviles por tipo de metadatos ( $n=157$ sitios web).

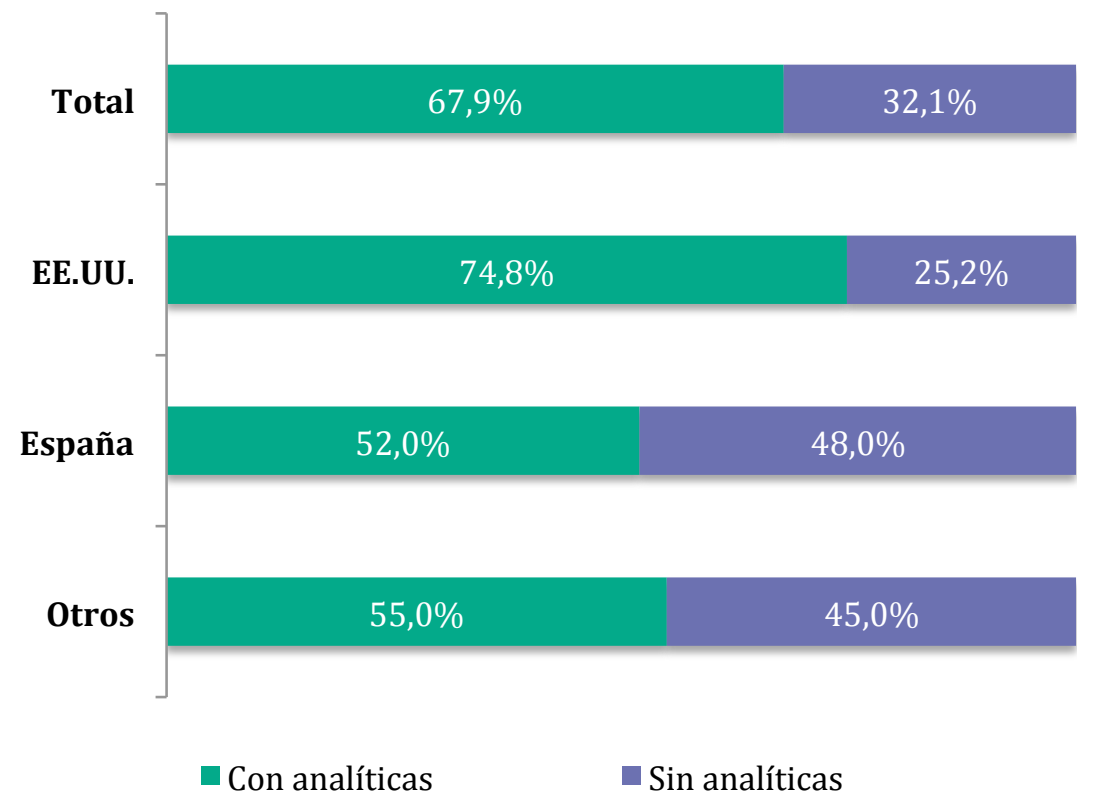

Gráfico 27. Uso de analíticas en los sitios web de la muestra ( $n=196$ sitios web). 


\subsubsection{Analíticas web}

El 67,9\% de los sitios web analizados - y aquí se tiene en cuenta toda la muestrautilizan Google Analytics para la medición de las estadísticas de uso del sitio web. Este ratio es mayor en Estados Unidos, donde alcanza casi las tres cuartas partes $(74,8 \%)$, pero se reduce a la mitad en España (52,0\%) y en otros países (55,0\%). Curiosamente se observa un mayor uso de analíticas en los sitios con diseño adaptativo (el 83,3\% de ellos utilizan Google Analytics) que entre los sitios web con páginas diferenciadas para dispositivos móviles (63,7\%).

Con el tiempo aumenta el ratio de sitios que utilizan analíticas web. El año 2011 marca un punto de inflexión: en los sitios creados entre 2007 y 2010 (ambos incluidos) la mitad utiliza analíticas. Entre 2011 y 2013 el número de sitios que no ha implementado analíticas web se reduce a menos de la quinta parte $(18,8 \%)$. Esto demuestra un mayor interés por conocer cómo están utilizando los usuarios los sitios web de las bibliotecas.

\subsection{Elementos de navegación}

Los sitios web para móviles presentan elementos de navegación muy variados y peculiaridades propias, teniendo en cuenta las características del dispositivo y de las condiciones de acceso a la información. Como se verá a continuación, algunos elementos han sido heredados de los sitios web para grandes pantallas, mientras que otros se han adaptado o son propios. Se describen a continuación los elementos de navegación detectados en la muestra. Para su clasificación y descripción se ha acudido a Pérez-Montoro (2010), siempre que ha sido posible.

- Menú en la página principal. Se trata de un diseño muy habitual en los sitios web para dispositivos móviles, especialmente para smartphones, en el que la página principal es ocupada por un menú en forma de lista o de iconos. De esta forma la navegación cobra todo el protagonismo frente a los contenidos, a diferencia de lo que sucede en los sitios web para grandes pantallas.

- Menú horizontal superior. Se trata de un sistema constante de navegación muy popular en los sitios web para grandes pantallas y que consiste en una barra horizontal con los enlaces principales del sitio web. Esta barra se muestra en todas las páginas del sitio y por ello sirve de guía constante 
de navegación. Este elemento es poco común en sitios web para dispositivos móviles, puesto que ocupa el espacio más visible de la página de forma permanente.

- Menú horizontal inferior. Una solución que se ha observado en los sitios web para dispositivos móviles es disponer las opciones del menú, de forma permanente, en un menú inferior en forma de listado, aunque en ocasiones aparece como una barra vertical, sobre todo en diseños más recientes. De esta forma el menú no invade una parte visible de la página pero es una constante (figura 16).

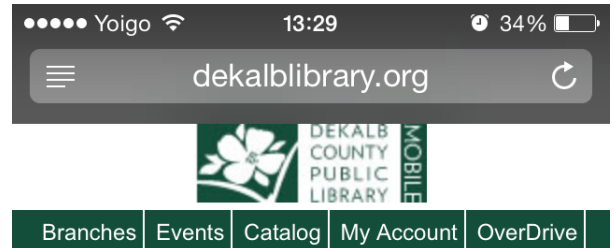

\section{LIBRARY NEWS}

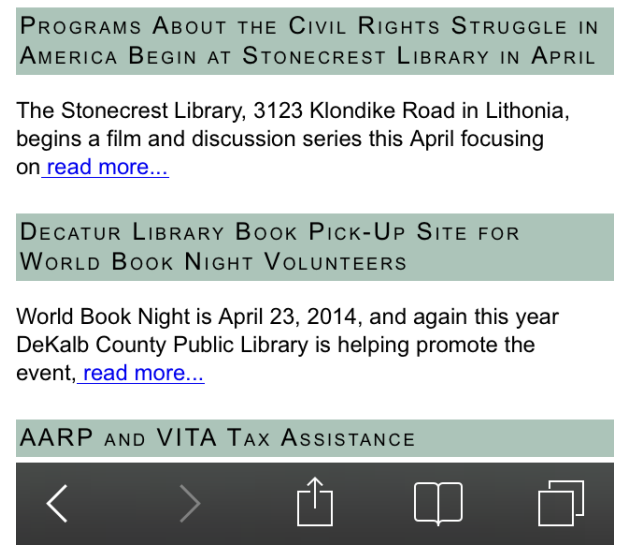

13:31
bibliotecascsic.ubik.net
committed for managing CSIC Union Catalogue,
providing access to e-resources through CSIC
Virtual Library, preserving and providing access to
CSIC scientific production through Digital.CSIC
repository, computerizing CSIC historical
archives, regulating library services provided by
CSIC libraries, coordinating collection
development, facilitating documentation and
training to CSIC librarians, maintaining and
developing Library Network website and other
communication channels, acting as CSIC
representative in library cooperation forums and
developing, along with CSIC authorities, the
Institutional scientific information policy.
[1] conectados.0: Web móvil de la Red de
Bibliotecas del CSIC / CSIC Library Network
Adapted Web
[2] Noticias de la Red / News
[3] Bibliotecas / Libraries
[4] Archivos / Archives
[5] Servicios / Services
[6] Blog ECo
[7] Contacto / Contact
[8] Galeria de imágenes / Images gallery
[9] Ir a la Web normal / Go to normal view

Figura 16. Sitios web con sistema de navegación contextual y menú en la parte inferior.

- Menú desplegable. Como explica Pérez-Montoro (2010), «se utilizan cuando hay poco espacio para mostrar muchos vínculos y se presentan como un dispositivo que, al activar una etiqueta del sistema de navegación, se despliega y muestra un listado de enlaces.» Suele colocarse en la parte superior de la página, la más visible, bajo la apariencia de un botón o de lista desplegable (figura 17). Se convierte por lo tanto en un sistema idóneo en el caso de sitios web para pequeñas pantallas.

- La búsqueda en el sitio web es muy habitual de las versiones para grandes pantallas, pero pierde importancia en las versiones móviles. 
- Los sistemas contextuales, explica Pérez-Montoro (2010), suelen introducirse mediante enlaces en el texto o imágenes de una página. En definitiva, se concretan en enlaces en el cuerpo del texto de la página (figura 16).

- Home, volver o subir son elementos de navegación que no contextualizan en qué lugar de la página se encuentra el visitante. En el caso de los sitios web para dispositivos móviles, que apenas tienen profundidad ${ }^{97}$, las opciones volver y home pueden ser suficientes para una navegación cómoda. La segunda de ellas cobra cierta importancia cuando la página principal sirve de menú. Por otra parte, la opción subir es especialmente útil para moverse dentro de la página cuando la longitud se alarga verticalmente, como es el caso de muchos sitios web para dispositivos móviles.
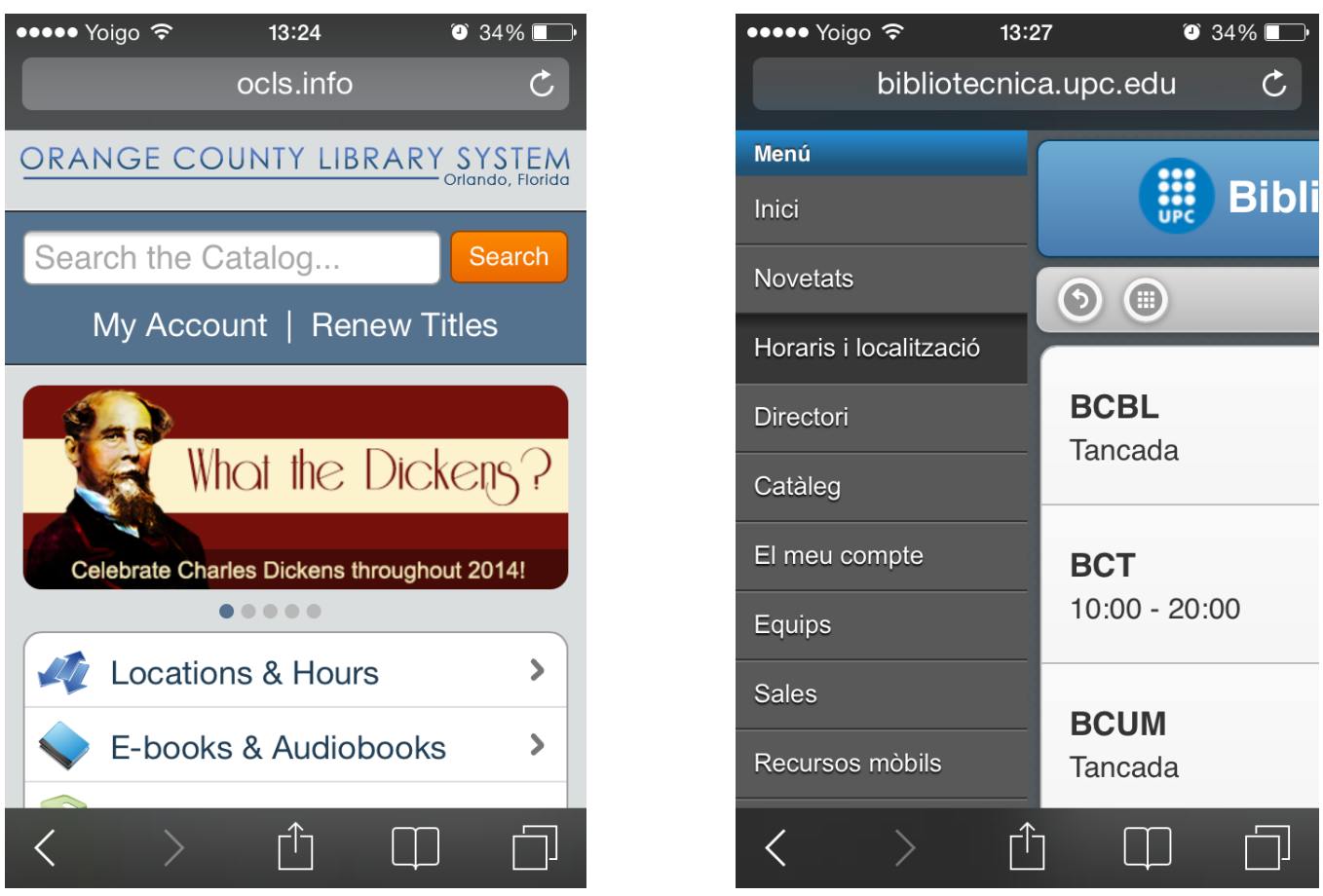

Figura 17. Sitios web con banner con diapositivas y menú desplegable lateral.

- Las migas de pan localizadoras (breadcrumbs) informan sobre en qué lugar dentro de la página se está navegando. Así, vienen a trazar un hilo

97 Se define la profundidad de un sitio web como en número de niveles dentro del sitio, siendo el nivel 0 ó 1 la home page y marcando cada directorio anidado un nuevo nivel (Aguillo, 2002). 
que sitúa al visitante dentro de la estructura del sitio web y suelen tener una sintaxis de este tipo:

\section{Home $>$ Bibliotecas $>$ Jaume Fuster}

Se muestran de forma jerárquica y trazando un hilo. La profundidad jerárquica de los sitios web para dispositivos móviles intenta reducirse al mínimo, de manera que este sistema puede ser prescindible en sitios con poca profundidad. Sigue siendo útil, sin embargo, en los sitios con diseño web adaptativo, que no han reducido sus contenidos ni la estructura de sus sitios.

- El mapa del sitio proporciona una visión general de la estructura de un sitio web y de sus contenidos, permitiendo además la navegación. La escasa profundidad de los sitios web para móviles hace prescindible a este elemento, que cobra mayor importancia en el caso de los sitios web adaptados mediante diseño adaptativo u hojas de estilo.

- Los banners con formato de diapositivas constituyen una manera vistosa de llamar la atención sobre contenidos destacados de un sitio, pues ocupan una gran superficie con una sola imagen enlazada que va cambiando periódicamente (figura 17). Son un elemento más novedoso, poco habitual en los primeros sitios web para dispositivos móviles pero que poco a poco se ha ido introduciendo en algunos casos.

Cabe destacar la ausencia de columnas laterales como elementos de navegación, que reducirían el ancho de la pantalla principal y que son sustituidos por otros elementos, como los menús desplegables. Así, en los sitios web para dispositivos móviles analizados se han encontrado algunos elementos de navegación más propios de las grandes pantallas, como las casillas de búsqueda, los menús horizontales superiores, los mapas del sitio, las migas de pan o los banners en forma de diapositivas. En algunos casos se heredan en los sitios web con diseño adaptativo u hojas de estilo, pero también se encuentran en sitios web con páginas diferenciadas.

Se observan claras diferencias en los elementos de navegación en función de la solución de movilidad adoptada. En los sitios web con páginas diferenciadas para dispositivos móviles el principal elemento de navegación suele ser el menú que ocupa la página principal, presente en el 94,9\% de este tipo de sitios. Los enlaces a la Home y para volver a la página anterior, que sirven como complemento al menú de la página principal, son frecuentes (45,9\% y 28,7\%). En algunos casos se encuentran otros elementos, pero de forma anecdótica: búsqueda (14,6\%), miga de pan $(13,4 \%)$, menú inferior $(10,2 \%)$, sistemas contextuales $(8,9 \%)$, menú 
horizontal (8,3\%), menú desplegable (7,6\%), subir (5,1\%), banner con diapositivas $(1,9 \%)$ y mapa del sitio $(0,6 \%)$, como se puede observar en el gráfico 28.

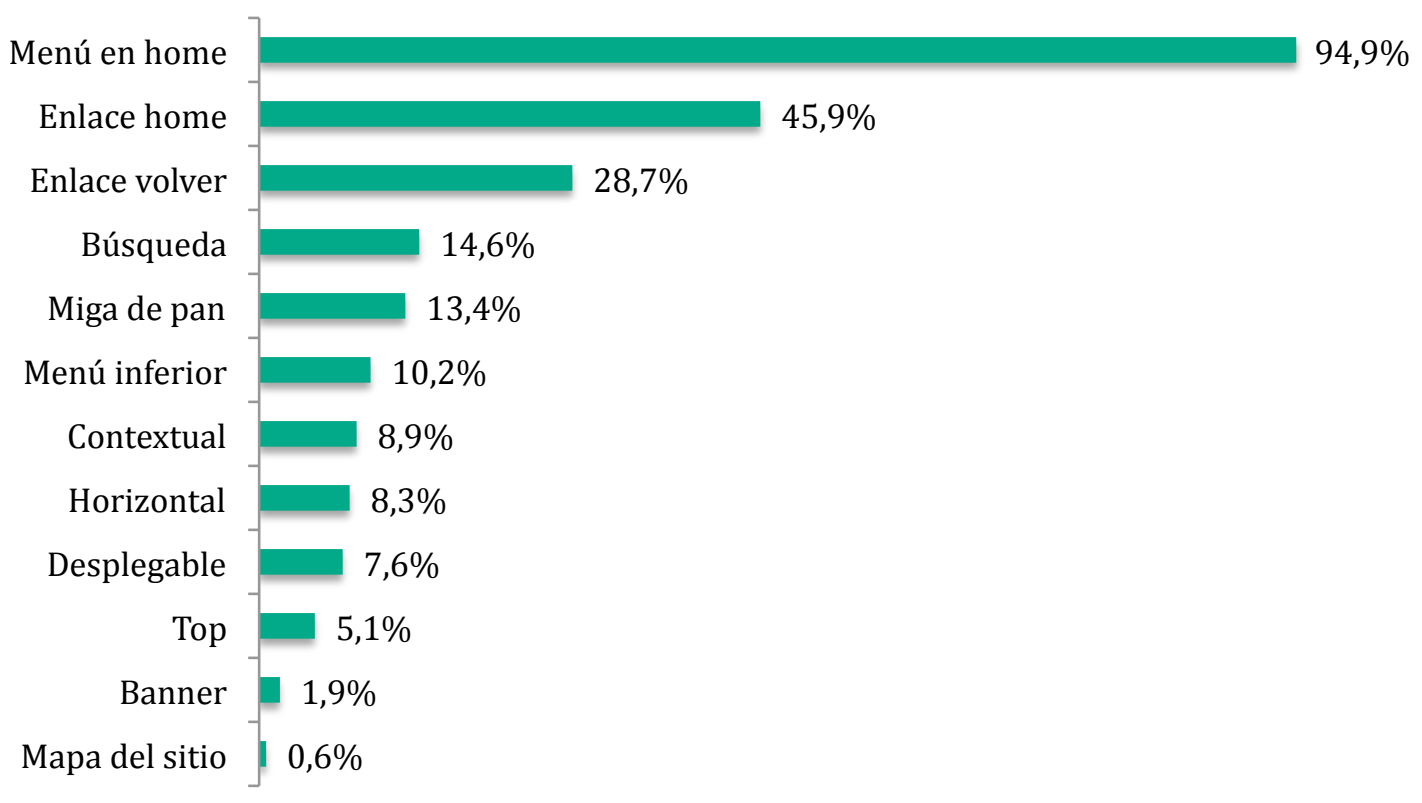

Gráfico 28. Sitios web con páginas diferenciadas para dispositivos móviles por elementos de navegación ( $n=157$ sitios web).
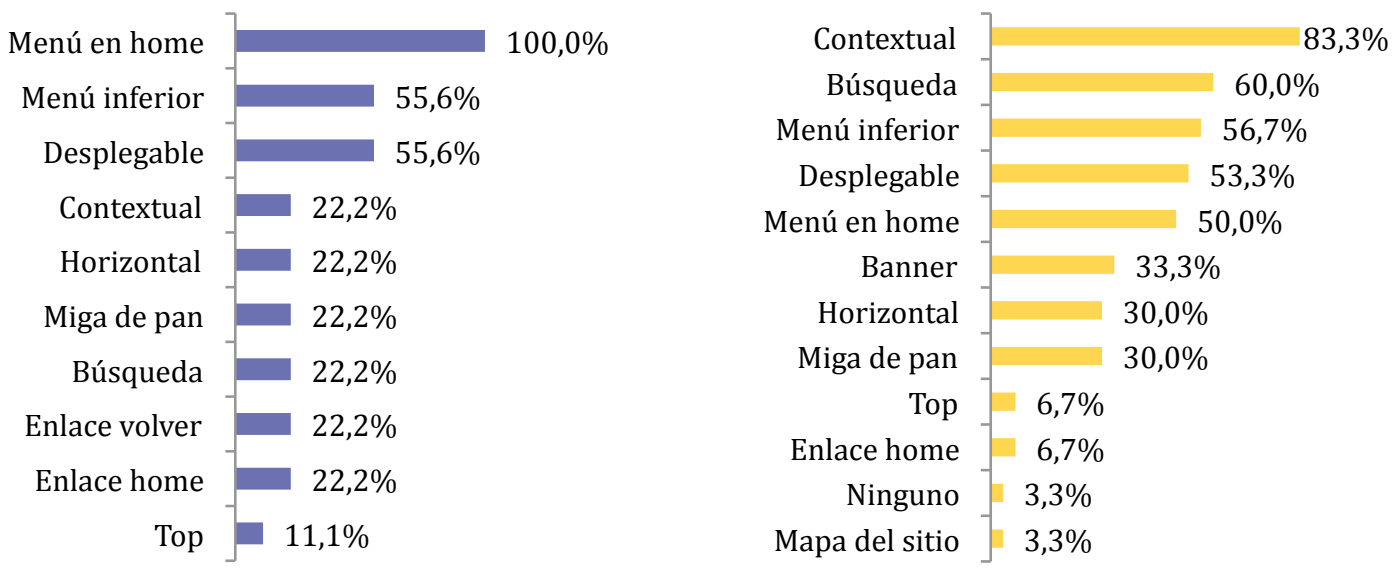

Gráfico 29. Sitios web adaptados mediante hojas de estilo (izquierda) y diseño adaptativo (derecha) $\left(n_{1}=9\right.$ y $n_{2}=30$ sitios web).

A los sitios web con diseño adaptativo se asocian elementos contextuales (en el $83,3 \%$ de ese tipo de sitios), que apenas se observan en los sitios web con páginas 
diferenciadas $(8,9 \%)$ y no se han encontrado en los sitios con hojas de estilo. Este diseño también se asocia a la búsqueda $(60,0 \%)$, el uso de menús inferiores $(56,7 \%)$ y de menús desplegables $(53,3 \%)$. Y muestra más a menudo que en otros tipos de sitios banners y menús horizontales. En la mitad de estos sitios se ha encontrado que se adaptan las home pages en formato de menú, pero no siempre es así y también se utilizan diseños de módulos (gráfico 29).

Los sitios web adaptados mediante hojas de estilo parecen un híbrido entre las anteriores soluciones en lo referente a los elementos de navegación. Con los sitios web con páginas diferenciadas comparten la preferencia por el menú en la home y con el diseño adaptativo los menús inferior y desplegable (gráfico 29).

En los sitios web de bibliotecas españolas los elementos de navegación más utilizados coinciden con los de los sitios web con páginas diferenciadas, ya que no hay ningún ejemplo de diseño adaptativo y son muy pocos los de hojas de estilo. Los más utilizados son el menú en la página principal y el menú inferior. No se ha encontrado ningún ejemplo de uso de banners, de menú horizontal o de mapa del sitio. Sin embargo, se observa que el uso de menús desplegables es más habitual que en otros países (gráfico 30).
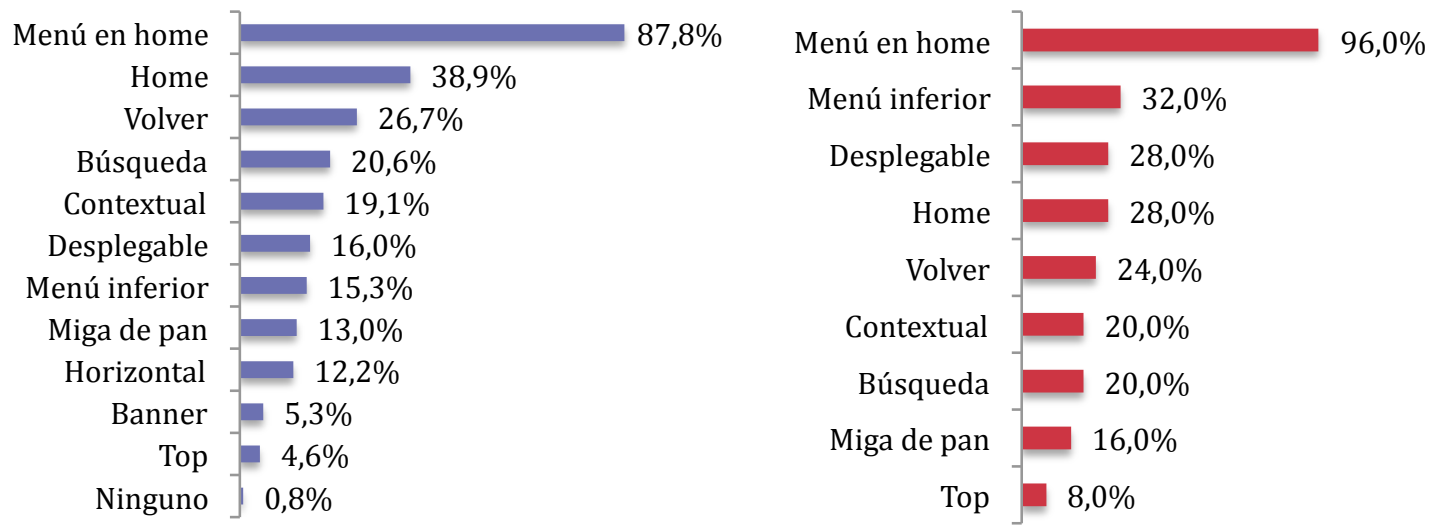

Gráfico 30. Sitios web por elementos de navegación en Estados Unidos (izquierda) y España (derecha) ( $n_{1}=131$ y $n_{2}=25$ sitios web).

El 67,3\% de los sitios web analizados incluyen páginas de acceso restringido, aunque no es posible determinar si esas páginas están o no adaptadas para dispositivos móviles por no poder acceder a ellas. Se trata de opciones que permiten realizar transacciones (reservas o renovaciones de préstamos), consultar información sobre la relación con la biblioteca (datos de contacto o fecha de vencimiento del préstamo) o utilizar servicios exclusivos para usuarios (como 
reservar ordenadores o consultar contenidos bases de datos), entre otras posibilidades.

La proporción de espacios restringidos es ligeramente mayor en las bibliotecas universitarias $(70,6 \%)$ que en las públicas $(65,5 \%)$ o en las especializadas (50,0\%). En España es menos frecuente, pues sólo se da en menos de la mitad de los sitios analizados (48,0\%), y es que requiere de un desarrollo más complejo. Sin embargo, estos enlaces no deben interpretarse como que una parte del sitio incluye páginas de acceso con contraseña, sino simplemente que se enlaza a ellas, aunque podría ser que no estuvieran adaptadas para móviles o que formaran parte de otro sitio.

\begin{tabular}{lrrrrrr} 
& \multicolumn{1}{c}{ Smartphone } & \multicolumn{3}{c}{ Tableta } & \multicolumn{2}{c}{ Teléfono móvil } \\
\hline & Sitios web & \multicolumn{1}{c}{$\%$} & Sitios web & \multicolumn{1}{c}{$\%$} & Sitios web & \% \\
\hline Menú en home & 167 & $88,4 \%$ & 11 & $61,1 \%$ & 5 & $100,0 \%$ \\
\hline Home & 74 & $39,2 \%$ & 3 & $16,7 \%$ & 2 & $40,0 \%$ \\
\hline Volver & 47 & $24,9 \%$ & 0 & $0,0 \%$ & 0 & $0,0 \%$ \\
\hline Búsqueda & 43 & $22,8 \%$ & 8 & $44,4 \%$ & 0 & $0,0 \%$ \\
\hline Contextual & 41 & $21,7 \%$ & 11 & $61,1 \%$ & 0 & $0,0 \%$ \\
\hline Menú inferior & 37 & $19,6 \%$ & 9 & $50,0 \%$ & 0 & $0,0 \%$ \\
\hline Miga de pan & 32 & $16,9 \%$ & 3 & $16,7 \%$ & 0 & $0,0 \%$ \\
\hline Desplegable & 32 & $16,9 \%$ & 8 & $44,4 \%$ & 0 & $0,0 \%$ \\
\hline Horizontal & 23 & $12,2 \%$ & 7 & $38,9 \%$ & 0 & $0,0 \%$ \\
\hline Banner & 13 & $6,9 \%$ & 6 & $33,3 \%$ & 0 & $0,0 \%$ \\
\hline Top & 11 & $5,8 \%$ & 2 & $11,1 \%$ & 0 & $0,0 \%$ \\
\hline Mapa del sitio & 2 & $1,1 \%$ & 0 & $0,0 \%$ & 0 & $0,0 \%$ \\
\hline Total & 189 & & 18 & & 5 & \\
\hline
\end{tabular}

Tabla 16. Sitios web por elementos de navegación y tipo de dispositivo ( $n=196$ sitios web).

El tipo de dispositivo es otro de los elementos determinantes en la elección de unos elementos de navegación u otros. En los sitios web diseñados para smartphones está muy extendido el menú en la página principal, en el 88,4\% de los sitios (tabla 16). En los diseños para tabletas pierde algo de importancia el menú en la página principal y la ganan otros elementos más propios de pantallas más grandes, como la búsqueda $(44,4 \%)$, los elementos contextuales $(61,1 \%)$, el menú horizontal superior $(38,9 \%)$ o los banners $(33,3 \%)$.

En los sitios web diseñados para teléfonos móviles apenas se han encontrado elementos de navegación: el menú en la página principal está presente en todos los 
casos y solo en algunas ocasiones se incluyen enlaces a la página principal y al sitio completo.

\subsection{Aprovechamiento de las funciones del dispositivo}

Los dispositivos móviles presentan algunas funciones que les diferencian de los ordenadores. Básicamente, son pequeños ordenadores, pero además incorporan telefonía móvil, son herramientas de productividad y tienen la capacidad de detectar la posición geográfica. El World Wide Web Consortium (Rabin y McCathieNevile, 2008) recomienda «utilizar las capacidades del dispositivo para ofrecer una mejor experiencia de usuario en dispositivos más capaces.»

Además, a través del navegador es posible enlazar con dichas funciones facilitando algunas tareas al usuario:

- Llamar directamente a un número de teléfono, enviarle un mensaje SMS o guardarlo en la agenda al hacer clic en el enlace que aparece en la web. Para hacerlo posible el sitio web debe tener habilitado un enlace especial para cada una de esas funciones.

- Enviar un correo electrónico a una dirección previamente enlazada, o guardar esa dirección en la agenda. Estas funciones también se encuentran en ordenadores portátiles o de sobremesa.

- Detectar la posición del usuario y ofrecerle información sobre contenidos o servicios a su alrededor o trazar la mejor ruta para llegar a un lugar.

De todas ellas, la opción que más a menudo se aprovecha en los sitios web de las bibliotecas son los enlaces que cumplen la función de enviar un correo electrónico a la dirección indicada $(66,8 \%)$. Esto podría deberse a que es la opción con la que se está más familiarizado, ya que se utiliza también en los sitios web para grandes pantallas, y por lo tanto aparece también en los sitios web con diseño adaptativo. Apenas hay diferencias en función del área geográfica, aunque se observa una mayor incidencia de este elemento en los sitios web de países diferentes a Estados Unidos y España $(77,5 \%)$.

Los enlaces a llamadas telefónicas son la siguiente función más utilizada, están presentes en algo más de la mitad de la muestra (52,0\%). Sin embargo, sí se observan más a menudo en las bibliotecas de Estados Unidos $(59,5 \%)$ que en España $(32,0 \%)$ u otros países $(40,0 \%)$. En una tercera parte de los sitios web 
analizados (33,2\% de la muestra) se han encontrado números de teléfono sin enlazar. Esto es muy habitual en los sitios web con diseño adaptativo — se da en el $63,3 \%$ de este tipo de sitios-, ya que los enlaces no son una cuestión de estilo, sino de contenidos. Se han encontrado excepciones en las que, desde el sitio web completo, se enlaza a un número de teléfono, y por lo tanto también en las demás versiones. Por el contrario, es muy poco habitual encontrar correos electrónicos sin enlazar $(3,1 \%$ de los sitios analizados $)$.

Total

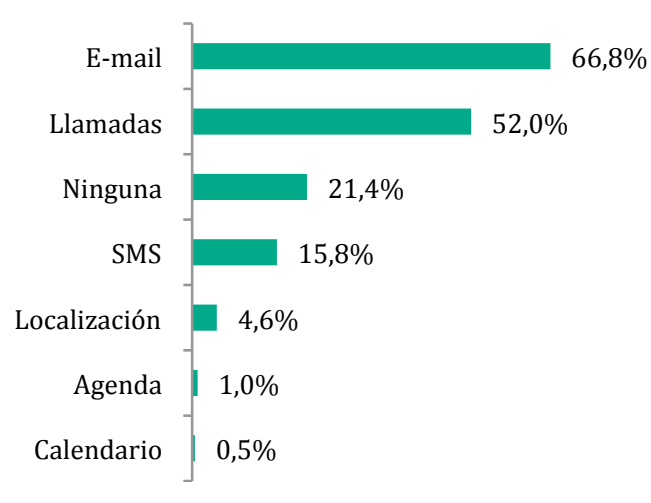

España

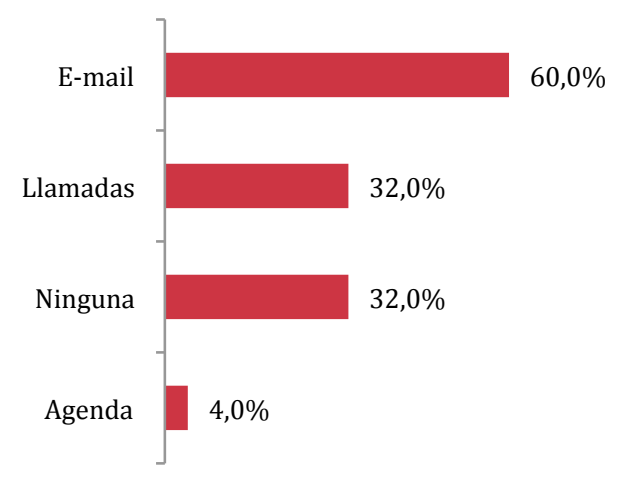

Estados Unidos

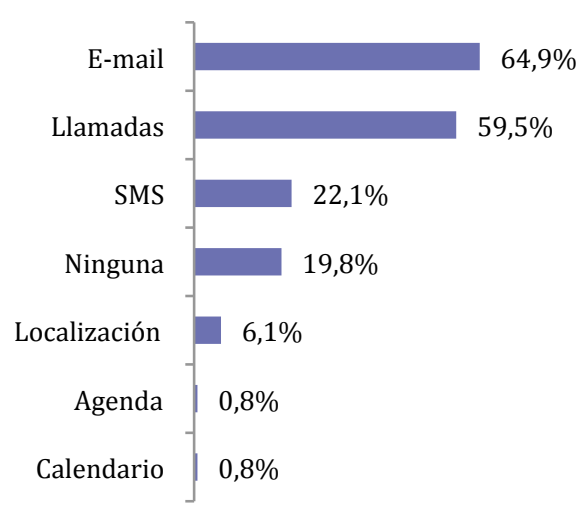

Gráfico 31. Sitios web según el aprovechamiento de las funciones del dispositivo ( $n=196$ sitios web).

Son muy poco utilizadas otras funciones, como los enlaces para incluir contactos en la agenda, guardar fechas en el calendario o la geolocalización. Los sitios web 
con geolocalización se hallan por primera vez en 2010 y 2011 y solo se han encontrado 9, 8 en bibliotecas estadounidenses y una en el Reino Unido. Se utiliza para:

- Mostrar las bibliotecas más cercanas a la posición del usuario en un mapa Google incrustado. Lo utilizan los sitios web WolfWalk y BeaverTracks y las bibliotecas de la Berkeley University, Alvin Sherman Library (Nova Southwest University) y Brooklyn Public Library.

- Localizar las sedes de la biblioteca en un listado, por orden de proximidad, en el Orange County Library System.

- Localizar la biblioteca más cercana en que se encuentra un libro del catálogo, en las bibliotecas de Oxford y Harvard.

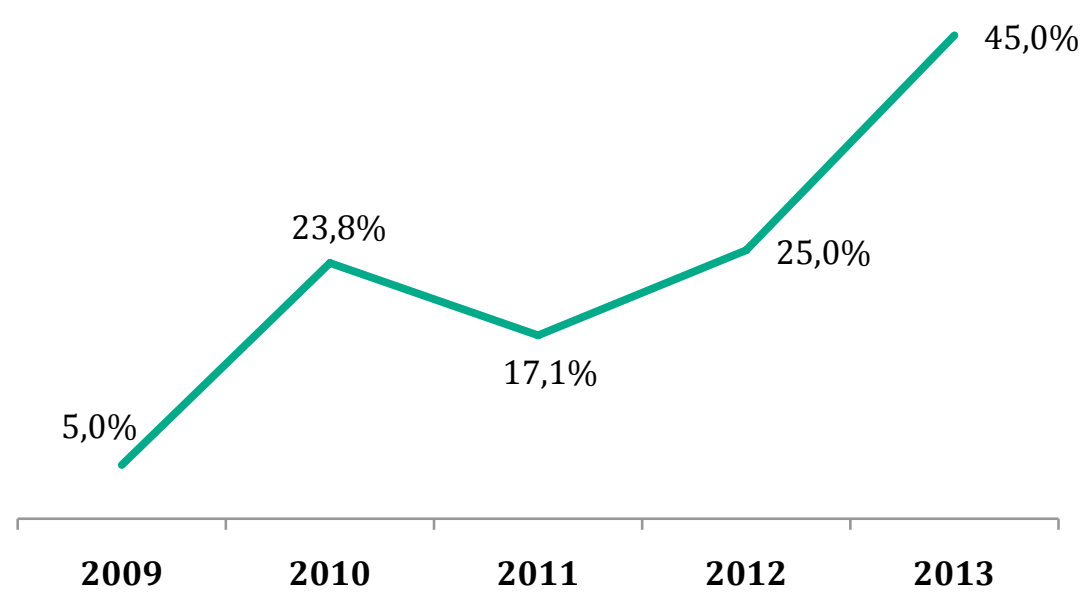

Gráfico 32. Evolución en el número de sitios web que no aprovechan ninguna función del dispositivo ( $n=171$ sitios web).

En España es mayor la proporción de bibliotecas que no aprovechan ninguna de las funciones descritas $(32,0 \%)$ que en otros países: en el total de la muestra es algo más de una quinta parte $(21,4 \%)$. Lo cierto es que ese porcentaje de sitios web que no hacen uso de las funciones del dispositivo aumenta a lo largo del tiempo. En el caso de los sitios web con diseño adaptativo la proporción $(40,0 \%)$ es también mayor que en el resto: en los sitios que emplean hojas de estilo supone el $22,2 \%$ y en aquellos con páginas diferentes para dispositivos móviles el 17,8\%. En definitiva, se puede decir que en los sitios web con diseño adaptativo se utilizan menos las funciones de los dispositivos móviles y en menor medida y son más los sitios web que no aprovechan ninguna función. 


\subsection{Formato de los contenidos}

Texto e imagen son los formatos más habituales en los sitios web analizados, pero no son tan usuales otros, como documentos $(16,8 \%)$, vídeo $(13,8 \%)$ o audio $(4,1 \%)$. Estos formatos están más presentes en sitios web que han optado por hojas de estilo y diseño adaptativo.

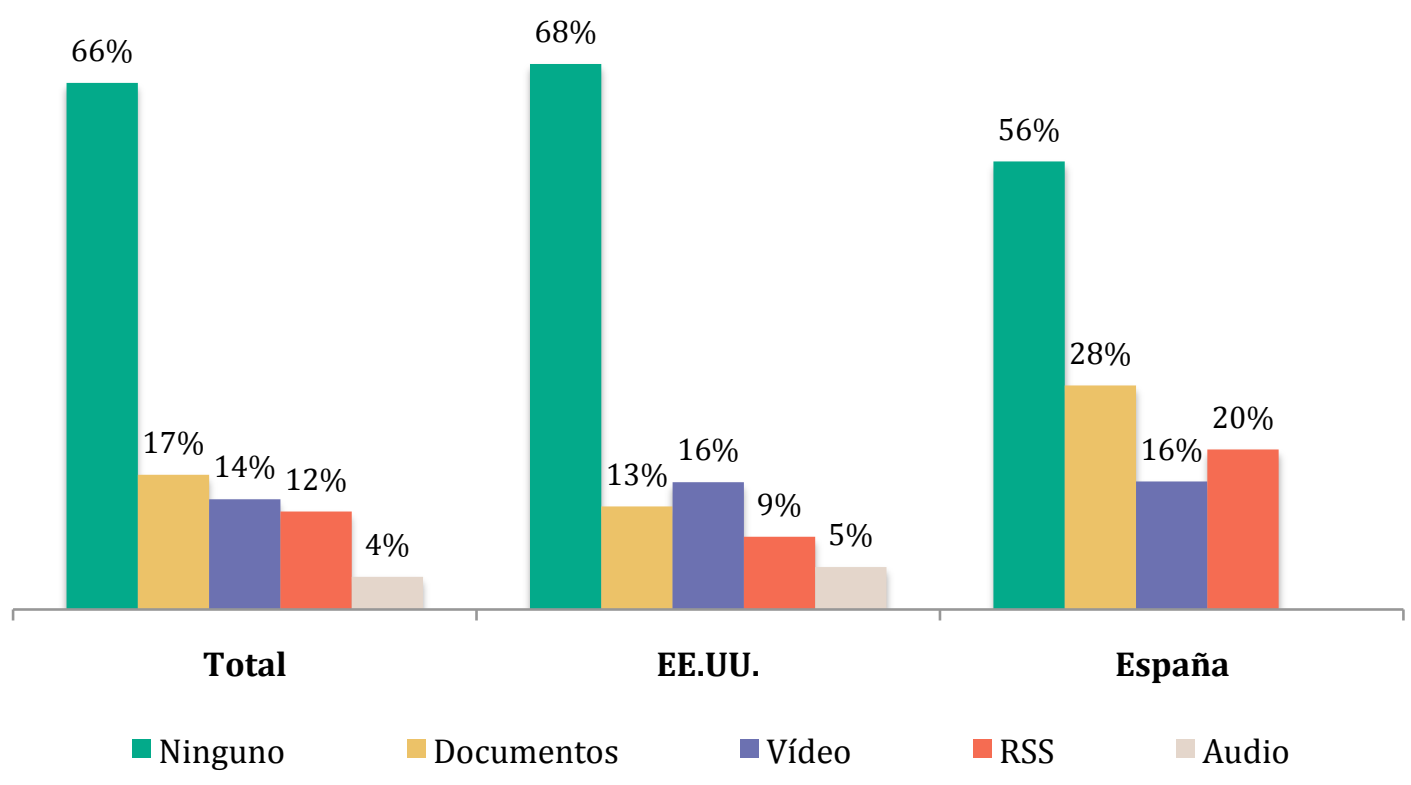

Gráfico 33. Sitios web por formatos de los contenidos y país ( $n=196$ sitios web).

La mayor parte de los sitios web con páginas diferenciadas para dispositivos móviles $(72,6 \%)$ no contienen ninguno de estos formatos, pero el porcentaje se reduce considerablemente cuando las soluciones de movilidad son diseño adaptativo (36,7\%) y hojas de estilo $(44,4 \%)$, como se aprecia en el gráfico 34.

Se han encontrado además varios sitios web que incluyen un enlace a un fichero RSS para suscribirse a un canal de noticias. Esta opción no se considera especialmente útil desde un dispositivo móvil, debido a que no cumple una de las recomendaciones fundamentales para este tipo de dispositivos: hacer que las tareas sean fáciles y rápidas. Al abrir un fichero RSS desde los navegadores incorporados en sistemas operativos Android y Windows Phone, estos se limitan a mostrar el fichero RSS, y lo mismo sucede en un iPad. El usuario debería, por lo 
tanto, copiar la dirección, abrir el programa lector de RSS que tenga incorporado en su dispositivo, escoger la opción suscribir y pegar allí el URL copiado. El navegador Safari para iPhone, sin embargo, se intenta suscribir al RSS a través del programa para podcasts con nulos resultados, pues este programa está diseñado para ficheros de audio. En sitios web diseñados para este tipo de dispositivos, por lo tanto, podría ser de interés un enlace a un fichero RSS para suscribirse a un podcast, como en la Biblioteca Duggan (Hanover College).

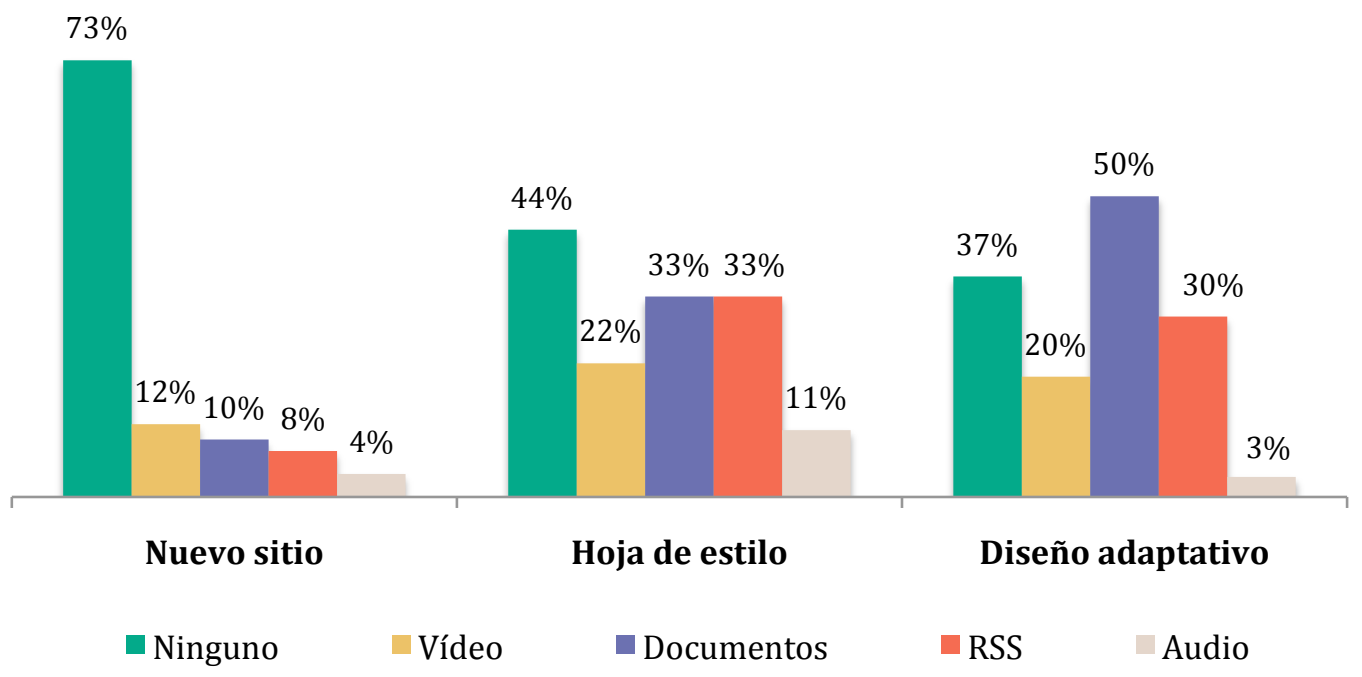

Gráfico 34. Sitios web por formatos de los contenidos y solución de movilidad adoptada ( $n=196$ sitios web).

Una cuestión que merece la pena destacar es la de los documentos, pues la mayor parte de los que se han detectado están en formato pdf, un formato que no se adapta a las pantallas y creado para pantallas grandes o para ser impreso. Cuando se enlaza un documento desde un smartphone es recomendable que su formato sea fácilmente legible desde una pantalla de dimensiones reducidas, como el ePub, que se adapta a las pantallas. No se ha encontrado ningún sitio web para móviles que enlace sus documentos en un formato ePub. 


\subsection{Contenidos y servicios}

El World Wide Web Consortium define la adaptación de contenidos como el proceso de alteración del contenido para mejorar la experiencia de usuario en determinados dispositivos (Rabin y McCathieNevile, 2008). Nielsen y Budiu (2013) sugieren, al crear sitios web para móviles, prescindir de aquellos contenidos y opciones que sean innecesarios, manteniendo solo los que tengan utilidad para el usuario de dispositivos móviles. La razón es que la comprensión se reduce en las pantallas pequeñas porque los usuarios pueden ver menos contenidos al mismo tiempo y deben moverse más por la página, utilizando el scroll, por lo que el contenido debe ser fácil de leer y escanear. Esto supone todo un reto, pues la respuesta a una necesidad de información no debería variar en función del dispositivo.

Por lo tanto, una de las preguntas que más interés ha suscitado en la bibliografía especializada es la siguiente: ¿cuáles son la información y servicios más relevantes para los usuarios de una biblioteca cuando acceden desde un dispositivo móvil a su sitio web? En este apartado se analizan las soluciones que han dado las bibliotecas en los sitios web analizados.

Se analizarán en este apartado los sitios web cuyas páginas son diferentes de las del sitio web para grandes pantallas y que representan a la biblioteca, para salvaguardar la homogeneidad, puesto que el resto de los casos -OPAC y otras utilidades - presentarían contenidos y servicios muy diferentes. En los sitios web para dispositivos móviles que utilizan diseño adaptativo u hojas de estilo los contenidos son idénticos a los sitios con pantallas completas, mientras que en los sitios web con páginas diferenciadas se ha realizado un proceso de adaptación de contenidos, objeto de análisis de este trabajo. Por otra parte, la mayor parte de los sitios web estudiados representan a la biblioteca y contienen su información básica, mientras que sólo un pequeño porcentaje $(5,6 \%)$ tienen una utilidad diferente, una cantidad demasiado pequeña como para arrojar resultados significativos.

En los sitios web con páginas diferenciadas y que representan a la biblioteca se han encontrado los siguientes contenidos y servicios:

- Datos de contacto, como número de teléfono o correo electrónico.

- Datos de localización, que sería la dirección del centro. Se marca esta opción siempre y cuando se den los datos de forma escrita y no situando a la biblioteca en un mapa, en cuyo caso se ha indicado la siguiente opción.

- Mapa con la situación de la biblioteca o de los puntos de servicio de la red, en ocasiones enlazando a un mapa de Google Maps o incrustándolo, pero también en forma de imagen. 
- Cómo llegar. Es un apartado con información textual con indicaciones escritas sobre cómo llegar a la biblioteca desde un lugar determinado o las rutas de transporte público que hay que tomar. No se incluyen en este apartado los mapas que indican la ruta para llegar.

- Mapa de planta, que ayuda a ubicarse en las diferentes plantas del edificio.

- Mapa de signatura, que incluye información sobre las secciones de la biblioteca y su organización con el fin de localizar los fondos.

- Horario de apertura de la biblioteca.

- Directorio de bibliotecas, con información de contacto y/o localización sobre cada una de las sedes. Este apartado se encuentra únicamente en bibliotecas con varios puntos de servicio.

- Directorio de personal. Organizado por orden alfabético, por departamentos o en forma de buscador, proporciona información de contacto del personal de la biblioteca.

- Información sobre los servicios que presta la biblioteca.

- Noticias sobre la biblioteca u otros aspectos relacionados con sus ámbitos de trabajo.

- Eventos que organiza la biblioteca. En este apartado y el anterior es común que se enlace a cada pieza de contenido en un blog u otra página web, de manera que el sitio para móviles no contiene la noticia completa.

- Recomendación de lecturas, música, películas u otros materiales que se encuentran en la biblioteca.

- Selección de novedades. Muy similar al anterior, tan solo se diferencia en que el criterio de selección es que los documentos de la lista se hayan incorporado recientemente a la colección.

- Enlaces de interés sobre temas determinados. Se trata de listados con enlaces recomendados por la biblioteca. Se ha diferenciado este apartado de las guías de investigación, que se presentan a continuación.

- Guías de investigación, que en las bibliotecas universitarias estadounidenses suele ofrecerse a través del servicio LibGuides. Se trata de una recopilación de recursos y enlaces de utilidad para el personal investigador.

- Disponibilidad de salas en grupo, ordenadores de uso público u otros servicios y recursos de la biblioteca.

- Reserva de salas en grupo, de ordenadores o de material específico para algunos cursos. Esto último es habitual en las bibliotecas estadounidenses y no se ha encontrado en las bibliotecas españolas.

- Enlaces a los perfiles en redes sociales de la biblioteca: Facebook, Twitter u otras.

- Acceso al catálogo de la biblioteca. 
- Herramienta de descubrimiento, que Fagan, et al. (2012) definen como un «software web que busca metadatos de artículos de revista y del catálogo en un índice unificado y presenta los resultados en una única interfaz. Esto difiere del software de búsqueda federada, que busca en múltiples bases de datos y agrega los resultados.». En algunos casos se han detectado bibliotecas que mantienen simultáneamente dos versiones del catálogo o catálogo y herramienta de descubrimiento.

- Revistas electrónicas. Este servicio suele darse en forma de listado, aunque a veces también se puede consultar a través de un buscador a medida o de un servicio como EBSCOhost.

- Acceso a bases de datos contratadas por la biblioteca u otras. A menudo se presenta como un servicio de acceso restringido para usuarios de la biblioteca.

- Préstamo de libros electrónicos, a través de servicios como OverDrive o BiblioCommons.

- Colección digital. En algunas bibliotecas, de forma puntual, se han encontrado colecciones de fotografías o documentos que se muestran como si de una colección digital se tratara.

- Cuenta de usuario es el apartado en el que el usuario puede conocer el estado de sus préstamos y gestionar reservas o renovaciones, por ejemplo. Al tratarse de un servicio exclusivo para socios y estar protegido por contraseña ha sido imposible estudiar qué opciones incluye.

- Servicio de referencia, a través del cual se ofrece la posibilidad de formular consultas al personal de la biblioteca a través del correo electrónico, teléfono o mensajería SMS, de formularios, de chats o de servicios similares, siempre que estén bajo el epígrafe Pregunta a la biblioteca. Es preciso diferenciar el servicio de referencia de los directorios de personal en los que se incluyen los datos de contacto.

- Visitas guiadas y tutoriales. Se trata de vídeos o ficheros de audio en los que se explica el funcionamiento de la biblioteca, sus instalaciones u otros aspectos relacionados con el uso de la información.

- Juegos. En algunos sitios web se han encontrado enlaces a juegos en línea o videojuegos.

- Recomendación de aplicaciones nativas para móviles, diferentes de la aplicación de la biblioteca. Se trata de aplicaciones con una temática determinada que puedan ser de utilidad a los usuarios.

- Descarga de aplicaciones de la biblioteca. Se trata de enlazar la app de la biblioteca para su descarga desde la versión móvil del sitio web. 
- Feedback, que se suele presentar en forma de formulario o de encuesta sobre aspectos concretos. Por ejemplo, en algunas bibliotecas se han encontrado cuestionarios sobre el sitio web para móviles.

- Preguntas frecuentes o FAQ. Se trata de un apartado en el que se explican cuestiones que suelen consultar los usuarios con relativa frecuencia.

- About, que explica quién está detrás del sitio web.

- Ayuda, con información sobre el uso del sitio web.

En todos estos contenidos y servicios se diferenciarán además aquellos casos en que las páginas forman parte del mismo sitio web (enlaces internos) o de otros sitios web (enlaces externos). Esto último sucede cuando los contenidos externos están soportados por otros servicios, como LibGuides, Google Maps o determinado software para el catálogo, o cuando se enlaza a otro sitio web, por ejemplo al blog de la biblioteca o a una versión del catálogo desarrollada por la propia biblioteca pero alojada en una sede web diferente. Hasta el momento no se conoce ningún estudio que haya tenido en cuenta esta variable, a pesar de la importancia cualitativa que supone, por cuanto tiene en consideración la diferencia entre enlazar páginas externas o mostrar contenidos y servicios en el propio sitio. En algunos casos extremos se ha observado que la versión para móviles del sitio web de la biblioteca funciona como mero portal y contiene enlaces a diferentes apartados que se encuentran en el sitio web completo, por lo que se ofrecen en enlaces externos.

Cuando los contenidos enlazados desde la página principal están incluidos dentro del propio sitio web para móviles, el diseño de estas páginas enlazadas está adaptado para dispositivos móviles. Pero no siempre es así cuando las páginas están fuera del sitio web: en algunos casos sí están adaptadas y en otras no. Este aspecto se analizará más adelante, en el apartado 4.11, sobre ajuste a las características del dispositivo.

Al analizar qué contenidos y servicios incluyen los sitios web para móviles el gráfico resultante muestra una distribución en forma de larga cola (gráfico 35). Esto significa que hay unos pocos contenidos que son muy usuales y muchos contenidos que aparecen en unos pocos sitios web. El gráfico 35 muestra cómo sólo dos de los contenidos analizados están presentes en más de las tres cuartas partes de los sitios web $-\mathrm{y}$ por lo tanto hay consenso en cuanto a su importancia-, mientras que más de la mitad de los contenidos (21 de 35) está presente en menos de un tercio de los sitios web. Esto es un claro indicativo de la gran variedad en los contenidos y servicios que aparecen en los sitios web para móviles de las bibliotecas, pero también refleja las diferencias entre tipos de bibliotecas. 


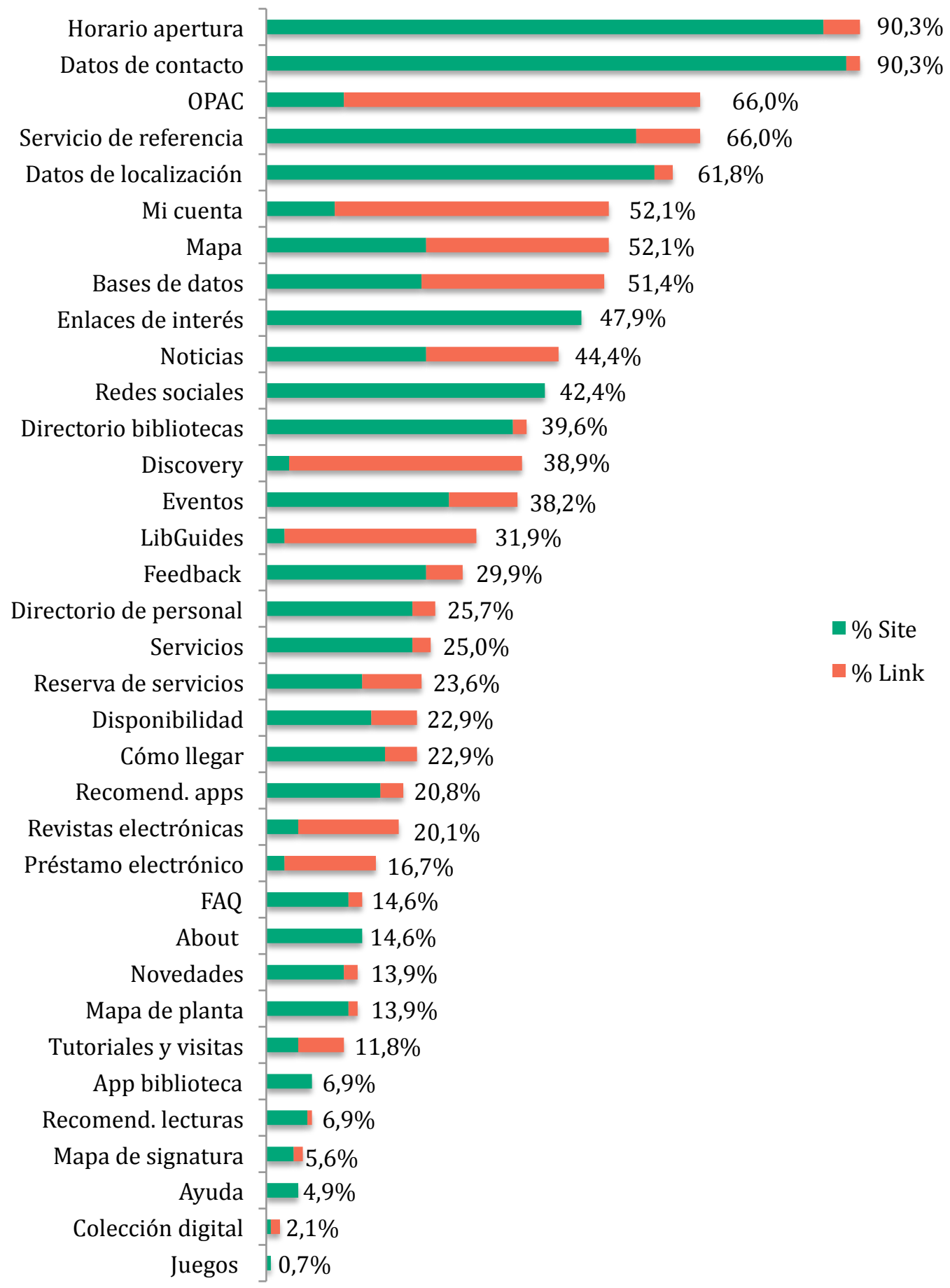

Gráfico 35. Contenidos y servicios en los sitios web para dispositivos móviles de la biblioteca con páginas diferenciadas en el conjunto de la muestra ( $n=144$ sitios web).

Como se aprecia en el gráfico 35, los contenidos más habituales en los sitios web para móviles analizados son el horario de apertura y los datos de contacto (presentes ambos en el 90,3\% de los sitios web analizados). El catálogo y el 
servicio de referencia comparten la tercera posición en este ranking y se encuentran en el 66,0\% de los sitios web estudiados. Más de la mitad de los sitios web incluye además datos de localización $(61,8 \%)$, cuenta de usuario $(52,1 \%)$, localización de las bibliotecas en el mapa $(52,1 \%)$ y acceso a bases de datos $(51,4 \%)$.

En un segmento intermedio se encuentran contenidos como los enlaces de interés $(47,9 \%)$, noticias $(44,4 \%)$, directorios de bibliotecas $(39,6 \%)$, herramientas de descubrimiento $(38,9 \%)$, eventos $(38,2 \%)$, guías de investigación o LibGuides $(31,9 \%)$, feedback $(29,9 \%)$, directorios de personal $(25,7 \%)$, servicios $(25,0 \%)$, reserva de servicios $(23,6 \%)$, disponibilidad de recursos $(22,9 \%)$, indicaciones de cómo llegar a la biblioteca $(22,9 \%)$ y recomendación de aplicaciones $(20,8 \%)$.

Son contenidos poco usuales las revistas electrónicas $(20,1 \%)$, el préstamo de libros electrónicos $(16,7 \%$, aunque posiblemente en el caso de las bibliotecas estadounidenses sean más las que lo proporcionan), preguntas frecuentes $(14,6 \%)$, About $(14,6 \%)$, novedades $(13,9 \%)$, mapa de planta $(13,9 \%)$ y tutoriales y visitas guiadas $(11,8 \%)$. Es muy poco frecuente, más bien anecdótica, la presencia de los siguientes secciones: enlace a la app de la biblioteca $(6,9 \%)$, recomendación de lecturas $(6,9 \%)$, mapa de signatura $(5,6 \%)$, ayuda $(4,9 \%)$, colección digital $(2,1 \%)$ y juegos $(0,7 \%)$. Se han encontrado en diez casos o menos.

Este análisis revela un desaprovechamiento de oportunidades en algunos aspectos, como enlazar a los perfiles en medios sociales y a la app de la biblioteca desde el sitio web para móviles. A pesar de que casi todas las bibliotecas analizadas están presentes en los medios sociales — tal y como se apuntó en el apartado 4.1.2., el $96,4 \%$ de las bibliotecas con sitios web diseñados para dispositivos móviles está presente en la web social-, menos de la mitad $(42,4 \%)$ enlaza a sus perfiles desde sus sitios web para móviles. En el caso de las apps, solo el 31,6\% de las bibliotecas que tienen sitio web diseñado para dispositivos móviles y alguna aplicación nativa enlaza a la app desde el sitio web para móviles.

Los servicios que se presentan en páginas externas al sitio web para móviles suelen ser aquellos para los que se contratan servicios de empresas externas: herramientas de descubrimiento (son externas en el 91,1\% de los sitios web que las enlazan) y OPAC $(82,1 \%)$, bases de datos $(54,1 \%)$, préstamo de libros electrónicos $(83,3 \%)$, cuenta de usuario $(80,0 \%)$, revistas electrónicas $(75,9 \%)$, guías de investigación, que en el $91,3 \%$ de los casos se prestan a través de LibGuides.

También la localización de las bibliotecas en el mapa y las noticias se presentan a menudo en páginas externas. En el caso de la localización, se enlaza al mapa de Google Maps en el 53,3\% de los casos, en lugar de incrustarlo en el sitio, que es la 
opción del porcentaje restante. El texto completo de las noticias aparece con frecuencia en el blog de la biblioteca (45,3\%), que es externo al sitio web para móviles, o en otras páginas de la web completa.

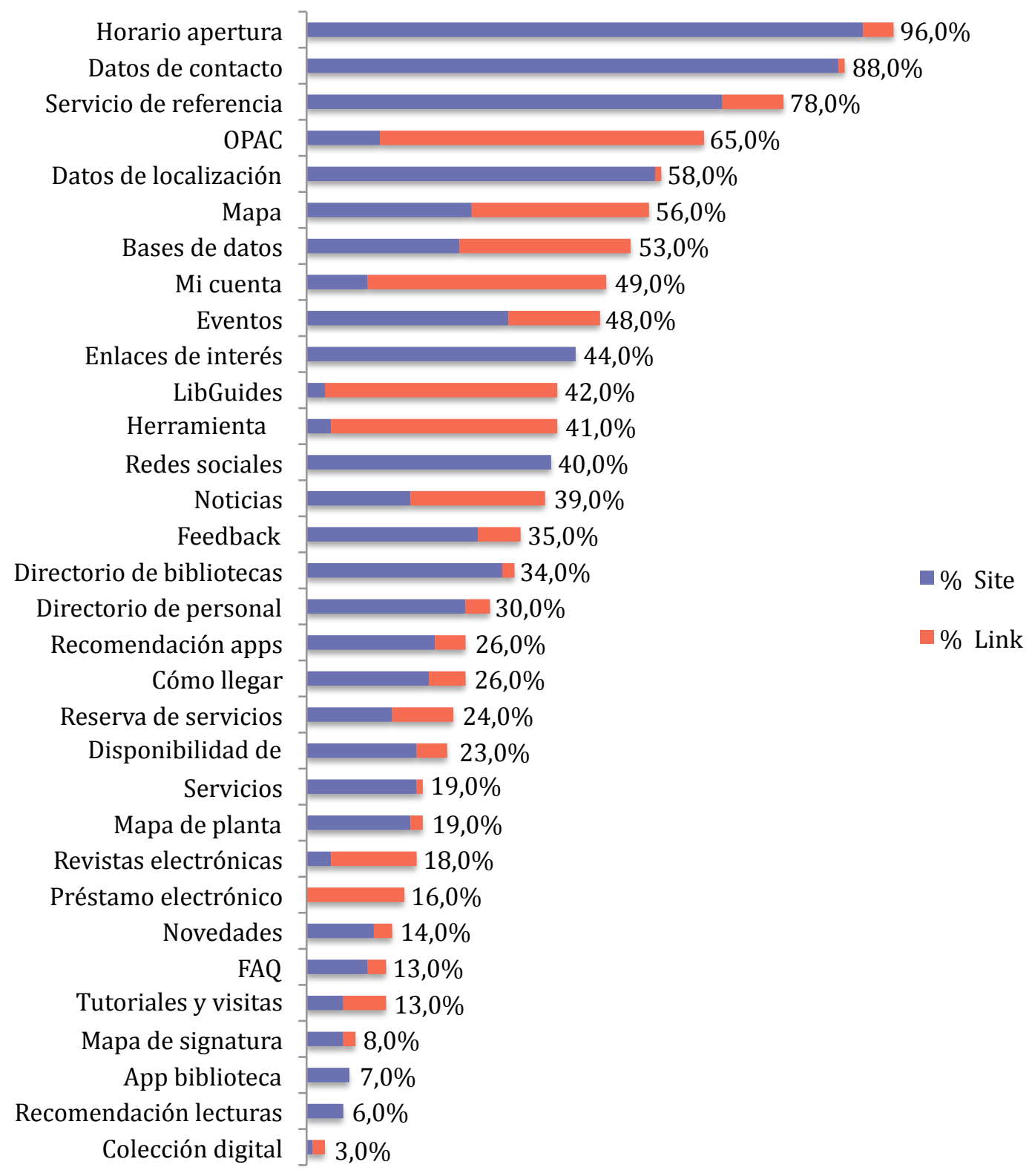

Gráfico 36. Contenidos y servicios en los sitios web para dispositivos móviles de la biblioteca con páginas diferenciadas en Estados Unidos ( $n=100$ sitios web).

Se observan significativas diferencias entre países, especialmente entre Estados Unidos y España, en lo referente a los contenidos y servicios en los sitios web para dispositivos móviles. En Estados Unidos el contenido más frecuente es el horario 
de apertura, presente en prácticamente todos los sitios web para móviles analizados $(96,0 \%)$. Le siguen en importancia los datos de contacto de la biblioteca $(88,0 \%)$, el servicio de referencia $(78,0 \%)$ y el catálogo $(65,0 \%)$. Teniendo en cuenta que la mayor parte de los casos analizados en el conjunto de la muestra corresponden a bibliotecas estadounidenses, el gráfico resultante (gráfico 36) es muy similar al del conjunto.

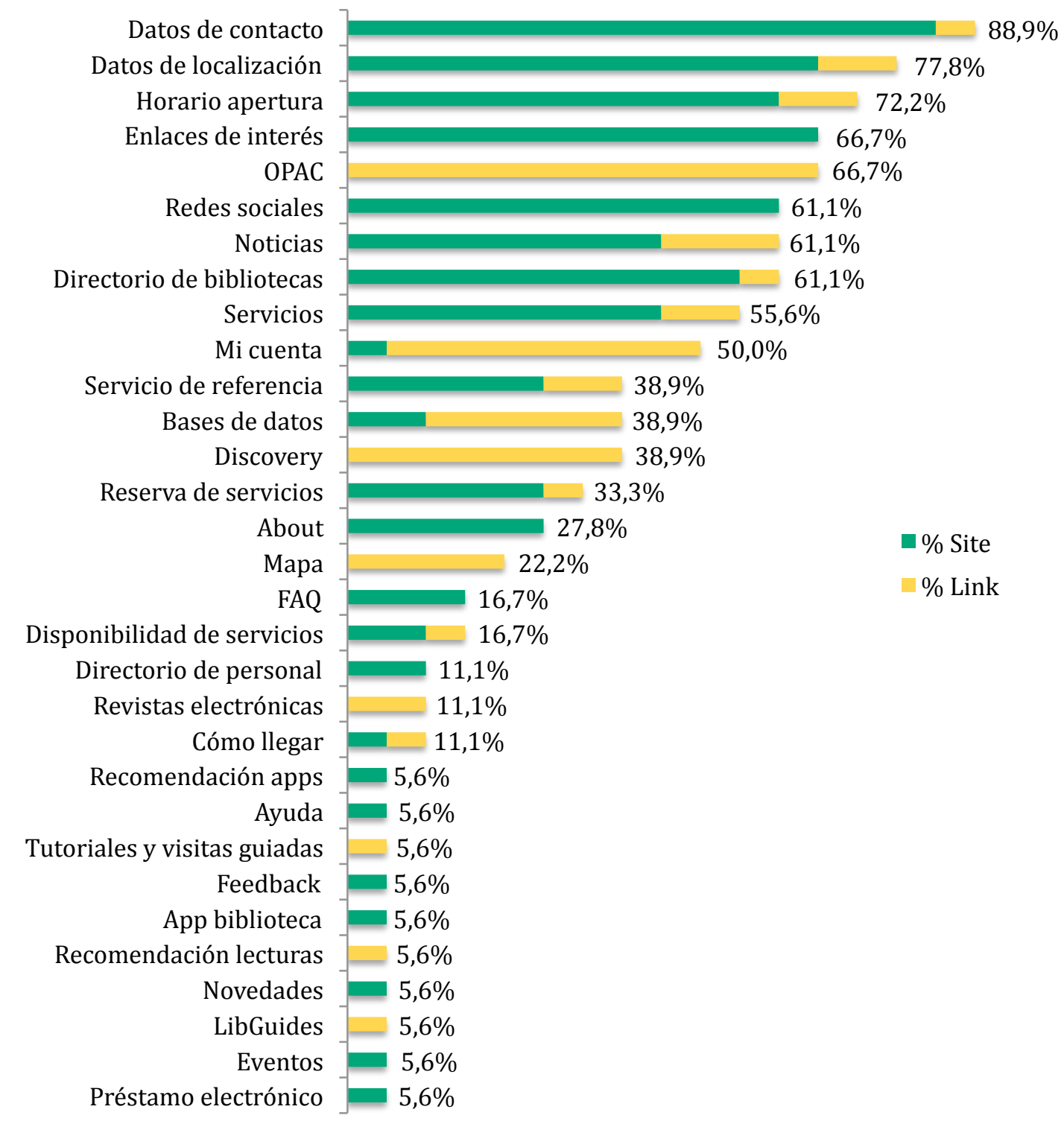

Gráfico 37. Contenidos y servicios en los sitios web para dispositivos móviles de la biblioteca con páginas diferenciadas en España ( $n=18$ sitios web). 
En España se observa un mayor consenso en los contenidos de los sitios web para móviles de las bibliotecas: casi un tercio de los contenidos se han encontrado en más de la mitad de los sitios analizados. Pero también se acentúa el efecto de larga cola, con una gran cantidad de contenidos muy poco utilizados: casi la mitad de los apartados $(45,2 \%)$ se han detectado en tan solo uno o dos casos. Así, emergen tres grandes grupos aproximadamente del mismo tamaño: los contenidos y servicios muy frecuentes (en más de la mitad de los casos), los muy poco frecuentes (aparecen una o dos veces) y una zona intermedia. No se ha encontrado ningún sitio web en las bibliotecas españolas con mapa de planta o de signatura, juegos o que incluya una colección digital.

En los sitios web de las bibliotecas españolas (gráfico 37) los contenidos más frecuentes son los datos de contacto $(88,9 \%)$ y localización $(77,8 \%)$, los horarios de apertura (72,2\%), enlaces de interés $(66,7 \%)$ y el OPAC $(66,7 \%)$. Los servicios de referencia y las guías de investigación, tan frecuentes en Estados Unidos (78,0\% y 42,0\%), apenas están presentes (38,9\% y 5,6\% respectivamente). En España también son menos habituales contenidos como la localización en el mapa $(22,2 \%$ en España y 56,0\% en Estados Unidos), información sobre cómo llegar (en dos casos en España, 26,0\% en Estados Unidos), directorio de personal (en dos casos en España, 30,0\% en Estados Unidos) y feedback (en un caso en España, 35,0\% en Estados Unidos). Se sospecha que algunas de esas diferencias tengan que ver con el peso de las bibliotecas públicas y universitarias en el conjunto de la muestra.

En España el préstamo de libros electrónicos en bibliotecas es anecdótico en el momento del análisis de la muestra y por lo tanto sólo se ha encontrado un sitio web que permite el préstamo: Saludteca, el sitio web de la Red de Bibliotecas del Sistema Sanitario Público de Extremadura. En Estados Unidos es más común $(16,0 \%)$, aunque no se puede decir que esta opción esté a menudo enlazada desde las versiones móviles de los sitios web de las bibliotecas, a pesar de que sería un servicio óptimo para ser consultado desde el móvil, teniendo en cuenta que los smartphones y tabletas son también dispositivos de lectura.

Por el contrario, son más frecuentes opciones como los enlaces de interés $(66,7 \%$ de los casos en España, 44,0\% en Estados Unidos), enlazar a las redes sociales (61,1\% en España, 40,0\% en Estados Unidos), noticias (61,1\% en España, 39,0\% en Estados Unidos), directorio de bibliotecas (61,1\% en España, 34,0\% en Estados Unidos) y servicios (55,6\% en España, 19,0\% en Estados Unidos).

La tendencia a externalizar servicios es más fuerte en España y apenas se encuentran desarrollos propios: en el caso de las herramientas de descubrimiento y de los catálogos, todos los detectados se presentan en páginas externas al sitio web. 


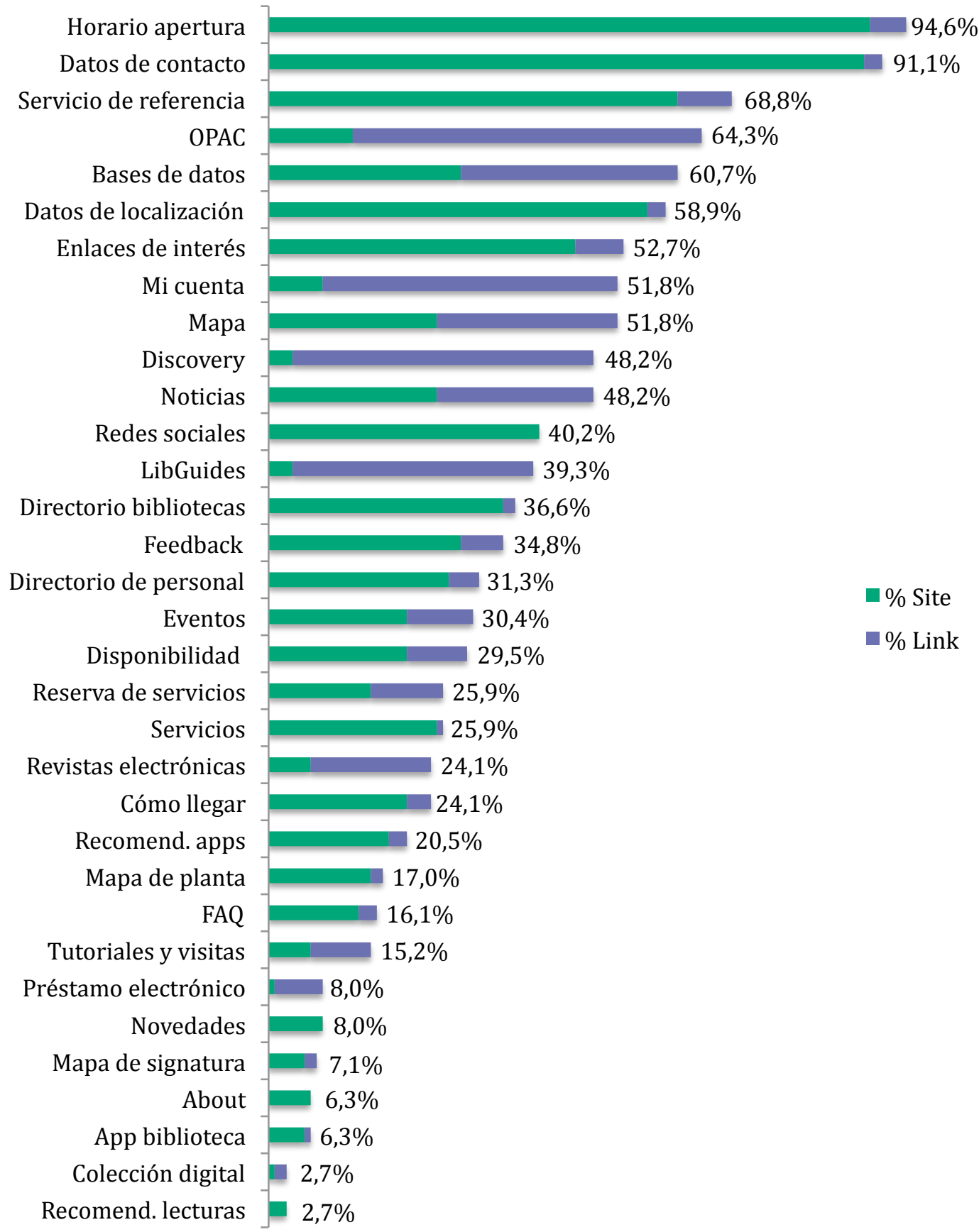

Gráfico 38. Contenidos y servicios en los sitios web para dispositivos móviles de la biblioteca con páginas diferenciadas en bibliotecas universitarias ( $n=112$ sitios web).

También se observan diferencias importantes entre los sitios web para móviles según el tipo de biblioteca. Contenidos como los datos de contacto, el horario de apertura, el catálogo, servicios de referencia y datos de localización están entre los 
más comunes tanto en bibliotecas públicas como universitarias (gráficos 38 y 39). Sin embargo, la frecuencia de aparición de estos tres últimos contenidos varía entre ambos tipos de bibliotecas y es bastante menor en las bibliotecas universitarias. En las públicas se observa un mayor consenso, con estos cinco contenidos en más de las cuatro quintas partes de la muestra.

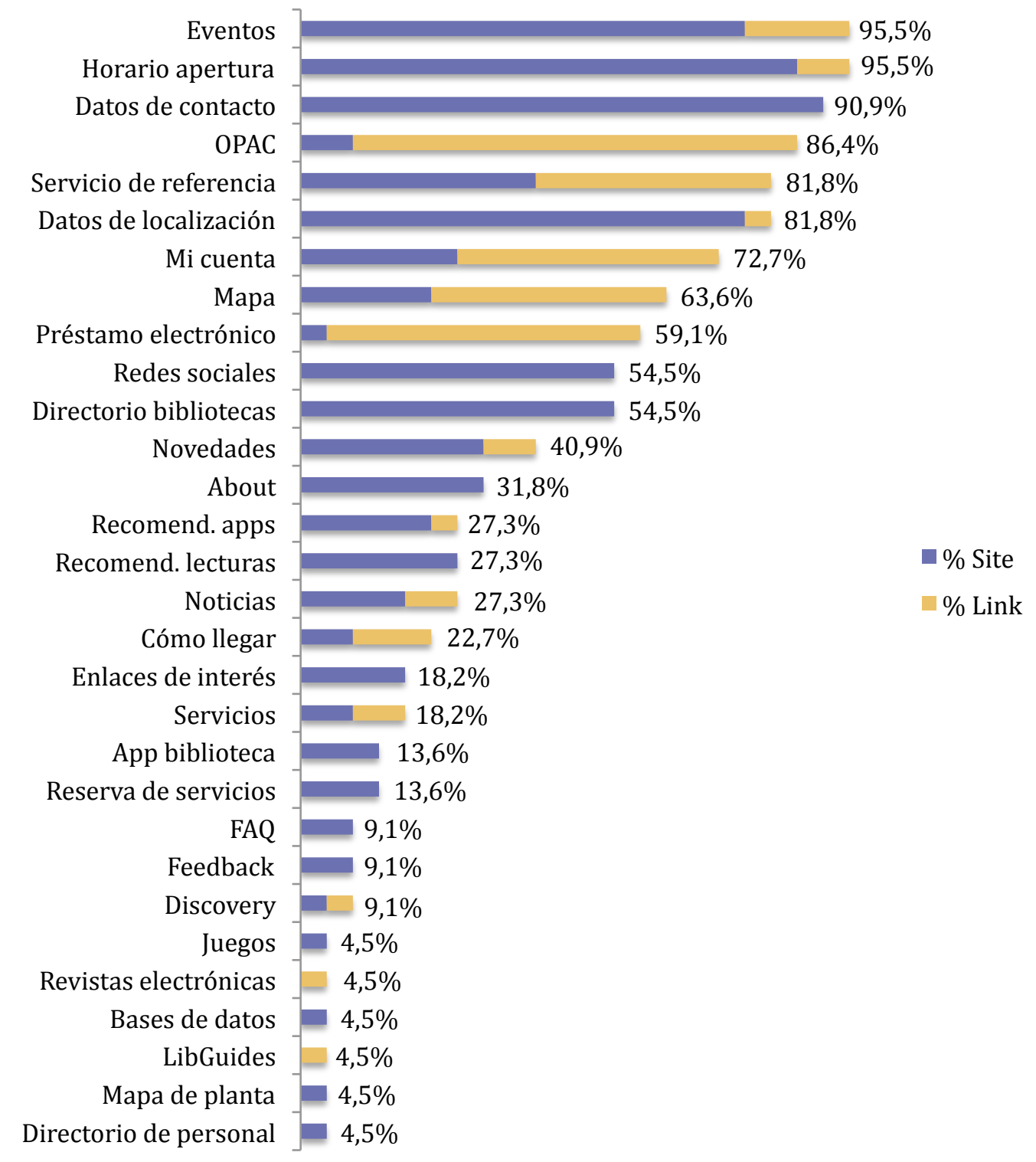

Gráfico 39. Contenidos y servicios en los sitios web de la biblioteca con páginas diferenciadas en bibliotecas públicas ( $n=22$ sitios web).

En las bibliotecas públicas uno de los dos contenidos más frecuentes son los eventos organizados, que se muestran en la mayor parte de los sitios analizados 
$(95,5 \%)$, mientras que en las universitarias solo aparece en menos de la tercera parte $(30,4 \%)$. Esto pone de relieve la importancia que se concede en las bibliotecas públicas a la difusión del programa de actividades.

Los gráficos 38 y 39 reflejan perfectamente las diferencias entre los servicios que se prestan en bibliotecas públicas y universitarias. En las bibliotecas públicas es más frecuente encontrar listados de novedades $(40,9 \%$ en públicas frente al $8,0 \%$ en universitarias), préstamo electrónico $(59,1 \%$ en públicas y $8,0 \%$ en universitarias), recomendaciones de lecturas $(27,3 \%$ en públicas y $2,7 \%$ en universitarias) y recomendaciones de aplicaciones (27,3\%).

Por el contrario, servicios más propios de las bibliotecas universitarias son bases de datos $(60,7 \%)$, enlaces de interés $(52,7 \%$ en universitarias y $18,2 \%$ en públicas), herramienta de descubrimiento $(48,2 \%$ en universitarias y $9,1 \%$ en públicas), LibGuides (39,3\% en universitarias y 4,5\% en públicas), revistas electrónicas $(24,1 \%$ en universitarias y $4,5 \%$ en públicas). También el directorio de personal se utiliza más en sitios web de bibliotecas universitarias $(31,3 \%, 4,5 \%$ en públicas).

También se observan diferencias en otros contenidos y servicios: enlaces a redes sociales (54,5\% en públicas y $40,2 \%$ en universitarias), enlace a la app de la biblioteca $(13,6 \%$ en públicas y $6,3 \%$ en universitarias $)$, noticias $(48,2 \%$ en universitarias y $27,3 \%$ en públicas) y reserva de servicios $(25,9 \%$ en universitarias y $13,6 \%$ en públicas).

Los datos presentados en este apartado guardan ciertas similitudes, en cuanto a los contenidos más frecuentes, con los resultados publicados en trabajos anteriores, mencionados en el apartado 2.2.2.2, como los de Aldrich (2010), Jackson (2013), Canuel y Crichton (2011) y Han y Jeong (2012) sobre los contenidos de los sitios web para móviles en bibliotecas universitarias - los dos primeros en Estados Unidos, el tercero en Canadá y el último con carácter general-. Sin embargo, se encuentran notables diferencias en cuanto a la frecuencia de aparición de unos servicios u otros, algo de esperar teniendo en cuenta las diferencias en las muestras analizadas en cada caso. 


\subsection{Ajuste a las características del dispositivo}

En este apartado se analiza el grado de adaptación de los sitios web para smartphones a las características del dispositivo en función de dos parámetros: los contenidos y los enlaces. Nielsen y Budiu (2013) recomiendan «eliminar el material secundario cuando se escriba para usuarios móviles», prescindir de todo lo superficial y reducir el número de opciones. Las pantallas pequeñas reducen la comprensión por dos motivos: los usuarios ven menos contenidos de una sola vez, por lo que tienen que hacer un mayor esfuerzo de memorizar, y se tienen que mover más por la página, haciendo scroll, señalan Nielsen y Budiu (2013). Y el scroll conlleva más tiempo, distrae la atención y hay que reubicarse en la página.

También el World Wide Web Consortium (Rabin y McCathieNevile, 2008) recomienda pensar en la situación de movilidad de los usuarios, y para ello que se provea de información compacta «cuando el tiempo es corto y la distracción mucha». Y para Firtman (2013) «el $80 \%$ de tu sitio web para ordenadores de sobremesa y portátiles no será útil para los usuarios de smartphones. Por ello debes investigar cuál ese $20 \%$ en el que debes centrarte.»

Por lo tanto, cuidar la extensión de los contenidos y que estos sean concretos y directos es una de las recomendaciones a tener en cuenta a la hora de diseñar un sitio web para dispositivos móviles, especialmente en el caso de aquellos con pantallas más pequeñas, como los smartphones.

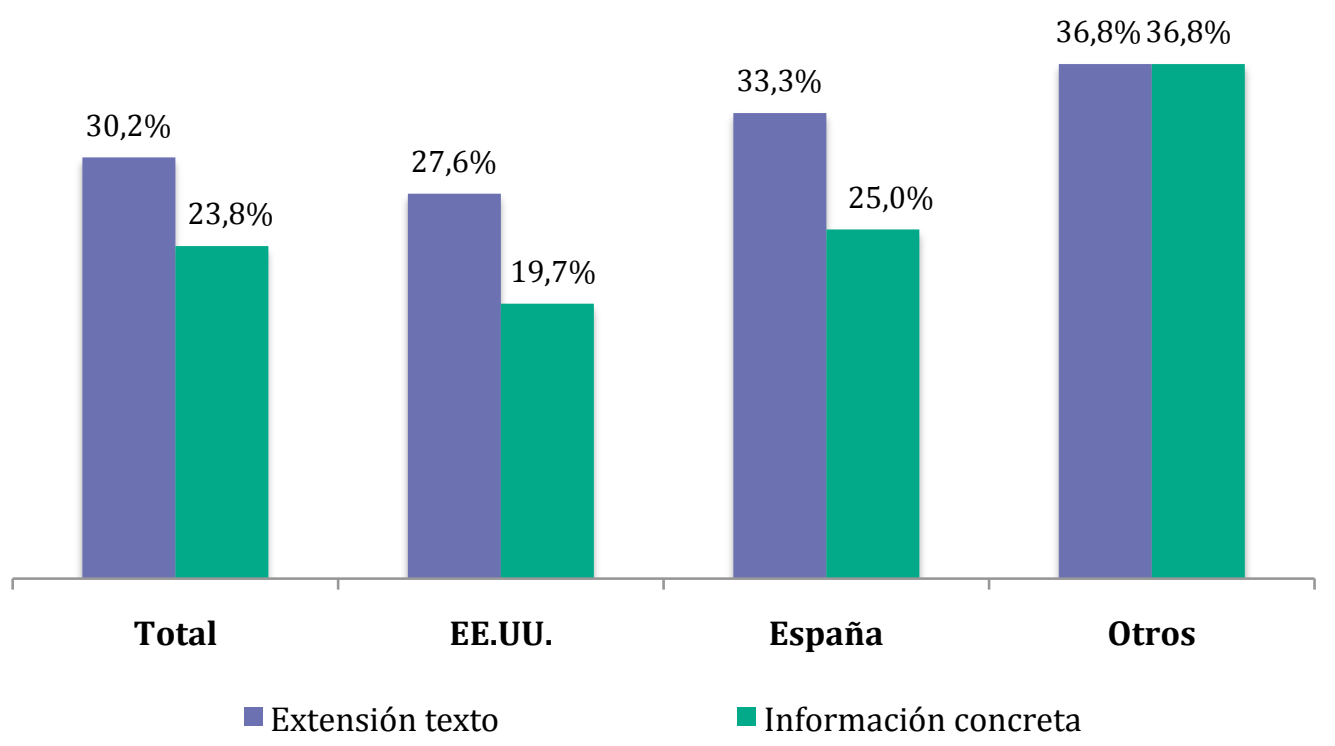

Gráfico 40. Sitios web para smartphones en los que la longitud del texto no se adecua a las características del dispositivo ( $n=189$ sitios web). 
Casi una tercera parte de los sitios web para smartphones analizados $(30,2 \%)$ presentan contenidos demasiado extensos. Esto es especialmente frecuente en los sitios web que utilizan diseño web adaptativo $(83,3 \%)$ u hojas de estilo $(55,6 \%)$ como soluciones de movilidad, y mucho menos, aunque también se da, en los sitios web con páginas diferenciadas para la versión móvil $(18,0 \%)$.

Algo más frecuente es encontrar contenidos directos y concretos, es decir, que eliminan todo lo superficial $(76,2 \%)$. En este aspecto también se observan grandes diferencias entre sitios web con páginas diferenciadas y los sitios web con diseño adaptativo $\mathrm{u}$ hojas de estilo: son menos aquellos con contenidos directos $\mathrm{y}$ concretos en los dos últimos grupos $(16,7 \%$ y 44,4\% respectivamente) que en el primero $(90,0 \%)$. Este último dato revela un porcentaje de sitios web con páginas diferenciadas para móviles en los que no se realiza un esfuerzo por adaptar los contenidos.

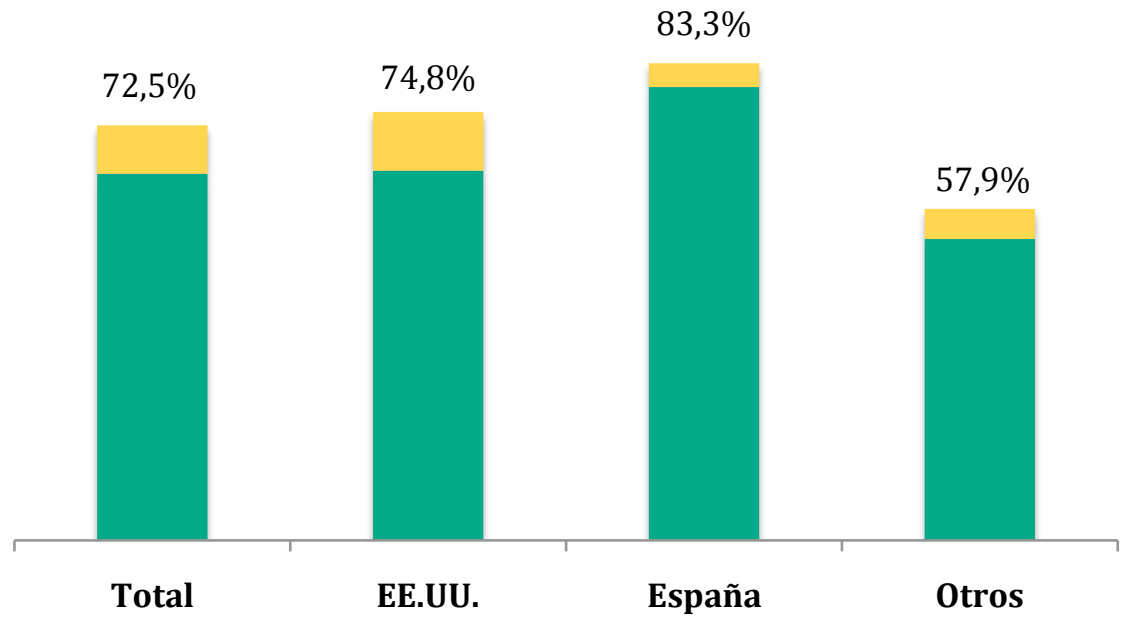

Gráfico 41. Sitios web para smartphones con enlaces a páginas web no adaptadas para dispositivos móviles. En amarillo, aquellos en los que se indica de alguna forma que se trata de una página no adaptada ( $n=189$ sitios web).

Cuando se diseña un sitio web para smartphones lo óptimo es enlazar siempre a otras páginas web también adaptadas, con el fin de facilitar así la navegación al usuario. Clark (2012), uno de los defensores del diseño web adaptativo, señala lo frustrante que resulta la experiencia de enlazar a una página que no esté adaptada. Esto no se considera tan necesario en el caso de las tabletas, en las que la pantalla permite que cualquier página web se pueda consultar cómodamente.

Sin embargo, en los sitios web de las bibliotecas diseñados para smartphones se ha encontrado que es frecuente enlazar a páginas no adaptadas: el 72,5\% de los sitios 
para smartphones analizados incluían algún enlace a páginas no adaptadas. En España el ratio es aún mayor y alcanza el 83,3\% (gráfico 41). Sólo en algunos casos puntuales (8,5\% de media) se indica de alguna forma, mediante un símbolo o un texto, que se enlaza a una página no adaptada. En España esta práctica es aún menos frecuente, solo se da en el $4,2 \%$ de los casos.

\subsection{Buenas prácticas}

Identificar las mejores prácticas es un ejercicio que proporciona modelos a seguir. Con esa finalidad se han extraído de entre los sitios web que componen la muestra los casos que se consideran ejemplos a seguir por otras bibliotecas. Para su identificación se han tenido en cuenta los parámetros analizados en los apartados anteriores de este capítulo y representan ejemplos destacables en su conjunto. Además, podrían señalarse otros por aspectos concretos que se pueden considerar bien resueltos.

No se han tenido en cuenta aspectos como el diseño de la interfaz, el sistema de adaptación escogido, los lenguajes y metadatos empleados, el porcentaje obtenido en el test Mobile OK Checker, los elementos de navegación que emplea, el formato de los contenidos o los contenidos en sí. Sin embargo, sí se ha valorado que sea un sitio web optimizado para navegar desde un smartphone y con contenidos básicos de la biblioteca.

Como se ha explicado en capítulos anteriores, son muchas las bibliotecas que han creado una versión móvil de su sitio web. De ellas, se pueden considerar buenas prácticas en su conjunto los sitios web de las bibliotecas de las universidades de Michigan, Berkeley y Cambridge, así como el del Sistema de Bibliotecas del Condado de Orange, todas ellas en Estados Unidos. Los puntos en común que cabe destacar en todas ellas son:

- La facilidad de acceso desde el sitio web completo, bien por contar con un sistema de detección de dispositivo o un enlace visible. También por un URL corto y significativo, que resulta sencillo de teclear.

- La estructura de navegación es clara y sencilla. Priman los menús en la página de inicio, a la que se vuelve siempre para cambiar de opción.

- Saben aprovechar las capacidades del dispositivo, por ejemplo enlazando los números de teléfono o incluyendo un mapa para mostrar la localización. 
- Se ajustan a las características del dispositivo, con contenidos breves y concisos, bien organizados y a los que se llega fácilmente, sin rodeos.

- Evitan los enlaces a páginas web o archivos no adaptados para móviles, y cuando lo hacen se indica.

El sitio web para móviles de la biblioteca de la Universidad de Cambridge ${ }^{98}$ es el más sencillo de todos ellos. Con tan solo cuatro opciones en su menú principal, está enfocado hacia la búsqueda en el catálogo, la gestión de la cuenta del usuario y proporciona información básica sobre cada una de las bibliotecas de la red: horario de apertura, el lugar en el que se encuentra y enlace a su página web. Su diseño es extremadamente sencillo, sin imágenes. Su catálogo sigue los mismos principios de sencillez y brevedad: se llega a cada registro en tan solo tres pasos (contando la pantalla de búsqueda) y en cada uno de esos registros se da información básica para identificar al documento y saber si está disponible o no y en qué bibliotecas encontrarlo.

El sitio web de la biblioteca de la Universidad de Michigan ${ }^{99}$ contiene más información que el caso anterior, pero también de carácter básico: búsqueda en el catálogo, listado de bases de datos con interfaces móviles, horarios y localización de las bibliotecas, servicio de referencia, Research Guides, noticias y eventos y otros datos de contacto sobre la biblioteca. Además incluye un enlace a la versión completa del sitio web. Destaca la manera de mostrar las noticias y eventos, que primero se ven como un listado con el título y la fecha y, al enlazar cada titular, se obtiene la noticia completa, con un breve texto.

El catálogo de esta biblioteca, integrado en la misma sede web, también presenta la información básica de cada registro, pero con algunos elementos más, sin perder su sencillez: limitadores en la casilla de búsqueda y la posibilidad de enviar cada registro por correo electrónico y SMS, citarlo y añadirlo a una lista de favoritos. Lo interesante de este catálogo es que se integra perfectamente en el diseño del sitio web.

Muy similar a los anteriores, a rasgos generales, es el sitio web para smartphones de la biblioteca de la Universidad de Berkeley ${ }^{100}$. Muestra algunas peculiaridades: incluye un chat con el servicio Questionpoint y la información de localización de cada biblioteca se muestra directamente en el mapa, que incluye uso de la geolocalización para detectar la posición del usuario. Los eventos se muestran ordenados por fechas, en una ficha con información breve en la que se destaca el

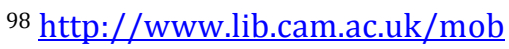

99 http://m.lib.umich.edu

100 http://mobile.lib.berkeley.edu
} 
título, el lugar y fecha de cada evento y una breve descripción. Como en las anteriores, se incluye el acceso al catálogo en dos versiones diferentes, independientes del sitio web.

El sitio web para móviles del Sistema de Bibliotecas del Condado de Orange ${ }^{101}$ muestra el listado de bibliotecas ordenadas según la localización del usuario: las más cercanas aparecen primero. Además de la información básica de cada una de ellas se muestran recomendaciones de aplicaciones nativas para móviles, un listado de los títulos más populares de la colección y eventos. Desde este sitio se enlaza a todos los perfiles en medios sociales de la biblioteca.

\subsubsection{Diseño web adaptativo}

Teniendo en cuenta las características del diseño web adaptativo, los sitios web que emplean este sistema no han adaptado sus contenidos ni aprovechan las características específicas del dispositivo, al menos en gran medida. Esto significa que tienen pocas posibilidades de ser incluidos entre las buenas prácticas escogidas, en cuya selección entran precisamente esos parámetros. Por ejemplo, es común que los números de teléfono estén sin enlazar, se enlaza a páginas externas no adaptadas o no se seleccionan los contenidos, sino que son los mismos de la web completa. Una de las malas prácticas detectadas en este sentido es que en ocasiones solo se adaptan algunas páginas de la sede, pero no todas. Son normalmente sitios web con dos pantallas, pocas tienen una pantalla intermedia para iPad.

Al examinar los sitios web con diseño adaptativo analizados se ha comprobado que en ninguno de ellos se ha realizado una selección de contenidos, diferentes de la versión para grandes pantallas, sino que incluyen los mismas opciones en sus menús. Por otra parte, los contenidos en la mayor parte de los sitios analizados son igualmente extensos. Es posible que se haya realizado un trabajo previo de reducción de contenidos, como señala Reidsma (2013) respecto al sitio de la biblioteca de la Grand Valley State University, y que se emplee el diseño adaptativo en conjunción con el sistema Mobile first, pero no es posible saberlo para el resto de los sitios, puesto que la versión anterior del sitio ha desaparecido y no es hay manera de observar los cambios. Si bien no son fáciles de detectar, no se observan rastros de otras técnicas complementarias al diseño web adaptativo en los sitios

101 http://m.ocls.info 
web para móviles de las bibliotecas —enumeradas en el apartado 1.2.3.3- La única que quizás se podría estar utilizando es Mobile first.

Se han encontrado algunos casos en los que sí parece que los contenidos se hayan abreviado en los sitios de las bibliotecas de la Duke University ${ }^{102}$, Oxford University ${ }^{103}$ y de la Norwegian Business School Library ${ }^{104}$.

Menos de la mitad de los sitios analizados con diseño adaptativo presentan tres diseños, uno para pantallas grandes, otro para tabletas y otro para smartphones. Los 16 restantes tienen dos pantallas, para smartphones y ordenadores.

Entre los sitios web analizados con diseño adaptativo se detectan dos casos de buenas prácticas: My \#HuntLibrary ${ }^{105}$ y Bookfinder ${ }^{106}$. La primera de ellas es un desarrollo de la Biblioteca de North Carolina State University (Estados Unidos) para un concurso de fotografías sobre la Biblioteca Hunt. En este caso concreto la opción del diseño web adaptativo es una buena elección porque los contenidos del sitio, que son las imágenes de la biblioteca etiquetadas en Instagram como \#MyHuntLibrary, son idénticos desde el móvil y desde un ordenador de sobremesa, por lo que adaptar solo el diseño resulta adecuado.

Lo mismo sucede con el BookFinder de la Ryerson University (Canadá), que ha desarrollado un catálogo orientado específicamente a la localización de los libros en las estanterías, un servicio donde los contenidos, que son el plano de la biblioteca con el lugar en que se encuentra señalado el libro buscado, son idénticos.

\footnotetext{
$102 \mathrm{http}: / /$ library.duke.edu

${ }^{103} \mathrm{http}: / /$ www.bodleian.ox.ac.uk

${ }^{104}$ http://www.bi.edu/library

105 http://d.lib.ncsu.edu/myhuntlibrary

106 http://apps.library.ryerson.ca/bookfinder
} 


\section{Capítulo 5. Aplicaciones nativas en bibliotecas. Resultados}

Se describen en este apartado los resultados obtenidos del análisis de 73 aplicaciones nativas creadas por bibliotecas de todo el mundo. Al igual que en el apartado anterior, sobre sitios web, se describe la muestra en función del tipo de biblioteca, su procedencia geográfica, idioma, fecha de creación y utilidad que desempeña. Después se profundizará en aspectos como su diseño, forma de acceso, navegación, formato de los contenidos, aprovechamiento de las funciones del dispositivo, contenidos y servicios que ofrecen y la adaptación a la situación de movilidad.

También se examina en este capítulo la información que proporcionan las tiendas de aplicaciones, como el número de descargas efectuadas, el peso o la fecha de la última actualización, entre otras. Para ello se atenderá a variables como la procedencia geográfica, el tipo de bibliotecas y la utilidad de las aplicaciones. 



\subsection{Descripción de la muestra}

Se han analizado un total de 73 aplicaciones nativas para smartphones y tabletas correspondientes a 53 bibliotecas procedentes de todo el mundo. Tan solo 8 bibliotecas han creado más de una aplicación y la mitad de ellas son bibliotecas nacionales de diferentes países -Francia, Australia, Colombia y la British Library-. La función de las apps de estas bibliotecas es sacar a la luz fondos patrimoniales. El resto proceden del ámbito de las bibliotecas públicas (New York Public Library, Bayerische Staatsbibliothek y National Library Board Singapore) y universitarias (biblioteca de la University of Illinois at Urbana-Champaign). La razón de estas bibliotecas para desarrollar más de una aplicación nativa es, por lo tanto, temática, pues sus contenidos son diferentes.

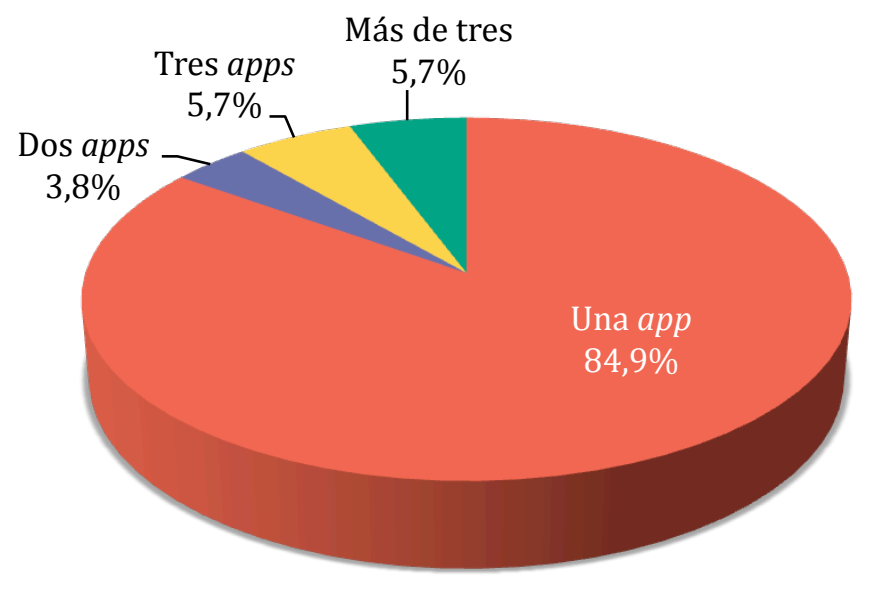

Gráfico 42. Bibliotecas en función del número de aplicaciones que han desarrollado $(n=53$ bibliotecas).

\subsection{1. Área geográfica e idioma}

La muestra de aplicaciones nativas analizadas es bastante más equilibrada que en el caso de los sitios web. El país más representado por número de aplicaciones sigue siendo Estados Unidos, pero su peso apenas alcanza un tercio de la muestra $(27,4 \%)$, ya que, como se ha explicado previamente (apartado 3.2.1), no se han 
analizado todas las apps encontradas. Europa es el área geográfica con más peso en el conjunto, supone un 48,0\% del total, incluyendo a España (gráfico 43). El número de aplicaciones de las bibliotecas españolas supone el 19,2\% de la muestra. En este país se ha realizado una búsqueda especialmente exhaustiva, por lo que se considera que la muestra es altamente representativa de lo que sucede en el conjunto de las bibliotecas de este país. Los países latinoamericanos $(11,0 \%)$ y otros países como Australia, Canadá, Singapur y Hong Kong $(13,7 \%)$ completan el total de la muestra. Se observa un especial interés, que no se da en otras regiones de España, por las apps en las bibliotecas catalanas. Hasta el momento constituyen más de una tercera parte $(35,7 \%)$ de las apps creadas en el país.

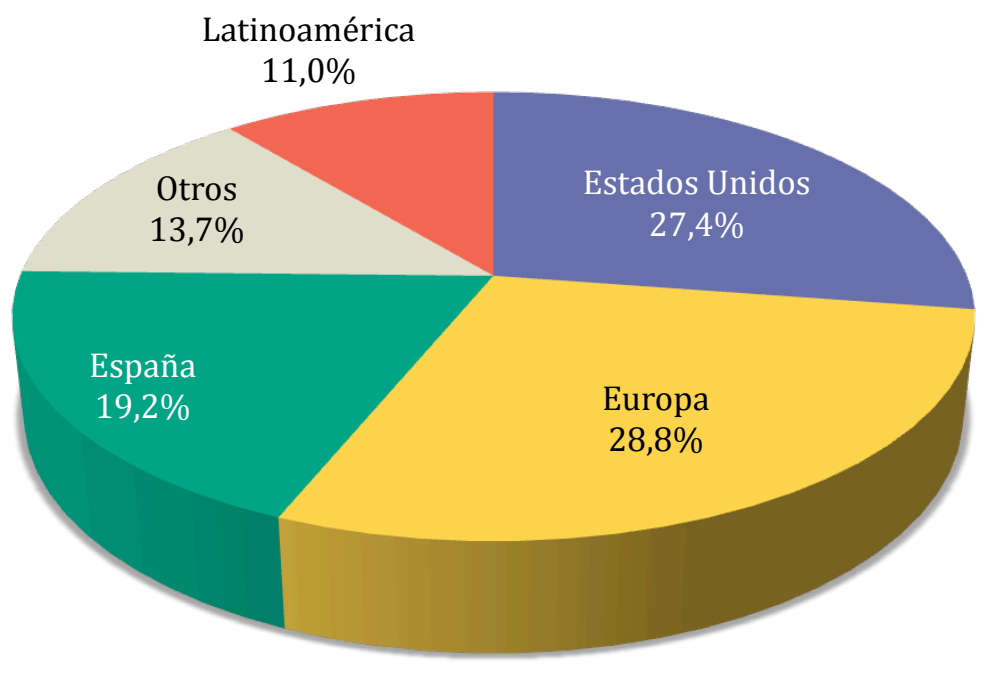

Gráfico 43. Aplicaciones analizadas por área geográfica ( $n=73$ apps).

El idioma más habitual es el inglés, presente en el 61,6\% de las aplicaciones. Esto se debe a que el peso de los países angloparlantes - Estados Unidos, Reino Unido, Canadá y Australia - en el conjunto de la muestra es mayor que otros (el 41,1\% de las apps analizadas procede de ellos), pero también porque el inglés es el idioma internacional por excelencia: una tercera parte de las apps en inglés $(33,3 \%)$ no pertenecen a países angloparlantes. En ocho de las apps el inglés comparte espacio con otras lenguas.

Debido a la especial exhaustividad en la búsqueda de aplicaciones pertenecientes a bibliotecas españolas y a que a ellas se han sumado las latinoamericanas, el español es la segunda lengua con más peso en el conjunto de la muestra (está presente en el $21,9 \%$ de las apps). En siete de las ocho apps de países 
latinoamericanos el español es idioma exclusivo - algo que también sucede en gran parte de las apps de bibliotecas españolas (42,9\%)-, mientras que en la app restante, de origen brasileño, lo es el portugués. En España el español comparte espacio con el euskera en la aplicación de las bibliotecas vascas, Liburutegiak y en la de las Bibliotecas de Navarra, y con el inglés en BiblioUSAL.

Otros idiomas presentes son el francés, en cinco apps francesas, una canadiense y otra belga; el alemán, en cinco apps alemanas y una belga; el danés, en la app de ese país; y el chino, en la app de Hong Kong.

\subsubsection{Tipo de bibliotecas}

A diferencia de lo que sucedía con los sitios web, en las apps son las bibliotecas públicas las que parecen mejor representadas, pues constituyen el 47,9\% de la muestra. Detrás quedan las universitarias $(26,0 \%)$ y las bibliotecas nacionales, cuyas aplicaciones suponen un 19,2\%. También hay algunas apps de bibliotecas especializadas $(5,5 \%)$ y una de la biblioteca digital Europeana (gráfico 44).

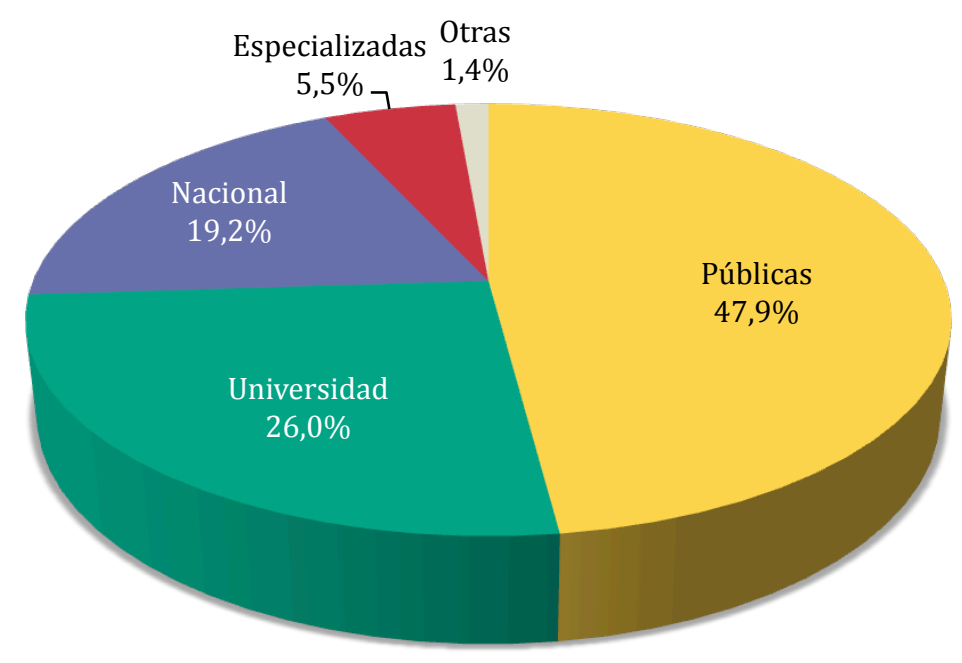

Gráfico 44. Aplicaciones por tipo de biblioteca ( $n=73$ apps).

Se han encontrado menos apps de bibliotecas universitarias de lo que cabría esperar, y es que se sospecha que en muchas de las universidades, especialmente en Estados Unidos, la biblioteca ya ocupa un espacio dentro de la app de la universidad (Tay, 2010b) y, por lo tanto, no dispone de una app propia. En España 
las bibliotecas públicas y universitarias, con siete y cinco aplicaciones respectivamente, van casi a la par cuantitativa y porcentualmente. De las 75 bibliotecas universitarias que forman parte de REBIUN sólo seis -incluyendo a la Biblioteca de la Universidad de Burgos - tenían una aplicación nativa en el momento del análisis, lo que suponía el 8,0\%. En 2014 se ha creado una aplicación más, la de la Biblioteca de la Universidad de Valladolid, que ha hecho ascender el ratio al 9,3\%. En las bibliotecas públicas el 13,3\% de las unidades administrativas quedan representadas por alguna app.

\section{Estados Unidos}

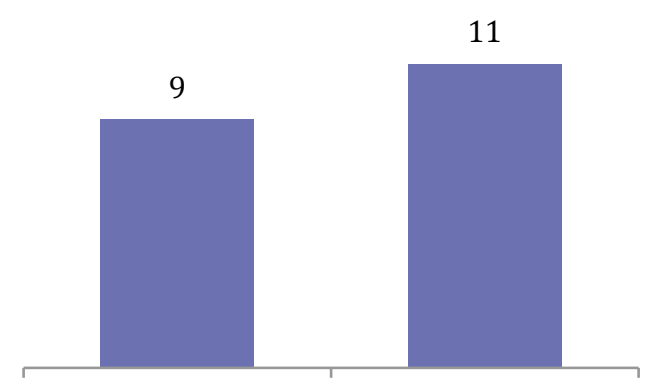

$\mathrm{BU}$

$\mathrm{BP}$
Europa

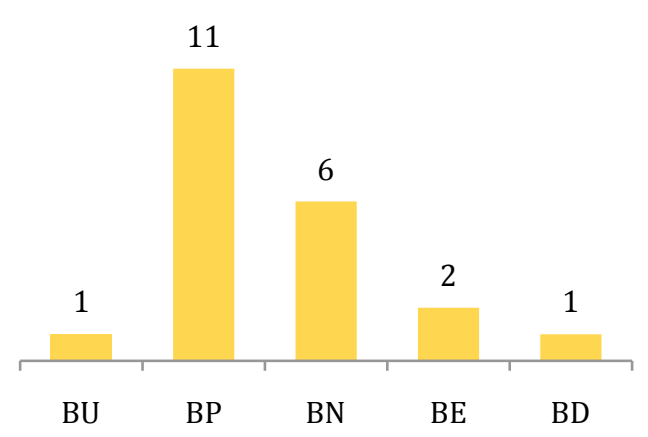

España

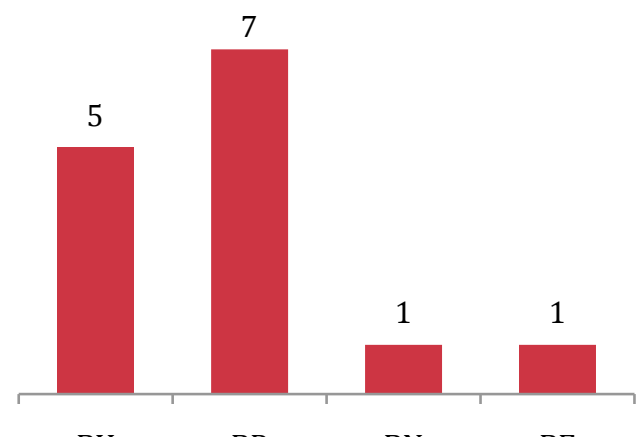

BU

\section{Otros}

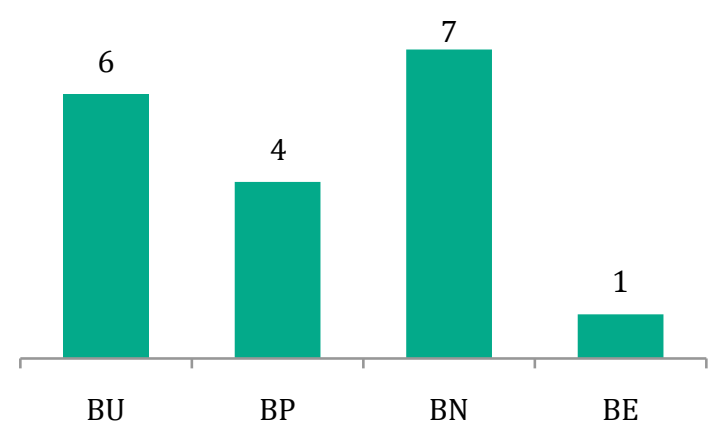

Gráfico 45. Aplicaciones por tipo de biblioteca y país ( $\mathrm{n}=73$ apps). Leyenda: $\mathrm{BU}=$ bibliotecas universitarias. $\mathrm{BP}=$ bibliotecas públicas. $\mathrm{BN}=$ bibliotecas nacionales. $\mathrm{BE}=$ bibliotecas especializadas. $\mathrm{BD}=$ bibliotecas digitales.

En las bibliotecas públicas la producción de apps suele estar a cargo de redes de bibliotecas, ya sea de carácter nacional o regional (como el National Library Board de Singapur y el Orange County Library System), de consorcios (The Regional Automation Consortium, en Canadá) o grandes redes de bibliotecas municipales 
(New York Public Library o Bibliotecas de Manchester, por citar solo algunas). Tan solo en unos pocos casos - la Biblioteca de Mollerussa (Lleida, España), el Centro Internacional del Libro Infantil y Juvenil (España) y la Biblioteca del Estado de Baviera (Alemania), una de las más importantes del mundo por la riqueza de fondos documentales - son bibliotecas a título individual las encargadas de la creación de las apps (gráfico 46).

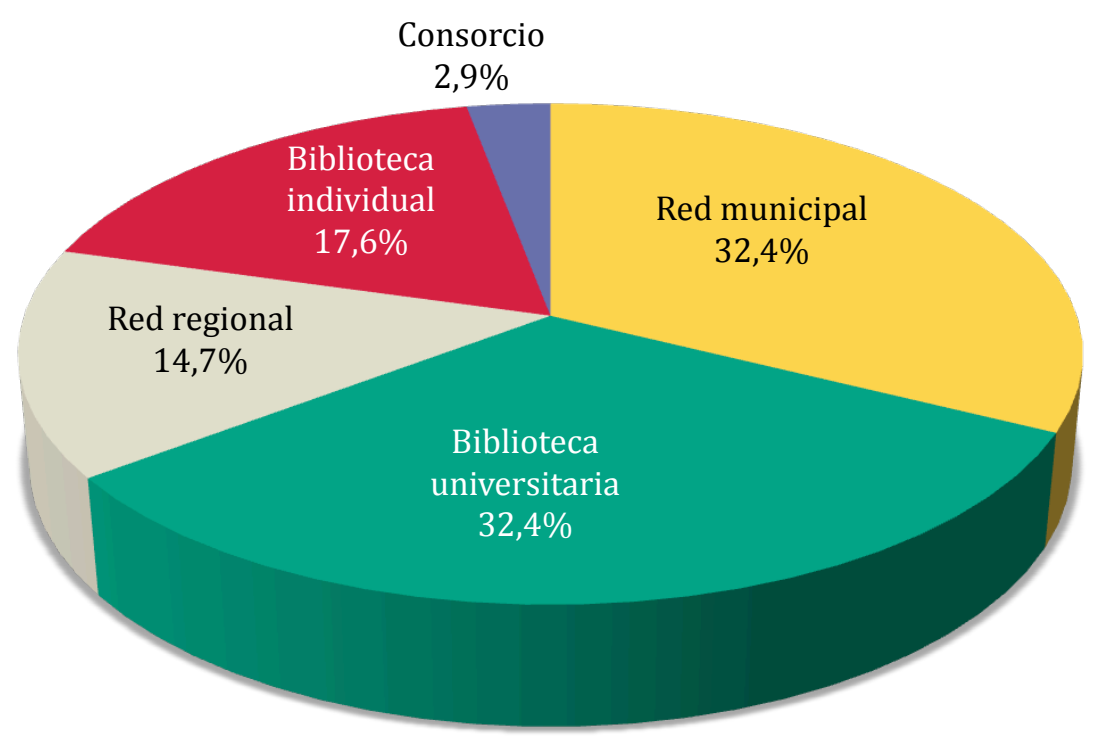

Gráfico 46. Aplicaciones que reproducen los contenidos del sitio web de la biblioteca o el catálogo por el tipo de institución que las ha creado ( $n=34$ apps).

En España son las redes de bibliotecas quienes están asumiendo la creación de apps, con los ejemplos de la Red de Lectura Pública de Euskadi o la Xarxa de Biblioteques de la Diputación de Barcelona. Sin embargo, no existe ningún acuerdo sobre quiénes deben ser los encargados y se refleja la división administrativa en comunidades autónomas, provincias, comarcas y municipios. Incluso se producen casos de solapamiento, como en la app de las Biblioteques del Maresme, que deberían estar incluidas en la aplicación de la Xarxa de Biblioteques de la Diputación de Barcelona.

Como ya se avanzó, las bibliotecas públicas catalanas muestran un especial interés por la creación de apps, pues destacan en el conjunto de España: de las seis apps de bibliotecas públicas analizadas, cuatro son catalanas.

De las 34 apps de bibliotecas de todo tipo que tienen como utilidad reproducir los contenidos del sitio web o el OPAC, el 61,8\% no habían adaptado su sitio web a los 
smartphones en el momento del análisis. Después se han encontrado tres bibliotecas que han incorporado el sitio web para móviles en versión adaptativa ${ }^{107}$. Esto indica que la mayoría de las apps en estos casos se convierten en la única versión para dispositivos móviles de los contenidos de la biblioteca. Las apps nunca deben ser un sustituto de la web de la biblioteca, sino un complemento. Las utilidades y la consulta de fondos patrimoniales en forma de aplicación sí pueden ser un extra, pues no se trata de información básica de la biblioteca.

\subsubsection{Año de creación}

Las primeras aplicaciones nativas en bibliotecas se crearon en 2009, como refleja la muestra (gráfico 47). Con los años el número de apps ha ido creciendo y todo apunta, al observar las progresivas incorporaciones que se han ido produciendo en las tiendas de aplicaciones durante la redacción de este trabajo de investigación, que seguirá haciéndolo. Estados Unidos es el país donde surge la primera aplicación analizada, la de la Washington DC Public Library.

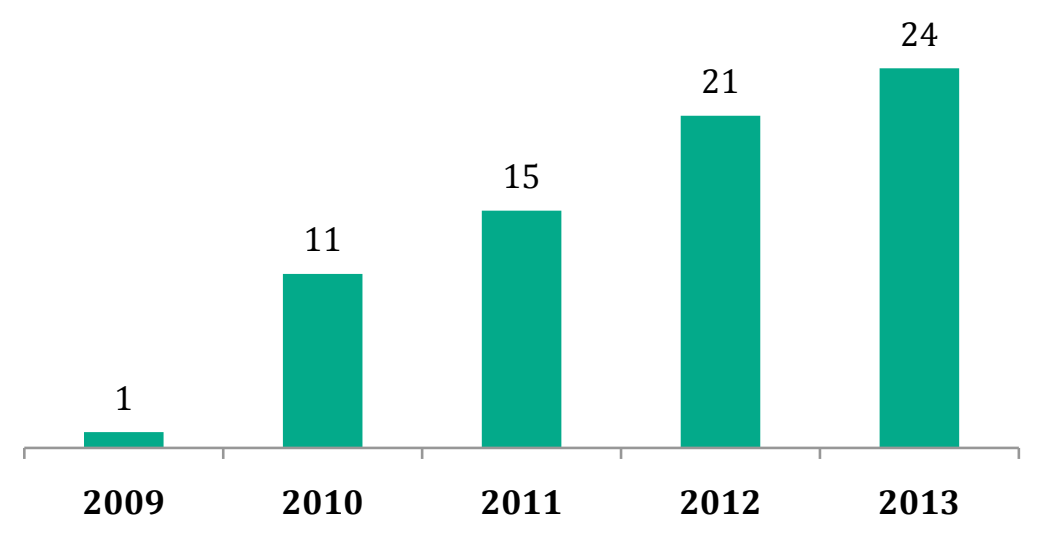

Gráfico 47. Aplicaciones analizadas por año de creación ( $\mathrm{n}=72$ apps).

En 2010 la muestra solo recoge aplicaciones procedentes de Estados Unidos y varios países de Europa: Alemania, Bélgica, Dinamarca y Reino Unido aportan cuatro nuevas apps. Si bien la mayor parte de las aplicaciones de ese año tienen como finalidad reproducir los contenidos del sitio web de la biblioteca, comienzan

107 Datos observados el 19 de abril de 2014. 
a surgir ese mismo año otras utilidades: sacar a la luz fondos patrimoniales, como el Archivo de John Murray (abril 2010) o los tesoros de la Biblioteca Estatal de Bavaria (julio de 2010); la recomendación de lecturas con Shake it! (julio 2010), del Orange County Library System; recoger las novedades que llegan a la biblioteca sobre un tema (New Germanic Books, New French Books y New LIS Books, de la biblioteca de la University of Illinois at Urbana-Champaign); o la entonces innovadora WolfWalk (junio de 2010), que sitúa las fotografías antiguas de la North Carolina State University en un mapa del campus, lo que permite verlas en contexto. Hay una app para la que no se ha podido determinar la fecha de creación: TRACpac, de The Regional Automation Consortium.

\section{Estados Unidos}

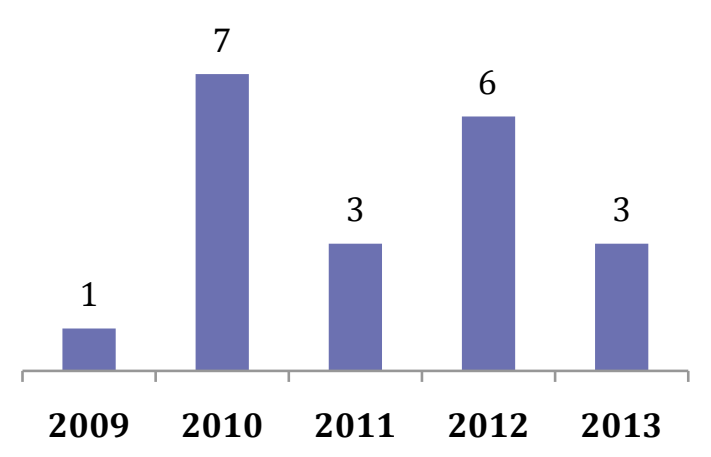

Europa

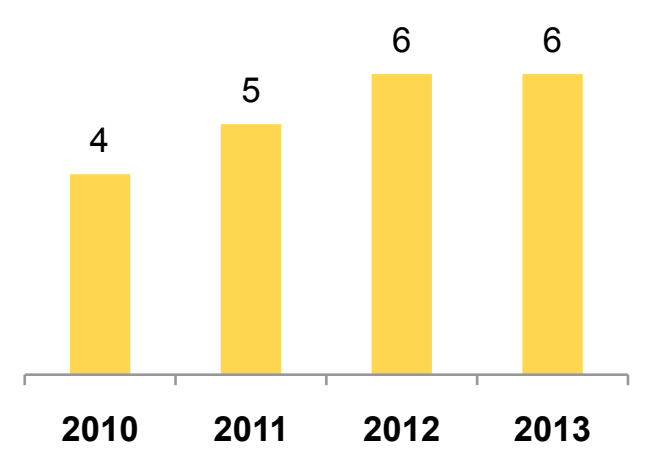

España

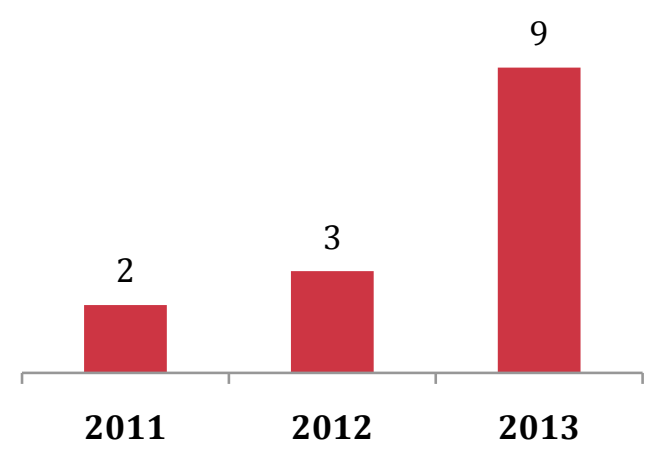

Otros países

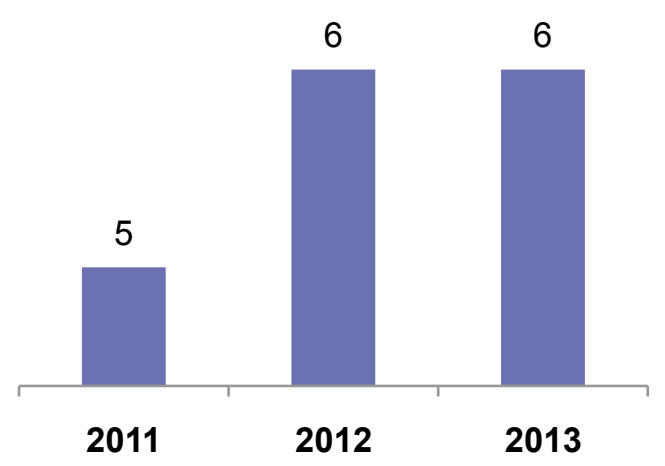

Gráfico 48. Aplicaciones por país y fecha de creación ( $n=72$ apps).

En España la primera app registrada, la de la Biblioteca de la Universidad de Salamanca, se lanzó en noviembre de 2011 (Merlo-Vega, 2012). Un mes después la Biblioteca Nacional publicó la aplicación sobre la exposición organizada con 
motivo de su tricentenario. En 2012 se registraron las aplicaciones de la UNED y la Biblioteca de la Universidad de Cádiz. El año 2013 parece ser el que inaugura la explosión de apps, con un total de once nuevas (gráfico 48). El interés de nuestras bibliotecas por las apps parece más tardío que en países como Estados Unidos.

Las ocho aplicaciones latinoamericanas registradas también son de reciente creación, entre 2012 y 2013. Es en este último año cuando parece abrirse camino a la creación de apps en las bibliotecas de esta área geográfica.

Sin embargo, no resulta fácil estudiar cómo han evolucionado las características de las apps con el tiempo puesto que, aunque se disponga de la fecha de creación, pueden haber sido modificadas en las versiones posteriores.

\subsubsection{Utilidad de las apps}

Se han detectado en la muestra analizada una gran diversidad de aplicaciones y aunque la principal sigue siendo la reproducción de los contenidos del sitio web de la biblioteca (se da en el 34,2\% de los casos). Si a ellas se suman las apps para la consulta del catálogo el ratio asciende al 46,6\%. Se estima que realmente estas utilidades tienen un peso mucho mayor, alrededor del 90,2\% si se contabilizan las apps que han sido excluidas de la muestra (tabla 17). En total se han identificado 398 apps creadas por bibliotecas de todo el mundo con el fin de reproducir los contenidos del sitio web y/o de hacer accesible el OPAC.

Tras un análisis de las apps disponibles en las tiendas de aplicaciones Google Play y App Store, realizado el 18 de abril de 2014, se han obtenido los siguientes datos sobre diferentes empresas dedicadas a la creación de apps para bibliotecas:

- Boopsie, de la que se han encontrado 283 apps diferentes. Todas ellas tienen versión para Android y se han encontrado en la App Store 29 para iPad y 31 para iPhone. La diferencia numérica entre ambas tiendas no parece deberse a que las apps se desarrollan más a menudo para Android, sino a que en la versión para iTunes no es la empresa quien aparece como desarrollador, sino la propia biblioteca.

- BiblioCommons: 30 apps para iPhone en iTunes y otras 30 en Google Play. El 18 de abril de 2014 eran un total de 37 en ambas tiendas.

- BiblioLabs: 161 apps para iPad en total. De ellas, sólo 3 parecen haber sido creadas por bibliotecas. No se ha encontrado ninguna en Google Play.

- LibraryThing: 9 apps de bibliotecas para iPhone y iPad. Una de ellas (LinkCat) es de un catálogo. Además, las mismas 9 se encuentran en Google Play. 
- Solus UK: 26 apps de bibliotecas para iPhone y iPad (las mismas). En Google Play, un total de 21.

- CG SOLUZIONI INFORMATICHE SRL: 6 apps para iPhone en la App Store y otras 6 en Google Play.

- VTLS: 3 apps de bibliotecas para iPhone más otras dos propias. No se ha encontrado ninguna en Android.

\begin{tabular}{|c|c|c|c|c|}
\hline & Sitio web / OPAC & Patrimonial & Utilidades & Total \\
\hline Tiendas de apps & 364 & 3 & 0 & 368 \\
\hline Boopsie & 283 & 0 & 0 & 283 \\
\hline BiblioCommons & 37 & 0 & 0 & 37 \\
\hline BiblioLabs & 0 & 3 & 0 & 3 \\
\hline LibraryThing & 9 & 0 & 0 & 9 \\
\hline Solus UK & 25 & 0 & 1 & 26 \\
\hline CG Soluzione... & 6 & 0 & 0 & 6 \\
\hline VTLS & 3 & 0 & 0 & 3 \\
\hline Otras & 1 & 0 & 0 & 1 \\
\hline Apps analizadas & 34 & 21 & 18 & 73 \\
\hline \multirow[t]{2}{*}{ Total } & 398 & 24 & 19 & 441 \\
\hline & $90,2 \%$ & $5,4 \%$ & $4,3 \%$ & \\
\hline
\end{tabular}

Tabla 17. Aplicaciones de la muestra y otras encontradas en las tiendas de aplicaciones según su utilidad ( $n=441$ apps).

Algo más de la cuarta parte de las aplicaciones analizadas (28,8\%) tienen como finalidad sacar a la luz fondos patrimoniales. Se trata de la utilidad por excelencia en las bibliotecas nacionales y refleja muy bien sus funciones. En algunos casos son aplicaciones que reproducen exposiciones físicas $(9,6 \%$ del total), como la exposición celebrada con motivo del tricentenario de la Biblioteca Nacional de España, o que exponen la biografía de algún personaje histórico (2,7\% del total) en las apps de la Bayerische Staatsbibliothek sobre Ludwig II y Jean Paul-. En el caso de las exposiciones, todas están dedicadas a una sola exposición, con la excepción de Exhibiciones virtuales, la app de la Red de Bibliotecas de Medellín (Colombia), que está pensada para albergar a varias.

La tercera utilidad más representada en la muestra es la consulta del catálogo de la biblioteca o de otras herramientas de búsqueda. En el 12,3\% de las apps analizadas ésta constituye la función principal, pero además la búsqueda en el catálogo está presente en muchas otras apps. 


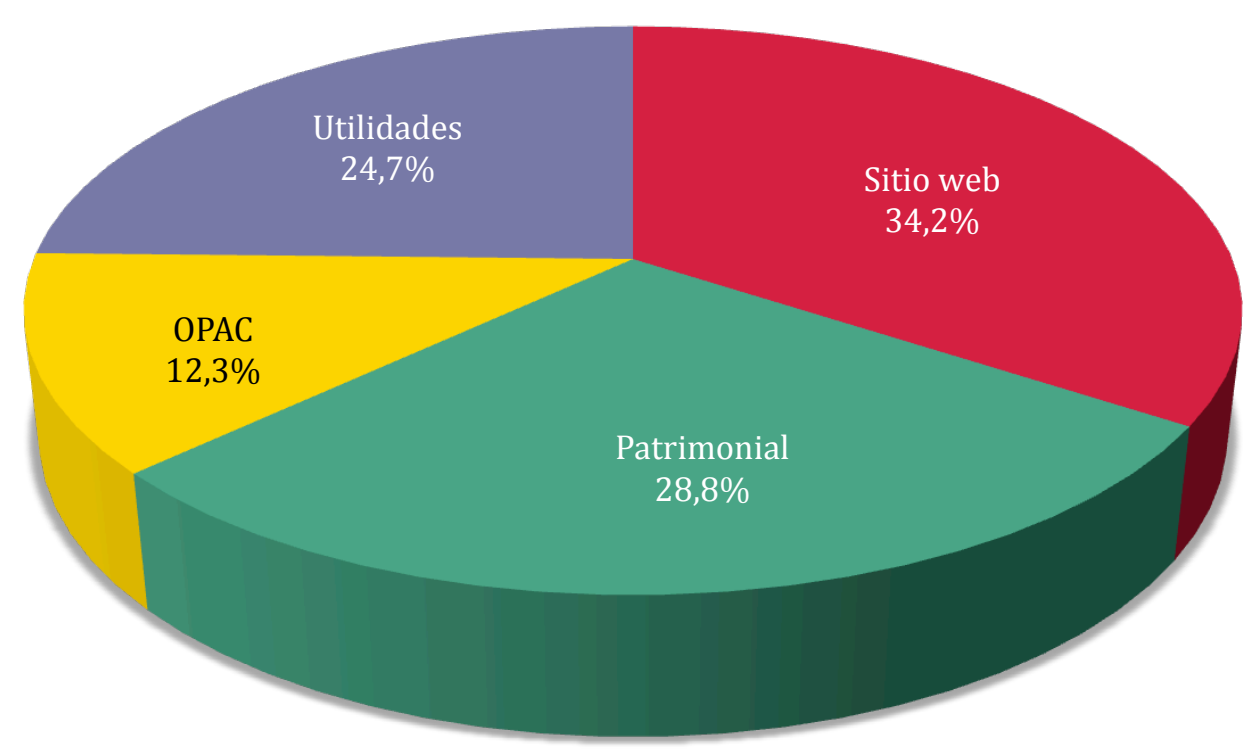

Gráfico 49. Aplicaciones en función de su utilidad ( $n=73$ apps).

Se ha creado además un grupo de aplicaciones denominado «Utilidades» y que recoge varios casos muy diferentes:

- Apps que simulan una visita a la biblioteca, como ugl4eva y la Visita virtual - Biblioteca Nacional de Chile.

- Aplicaciones para gestionar la agenda de actividades organizadas desde las bibliotecas de Barcelona, como BibliosBCN.

- Medir el tiempo de lectura, como READometer, un cronómetro que permite además compartir el tiempo que dedicamos a la lectura en los medios sociales

- Recomendar libros, como OCLS Shake It!.

- Selección de video-cuentos, como DeCuentos, que contiene varios vídeos.

- Compartir fotografías o vídeos, como SG Memory, que pretende comprometer a los usuarios para que compartan fotografías de la ciudad de Singapur, y HKBUtube, una selección de vídeos educativos.

- Juegos, como la app de la New York Public Library Find the Future, que consiste en buscar cien códigos QR en el edificio de la biblioteca con el fin de acumular puntos.

- Para detectar los libros mal ordenados en la estantería. Es el caso de ShelvAR, desarrollada en la Universidad de Miami.

- Como servicio de referencia. Es el caso de Ask a librarian, que creada para formular cuestiones a un bibliotecario. 
- Difusión de novedades en la biblioteca, como en las tres apps de la biblioteca de la University of Illinois at Urbana-Champaign New Germanic Books, New French Books y New LIS Books.

- Publicar las noticias de la biblioteca, como en Biblioteca UCS, de la biblioteca de la Universidade de Caxias do Sul.

- Lectura, que es la principal utilidad de las aplicaciones MobileRead (National Library Board Singapore), Ediciones Biblioteca Nacional y Colección Libro al Viento, ambas de la Biblioteca Nacional de Colombia.

Algunas de ellas - ShelvAR, READometer, Find the Future, SG Memory y OCLS Shake It!, por ejemplo- denotan una gran originalidad en el planteamiento y son testimonio de la cantidad de posibilidades que quedan por explotar en las apps bibliotecarias.

No se observan diferencias significativas a lo largo del tiempo en cuanto al tipo de utilidad de las aplicaciones. Quizás sí hay en el último año más aplicaciones con utilidades diferentes de la mera reproducción del sitio web, OPAC o el uso patrimonial. Esto se debe a las novedades españolas, BibliosBCN y DeCuentos, y latinoamericanas. En Estados Unidos se suman READometer, ShelvAR y AskALibrarian.

\subsection{Dispositivos y sistemas operativos}

Teniendo en cuenta que el smartphone es el dispositivo móvil más extendido, la mayor parte de las aplicaciones han sido diseñadas para smartphones y tabletas $(45,2 \%)$ o exclusivamente para smartphones $(41,1 \%)$. Tan solo un $13,7 \%$ han sido diseñadas solo para tabletas (gráfico 50). En este último grupo se encuentran aplicaciones cuya utilidad es sacar a la luz fondos patrimoniales, pero también una app pensada para la lectura: Ediciones Biblioteca Nacional. En España no se ha encontrado ninguna app solo para tabletas. Las aplicaciones cuya utilidad es reproducir los contenidos del sitio web de la biblioteca no se diseñan exclusivamente para tableta, sino que se suelen diseñar para smartphone o para ambos dispositivos.

Las primeras apps exclusivamente para tabletas de la muestra aparecen en 2011, por lo que se supone que ese es el año en que se inauguran. El iPad se comercializó a partir de abril de 2010 y en mayo de 2011 se tiene constancia de la primera app de bibliotecas para ese dispositivo: NYPL Biblion: World's Fair. A finales de ese 
mismo año aparece también Victorian Christmas, la app de la British Library. En los dos años siguientes irán surgiendo otras con la misma filosofía. Las apps diseñadas exclusivamente para tabletas suelen funcionar en sistema operativo iOS; tan solo se ha encontrado una que también funciona en Android, Ediciones Biblioteca Nacional de Colombia.

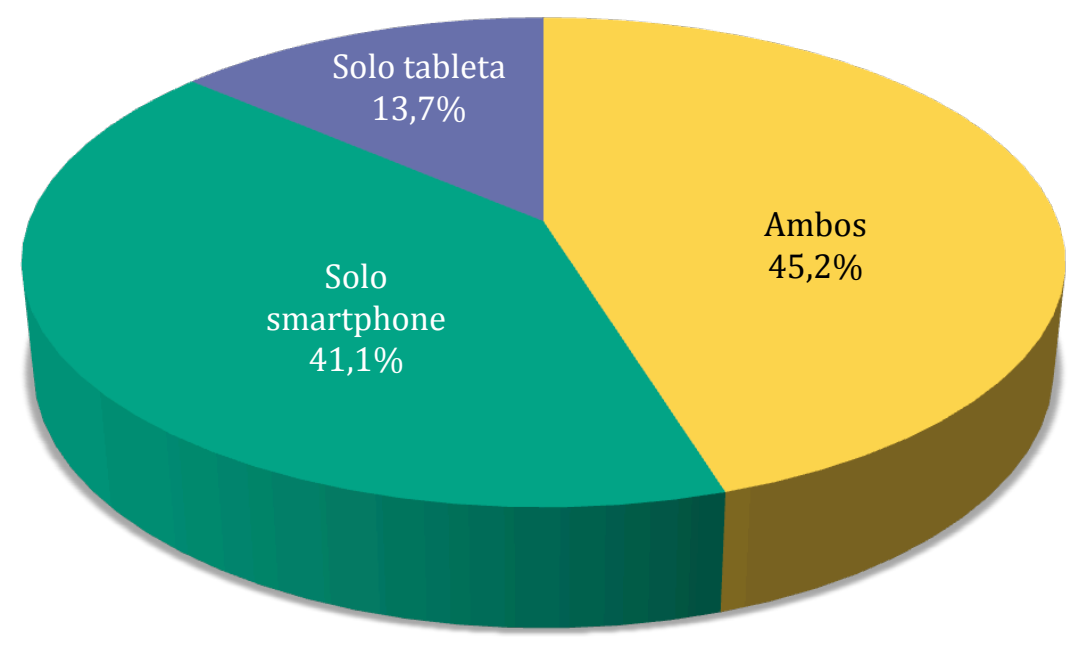

Gráfico 50. Apps por tipo de dispositivo ( $n=73$ apps).

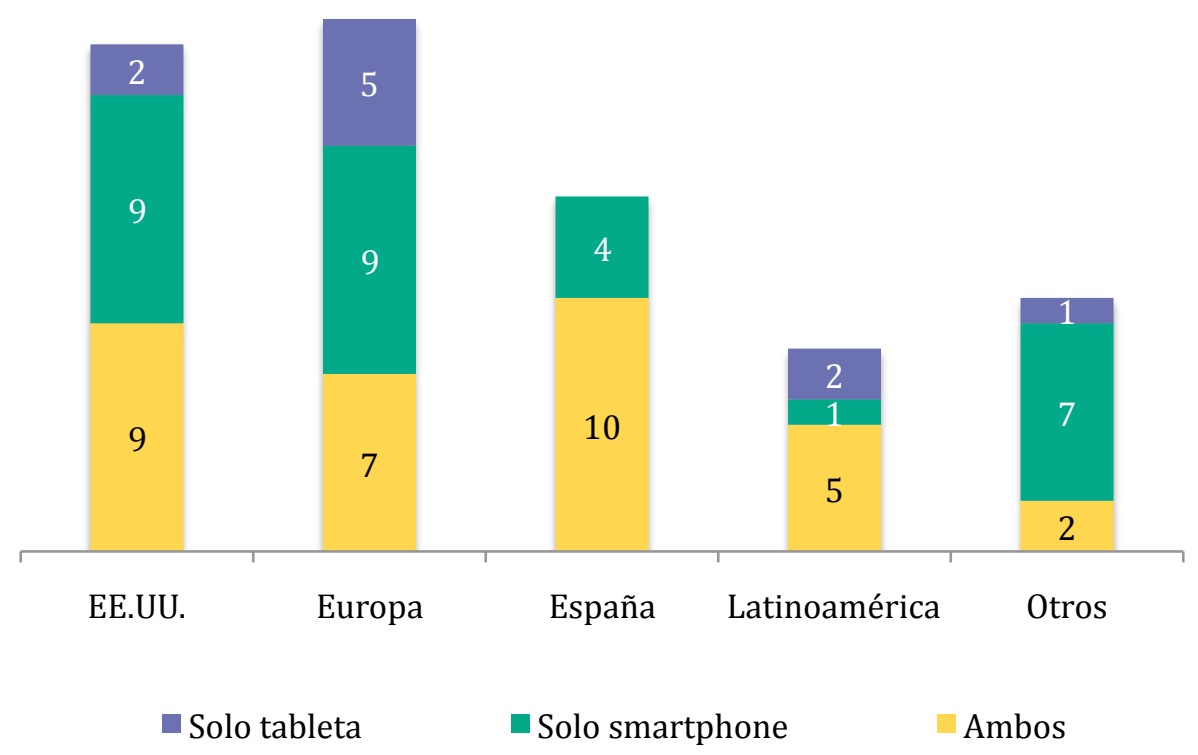

Gráfico 51. Aplicaciones por tipo de dispositivo y área geográfica ( $n=73$ apps). 
La mayor parte de las apps analizadas han sido diseñadas para iOS y Android $(52,1 \%)$, los dos sistemas operativos para dispositivos móviles más extendidos. Sólo un 9,6\% han sido diseñadas exclusivamente para Android y el 38,4\% funciona exclusivamente en iOS (gráfico 52). La tendencia más generalizada es, por lo tanto, diseñar para esos dos sistemas operativos, pero hay excepciones.

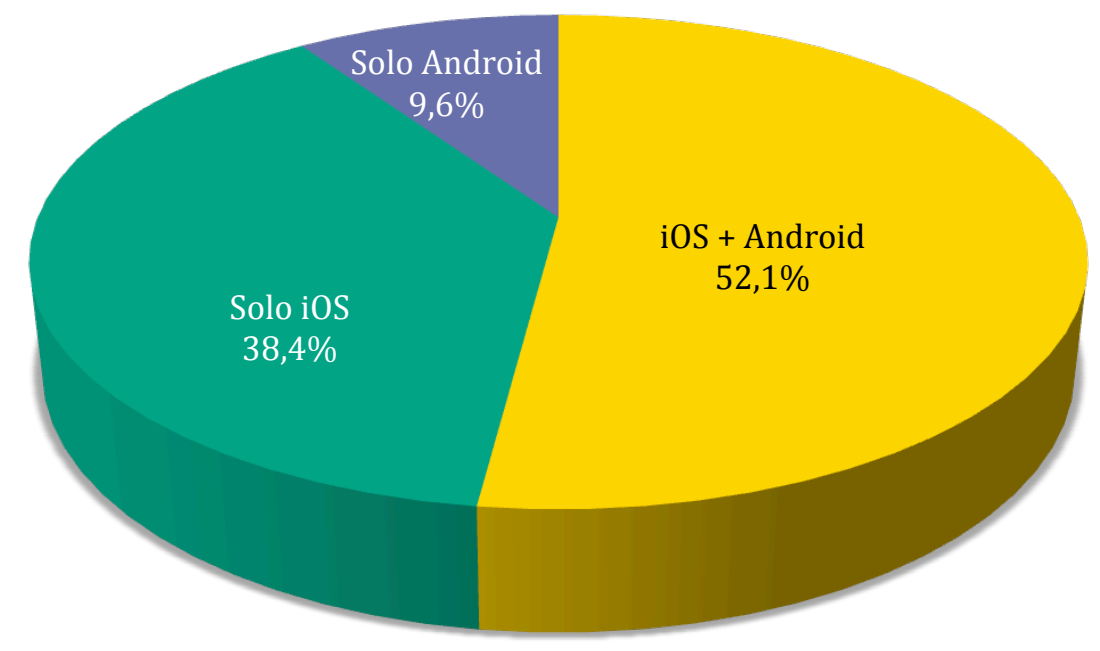

Gráfico 52. Aplicaciones por sistema operativo ( $n=73$ apps).

Por regla general, las apps que publican fondos patrimoniales, para realizar visitas virtuales o las dedicadas a la lectura prefieren iOS. Por otra parte, solo se han localizado tres apps que reproducen el sitio web de la biblioteca diseñadas exclusivamente para Android.

En España, el 64,3\% de las aplicaciones están diseñadas para ambos sistemas operativos. El resto sólo están diseñadas para Android y no hay ninguna diseñada exclusivamente para dispositivos de Apple. Esta situación es muy diferente del resto de los países analizados, donde se prefiere iOS frente a Android (gráfico 53). La mayor facilidad para publicar apps en Android y la creciente popularidad de este sistema operativo en nuestro país podrían ser las causas. Además, las bibliotecas españolas han comenzado a crear apps más tarde que otros países, cuando los dispositivos con Android ya estaban asentados en el mercado.

En las apps con versión Android no se especifica si están diseñadas para tableta o para smartphone. Hay seis apps de bibliotecas con versión para Android en esta situación, de manera que se ha entendido que tienen versión para tableta también, 
pues desde la versión 4.0 (Ice Cream Sandwich) el sistema operativo Android es indistinto para smartphones o tabletas. Se trata de las aplicaciones BibliotequesXBM, Biblioteca UCS, Catàleg de biblioteques UAB, Colección Libro al Viento y Biblioteca Móvil de la UCA.

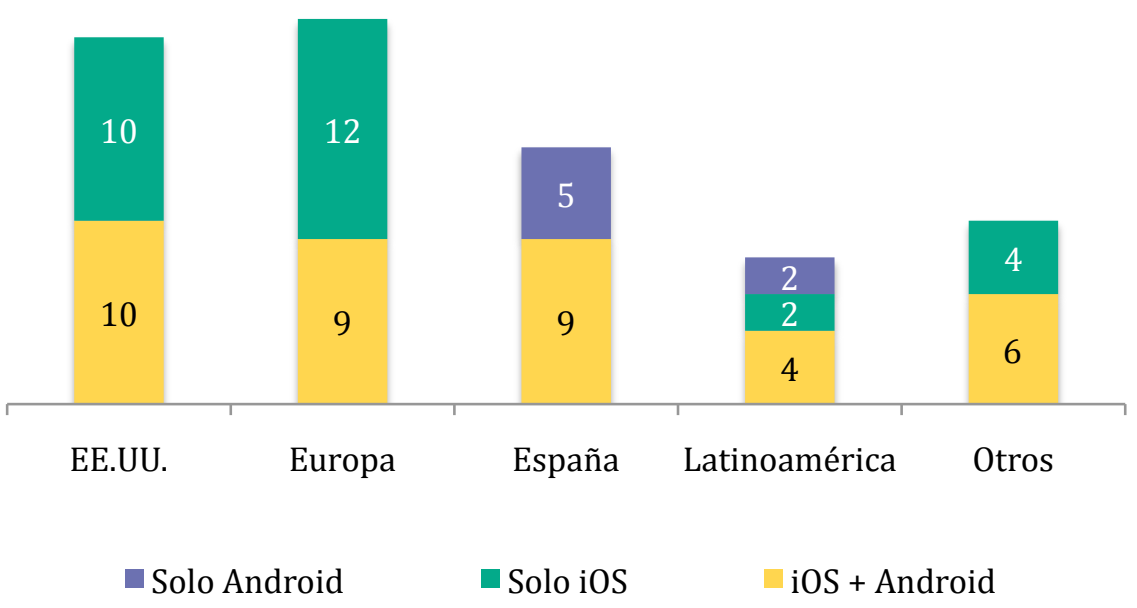

Gráfico 53. Aplicaciones por sistema operativo y área geográfica ( $n=73$ apps).

\subsection{Información de la tienda de aplicaciones}

Se analizan en este apartado diferentes datos extraídos de la tienda de aplicaciones: la categoría temática en la que se puede encontrar, para qué edades están indicadas, la fecha de la última versión, el tamaño que ocupan al instalarlas en el dispositivo, el número de descargas y la valoración que los usuarios hacen de ellas.

También ha sido analizado el coste de las aplicaciones en la tienda de apps. Se puede afirmar que prácticamente todas las aplicaciones de bibliotecas son completamente gratuitas para el usuario. De las analizadas, solo la app de la British Library, Victorian Christmas, es de pago y tiene un coste de 8,99€. 


\subsubsection{Categorías temáticas}

Las tiendas de Apple y Android clasifican las apps en 24 categorías diferentes cada una. Como se puede apreciar en la tabla 18, entre ambas tiendas hay coincidencias en esas categorías, pero en algunos casos no. Al colocar una app en la tienda de aplicaciones para su distribución, el desarrollador le asigna una categoría de las disponibles. La asignación de una categoría u otra influirá en la recuperación de la app por parte del usuario.

Las apps de bibliotecas analizadas se pueden encontrar en unas pocas categorías temáticas de las tiendas de aplicaciones: catálogos, educación, estilo de vida, libros, referencia, entretenimiento, viajes, juegos, utilidades y Libraries \& Demo. Como se puede apreciar en los gráficos 54 y 55, esta categorización presenta diferencias en función de la utilidad de la app y de la tienda de aplicaciones y queda patente que se trata de una elección subjetiva, dadas las diferencias dentro de las apps con una misma utilidad. Así, en la App Store más de la mitad de las aplicaciones que reproducen el sitio web de la biblioteca quedan clasificadas en el apartado de educación (59,1\%). El resto se encuentra en los capítulos de libros $(13,6 \%)$, estilo de vida $(13,6 \%)$, catálogos $(9,1 \%)$ y referencia $(4,5 \%)$.

Educación $(54,5 \%)$ y libros y referencia $(36,4 \%)$ son las principales categorías en que se encuentran este tipo de apps en la tienda de Android: nueve de cada diez aplicaciones de bibliotecas están en esas categorías (90,9\%). En último lugar se sitúa Libraries \& demo $(9,1 \%)$, una categoría que puede causar confusión, puesto que el término Libraries no se refiere aquí a bibliotecas como espacios de información y lectura, sino a un término del área de informática.

En este tipo de aplicaciones que reproducen los contenidos del sitio web de la biblioteca se ha observado que en algunas ocasiones (siete apps) se asignan categorías diferentes en la tienda de Apple y en la de Android para una misma app. No parece una solución lógica, teniendo en cuenta que se trata de una misma aplicación y que existen categorías idénticas en esos apartados en ambas tiendas de aplicaciones. En el resto de las apps analizadas esto no sucede, con una única excepción.

Existe un mayor consenso en la categorización de las apps cuya principal utilidad es la consulta del catálogo, que se agrupan en las categorías de referencia y educación, tanto en la tienda de Apple como en la de Android.

Las aplicaciones con función patrimonial se encuentran sobre todo en la categoría de educación (52,4\% en Apple y 62,5\% en Android), pero también en libros, entretenimiento y referencia. Es curiosa la asignación de las tres apps de la Bayerische Staatsbibliothek, sobre mapas históricos y las biografías de Ludwig II y 
Jean Paul en el apartado de viajes. Pero el apartado con mayor diversidad es el de aplicaciones con utilidades variadas, en el que aparecen juegos y otras utilidades.

En definitiva, la clasificación temática de las tiendas de aplicaciones no constituye en la práctica un elemento para el descubrimiento de las apps de las bibliotecas, ya que no existe consenso sobre en qué categoría incluirlas.

\begin{tabular}{|c|c|}
\hline Apple Store & Google Play \\
\hline \multicolumn{2}{|l|}{ Catálogos } \\
\hline & Cómics \\
\hline \multicolumn{2}{|l|}{ Comida y bebidas } \\
\hline & Compras \\
\hline & Comunicación \\
\hline Deportes & Deportes \\
\hline Economía y empresa & Negocios \\
\hline Educación & Educación \\
\hline Entretenimiento & Entretenimiento \\
\hline Estilo de vida & Estilo de vida \\
\hline Finanzas & Finanzas \\
\hline \multirow{2}{*}{ Foto y vídeo } & Fotografía \\
\hline & Media \& Video \\
\hline \multirow[t]{3}{*}{ Juegos } & Juegos \\
\hline & Live Wallpaper \\
\hline & Libraries \& Demo \\
\hline Libros & \multirow{2}{*}{ Libros y referencia } \\
\hline Referencia & \\
\hline Medicina & Medicina \\
\hline Música & Música y audio \\
\hline \multicolumn{2}{|l|}{ Navegación } \\
\hline \multicolumn{2}{|l|}{ Niños } \\
\hline Noticias & \multirow{2}{*}{ Noticias y revistas } \\
\hline \multirow[t]{2}{*}{ Quiosco } & \\
\hline & Personalización \\
\hline Productividad & Productividad \\
\hline Redes sociales & Social \\
\hline Salud y forma física & Salud y fitness \\
\hline \multicolumn{2}{|l|}{ Tiempo } \\
\hline Utilidades & Utilidades \\
\hline Viajes & Transporte \\
\hline
\end{tabular}

Tabla 18. Correspondencia de las categorías en las tiendas de aplicaciones de Apple (Apple Store) y Android (Google Play). 


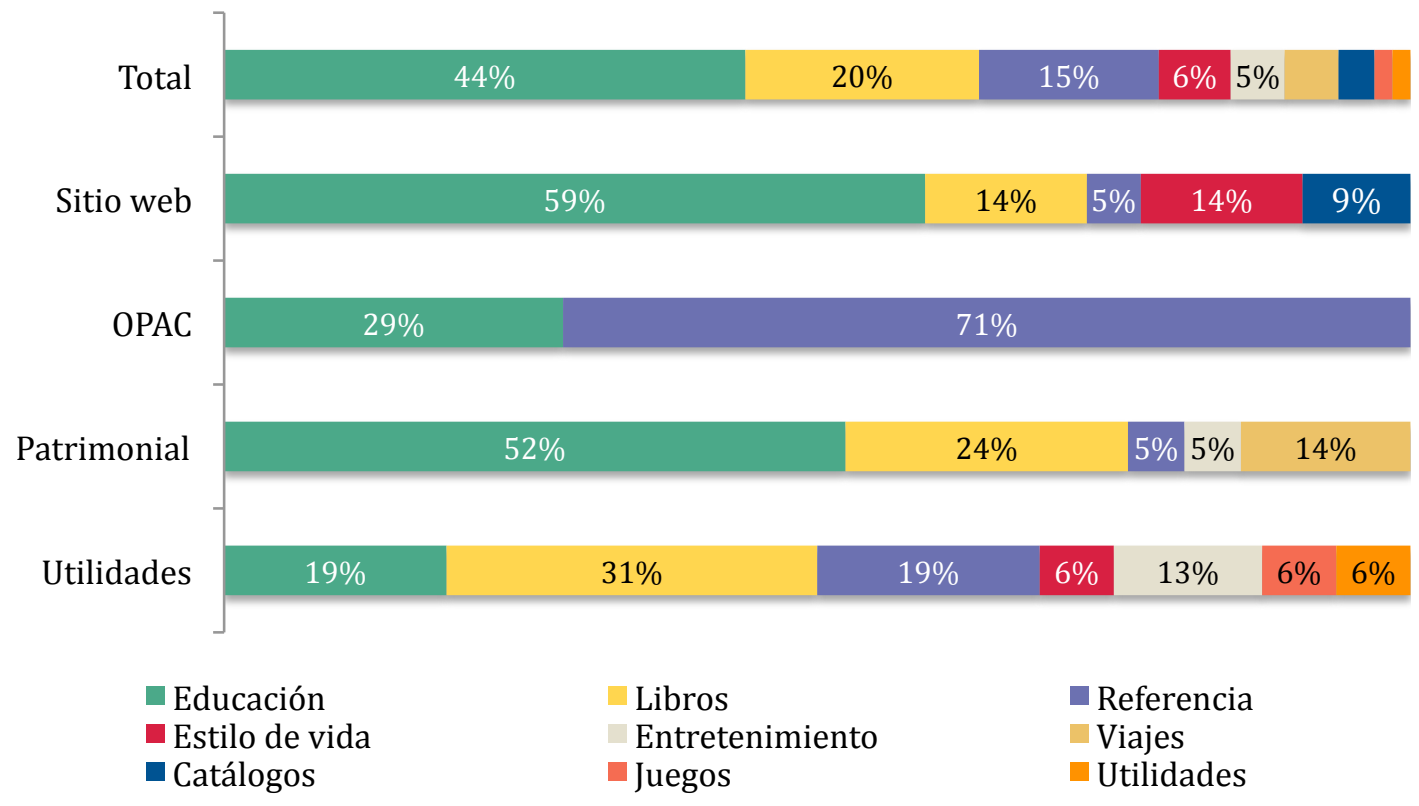

Gráfico 54. Aplicaciones para iOS según su clasificación en las categorías en la App Store $(n=66$ apps $)$.

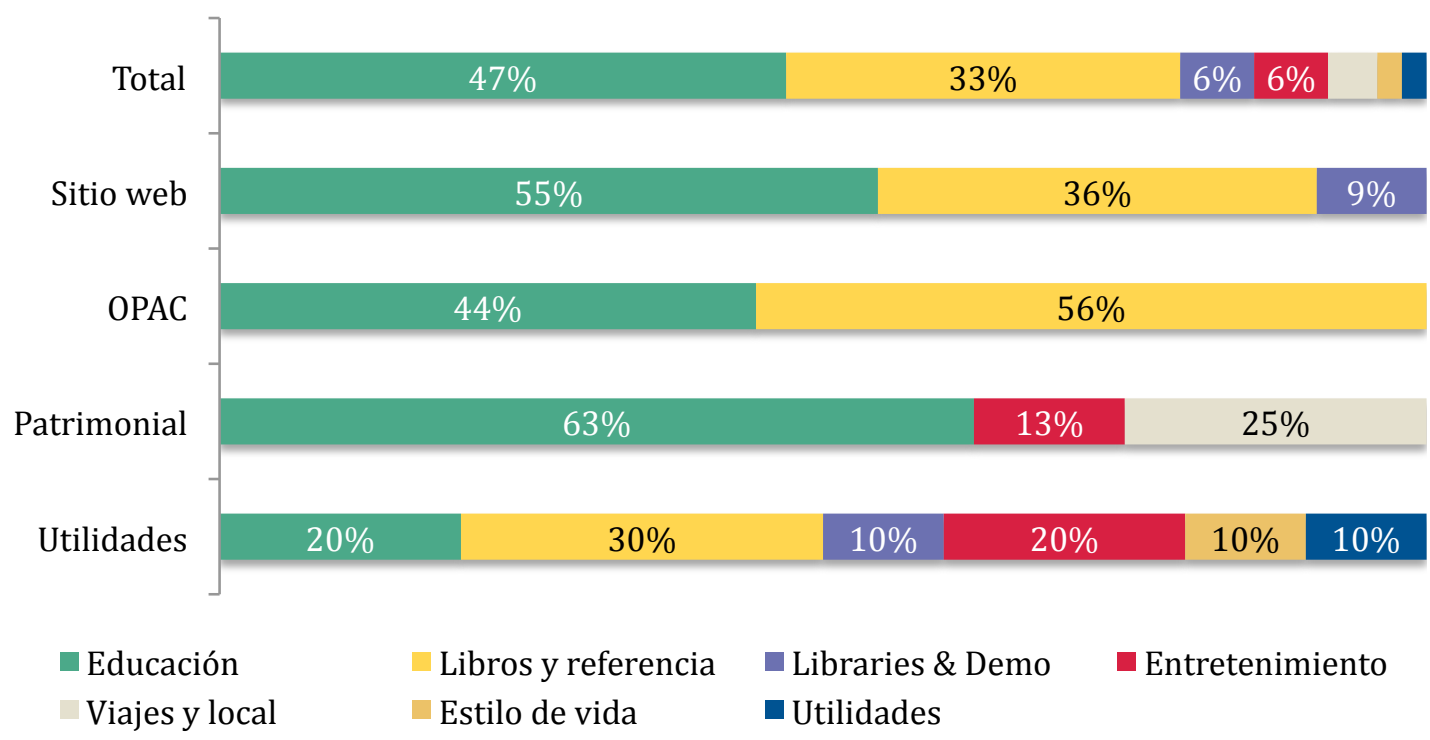

Gráfico 55. Aplicaciones para Android según su clasificación en las categorías en Google Play ( $n=49$ apps).

\subsubsection{Clasificación por edades}

La tienda de aplicaciones de Apple establece una clasificación por edades con el fin de señalar contenidos inapropiados para los menores de edad. La mayor parte de 
las apps de bibliotecas en iTunes (90,9\%) está clasificada en la opción 4+, que es la más baja e indica que no contiene ningún material inconveniente. Se han encontrado cuatro apps clasificadas en la categoría 9+, que indica que «puede contener violencia moderada y poco frecuente en dibujos o escenas fantásticas o realistas y ocasionalmente temas para adultos, sugestivos o de terror que pueden no ser adecuados para menores de 9 años de edad.» Se trata de las siguientes:

- La District of Columbia Public library señala esta categoría por: «blasfemias o humor vulgar poco frecuentes/ocasionales. Temas de horror / miedo poco frecuentes / ocasionales.»

- Frankenstein, de la New York Public Library, por: «temas de horror/miedo poco frecuentes / ocasionales. Violencia en dibujos animados o en imágenes fantásticas poco frecuente / ocasional.»

- World's Fair, de la New York Public Library, por: «temas para adultos / provocativos poco frecuentes / ocasionales.»

- HKBUtube, de la Hong Kong Baptist University Library, cuyas causas para escoger esta categoría no se han podido determinar.

Además, se han encontrado otras dos apps clasificadas como $12+$ por contenido sexual o desnudez poco frecuentes/ocasionales, consumo de alcohol, tabaco o drogas o referencias al mismo poco frecuentes/ocasionales y violencia realista poco frecuente/ocasional. Son Miniatures flamandes de la cour de Bourgogne y Gallica, ambas de la Bibliothèque Nationale de France.

\subsubsection{Actualización y versión}

La actualización periódica de las apps tras su lanzamiento permite introducir nuevas funciones, mejorar las ya existentes y corregir posibles errores, además de modificar su diseño para ofrecer una imagen más actual y una mejor integración con las nuevas versiones de su sistema operativo. Las apps que no se actualizan dan una sensación de abandono. Por otra parte, la actualización de una aplicación siempre es un buen motivo para promocionarla de nuevo. Cabe aclarar que en este apartado nos referimos a la actualización de software, y no de contenidos, que necesitan ser actualizados con mayor frecuencia aún.

El 43,8\% de las aplicaciones de la muestra creadas en años anteriores a 2012 no han sido actualizadas nunca o tan solo lo han hecho en los meses posteriores al lanzamiento, para depurar algún error. Eso significa que la mayor parte de las apps creadas en esos años $(56,3 \%)$ han sido actualizadas alguna vez. 


\begin{tabular}{rrrrrrr} 
& \multicolumn{2}{c}{ Actualizadas } & \multicolumn{2}{c}{ No actualizadas } & \multirow{2}{*}{ Total } \\
\cline { 2 - 5 } & Apps & \multicolumn{1}{c}{$\%$} & Apps & \multicolumn{1}{c}{$\%$} & \\
\hline $\mathbf{2 0 0 9}$ & 1 & $100,0 \%$ & 0 & $0,0 \%$ & 1 \\
\hline $\mathbf{2 0 1 0}$ & 6 & $54,5 \%$ & 5 & $45,5 \%$ & 11 \\
\hline $\mathbf{2 0 1 1}$ & 13 & $86,7 \%$ & 2 & $13,3 \%$ & 15 \\
\hline $\mathbf{2 0 1 2}$ & 7 & $33,3 \%$ & 14 & $66,7 \%$ & 21 \\
\hline $\mathbf{2 0 1 3}$ & 0 & $0,0 \%$ & 24 & $100,0 \%$ & 24 \\
\hline Total & 27 & & 45 & & 72 \\
\hline
\end{tabular}

Tabla 19. Aplicaciones que se han actualizado alguna vez o nunca por año de creación (n=72 apps).

En Estados Unidos el 65,0\% de las apps no se actualiza desde hace más de un año. Incluso hay un alto porcentaje que supera los dos años $(40,0 \%)$. Y algunas llegan a los tres años: OCLS Shake It! y las de la University of Illinois at Urbana-Champaign, entre las que se encuentra una app que en el momento de escribir estas líneas ha desaparecido de la tienda de aplicaciones (ugl4eva). Las apps de esta universidad no parecen haberse actualizado nunca, pero los contenidos sí se mantienen al día, por lo que han envejecido bien. Esto demuestra cómo un buen diseño con una actualización de contenidos frecuente puede alargar mucho la vida de una app. Es por ello que, a pesar de ser el grupo de apps más joven, las clasificadas en la categoría de utilidades son también las que menos actualizadas se encuentran.

En España las apps están bastante actualizadas, la inmensa mayoría $(85,7 \%)$ tienen menos de seis meses desde la última actualización. Incluso la primera app, Bibliotecas USAL, se ha actualizado varias veces, está entre las que se han modificado hace seis meses o menos. Sobre todo teniendo en cuenta que la mayor parte de ellas son de reciente creación: el 64,3\% nacieron en 2013. Sin embargo, la app BNE 300 es la menos actualizada, entre uno y dos años. Hay que tener en cuenta que se creó con un motivo muy especial, la celebración del tricentenario de la Biblioteca Nacional.

Lo mismo sucede en Latinoamérica: las apps son de muy reciente creación y por lo tanto la mayoría tienen menos de seis meses de actualización (87,5\%). Evidentemente, las aplicaciones de más reciente creación tendrán un grado de actualización mayor, mientras que hay más probabilidades de que en las antiguas haya pasado más tiempo desde la última versión (gráfico 56). Así, una tercera parte de las apps creadas entre 2009 y 2011 se han actualizado en el año anterior al análisis realizado en esta tesis doctoral $(33,3 \%)$. 


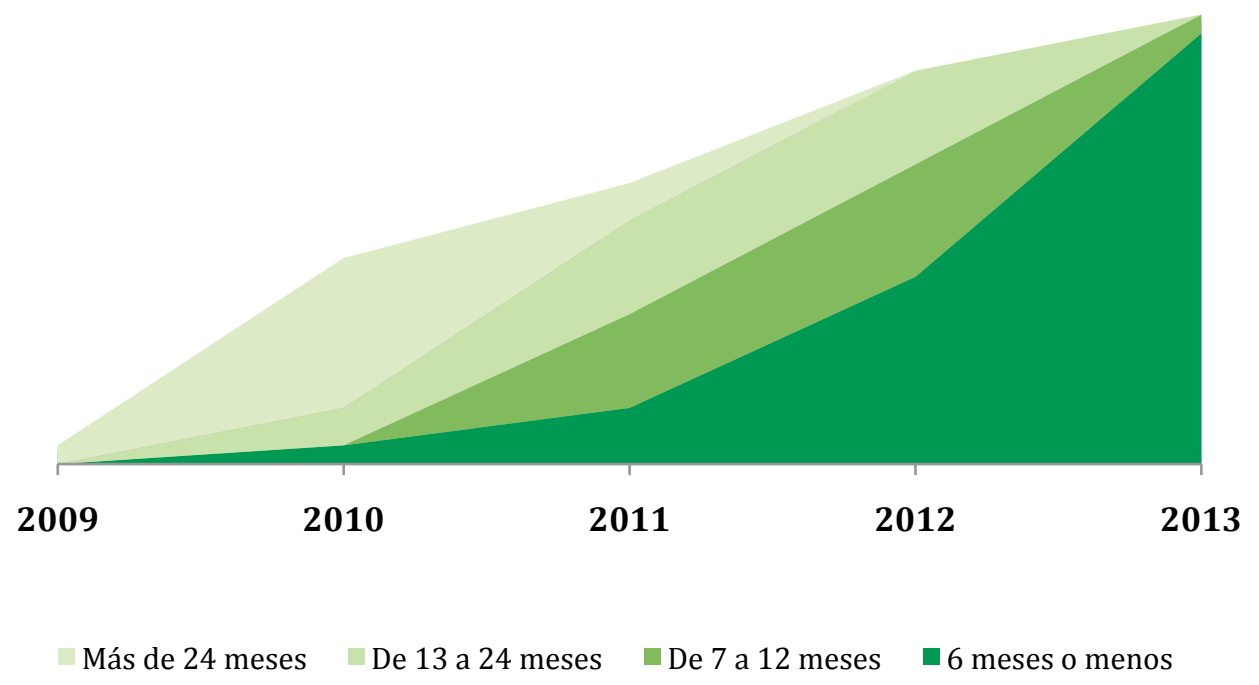

Gráfico 56. Aplicaciones en función del tiempo pasado desde su última actualización ( $n=72$ apps).

\subsubsection{Tamaño}

De forma general, las aplicaciones de bibliotecas no son muy pesadas. El tamaño medio de las apps de bibliotecas que reproducen los contenidos del sitio web es de 6,9 MB en la App Store de Apple y 3,2 MB en Google Play (Android). El tamaño varía mucho entre unas aplicaciones y otras y depende sobre todo de la utilidad de la app y de la tienda. Así, en la App Store de Apple la app más ligera ocupa 0,3 MB, mientras que la más pesada llega a 1,09 GB. Se trata de la app de la New York Public Library Biblion: Frankenstein. El gran inconveniente de las apps tan pesadas es que la descarga conlleva bastante tiempo y que ocupan una gran cantidad de espacio en el dispositivo. Sin embargo, en Google Play la app más pesada alcanza los 310,0 MB y la más ligera ocupa 0,2 MB. Por otra parte, en las apps con versiones tanto para Android como para iPhone la media del tamaño es mayor en la segunda $(19,8 \mathrm{MB})$ que en la primera $(15,5 \mathrm{MB})^{108}$.

108 En este cálculo no interviene la app más grande, puesto que solo está disponible en versión para dispositivos Apple. 


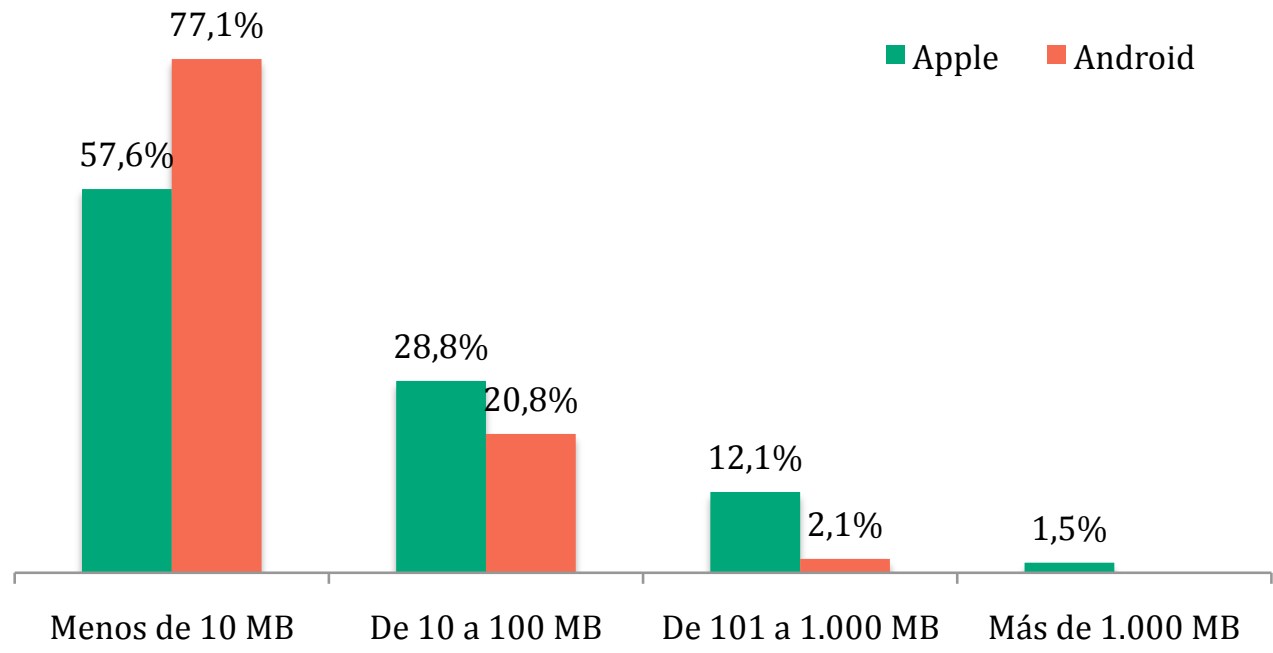

Gráfico 57. Aplicaciones en función del tamaño que ocupan y de la tienda de aplicaciones $\left(n_{1}=66\right.$ y $n_{2}=48$ apps $)$.

La mayor parte de las aplicaciones analizadas tienen un tamaño de menos de 10 MB (el 57,6\% en la tienda de Apple y el 77,1\% en la de Android) y no son muchas las que superan los $100 \mathrm{MB}$ : nueve en Apple y una en Android. Las apps más pesadas son las que cumplen una función patrimonial, debido a que sus contenidos suelen ser gráficos: imágenes que representan a las colecciones publicadas o vídeos a modo de visitas guiadas. Así, es en este grupo donde están las apps que ocupan más de $100 \mathrm{MB}$.

\begin{tabular}{rlrrrr} 
& & \multicolumn{1}{c}{ Mínimo } & \multicolumn{1}{c}{ Máximo } & \multicolumn{1}{c}{ Media } & \multicolumn{1}{c}{$\boldsymbol{n}$} \\
\hline \multirow{3}{*}{ App Store } & \multicolumn{1}{c}{ Sitio web } & 0,4 & 33,0 & 6,9 & 22 \\
\cline { 2 - 6 } & OPAC & 1,3 & 48,1 & 9,8 & 7 \\
\cline { 2 - 6 } & Patrimonial & 1,9 & $1.116,2$ & 143,6 & 21 \\
\cline { 2 - 6 } & Utilidades & 0,3 & 80,9 & 12,1 & 16 \\
\cline { 2 - 6 } Gotal & Sitio web & 0,3 & $1.116,2$ & 52,0 & 66 \\
\cline { 2 - 6 } & OPAC & 0,2 & 14,0 & 3,2 & 22 \\
\cline { 2 - 6 } & Patrimonial & 8,5 & 48,0 & 6,3 & 9 \\
\cline { 2 - 6 } & Utilidades & 0,7 & 310,0 & 65,7 & 7 \\
\cline { 2 - 6 } & Total & 0,2 & 310,0 & 14,0 & 48 \\
\hline
\end{tabular}

Tabla 20. Tamaño de las apps de bibliotecas en las tiendas de aplicaciones de Apple y Android ( $n=72$ apps). 
Las apps que representan al sitio web de la biblioteca son, por el contrario, las más ligeras: oscilan entre 0,4 y 33,0 MB en la tienda de Apple y entre 0,2 y 14,0 MB en Android. Los OPAC son algo más pesados, pero no mucho más: entre 1,3 y 48,1 MB en Apple y de 0,5 a 48,0 MB en Android.

\subsubsection{Número de descargas}

Más de las tres cuartas partes de las apps de bibliotecas para Android son descargadas entre 100 y 5.000 veces $(77,6 \%)$. Sólo unas pocas excepcionalmente consiguen un número superior de descargas: una ha sido descargada entre $5.000 \mathrm{y}$ 10.000 veces y tres entre 10.000 y 50.000. Otras siete no han llegado a las 100 descargas, a pesar de no ser de reciente creación. Como se explicó previamente, la tienda de aplicaciones de Apple no publica información sobre el número de descargas y la de Android solo lo hace en forma de intervalo, sin precisar el número exacto.

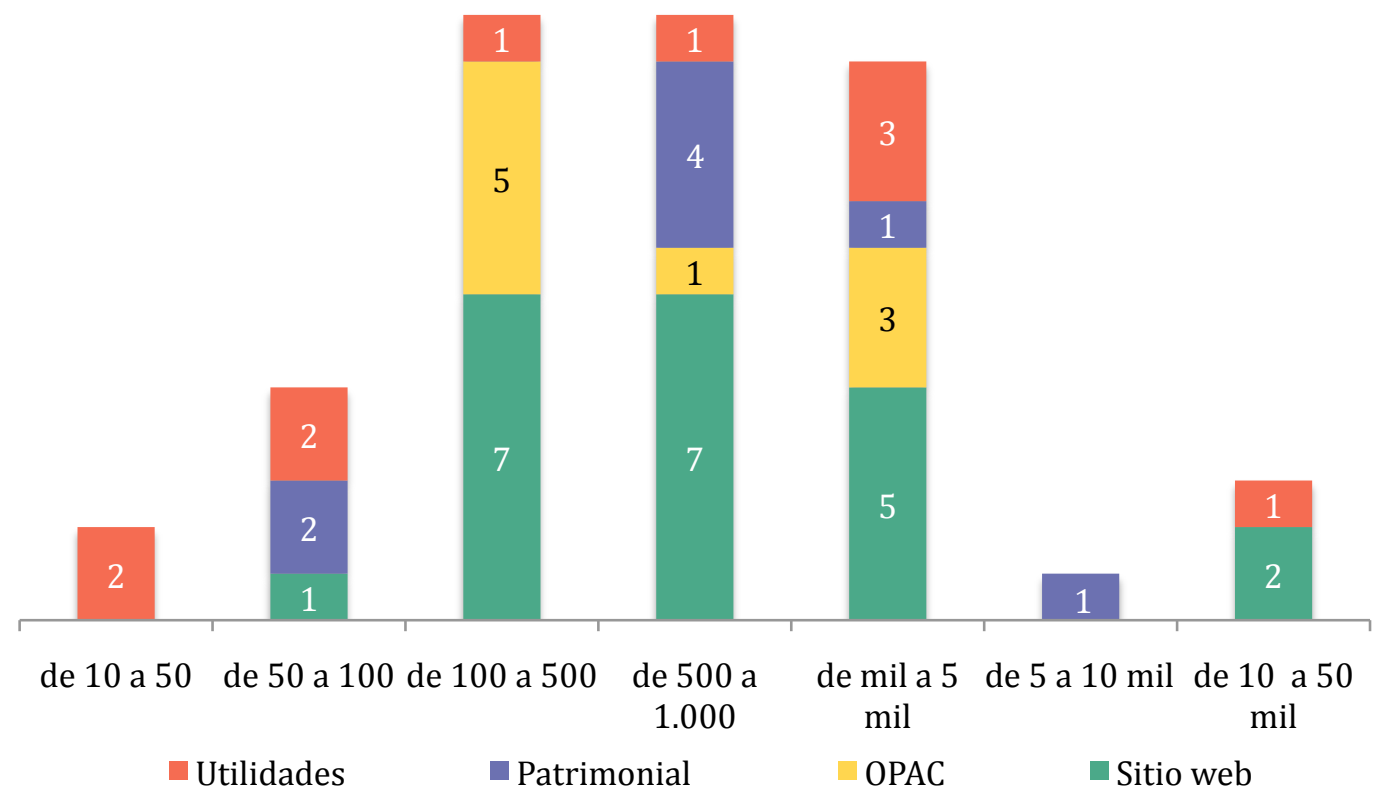

Gráfico 58. Apps según número de descargas y utilidad de la aplicación ( $n=49$ apps).

Es de esperar que aplicaciones como ShelvAR, enfocadas al público bibliotecario y difusión limitada, consigan un pequeño número de descargas. Sin embargo, que AskALibrarian, una app dirigida a los ciudadanos del Estado de Florida y en 
funcionamiento desde febrero de 2013, no haya superado las 50 descargas, resulta desalentador.

Las aplicaciones que han sido descargadas entre 50 y 100 veces son: Exhibiciones virtuales; Colección Libro al viento y Ediciones Biblioteca Nacional, de la Biblioteca Nacional de Colombia, BiblioMaresme y Jean Paul, de la Biblioteca del Estado de Baviera. A pesar de que su última actualización aparece entre abril y agosto de 2013 y, por lo tanto, ya tienen varios meses de vida.

¿Cuál es la clave del éxito de las apps con más descargas? La app de la Seattle Public Library es una de las más antiguas y de las primeras en aparecer en bibliotecas (2010), por lo que se ha convertido en un referente. Por otra parte, la ciudad de Seattle tiene una población de más de 650.000 habitantes. La app de la New York Public Library y TeleRead tienen un amplio público y llevan en funcionamiento desde 2011. La primera ha conseguido llegar al 0,6\% de los neoyorquinos y la segunda a un $1 \%$ de su público, todo Singapur ${ }^{109}$. Para poner en contexto estos datos de la New York Public Library, más de 100.000 personas participaron como voluntarias en el proyecto What's on the menu110.

En España el tramo máximo alcanzado es de 1.000 a 5.000 (Bibliotecas USAL, Biblioteca móvil de la UCA, DeCuentos y BibliosBCN). La mayor parte se encuentra en los tramos entre 100 y 1.000 descargas (64,3\%) y sólo la app de las Biblioteques del Maresme no ha superado las 100 descargas.

El número de descargas conseguidas por las apps de bibliotecas en España parece escaso, teniendo en cuenta su público objetivo. Se relatan a continuación algunos ejemplos que lo ilustran, con datos aproximados del número de usuarios en algunos casos, pues no se dispone de otros:

- Según los datos publicados por las Bibliotecas de Barcelona111, en 2013 tuvieron 905.060 usuarios y, por lo tanto, sería de esperar que su aplicación nativa BibliosBCN tenga un gran número de descargas. Sin embargo, no supera las 5.000. Estos datos, tomados a cuatro meses de su creación, han sido superados un año después y en enero de 2015 ha pasado al tramo de 5.000 a 10.000 . Eso significa que la ha descargado entre el $0,6 \%$ y el $1,1 \%$ de sus usuarios. Teniendo solo en cuenta a los

\footnotetext{
${ }^{109}$ El cálculo se ha realizado sobre la cifra más alta del intervalo.

110 Según el Informe anual 2012 de la propia biblioteca, disponible en http://www.nypl.org/sites/default/files/nypl annualreport_2012.pdf

111 Estadístiques 2013 de la Xarxa de Biblioteques de Barcelona http://w110.bcn.cat/Biblioteques/Continguts/Documents/Indicadors x web.pdf
} 
usuarios mayores de 15 años (813.221), el ratio oscila entre el 0,6\% y el $1,2 \%$.

- Siguiendo con las bibliotecas públicas, similares son los datos de Liburutegiak, la app de la Red de Lectura Pública de Euskadi. En 2012, último año con datos disponibles, esta Red registró un total de 1.049 .640 usuarios inscritos ${ }^{112}$ y en enero de 2015, un año después de su creación, la versión para Android registraba entre 1.000 y 5.000 descargas, lo que significaría que entre el 0,1\% y el 0,5\% de sus usuarios la han instalado.

- La Xarxa de Biblioteques Municipals de la Diputació de Barcelona registró en 20132.539 .357 usuarios inscritos ${ }^{113}$. Si en enero de 2015 su app BibliotequesBXM alcanzó entre 1.000 y 5.000 descargas, el porcentaje de usuarios que la tiene en su móvil estaría entre el 0,04\% y el 0,2\%.

- La app de las Bibliotecas del Maresme da servicio a 426.565 habitantes de la comarca del Maresme (téngase en cuenta que el número de usuarios será menor). Si el número de descargas está entre 50 y 100, según los datos de Google Play, se podría decir que sólo la ha descargado entre el $0,01 \%$ y el 0,02\%. Posteriormente esta app ha alcanzado el tramo de 100 a 500 descargas, en cuyo caso habría llegado a entre el 0,02\% y el 0,12\%.

Desde luego, no cabe esperar que todos los usuarios de una biblioteca instalen su aplicación, pero los porcentajes que se han señalado hasta el momento parecen muy bajos en la mayor parte de los casos. En las aplicaciones de bibliotecas universitarias españolas los datos son algo superiores: la app de la Biblioteca de la Universidad de Cádiz la habrían descargado entre el 4,4\% y el 22,0\%, la de Salamanca entre el 2,6\% y el 13,1\% y la de la Autónoma del Barcelona entre el $2,0 \%$ y el 10,1\%, como se puede apreciar en la tabla 21 . Los datos de usuarios han sido proporcionados por Rebiun y corresponden a 2012, último año del que se dispone de datos (tabla 21).

El número de descargas solo indica el número de veces que una aplicación ha sido descargada, pero no cuántas personas la mantienen instalada, sin haberla desinstalado, ni cuántas la utilizan. Como se explicará en el análisis del caso de la Biblioteca de la Universidad de Salamanca, en el séptimo capítulo, estos datos solo están disponibles para el desarrollador de la app.

\footnotetext{
112 Datos del Ministerio de Educación, Cultura y Deporte http://www.mecd.gob.es/culturamecd/areas-cultura/bibliotecas/mc/ebp/portada.html

113 Dades del conjunt de municipis amb servei de biblioteca, 2009-2013.

http://www.diba.cat/documents/16060163/23736346/FPT 2013 TOTALBIB TotalBiblioteques.p df/8757b691-32a8-4f72-aace-5375a31e48be
} 


\begin{tabular}{lrrrrrr} 
& \multirow{2}{*}{$\begin{array}{c}\text { Año de } \\
\text { creación }\end{array}$} & $\begin{array}{c}\text { Usuarios } \\
\text { propios }\end{array}$ & \multicolumn{4}{c}{ Descargas (por tramo) } \\
\cline { 5 - 8 } & & Inferior & \% & Superior & \multicolumn{1}{c}{ \% } \\
\hline Aut. de Barcelona & 2013 & 49.505 & 1.000 & $2,0 \%$ & 5.000 & $10,1 \%$ \\
\hline A Coruña & 2012 & 24.334 & 500 & $2,1 \%$ & 1.000 & $4,1 \%$ \\
\hline Cádiz & 2012 & 22.755 & 1.000 & $4,4 \%$ & 5.000 & $22,0 \%$ \\
\hline Salamanca & 2011 & 38.046 & 1.000 & $2,6 \%$ & 5.000 & $13,1 \%$ \\
\hline UNED & 2012 & 240.887 & 100 & $0,0 \%$ & 500 & $0,2 \%$ \\
\hline
\end{tabular}

Tabla 21. Descargas de apps según el número de usuarios de bibliotecas universitarias.

Los datos presentados serían metodológicamente mejorables de disponer de series homogéneas, especialmente en el caso de las bibliotecas públicas, cuyo número de usuarios se ha tomado de diversas fuentes y que en ocasiones mide cosas diferentes. Por ello deben considerarse con ciertas reservas. El número de descargas consignado ha sido el que registraba la tienda de aplicaciones de Android el 31 de enero de 2015. Se ha preferido el dato más reciente, en lugar del consignado durante la recogida de datos (finales de 2013 o principios de 2014), porque el tiempo de disponibilidad de una app parece un factor fundamental en el número de descargas. De hecho, se ha observado que en ese intervalo de tiempo de un año algunas apps han ascendido al tramo superior en el número de descargas.

\subsubsection{Valoración de los usuarios}

La valoración media que reciben las apps de bibliotecas en las tiendas de aplicaciones es de 4,02 en la App Store y 4,18 en Google Play, en una puntuación de uno a cinco. La mayor parte de las apps en la App Store $(68,2 \%)$ no reciben ninguna valoración por parte de los usuarios y casi la mitad de las que son valoradas son puntuadas por tan solo un máximo de diez personas $(47,6 \%)$.

En Google Play son pocas las que no han recibido ninguna valoración (8,2\%), pero la mayor parte tienen menos de 10 valoraciones $(57,1 \%)$. En la tienda de Apple el $83,3 \%$ de las apps no recibe ninguna valoración o recibe hasta diez. Solo algunas consiguen un gran número de valoraciones, lo que puede considerarse un indicativo de su popularidad (gráfico 59).

\footnotetext{
114 Fuente: Rebiun. Indicadores de las bibliotecas

http://estadisticas.rebiun.org/cuestionarios/indicadores/indicadores main.asp\#
} 


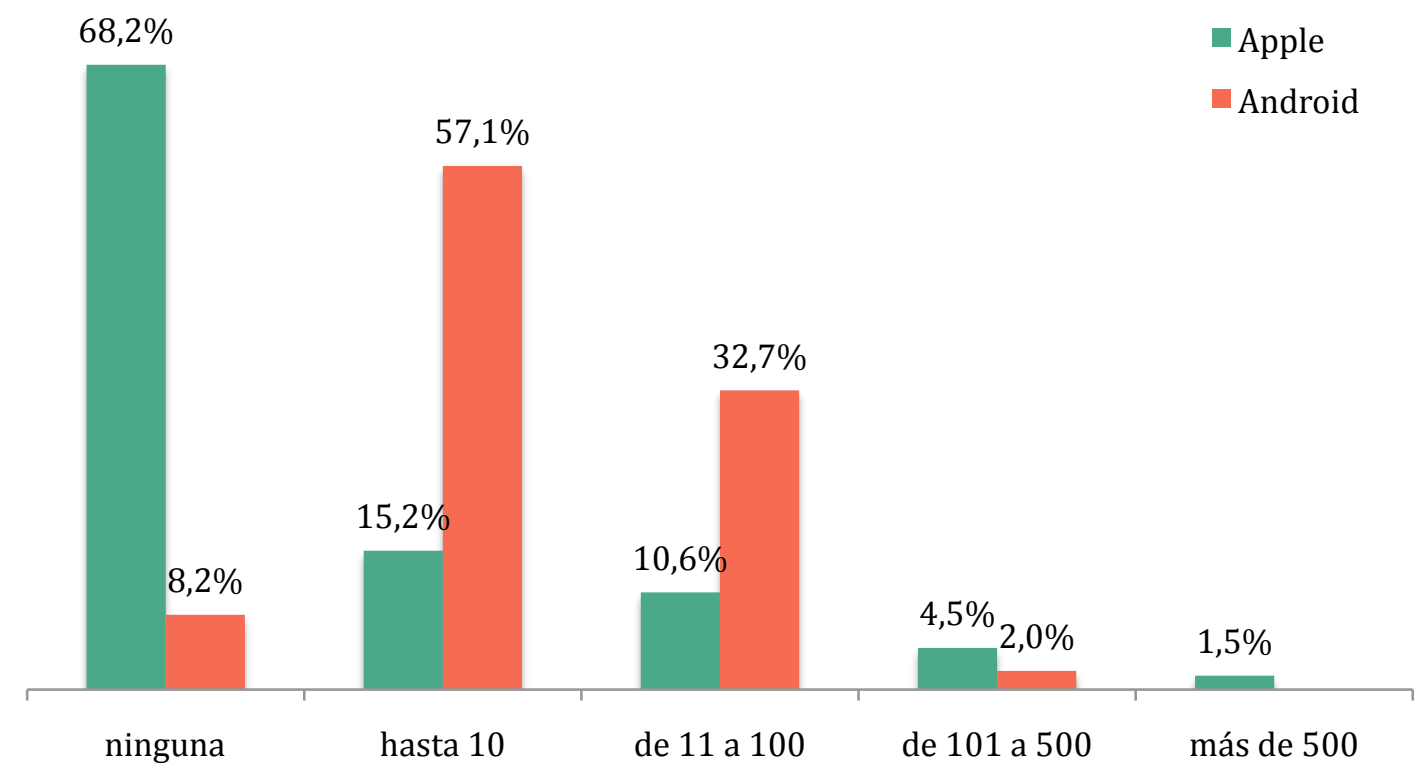

Gráfico 59. Aplicaciones por número de valoraciones recibidas en las tiendas de aplicaciones de Apple y Android ( $n_{1}=66$ apps y $n_{2}=49$ apps).

La aplicación más popular, por ser la que más valoraciones ha recibido, es $N Y P L$ Biblion: World's Fair, que ha sido valorada por 765 personas en la App Store. Otras apps muy populares son las de la District of Columbia Public Library, con 247 valoraciones, la de la Seattle Public Library (162 valoraciones) y NYPL Mobile (115), también de la New York Public Library. Estas están también entre las apps más descargadas, así que cabe esperar que, a mayor número de personas que descargue la $a p p$, el número de valoraciones puede crecer. En definitiva, se puede afirmar que en la App Store hay aplicaciones mucho más populares —si se mide la popularidad en función del número de valoraciones-, aunque en general es mayor el número de aplicaciones puntuadas en Google Play. 


\subsection{Acceso a las aplicaciones nativas}

Enlazar la app desde el sitio web de la biblioteca es fundamental para que los usuarios la conozcan. Este detalle cobra aún más relevancia cuando se trata de la versión para smartphones del sitio web, puesto que quien accede a él lo está haciendo posiblemente desde un móvil y por lo tanto la descarga de la app puede serle de interés. Por otra parte, que el enlace sea visible y directo, sin pasar por una o varias páginas intermedias, facilitará el acceso a la $a p p$.

Sin embargo, en el $32,9 \%$ de las apps analizadas no se ha encontrado un enlace desde el sitio web de la biblioteca o de la institución que la representa. De aquellas apps que sí están enlazadas, más de la mitad $(57,1 \%)$ no lo están desde la página principal, sino desde una página intermedia en la que se habla de la app - lo que obliga a hacer dos clics al lector para descargarla - o desde otra página del sitio web.

En España es menor el porcentaje de aplicaciones que están enlazadas desde el sitio web de la biblioteca, el 57,1\%, mientras que en Europa y Estados Unidos es mayor que la media de la muestra (81,0\% y 75,0\% respectivamente). En los países latinoamericanos sólo se ha encontrado una app enlazada desde el sitio web.

De las apps que representan al sitio web de la biblioteca, casi la mitad (48,0\%) no están enlazadas desde el sitio web. Y de las 13 que sí lo están, 5 no están enlazadas directamente, sino a través de una página intermedia o de otra página del sitio. El ratio de enlace es mayor en el caso de las apps con función de difusión del patrimonio (el $85,7 \%$ sí están enlazadas), acceso al catálogo $(77,8 \%)$ y otras utilidades $(61,1 \%)$.

En la muestra de sitios web para móviles analizados se han encontrado 7 bibliotecas que tienen tanto versión móvil de su sitio web como app, lo que significa que la mayoría de las bibliotecas están escogiendo una u otra opción. Además, se han encontrado otros tipos de sitios web que también tienen ambas versiones, tanto web móvil como app: WolfWalk y el servicio de referencia AskALibrarian.org. En España son cuatro las bibliotecas que tienen tanto versión móvil de su sitio web como aplicación: bibliotecas Públicas de Navarra, Universidad de Salamanca, UNED y Universidad de Cádiz.

De las bibliotecas que tienen tanto versión móvil del sitio web como aplicación nativa, solo dos enlazan desde la página principal de la versión móvil a la aplicación -Worthington Libraries y la Biblioteca de la Northwestern University-, perdiendo así una excelente oportunidad para dar a conocer su app, en la que tanto esfuerzo se ha invertido. Además, se han hallado 7 bibliotecas que tienen versión móvil del sitio web y que además tienen aplicaciones nativas que 
cumplen otras funciones, como dar a conocer los fondos de la biblioteca u otras utilidades.
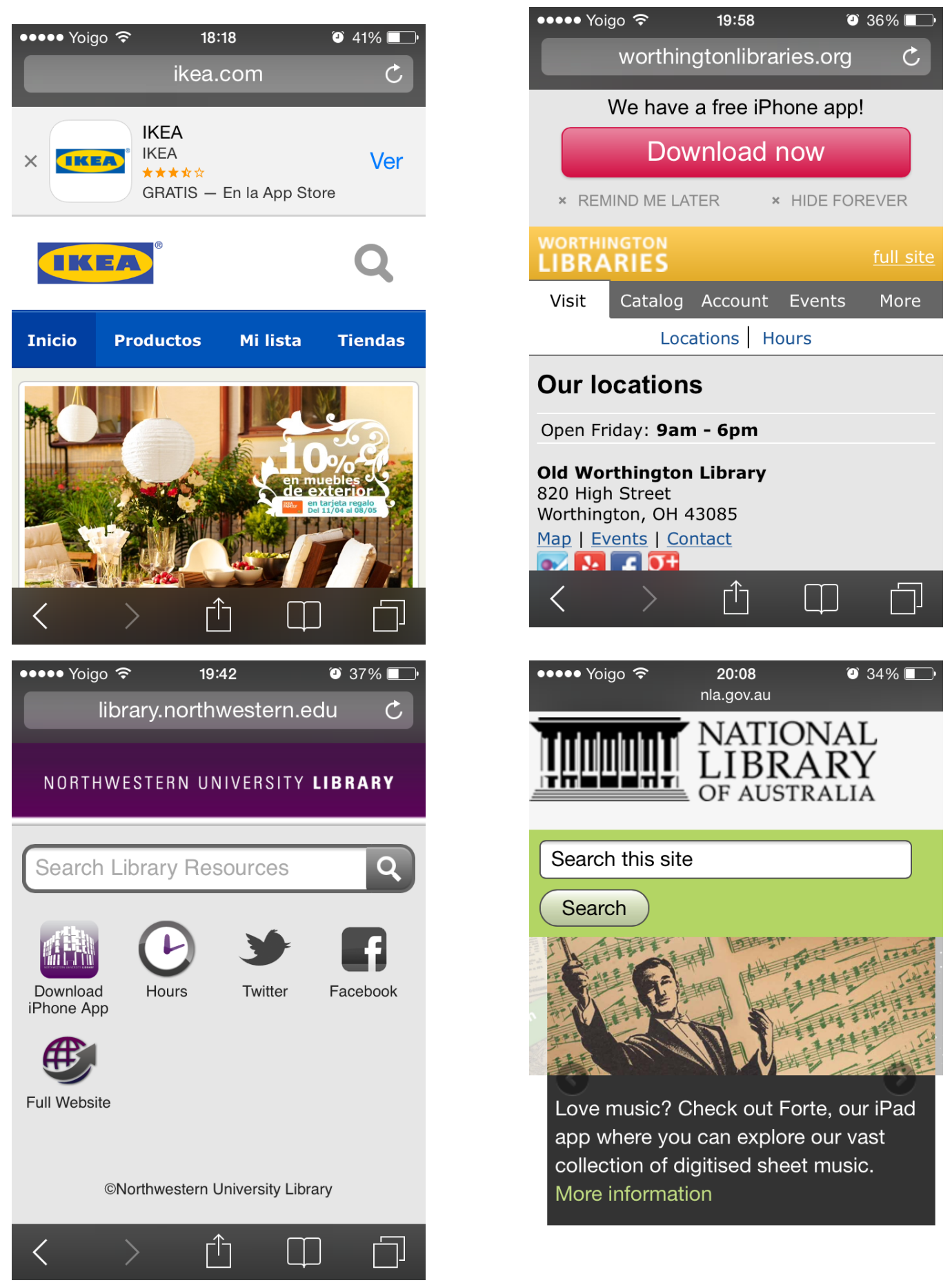

\section{Our locations}

Open Friday: 9am - 6pm

\section{Old Worthington Library}

820 High Street

Worthington, $\mathrm{OH} 43085$

Map | Events | Contact

a de
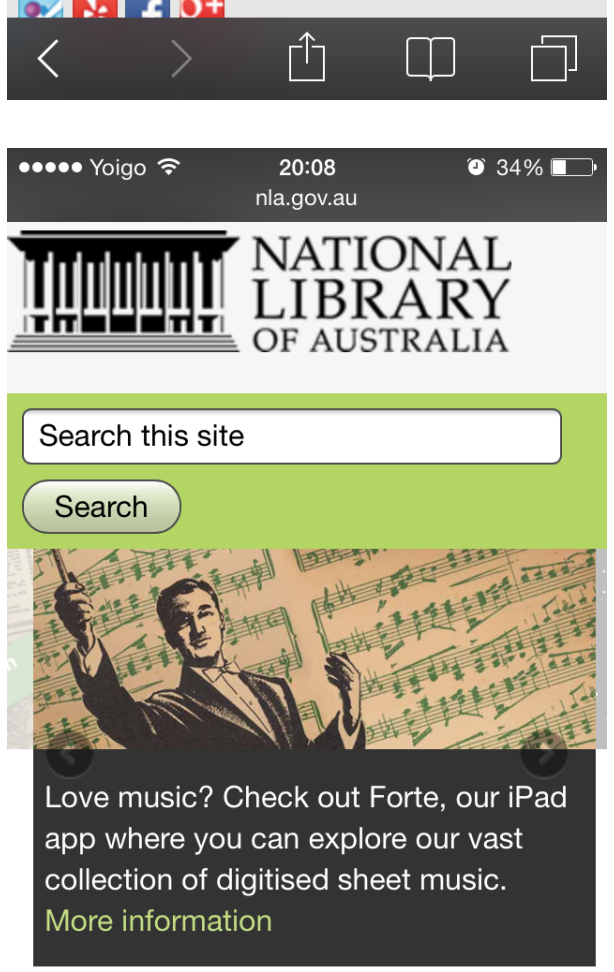

Figura 18. Diferentes formas de enlazar a la app desde el sitio web móvil. 
¿De qué formas se puede enlazar a la aplicación desde la versión móvil del sitio web? Lo más recomendable es que se haga de forma visible y enlazando directamente a la correspondiente página en la tienda de aplicaciones, para que la descarga sea lo más fácil y rápida posible. En otras instituciones, ajenas al mundo bibliotecario, se está generalizando la opción de colocan un banner en la parte superior de la página, que se verá sólo cuando se accede desde un dispositivo móvil (figura 18). Esa misma opción han seguido las bibliotecas de Worthington y la app WolfWalk (Estados Unidos). La biblioteca de la Northwestern University ha situado en un lugar preferente el enlace, mientras que la Biblioteca Nacional de Australia publicita su última aplicación Forte desde un banner. Sin embargo, es de prever que esta última opción no será permanente, porque los banners suelen cambiar sus contenidos a menudo.

Los códigos QR son utilizados por algunas bibliotecas para facilitar la descarga de la app desde el sitio web para grandes pantallas. Sin embargo, esta práctica no es muy común, tan solo se han encontrado en seis de las 73 apps analizadas (8,2\%). La mayor parte de esos casos se da en bibliotecas públicas, sólo uno en universitarias.

\subsection{Diseño de la interfaz}

Las aplicaciones de bibliotecas que reproducen los contenidos del sitio web tienden a replicar el diseño de los sitios web para móviles, aunque aparecen algunas novedades y elementos propios de las apps. Estos elementos son dos:

- Cortinilla. Al arrancar la aplicación, en algunos casos se abre con una cortinilla de carácter visual que dura unos segundos y sirve a modo de introducción, dando paso después a la interfaz de la app. Normalmente se trata de una sola pantalla con el logotipo de la app o de la institución, pero puede llegar a ocupar varias pantallas (figura 19).

- Menú horizontal inferior con iconos. Se trata de un elemento de navegación muy extendido en las apps que se mantiene en todas las páginas. Su uso evita ocupar la página inicial con un menú, pudiendo visualizar en ella los contenidos que aparecen en el menú inferior. Este elemento se hace más necesario en las apps que en los sitios web, ya que los navegadores incorporan botones para moverse a la página anterior y a la siguiente también a modo de menú horizontal inferior, pero las 
aplicaciones no, por lo que es importante incluir algún sistema de navegación constante (figura 19).
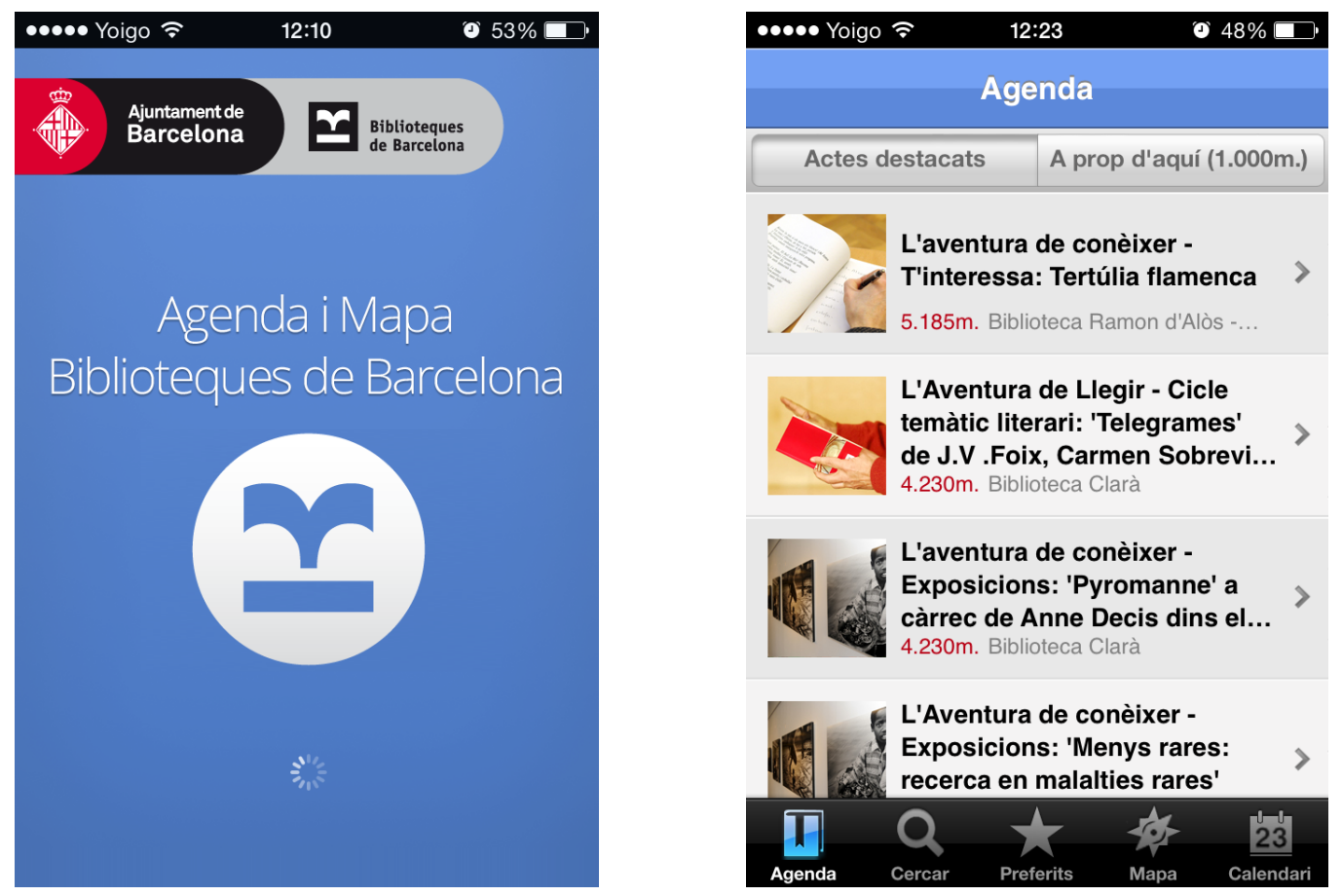

Figura 19. Cortinilla y menú horizontal inferior en la aplicación BibliosBCN.

Prácticamente tres de cada cuatro apps analizadas (74,0\%) incluyen una cortinilla inicial. En España esta práctica no es tan habitual, se da en el 57,1\% de las aplicaciones. El menú horizontal de iconos, en la parte inferior de la app, es utilizado en el 47,9\% de los casos, junto con otros elementos. Una variante de este diseño consiste en trasladar el menú a la parte superior de la página, con forma de pestañas, y se ha encontrado en las aplicaciones BibliotequesXBM y Catàleg de Biblioteques $U A B$, ya incluidas en ese $47,9 \%$ antes mencionado.

En las apps que reproducen los contenidos del sitio web y del OPAC se repiten las mismas plantillas de diseño de los sitios web para móviles: retícula de iconos, menús verticales con y sin iconos y textual. Se suma a ellos uno más y que precisamente es el que más éxito tiene: la plantilla de contenidos, en la que no se muestra un menú, como en las anteriores, sino directamente los contenidos de la app; está presente en el 47,1\% de los casos. Esta plantilla se combina con el menú inferior mencionado en el párrafo anterior. Sólo se ha encontrado una excepción, la app Shake it!, de recomendación de lecturas, que no requiere un menú inferior porque consta de la pantalla de selección y las fichas de las lecturas recomendadas. 
También se han encontrado otras plantillas de diseño en este mismo tipo de apps y que constan de un menú inferior además del menú central en forma de retícula de iconos o de menú vertical textual, con y sin iconos. Sin embargo, estos casos no son tan frecuentes como el anterior.

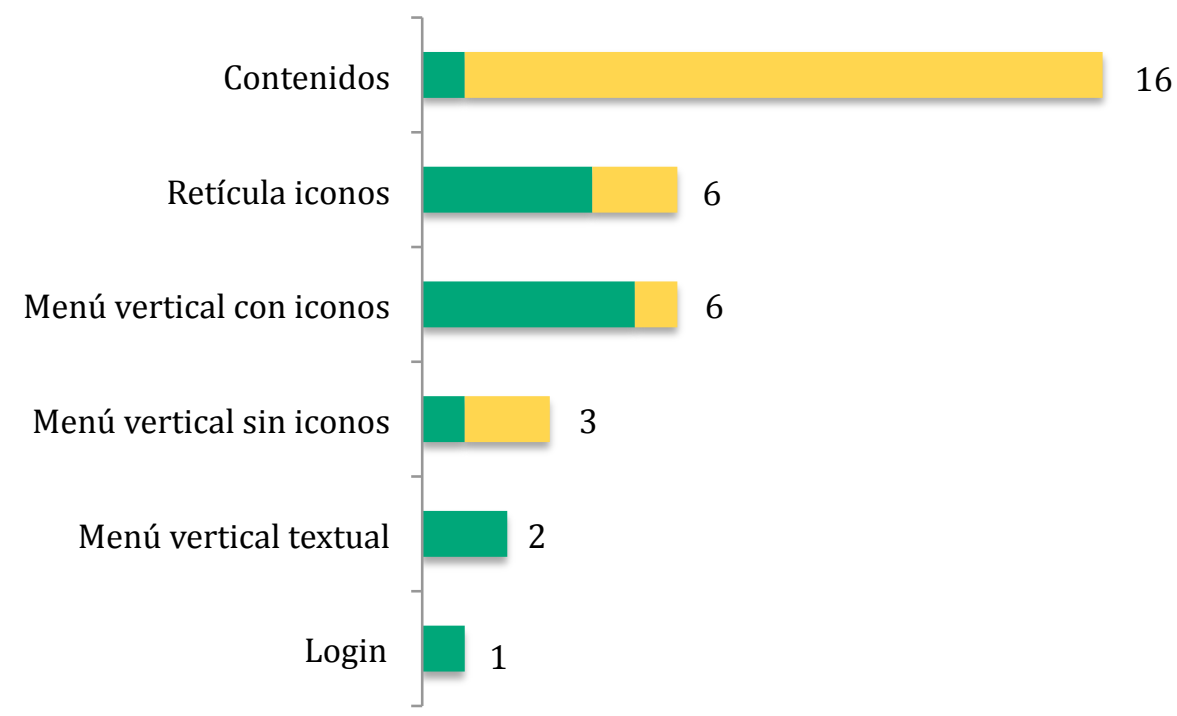

Gráfico 60. Aplicaciones que reproducen los contenidos del sitio web de la biblioteca y del OPAC en función de su plantilla de diseño. Se señalan en amarillo aquellas que además incluyen un menú inferior y en verde las que no. ( $n=34$ apps).

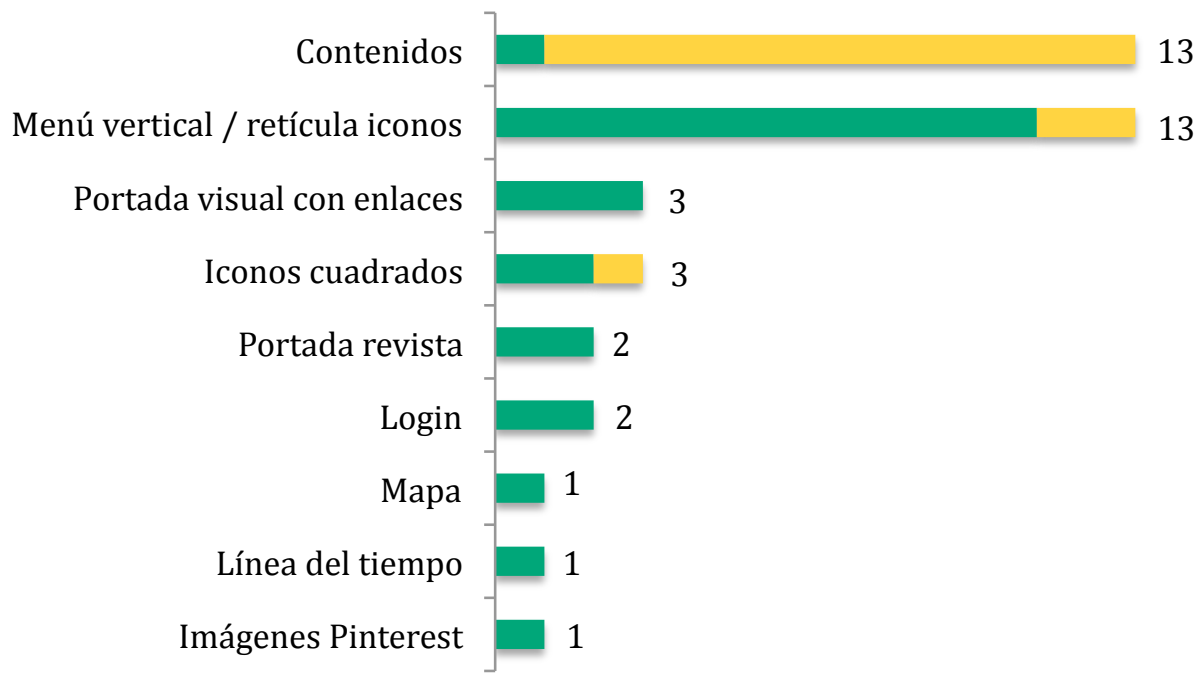

Gráfico 61. Aplicaciones con fondos patrimoniales y otras utilidades en función de su plantilla de diseño. Se señalan en amarillo aquellas que además incluyen un menú inferior y en verde las que no ( $n=39$ apps). 
Las aplicaciones clasificadas en los apartados patrimonial y de utilidades (gráfico 61) muestran una mayor variedad de diseños que dependen en gran medida de su función. Siguen teniendo mucho éxito los diseños en los que el menú inferior se combina con los contenidos (presente en casi un tercio de estas apps) y los menús verticales y de retícula de iconos (33,3\%), pero también aparecen otros nuevos que se dan de forma puntual en unas pocas apps a lo sumo: iconos cuadrados, login, imágenes tipo Pinterest, línea del tiempo, mapa, portada revista y portada visual con enlaces conforman el otro tercio restante. El menú inferior está presente en cuatro de cada diez apps de uso patrimonial y otras utilidades.

\subsection{Elementos de navegación}

Se observan notables diferencias entre los elementos de navegación en las aplicaciones nativas y los sitios web. Al examinar aquellos que reproducen los contenidos del sitio web o del catálogo se observa cómo en las apps dejan de tener importancia los elementos más utilizados en los sitios web para móviles - uso de la página principal como menú y el enlace al sitio web completo- y ganan peso otros, como el menú horizontal en la parte inferior o el botón volver.

Todos los navegadores incluyen siempre opciones para volver a la anterior página visitada o pasar a la siguiente, de manera que se facilita la navegación. A diferencia del navegador, las aplicaciones no incluyen esta opción por defecto, por lo que es necesario programarla si se desea que intervenga. Esta es la razón por la que es la más popular en las apps, se ha encontrado en el 76,0\% de las analizadas.

El menú horizontal inferior (o menú iPhone) es un elemento de navegación constante característico de las apps, como se indicó en el anterior apartado, y se convierte en el segundo elemento más frecuente $(61,8 \%)$. En los sitios web este elemento no aparecía. Por otra parte, el uso de la página principal como menú se da sólo en la mitad de las analizadas (50,0\%), mientras que aparecía en más de nueve de cada diez sitios web para móviles. Y el enlace a la versión completa del sitio web se da en menos de dos de cada diez apps (17,6\%), mientras que estaba presente en el 68,6\% de los sitios web para móviles.

En las apps desaparecen totalmente elementos de navegación como las migas de pan localizadoras, el mapa del sitio, volver a la parte superior de la página, los 
banners, y los menús contextuales. La variedad de elementos de navegación, por lo tanto, es mucho menor que en los sitios web, si hablamos de aquellas apps que reproducen los contenidos del sitio de la biblioteca.

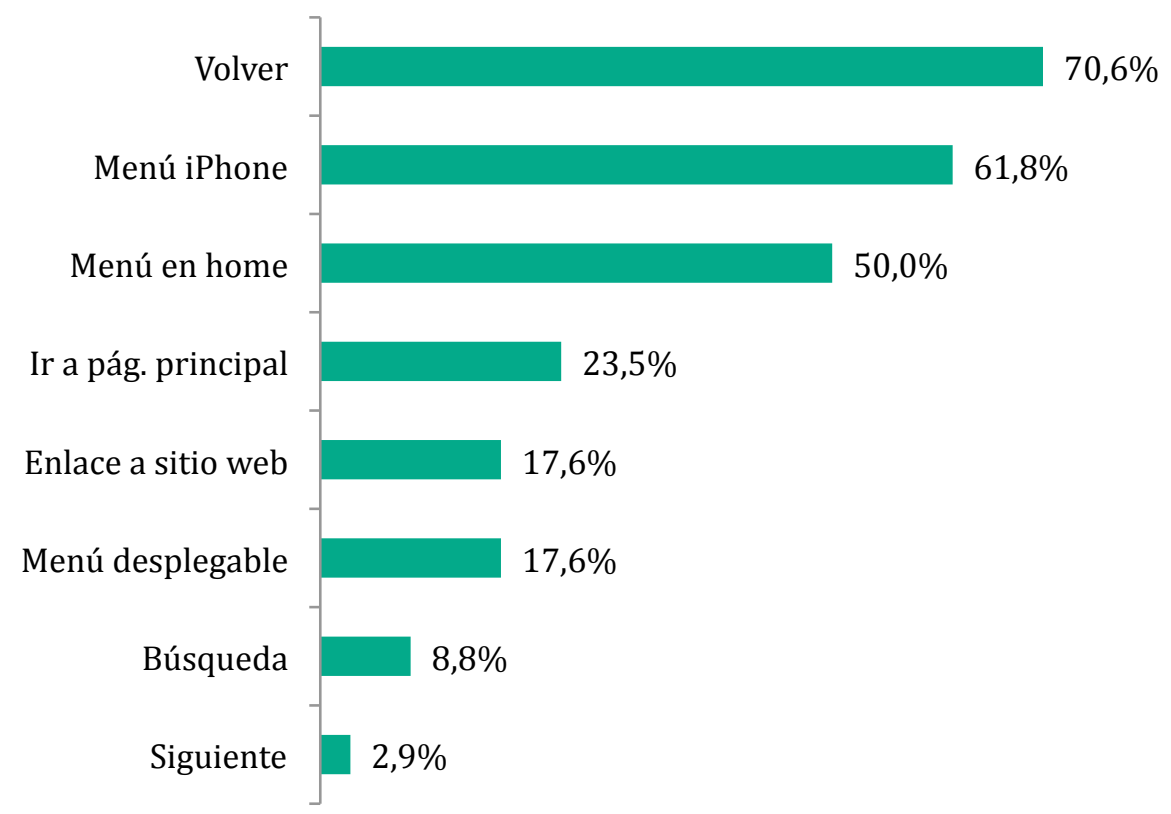

Gráfico 62. Aplicaciones que reproducen el sitio web o el catálogo de la biblioteca según la frecuencia de aparición de los elementos de navegación ( $n=34$ apps).
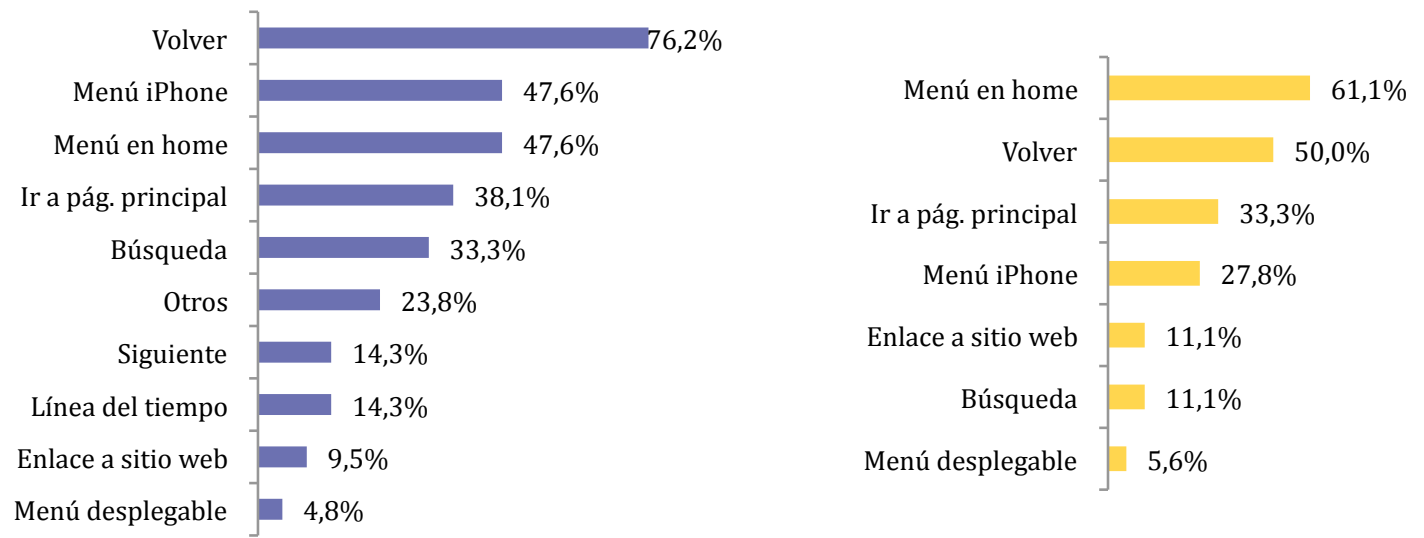

Gráfico 63. Aplicaciones de uso patrimonial (a la izquierda) y con otras utilidades (derecha) según la frecuencia de aparición de los elementos de navegación $\left(n_{1}=21\right.$ y $n_{2}=18$ apps).

En las aplicaciones de uso patrimonial y otras utilidades los elementos de navegación más utilizados siguen siendo los mismos que en el grupo anterior: la 
opción volver, el menú horizontal inferior (menú iPhone) y el uso de la página principal como menú de navegación. En las apps con otras utilidades el elemento más frecuente es el uso de la página principal como menú de navegación y el menú horizontal inferior es menos usual (gráfico 63). En tipo de aplicaciones se observa una mayor variedad y originalidad en los elementos de navegación debido a la aparición de nuevos elementos, pero también un menor consenso: el botón volver sigue siendo el más utilizado en las aplicaciones patrimoniales $(76,2 \%)$, pero el resto ya se da en menos de la mitad de las apps.
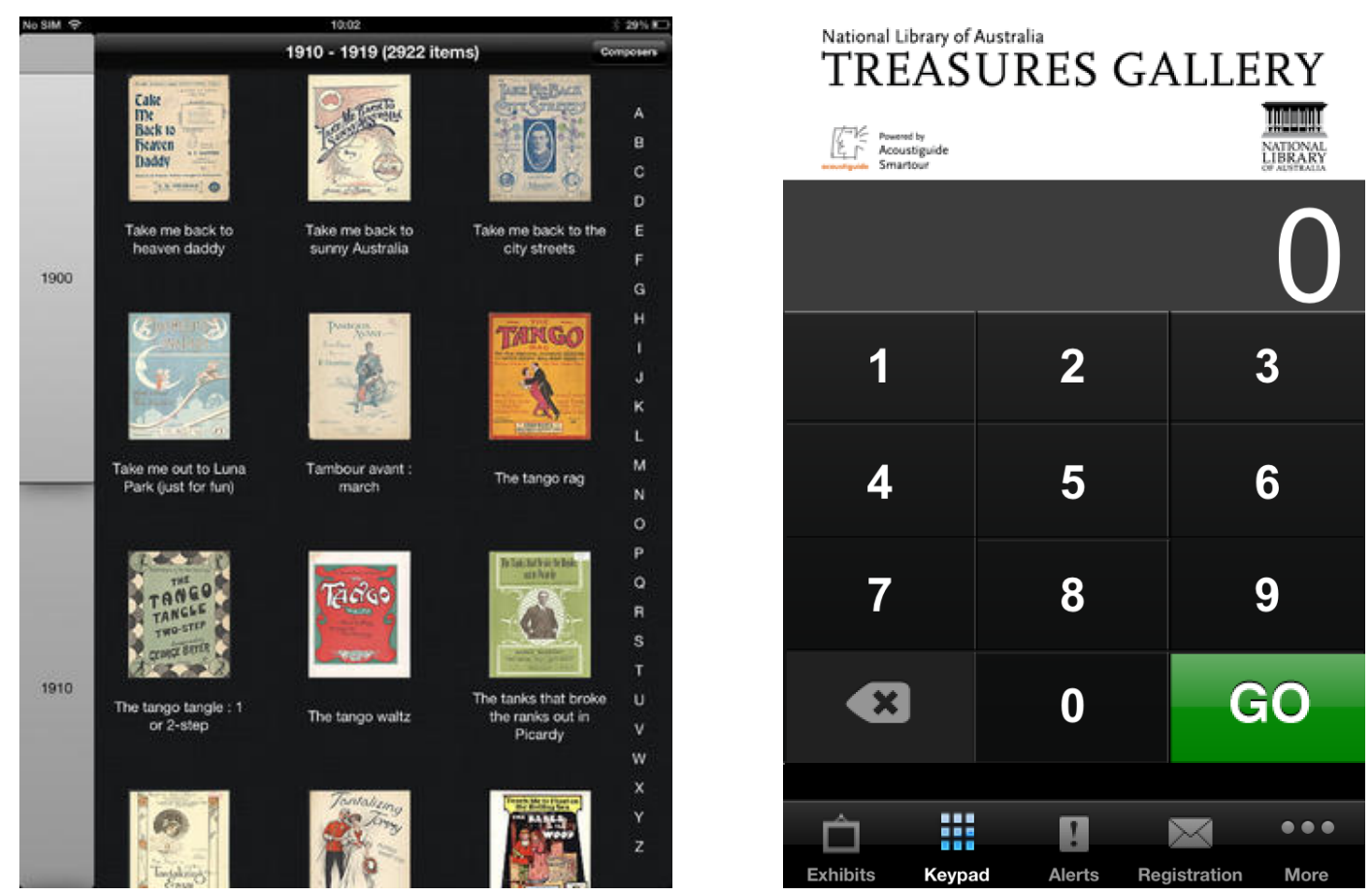

Figura 20. Menús cronológico y numérico.

En estos dos grupos de apps, las de uso patrimonial y otras utilidades, se suman además otros elementos de navegación muy originales:

- Menús gestuales. Una de las formas de navegación que permiten las pantallas táctiles es el desplazamiento gestual, por ejemplo en la misma forma que un álbum de imágenes, como en las aplicaciones de la Biblioteca Nacional Francesa (figura 21). Se trata de una serie de imágenes que se pueden pasar haciendo un gesto. También gestual es el menú horizontal de Exhibiciones virtuales, que consiste en una serie de iconos que se deslizan hasta situarse en la posición de selección.

- Menú cronológico y alfanumérico de la app Forte, de la Biblioteca Nacional de Australia (figura 20). 
- Menú numérico de Treasures, de la Biblioteca Nacional de Australia. Se puede ir a una opción concreta tecleando el código de la opción, tal y como se puede apreciar en la figura 20.

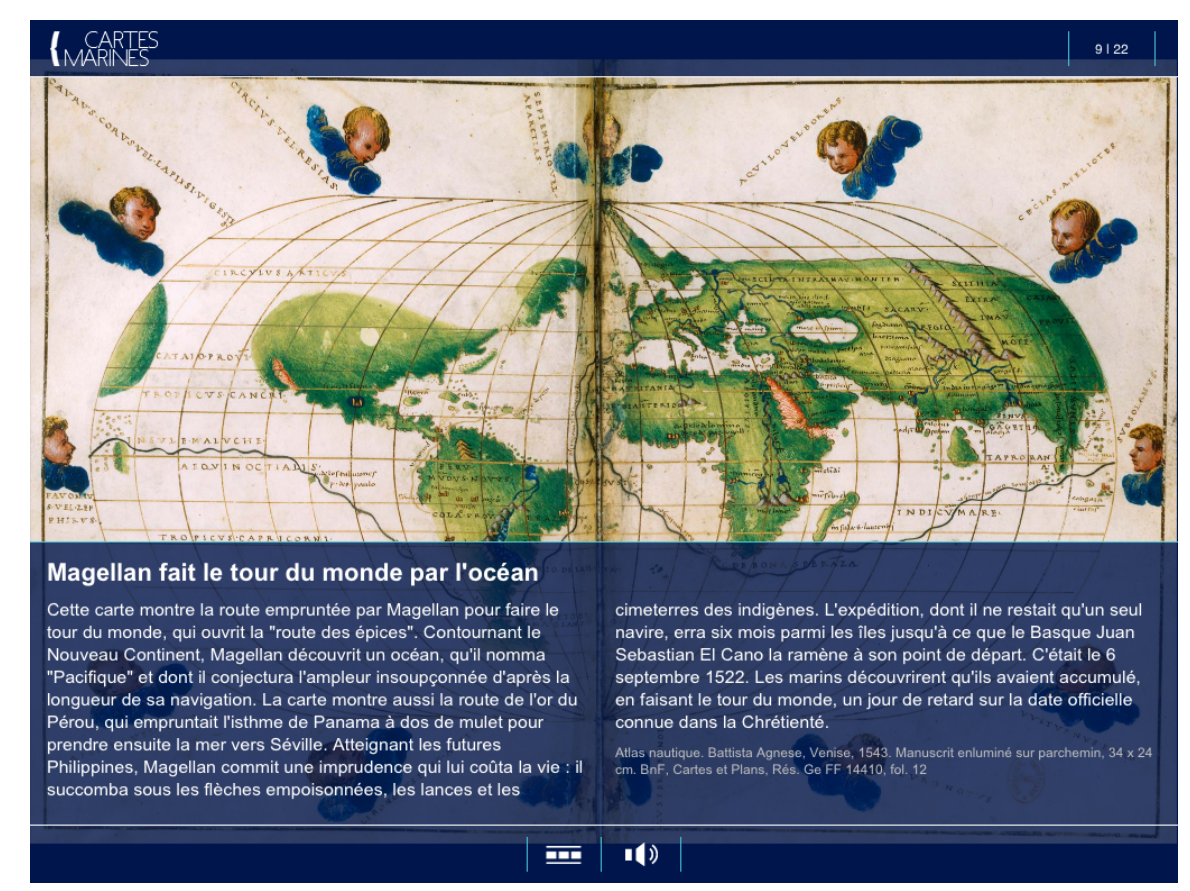

Figura 21. Menú gestual en forma de galería de imágenes de la aplicación Cartes Marines.

\subsection{Formato de los contenidos}

De forma general, las aplicaciones de bibliotecas no suelen utilizar formatos diferentes de texto e imágenes para sus contenidos. El 61,6\% de las apps analizadas no incluye audio, vídeo o documentos. No obstante, esto depende sobre todo de la utilidad de la aplicación. Las aplicaciones con utilidad patrimonial analizadas suelen utilizar más habitualmente los formatos de vídeo, audio y documentos - dos terceras partes utiliza alguno de ellos-, mientras que las apps que reproducen los contenidos del sitio web y el catálogo de la biblioteca los utilizan con menor frecuencia (el 24,0\% y el 11,1\% respectivamente). El grupo de aplicaciones clasificado como otras utilidades, que incluye a una gran variedad de apps, se sitúa en un punto intermedio. Es por eso que las apps latinoamericanas y europeas (sin contar a España) son las que más uso hacen de alguno de estos 
formatos (el 37,5\% y el 42,9\% respectivamente no utiliza ninguno de estos formatos), porque son en su mayoría aplicaciones nativas con utilidad patrimonial (gráfico 65).

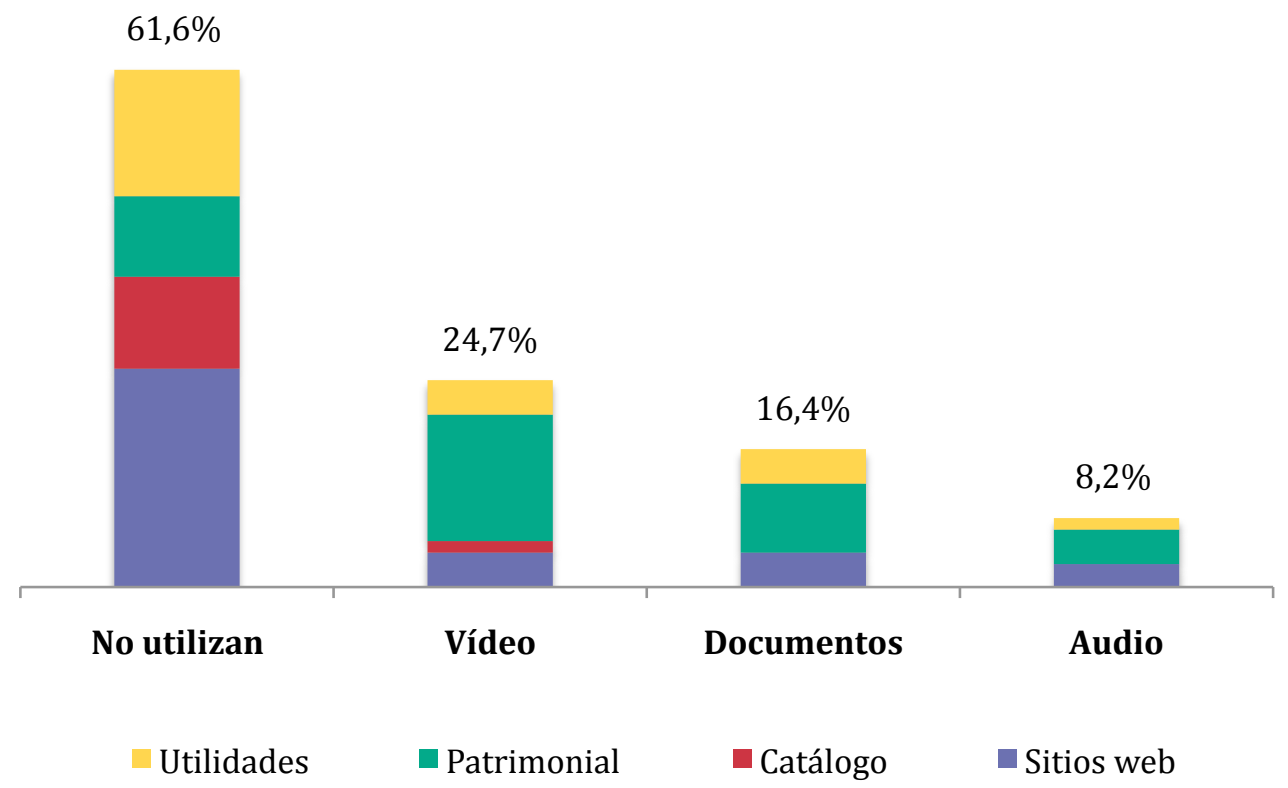

Gráfico 64. Aplicaciones en función del uso de formatos de vídeo, audio y documentos y por utilidad ( $n=73$ apps).

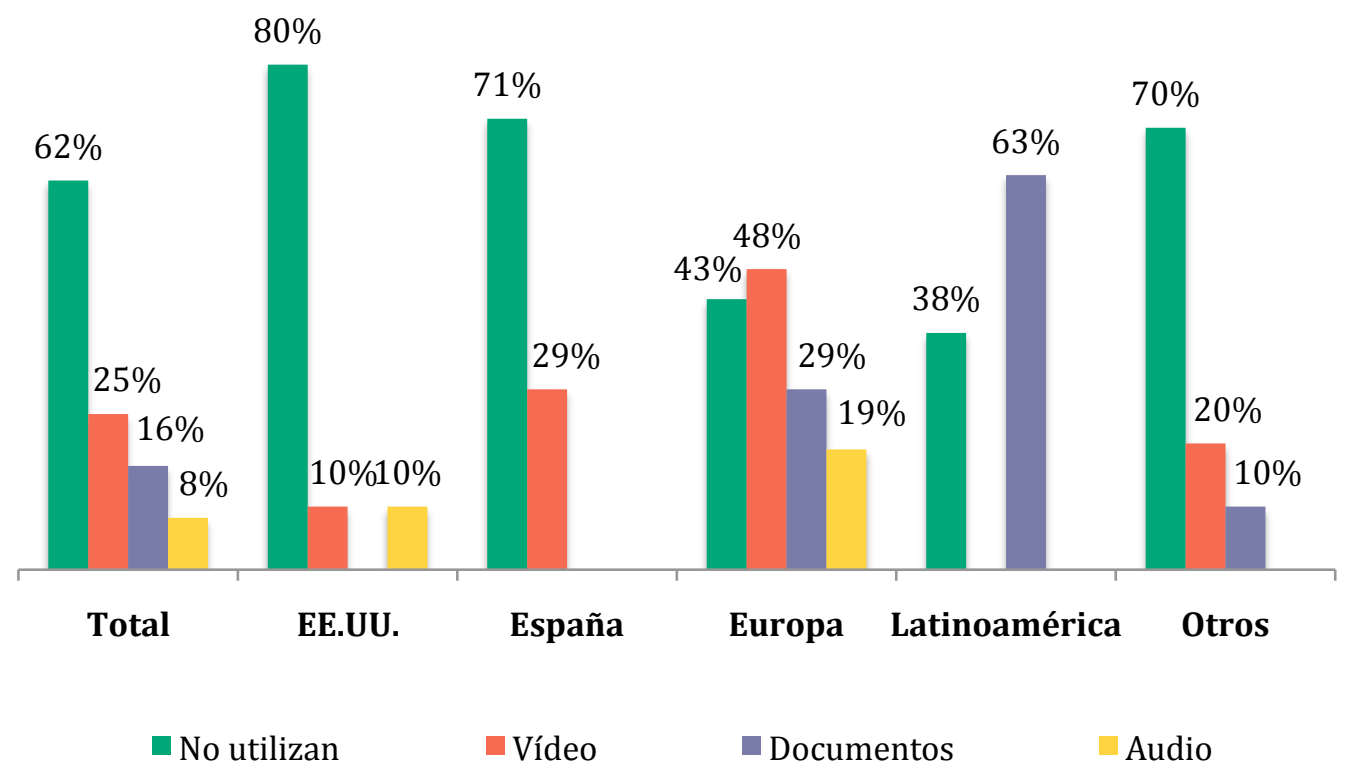

Gráfico 65. Aplicaciones en función del uso de formatos de vídeo, audio y documentos y por área geográfica $(n=73$ apps). 
De los formatos analizados, el vídeo es el más utilizado (presente en el 24,7\% de las apps analizadas), especialmente en el grupo de aplicaciones patrimoniales, donde se usa para las visitas guiadas en las exposiciones. Tan solo se han encontrado seis apps $(8,2 \%)$ con formato de audio, el formato menos frecuente. Los documentos, que suelen estar en formato pdf y tienen contenidos adicionales, se encuentran en una posición intermedia $(16,4 \%)$.

En Estados Unidos y España, países en que la gran mayoría de las apps reproducen los contenidos del sitio web de la biblioteca, se observa una tendencia que se apreciaba también en los sitios web para móviles: en Estados Unidos se hace uso de los formatos de audio, pero no en España, donde se prefiere el vídeo.

\subsection{Aprovechamiento de las funciones del dispositivo}

Como se explicó anteriormente de este trabajo, una de las ventajas que presentan las apps frente a la web y que justifica su inversión es que permiten aprovechar un mayor número de funciones del dispositivo. En las aplicaciones analizadas se ha detectado el uso de las siguientes funciones:

- Enlaces para realizar llamadas, enviar SMS o correos electrónicos, que también funcionaban en los sitios web para móviles.

- Localización, que consiste en detectar la posición del dispositivo para ofertar información y servicios personalizados, como la ruta para llegar a un lugar determinado. Esta función se da también en los sitios web para móviles.

- Notificaciones push. Se trata de los avisos que se reciben en la pantalla del dispositivo procedente de una aplicación. Las notificaciones push no requieren que la aplicación esté ejecutándose en el dispositivo y realizando llamadas constantes al servidor, sino que permite que esta comunicación se mantenga en segundo plano y se active al recibir un mensaje.

- Rotación de pantalla. Gracias a los sensores (Alasdair, 2010) que incorporan los dispositivos móviles es posible detectar si la pantalla se encuentra en posición horizontal y vertical y cambiar en consecuencia la orientación de la página que se está visualizando. El navegador realiza esta operación con los contenidos web sin que el desarrollador lo programe, 
pero las apps deben ser programadas para que la rotación de pantalla funcione.

- Escaneado de códigos. Gracias a la cámara de fotos, el dispositivo es capaz de leer un código de barras o bidimensional, decodificarlo y realizar la búsqueda de los datos obtenidos en una base de datos. La principal utilidad que se le ha dado en bibliotecas es la consulta en el catálogo.

- Otras funciones, como la linterna y la realidad aumentada, son menos usuales, pero también se ha encontrado en la muestra, de forma anecdótica.

El 80,8\% de las aplicaciones nativas en bibliotecas hacen uso de alguna de las funciones del dispositivo mencionadas. Las funcionalidades más aprovechadas son la localización y la rotación de pantalla, que utilizan el 34,2\% de las apps. Casi la tercera parte de ellas aprovecha los enlaces para realizar llamadas telefónicas a un número determinado $(30,1 \%)$ y los enlaces a correos electrónicos para escribir un mensaje $(30,1 \%)$. No se han encontrado casos en que los enlaces al número de teléfono o al correo electrónico sirva para guardar en la agenda esos datos. Por otro lado, sólo se han encontrado tres apps de bibliotecas con enlaces para el envío de SMS $(4,1 \%)$.

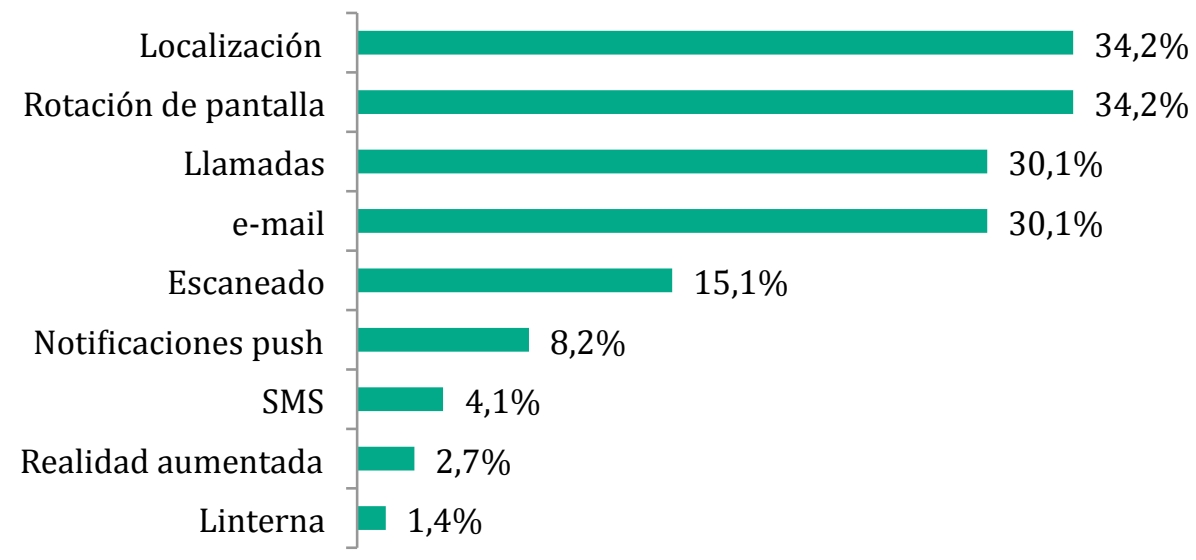

Gráfico 66. Aprovechamiento de las funciones del dispositivo en las aplicaciones de bibliotecas ( $n=73$ apps).

Pero también se dan casos en los que se desaprovecha la oportunidad de mejorar la aplicación con terminadas funciones. Se han encontrado tres apps en las que aparece el número de teléfono de la biblioteca, pero no está enlazado para poder realizar una llamada telefónica al hacer clic. Dos de esas apps pertenecen a bibliotecas españolas: UNED Biblioteca y BiblioMaresme. El resto de las apps que no 
utilizan enlaces telefónicos no incluye ese dato, por lo que está justificado. En el caso de los enlaces a correos electrónicos no se ha encontrado ningún correo sin enlazar.

\begin{tabular}{lrrrrrrrrr} 
& \multicolumn{2}{c}{ Sitios web } & \multicolumn{2}{c}{ OPAC } & \multicolumn{2}{c}{ Patrimonial } & \multicolumn{2}{c}{ Utilidades } \\
\hline & \multicolumn{1}{c}{ Apps } & \multicolumn{1}{c}{$\%$} & \multicolumn{1}{c}{ Apps } & \multicolumn{1}{c}{$\%$} & \multicolumn{1}{c}{ Apps } & \multicolumn{1}{c}{$\%$} & Apps & \multicolumn{1}{c}{$\%$} \\
\hline Localización & 15 & $60,0 \%$ & 3 & $33,3 \%$ & 5 & $23,8 \%$ & 2 & $11,1 \%$ \\
\hline Rotar pantalla & 5 & $20,0 \%$ & 3 & $33,3 \%$ & 8 & $38,1 \%$ & 9 & $50,0 \%$ \\
\hline Llamadas & 18 & $72,0 \%$ & 0 & $0,0 \%$ & 4 & $19,0 \%$ & 0 & $0,0 \%$ \\
\hline e-mail & 16 & $64,0 \%$ & 0 & $0,0 \%$ & 4 & $19,0 \%$ & 2 & $11,1 \%$ \\
\hline Escaneado & 8 & $32,0 \%$ & 2 & $22,2 \%$ & 0 & $0,0 \%$ & 1 & $5,6 \%$ \\
\hline Notificaciones push & 3 & $12,0 \%$ & 0 & $0,0 \%$ & 1 & $4,8 \%$ & 2 & $11,1 \%$ \\
\hline SMS & 2 & $8,0 \%$ & 0 & $0,0 \%$ & 0 & $0,0 \%$ & 1 & $5,6 \%$ \\
\hline Realidad aumentada & 0 & $0,0 \%$ & 0 & $0,0 \%$ & 1 & $4,8 \%$ & 1 & $5,6 \%$ \\
\hline Linterna & 0 & $0,0 \%$ & 0 & $0,0 \%$ & 0 & $0,0 \%$ & 1 & $5,6 \%$ \\
\hline Total & 25 & & 9 & & 21 & & 18 & \\
\hline
\end{tabular}

Tabla 22. Aplicaciones según el aprovechamiento que hacen de las funciones del dispositivo y por utilidad ( $n=73$ apps).

A pesar del interés que puede tener para el envío de notificaciones a los usuarios, sólo se han encontrado seis apps (8,2\%) que hacen uso de las notificaciones push. El escaneado, casi siempre asociado a la búsqueda en el catálogo, tampoco es muy común $(15,1 \%$ de la muestra). De forma anecdótica, se han encontrado una aplicación que hace uso de la linterna, ShelvAR (gráfico 66).

Se observan importantes variaciones en las funciones utilizadas según el tipo de app. Como se puede apreciar en la tabla 22, las aplicaciones que reproducen los contenidos del sitio web utilizan más a menudo los enlaces a números de teléfono $(72,0 \%)$, los enlaces al correo electrónico $(64,0 \%)$ y la geolocalización $(60,0 \%)$ que el resto. Por el contrario, es menos usual en este tipo de aplicaciones la rotación de pantalla $(20,0 \%)$.

Las aplicaciones de uso patrimonial hacen mayor uso de las funciones que implican elementos gráficos, como la rotación de pantalla (38,1\%). En este tipo de apps y en el grupo de otras utilidades, con objetivo menos informativo, se hace un menor uso de las funciones de enlaces telefónicos y a correos electrónicos. En las apps cuyo uso principal es la consulta al catálogo priman la rotación de pantalla y la localización, que se han encontrado en un tercio de las apps de este tipo. 


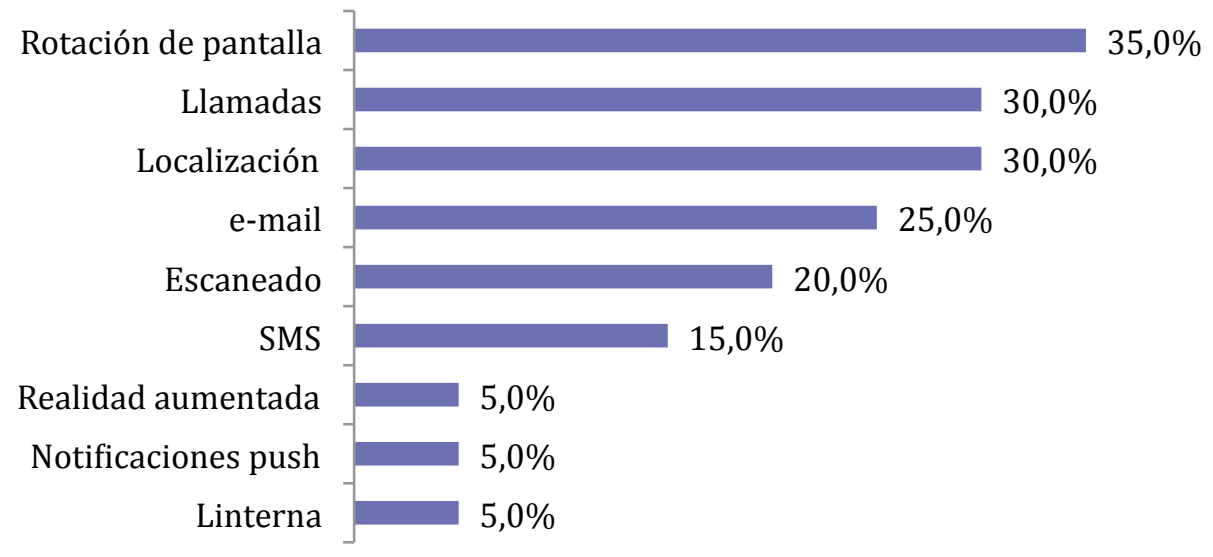

Gráfico 67. Aprovechamiento de las funciones del dispositivo en las aplicaciones de bibliotecas estadounidenses ( $n=20$ apps).

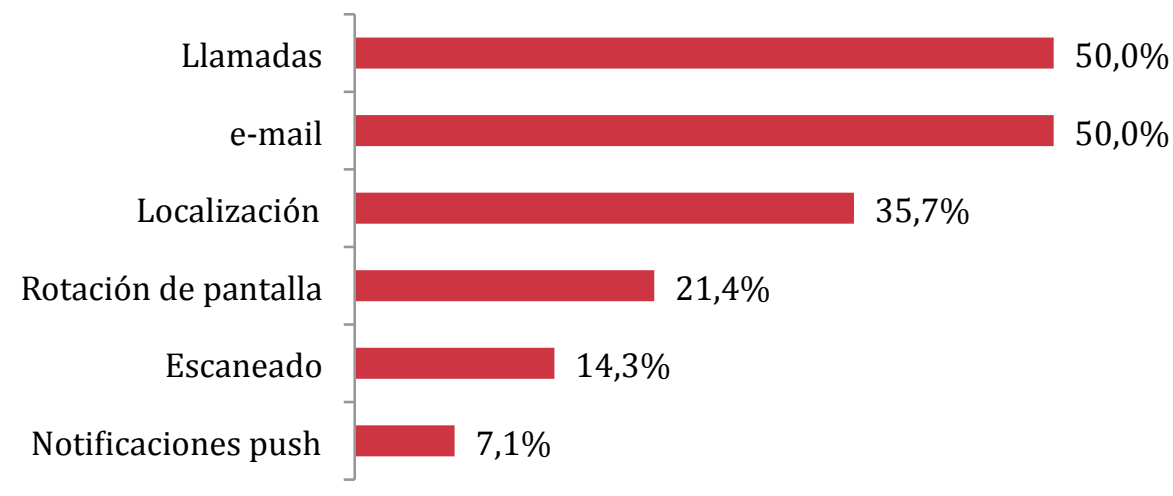

Gráfico 68. Aprovechamiento de las funciones del dispositivo en las aplicaciones de bibliotecas españolas $(n=14)$.

Las bibliotecas estadounidenses presentan un mayor grado de originalidad en el aprovechamiento de algunas funciones del dispositivo. Así, son las únicas que hacen uso de la linterna y de los enlaces para el envío de SMS. Las llamadas, la localización y la rotación de pantalla son las funciones más utilizadas por estas bibliotecas, cada una de ellas presentes en una tercera parte de las apps analizadas (gráfico 67).

En España las funciones más utilizadas son los enlaces a números de teléfono y correos electrónicos, presentes cada una de ellas en la mitad de las apps analizadas (gráfico 68). Algo más de un tercio de estas apps utiliza además la localización $(35,7 \%)$. Se han encontrado dos aplicaciones que hacen uso del escaneado de códigos de barras (Catàleg de biblioteques UAB y BiblioUSAL) y otra de las notificaciones push (Biblioteca de Mollerussa). 


\subsection{Contenidos y servicios}

El análisis de los contenidos y servicios se hace complejo por la gran cantidad de elementos hallados y debido al número de variables que entran en juego. Así, se han encontrado diferencias importantes en función del país y de la utilidad de la app -aquellas que reproducen los contenidos del sitio web, el catálogo, sacar a la luz fondos patrimoniales y otras utilidades-. Por ello se analizarán los contenidos y servicios que las aplicaciones de bibliotecas ofrecen en función de su utilidad.

\subsubsection{Aplicaciones que reproducen el sitio web para móviles}

En el caso de las apps que reproducen los contenidos del sitio web y aquellas que cumplen las funciones de catálogo, los contenidos y servicios son muy similares a los de los sitios web. Sin embargo, también se han encontrado algunos nuevos:

- Compartir en medios sociales y a través de correo electrónico los recursos, como los registros que componen la colección patrimonial.

- Guardar en favoritos. Se habilita una opción en la app que hace posible guardar algunos registros para su posterior acceso. Esta opción se da especialmente en el caso de las aplicaciones con función patrimonial, pero se ha encontrado también en otro tipo de apps.

- Configuración de opciones como el idioma, el tamaño de la fuente y otras opciones de visualización.

- Consulta del catálogo escaneando el código de barras. Esta función, sin embargo, no se estudia en este apartado, pues ya se analizó en el apartado 5.8, sobre aprovechamiento de las funciones del dispositivo.

Al igual que sucedía al analizar los sitios web para móviles, la distribución de las funciones tiene forma de larga cola, como se puede apreciar en el gráfico 69, puesto que hay algunos contenidos y servicios que se dan en la mayor parte de las apps analizadas y muchos que sólo se dan en unas pocas. Así, son 8 las funciones que se dan en más de la mitad de las apps y 26 en menos de la mitad. Las apps que reproducen los contenidos del sitio web tienden a priorizar los mismos contenidos que los sitios web para móviles: horario (presente en el 92,0\% de las apps), datos de contacto $(88,0 \%)$, catálogo $(84,0 \%)$ y datos de localización $(72,0 \%)$. 


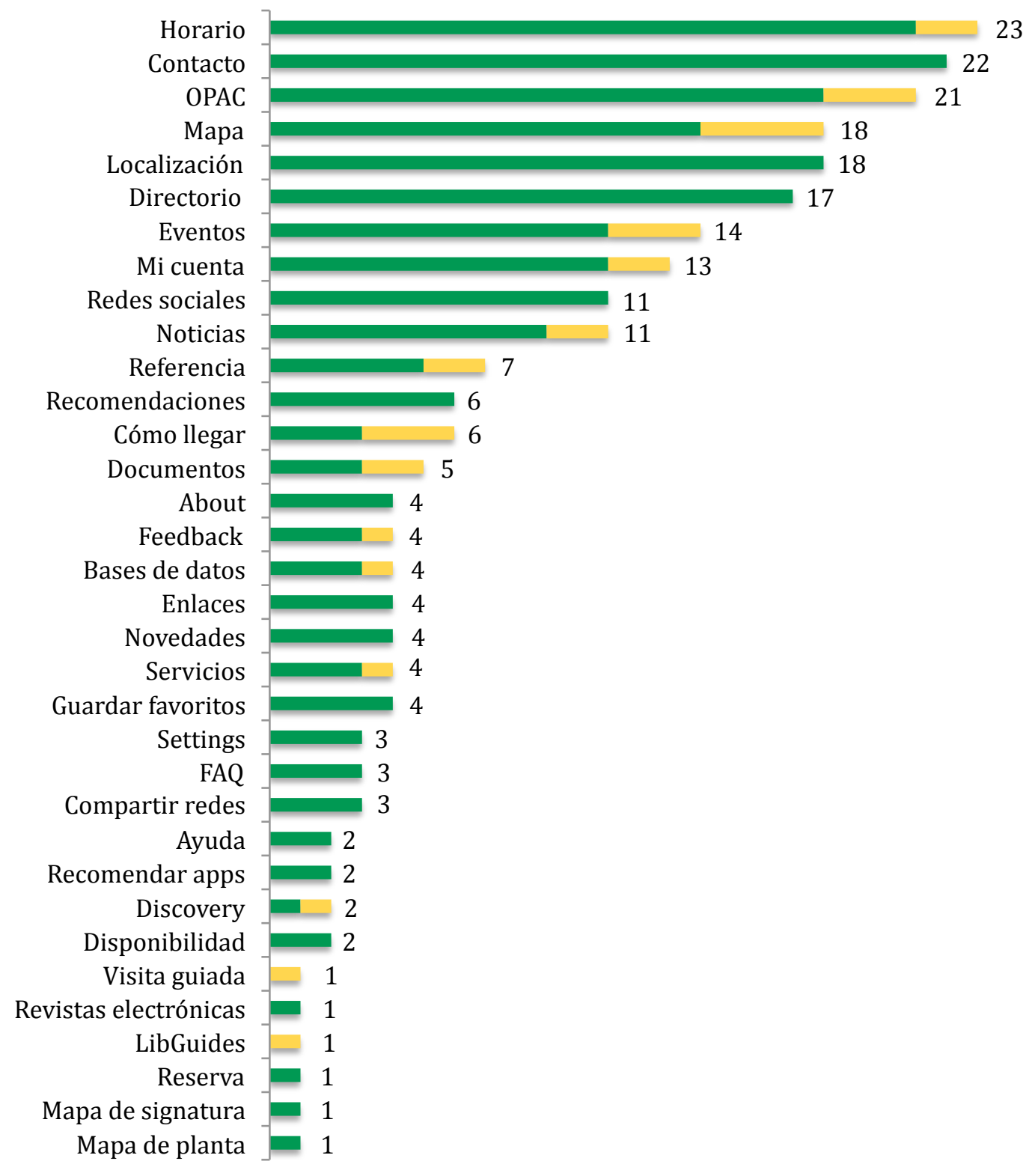

Gráfico 69. Aplicaciones que reproducen los contenidos del sitio web de la biblioteca por tipo de contenidos y servicios ( $n=25$ apps).

Otros contenidos habituales en estas apps son el mapa con la localización de las bibliotecas $(72,0 \%)$ y el directorio de bibliotecas $(68,0 \%)$. Se han encontrado cuatro aplicaciones que prefieren dar los datos de localización sin mostrarlos en el mapa, enlazándolos o incrustándolos, a pesar de que sería más fácil de localizar. Además se han encontrado espacios personalizados o cuenta de usuario y eventos en algo más de la mitad de las apps (52,0\% y 56,0\% respectivamente). Las noticias y enlaces a las redes sociales se dan en el 44,0\% de las apps. Todas las demás funciones se dan en menos de un tercio de las apps. 
Algunos contenidos y servicios se han encontrado en uno o dos casos, únicamente: visitas guiadas, revistas electrónicas, LibGuides, reserva de recursos de la biblioteca, mapa de signatura y mapa de planta (todos ellos en un solo caso) y ayuda, recomendación de otras apps, herramientas de descubrimiento y disponibilidad de los recursos en dos casos.

Teniendo en cuenta que la función es la misma, los contenidos pueden ser similares en apps y sitios web diseñados para dispositivos móviles, aunque sí es cierto que un mayor aprovechamiento de las funciones del dispositivo podría plasmarse en algunas funciones diferentes, algo que sucede de manera más bien anecdótica. Tan solo se añaden las funciones antes adelantadas: la configuración de opciones aparece en tres apps y guardar en favoritos en cuatro. Compartir en redes sociales, otra de las funciones que se da en las apps y no en los sitios web, aunque no hay causas técnicas que lo impidan, está presente en el 12,0\% de las apps.

Una de las grandes diferencias entre los sitios web para móviles y las apps, es que en estas últimas los contenidos tienden a estar incluidos dentro de la aplicación, sin que sea necesario navegar fuera de ella. En los sitios web encontrábamos una gran cantidad de contenidos enlazados, que dirigían fuera del sitio (apartado 4.10), especialmente en servicios que se externalizan, como el catálogo.

LibGuides es el único servicio que se presta completamente fuera de la $a p p$, sin integrarse en ella, en todos los ejemplos analizados. Los catálogos, herramientas de descubrimiento, servicios de préstamo de libros electrónicos, bases de datos, revistas electrónicas, cuenta de usuario y mapa, que en los sitios web para móviles se prestaban en otros sitios, en las apps se integran. Los mapas de Google con las sedes de la biblioteca marcadas se integran también en la app, mientras que en la mitad de los sitios web se enlazaba fuera del sitio. Lo mismo sucede con las noticias y eventos.

A diferencia de lo que sucedía en el caso de los sitios web para móviles, el servicio de referencia no es tan habitual. Esto puede deberse al menor peso de las bibliotecas estadounidenses en el conjunto de la muestra de aplicaciones nativas. Otra diferencia significativa es que en las apps no se han encontrado el directorio de personal ni apenas herramientas de descubrimiento (tan solo en dos casos), aunque no existe ningún motivo especial para ello. También se observa un menor uso de las bases de datos y revistas electrónicas, información sobre los servicios que la biblioteca presta, selecciones de enlaces de interés, disponibilidad de los recursos de la biblioteca y LibGuides. Por el contrario, son más frecuentes los directorios de bibliotecas, los eventos, los enlaces a redes sociales y las recomendaciones de lecturas, posiblemente debido a una mayor peso de las bibliotecas públicas en el conjunto de la muestra. 
Si se analizan las apps por países se revela una menor diversidad en los contenidos y un mayor consenso. Tanto en Estados Unidos (gráfico 70) como en España (gráfico 71) se observa un menor número de categorías de contenidos localizados. El OPAC, el horario y los datos de contacto se encuentran en todas las apps de las bibliotecas estadounidenses. En España también hay coincidencia en tres categorías en todas las apps: horario, contacto y mapa de localización.

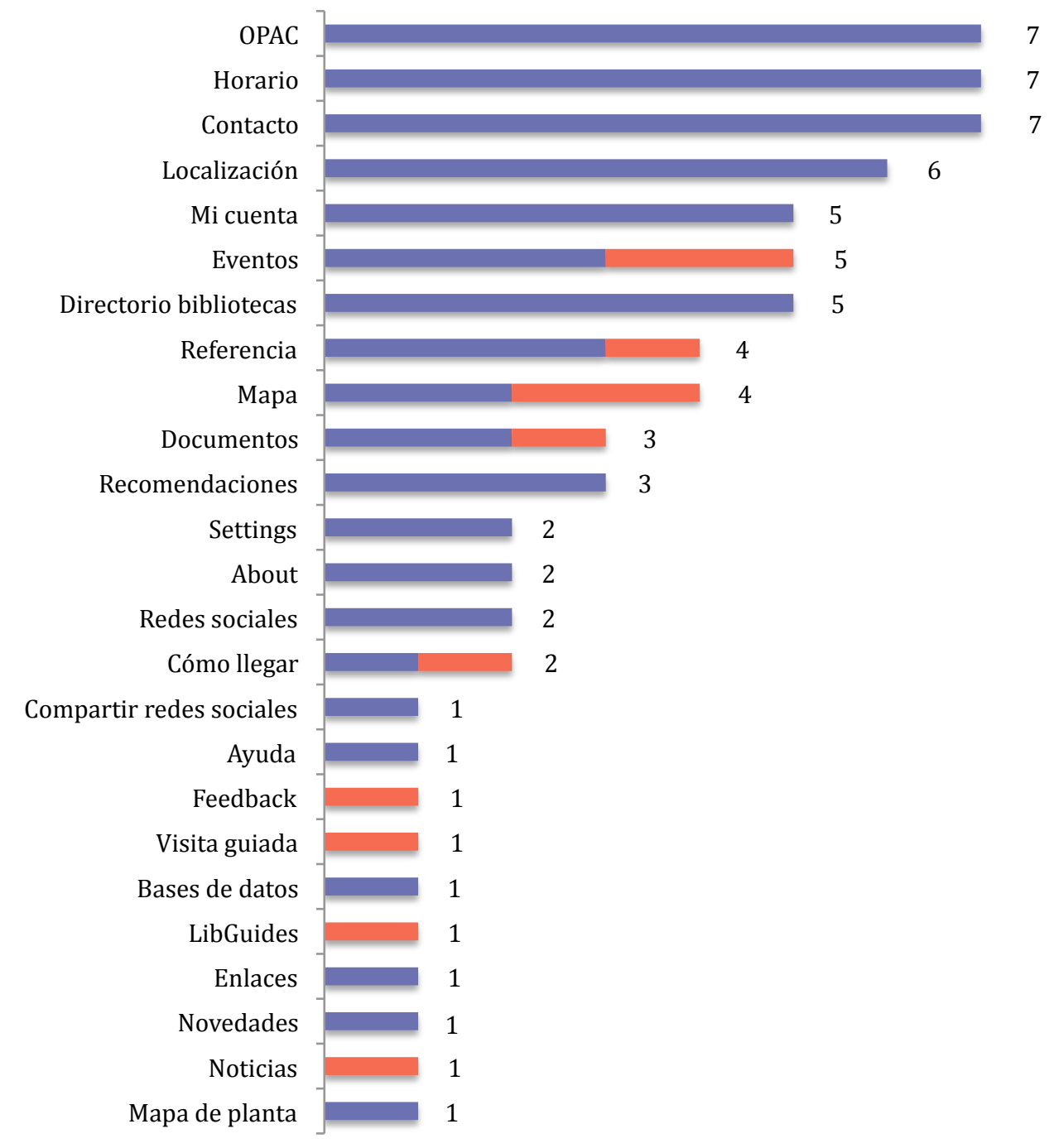

Gráfico 70. Aplicaciones que reproducen los contenidos del sitio web de la biblioteca por tipo de contenidos y servicios. Estados Unidos $(n=7)$.

Otros contenidos que se dan muy frecuentemente en las apps de las bibliotecas españolas son los datos de localización, el catálogo, directorio de bibliotecas, enlaces a las redes sociales, y noticias y eventos. En el caso de los enlaces a los 
perfiles en redes sociales sucede lo mismo que con los sitios web, aunque en menor medida: aunque prácticamente todas las bibliotecas analizadas están en los medios sociales, no son todas las que los enlazan.

En las bibliotecas estadounidenses son frecuentes la localización, cuenta de usuario, los directorios de bibliotecas, el servicio de referencia y eventos. Se ha localizado un mayor número de funciones debido a que hay algunas de ellas que se encuentran solo en una o dos apps.

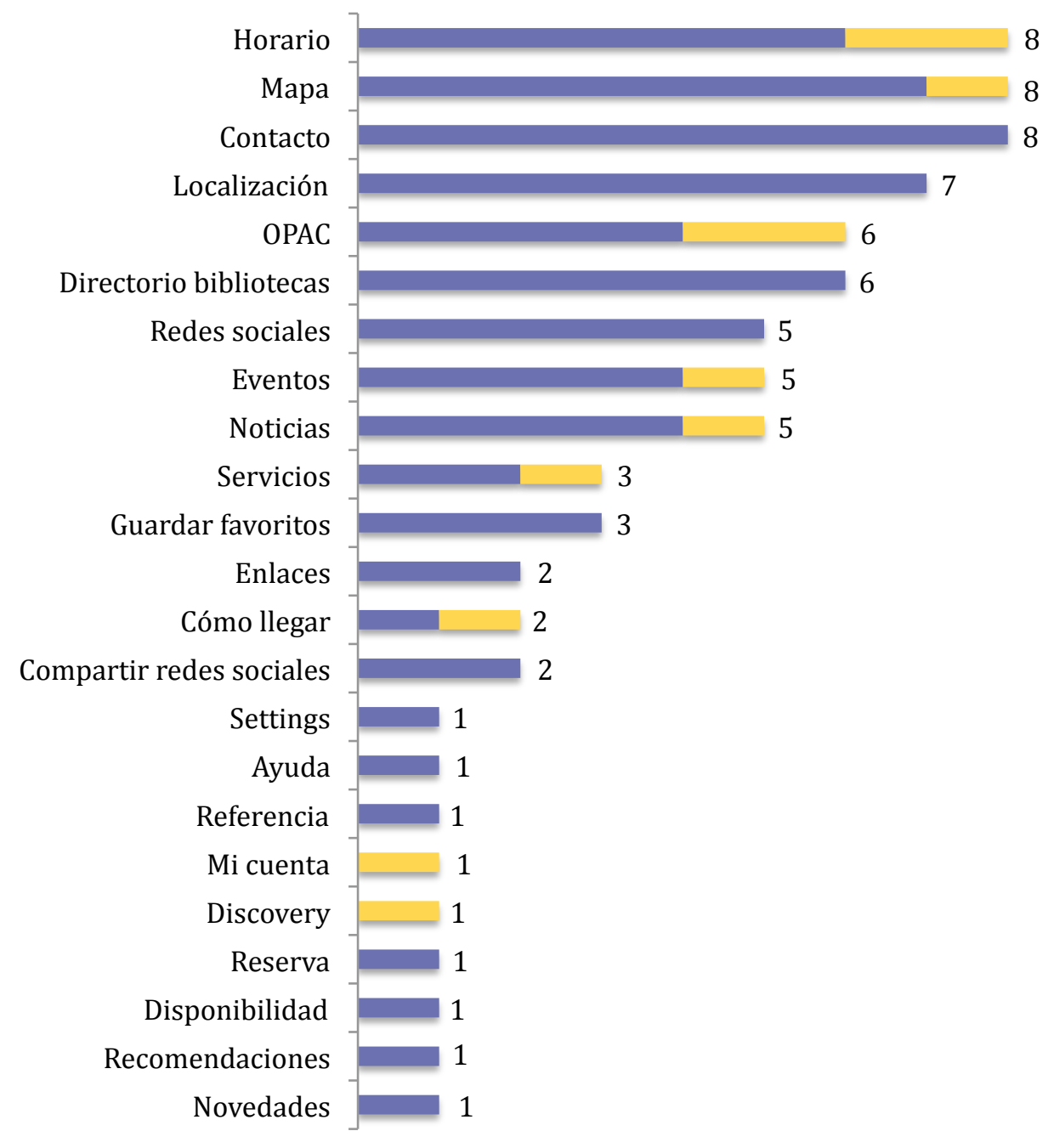

Gráfico 71. Aplicaciones que reproducen los contenidos del sitio web de la biblioteca por tipo de contenidos y servicios. España $(n=8)$. 


\subsubsection{Utilidad patrimonial}

La colección digital y las visitas guiadas son las principales utilidades de las aplicaciones nativas de uso patrimonial, y no tanto por la frecuencia con que se encuentran en este tipo de apps como por la importancia que tienen en la configuración de la app (gráfico 72). Las colecciones digitales se han encontrado en el 90,5\% de las 21 apps con función patrimonial. Las apps que no contienen esta función se basan en visitas guiadas, que se han encontrado en el $23,8 \%$ de los casos. Algunas apps de uso patrimonial permiten compartir en redes sociales y guardar en la sección de favoritos los registros de la colección.

Estas dos funciones se complementan con otras: about, localización, datos de contacto y feedback. Otros contenidos, como las opciones de configuración, ayuda, enlaces a redes sociales, horario, información sobre cómo llegar, noticias y mapas de planta y localización se han encontrado en tan solo uno o dos casos.

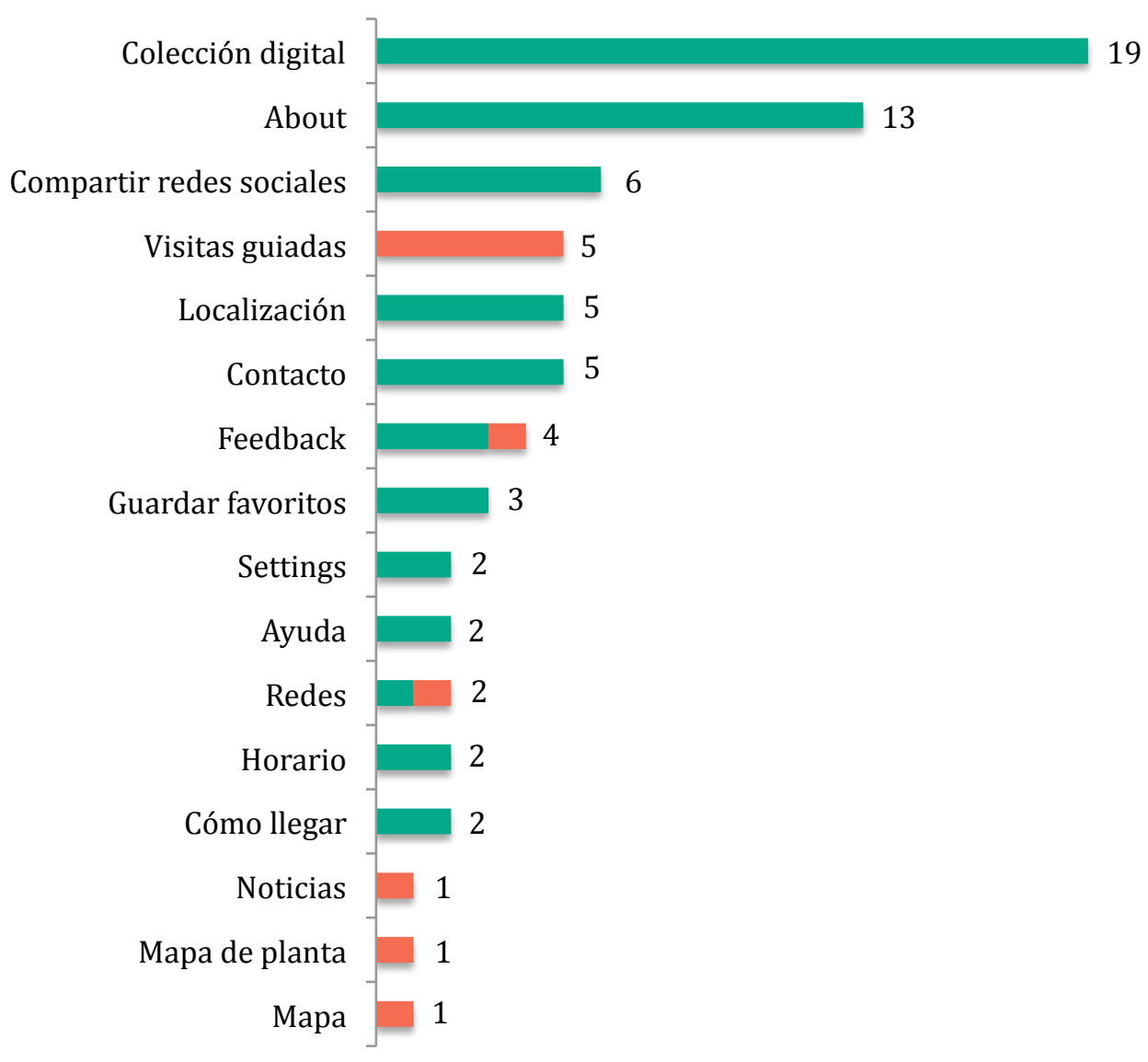

Gráfico 72. Aplicaciones de utilidad patrimonial según los contenidos y servicios que incluye $(n=21)$. 


\subsection{Ajuste a las características del dispositivo}

$\mathrm{Al}$ igual que en el caso de los sitios web para móviles, respecto a las aplicaciones nativas se han tenido en cuenta dos aspectos para medir el ajuste a las características del dispositivo: la extensión del texto y la inclusión de enlaces a páginas web no adaptadas. También se valora si al enlazar a páginas no adaptadas se indica o no de alguna manera. En el análisis se han tenido en cuenta sólo las aplicaciones diseñadas para smartphones.

Según estos parámetros se observa un mayor grado de ajuste a las características del dispositivo en las apps para smartphones de las bibliotecas que la que había en los sitios web. Sólo se ha encontrado una app en la que la extensión de los contenidos se ha considerado grande: Biblioteca UCS, de la Universidade de Caxias do Sul (Brasil).

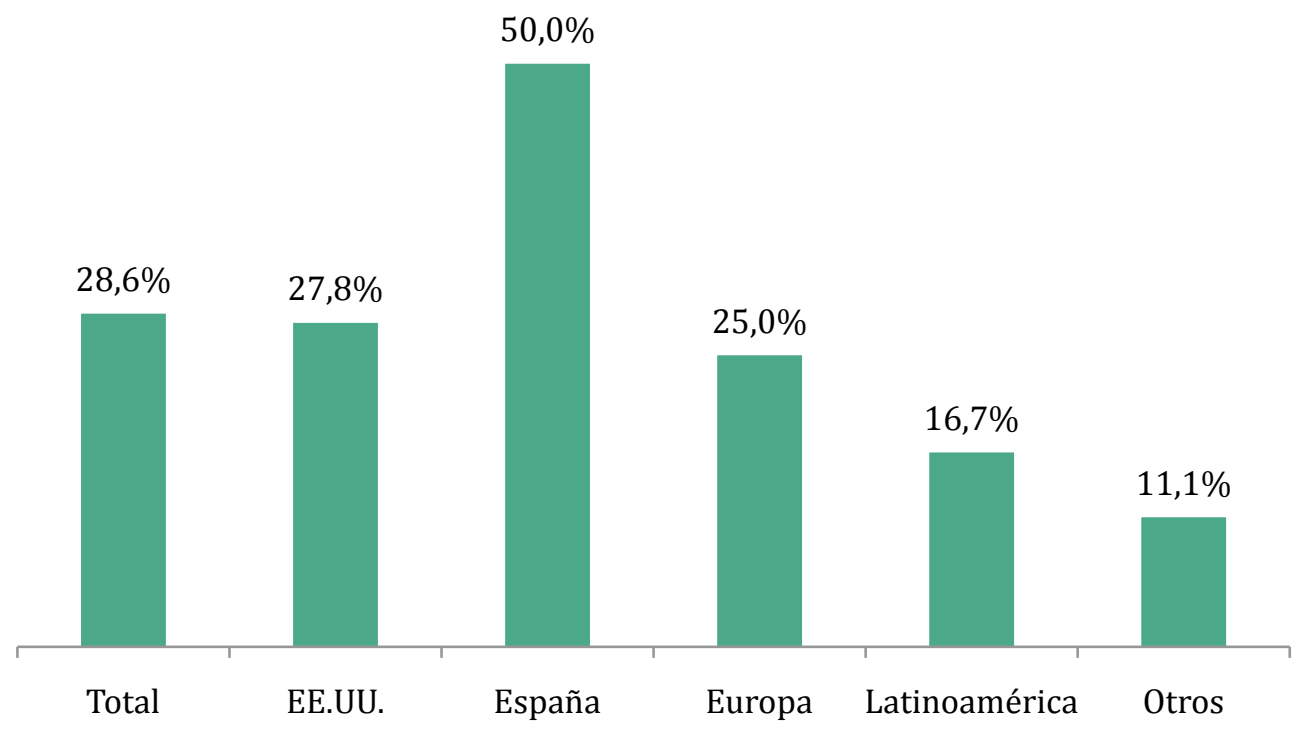

Gráfico 73. Aplicaciones para smartphones con enlaces a sitios web no adaptados para dispositivos móviles, por países ( $n=63$ apps).

Por otra parte, también se reduce considerablemente el ratio de apps en las que se enlaza a páginas web con los contenidos no adaptados a la pantalla de un smartphone: si en el caso de los sitios web para smartphones se consideraba una práctica habitual y alcanzaba el 72,5\%, en las apps no llega a un tercio de los casos 
en el conjunto de la muestra (28,6\%). Esto puede deberse a que el número de enlaces externos es menor, algo que se apuntaba en el análisis de los contenidos. Sin embargo, no se han encontrado apps en las que se indique mediante un símbolo o de otra forma que los enlaces externos dirigen a una página no adaptada, algo que sí sucedía en los sitios web para móviles. En España es más común que en otros países enlazar a páginas no adaptadas y se ha detectado en la mitad de los casos (gráfico 73).

A diferencia de lo que sucede con los sitios web, en los que hay una tendencia a incluir los mismos contenidos en la versión móvil que en la completa, al amparo del diseño web adaptativo, en las aplicaciones no está sucediendo esto, ni siquiera en las creadas en los dos últimos años, sino que se está manteniendo el criterio de reducir y acortar contenidos, adaptándolos a una pantalla menor.

\subsection{Buenas prácticas}

De forma similar a los sitios web para móviles, se han detectado las buenas prácticas en aplicaciones nativas en bibliotecas, pero atendiendo a diferentes criterios, dadas las diferencias entre ambas. En este caso se ha valorado especialmente el aprovechamiento de las capacidades del dispositivo, que en el caso de las apps ofrecen más posibilidades, y la originalidad de las propuestas. En función de estos parámetros las mejores prácticas serían READometer, ShelvAR, DeCuentos y OCLS Shake it!

READometer es una aplicación creada por el King County Library System (Estados Unidos) cuya principal utilidad es medir el tiempo que se pasa leyendo. Al registrarse como usuario, la aplicación almacena los tiempos de lecturas anteriores, que se pueden compartir en Facebook y Twitter. Además tiene un mapa con la localización de las bibliotecas, cuyos datos se pueden añadir a los contactos. También se puede trazar la ruta para llegar a cada biblioteca y guardarlas en un espacio personal. La originalidad de esta aplicación está en darle una utilidad adicional a una app de la biblioteca, haciéndola más atractiva.

ShelvAR es una app desarrollada por las Bibliotecas de la Miami University (Estados Unidos) para facilitar la detección de los libros situados en el lugar incorrecto en la estantería. Se vale de la realidad aumentada para ello: haciendo uso de la cámara de fotos lee un código que previamente se ha situado en el tejuelo de cada libro previamente y señala los que están bien colocados en color verde y 
los que no con un aspa rojo. El interés especial de esta aplicación está en el aprovechamiento de las funciones del dispositivo para el trabajo de biblioteca.

OCLS Shake it! es una aplicación para recomendar lecturas creada por el Sistema de Bibliotecas del Orange County Library System (Estados Unidos). Su utilidad, la recomendación de lecturas sobre un tema determinado, es una de las más originales de las analizadas, y también lo es la manera en que las ruedecillas, que emulan a las de una máquinas de juegos, echan a girar cuando se agita el dispositivo.

SG Memory, desarrollada por el National Library Board Singapore, es una red social para compartir imágenes y otros recuerdos relacionados con la ciudad de Singapur que recuerda a Instagram. Hace uso de la cámara de fotos para capturar directamente imágenes.

En el apartado de fondos patrimoniales se encuentran algunas de las mejores aplicaciones nativas creadas por bibliotecas. Las dos aplicaciones de la New York Public Library sobre la Feria Internacional y el personaje de Frankenstein están entre las mejores en esta categoría. De ellas destaca la importante labor de selección de fondos sobre los temas correspondientes, el gran trabajo de documentación y la gran cantidad de información que contienen, pero sobre todo la elegante y vistosa forma en la que son presentadas, aprovechando la pantalla táctil y la rotación de las tabletas para una navegación más intuitiva.

Ludwig II - Walking in the Footsteps of a Fairytale King es una aplicación de la de la Biblioteca Estatal de Baviera (Alemania) sobre el personaje de Luis II. Sus contenidos están divididos en un menú con cinco opciones: lugares, gente, temas, calendario y álbum. Con esta aplicación se intenta acercar un personaje histórico del siglo XIX a la gente del siglo XXI. Como explica Ceynowa (2013), incluye gamificación, un sistema que premia a aquellos que visitan los lugares relacionados con Luis II y hacen check-in a través de esta app. También utiliza la realidad aumentada para mostrar vistas de algunos lugares.

Bayern in historischen Karten es una app de la Biblioteca Estatal de Baviera que sitúa lugares con un significado histórico de esta zona geográfica en mapas de diferentes épocas. Su originalidad, por lo tanto, está en utilizar la documentación histórica de los mapas para visualizar en ellos lugares reales gracias a la geolocalización del dispositivo móvil. WolfWalk fue la primera aplicación conocida en mostrar documentación patrimonial en el mapa. Así, proporciona un viaje en el tiempo a quienes visitan el campus de la North Carolina State University, relacionándola con un lugar.

Las mejores aplicaciones que reproducen el sitio web de la biblioteca no han sido fáciles de escoger, debido a la gran semejanza entre ellas. Estas apps se 
caracterizan especialmente por su escasa originalidad y el poco aprovechamiento que hacen de las capacidades del dispositivo, que se limitan a los enlaces telefónicos, la geolocalización en algunas ocasiones y la búsqueda en el catálogo escaneando el código de barras.

OPL Mobile, de la Biblioteca Pública de Ottawa (Canadá), y NYPL Mobile, de la New York Public Library, han sido creadas por la empresa BiblioCommons. Ambas incluyen información básica sobre los diferentes puntos de servicio de la red, en el mapa y en una lista, búsqueda en el catálogo, gestión de la cuenta de usuario - con información sobre los libros en préstamo, reservas y libros guardados- y un listado de recomendaciones. El catálogo emplea una búsqueda sencilla y permite el escaneado del código de barras. Además proporciona información básica sobre cada registro y su disponibilidad, con comentarios y valoración de los usuarios y, en el caso de la New York Public Library, enlace para la descarga de libros electrónicos. Estas aplicaciones incluyen un apartado para configurar algunas opciones: biblioteca preferida, idioma y limpieza de la caché.

La navegación se resuelve con un menú inferior constante con las principales opciones y botones para volver a la página anterior. Por otra parte, en ambos casos las apps se enlazan desde la página web de la biblioteca.

BiblioUSAL, la aplicación de la Biblioteca de la Universidad de Salamanca, se puede considerar también una buena práctica, a pesar de que enlaza a algunas páginas no adaptadas. Su diseño es claro y los contenidos están organizados de forma que se facilita la navegación. Es una de las mas originales, ya que incluye la posibilidad de introducir el número de usuario escaneando el código de barras del carné de biblioteca. Incluye una opción para guardar los registros del catálogo en un espacio personalizado y la posibilidad de exportarlos a Mendeley, Zotero y por correo electrónico.

Las apps de las bibliotecas de Worthington y del Tulare County (Estados Unidos) son dos ejemplos de aplicaciones creadas por la empresa Boopsie. Los contenidos que incluyen son la búsqueda en el catálogo, gestión de cuenta de usuario, acceso a los libros electrónicos y otros medios digitales, localización de las bibliotecas, eventos, contacto, medios sociales y acceso al sitio web móvil. El catálogo contiene un sistema de búsqueda predictiva propio. También contiene un espacio para la configuración de varias opciones, como definir el tamaño de la letra. El sistema de navegación es similar al de los sitios web, con un menú en la página principal y botones para volver en el resto de las páginas.

Una de las más originales apps de este tipo es Liburutegiak, de la Red de Lectura del País Vasco (España). Su originalidad reside en las opciones de interacción: se puede hacer check-in en las bibliotecas de la red, como en Foursquare, y votarlas. 
El usuario va formando con sus intervenciones su propia reputación, que queda registrada, junto a su actividad, en su perfil de usuario. Este perfil es independiente de su carnet de biblioteca y cualquier persona, incluso quienes que no son usuarios de la red, pueden crear uno. Sin embargo, una de las asignaturas pendientes de esta aplicación es la adaptación del catálogo, al que se puede acceder desde la aplicación en su versión completa.

BibliosBCN, la app de las Bibliotecas de Barcelona, se diferencia de otras aplicaciones de bibliotecas porque su utilidad está en gestionar las actividades que organizan las bibliotecas. Las actividades se pueden visualizar en un calendario y se pueden guardar en el espacio privado del usuario. A diferencia de otras, esta app se enfoca realizar alguna acción, en lugar de proporcionar información. 



\section{Capítulo 6. El catálogo móvil. Resultados}

Son varios los trabajos que señalan el acceso al catálogo como uno de los servicios más interesantes para los usuarios de dispositivos móviles. En el presente apartado se analizan los catálogos y herramientas de descubrimiento adaptados para smartphones y teléfonos móviles con el propósito de conocer qué soluciones están adoptando las bibliotecas y cuáles son las funciones que incorporan estas herramientas de búsqueda. Se estudian por separado los catálogos que se presentan a través de la web y de aplicaciones nativas. 

En este apartado se analizará cómo las bibliotecas están adaptando sus catálogos para su consulta a través de dispositivos móviles. Para ello se intentará dar solución a las siguientes cuestiones:

1. Cuántas bibliotecas disponen de un catálogo móvil.

2. Qué solución han adoptado a la hora de adaptar los catálogos a los dispositivos móviles.

3. Qué opciones presentan las interfaces de los catálogos móviles.

4. Cómo son los catálogos que se consultan a través de aplicaciones nativas.

Para dar respuesta a estas cuestiones se ha partido de los 196 sitios web analizados en el cuarto capítulo de esta tesis doctoral y se han incluido además otros 12 sitios web cuya finalidad principal es el acceso al catálogo de la biblioteca. Además, se han analizado 19 catálogos incluidos en apps.

La Library of Congress define el catálogo en línea como «una herramienta de acceso y guía de recursos a las colecciones de la biblioteca o bibliotecas, que contiene grupos interrelacionados de datos bibliográficos en un formato legible por máquinas y que pueden ser buscados de forma interactiva desde un terminal por los usuarios.»

En el presente estudio se han incluido además las herramientas de descubrimiento, Discovery Tools en inglés, que son definidas por Fagan, et al. (2012) como un «software web que busca metadatos de artículos de revista y del catálogo en un índice unificado y presenta los resultados en una única interfaz. Esto difiere del software de búsqueda federada, que busca en múltiples bases de datos y agrega los resultados.» Según Marshall Breeding, «los productos de descubrimiento tienden a ser independientes de las aplicaciones específicas que las bibliotecas implementan para gestionar los recursos, como sistemas integrados de gestión bibliotecaria, plataformas de servicios bibliotecarios, repositorios o sistemas de gestión de recursos electrónicos.» (Breeding, s.d.).

A efectos de esta investigación, y siguiendo el listado de Breeding115, se han considerado herramientas de descubrimiento las siguientes: Aquabrowser, BiblioCommons, Blacklight, Ebsco Discovery Service, Encore, Primo, Summon, VuFind y WorldCat Local.

115 http://www.librarytechnology.org/discovery.pl 


\subsection{Catálogos móviles y herramientas de descubrimiento}

Prácticamente nueve de cada diez sitios web para móviles que representan a la biblioteca enlazan a alguna herramienta de búsqueda, ya sea el catálogo o una herramienta de descubrimiento, tanto en su versión móvil como completa. Este dato coincide con los resultados del trabajo de Tay y Travis (2011). En España este porcentaje $(77,3 \%)$ es algo menor que en Estados Unidos $(91,0 \%)$ y que la media de la muestra $(89,5 \%)$.

Sin embargo, cuando se trata de enlazar a la versión móvil se reduce: el 43,1\% de los sitios analizados enlaza a una versión móvil del catálogo y el 35,4\% a la versión móvil de la herramienta de descubrimiento. En España el 31,8\% de los sitios enlaza al catálogo móvil y en Estados Unidos son el 45,9\%. Esto significa que una tercera parte de las veces que se enlaza al catálogo desde la versión móvil del sitio web de la biblioteca se dirige a la versión completa.

Total

EE.UU.

España

\begin{tabular}{|c|c|c|c|c|c|c|}
\hline & Sitios web & $\%$ & Sitios web & $\%$ & Sitios web & $\%$ \\
\hline OPAC & 115 & $63,5 \%$ & 78 & $63,9 \%$ & 14 & $63,6 \%$ \\
\hline Móvil & 78 & $43,1 \%$ & 56 & $45,9 \%$ & 7 & $31,8 \%$ \\
\hline Completo & 37 & $20,4 \%$ & 22 & $18,0 \%$ & 7 & $31,8 \%$ \\
\hline Discovery & 76 & $42,0 \%$ & 54 & $44,3 \%$ & 9 & $40,9 \%$ \\
\hline Móvil & 64 & $35,4 \%$ & 47 & $38,5 \%$ & 7 & $31,8 \%$ \\
\hline Completo & 13 & $7,2 \%$ & 8 & $6,6 \%$ & 2 & $9,1 \%$ \\
\hline OPAC + Discovery & 29 & $16,0 \%$ & 21 & $17,2 \%$ & 6 & $27,3 \%$ \\
\hline Ninguno & 19 & $10,5 \%$ & 11 & $9,0 \%$ & 5 & $22,7 \%$ \\
\hline Total & 181 & & 122 & & 22 & \\
\hline
\end{tabular}

Tabla 23. Sitios web para dispositivos móviles que representan a la web de la biblioteca en función de si incluyen o no enlace al catálogo y/o herramienta de descubrimiento, por países ( $\mathrm{n}=181$ sitios web).

La situación cambia en función del tipo de biblioteca: en las bibliotecas públicas se han encontrado más enlaces al catálogo $(80,8 \%)$ y se enlaza con más frecuencia a la versión móvil (en el 65,4\% de los casos). En este tipo de bibliotecas no suelen aparecer las herramientas de descubrimiento. 
Es en las bibliotecas universitarias donde más a menudo se enlazan las herramientas de descubrimiento, en prácticamente la mitad de los sitios consultados $(49,6 \%)$, lo que significa que casi todos los enlaces a herramientas de descubrimiento proceden de este tipo de bibliotecas. Es el único tipo de bibliotecas en que se da solapamiento de catálogo y herramienta de descubrimiento $(20,6 \%$ de los casos), algo que en públicas y bibliotecas especializadas no sucede. En las especializadas es donde menos se enlazan las herramientas de búsqueda, solo en la mitad de los diez casos analizados se ha localizado un catálogo o una herramienta de descubrimiento (tabla 24).

\begin{tabular}{lrrrrrr} 
& \multicolumn{2}{c}{ Universidades } & \multicolumn{2}{c}{ Públicas } & \multicolumn{2}{c}{ Especializadas } \\
\hline & Sitios web & \multicolumn{1}{c}{$\%$} & Sitios web & $\mathbf{\%}$ & Sitios web & $\%$ \\
\hline OPAC & 90 & $63,8 \%$ & 21 & $80,8 \%$ & 3 & $30,0 \%$ \\
\hline \multicolumn{1}{c}{ Móvil } & 60 & $42,6 \%$ & 17 & $65,4 \%$ & 1 & $10,0 \%$ \\
\hline \multicolumn{1}{c}{ Completo } & 30 & $21,3 \%$ & 4 & $15,4 \%$ & 2 & $20,0 \%$ \\
\hline Discovery & 70 & $49,6 \%$ & 3 & $11,5 \%$ & 2 & $20,0 \%$ \\
\hline \multicolumn{1}{c}{ Móvil } & 61 & $43,3 \%$ & 2 & $7,7 \%$ & 1 & $10,0 \%$ \\
\hline \multicolumn{1}{c}{ Completo } & 10 & $7,1 \%$ & 1 & $3,8 \%$ & 1 & $10,0 \%$ \\
\hline OPAC + Discovery & 29 & $20,6 \%$ & 0 & $0,0 \%$ & 0 & $0,0 \%$ \\
\hline Ninguno & 10 & $7,1 \%$ & 2 & $7,7 \%$ & 5 & $50,0 \%$ \\
\hline Total & 141 & & 26 & & 10 & \\
\hline
\end{tabular}

Tabla 24. Sitios web para dispositivos móviles que representan a la web de la biblioteca en función de si incluyen o no enlace al catálogo y/o herramienta de descubrimiento, por tipo de biblioteca ( $\mathrm{n}=177$ sitios web).

Estos datos muestran la importancia del catálogo y de las herramientas de descubrimiento en los sitios web para móviles de las bibliotecas y revelan la existencia de una proporción de enlaces a la versión completa del catálogo, en lugar de a la versión móvil, que sería lo más adecuado.

\subsection{Soluciones de movilidad}

En este apartado se responderá a la cuestión sobre qué soluciones están adoptando las bibliotecas a la hora de adaptar sus herramientas de búsqueda 
(catálogos y herramientas de descubrimiento) a los smartphones. Como ya se avanzó en el apartado 2.2.6, se han detectado tres soluciones de movilidad:

1. Software añadido al sistema integrado de bibliotecas. Son varias las empresas proveedoras de software para bibliotecas que comercializan servicios adicionales para adaptar la interfaz del catálogo.

2. Software de terceros, específico para tal fin. Se trata de soluciones que no se adscriben a ningún producto comercial específico, sino que se integran con varios de ellos. Es el caso de Library Anywere, de la empresa LibraryThing.

3. Desarrollos propios y/o software libre. Algunas bibliotecas han optado por desarrollar ellas mismas las interfaces móviles para el catálogo.

\subsubsection{Catálogos}

Uno de los problemas encontrados a la hora de conocer las soluciones de movilidad adoptadas por las bibliotecas para sus catálogos es que en la mayor parte de ellos no se especifica qué tipo de software se está utilizando, por lo que hubo que consultar a algunas bibliotecas qué software está detrás de sus catálogos y de qué forma se han adaptado a los smartphones. Se consultó a 56 bibliotecas cuyo software planteaba dudas y respondieron un total de 36. De las 20 restantes no se tuvo noticia, pero gracias a las respuestas de otras bibliotecas ha sido posible deducir qué software las soporta, con excepción de una, la Boise Public Library.

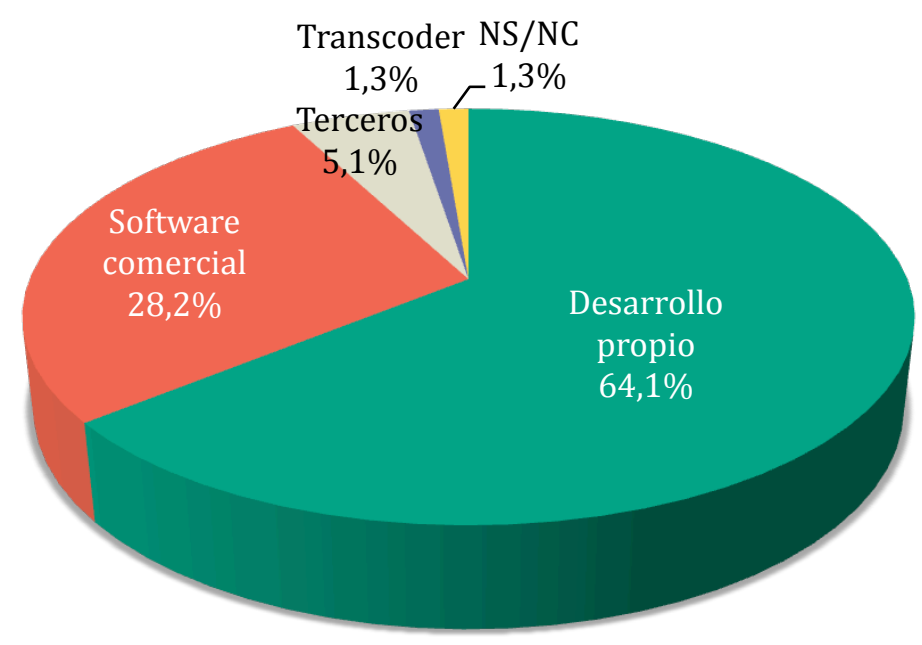

Gráfico 74. Catálogos móviles por solución de movilidad adoptada ( $n=83$ bibliotecas). 
El 64,1\% de las bibliotecas analizadas han preferido desarrollar su propia interfaz para dispositivos móviles, siendo esta la opción más popular. La segunda opción más frecuente es contratar el servicio a la misma empresa proveedora del software que sustenta el catálogo (28,2\%). Otra opción menos habitual es recurrir al software de terceros $(5,1 \%)$. También se ha hallado un caso en el que el catálogo ha sido adaptado con la ayuda de un transcodificador.

Se han encontrado cuatro bibliotecas universitarias en las que se enlazan dos versiones diferentes del catálogo. Tres de ellas mantienen versiones de WorldCat paralelas al catálogo, mientras que en la cuarta se mantiene un catálogo consorciado, denominado Aladin.

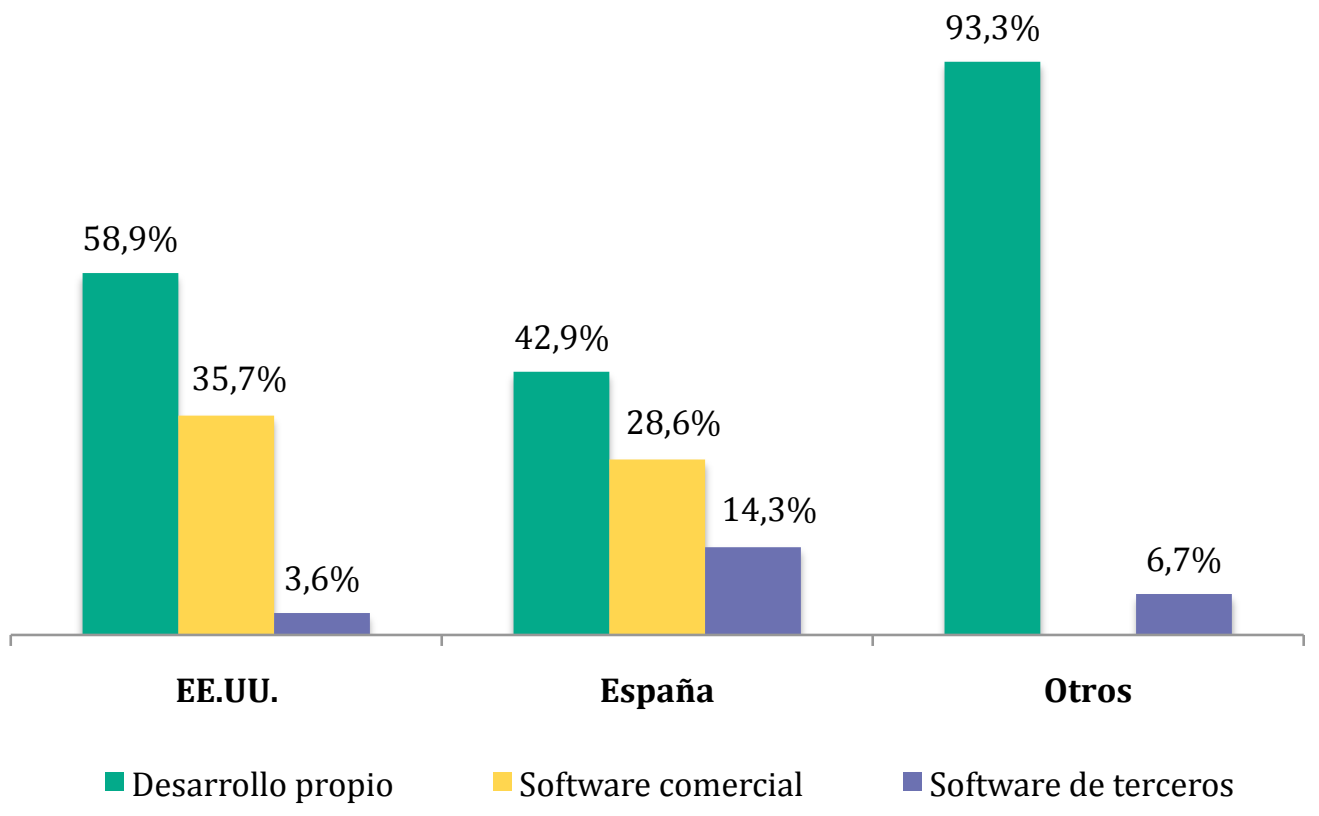

Gráfico 75. Catálogos móviles por solución adoptada y país ( $n=78$ bibliotecas).

En España no está extendida la adaptación de los catálogos a las interfaces móviles. Partiendo de los sitios web analizados en la muestra de sitios web se han detectado un total de siete. Sin embargo, existe constancia de que son más: al menos otras dos bibliotecas universitarias utilizan el servicio Library Anywhere (la Biblioteca de la Universidad de León y la Madrid Campus Library de la Universidad de Saint Louis) y son varias las bibliotecas del Consorcio de Bibliotecas de Castilla y León (BUCLE), además de Salamanca, las que han implementado WorldCat Local.

En España se han encontrado tres bibliotecas en el conjunto de la muestra que han optado por desarrollos propios y dos que han escogido módulos adicionales. 
También se ha encontrado un caso de uso de software de terceros, Library Anywhere, en la Universidad Pompeu Fabra.

El software comercial que más se ha utilizado en los catálogos móviles de la muestra es AirPac. Es, con diferencia, el software comercial más empleado como solución de movilidad. Otros programas comerciales que se han hallado son bicatWISE, Polaris Mobile PAC y WorldCat (tabla 25).

\begin{tabular}{lr}
\multicolumn{1}{c}{ Software } & Catálogos \\
\hline AirPac & 18 \\
\hline bicatWISE & 1 \\
\hline Polaris Mobile PAC (MPAC) & 4 \\
\hline WorldCat & 1 \\
\hline
\end{tabular}

Tabla 25. Software comercial en los catálogos de la muestra ( $n=24$ catálogos).

\subsubsection{Herramientas de descubrimiento}

Desde su irrupción en el mercado, aproximadamente en 2009, las herramientas de descubrimiento están tomando fuerza (Breeding, 2014) y su importancia se observa en los sitios web para móviles analizados: algo más de cuatro de cada diez sitios enlazan a alguna (tabla 23). Este fenómeno es más habitual en las bibliotecas universitarias, en las cuales la mitad de los sitios analizados tienen una.

La mayor parte de las herramientas de descubrimiento detectadas han adaptado su interfaz a los smartphones (84,2\%), mientras que en los catálogos la proporción alcanzaba el 67,8\%. Esto puede deberse a las facilidades que estas herramientas de descubrimiento incorporan, ya que la solución adoptada más habitualmente es el uso de software comercial, en el $90,6 \%$ de los casos. Este porcentaje podría ascender al $95,3 \%$ si se suman los tres casos que utilizan VuFind, pues este software libre permite personalizar las interfaces.

A diferencia de lo que sucedía en los catálogos, donde la solución más frecuente eran los desarrollos propios, en el caso de las herramientas de descubrimiento solo se han encontrado tres casos (sin incluir VuFind) que pueden considerarse desarrollos propios: dos con Aquabrowser y uno con EBSCO Discovery Services.

Se describen en los siguientes puntos las herramientas de descubrimiento localizadas en el análisis realizado. 
- Se han identificado dos bibliotecas que utilizan Aquabrowser: la Mount Prospect Public Library y la Harvard College Library. Ambas han optado por interfaces de desarrollo propio para adaptar el catálogo a los smartphones.

- BiblioCommons se ha localizado en una biblioteca pública en el conjunto de la muestra, la Brooklyn Public Library.

- Encore se ha encontrado en una de las bibliotecas analizadas, la Penrose Library.

- Primo se ha detectado en un total de 19 bibliotecas, lo que supone casi una tercera parte de las herramientas de descubrimiento con interfaces para móviles en el conjunto de la muestra $(29,7 \%)$.

- Summon es el servicio que más peso tiene en el conjunto de la muestra, presente en el 35,9\% de las bibliotecas con herramienta de descubrimiento móvil.

- VuFind. Se han encontrado cuatro bibliotecas con herramienta de descubrimiento móvil que utilizan VuFind.

- WorldCat Local es la tercera opción más habitual en la muestra analizada, presente en una quinta parte $(20,3 \%)$ de las bibliotecas con herramientas de descubrimiento con interfaces móviles.

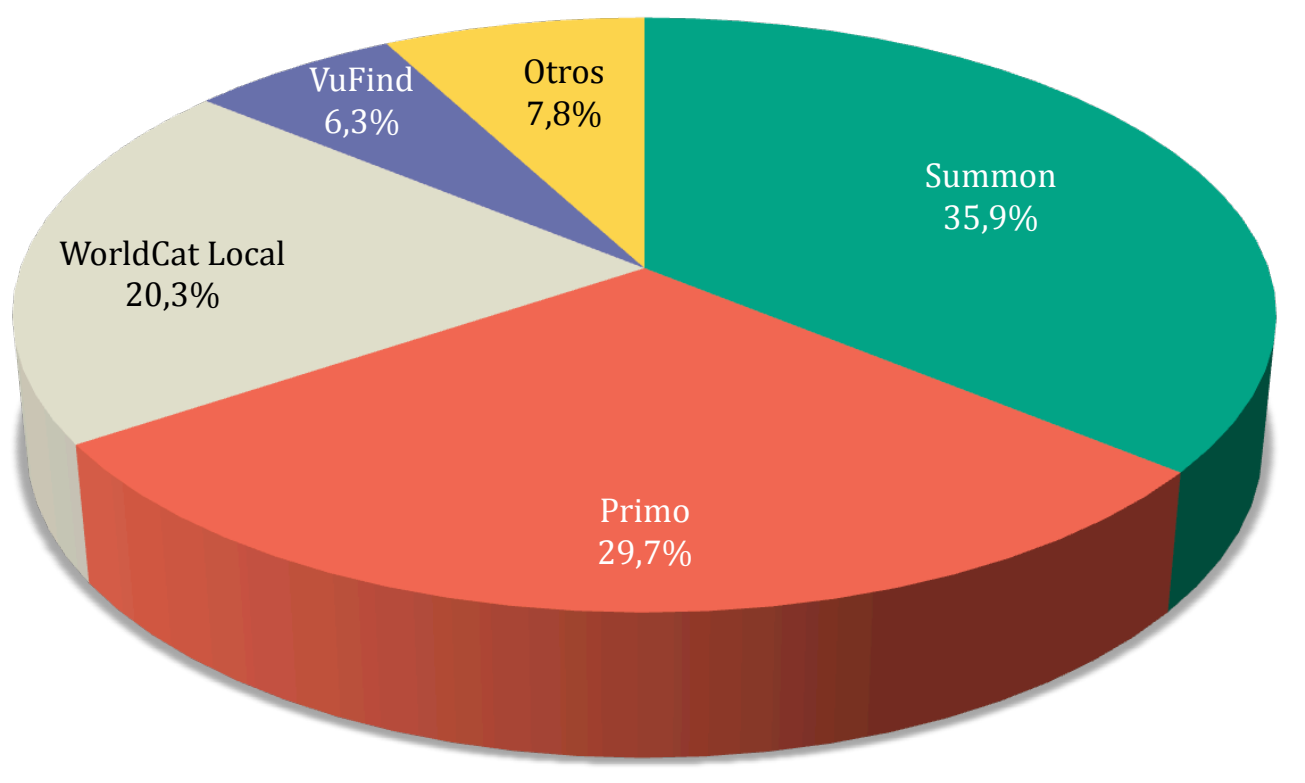

Gráfico 76. Herramientas de descubrimiento con interfaces móviles ( $n=64$ bibliotecas). 


\subsection{Características de las herramientas de búsqueda para móviles}

En este apartado se presentan los resultados del análisis de 46 catálogos y 6 herramientas de descubrimiento con interfaces diseñados para smartphones y/o teléfonos móviles. La selección de estas herramientas de búsqueda se ha realizado escogiendo un ejemplo de cada una de las interfaces de software comercial, para evitar repeticiones, y el resto -41 interfaces de catálogos y herramientas de descubrimiento- lo componen todos los desarrollos de las propias bibliotecas enlazados desde los sitios web para móviles de la muestra y algunos más. Solo dos de ellos, el catálogo del Centro Inter-Bibliotecario Universitá di Bologna y uno de los ejemplos de uso de AirPac, han sido diseñado para teléfonos móviles, mientras que el resto están pensados para smartphones.

Así, entre los 11 ejemplos de software comercial están representados las dos versiones de AirPac —una para teléfonos móviles, anterior, y otra para smartphones-, BicatWise, DDElibra MoBiblio, Library Anywhere, el módulo Mopac de AbsysNet, Polaris Mobile Pac, Prism, WorldCat Local y Xerxes.

Sólo se han analizado aquellos catálogos en los que están adaptadas las interfaces en todas las etapas de la búsqueda, desde que se realiza hasta que se obtiene el registro completo. $\mathrm{Y}$ es que se han encontrado algunos casos en los que solo la interfaz de búsqueda está adaptada, mientras que la lista de registros y la vista del registro completo están diseñados para pantallas completas. A modo de ejemplos valgan el Catálogo Franklin, de la Universidad de Pennsilvania ${ }^{116}$ y la interfaz de búsqueda diseñada por la Library Information Network for Community Colleges (Florida), adaptado hasta el nivel de la lista de registros ${ }^{117}$.

En el análisis realizado se han detectado las siguientes funciones:

- Búsqueda sencilla o con limitadores, que permiten restringir la búsqueda a campos concretos (autor, título o palabras clave, por ejemplo) o a una biblioteca.

- Búsqueda avanzada, que se muestra de forma diferenciada de la búsqueda general y permite realizar búsquedas complejas a través de una serie de operadores.

\footnotetext{
116 http://www.library.upenn.edu/m/

117 http://www.linccweb.org/mobile/
} 
- Acotar búsquedas una vez obtenidos los resultados, introduciendo nuevos elementos que las delimiten.

- Búsquedas recientes. Esta opción permite recuperar las últimas búsquedas realizadas.

- Guardar búsquedas, de manera que queden almacenadas en un espacio personalizado. Esta opción y todas aquellas que requieren el acceso por contraseña sólo se han podido detectar cuando no se accede a ellas desde la cuenta de usuario, por lo que se sospecha que podrían aparecer en más casos de los detectados.

- Guardar registros en el espacio personal para poder recuperarlos más tarde, en una especie de lista de deseos.

- Crear alertas de búsqueda, ya sea de forma interna o a través de RSS.

- Ordenar los registros según diferentes campos, como el año de publicación o el autor.

- Número de pasos para la consulta del registro completo.

- Descripción del documento breve o larga. En el primer caso implica la utilización de unos pocos elementos, como el título, el autor y la portada, que permitan la identificación, mientras que en el segundo se añaden elementos adicionales, como la descripción física, materias o el resumen del documento, haciendo más compleja la descripción.

- Datos para la localización del documento, como la signatura.

- Disponibilidad del documento para el préstamo.

- Cuenta de usuario. El acceso a esta opción mediante contraseña impide analizar las opciones que contiene con más detalle, por lo que solo se valorará aquí si está disponible esta opción o no.

- Envío de registros por e-mail o SMS, con el fin de recomendarlos a otras personas o a nosotros mismos.

- Compartir registros en redes sociales como Facebook o Twitter.

- Comentar y valorar los documentos en una escala de cinco estrellas.

- Exportar los registros a diferentes formatos bibliográficos, como RIS o Refworks, con el fin de elaborar bibliografías.

- Localización de los registros de la biblioteca en un mapa de planta o geográfico.

Lo más habitual es que el proceso de búsqueda y recuperación de la información se muestre en tres pasos, coincidiendo con los resultados de Hegarty y Wusteman (2011): en el primero se realiza la búsqueda, en el segundo se obtiene un listado con los documentos que cumplen las condiciones de dicha búsqueda y en el tercero se llega al registro completo. Sin embargo, hay casos en que son solo dos y en otros cuatro, como en las bibliotecas del Harvard College, que en el cuarto paso muestran la información de localización (figura 22). 
Las interfaces de las herramientas de búsqueda diseñadas para dispositivos móviles se caracterizan en su mayoría porque tienden a simplificar información y funciones. Siete de cada diez incluye solo la información básica de cada registro, prescindiendo de todo lo demás. Algunos, como Library Anywhere, el módulo Polaris Mobile Pac y la interfaz diseñada por la Bayerische Staatsbibliothek, han solucionado esta cuestión mostrando los datos más básicos y permitiendo el acceso al resto bajo la opción «más información». El resto muestra una gran cantidad de datos adicionales sobre cada registro. En este sentido, recordamos las ya mencionadas indicaciones de Nielsen y Budiu (2013): conviene prescindir de aquellos contenidos y opciones que sean innecesarios, manteniendo solo los que tengan utilidad para el usuario de dispositivos móviles.
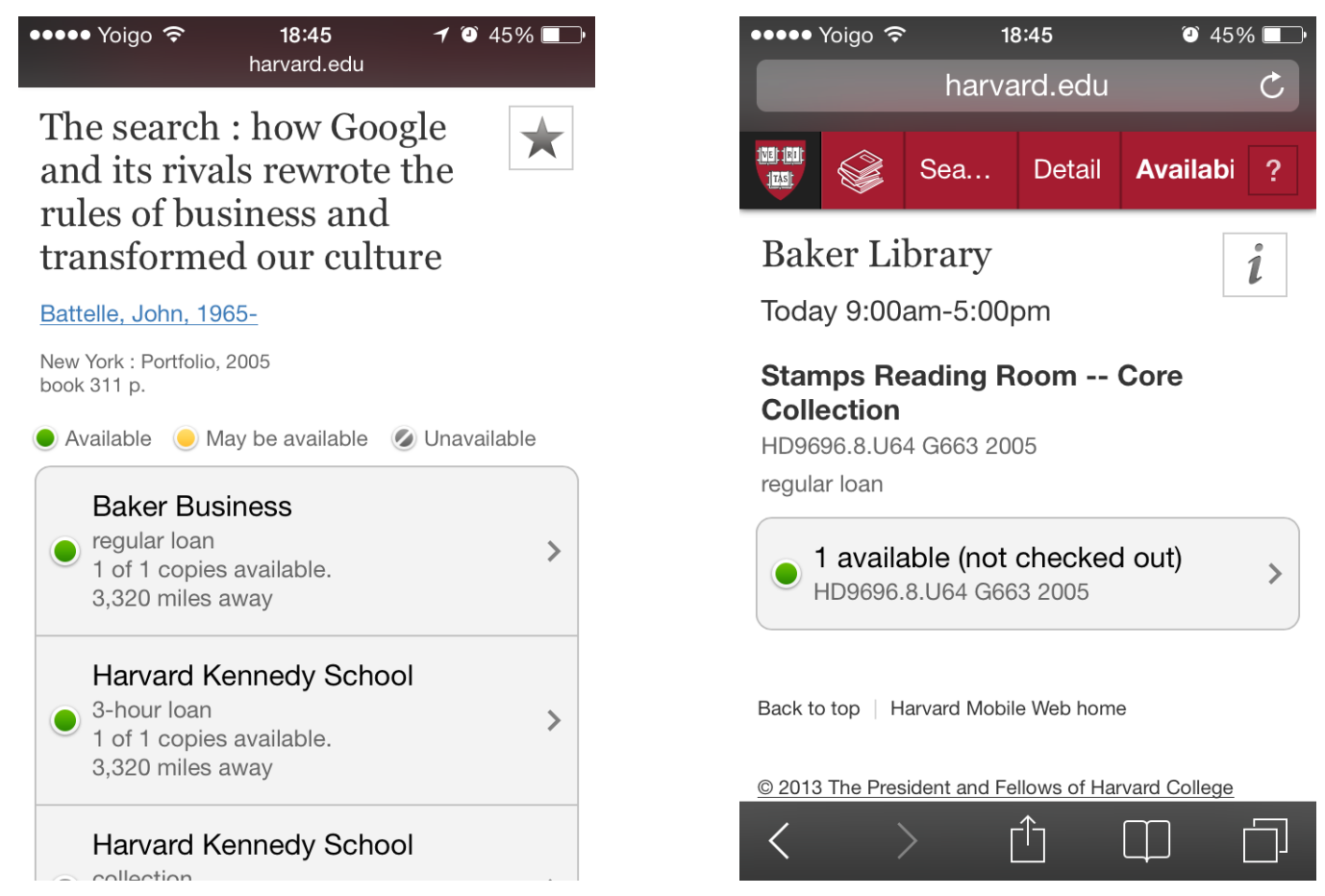

Figura 22. Información de disponibilidad y localización en el catálogo de la biblioteca de la Harvard College.

La mayoría de las herramientas de búsqueda analizadas se centra en unas pocas funciones y prescinde de las secundarias. Por otra parte, se han encontrado muy pocos elementos que sean muy comunes en este tipo de catálogos y muchos que aparecen de forma excepcional, lo que indica esa tendencia a simplificar opciones y una cierta diversidad.

Esta simplificación se observa en todos los pasos, comenzando por el proceso de búsqueda: las interfaces móviles tienden a evitar la búsqueda avanzada, que es 
menos frecuente en desarrollos propios (12,2\%) que en interfaces asociadas a un software $(36,4 \%)$, apenas se dan opciones para acotar las búsquedas una vez realizadas (solo se ha encontrado en el 14,6\% en desarrollos propios y en ninguna de las interfaces asociadas a un software), para guardar las búsquedas (solo en desarrollos propios, en el 7,3\% de los casos) u ordenar los registros (7,7\% del total de la muestra).

Así, la información de localización y disponibilidad del documento es la más habitual en las interfaces de desarrollo propio (en el 87,8\% y 78,0\% de los casos analizados respectivamente), y lo es más aún en aquellas que vienen asociadas al software comercial o libre (100,0\% y 81,8\%). La información de disponibilidad se muestra en ocasiones de forma visual, señalando en color verde los que están disponibles y en rojo los que no (figura 22).

$\begin{aligned} & 19: 30 \\ & \text { catalog.onlib.org }\end{aligned}$
Onondaga County Public
Library

\begin{tabular}{|l|}
\multicolumn{1}{|c|}{ en Todas las bibliotecas } \\
\multicolumn{1}{|c|}{ « negiarra.es } \\
\hline Autor: \\
Anderson, Kevin J. 2 de 86 ॥ \\
Título: \\
La búsqueda del Jedi / Kevin J. Anderson ; \\
[traducción de Albert Solé]. \\
Editorial: \\
Barcelona : Martínez Roca, [1995] \\
Descripción física: \\
347 p. ; 22 cm. \\
Colección: \\
Trilogía de la Academia Jedi ; 1La guerra \\
de las galaxias \\
Notas: \\
Título original: Jedi search. \\
ISBN: \\
84-270-1945-9 \\
CDU: \\
821.111(73)-31"19" \\
Autores: \\
Solè, Albert
\end{tabular}

Figura 23. Registros breve y largo. El de la izquierda corresponde a la Onondaga County Public Library y ha sido adaptado con el módulo Polaris Mobile Pac. El segundo es el catálogo de las Bibliotecas Públicas de Navarra, adaptado con el módulo Mopac de Baratz, y representa a un registro largo.

Se observan algunas diferencias entre los desarrollos propios y los productos asociados a un software (gráficos 77 y 78). Estos últimos son más propensos a incluir opciones que requieren espacios personalizados, como la cuenta de usuario o guardar registros, presentes en el $72,7 \%$ y el $54,5 \%$ de los casos. En los 
desarrollos propios estas funciones se dan en el 34,1\% y 12,2\% de la muestra respectivamente. Por otra parte, el software comercial también suele presentar interfaces de búsqueda sencillas, sin limitadores (72,7\%, frente al 29,3\% en los desarrollos propios).

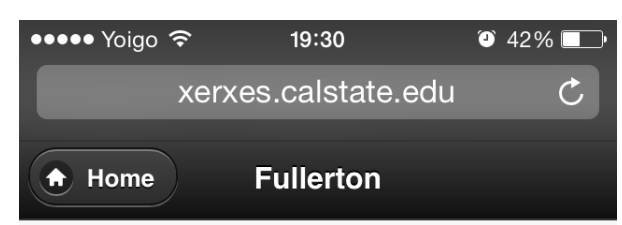

\section{Find Books}

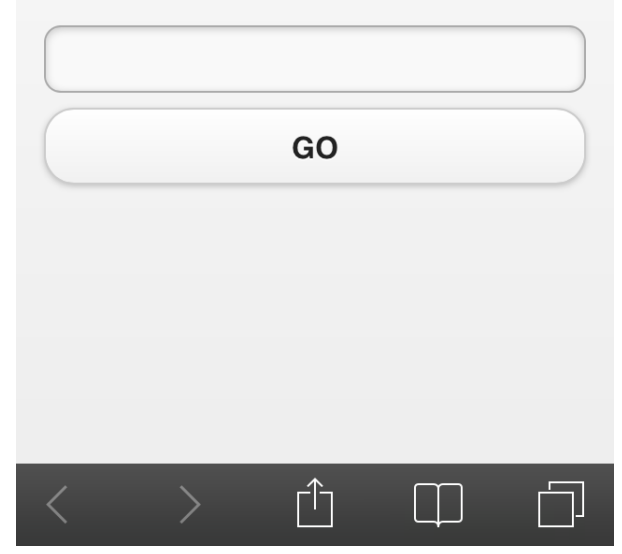

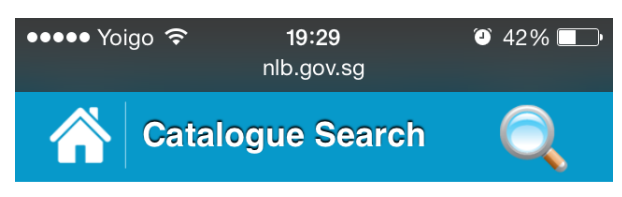

Search the library's full catalogue, view availability and reserve items.

Search for

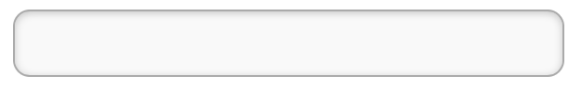

Search type

by Keyword

○

Limit by Library

Display Book Cover:

Figura 24. Búsqueda sencilla y con limitadores en la biblioteca Cal Poly Pomona (California State University), a la izquierda, y la National Library Board Singapore, a la derecha.

La gestión del préstamo fue identificada en el trabajo final del The M-Library Project (2011) como la más útil para los alumnos de las universidades de Edinburgh Napier, Queen Margaret y Highlands and Islands. Aunque no se puede asegurar con exactitud en qué porcentaje se presenta en los catálogos analizados, debido a que es una opción a la que se accede con contraseña de usuario, se presume que podría estar detrás de la cuenta de usuario y que, por lo tanto, no estará presente en más del 42,3\% de los catálogos y herramientas de descubrimiento analizados.

Las opciones de participación son poco frecuentes en los catálogos y herramientas de descubrimiento móviles: solo se han encontrado tres casos $(5,8 \%)$ en que es posible compartir los registros en los medios sociales y uno que permite comentarlos y valorarlos en una escala de cinco estrellas (1,9\%). Más frecuente es que se puedan compartir por correo electrónico o SMS $(30,8 \%)$ y algunos incluso 


\section{permiten compartir los registros en determinados formatos de referencias bibliográficas $(3,8 \%)$.}

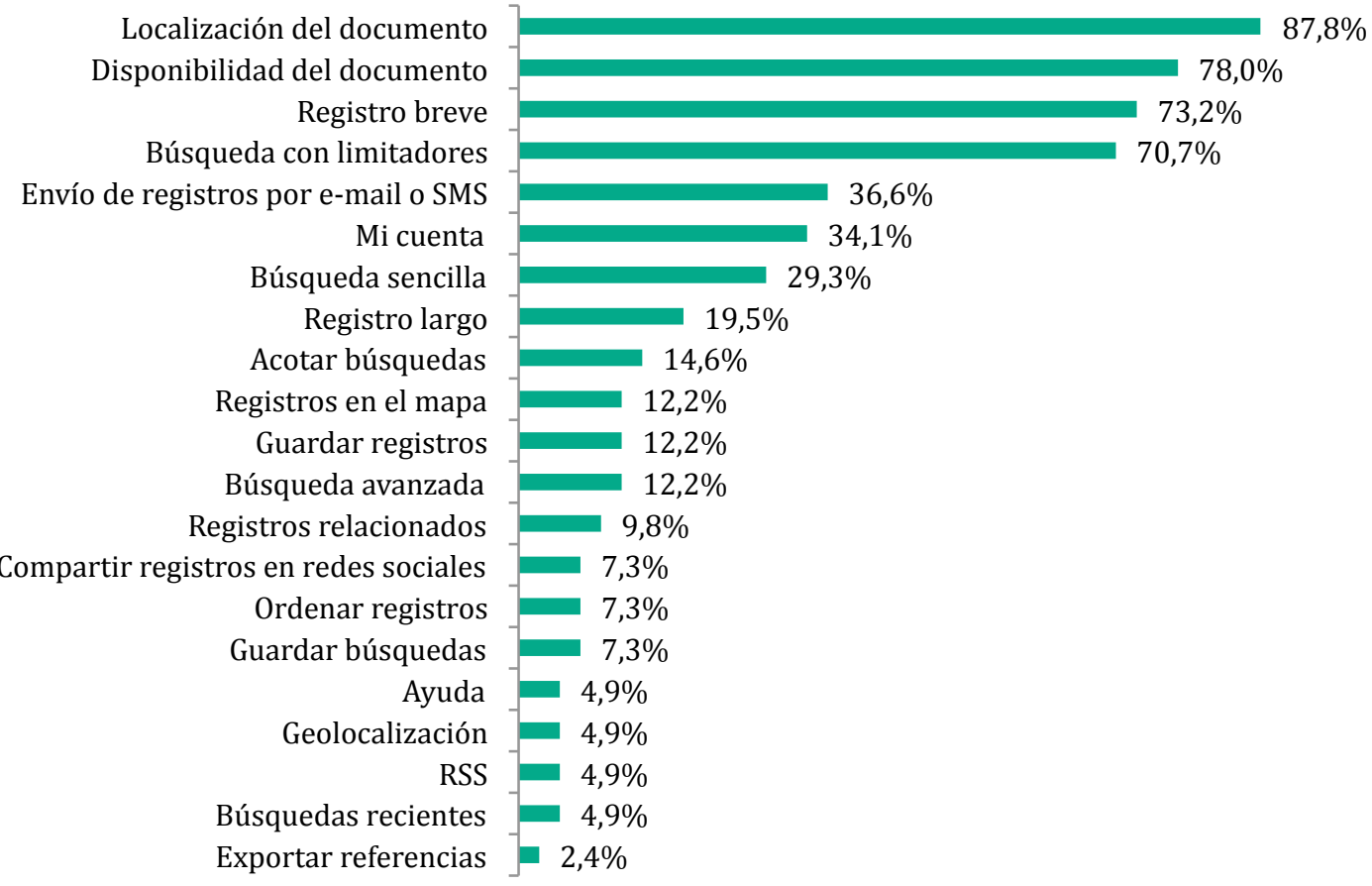

Gráfico 77. Catálogos y herramientas de descubrimiento móviles de desarrollo propio según las funciones que incluyen $(n=41)$.

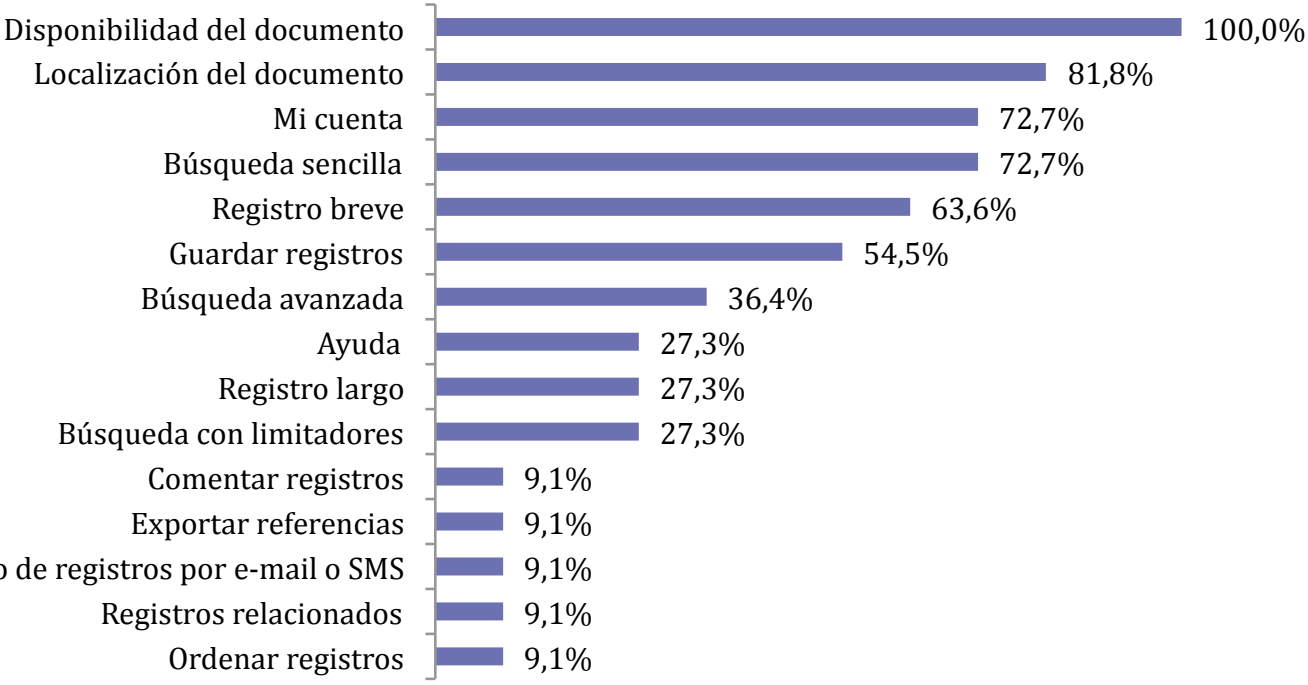

Gráfico 78. Catálogos y herramientas de descubrimiento móviles en el software comercial según las funciones que incluyen $(n=11)$. 
Se ha encontrado un caso, el de la Universidad de Oxford, en que se pueden compartir los resultados de una búsqueda en Facebook y Twitter, así como enviarlos a un correo electrónico. También se genera un código QR de acceso a esos mismos resultados, una opción a la que no se encuentra utilidad real, puesto que si el usuario accede al catálogo desde el móvil necesitará otro móvil diferente para poder escanear la pantalla del primero.

La localización del documento en el mapa aparece en algunos catálogos como una opción que complementa a la signatura para facilitar su recuperación. Se han detectado cuatro casos en que el documento en concreto se localiza en un mapa de planta - las bibliotecas de Lane Community College, Ryerson University, Universitat Politècnica de Catalunya y Langsdale, de la University of Baltimore- y uno - la biblioteca de la University of Oxford- en que se localiza en un mapa geográfico (figura 25).
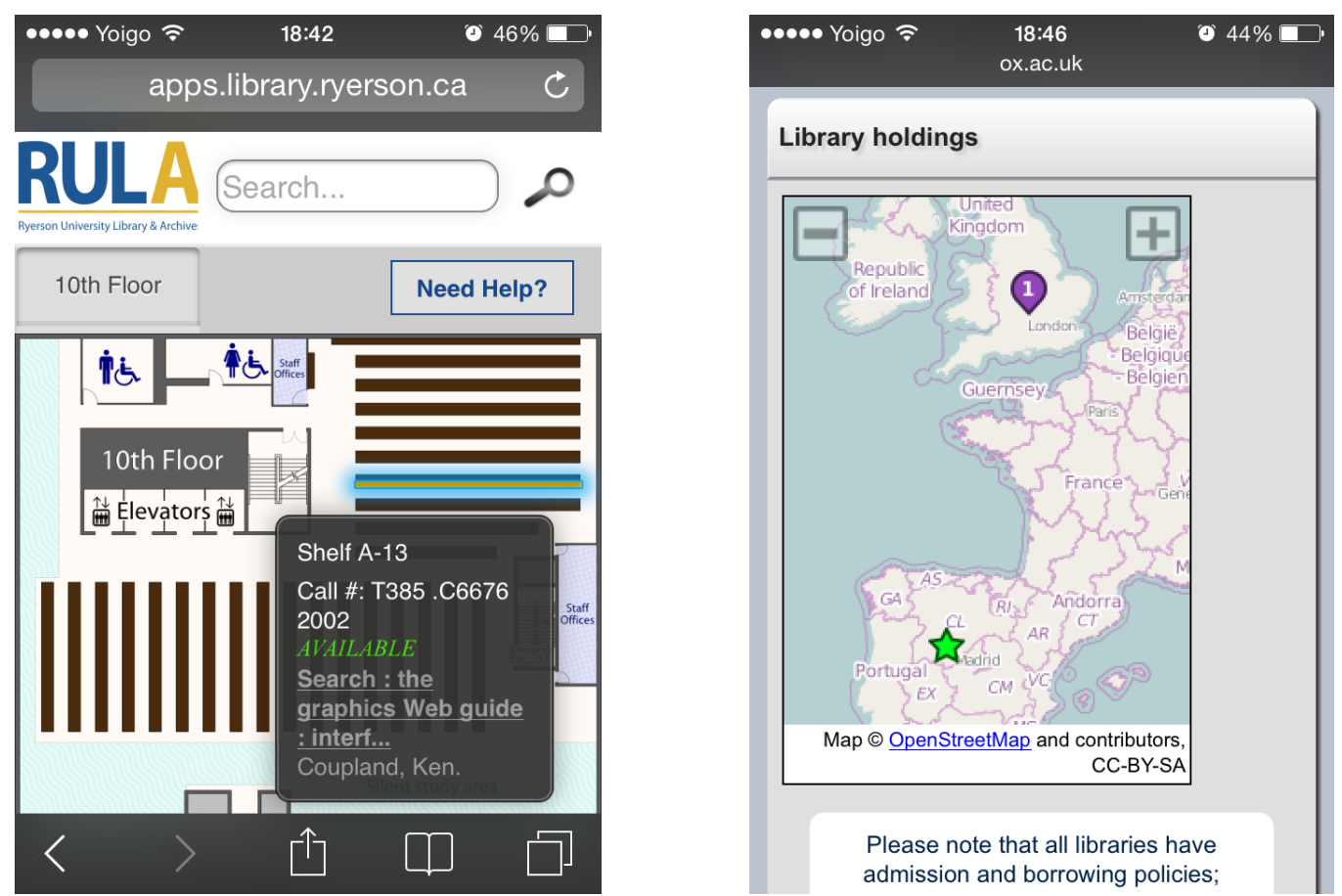

Figura 25. Localización de los registros en el mapa en los catálogos de las bibliotecas de Ryerson University (izquierda) y Oxford University (derecha).

Además, son dos los catálogos que hacen uso de la geolocalización: los de las bibliotecas de la University of Oxford y el Harvard College. En el primer caso esta información sirve para mostrar en el mapa el lugar en que se encuentra el usuario 
y dónde está la biblioteca en que se encuentra ese documento. En el segundo, para calcular la distancia en millas a la biblioteca en que se encuentra el documento. Especialmente original es el catálogo Bookfinder, de la Ryerson University Library \& Archives, cuya interfaz se dirige completamente a indicar la planta y estantería en que se encuentra cada uno de los documentos localizados (figura 25).

\subsection{Los catálogos móviles en aplicaciones nativas}

El acceso al catálogo es uno de los servicios más frecuentes en las aplicaciones nativas de las bibliotecas, ya sea integrado junto con otras funciones o de forma independiente, como función principal, tal y como se explicó en el apartado 5.1.4. En este apartado se analizan 19 catálogos incluidos en las apps de diferentes bibliotecas. De estas apps, nueve han sido desarrolladas por empresas especializadas en la creación de apps para bibliotecas:

- New York Public Library y OPL Mobile, desarrolladas por BiblioCommons.

- YourLibraryCa, por VTLS.

- Manchester Libraries, por SOLUS UK Ltd.

- TCLibToGo, por Library Anywhere.

- Biblioteche Venezia, por CG SOLUZIONI INFORMATICHE SRL.

- Bibli - Uppsala y Gladsaxe Public Libraries, por BridgeIT ApS.

- Worthington Libraries, por Boopsie.

No es frecuente que las empresas proveedoras de software para bibliotecas oferten el servicio de desarrollo de una aplicación para el catálogo, tan solo se han encontrado dos casos en el conjunto de la muestra: BiblioCommons y Library Anywhere, aunque hay constancia de que BookMyne y Boopsie también ofrecen este servicio. Por lo tanto en muchas ocasiones son las empresas desarrolladoras de apps quienes se encargan de abordar esta tarea, integrando la consulta al catálogo como un servicio más de la app.

Al analizar los catálogos detectados en las apps, siguiendo la misma metodología empleada con la versión para web móvil, se han encontrado grandes similitudes entre los catálogos a los que se accede desde una aplicación nativa y desde un sitio web diseñado para dispositivos móviles. La primera de ellas consiste en que las opciones detectadas son prácticamente las mismas, con algunas excepciones que se detallarán más adelante. Por lo tanto, se puede decir que las apps tienden a 
reproducir las mismas opciones del catálogo que en la versión web para smartphones.

Se mantiene también la tendencia a simplificar opciones e información y prevalece un estilo de registro con la información justa y necesaria (en el 73,7\% de las apps analizadas) e interfaces de búsqueda aún más sencillas: casi nunca se incluyen limitadores (solo en un 26,3\% de los casos) y las opciones de búsqueda avanzada sólo se han encontrado en un caso, mientras que al analizar los sitios web su incidencia era aún mayor $(17,3 \%)$. Sin embargo, son más las apps que incluyen opción de acotar la búsqueda una vez realizada (26,3\%). Como en el caso de los catálogos web, se han encontrado algunos ejemplos en que se incluye una opción para ver más detalles sobre cada registro: las apps TCLibToGo, Worthington Libraries, OPL Mobile y Biblioteca FM.

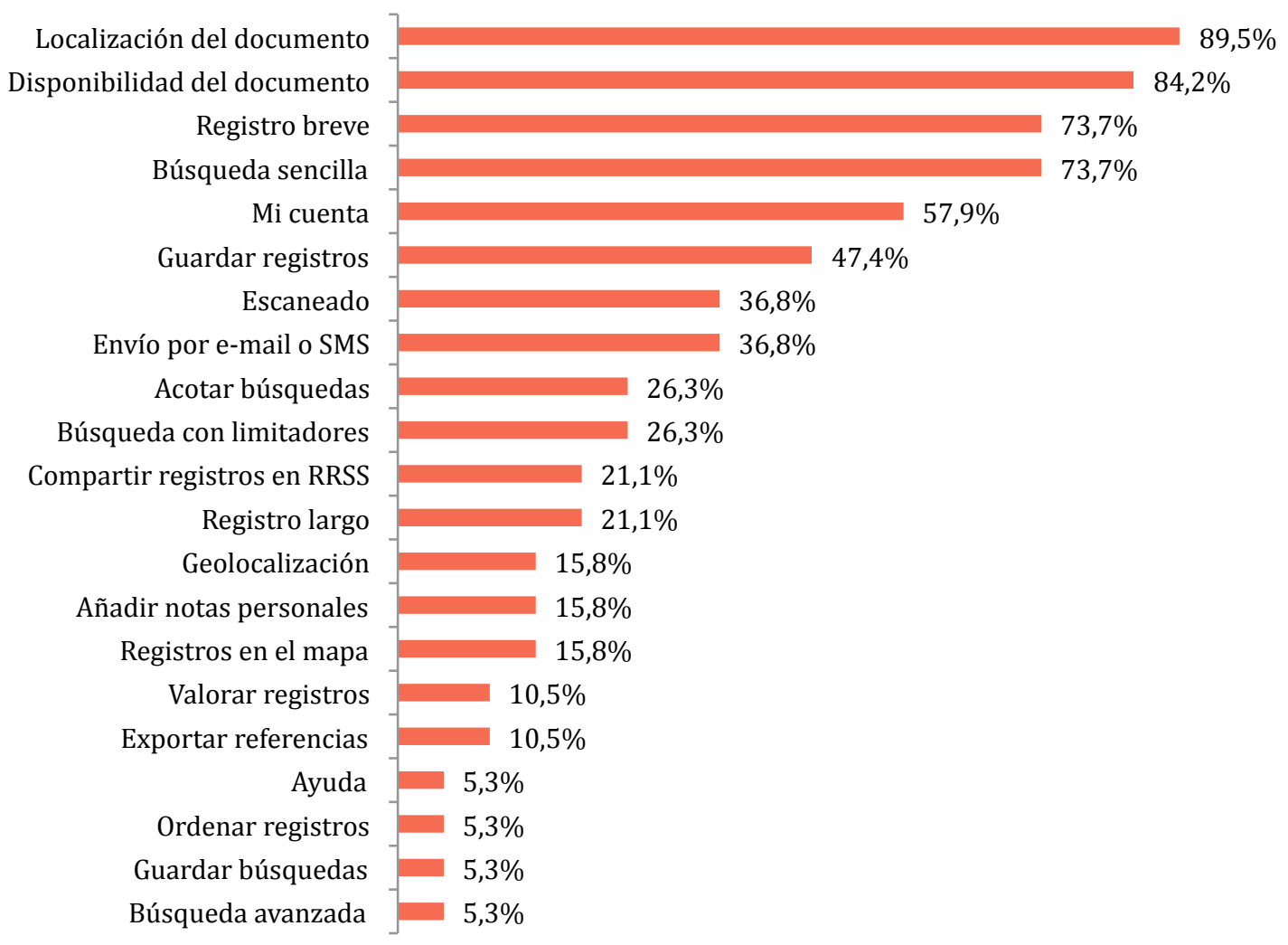

Gráfico 79. Catálogos en aplicaciones nativas según las funciones que incluyen $(n=19)$.

Los datos sobre la localización y disponibilidad del documento son también los más comunes, en prácticamente todos los catálogos analizados. En el caso de Biblio 
USAL, estos datos se facilitan en un enlace al registro completo donde se pueden visualizar, pero en una página web no adaptada para smartphones.

Las opciones sociales no son tampoco comunes en las apps. Si bien es cierto que hay un par de ejemplos que permiten valorar los registros en una escala de cinco estrellas, los comentarios han desaparecido y, sin embargo, aparece la opción de incluir notas personales sobre cada registro en tres casos. Esto pone de relieve la utilidad que los espacios personalizados pueden tener en los catálogos, aunque apenas se explotan.

Este tipo de espacios personalizados no requiere de un acceso a través de un nombre de usuario y contraseña o introduciendo el número de carné, a diferencia de los espacios para usuarios registrados, sino que pueden disfrutar de él todas aquellas personas que descarguen la app. Estos espacios se utilizan especialmente para guardar aquellos registros que interesen al usuario y desee poder recuperar después fácilmente. Los espacios para usuarios registrados están presentes en más de la mitad de las apps $(57,9 \%)$.

Los catálogos incluidos en las aplicaciones sí presentan un mayor grado de aprovechamiento de las capacidades del dispositivo que en sus versiones web, donde la función era meramente el acceso a la información. Y aunque en las apps también prima esa función, se observa un creciente interés en funciones como el uso de la geolocalización o de la cámara de fotos para consultar el catálogo escaneando el código de barras. Esta última función ha sido incorporada en más de la tercera parte de las apps analizadas $(36,8 \%)$ y se ha incorporado después del análisis realizado para este trabajo en la app TCLibToGo, como parte de las mejoras de la versión 1.91, disponible a partir del 23 de diciembre de 2013.

Es original el uso que Biblio USAL hace del escaneado, pues en lugar de servir para la consulta al catálogo constituye el punto de acceso a la cuenta de usuario, escaneando el código de barras del carné universitario. Este uso no se ha detectado en ningún otro catálogo de los analizados.

La función de geolocalización en las apps con catálogos se utiliza siempre para localizar en el mapa la biblioteca en que se encuentra cada registro. Aparece en tres casos, lo que representa el 15,8\%, y sigue siendo una función minoritaria, al igual que en las versiones web. No se han encontrado ejemplos en que la localización de los registros se ubique en un mapa de planta.

El envío de los registros del catálogo por correo electrónico o SMS es otra de las funciones que hacen uso de las capacidades únicas del dispositivo móvil y se encuentra en algo más de un tercio de las apps analizadas (36,8\%). La posibilidad de exportar referencias es igualmente poco utilizada por las aplicaciones nativas, $y$ solo se han detectado dos que las utilicen. 



\section{Capítulo 7. La Biblioteca de la Universidad de Salamanca. Resultados}

La Biblioteca de la Universidad de Salamanca ha puesto en marcha varias iniciativas relacionadas con los dispositivos móviles, entre las que se encuentran la aplicación nativa Biblio USAL y la adaptación del portal bibliotecas.usal.es. Además, estas bibliotecas cooperan con el catálogo WorldCat Local, que incluye una versión para móviles entre sus prestaciones.

En los siguientes apartados se analizan detalladamente las principales características de la aplicación nativa y el sitio web para móviles de la Biblioteca de la Universidad de Salamanca según los criterios expuestos en los capítulos anteriores. Además se estudiarán los datos de uso de ambos desde dispositivos móviles, además del catálogo, lo que aportará información adicional sobre cómo los utilizan los usuarios. Todo ello servirá para conocer las demandas de los usuarios de estos dispositivos y poder extraer conclusiones para optimizar la experiencia de uso. 



\subsection{Análisis del sitio web para móviles}

\subsubsection{Descripción del sitio web}

El 14 de febrero de 2013 la Biblioteca de la Universidad de Salamanca publicó la versión para smartphones y tabletas de su sitio web. La técnica empleada fue la de agregar una hoja de estilo específica para smartphones y tabletas, manteniendo prácticamente los mismos contenidos de la versión completa.

Además de un sistema de detección de dispositivo, hay un enlace en la página principal de la versión para escritorio que dirige a la versión móvil. Aunque está situada en un lugar visible - la parte superior de la cabecera de la página-, el tamaño de las letras es pequeño y se confunde con el resto de las opciones, lo que obligaría a quien accede desde una pantalla pequeña a buscarlo. En la versión móvil hay también un enlace en la versión de escritorio. Todos estos elementos y la corta longitud del URL facilitan el acceso desde dispositivos móviles.

El diseño de la página principal consiste en un menú vertical de botones con iconos. Aunque los contenidos son prácticamente idénticos en las versiones de escritorio y móvil, esta última prioriza determinados contenidos en el menú y establece tres áreas diferenciadas por el diseño que cumplen esa función de dar más o menos relevancia:

- En la parte superior derecha, en la cabecera, se sitúan dos botones: horarios y buscar. Ambos se ven en todas las páginas del sitio.

- Bajo la cabecera aparecen cuatro botones dispuestos en vertical que constituyen un segundo nivel de prioridad y que dan acceso a los apartados de Bibliotecas, Recursos, Servicios y Formación, que son los mismos que aparecen destacados en la versión de escritorio.

- Al final de la página aparecen seis botones, también dispuestos en vertical pero más pequeños, en color gris y sin iconos, lo que les destaca menos. Horarios, Noticias, Agenda, Acceso remoto, Pregúntenos y Mi Biblioteca (con el acceso a la cuenta de usuario).

Tanto los botones junto a la cabecera como los cuatro que aparecen bajo ella quedan visibles al acceder a la página, lo que les sitúa en un lugar prioritario frente a sus botones grises. 

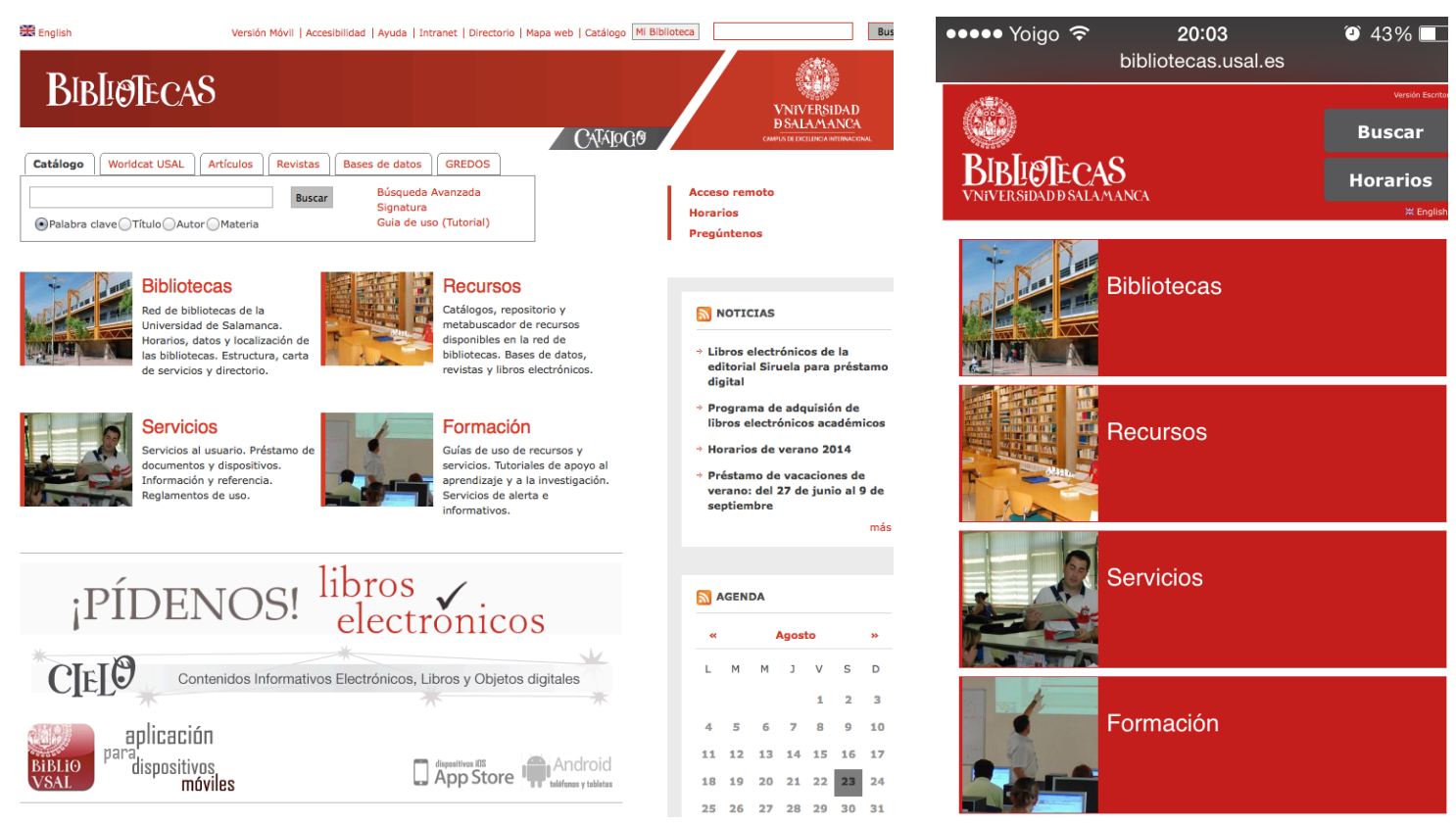

Figura 26. Sitio web de la Biblioteca de la Universidad de Salamanca en su versión de escritorio y móvil.

La versión para móviles se caracteriza por una organización jerárquica de los contenidos, prácticamente los mismos que en la versión de escritorio, que se agrupan en los mencionados apartados y se van subdividiendo en subapartados. Por ejemplo, tras el botón Buscar se llega a otra página con enlaces a diferentes herramientas de búsqueda: el catálogo, el repositorio, revistas electrónicas y bases de datos, etc. En algunos casos, la estructura jerárquica llega hasta cuatro niveles, como es el caso del apartado Bibliotecas, donde el usuario debe pasar por tres páginas, incluida la principal, antes de llegar al contenido.

En ocasiones esta estructura puede resultar compleja, puesto que hay varios enlaces a una misma página. Es el caso de la página con los horarios, a la que se llega desde tres enlaces: uno situado en la cabecera de la página principal, otro al final de esa misma página y otro en el apartado de bibliotecas. Los elementos de navegación son escasos, lo que obliga a utilizar los botones para ir a la siguiente página o a la anterior en el navegador, algo que no complica la navegación.

En el apartado de aprovechamiento de las capacidades del dispositivo se han encontrado enlaces a las cuentas de correo electrónico en los datos de contacto y mapas de Google incrustados, señalando la ubicación de cada biblioteca. No se enlazan sin embargo los números de teléfono, una consecuencia evidente del uso de hojas de estilo diferenciadas. 
En general es un sitio web con muchos contenidos, algo habitual cuando se mantienen las mismas páginas y solo se modifica el diseño. La bibliografía y el análisis realizado en el presente trabajo de investigación muestran que mantener los mismos contenidos en la versión móvil que en la de escritorio es una tendencia común en los últimos años, mientras que anteriormente se recortaban funciones contenidos.

Una asignatura pendiente es la adaptación del catálogo WebPAC PRO y de otras herramientas de búsqueda. La versión móvil incluye una interfaz de búsqueda adaptada al catálogo, al repositorio Gredos, la plataforma de libros electrónicos Cielo, revistas electrónicas, bases de datos y WorldCat, pero solo Cielo y WorldCat están adaptados por completo, mientras que en los demás los resultados de búsqueda solo tienen vista para ordenadores de escritorio. Esto es algo habitual en muchas bibliotecas, como se ha podido observar en los resultados del análisis.

\subsubsection{Datos de acceso desde dispositivos móviles}

Se analizan en este apartado los datos de acceso a la web de la Biblioteca de la Universidad de Salamanca desde dispositivos móviles. El sistema de adaptación escogido impide tener datos específicos sobre el uso de la versión móvil. En este sitio web se ha implantado un sistema de detección de dispositivo y es muy posible que la mayor parte de quienes accedan desde un smartphone lleguen a la versión móvil, pero es imposible de cuantificar.

Teniendo en cuenta que se trata de una biblioteca universitaria, se analizan los datos de uso en períodos que coinciden con el curso académico, que transcurriría entre septiembre de un año y agosto del siguiente. En el apartado 3.3. se definieron los datos que se exponen a continuación, así como otros aspectos metodológicos.

\subsubsection{Acceso desde dispositivos móviles}

En el último curso, 2013-2014, una de cada diez sesiones registradas en la web de la Biblioteca de la Universidad de Salamanca procedió de un dispositivo móvil. El porcentaje ha ido en aumento en los tres últimos cursos - en 2011-2012 eran una de cada veinte- y se espera que siga creciendo en los siguientes. Son más los accesos que proceden desde smartphones $(7,6 \%$ en el último curso) que desde tabletas $(2,7 \%)$.

Estos datos son algo mayores que los de otras bibliotecas universitarias españolas, según las estadísticas publicadas por Nieves González (2013) y que registraban un 
3,3\% de tráfico desde dispositivos móviles en enero de 2012 y un 5,5\% en abril de 2013 en una selección de once bibliotecas cuya identidad se desconoce.

\begin{tabular}{lrrrrrr} 
& \multicolumn{2}{c}{$\mathbf{2 0 1 1 - 2 0 1 2}$} & \multicolumn{2}{c}{$\mathbf{2 0 1 2 - 2 0 1 3}$} & \multicolumn{2}{c}{$\mathbf{2 0 1 3 - 2 0 1 4}$} \\
\hline & Sesiones & \% & Sesiones & \multicolumn{1}{c}{$\%$} & Sesiones & \% \\
\hline Ordenador & 276.027 & $94,7 \%$ & 379.743 & $92,7 \%$ & 378.982 & $89,7 \%$ \\
\hline Móvil & 12.947 & $4,4 \%$ & 22.562 & $5,5 \%$ & 32.275 & $7,6 \%$ \\
\hline Tableta & 2.380 & $0,8 \%$ & 7.305 & $1,8 \%$ & 11.459 & $2,7 \%$ \\
\hline Total & 291.354 & & 409.610 & & 422.716 & \\
\hline
\end{tabular}

Tabla 26. Sesiones registradas en el sitio web de la Biblioteca de la Universidad de Salamanca por tipo de dispositivo y curso académico.

Se observa un importante crecimiento en el número de sesiones entre el curso 2011-2012 y el siguiente, 2012-2013, con 118.256 más. En el curso 2013-2014 se produjo un ligero crecimiento, debido al incremento en el número de accesos desde smartphones y tabletas, pues los accesos desde ordenadores portátiles y de sobremesa descendieron ligeramente (761 visitas menos).

No existen evidencias suficientes para afirmar que el lanzamiento de la versión móvil, en febrero de 2013, provocara un incremento del tráfico desde dispositivos móviles, algo que Clarke, Hui y Li (2013) sugieren que podría suceder. Más bien parece que ese incremento haya sido provocado de forma natural por un aumento en los índices de uso de smartphones y tabletas entre los usuarios, puesto que no hay diferencias significativas a partir de esa fecha, aunque también cabe la posibilidad de que el crecimiento sea gradual.

\begin{tabular}{lrrr} 
& $\mathbf{2 0 1 1 - 2 0 1 2}$ & $\mathbf{2 0 1 2 - 2 0 1 3}$ & $\mathbf{2 0 1 3 - 2 0 1 4}$ \\
\hline Ordenador & 3,05 & 2,78 & 2,83 \\
\hline Móvil & 2,40 & 2,50 & 2,39 \\
\hline Tableta & 2,66 & 2,98 & 3,06 \\
\hline Total & 3,02 & 2,78 & 2,80 \\
\hline
\end{tabular}

Tabla 27. Número de páginas vistas por sesión y por tipo de dispositivo y curso.

Se encuentran diferencias significativas en el uso que los usuarios de smartphones hacen del sitio web: ven menos páginas y las sesiones son más cortas (tabla 27). Quienes accedieron desde un smartphone o un teléfono móvil a este sitio web vieron de media 2,39 páginas por cada sesión en el último curso, menos que desde 
un ordenador $(2,83)$. Son los usuarios de tabletas los que más páginas visitan por cada sesión, 3,06. Por otra parte, el número de páginas por sesión parece crecer ligeramente con el tiempo en las visitas desde tabletas, mientras que desciende en las visitas desde ordenadores.

\begin{tabular}{lrrr} 
& $\mathbf{2 0 1 1 - 2 0 1 2}$ & $\mathbf{2 0 1 2 - 2 0 1 3}$ & $\mathbf{2 0 1 3 - 2 0 1 4}$ \\
\hline Ordenador & $0: 03: 28$ & $0: 12: 32$ & $0: 14: 00$ \\
\hline Móvil & $0: 01: 19$ & $0: 16: 29$ & $0: 20: 25$ \\
\hline Tableta & $0: 02: 32$ & $0: 07: 43$ & $0: 08: 47$ \\
\hline Total & $0: 03: 22$ & $0: 12: 40$ & $0: 14: 21$ \\
\hline
\end{tabular}

Tabla 28. Duración media de las sesiones por tipo de dispositivo y curso.

\begin{tabular}{lccr} 
& $\mathbf{2 0 1 1 - 2 0 1 2}$ & $\mathbf{2 0 1 2 - 2 0 1 3}$ & $\mathbf{2 0 1 3 - 2 0 1 4}$ \\
\hline Android & $0: 01: 30$ & $0: 23: 57$ & $0: 29: 07$ \\
\hline iOS & $0: 00: 44$ & $0: 01: 36$ & $0: 00: 56$ \\
\hline Windows Phone & $0: 01: 06$ & $0: 00: 52$ & $0: 01: 45$ \\
\hline BlackBerry & $0: 01: 33$ & $0: 08: 52$ & $0: 09: 02$ \\
\hline SymbianOS & $0: 01: 43$ & $0: 02: 46$ & $0: 04: 26$ \\
\hline Nokia & $0: 01: 18$ & $0: 01: 06$ & $0: 01: 15$ \\
\hline Samsung & $0: 00: 39$ & $0: 00: 51$ & \\
\hline (not set) & & $0: 00: 13$ & $0: 01: 06$ \\
\hline Series40 & & $0: 00: 22$ & $0: 00: 07$ \\
\hline Bada & $0: 01: 19$ & $0: 16: 29$ & $0: 20: 43$ \\
\hline Total móvil & & & $0: 02: 16$ \\
\hline
\end{tabular}

Tabla 29. Duración media de las sesiones a la web desde smartphones por sistema operativo y curso ${ }^{118}$.

Los usuarios de smartphones y teléfonos móviles realizan visitas más cortas que las de los usuarios de ordenadores de sobremesa y que los de tabletas. Esta afirmación puede parecer extraña a la luz de la tabla 28, que refleja una mayor duración en las sesiones desde smartphones en los dos últimos cursos. Sin embargo, al analizar los datos con mayor detalle se ha observado que esto sucede exclusivamente desde

\footnotetext{
118 Los datos para cada curso no representan al total de las sesiones, sino a una muestra que supone el 85,74\% en 2011-2012, al 60,99\% en 2012-2013 y al 59,10\% en 2013-2014. Esa es la razón por la que no coinciden los datos totales con los de la tabla 28.
} 
smartphones Android, cuyas visitas alcanzan una media de casi 24 minutos en 2012-2013 y de más de 29 minutos en 2013-2014. En el resto de los sistemas operativos las sesiones oscilan alrededor del minuto, incluso llegan a dos (tabla 29). Otra excepción son los dispositivos BlackBerry, cuyas visitas duran unos 9 minutos en los dos últimos cursos.

Si se observan los datos con mayor detalle se encuentra que son sesiones concretas las que producen estos datos altos de manera artificial. Así, se registra en el último curso una duración media de las sesiones desde la versión 4.0.9 de Android de 5 horas y 39 minutos, de 2 horas 53 minutos desde la versión 4.3 .1 y de 1 hora y 39 minutos desde la 4.1. Teniendo en cuenta que el número de páginas por sesión en esas tres versiones es de 1,71, 2,76 y 1,61 páginas respectivamente en ese mismo curso, es lógico pensar que existe algún factor adicional que contamina los datos, pues no se imagina que alguien pueda estar visitando dos páginas desde un smartphone durante cinco, dos o una hora, sin efectuar ninguna interacción, por lo que estos datos no se consideran válidos. La lógica induce a pensar que los datos registrados por dispositivos móviles con sistemas operativos iOS, Windows Phone, Nokia y otros son más realistas que los obtenidos en Android, puesto que la diferencia es demasiado grande.

La Pollak Library (California State University, Fullerton, Estados Unidos) recibe visitas a su sitio web de poco más de un minuto de duración desde dispositivos móviles, mientras que quienes acceden desde un ordenador permanecen más de tres minutos de media (DeMars, 2012). Por otra parte, la biblioteca de la Hong Kong Baptist University registró en su sitio web para móviles datos similares la duración media de la visita, de un minuto y 23 segundos entre el número de visitas entre el 9 de enero y el 10 de abril de 2012 (Chan, 2012). Sin embargo, el número de páginas por sesión es mayor en la Biblioteca de la Universidad de Salamanca, con 2,40 páginas por sesión desde smartphones y 2,66 desde tabletas en el curso 2011-2012, mientras que en la HKBU se recogen 2,17.

Según las indicaciones de Avinash Kausik (2009), un porcentaje de rebote alrededor del $30 \%$ es aceptable. Como se puede observar en la tabla 30, el porcentaje de rebote del sitio web de la Biblioteca de la Universidad de Salamanca alcanza el 53,8\% en el último curso analizado. Este dato tan alto puede deberse, como explican Farney y McHale (2013) a que Google Analytics no permite analizar los enlaces salientes. El catálogo, uno de los recursos más consultados en las bibliotecas, se encuentra precisamente en un directorio diferente, brumario.usal.es, y por lo tanto se consideraría enlace saliente. Es decir, que todas aquellas visitas en las que se accede al sitio web de la biblioteca y se consulta el catálogo inmediatamente después se considerarían visitas con una única página, incrementando así el porcentaje de rebote. 


\begin{tabular}{lrrr} 
& $\mathbf{2 0 1 1 - 2 0 1 2}$ & $\mathbf{2 0 1 2 - 2 0 1 3}$ & $\mathbf{2 0 1 3 - 2 0 1 4}$ \\
\hline Ordenador & $47,6 \%$ & $54,3 \%$ & $54,0 \%$ \\
\hline Móvil & $53,2 \%$ & $54,3 \%$ & $53,6 \%$ \\
\hline Tableta & $51,0 \%$ & $47,5 \%$ & $47,7 \%$ \\
\hline Total & $47,8 \%$ & $54,2 \%$ & $53,8 \%$ \\
\hline
\end{tabular}

Tabla 30. Porcentaje de rebote por tipo de dispositivo y curso.

En la versión para escritorio del sitio web, el catálogo está situado en la parte más visible de la página, por lo que esta podría ser una razón de peso para que la tasa se vea aumentada. Sin embargo, en la versión móvil el catálogo no está tan accesible y la tasa de rebote desde dispositivos móviles sigue estando a un nivel similar $(53,6 \%)$. Esta tasa para la versión móvil es muy similar a la que presentan otras bibliotecas universitarias españolas, según los datos publicados por Nieves González (2013), de entre el 50\% y el 65\%. González recuerda que en un estudio realizado sobre Europeana la tasa de rebote de su sitio web era del 52\%.

En los dos últimos cursos la tasa de rebote desde dispositivos móviles se ha situado incluso ligeramente por debajo de la que muestra la versión de escritorio. Pero la tasa más baja se produce entre quienes acceden desde tabletas $(47,7 \%)$.

Siete de cada diez sesiones registradas desde smartphones y teléfonos móviles son nuevas sesiones (16.843 frente a 8.703). Con la tableta el porcentaje es mucho menor: 5.586 son nuevas en 2013 , mientras que 3.315 ya la habían visitado antes (tabla 31).

\begin{tabular}{lrrr} 
& $\mathbf{2 0 1 1} \mathbf{- 2 0 1 2}$ & $\mathbf{2 0 1 2}-\mathbf{2 0 1 3}$ & $\mathbf{2 0 1 3 - 2 0 1 4}$ \\
\hline Ordenador & $45,4 \%$ & $61,7 \%$ & $63,5 \%$ \\
\hline Móvil & $51,4 \%$ & $60,3 \%$ & $70,8 \%$ \\
\hline Tableta & $45,7 \%$ & $60,5 \%$ & $59,4 \%$ \\
\hline Total & $45,7 \%$ & $61,6 \%$ & $64,0 \%$ \\
\hline
\end{tabular}

Tabla 31. Porcentaje de nuevas sesiones por tipo de dispositivo y curso.

\subsubsection{Dispositivos utilizados}

Las sesiones registradas desde smartphones, teléfonos móviles y tabletas reflejan muy bien las tendencias en el mercado de los dispositivos móviles. Como se puede apreciar en los gráficos 80 y 81, las dos plataformas más utilizadas son iOS y 
Android, tanto en tabletas como en smartphones. Entre ambos acumulan el 96,1\% de las visitas desde smartphones y el 98,6\% desde tabletas. El sistema operativo de Apple partía de una mejor situación en el primer semestre del curso 2011-2012, pues estaba presente en los dispositivos desde los que se accedía en la mitad de las sesiones desde smartphones $(48,1 \%)$. Android le ha ido superando con el tiempo hasta acaparar las dos terceras partes de las sesiones $(69,4 \%)$ en el último semestre del curso 2013-2014 y dejando a los iPhone y iPod con algo más de una cuarta parte $(26,7 \%)$.
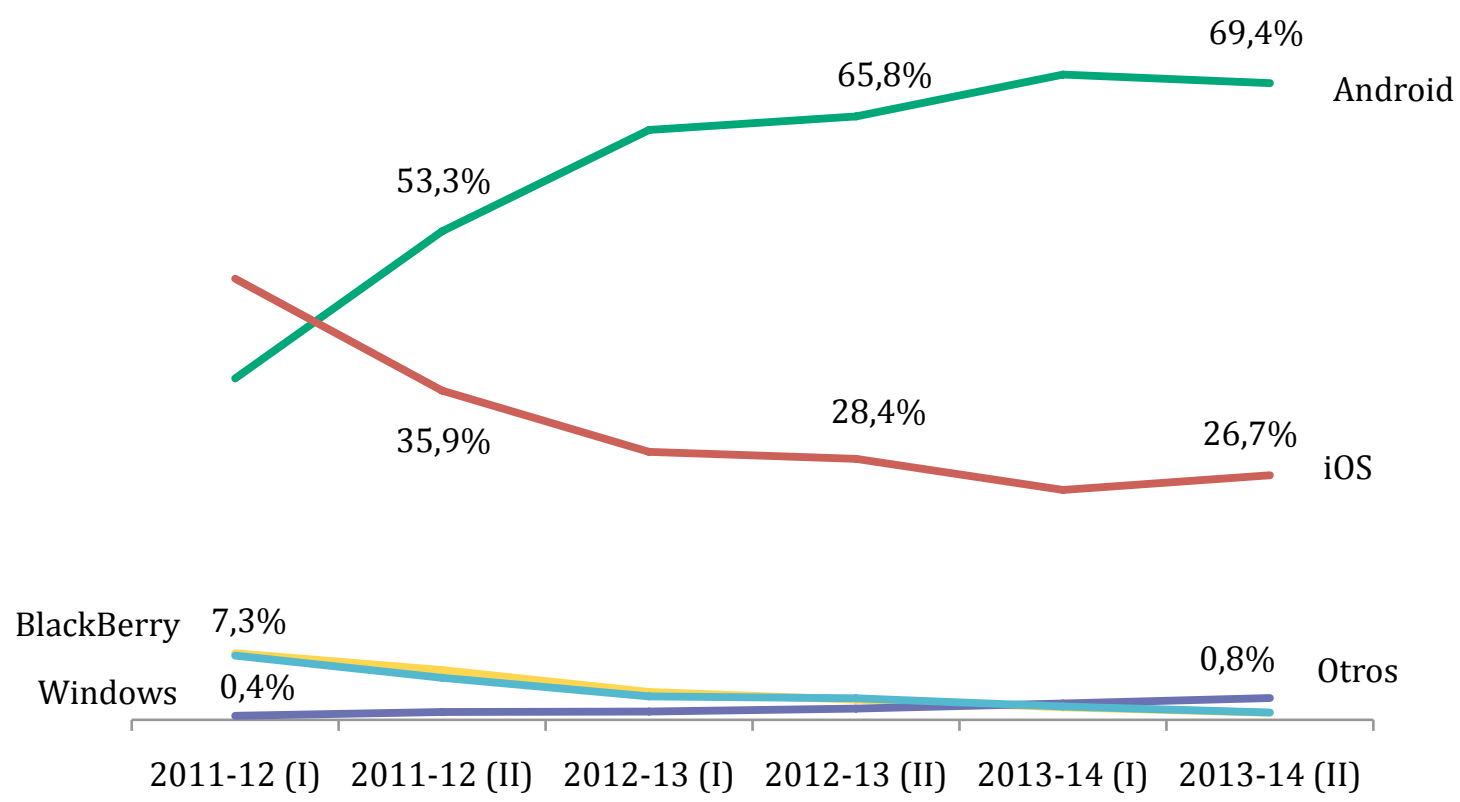

Gráfico 80. Sesiones registradas desde smartphones y teléfonos móviles por sistema operativo y semestre.

El resto de los sistemas operativos pierden cuota. BlackBerry, del que procedían un 7,3\% de las sesiones en el primer semestre del curso 2011-2012, ha pasado a un escaso $0,8 \%$ en el último semestre analizado. Una trayectoria similar ha seguido el grupo de otros sistemas operativos ${ }^{119}$, que partía de un 7,0\% de cuota entonces incluía Symbian, Nokia, Samsung y Sony- y finalmente ha quedado en un 0,4\%. Windows Phone, sin embargo, ha ganado ligeramente en estos tres cursos, pasando del 0,4\% al 2,4\% de las sesiones desde smartphones. Entre estos

${ }^{119}$ El grupo de otros sistemas operativos aglutina a los dispositivos Nokia, Samsung, Sony, MOT, LG, Firefox OS, Bada, Series40, Playstation Vita, Nintendo 3DS y un grupo sin identificar. 
otros sistemas operativos se incluyen dos que funcionan exclusivamente en videoconsolas portátiles, Playstation Vita y Nintendo 3DS, lo que significa que Google Analytics no diferencia este tipo de dispositivos de los smartphones. El número de accesos registrados desde videoconsolas portátiles es anecdótico: dos sesiones en primer semestre del curso 2013-2014 desde Playstation Vita y una sesión en el segundo semestre de ese mismo curso desde Nintendo 3DS.
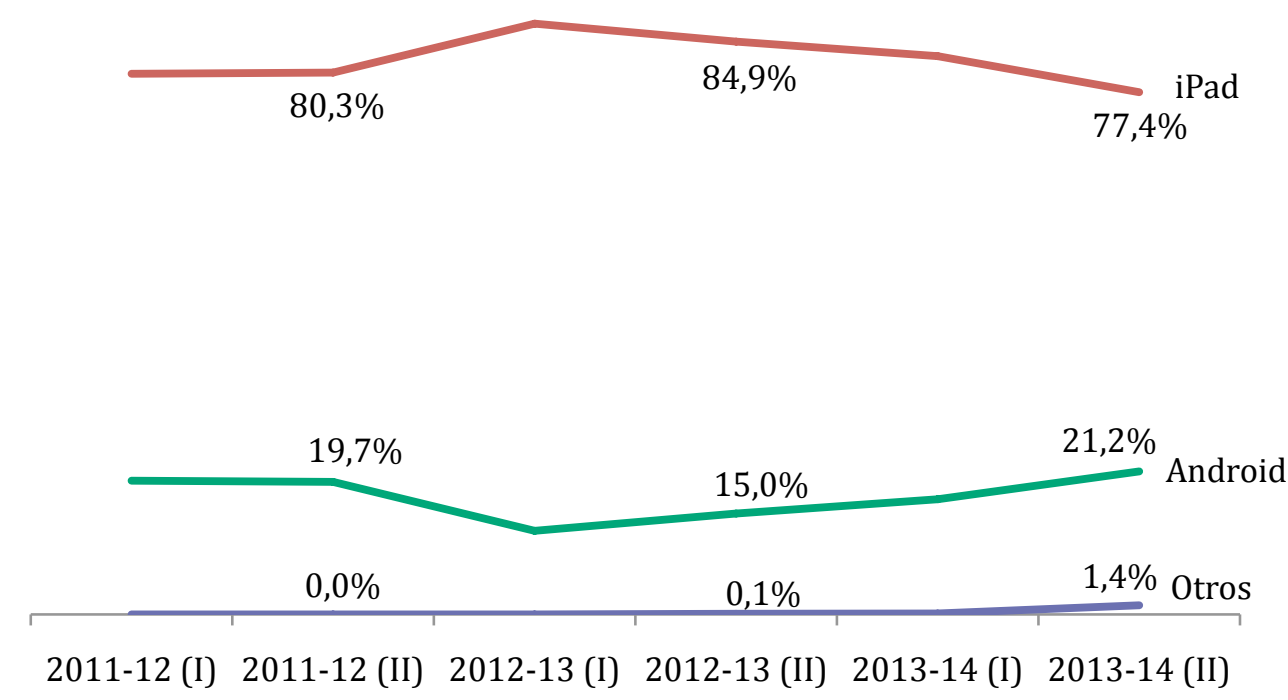

Gráfico 81. Sesiones registradas desde tabletas por sistema operativo y semestre.

En el apartado de tabletas aún son más quienes acceden a la web de la biblioteca desde un iPad $(77,4 \%)$ que desde cualquier otro sistema operativo. Sin embargo, se observa una tendencia similar a la de los smartphones, con el repunte de Android, que gana terreno al iPad, aunque aún representa un 21,2\% de las visitas. En lo que a tabletas se refiere la diversidad es escasa y solo a partir del segundo semestre de 2012-2013 se producen visitas desde BlackBerry $(0,1 \%)$ y más tarde, en el último semestre de 2013-2014, desde Windows (1,2\%).

La mayor parte de quienes accedieron a la web de la Biblioteca de la Universidad de Salamanca desde una tableta, un smartphone o un teléfono móvil lo hicieron desde una pantalla táctil $(89,9 \%)$. Este porcentaje ha ido en aumento durante los tres cursos en que se dispone de datos. Existe un grupo de sesiones para las cuales no ha sido identificado el método de entrada de datos y que supone el 9,7\% en el curso 2013-2014 (gráfico 82). El porcentaje restante lo compone un grupo heterogéneo de dispositivos cuyo sistema de entrada de datos son el trackpad 
$(0,2 \%$ en el último curso) y el joystick ( $0,1 \%)$, que es típico de los videojuegos entre los sistemas operativos analizados en este mismo apartado se encontraban dos que funcionan en videoconsolas, Nintendo 3DS y Playstation Vita-. Además, se han registrado algunas visitas desde dispositivos con TrackBall y stylus, que por separado no alcanzan el 0,1\%, y con clickwheel, que en el primer semestre del curso 2011-2012 supusieron el 3,4\% de las visitas y ha ido descendiendo hasta un total de 3 visitas en el último semestre analizado.

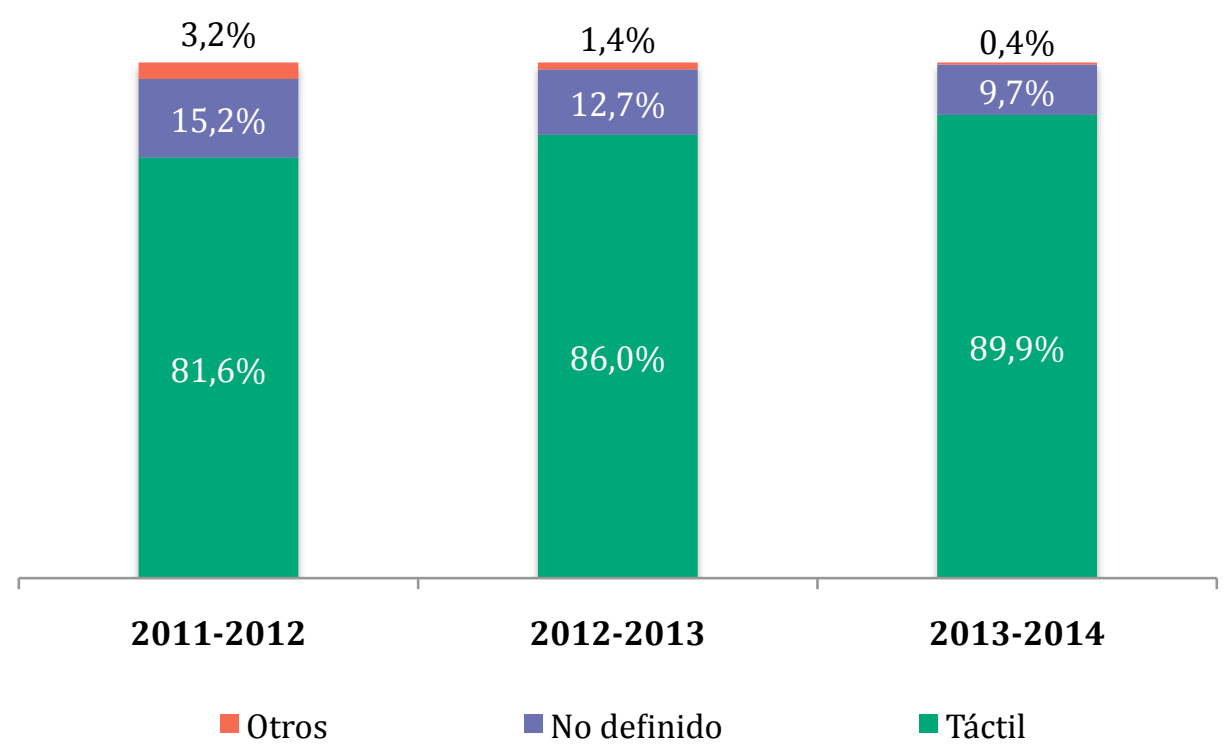

Gráfico 82. Sesiones desde dispositivos móviles por sistema de entrada de datos y curso.

\subsubsection{Contenidos más demandados}

Los contenidos que más se consultan desde dispositivos móviles no son los mismos que se demandan desde el ordenador. La estructura de la página principal en el sitio web de la Biblioteca de la Universidad de Salamanca, que divide los contenidos en grandes grupos - bibliotecas, recursos, servicios y formación- y la organización jerárquica del sitio permiten identificar mejor los principales intereses. Sin embargo, no permite obtener resultados muy detallados por esa misma razón: las páginas de navegación, que representan a los grandes grupos de contenidos, serán siempre más visitadas por ser lugar de paso obligado.

A efectos de este trabajo se establecen además varios apartados de contenidos y servicios que permitirán establecer comparaciones con los sitios web de otras bibliotecas: páginas de navegación —como la página principal o los menús-, 
información sobre las bibliotecas - horarios, datos de contacto y localización y servicios que prestan-, servicios de búsqueda e investigación —catálogo y bases de datos son los fundamentales- y acceso a la cuenta de usuario, donde se accede a información sobre los documentos prestados y se permiten realizar gestiones como reservas o la renovación del préstamo.

La página más visitada por los usuarios que acceden al sitio desde un ordenador es la página principal $(37,1 \%$ del total de páginas vistas), con una gran diferencia sobre otras. Le siguen el apartado de recursos $(5,1 \%$ de las visitas), bases de datos $(4,6 \%)$, información de la biblioteca $(3,8 \%)$ y el acceso al registro de usuario $(2,8 \%)$.

Páginas más vistas desde el móvil

\begin{tabular}{lr}
\hline Horarios & $20,8 \%$ \\
\hline Página principal & $13,2 \%$ \\
\hline La biblioteca & $5,5 \%$ \\
\hline Noticia sobre horarios & $5,0 \%$ \\
\hline Horarios & $4,5 \%$ \\
\hline Bibliotecas & $4,0 \%$ \\
\hline Mi biblioteca (cuenta de usuario) & $3,1 \%$ \\
\hline Buscar & $3,1 \%$ \\
\hline Catálogo & $2,6 \%$ \\
\hline Horario Sta. Ma. de los Ángeles & $1,8 \%$ \\
\hline Total de páginas vistas & 78.950 \\
\hline
\end{tabular}

Páginas más vistas desde tabletas

\begin{tabular}{lr}
\hline Página principal & $17,5 \%$ \\
\hline Horarios & $5,6 \%$ \\
\hline Recursos & $4,5 \%$ \\
\hline Búsqueda & $4,2 \%$ \\
\hline Catálogo & $4,1 \%$ \\
\hline La biblioteca & $4,1 \%$ \\
\hline Directorio bibliotecas & $3,1 \%$ \\
\hline Bases de datos & $2,8 \%$ \\
\hline Mi biblioteca (cuenta de usuario) & $2,1 \%$ \\
\hline Servicios & $2,0 \%$ \\
\hline Total de páginas vistas & 37.057 \\
\hline
\end{tabular}

Tabla 32. Páginas más vistas por los usuarios desde smartphones y tabletas durante el curso 2013-2014. Datos basados en el 59,1\% de las sesiones.

Sin embargo, cuando se accede desde un smartphone o desde un teléfono móvil las páginas más visitadas durante el último curso, 2013-2014, son las que contienen información sobre los horarios, que acumulan casi un tercio de las visitas entre cuatro de ellas $(32,1 \%)$. En total son cuatro las páginas de horarios en la lista de las diez más vistas, señal indiscutible del interés por esta información. Entre las páginas más visitadas se encuentra una noticia con el horario de una biblioteca en concreto, Santa María de los Ángeles (1,8\%), que en horarios de exámenes amplía el margen de apertura. Una de las páginas del sitio con información sobre horarios es incluso más visitada que la páginas principal (tabla 32). Eso significa que para algunos es la página de entrada al sitio web. 
Estas páginas con los horarios también tienen un porcentaje de rebote muy alto, lo que lleva a pensar que en algunos casos los usuarios acceden exclusivamente para consultar el horario en el sitio y se van. Otras páginas que interesan a los usuarios de smartphones son las dos que contienen información sobre las bibliotecas $(9,5 \%)$, la cuenta de usuario $(3,1 \%)$ y el catálogo $(2,6 \%)$.

Teniendo en cuenta que varias de las páginas más vistas están enlazadas desde la home page, surge la siguiente pregunta: ¿cómo influye la organización del menú principal en las visitas? Aunque es muy posible que guarde una cierta relación, y más cuando algunas son páginas de navegación también —Buscar, Bibliotecas y Recursos son a su vez menús que dirigen a los contenidos-, parece que los intereses temáticos no se ven afectados por esta cuestión.

Un claro ejemplo de ello es la información sobre los horarios de apertura de las bibliotecas, que es indiscutiblemente la más consultada. Bien es cierto que una de las páginas de horarios está enlazada en el lugar más visible, en la cabecera, y se encuentra en todas las páginas del sitio. Sin embargo, no es la única página de horarios entre las más visitadas, lo que lleva a pensar que se trata de un interés real. También la opción Mi biblioteca está enlazada al final de la home page y sin embargo tiene más visitas que las páginas sobre Recursos y Servicios, más visibles.

Páginas más visitadas desde ordenadores

\begin{tabular}{lr}
\hline Página principal & $37,1 \%$ \\
\hline Recursos & $5,1 \%$ \\
\hline Bases de datos & $4,6 \%$ \\
\hline La biblioteca & $3,8 \%$ \\
\hline Mi biblioteca (cuenta de usuario) & $2,8 \%$ \\
\hline Servicios & $2,6 \%$ \\
\hline Directorio bibliotecas & $2,2 \%$ \\
\hline Horarios & $1,9 \%$ \\
\hline Acceso remoto & $1,4 \%$ \\
\hline Revistas electrónicas & $1,3 \%$ \\
\hline Total de páginas vistas & 1.103 .200 \\
\hline
\end{tabular}

Tabla 33. Páginas más vistas por los usuarios desde ordenadores durante el curso 20132014. Datos basados en el 59,1\% de las sesiones.

Aunque el diseño para tabletas es el mismo que en la versión móvil, los accesos desde este tipo de dispositivos reflejan diferentes intereses (tabla 32). Aunque también los horarios son uno de los contenidos más visitados (5,6\% de las páginas 
vistas), no lo son de forma tan rotunda como en los smartphones. Desde las tabletas la página más consultada es la página principal $(17,5 \%)$. A diferencia de los smartphones, las páginas de Recursos, Directorio de bibliotecas, las bases de datos y los Servicios entran entre las diez páginas más vistas. El acceso a los datos de usuario sigue siendo importante. Todo parece indicar, por lo tanto, que en las tabletas cobran mayor importancia los servicios relacionados con la investigación (Catálogo y Bases de datos).

Estos datos están en consonancia con los estudios realizados por diferentes autores, en los que los usuarios identifican el acceso al catálogo y a bases de datos, la cuenta de usuario y los horarios como los contenidos y servicios que más les interesaría consultar desde dispositivos móviles (ver apartado 2.2.2.1). Y se acercan especialmente a los resultados de Mills (2009) y Rempel y Bridges (2013) en otras bibliotecas universitarias (Cambridge University y la Open University el primer trabajo, Oregon State University en el segundo), donde los horarios ocupan la primera posición entre los usuarios de smartphones. La búsqueda en el catálogo y en bases de datos, las más demandadas en este tipo de estudios por los usuarios, quedan sin embargo algo más alejadas en el ranking de las páginas más visitadas desde smartphones, pero cobran mayor protagonismo desde tabletas.

Se exponen a continuación las direcciones de las páginas que aparecen en las tablas de las más vistas.

Páginas más vistas desde el smartphone:

1. Horarios de apertura generales de las bibliotecas. http://bibliotecas.usal.es/?q=horarios

2. Página principal del sitio. http://bibliotecas.usal.es

3. La biblioteca. Página intermedia que da acceso a diferentes secciones sobre las bibliotecas: horarios y localización, directorio de bibliotecas, carta de servicios y ¿Quiénes somos? http://bibliotecas.usal.es/?q=labiblioteca

4. Noticia sobre horarios. Noticia publicada el 13 de diciembre de 2013 que informaba sobre los horarios extraordinarios de las bibliotecas durante las vacaciones de Navidad. http://bibliotecas.usal.es/?q=noticia/horarios-debibliotecas-diciembre-2013-enero-y-febrero-2014

5. Horarios de apertura generales de las Bibliotecas. Esta página tiene los mismos contenidos que la que aparece en segunda posición, la única diferencia es que ésta es la que se enlaza desde el botón de esquina superior derecha que aparece en la página principal.

http://bibliotecas.usal.es/horarios 
6. Bibliotecas. Listado de las bibliotecas de la Universidad que da acceso a la página de cada biblioteca y a información sobre sus horarios, localización e información general. http://bibliotecas.usal.es/?q=bibliotecas

7. Mi biblioteca. A través de esta página se accede a los datos personales del usuario e información sobre los préstamos. http://bibliotecas.usal.es/?q=mi-biblioteca

8. Buscar. Listado con las herramientas de búsqueda de las bibliotecas y que da acceso al catálogo, repositorio, bases de datos y revistas electrónicas, libros electrónicos y otros. http://bibliotecas.usal.es/?q=buscadores$\underline{\text { mobile }}$

9. Catálogo. Formulario de búsqueda en el catálogo. http://bibliotecas.usal.es/?q=brumarioform-mobile

10. Horario de la biblioteca Santa María de los Ángeles. Es la página en la que se explican los horarios de esta biblioteca en concreto.

http://bibliotecas.usal.es/?q=node/1087/horario localizacion

Páginas más vistas desde tabletas:

1. Página principal. http://bibliotecas.usal.es

2. Horarios de apertura generales de las bibliotecas. http://bibliotecas.usal.es/?q=horarios

3. Recursos. Página intermedia con un listado de los recursos electrónicos de las bibliotecas y que da acceso a cada uno de ellos. http://bibliotecas.usal.es/?q=recursos

4. Buscar. Listado con las herramientas de búsqueda de las bibliotecas y que da acceso al catálogo, repositorio, bases de datos y revistas electrónicas, libros electrónicos y otros. http://bibliotecas.usal.es/?q=buscadoresmobile

5. Catálogo. Formulario de búsqueda en el catálogo. http://bibliotecas.usal.es/?q=brumarioform-mobile

6. La biblioteca. Página intermedia que da acceso a diferentes secciones sobre las bibliotecas: horarios y localización, directorio de bibliotecas, carta de servicios y ¿Quiénes somos? http://bibliotecas.usal.es/?q=labiblioteca

7. Directorio de bibliotecas. Listado de las bibliotecas de la Universidad que da acceso a la página de cada biblioteca y a información sobre sus horarios, localización e información general. http://bibliotecas.usal.es/?q=bibliotecas

8. Bases de datos. Listado de las bases de datos a las que da acceso la biblioteca. http://bibliotecas.usal.es/?q=basesdatosform 
9. Mi biblioteca. A través de esta página se accede a los datos personales del usuario e información sobre los préstamos. http://bibliotecas.usal.es/?q=mi-biblioteca

10. Servicios. Página intermedia con un listado de los servicios que proporcionan las bibliotecas y que da acceso a cada uno de ellos. http://bibliotecas.usal.es/?q=mi-biblioteca

Páginas más vistas desde el ordenador:

1. Página principal del sitio. http://bibliotecas.usal.es

2. Recursos. Página intermedia con un listado de los recursos electrónicos de las bibliotecas y que da acceso a cada uno de ellos. http://bibliotecas.usal.es/?q=recursos

3. Bases de datos http://bibliotecas.usal.es/?q=basesdatosform

4. La biblioteca. Página intermedia que da acceso a diferentes secciones sobre las bibliotecas: horarios y localización, directorio de bibliotecas, carta de servicios y ¿Quiénes somos? http://bibliotecas.usal.es/?q=labiblioteca

5. Mi biblioteca. A través de esta página se accede a los datos personales del usuario e información sobre los préstamos. http://bibliotecas.usal.es/?q=mi-biblioteca

6. Servicios. Página intermedia con un listado de los servicios que proporcionan las bibliotecas y que da acceso a cada uno de ellos. http://bibliotecas.usal.es/?q=servicios

7. Directorio de bibliotecas. Listado de las bibliotecas de la Universidad que da acceso a la página de cada biblioteca y a información sobre sus horarios, localización e información general. http://bibliotecas.usal.es/?q=bibliotecas

8. Horarios de apertura generales de las bibliotecas. http://bibliotecas.usal.es/?q=horarios

9. Acceso remoto. Información sobre cómo acceder a los recursos de la biblioteca desde fuera de la universidad. http://bibliotecas.usal.es/?q=acceso-remoto

10. Revistas electrónicas. Listado de revistas electrónicas a las que da acceso la biblioteca. http://bibliotecas.usal.es/?q=revistasform 


\subsection{El catálogo}

Se puede acceder al catálogo de la Biblioteca de la Universidad de Salamanca de dos formas: a través del software WebPAC PRO, de Innovative Interfaces, y de WorldCat. Se analizan en este apartado los datos de uso de ambos catálogos desde dispositivos móviles.

\section{CTATOGO}
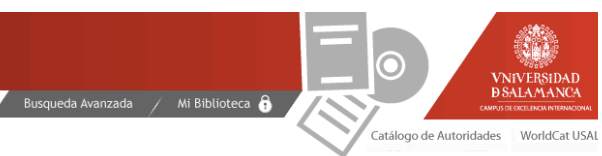

Palabra Clave Q BUSCAR

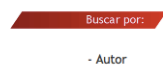
- Autor

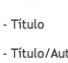

- Titulo/Autor - Nateria en Españo - Materia en Inglés

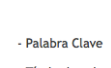

- Palabra Clave

- Título de colección
- Publicaciones periódicas

- Publicaciones
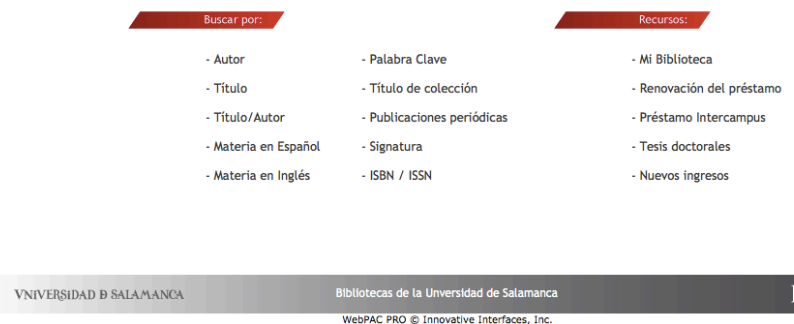
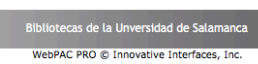

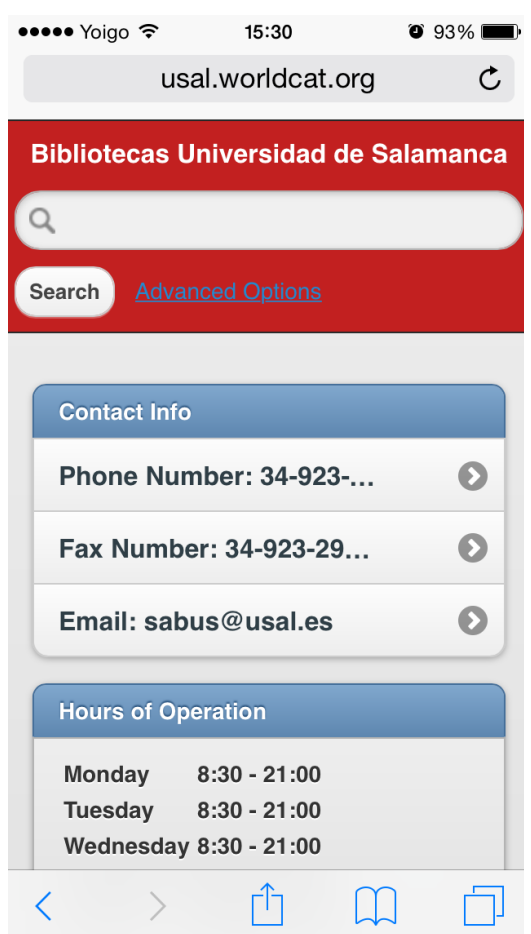

Figura 27. Catálogos de la Biblioteca de la Universidad de Salamanca: WebPAC PRO (izquierda) y la versión móvil de WorldCat (derecha).

El primero de estos catálogos, que funciona con WebPAC PRO ${ }^{120}$, no dispone de versión móvil. Como ya se ha explicado, en la versión móvil de la web se incluye una interfaz de búsqueda adaptada, pero los resultados se ven en versión para pantallas grandes. El índice de uso desde dispositivos móviles es menor que en el caso del sitio web (6,7\% en el curso 2013-2014). Esto podría deberse a que no está adaptado, pero no existen pruebas suficientes para asegurarlo.

Como sucedía con los sitios web, el comportamiento desde dispositivos móviles es diferente al de los usuarios que acceden al catálogo desde un ordenador: las sesiones son más cortas, de un minuto y 24 segundos desde el móvil y de 1 minuto

120 http://brumario.usal.es 
y 25 segundos desde la tableta en el último curso, mientras que la duración media desde el ordenador es dos minutos 33 segundos.

\begin{tabular}{lrrrrrr} 
& \multicolumn{2}{c}{$\mathbf{2 0 1 1 - 2 0 1 2}$} & \multicolumn{2}{c}{$\mathbf{2 0 1 2 - 2 0 1 3}$} & \multicolumn{2}{c}{$\mathbf{2 0 1 3 - 2 0 1 4}$} \\
\hline & \multicolumn{1}{c}{ Sesiones } & \multicolumn{1}{c}{ \% } & Sesiones & \multicolumn{1}{c}{$\%$} & Sesiones & \% \\
\hline Ordenador & 61.410 & $98,2 \%$ & 112.490 & $96,1 \%$ & 101.741 & $93,3 \%$ \\
\hline Móvil & 889 & $1,4 \%$ & 3.198 & $2,7 \%$ & 5.235 & $4,8 \%$ \\
\hline Tableta & 216 & $0,3 \%$ & 1.319 & $1,1 \%$ & 2.030 & $1,9 \%$ \\
\hline Total & 62.515 & & 117.007 & & 109.006 & \\
\hline
\end{tabular}

Tabla 34. Número de sesiones al catálogo por tipo de dispositivo y curso.

\begin{tabular}{lrrr} 
& \multicolumn{1}{c}{ 2011-2012 } & 2012-2013 & 2013-2014 \\
\hline Ordenador & $0: 02: 01$ & $0: 02: 38$ & $0: 02: 33$ \\
\hline Móvil & $0: 00: 59$ & $0: 01: 36$ & $0: 01: 24$ \\
\hline Tableta & $0: 00: 54$ & $0: 01: 58$ & $0: 01: 25$ \\
\hline Total & $0: 02: 00$ & $0: 02: 36$ & $0: 02: 29$ \\
\hline
\end{tabular}

Tabla 35. Duración media de cada sesión por tipo de dispositivo y curso.

\begin{tabular}{lrrr} 
& $\mathbf{2 0 1 1 - 2 0 1 2}$ & $\mathbf{2 0 1 2 - 2 0 1 3}$ & $\mathbf{2 0 1 3 - 2 0 1 4}$ \\
\hline Ordenador & 1,35 & 1,57 & 1,55 \\
\hline Móvil & 1,19 & 1,35 & 1,36 \\
\hline Tableta & 1,23 & 1,49 & 1,39 \\
\hline Total & 1,34 & 1,56 & 1,53 \\
\hline
\end{tabular}

Tabla 36. Número de páginas por sesión por tipo de dispositivo y curso.

El número de páginas vistas por cada sesión es también significativamente menor en el caso de móviles $(1,36)$ y tabletas $(1,39)$ que en ordenadores $(1,55)$. El porcentaje de rebote es también mayor cuando se accede desde un móvil $(76,7 \%)$ o una tableta $(77,6 \%)$. En el caso del catálogo se observa un porcentaje de rebote mucho mayor que en el sitio web.

A finales de abril de 2011 el Consorcio de Bibliotecas Universitarias de Castilla y León (BUCLE), del que forma parte la Biblioteca de la Universidad de Salamanca, implementó Worldcat Local como catálogo colectivo ${ }^{121}$. A este catálogo se accede

121 http://www.oclc.org/es-americalatina/news/releases/2011/201122.html 
desde la dirección usal.worldcat.org y tiene una versión móvil, usal.worldcat.org/m.

\begin{tabular}{lrrr} 
& $\mathbf{2 0 1 1} \mathbf{- 2 0 1 2}$ & $\mathbf{2 0 1 2}-\mathbf{2 0 1 3}$ & $\mathbf{2 0 1 3 - 2 0 1 4}$ \\
\hline Ordenador & $71,7 \%$ & $78,8 \%$ & $72,6 \%$ \\
\hline Móvil & $77,1 \%$ & $85,7 \%$ & $76,7 \%$ \\
\hline Tableta & $72,3 \%$ & $85,7 \%$ & $77,6 \%$ \\
\hline Total & $71,9 \%$ & $79,0 \%$ & $72,9 \%$ \\
\hline
\end{tabular}

Tabla 37. Porcentaje de rebote por tipo de dispositivo y curso.

Al analizar este conjunto de datos hay que tener en cuenta que la herramienta utilizada para extraer lo datos de este segundo catálogo no es Google Analytics, como en las anteriores, sino Omniture, de Adobe Systems. Por lo tanto, las métricas utilizadas variarán en función de la disponibilidad de datos. Los datos anteriores a noviembre de 2013 eran recogidos por un software anterior, SiteCatalyst, y Omniture advierte de que su fiabilidad puede ser menor. Por eso solo se analizan en este capítulo las visitas entre el 1 de septiembre de 2013 y el 31 de agosto de 2014.

Durante ese período se registraron en el catálogo WorldCat 20.586 visitas, de las cuales el 97,2\% se realizó desde un ordenador portátil o de sobremesa y el 2,8\% restante desde un dispositivo móvil (tabla 39). A diferencia del catálogo WebPAC PRO, fueron más las visitas desde tabletas $(1,8 \%$ del total) que desde smartphones $(1,0 \%)$. El sistema operativo móvil desde el que más visitas se registraron fue iOS (1,6\% del total), seguido de Android (1,1\%) y Windows (0,1\%). Estos últimos datos se deben al mayor número de visitas desde tabletas, mientras que en las visitas desde smartphones son más quienes acceden desde Android (tabla 38).

\begin{tabular}{lrrrr} 
& \multicolumn{2}{c}{ Smartphone } & \multicolumn{2}{c}{ Tableta } \\
\hline & Visitas & \multicolumn{1}{c}{$\%$} & Visitas & \multicolumn{1}{c}{$\%$} \\
\hline iOS & 39 & $19,1 \%$ & 236 & $63,1 \%$ \\
\hline Android & 139 & $68,1 \%$ & 47 & $12,6 \%$ \\
\hline Windows & 7 & $3,4 \%$ & 16 & $4,3 \%$ \\
\hline RIM & 1 & $0,5 \%$ & & \\
Total & 204 & & 374 & \\
\hline
\end{tabular}

Tabla 38. Visitas al catálogo WorldCat desde dispositivos móviles, curso 2013-2014. 
El número de visitas recibidas por el catálogo WorldCat es una quinta parte de las registradas en WebPAC PRO. Sin embargo, el número de páginas por visita es bastante mayor, con una media de 7,46.

\begin{tabular}{lrrr} 
& \multicolumn{1}{c}{ Visitas } & Páginas vistas & Páginas / visita \\
\hline Ordenador & 20.007 & 149.291 & 7,46 \\
\hline Móvil & 204 & 574 & 2,81 \\
\hline Tableta & 374 & 2.346 & 6,27 \\
\hline Total & 20.586 & 152.250 & 7,40 \\
\hline
\end{tabular}

Tabla 39. Páginas por visita al catálogo WorldCat desde dispositivos móviles, curso 20132014.

Como se puede apreciar en la tabla 40, no es posible comparar el tiempo medio de cada visita en ambos catálogos, puesto que los datos se presentan de formas diferentes. Por otra parte, parece que esta herramienta de analíticas no proporciona el tiempo de duración de todas las visitas, sino que queda un porcentaje sin datos. Así, para hacer posible la comparación entre los diferentes tipos de dispositivo, se han calculado los porcentajes de visitas en cada intervalo en relación a las visitas de las que se dispone de datos.

\begin{tabular}{lrrrrrrr} 
& \multicolumn{2}{c}{ Ordenador } & \multicolumn{2}{c}{ Smartphone } & \multicolumn{2}{c}{ Tableta } \\
\hline & Visitas & \multicolumn{1}{c}{$\%$} & Visitas & \% & Visitas & \multicolumn{1}{c}{$\%$} \\
\hline Menos de 1 min. & 4.124 & $28,9 \%$ & 31 & $35,2 \%$ & 48 & $28,1 \%$ \\
\hline De 1 a 5 min. & 4.591 & $32,2 \%$ & 40 & $45,5 \%$ & 70 & $40,9 \%$ \\
\hline De 5 a 10 min. & 1.770 & $12,4 \%$ & 6 & $6,8 \%$ & 17 & $9,9 \%$ \\
\hline De 10 a 30 min. & 2.648 & $18,5 \%$ & 10 & $11,4 \%$ & 26 & $15,2 \%$ \\
\hline De 30 a 60 min. & 855 & $6,0 \%$ & 1 & $1,1 \%$ & 7 & $4,1 \%$ \\
\hline De 1 a 2 horas & 258 & $1,8 \%$ & 0 & $0,0 \%$ & 3 & $1,8 \%$ \\
\hline De 2 a 5 horas & 30 & $0,2 \%$ & 0 & $0,0 \%$ & 0 & $0,0 \%$ \\
\hline n válido & 14.276 & & 88 & & 171 & \\
\hline Total & 20.007 & & 204 & & 374 & \\
\hline
\end{tabular}

Tabla 40. Duración de las visitas al catálogo WorldCat por tipo de dispositivo, 2013-2014.

Los intervalos con la duración de cada visita que proporciona Omniture también dejan ver que las visitas a WorldCat desde el ordenador son más largas que desde la tableta y el smartphone. El 80,7\% de las visitas desde el smartphone tienen una 
duración inferior a los cinco minutos, mientras que en las tabletas se sitúan en ese intervalo el 69,0\% y en ordenadores el 61,0\%. En los dispositivos con pantallas más pequeñas solo se registra una visita de más de treinta minutos de duración, pero sí se dan en tabletas $(5,8 \%)$ y ordenadores $(8,0 \%)$.

En definitiva, se puede concluir que el catálogo WorldCat es menos visitado que la versión WebPAC PRO, quizás debido a que este último está situado en lugar preferente en la web de la biblioteca, tanto en la versión de escritorio como en la versión móvil. En la app BiblioUSAL la interfaz de búsqueda también funciona en el catálogo de Innovative Interfaces. Resulta paradójico que, aunque WorldCat sí tiene una versión adaptada para dispositivos móviles, el número de visitas desde tabletas y smartphones es sensiblemente menor que al catálogo WebPAC PRO. Sin embargo, el uso que se hace de este catálogo es mucho más intensivo.

\subsection{La aplicación Biblio USAL}

\subsubsection{Descripción de Biblio USAL}

La aplicación nativa Biblio USAL para smartphones y tabletas está disponible en la App Store desde el 10 de noviembre de 2011 y en Android Market a partir del 9 de diciembre de 2011. En enero de 2013 se actualizó a la versión 2.0 (Merlo-Vega, 2012) con la incorporación de varias novedades. Esta app ha sido desarrollada por una empresa externa contratada por la Biblioteca de la Universidad de Salamanca, Obture Code.

Esta aplicación reproduce los contenidos del sitio web de la biblioteca. Su menú inicial, que se carga tras una cortinilla con el logotipo de la universidad, incluye las mismas opciones que la versión móvil del sitio web: bibliotecas, servicios, catalogo y noticias. Sin embargo, a diferencia de la web, no incluye los botones de acceso rápido hacia los horarios y la búsqueda, ni tampoco los que aparecían al final de la página.

Los elementos de navegación consisten en el ya mencionado menú de la página inicial y en una barra horizontal en la parte inferior, que funciona como sistema constante e incorpora las mismas opciones del menú inicial, además de una quinta, Mi biblioteca. Además se incluyen botones para volver y regresar a la página principal. 
El acceso desde el sitio web de la biblioteca, en su versión para grandes pantallas, se anuncia claramente y de forma visible en la página principal. No así en la versión móvil, donde no se ha encontrado en el menú inicial.

Una de las diferencias con respecto al sitio web está en la profundidad de la estructura del sitio, que en la aplicación es menor: cuando se accede a la opción de bibliotecas se llega directamente al listado con las bibliotecas, mientras que en la versión móvil de la web la navegación se fragmentaba en diversos sub-apartados -Horarios y Localización, Bibliotecas, Carta de servicios y ¿Quiénes somos?-, y se volvía a dividir una vez más para llegar a la información de cada biblioteca.

Biblio USAL ocupa 7,0 MB de espacio en la versión para dispositivos de Apple y 6,2 en la versión para Android. Esto la sitúa prácticamente en la media del resto de las aplicaciones para iOS analizadas (6,9 MB), pero por encima de la media en Android (3,2 MB). En el momento del análisis solo había recibido 10 valoraciones y una puntuación de 4,5 sobre 5 .
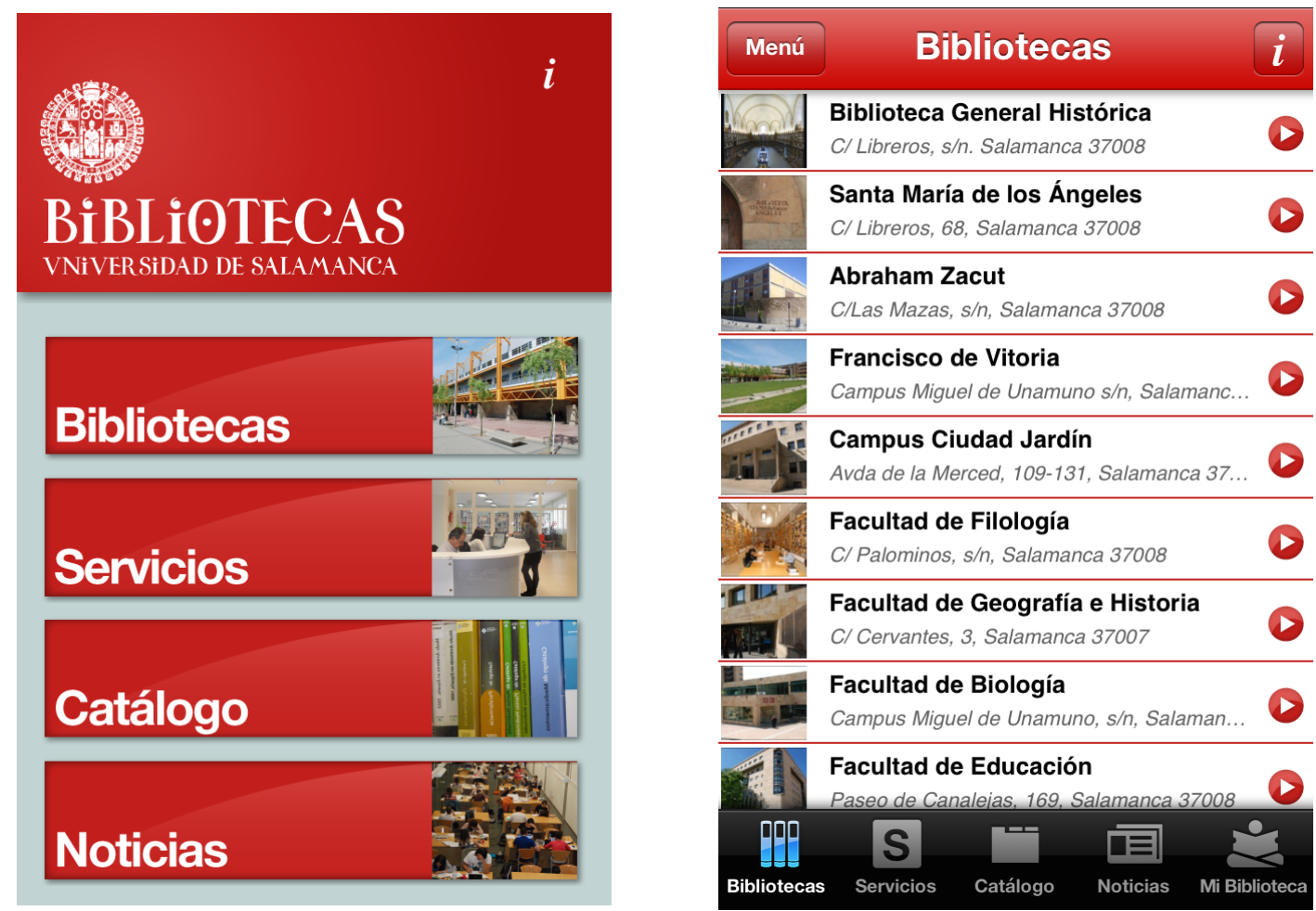

Figura 28. BiblioUSAL, la aplicación de la Biblioteca de la Universidad de Salamanca.

Los contenidos son únicamente textos e imágenes, pues no se han encontrado vídeos, ficheros de audio o documentos. En lo referente al aprovechamiento de las funciones del dispositivo, esta aplicación destaca, como ya se ha comentado, por el 
uso de la cámara de fotos para el escaneado del código de barras del carné para acceder a la zona de usuarios. Además, aprovecha los enlaces a números de teléfono y correos electrónicos y los mapas de Google, incrustados, para marcar la ubicación de las bibliotecas.

Biblio USAL incorpora los siguientes contenidos y funciones: datos de contacto y localización, directorio de bibliotecas, horarios de apertura, servicios que la biblioteca presta, noticias y eventos y acceso al catálogo. Este último, el catálogo, permite la posibilidad de refinar las búsquedas y cada registro contiene información básica, la posibilidad de ser guardado en el espacio personalizado y exportarlo a Mendeley y Zotero y enviarlo por correo electrónico. Sin embargo, aunque incluye un enlace para comprobar la disponibilidad del registro, se dirige a una página web no adaptada cuya consulta se ve dificultada desde una pantalla pequeña.

En la versión 2.0 se incorporan varias novedades, según se explica en su sitio web $^{122}$ :

- Creación de un área privada que se conecta con el Registro de usuario / Mi Biblioteca para facilitar las renovaciones y reservas de documentos.

- Acceso al área privada utilizando la cámara para escanear el código de barras del Carné Universitario.

- Almacenamiento de referencias de ejemplares para futuras consultas (bloc de notas).

- Exportación directa a gestores de referencias (Mendeley y Zotero) y en formato RIS (correo electrónico).

- Envío de noticias a servicio de lectura diferida (Pocket e Instapaper).

- Indicador de noticias leídas y no leídas.

- Integración con redes sociales (Twitter y Facebook) para compartir noticias desde la aplicación.

- Envío de noticias a correos electrónicos.

- Otras mejoras de usabilidad en el módulo de noticias.

\subsubsection{Datos de uso}

Para analizar el uso de la app Biblio USAL se ha contado con los datos procedentes de las tiendas de aplicaciones y Google Analytics. Como se trata de una app híbrida, sus contenidos están alojados en páginas web y se pueden utilizar las mismas

122 Fuente: http://bibliotecas.usal.es/aplicaciones-moviles-0 
herramientas de métricas que se emplean en los sitios web. Una de las limitaciones que se han encontrado es que solo se recogen los datos procedentes de sistemas operativos iOS, aunque también existe una versión para sistemas operativos Android. Por lo tanto hay que tener en cuenta que los datos disponibles son parciales y solo representan a un porcentaje del total.

\subsubsection{Descargas}

Desgraciadamente, cada tienda de aplicaciones ofrece datos completamente diferentes sobre una misma $a p p$, lo que hace que sea difícil tener una visión completa sobre ella.

La aplicación Biblio USAL ha sido descargada 4.653 veces desde la tienda de aplicaciones de Apple desde que fue creada, en 2011, hasta febrero de 2015. A ellas hay que sumar otras 4.069 descargas desde la tienda para Android, Google Play, lo que en total hace 8.843 descargas. A diferencia de Apple, Google no proporciona datos mensuales del número de descargas, sino la suma total acumulada.

Sin embargo, Google proporciona datos sobre el número de descargas activas, pero sí se sabe que el 23,1\% de las aplicaciones descargadas en dispositivos Android sigue en activo, es decir, se mantenía instalada en febrero de 2015.

\begin{tabular}{lr}
\multicolumn{2}{c}{ Descargas App Store } \\
\hline \multicolumn{1}{c}{ Período } & \multicolumn{1}{c}{ Descargas } \\
\hline $2011-2012$ & 1.480 \\
\hline $2012-2013$ & 1.500 \\
\hline $2013-2014$ & 877 \\
\hline Total & 3.857 \\
\hline
\end{tabular}

\begin{tabular}{lr}
\multicolumn{2}{c}{ Instalaciones activas en Android } \\
\hline \multicolumn{1}{c}{ Período } & \multicolumn{1}{c}{ Instalaciones } \\
\hline $2011-2012$ & 284 \\
\hline $2012-2013$ & 637 \\
\hline $2013-2014$ & 845 \\
\hline Total & 1.766 \\
\hline
\end{tabular}

Tabla 41. Número de descargas de la aplicación Biblio USAL desde la tienda de aplicaciones de Apple (App Store) e instalaciones activas en dispositivos Android.

\subsubsection{Acceso a Biblio USAL}

Aunque son menos quienes consultan BiblioUSAL que quienes acceden a la versión web, hacen un uso considerablemente más intensivo de ella. Esta es la principal conclusión que se extrae al analizar los datos de uso. En el último curso, 20132014, se registraron 5.424 sesiones en Biblio USAL, un 1,4\% más que el curso anterior. En el sitio web se registraron ese mismo curso 8.348 sesiones solo desde dispositivos iOS. Mientras que el uso de la app se mantiene estable, con escaso 
crecimiento con respecto al anterior curso, las visitas a la web desde dispositivos móviles con sistema operativo iOS aumentaron en un $28,4 \%$ en el mismo período.

\begin{tabular}{lcccccc} 
& \multicolumn{2}{c}{$\mathbf{2 0 1 1 - 2 0 1 2}$} & \multicolumn{2}{c}{$\mathbf{2 0 1 2 - 2 0 1 3}$} & \multicolumn{2}{c}{$\mathbf{2 0 1 3 - 2 0 1 4}$} \\
\hline Sesiones & $\mathbf{0}$ & Sesiones & \% & Sesiones & \% \\
\hline Móvil & 2.845 & $75,4 \%$ & 3.953 & $73,9 \%$ & 4.056 & $74,8 \%$ \\
\hline Tableta & 927 & $24,6 \%$ & 1.397 & $26,1 \%$ & 1.368 & $25,2 \%$ \\
\hline Total & 3.772 & & 5.350 & \multicolumn{3}{c}{5.424} \\
\hline
\end{tabular}

Tabla 42. Número de sesiones en BiblioUSAL por tipo de dispositivo y curso.

La duración media por sesión es considerablemente más alta que en la página web: en el último curso fue de 4 minutos 17 segundos desde el móvil y de 10 minutos 33 segundos desde una tableta. Al observar la evolución desde la creación de la aplicación se aprecia que la duración media de cada visita ha ido descendiendo ligeramente cada año y en el caso de los smartphones se ha reducido a la mitad, pasando de casi diez minutos a más de cuatro. En el curso 2013-2014 la duración media de cada sesión en el sitio web desde smartphones iOS fue de 56 segundos y desde tabletas de 3 minutos 32 segundos (tabla 43).

\begin{tabular}{lrrr} 
& $\mathbf{2 0 1 1 - 2 0 1 2}$ & $\mathbf{2 0 1 2 - 2 0 1 3}$ & $\mathbf{2 0 1 3 - 2 0 1 4}$ \\
\hline Móvil & $0: 11: 39$ & $0: 09: 51$ & $0: 04: 17$ \\
\hline Tableta & $0: 12: 28$ & $0: 11: 02$ & $0: 10: 33$ \\
\hline Total & $0: 11: 51$ & $0: 10: 09$ & $0: 05: 52$ \\
\hline
\end{tabular}

Tabla 43. Duración media de las sesiones en BiblioUSAL por tipo de dispositivo y curso.

\begin{tabular}{lrrr} 
& $\mathbf{2 0 1 1 - 2 0 1 2}$ & $\mathbf{2 0 1 2 - 2 0 1 3}$ & $\mathbf{2 0 1 3 - 2 0 1 4}$ \\
\hline Móvil & 8,1 & 7,5 & 7,3 \\
\hline Tableta & 9,3 & 8,5 & 10,0 \\
\hline Total & 8,4 & 7,8 & 8,0 \\
\hline
\end{tabular}

Tabla 44. Número de páginas por sesión en BiblioUSAL, por tipo de dispositivo y curso.

También es bastante mayor el número de páginas vistas por cada sesión, con una media de 8,0 en smartphones y tabletas. En estas últimas es algo mayor, de 10,0 (tabla 44). En cada sesión registrada en el sitio web se vieron una media de 2,14 páginas desde smartphones con sistemas operativos iOS y 3,44 páginas desde iPad 
en el curso 2013-2014. La media para todos los sistemas operativos fue de 2,43 en smartphones y de 3,16 en tabletas.

\begin{tabular}{lrrr} 
& 2011-2012 & $\mathbf{2 0 1 2 - 2 0 1 3}$ & $\mathbf{2 0 1 3 - 2 0 1 4}$ \\
\hline Móvil & $0,39 \%$ & $0,30 \%$ & $1,58 \%$ \\
\hline Tableta & $0,32 \%$ & $0,07 \%$ & $1,46 \%$ \\
\hline Total & $0,37 \%$ & $0,24 \%$ & $1,55 \%$ \\
\hline
\end{tabular}

Tabla 45. Porcentaje de rebote en la app BiblioUSAL, por tipo de dispositivo y curso.

El porcentaje de rebote al consultar la app es escaso, de 1,58\% en smartphones y $1,46 \%$ en tabletas en el último curso. Se ha incrementado en los últimos dos cursos, pues partía del 0,37\% de media en el curso 2011-2012. En smartphones con sistema operativo iOS que visitan el sitio web el porcentaje de rebote alcanza el $57,9 \%$ y en tabletas el $45,1 \%$.

\subsubsection{Contenidos más demandados}

El contenido de Biblio USAL que más se consulta desde smartphones iOS es la información sobre las bibliotecas (22,7\% de las páginas vistas). Posiblemente para consultar los horarios de apertura, aunque es imposible decirlo a ciencia cierta porque las páginas de cada biblioteca contienen también información de contacto y localización. En la lista de las diez páginas más visitadas aparecen también tres bibliotecas. Otros contenidos muy visitados son la página principal $(14,3 \%)$ el catálogo $(11,7 \%)$, los servicios (7,3\%), noticias (5,5\%) y la opción Mi biblioteca $(3,0 \%)$, que permite al usuario guardar registros del catálogo. La mayor parte de estos contenidos coincide con las opciones más accesibles en el menú de navegación de la app.

En los accesos a la app desde tabletas el catálogo es lo más demandado (21,2\% de las páginas vistas). Le siguen la información sobre las bibliotecas $(14,8 \%)$, página principal $(9,6 \%)$, servicios $(6,4 \%)$, noticias $(3,1 \%)$ y Mi biblioteca $(2,8 \%)$. No se aprecian grandes diferencias con respecto a las visitas desde smartphones, salvo en la prioridad por el catálogo.

Tampoco se observan grandes diferencias al comparar el listado de las diez páginas más vistas desde la app con el resultante de las sesiones al sitio web desde smartphones y tabletas (tabla 32). En ambos se demandan sobre todo información sobre los horarios y las bibliotecas, así como el acceso al catálogo. Las diferencias 
entre la app y el sitio web no están por lo tanto en los contenidos, sino más bien en la intensidad del uso, mucho mayor desde la app.

\section{Páginas más vistas desde el móvil}

\begin{tabular}{lr}
\hline Bibliotecas & $22,7 \%$ \\
\hline Página principal & $14,3 \%$ \\
\hline Catálogo & $11,7 \%$ \\
\hline Servicios & $7,3 \%$ \\
\hline Noticias & $5,5 \%$ \\
\hline Mi biblioteca & $3,0 \%$ \\
\hline Biblioteca Sta. María de los Ángeles & $2,3 \%$ \\
\hline Biblioteca Francisco de Vitoria & $2,3 \%$ \\
\hline Información & $2,0 \%$ \\
\hline Biblioteca Abraham Zacut & $1,6 \%$ \\
\hline Total de páginas vistas & 29.755 \\
\hline
\end{tabular}

Páginas más vistas desde tabletas

\begin{tabular}{lr}
\hline Catálogo & $21,2 \%$ \\
\hline Bibliotecas & $14,8 \%$ \\
\hline Página principal & $9,6 \%$ \\
\hline Servicios & $6,4 \%$ \\
\hline Noticias & $3,1 \%$ \\
\hline Mi biblioteca & $2,8 \%$ \\
\hline Biblioteca Francisco de Vitoria & $1,5 \%$ \\
\hline Biblioteca General Histórica & $1,2 \%$ \\
\hline Recursos electrónicos & $1,0 \%$ \\
\hline Información sobre cuenta de usuario & $0,8 \%$ \\
\hline Total de páginas vistas & 13.740 \\
\hline
\end{tabular}

Tabla 46. Páginas de BiblioUSAL más vistas desde smartphones y tabletas durante el curso 2013-2014. 


\section{Capítulo 8. Recomendaciones para bibliotecas}

El análisis de los sitios web para dispositivos móviles y aplicaciones nativas ha permitido identificar una serie de pautas a tener en cuenta durante el proceso de creación. Se presenta en este capítulo un listado de recomendaciones de carácter básico con la intención de que puedan servir a las bibliotecas de forma práctica y a un nivel muy general a la hora de crear la versión móvil de un sitio web o una aplicación. 



\subsection{Pautas para sitios web y aplicaciones nativas}

Durante la elaboración del listado de variables y parámetros para el análisis de sitios web y aplicaciones nativas han surgido algunas pautas a tener en cuenta a la hora de crear una versión móvil de un sitio web o una aplicación nativa. Estas pautas han sido recopiladas a partir de la bibliografía existente, por lo que no son un resultado original de esta tesis doctoral. Se han querido reunir como un recurso de utilidad práctica que pueda servir a las bibliotecas que están pensando en crear un sitio web para móviles o una aplicación nativa y también para aquellas que ya lo han hecho.

La intención de estas pautas es meramente práctica. Por eso se ha querido elaborar un listado escueto que resulte fácil de utilizar en la práctica y cuyos puntos se puedan repasar rápidamente. No se ha creído necesario redundar en la explicación del porqué de cada punto, puesto que han sido explicados en los capítulos anteriores.

También se ha querido que estas recomendaciones sean asequibles para cualquier profesional de las bibliotecas. Por ello se ha puesto el acento en los resultados finales del sitio y no en el cómo, evitando cuestiones demasiado técnicas. De ahí también que el listado pueda servir tanto para sitios web como para aplicaciones nativas, a pesar de sus diferencias.

El resultado es un listado muy general y sencillo, centrado en el resultado y que pueda ser utilizado en la práctica. Desde luego, todas estas pautas pueden resultar obvias, pero los resultados de este trabajo de investigación han demostrado que no siempre se cumplen.

\section{Facilitar el acceso}

Ayuda a los usuarios a llegar a la versión móvil del sitio web o a la aplicación.

- Utiliza un sistema de detección de dispositivo en los sitios web para dispositivos móviles.

- Coloca un enlace visible a la versión móvil o a la aplicación desde la versión para grandes pantallas.

- Define un URL corto para la versión móvil de tu sitio web siempre que sea posible. 


\section{Facilitar el acceso a los contenidos}

El objetivo es encontrar lo que se busca de la manera más rápida posible.

- Define una estructura clara y sencilla para el sitio web o aplicación.

- Escoge nombres que identifiquen claramente las opciones de los menús, para que el usuario sepa lo que encontrará detrás de cada opción.

- Incluye un enlace a la versión para grandes pantallas.

\section{Contenidos y funciones}

Facilita la lectura de los contenidos desde pantallas pequeñas.

- Elimina todos los contenidos y funciones superficiales e innecesarios.

- Presenta los contenidos de forma concreta y directa.

- Utiliza las métricas web para conocer qué contenidos interesan más.

\section{Tener en cuenta las características del dispositivo}

Los smartphones tienen características que les distinguen de otros dispositivos. No deben olvidarse, pues tenerlas en cuenta mejorará la experiencia de uso.

- Deja espacio suficiente alrededor de los elementos seleccionables para que se puedan pulsar con la yema del dedo.

- Evita los enlaces a páginas o documentos no adaptados para dispositivos móviles.

\section{Aprovechar las capacidades del dispositivo}

Piensa en las capacidades que tienen los dispositivos móviles y aprovéchalas para facilitar las tareas al usuario.

- Enlaza los números de teléfono y correos electrónicos siempre que incluyas alguno.

- Utiliza mapas incrustados para mostrar la ubicación exacta de la biblioteca y que los usuarios puedan trazar la ruta para llegar a ella.

- Mejora la utilidad de tu aplicación nativa con las funciones únicas que permiten los dispositivos móviles. 


Parte IV. Conclusiones 



\section{Capítulo 9. Conclusiones}

Se exponen en este capítulo las conclusiones del trabajo de investigación realizado en el marco de esta tesis doctoral. Se dividen en seis apartados, cuatro de los cuales se corresponden con los diferentes apartados de la investigación: sitios web de bibliotecas para dispositivos móviles, aplicaciones nativas, catálogos móviles y el caso de la Biblioteca de la Universidad de Salamanca. Los dos apartados restantes contienen conclusiones específicas sobre las bibliotecas españolas y conclusiones generales. 



\subsection{Sitios web para dispositivos móviles}

1. La prioridad de las bibliotecas con respecto a la web móvil hasta el momento está en adaptar su sitio web, incluido el catálogo, para ser consultado desde un smartphone. De los sitios web analizados, el 94,3\% es una adaptación del sitio web de la biblioteca o del catálogo y solo el 5,6\% restante cumple otras funciones. Algunas bibliotecas pioneras están innovando con otros desarrollos que muestran las posibilidades que los dispositivos móviles permiten y avanzan un panorama más diverso.

2. Los desarrollos para dispositivos móviles están muy ligados a los creados para grandes pantallas. Solo se ha identificado un sitio web nativo para móviles, WolfWalk, que no tiene una versión para ordenadores portátiles o de sobremesa.

3. El smartphone es el dispositivo móvil preferido por las bibliotecas para adaptar sus sitios web. El 88,3\% de los sitios web de la muestra están diseñados exclusivamente para smartphones. Se mantienen algunos sitios web para teléfonos móviles, que parecen destinados a desaparecer, ya que desde el año 2010 no se han creado otros nuevos. Las bibliotecas consideran a las tabletas un dispositivo secundario respecto a la web móvil. La mayor parte de los sitios web para tabletas son diseños adaptativos que sirven también para smartphones y ordenadores. Las bibliotecas rara vez diseñan sitios web específicos para tabletas: solo se han encontrado dos casos. Otros dispositivos apenas son tenidos en cuenta.

4. El diseño adaptativo ha emergido de manera significativa a partir de 2012 como una solución para adaptar el diseño de los sitios web de las bibliotecas, especialmente en Estados Unidos, pero también en otros países. En 2012 y 2013 el 43,3\% de los sitios web de la muestra creados optaron por él. El diseño adaptativo podría acabar sustituyendo a las anteriores versiones para móviles: se han detectado sitios web en el conjunto de la muestra que han sido sustituidos por este tipo de diseño. En España solo se ha encontrado un sitio web con diseño web adaptativo, posterior a la fecha de recogida de los datos, pero es de esperar que acabe extendiéndose próximamente.

5. Mejorar la visibilidad y el acceso a la versión para móviles constituye un reto pendiente para una gran parte de las bibliotecas. El acceso a la versión móvil constituye una tarea sin resolver para un grupo importante de los sitios web con páginas diferenciadas para dispositivos móviles. Casi 
una tercera parte de ellos (29,3\%) no aparecen enlazados desde la versión para grandes pantallas ni se emplean sistemas de detección de dispositivo, lo que dificulta su acceso. En España el porcentaje es muy similar $(28,6 \%)$. Por otra parte, en un tercio de los sitios web en los que se enlaza a la versión móvil $(33,8 \%)$, este enlace no se sitúa de forma lo suficientemente visible como para ser encontrado fácilmente desde una pantalla pequeña; en España la proporción aún es mayor, del 40,0\%.

6. La longitud de los URL de acceso a los sitios web para smartphones y teléfonos móviles es un aspecto que se descuida con frecuencia. En casi una tercera parte de los casos (28,5\%) la excesiva longitud constituía un elemento disuasorio para acceder a la versión para móviles tecleando el URL. Solo un 14,0\% de los analizados tenía menos de 15 caracteres.

7. Muy pocas bibliotecas están empleando metadatos descriptivos en la versión móvil del sitio web. La mayor parte de los sitios analizados no los emplean $(76,4 \%)$. Entre aquellos que los utilizan, la mayoría ha optado por etiquetas <meta> en html y son muy pocos los que utilizan otros como Open Graph o Dublin Core. En España el uso de metadatos es más habitual que en el conjunto de la muestra, se ha detectado el 42,9\% de los casos. En este país son las bibliotecas universitarias quienes incluyen metadatos más elaborados en sus sitios web para dispositivos móviles.

8. Cada vez son más los sitios web diseñados para dispositivos móviles que emplean Google Analytics para obtener métricas de su sitio web. Esto significa que se dispone de información sobre el uso que los usuarios están haciendo de estos sitios. Este porcentaje es mayor en Estados Unidos, donde alcanza casi las tres cuartas partes $(74,8 \%)$, pero se reduce a la mitad en España (52,0\%) y en otros países (55,0\%). Se observa un mayor uso de herramientas de analíticas en los sitios con diseño adaptativo (el $83,3 \%$ de ellos utilizan Google Analytics) que entre los sitios web con páginas diferenciadas para dispositivos móviles $(63,7 \%)$, lo que podría significar que se realiza el esfuerzo en la versión de escritorio pero se olvida en la versión para móviles.

9. Se ha producido un cambio de tendencia en los diseños de los sitios web para dispositivos móviles que representan al sitio web de la biblioteca en los últimos años. Si hace unos años era el diseño basado en el menú vertical el más habitual, en 2012-2013 el diseño de módulos gana importancia debido al diseño adaptativo. En España el diseño más habitual es el menú vertical $(57,1 \%)$, seguido de la retícula de iconos $(23,8 \%)$. El diseño de módulos se da en el 14,3\% de los sitios analizados, menos de la media del conjunto de la muestra $(20,6 \%)$ debido a que no hay casos de diseño web adaptativo. 
10. Determinados tipos de diseño parecen asociados a un tipo de sistema de adaptación. En los sitios web con páginas diferenciadas es más habitual el menú vertical (en casi las tres cuartas partes de los sitios analizados) y en forma de retícula de iconos (15,3\%), mientras que en los sitios web con diseño adaptativo el diseño de módulos es el más empleado (85,7\%).

11. La página principal o home page es el elemento de navegación más habitual en los sitios web con páginas diferenciadas para dispositivos móviles. Está presente en el $88,3 \%$ de todos los casos analizados. Se complementa a menudo con botones para volver a la página anterior o a la página principal. Al ser sitios con poca profundidad, este esquema que lleva una y otra vez a la página principal resulta efectivo. En los sitios con diseño adaptativo los elementos de navegación tienden a ser contextuales. Este tipo de diseño se asocia también a elementos como los menús en forma de listado en la parte inferior de la página y los menús desplegables.

12. Más de la quinta parte de los sitios web analizados no emplea ninguna función específica del dispositivo, como recomiendan los especialistas. Teniendo en cuenta la introducción del diseño web adaptativo, cada vez son más las bibliotecas que no aprovechan ninguna función del dispositivo: han pasado del 5,0\% en 2009 al 45,0\% en 2013. En España es mayor la proporción de bibliotecas que no aprovechan ninguna de las funciones descritas (32,0\%), a pesar de que el diseño web adaptativo no ha aparecido, por lo que puede interpretarse más bien como una falta de adaptación al medio.

13. Un alto porcentaje de bibliotecas desaprovecha de forma manifiesta las capacidades de los dispositivos móviles para facilitar determinadas tareas a los usuarios. Una tercera parte de los sitios web no enlaza los números de teléfono, a pesar de que sí se incluye ese dato (33,2\%). Esto es algo habitual en sitios web con diseño web adaptativo, pero también se da en el $28,0 \%$ de los sitios con páginas específicas para smartphones, lo que demuestra que se desconocen las posibilidades de los dispositivos móviles. En España, se han encontrado números de teléfono sin enlazar en más de una tercera parte de los sitios analizados (36,0\%).

14. El aprovechamiento de las funciones de los dispositivos móviles es muy elemental en la mayor parte de los sitios web para móviles de las bibliotecas. La función que más se aprovecha en los sitios web son los enlaces para enviar un correo electrónico, probablemente porque también se emplea en los sitios web para grandes pantallas. Los enlaces en números de teléfono para realizar llamadas son la siguiente función más empleada, en la mitad de la muestra, pero en España apenas alcanza una tercera parte $(32,0 \%)$. En nuestro país la función más habitual es también 
el enlace al correo electrónico $(60,0 \%)$. Solo en casos muy puntuales se han observado enlaces para enviar SMS, uso de la agenda y del calendario. El uso de la geolocalización no está muy extendido en los sitios web para móviles de las bibliotecas, pero es una de las funciones que más innovación podrían generar en los próximos años. Hasta el momento se ha utilizado sobre todo para mostrar las bibliotecas más cercanas a la situación del usuario.

15. Los contenidos y servicios más habituales en los sitios web para dispositivos móviles que representan al sitio web de la biblioteca son el horario de apertura y los datos de contacto, presentes en nueve de cada diez sitios. También cobran gran importancia el catálogo y el servicio de referencia, ambos en las dos terceras partes. Más de la mitad de los sitios web incluye además datos de localización, cuenta de usuario, situación de las bibliotecas en el mapa y acceso a bases de datos. Se han identificado 35 contenidos y servicios en los sitios web para dispositivos móviles de las bibliotecas.

16. En los sitios web para móviles de las bibliotecas españolas los contenidos más frecuentes son los datos de contacto $(88,9 \%)$ y localización $(77,8 \%)$, los horarios de apertura $(72,2 \%)$, enlaces de interés $(66,7 \%)$ y el OPAC $(66,7 \%)$.

17. Existen importantes diferencias en los contenidos y servicios de los sitios web para dispositivos móviles que representan a la web de la biblioteca en función del tipo de biblioteca. En las bibliotecas públicas es más frecuente encontrar información sobre eventos (95,5\%), préstamo electrónico $(59,1 \%)$, listados de novedades $(40,9 \%)$, recomendaciones de lecturas $(27,3 \%)$ y recomendaciones de aplicaciones $(27,3 \%)$. Servicios más propios de las bibliotecas universitarias son bases de datos $(60,7 \%)$, enlaces de interés $(52,7 \%)$, herramienta de descubrimiento $(48,2 \%)$, LibGuides $(39,3 \%)$ y revistas electrónicas $(24,1 \%)$.

18. No todos los contenidos que se enlazan desde el sitio web para móviles están integrados en él, en ocasiones se trata de servicios en sedes web diferentes. Los servicios que se presentan en páginas fuera del sitio web suelen ser aquellos para los que se contratan servicios de empresas externas: herramientas de descubrimiento y catálogo, cuenta de usuario, bases de datos, préstamo de libros electrónicos, revistas electrónicas, guías de investigación. También la localización de las bibliotecas en el mapa y las noticias se presentan a menudo en páginas externas.

19. Casi una tercera parte de los sitios web para smartphones analizados $(30,2 \%)$ desoyen las recomendaciones de reducir la extensión de los contenidos. Esto es habitual en los sitios web que utilizan como métodos 
de adaptación hojas de estilo y diseño web adaptativo, incluso en los que adoptan la filosofía Mobile first, y mucho menos, aunque también se da en algunos casos, en los sitios web con páginas diferenciadas para la versión móvil.

20. Apenas se emplean otros formatos diferentes de texto y las imágenes en los sitios web para dispositivos móviles. Vídeo, sonido o documentos son más habituales en sitios web con páginas diferenciadas.

21. A pesar de estar pensado para grandes pantallas y para imprimir, el pdf es el formato de los documentos que se encuentran en los sitios web de las bibliotecas, y que representan el 16,8\%. Sin embargo, no se ha encontrado ningún sitio web para móviles que enlace sus documentos en formato ePub, a pesar de que se adapta a cualquier pantalla.

22. Existe una estrecha relación entre la presencia en los medios sociales y disponer de un sitio web para móviles en las bibliotecas, que probablemente, venga determinada por un especial interés hacia la tecnología. El 96,4\% de las bibliotecas con sitios web para móviles analizados tienen presencia propia en los medios sociales. En las bibliotecas universitarias españolas la relación es aún mayor, pues todas aquellas con sitios web para móviles analizados tenían perfiles en los medios sociales, mientras que, según los datos publicados por Margaix (2013), el 68,0\% de estas bibliotecas estaba presente en los medios sociales en 2013.

\subsection{Aplicaciones nativas}

23. Las bibliotecas están utilizando las aplicaciones nativas principalmente como una opción para adaptar los contenidos y servicios de sus sitios web a los usuarios de dispositivos móviles. La mayor parte de las aplicaciones existentes reproducen los contenidos y servicios del sitio web, incluido el catálogo. La segunda utilidad más importante que se está dando a las apps desde las bibliotecas consiste en sacar a la luz sus fondos patrimoniales con una intención divulgativa. Un buen número de bibliotecas ha escogido las aplicaciones nativas como única forma de adaptar los contenidos de su sitio web y el catálogo para la consulta desde dispositivos móviles, sin habilitar una versión web. En la muestra de sitios web para móviles analizados se han encontrado solo siete bibliotecas que tienen tanto 
versión móvil de su sitio web como app, lo que significa que las bibliotecas están escogiendo una u otra opción. En España, la app es el único medio de acceso a los contenidos de la web adaptados para el móvil en cuatro de cada ocho bibliotecas cuyas apps tienen la función de representar al sitio web de la biblioteca.

24. A diferencia de lo que sucedía con los sitios web, donde las tabletas ocupaban un lugar secundario, en las aplicaciones nativas juegan un papel más importante, pero casi siempre acompañando a los smartphones. La mayor parte de las aplicaciones son diseñadas para smartphones y tabletas $(45,2 \%)$ o exclusivamente para smartphones $(41,1 \%)$. Tan solo un $13,7 \%$ han sido diseñadas solo para tabletas y suelen tener utilidad patrimonial.

25. Más de la mitad de las aplicaciones de bibliotecas analizadas funcionan indistintamente en dispositivos con sistemas operativos iOS y Android $(52,1 \%)$. Además se ha detectado un 9,6\% que solo funciona en Android - todas ellas de bibliotecas españolas y latinoamericanas-y un 38,4\% que solo funciona en dispositivos de Apple. En España el 64,3\% de las aplicaciones están diseñadas para ambos sistemas operativos.

26. Algo más de cuatro de cada diez aplicaciones de bibliotecas creadas en años anteriores a $2012(43,8 \%)$ no han sido actualizadas nunca o tan solo lo han hecho en los meses posteriores a la fecha de lanzamiento, para depurar algún error. Visto desde el otro punto de vista, la mayor parte de las apps creadas en esos años (56,3\%) han sido actualizadas alguna vez.

27. De forma general, y salvo algunas excepciones, las aplicaciones de bibliotecas no parecen estar atrayendo el interés de los usuarios, a juzgar por los datos de descargas que proporciona la tienda de aplicaciones de Android. Más de las tres cuartas partes de las aplicaciones analizadas han sido descargadas entre 100 y 5.000 veces. Sólo unas pocas excepcionalmente consiguen un número superior de descargas: una ha sido descargada entre 5.000 y 10.000 veces y tres entre 10.000 y 50.000 . Otras siete no han llegado a las 100 descargas, a pesar de no ser de reciente creación. El análisis de las descargas de las apps de bibliotecas españolas revela un bajo índice de éxito en comparación con el número de usuarios: en las bibliotecas públicas, entre el $0,02 \%$ y el $1,2 \%$ de los usuarios han descargado alguna vez la app de su biblioteca y entre las universitarias oscila entre el $0,0 \%$ y el 22,0\%. Si el número de descargas es tan bajo, más aún lo será el porcentaje de las que se mantienen instaladas.

28. El bajo índice de descargas que alcanzan las apps de bibliotecas podría deberse en parte a un bajo esfuerzo en su difusión y promoción. Casi una tercera parte de las apps analizadas no se enlazaban desde el sitio web de la biblioteca. De aquellas apps que sí están enlazadas, más de la mitad 
$(57,1 \%)$ no lo están desde la página principal, sino desde una página intermedia en la que se habla de la app - lo que obliga a hacer dos clics al lector para descargarla - o desde otra página del sitio web. De las apps que representan al sitio web de la biblioteca, casi la mitad (48,0\%) no están enlazadas desde la versión para grandes pantallas del sitio web. En España es menor el porcentaje de aplicaciones que están enlazadas desde el sitio web de la biblioteca, el 57,1\%.

29. Las bibliotecas que tienen tanto versión móvil de la web como app están perdiendo la oportunidad de dirigir desde la primera a la segunda y de dar así a conocer la aplicación a un grupo de usuarios que podría estar especialmente interesado en ella. Solo dos de las siete bibliotecas que disponen de ambas versiones lo hacen. En España son cuatro las bibliotecas que tienen tanto versión móvil de su sitio web como aplicación y ninguna de ellas enlaza desde la página principal de la versión móvil a la aplicación.

30. Las apps de bibliotecas son bien valoradas en las tiendas de aplicaciones. La valoración media que reciben las aplicaciones supera el aprobado: la media es de 4,02 sobre 5 en la tienda de Apple y de 4,18 en Google Play.

31. No hay consenso sobre en qué categoría se deben incluir las aplicaciones móviles que representan al sitio web de la biblioteca. Educación y Libros y referencia son las más comunes, pero también se han encontrado otras en las categorías Libraries \& demo, Estilo de vida y Catálogos.

32. Aunque algunas aplicaciones presentan las mismas plantillas de diseño que la versión móvil de sus sitios web, cobra especial interés uno nuevo: el menú horizontal inferior de navegación constante combinado con los contenidos de cada opción en la parte central. El empleo de una página principal como menú se reduce a la mitad de la muestra. Las opción para volver a la página anterior cobra especial importancia puesto que, a diferencia del navegador, las aplicaciones no incorporan ninguna opción de este tipo por defecto. En las aplicaciones con otras utilidades aparecen además otros diseños originales.

33. Seis de cada diez apps analizadas no incluye audio, vídeo o documentos. No obstante, esto depende sobre todo de la utilidad de la aplicación. Las aplicaciones con utilidad patrimonial suelen utilizar más habitualmente los formatos de vídeo, audio y documentos - dos terceras partes utiliza alguno de ellos-, mientras que las apps que reproducen los contenidos del sitio web y el catálogo de la biblioteca los utilizan con menor frecuencia (el 24,0\% y el 11,1\% respectivamente). Los documentos, que suelen estar en formato pdf, se encuentran en una posición intermedia $(16,4 \%)$. 
34. Las aplicaciones nativas hacen un mayor uso de las funciones de los dispositivos móviles que los sitios web para móviles y aparecen funciones únicas. El 80,8\% de las aplicaciones nativas en bibliotecas utilizan alguna de las funciones del dispositivo analizadas. La funcionalidad más aprovechada es la localización, que utiliza el 34,2\% de las apps y que apenas se empleaba en la versión móvil de los sitios web. El escaneado de códigos de barras, las notificaciones push, la linterna y la realidad aumentada son las funciones que se han encontrado en las apps de bibliotecas y que no se pueden dar en los sitios web para móviles.

35. Las funciones de los dispositivos móviles que más aprovechan las apps de las bibliotecas españolas son las más elementales: los enlaces a correos electrónicos y llamadas, seguidas de la geolocalización.

36. Los contenidos y servicios en las apps que reproducen los contenidos del sitio son muy similares a los sitios web móviles. Solo aparecen algunas funciones diferentes en algunos casos: compartir en medios sociales y a través de correo electrónico, guardar en favoritos y la configuración de opciones como el idioma, el tamaño de la fuente y otras opciones de visualización, y consulta del catálogo escaneando el código de barras. Las apps que reproducen los contenidos del sitio web tienden a priorizar los mismos contenidos que los sitios web para móviles: horario (92,0\% de las apps analizadas), datos de contacto (88,0\%), catálogo $(84,0 \%)$ y datos de localización (72,0\%). Horario, datos de contacto, catálogo, mapa y localización siguen siendo las más comunes.

37. En España también hay coincidencia en tres categorías de contenidos en todas las apps: horario, datos de contacto y mapa de localización. Otros contenidos que se dan muy frecuentemente en las apps de las bibliotecas españolas son los datos de localización, el catálogo, el directorio de bibliotecas, enlaces a las redes sociales, noticias y eventos.

38. En las aplicaciones nativas todos los contenidos y servicios suelen estar incluidos dentro de la propia app, sin que sea necesario salir de ella. Esto no sucedía en los sitios web, que en ocasiones presentaban algunas opciones en páginas externas a su sitio web.

39. Está surgiendo un número de aplicaciones de bibliotecas que muestran cómo la innovación es posible y que las capacidades de los dispositivos móviles pueden traer nuevas utilidades. Algunas de ellas - ShelvAR, READometer, Find the Future, SG Memory y OCLS Shake It!, por ejemplodenotan una gran originalidad en el planteamiento y son testimonio de la cantidad de posibilidades que quedan por explotar en las apps de bibliotecas. 
40. En las aplicaciones las bibliotecas se está realizando un trabajo de adaptación de los contenidos. A diferencia de los sitios web, donde el diseño adaptativo mantiene los mismos contenidos que en la versión para grandes pantallas, las aplicaciones de bibliotecas mantienen el criterio de adaptar los contenidos. En el conjunto de la muestra sólo se ha encontrado una app en la que los contenidos se han considerado extensos.

41. Las apps de las bibliotecas se ajustan en mayor medida a las características del dispositivo que los sitios web para móviles. Sólo se ha encontrado una app en la que la extensión de los contenidos se ha considerado grande y se reduce considerablemente el ratio de apps en las que se enlaza a páginas web no adaptadas. Recordemos que en los sitios web para smartphones se consideraba una práctica habitual y alcanzaba el 72,5\%, mientras que en las apps para ese tipo de dispositivos no llega a un tercio de los casos $(28,6 \%)$. En España ese ratio es mayor y alcanza la mitad.

42. De forma general, las aplicaciones de bibliotecas analizadas se adaptan mejor al entorno móvil que los sitios web de bibliotecas: hacen mayor uso de las funciones del dispositivo, mantienen en mayor medida la adaptación de contenidos, son más ricas en cuanto a formatos de contenidos y se ajustan en mayor medida a las características de los dispositivos móviles.

\subsection{Catálogos móviles}

43. El catálogo es uno de los elementos más importantes para su consulta desde el móvil por parte de las bibliotecas. Prácticamente nueve de cada diez sitios web para dispositivos móviles que representan a la biblioteca enlazan a alguna herramienta de búsqueda, ya sea el catálogo o una herramienta de descubrimiento, en su versión móvil o completa. Una tercera parte de los enlaces a los catálogos desde la versión móvil del sitio web de la biblioteca dirigen a la versión para grandes pantallas. 43,1\% de los sitios analizados enlaza a una versión móvil del catálogo y el 35,4\% a la versión móvil de la herramienta de descubrimiento. En España el 31,8\% de los sitios enlaza al catálogo móvil y en Estados Unidos son el 45,9\%.

44. La mayor parte de las bibliotecas analizadas han preferido crear su propia interfaz para al catálogo, a pesar de ser la opción más compleja. Se dan tres opciones para movilizar el catálogo: desarrollos propios, software 
asociado al del catálogo y software de terceros. Una tercera parte opta por el software comercial. El coste adicional y las opciones de personalización son los mayores problemas de este tipo de software. En España, tres bibliotecas han optado por desarrollos propios y dos por el uso de módulos adicionales (en otras tres). También se ha encontrado un caso de uso de software de terceros, Library Anywhere, en la Universidad Pompeu Fabra.

45. Cuatro de cada diez sitios web para móviles enlazan a alguna herramienta de descubrimiento en versión móvil (43,3\%). La mayor parte de las herramientas de descubrimiento detectadas tienen adaptada su interfaz a los smartphones $(84,2 \%)$. La solución adoptada más habitualmente es el software comercial, en el $90,6 \%$ de los casos. Primo y Summon son las herramientas de descubrimiento más habituales en los sitios web para móviles, juntas suponen el $65,6 \%$. WorldCat Local y VuFind son otras opciones.

46. Los catálogos móviles se caracterizan por su sencillez. Siete de cada diez incluye solo la información básica de cada registro, mientras que el resto muestra una gran cantidad de datos sobre cada uno de ellos. La mayor parte incluye funciones básicas y muy pocos facilitan opciones adicionales.

47. Conocer la localización y disponibilidad del documento parece ser el principal objetivo de los catálogos móviles, ya que esta información es la más común en ellos. Las opciones adicionales son poco frecuentes en los catálogos. Las opciones de participación son poco habituales, solo se han encontrado tres casos $(5,8 \%)$ en que es posible compartir los registros en los medios sociales y uno que permite comentarlos y valorarlos en una escala de cinco estrellas (1,9\%). Más frecuente es que se puedan compartir por correo electrónico o SMS (30,8\%) y algunos incluso permiten enviar los registros en determinados formatos de referencias bibliográficas $(3,8 \%)$. Esta última función es una de las debería potenciarse, dado el actual escenario multidispositivo en el que se manejan los internautas.

48. Se observan algunas diferencias entre los desarrollos propios y los productos comerciales. El software comercial muestra una apariencia más sencilla al usuario: se centra en la búsqueda sencilla, sin limitadores, la cuenta de usuario y la posibilidad de guardar los registros. Por otra parte, este tipo de software suele proporcionar opciones más sofisticadas que los desarrollos propios, como la cuenta de usuario o guardar registros.

49. Los catálogos en aplicaciones nativas son muy similares a los que se presentan en sitios web para móviles: los datos de localización y disponibilidad del documento son los más habituales, se mantiene la tendencia a simplificar opciones e información y en los registros se 
proporcionan solo los datos básicos. Las interfaces de búsqueda son aún más sencillas, solo en uno de cada cuatro casos se incluyen limitadores y la búsqueda avanzada es anecdótica. Las aplicaciones tampoco suelen hacer uso de opciones de participación.

50. Los catálogos en aplicaciones nativas muestran un mayor grado de aprovechamiento de las funciones del dispositivo que los que se presentan en páginas web. Algunas funciones que están aprovechando son el escaneado del código de barras para consultar el catálogo, que se ha encontrado en más de un tercio de los catálogos analizados, la geolocalización y los espacios personalizados.

\subsection{Las bibliotecas españolas}

51. A pesar de que España es uno de los países con mayor penetración de dispositivos móviles, las bibliotecas españolas se encuentran en un estadio inicial en cuanto a las iniciativas de movilidad. Los sitios web para móviles y las aplicaciones nativas aún se dan apenas en unas pocas bibliotecas y redes y hasta el momento resultan anecdóticos. La adaptación de los contenidos para dispositivos móviles se está produciendo de una manera más lenta que en Estados Unidos y con cierto retraso.

52. En España, las redes de bibliotecas públicas son las que están asumiendo la creación de apps para todos los puntos de servicio de la red y ya cubren al 13,3\% de las unidades administrativas en todo el estado español. Sin embargo, no está sucediendo lo mismo con la adaptación de los sitios web de las bibliotecas, que queda de la mano de cada biblioteca. Algunas bibliotecas a título individual han generado sus propias apps, produciendo situaciones de solapamiento con la app de su red.

53. Se ha encontrado un significativo grupo de bibliotecas en España que crean sus propios sitios web para móviles y aplicaciones, sin acudir a ninguna empresa especializada, lo que demuestra una tendencia al DIY (Do It Yourself, hazlo tú mismo). De los 25 sitios analizados, al menos 10 han sido creados por la propia biblioteca. En cuanto a las aplicaciones nativas, son al menos tres de las 14 analizadas, y podría ser alguna más. En España el uso de CMS es evidente en nueve de los 25 sitios web para móviles analizados: Joomla!, Drupal, WordPress, Google Sites, Ubik y Wirenode han sido las soluciones escogidas por las bibliotecas españolas 
para crear sus sitios web. El que sea el personal de la biblioteca la encargada de los desarrollos móviles conlleva un importante ahorro económico, pero en ocasiones se corre el riesgo de no contar con la experiencia de personal especializado y, por lo tanto, de que los resultados sean menos profesionales.

\subsection{La Biblioteca de la Universidad de Salamanca}

54. Los datos de la Biblioteca de la Universidad de Salamanca sugieren que la aplicación Biblio USAL es utilizada especialmente por los usuarios intensivos de la biblioteca, mientras que la web registra niveles mayores de uso desde dispositivos móviles. Aunque el número de visitas es mayor desde el sitio web, desde la app se visitan más páginas en cada sesión, las sesiones son más largas y el porcentaje de rebote es escaso. Los contenidos más visitados desde la app y desde el sitio web son prácticamente los mismos.

55. Cada vez son más quienes acceden al sitio web de la Biblioteca de la Universidad de Salamanca desde smartphones y tabletas y se espera que esta tendencia siga creciendo. En el curso 2013-2014 una de cada diez sesiones registradas procedió de un dispositivo móvil, ya fuera un smartphone $(7,6 \%$ del total) o una tableta $(2,7 \%)$.

56. El comportamiento de quienes acceden al sitio web de la Biblioteca de la Universidad de Salamanca es diferente en función del dispositivo desde el que acceden. Los usuarios de smartphones realizan visitas más cortas y ven menos páginas en cada sesión. Son los usuarios de tabletas quienes más páginas visitan en cada sesión, una media de 3,06, mientras que en el ordenador fueron 2,83 y desde el smartphone 2,39. Los datos del catálogo WebPAC PRO presentan un patrón similar. Estos datos confirman la idea de que los usuarios de smartphones están dispuestos a pasar menos tiempo navegando por el sitio web.

57. Los usuarios de dispositivos móviles demandan contenidos diferentes en el sitio web de la Biblioteca de la Universidad de Salamanca. Las páginas más visitadas desde smartphones durante el curso 2013-2014 fueron las que contenían información sobre los horarios, que acumulan un tercio de las visitas $(32,1 \%$ del total). Otras páginas que interesan a los usuarios de smartphones son las que contienen información sobre las bibliotecas 
(9,5\%), la cuenta de usuario (3,1\%) y el catálogo $(2,6 \%)$. Quienes accedieron desde una tableta demandaron más servicios relacionados con la investigación, como el catálogo y las bases de datos. Por lo tanto, si los contenidos que más se visitan varían, es recomendable priorizar unos $\mathrm{u}$ otros en función de cada versión.

58. Aunque la página del catálogo es una de las más consultadas desde dispositivos móviles en la web de la Biblioteca de la Universidad de Salamanca y en Biblio USAL, los catálogos reciben menos visitas desde dispositivos móviles que el sitio web de la Biblioteca, un 6,7\% del total en el caso de WebPAC PRO y el 2,8\% en WorldCat. La del catálogo es la tercera página más visitada desde el móvil en la app y la primera desde tabletas. En el sitio web el formulario de búsqueda es la novena página más consultada (2,6\% de las visitas) y desde tabletas la quinta $(4,1 \%$ de las visitas). Esta diferencia no parece deberse a una falta de interés.

59. No se han encontrado evidencias para asegurar que el disponer de una versión móvil del sitio web o del catálogo incremente las visitas. En el caso del sitio web, el lanzamiento de una versión móvil en febrero de 2013 no ha supuesto un incremento claro en el tráfico desde dispositivos móviles. En los catálogos, si bien es más intensivo el uso que se hace de WorldCat desde dispositivos móviles, es cierto que sucede lo mismo desde ordenadores.

60. Las estadísticas de acceso a la web de la Biblioteca de la Universidad de Salamanca reflejan muy bien el mercado de los dispositivos. Las dos plataformas más utilizadas son iOS y Android, tanto en tabletas como en smartphones. Entre ambos acumulan el $96,1 \%$ de las visitas desde smartphones y el $98,6 \%$ desde tabletas. Estos datos reflejan que, aunque la proporción de quienes tienen iOS en España es menor, la navegación que hacen es mayor. En el apartado de tabletas aún son más quienes acceden a la web de la biblioteca desde un iPad $(77,4 \%)$ que desde cualquier otro sistema operativo. Sin embargo, se observa una tendencia similar a la de los smartphones, con el repunte de Android, que gana terreno al iPad, aunque aún representa un $21,2 \%$ de las visitas.

\subsection{Conclusiones generales}

61. Las bibliotecas se encuentran en un estadio inicial en su relación con la tecnología móvil. En esta fase comienzan a adaptar sus sitios web para ser 
vistos desde un dispositivo móvil, bien a través de una versión para smartphones o de aplicaciones nativas. Se observan varias velocidades en cuanto a la movilidad: hay bibliotecas que aún no han adaptado su sitio web, otras que ya lo han hecho y/o han creado una aplicación nativa y, finalmente, unas pocas tienen varios desarrollos con diferentes propósitos. Además, un pequeño grupo de bibliotecas está innovando y encontrando nuevas utilidades de la tecnología móvil.

62. Las aplicaciones nativas de las bibliotecas no están obteniendo el éxito que se esperaba de ellas, a juzgar por el número de descargas. La experiencia de la Biblioteca de la Universidad de Salamanca, que muestra que estas aplicaciones son especialmente empleadas por usuarios más intensivos, lleva a plantear si merece la pena la inversión teniendo en cuenta su bajo uso. Es necesario replantear el papel y las funciones de las aplicaciones nativas en las bibliotecas y reconsiderar qué pueden aportar que no proporcione la versión para móviles del sitio web, qué motivos llevarían a un usuario a mantener e instalar la app de la biblioteca en su smartphone o tableta y a mantenerla allí. Por lo tanto, en este momento se recomienda a las bibliotecas invertir en una presencia web sólida.

63. Teniendo en cuenta que el diseño web adaptativo no cumple las recomendaciones de los expertos en cuanto a usabilidad, porque obvia la adaptación de contenidos y el aprovechamiento de las capacidades de los dispositivos móviles y sus características, se plantea la cuestión de si es la solución óptima para tener una versión para smartphones de los sitios web de las bibliotecas.

64. Mejorar la promoción de sitios web para móviles y las aplicaciones nativas es una de las asignaturas pendientes para un gran grupo de bibliotecas. Un gesto esencial consiste en enlazarlas de forma visible desde el sitio web.

65. Las bibliotecas tienen ante sí dos retos: entender el medio móvil para mejorar la experiencia de usuario y el rendimiento de sus sitios web para smartphones y tabletas y de sus aplicaciones nativas y aprovechar las capacidades de los dispositivos móviles. 




\section{Bibliografía}



Abarca Villoldo, Marta; Lloret Salom, Andrés; Pons Chaigneau, David M.; Rubio Montero, Francisco José; Vallés NAVARRo, Raquel (2012). How to mobilize your library at low cost. Liber Quarterly, vol. 22, núm. 2.

ACCART, Jean-Philippe (2014). Through the looking glass: envisioning new library technologies"Augmented reality in the (real) library world - part one. Library Hi Tech News, vol. 31, núm. 1

ACRL Research Planning and Review Committee (2014). Top trends in academic libraries. A review of the trends and issues affecting academic libraries in higher education. College \& Research Libraries News, vol. 75 núm. 6, pp. 294-302 http://crln.acrl.org/content/75/6/294.full

AGAR, Jon (2005). Constant Touch: A Global History of the Mobile Phone. Thriplow: Icon Books.

Aguillo, Isidro (2002). Web Characterization for Cybermetric Purposes:

Terminology and Definitions. En: Development of Web-Indicators, deliverable del proyecto EICSTES.

http://www.eicstes.org/EICSTES PDF/Deliverables/Development\%20of\%20Web \%20Indicators.PDF

Aharony, Noa (2013). Librarians' attitudes towards mobile services. Aslib Proceedings, vol. 65, núm. 4, pp. 358-375.

AitTola, Markus; RyhänEn, Tapio; OJAlA, Timo (2003). SmartLibrary: Locationaware mobile library service. En: Fifth International Symposium on Human Computer Interaction with Mobile Devices and Services, Udine, septiembre. http://www.mediateam.oulu.fi/publications/pdf/442.pdf

AlASDAIR, Allan (2010). Learning iPhone Programming: From Xcode to App Store. Sebastopol: O’Reilly Media. ISBN: 0596806434.

Alcock, Jo (2012). How are libraries using QR codes? En: Mobile Technologies in Libraries, 29 agosto. http://mlibraries.jiscinvolve.org/wp/2012/08/29/how-arelibraries-using-qr-codes/

AlCOCK, Jo; DALTON, Pete (2012). M-libraries on the hype cycle: where are we? En: Fourth International m-libraries Conference, Milton-Keines, 24-26 septiembre.

AlDRICH, Alan W. (2010). Universities and Libraries Move to the Mobile Web. EDUCAUSE Quarterly, vol. 10, núm. 2.

http://www.educause.edu/EDUCAUSE+Quarterly/EDUCAUSEQuarterlyMagazineV olum/UniversitiesandLibrariesMoveto/206531 
ALLY, Mohamed (2012). Education for all with mobile technology: the role of libraries. En: Ally, Mohamed; Needham, Gill (ed.). M-libraries 3. Transforming libraries with mobile technology. Londres: Facet, pp. 1-9. ISBN: 978-1-85604-776-0. Alonso ArÉvalo, Julio (2014). Aplicaciones de lectura e investigación. En: Aprender3c, 15 julio. Presentación disponible en: http://www.slideshare.net/Aprender3C/aprender3c-aplicaciones-mviles-delectura-e-investigacin-por-julio-alonso-arvalo

ANDERSON, Lisa; ANDREwS, Jonathan (2011). Portable devices - libraries trying to meet the demands of the iPhone generation. Library and Information Research, vol. 35, núm. 111, pp. 20-32.

http://www.lirgjournal.org.uk/lir/ojs/index.php/lir/article/view/455/525

APPBRAIN STATS. Consultado: 26 julio 2014. http://www.appbrain.com/stats/statsindex

ARroyo-VÁzQUEZ, Natalia (2009). Web móvil y bibliotecas. El profesional de la información, vol. 18, núm. 2, pp. 129-136.

ARRoYo-VÁZqueZ, Natalia (2010). Adaptando contenidos para la web móvil: pautas y herramientas para bibliotecas públicas. En: V Congreso Nacional de Bibliotecas Públicas, Gijón, 3-5 noviembre.

http://travesia.mcu.es/portalnb/ispui/handle/10421/4903

ARroyo-VÁzQUEZ, Natalia (2011a). Informe APEI sobre movilidad. Gijón: Asociación Profesional de Especialistas en Información (APEI). ISBN: 978-84-694-5655-2. http://www.apei.es/wp-content/uploads/2013/11/InformeAPEI-Movilidad.pdf ARroyo-VÁzQuEZ, Natalia (2011b). Información en el móvil. Barcelona: Editorial UOC. Colección El profesional de la información, 4. ISBN: 978-84-9788-496-9. ARRoYo-VÁzQUEZ, Natalia (2011c). La realidad aumentada al alcance de todos: creando capas de datos geolocalizados. Anuario ThinkEPI 2011, vol. 5, pp. 269-271. http://www.thinkepi.net/la-realidad-aumentada-al-alcance-de-todos-creandocapas-de-datos-geolocalizados

ARroyo-VÁzQUEZ, Natalia (2012a). Foursquare: tu biblioteca en el momento y en el lugar adecuados. El profesional de la información, vol. 21, núm. 3, pp. 326-328.

ARRoYo-VÁZQUEZ, Natalia (2012b). Tecnologías móviles para entornos bibliotecarios. En: XI Workshop REBIUN “Tecnología móvil y bibliotecas”. Barcelona, 23 de noviembre.

Arroyo-VÁZqueZ, Natalia (2012c). Desarrollo de aplicaciones móviles en bibliotecas. En: VI Congreso Nacional de Bibliotecas Públicas, Burgos, 9 al 11 de octubre de 2012. 
http://www.mcu.es/bibliotecas/docs/MC/2012/CongresoBP/Comunicaciones/D esarrolloaplicaciones.pdf

ARroyo-VÁZquEZ, Natalia (2012d). Omnívoros informacionales. Mi biblioteca, núm. 28, p. 16.

ARRoYo-VÁZQUEZ, Natalia (2013a). Tecnología NFC y códigos QR, su uso en la biblioteca y otras historias. En: Biblioblog, 11 junio.

http://biblioblog.org/2013/07/11/tecnologia-nfc-para-ampliar-la-informacionsobre-la-coleccion-de-la-biblioteca/

ARroyo-VÁzquEZ, Natalia (2013b). Bibliotecas móviles, contenidos móviles. En: $6^{\underline{o}}$ Congreso Nacional de Bibliotecas Móviles, Burgos, 18 al 20 de octubre. http://www.bibliobuses.com/documentos/narroyo bibliobus13.pdf

ARroyo-VÁZqueZ, Natalia (2013c). Smartphones, tabletas y bibliotecas públicas: entendiendo la nueva realidad en el consumo de información. En: XVII Jornadas Bibliotecarias de Andalucía. Jaén, 25 y 26 de octubre de 2013. http://eprints.rclis.org/20576/

Arroyo-VÁzquez, Natalia (2013d). Los códigos QR son difíciles de utilizar (bien). En: Biblioblog, 23 diciembre. http://biblioblog.org/2013/12/23/los-codigos-qrson-dificiles-de-utilizar-bien/

ARroyo-VÁzquEZ, Natalia (2013e). Estado de la \#bibliomovilidad en 2013. En:

Biblioblog, 29 mayo. http://biblioblog.org/2013/05/29/estado-de-la-

bibliomovilidad-en-2013/

ARroyo-VÁZquEZ, Natalia (2014a). Descubrimiento, selección y recomendación de aplicaciones nativas para móviles en bibliotecas. Anuario ThinkEPI, vol. 8, pp. 331333.

ARroyo-VÁzQuEZ, Natalia (2014b). Cómo llevar el carnet de la biblioteca en el móvil. Anuario ThinkEPI, vol. 9 [en imprenta].

ARroyo-VÁZquez, Natalia; PAREjA, Víctor (2003). Metodología para la obtención de datos con fines cibermétricos. En: III Taller de Indicadores Bibliométricos. Madrid, 3 al 5 marzo. http://internetlab.cindoc.csic.es/varios/Metodolog\%EDa datos ciberm\%E9tricos.pdf

AshFord, Robin; Zeigen, Laura (2012a). Mobile Technology in Libraries Survey: Public Libraries. http://www.ohsu.edu/xd/education/library/about/staffdirectory/upload/mobile survey PUBLIC final.pdf ASHFoRD, Robin; ZEIGEN, Laura (2012b). Mobile Technology in Libraries Survey: Academic Libraries. http://www.ohsu.edu/xd/education/library/about/staffdirectory/upload/mobile survey ACADEMIC final.pdf 
Augmented Reality brings campus alive! En: University of Bath, 2013, 6 junio. http://www.bath.ac.uk/learningandteaching/newsachievements/news/news 0037.html AzAvea (2011). Implementing Mobile Augmented reality Technology for Viewing Historic Images. Filadelfia: Azavea; Philadelphia Department of Records. http://www.azavea.com/index.php/download file/view/655/

Azuma, Ronald T. (1997). A Survey of Augmented Reality. Presence: Teleoperators and Virtual Environments, vol. 6, núm. 4, pp. 355-385.

http://www.ronaldazuma.com/papers/ARpresence.pdf

BaE, Kyung-Jae; Jeong, Yoon-Seok; SHIm, Woo-Sub; KwaK, Seung-Jin (2007). The Ubiquitous Library for the Blind and Physically Handicapped - a case study of the LG Sangnam Library, Korea. IFLA Journal, vol. 33, núm. 3, pp. 210-219.

BAIGET, Tomàs (1993). PDAs, la oficina bajo el brazo. Information World en español, núm. 16.

http://www.elprofesionaldelainformacion.com/contenidos/1993/julio/pdas la of icina bajo el brazo.html

BARKER, Kimberley R.; et al. (2012). The implementation of embedded quick response codes into library resources to improve service delivery. Journal of the Medical Library Association, vol. 100, núm. 1, pp. 68-71.

http://www.ncbi.nlm.nih.gov/pmc/articles/PMC3257488/

BARnes, Elizabeth; Brammer, Robert M. (2013). Bringing Augmented Reality to the Academic Law Library: Our experiences with an augmented reality app. AALL Spectrum, vol. 17, núm. 4, pp. 13. http://www.aallnet.org/mainmenu/Publications/spectrum/Archives/vol-17/No-4/augmented-reality.pdf BALAS, Janet L. (2007). Carrying the Library in Your Pocket. Computers in Libraries, vol. 27, núm. 8 , pp. 36-38.

BALlARD, Barbara (2007). Designing the Mobile User Experience. Chichester: Wiley. Ballard, Angela Fullington; Teague-Rector, Susan (2011). Building a library Web site. College \& Research Libraries News, vol. 72, núm. 3, pp. 132-135.

BARnES, Elizabeth; Brammer, Robert M. (2013). Bringing Augmented Reality to the Academic Law Library: Our experiences with an augmented reality app. AALL Spectrum, vol. 17, núm. 4, pp. 13. http://www.aallnet.org/mainmenu/Publications/spectrum/Archives/vol-17/No-4/augmented-reality.pdf Bauer, Kathleen; Friscia, Michael; Matheson, Scott (2012). From the Catalog to the Book on the Shelf: Building a Mapping Application for Vufind. Code4Lib Journal, núm. 17. http://journal.code4lib.org/articles/6924 
BECCARIA, Mike (2011). How to Provide Live Library Information via SMS Using Twilio. Code4lib Journal, núm. 14. http://journal.code4lib.org/articles/5542

BECKER, Danielle Andre; BonAdIE-JosePH, Ingrid; CAIN, Jonathan (2013). Developing and completing a library mobile technology survey to create a user-centered mobile presence. Library Hi Tech, vol. 31, núm. 4, pp. 688-699.

Benítez Juan, B., Clavero Campos, Javier; Codina Vila, Miquel; Pérez Gálvez, Andrés (2011). The Handheld Library: Developments at the Rector Gabriel Ferraté Library, UPC. Liber Quarterly, vol. 21, núm. 1, pp. 23-47.

http://upcommons.upc.edu/e-prints/bitstream/2117/14019/1/Handheld Library.pdf

BERJON, Robin, et al. (ed.) (2014) HTML5. A vocabulary and associated APIs for HTML and XHTML. World Wide Web Consortium, 28 octubre.

http://www.w3.org/html/wg/drafts/html/CR/

Besara, Rachel (2012). Apps for Assessment: A Starting Point. The Reference Librarian, vol. 53, núm. 3, pp. 304-309.

BlackBerry World. En: Wikipedia. Consultado: 26 julio 2014.

http://en.wikipedia.org/wiki/BlackBerry World

Bodenhamer, David J.; Corrigan, John; Harris, Trevor M. (ed.) (2010). The Spatial Humanities: GIS and the Future of Humanities Scholarship. Bloomington: Indiana University Press.

Bolorizadeh, Allison; Brannena, Michelle; GibBsa, Rabia; Mack, Thura (2012).

Making Instruction Mobile. The Reference Librarian, vol. 53, núm. 4.

Book Industry Communication (2014). Near Field Communication (NFC) and the use of Radio Frequency Identification (RFID) in Libraries. - Some information for librarians. En: Changing Libraries, 30 julio.

http://www.mickfortune.com//Store/NFC\%20and\%20RFID\%20\%20information\%20for\%20librarians.pdf

BoopsiE (2013). Tablet \& SmartPhone Users Search 2.4x More When They Type Less. En: Boopsie Web Site, 31 octubre. http://www.boopsie.com/smart-prefixsearch-drives-2-4x-more-searches/

Booth, Char; Brecher, Dani (2014). Ok, library. Implications and opportunities for Google Glass. ACRL TechConnect, vol. 75, núm. 5, pp. 234-239.

BoRG, Mathew (2013). Responsive web design for your library website. En: Ally, Mohamed; Needham, Gill (ed.). M-Libraries 4: From Margin To Mainstream. Londres: Facet, pp. 147-151. 
BOYER, Deborah (2011). From internet to iPhone: providing mobile geographic access to Philadelphia's historic photographs and other special collections. The Reference Librarian, vol. 52, núm. 1, pp. 47-56.

BREEDING, Marshall (2007). Next-Generation Library Catalogs. Library Technology Reports, vol. 43, núm. 4.

BREEDInG, Marshall (2009). Opening Up Systems through Web Services and SOA: Hype, or Reality? Library Technology Reports, vol. 45, núm. 8.

BREEDING, Marshall (2011). Mobile heads into the mainstream for libraries. Smart Libraries, vol. 21, núm. 10.

BreEding, Marshall (2014). Library Systems Report 2014. American Libraries, abril. http://www.americanlibrariesmagazine.org/article/library-systems-report-2014

BRIDGES, Karl (2002). Thoughts on the Future of Library Computing: Implications of the Use of Handheld Computers for Library Service. Library Philosophy and Practice, vol. 5, núm. 1. http://unllib.unl.edu/LPP/bridges.pdf

BRIDGES, Laurie M.; REMPEL, Hanna Gascho (2014). Continual Assessment Leads the Way: Best Practices in Mobile Website Design and Maintenance. En: 5th International m-Libraries Conference, Hong Kong, 27-30 mayo.

BRIDGES, Laurie M.; REMPEL, Hanna Gascho; GrigGS, Kim (2010). Making the case for a fully mobile library web site: from floor maps to the catalog. Reference Services Review, vol. 38, núm. 2, pp. 309-320.

BRINKMAN, Bo; BRINKMAN, Stacy (2013). AR in the library: A pilot study of multitarget acquisition usability. En: 2013 IEEE International Symposium on Mixed and Augmented Reality, ISMAR 2013, Adelaida, 1-4 octubre, pp. 241-242.

BRÖLl, Anna; CABRÉ, Anna; GÁNDARA, Dolors (2014). Online or onsite settings, two ways of reaching the users of Barcelona Libraries. En: IFLA Public Libraries Section 2014 Satellite Conference, Birmingham, 13 agosto.

http://www.cilip.org.uk/sites/default/files/Day\%202,\%2011.40\%20\%20Dolores\%20Gandara\%20Sanz.pdf

Broussard, Ramona; Zhou, Yongyi; Lease, Matthew (2010). Mobile phone search for library catalogs. Proceedings of the American Society for Information Science and Technology, vol. 47, núm. 1.

Brown, Scott (2012). The Top 40: Best Mobile Apps for Handheld Librarians. The Reference Librarian, vol. 53, núm. 4, pp. 456-465.

CAmeron, Chris (2010). Students explore their city with Expedition Deventer. En: Layar Blog, 16 diciembre. 
https://www.layar.com/news/blog/2010/12/16/students-explore-their-citywith-expedition-deventer/

CAnuel, Robin; CRICHTON, Chad (2011). Canadian academic libraries and the mobile web. New Library World, vol. 112, núm. 3/4, pp. 107-120.

CAPERON, Lizzie (2014). Developing Adaptable, Efficient Mobile Library Services: Librarians as Enablers. Ariadne, noviembre, núm. 73.

http://live.ariadne.ac.uk/issue73/caperon

CAPLAN, Victoria; LAM, Ki-Tat (2014). WhatsApp at HKUST Library - a new channel for user communication. En: 5th International m-Libraries Conference, Hong Kong, 27-30 mayo. http://m-lib5.lib.cuhk.edu.hk/files/pdf/presentation/1c 04.pdf

Carles-Pomar, Angels; Castellano lópez, Ana; Guerrero Rebollo, Fernando (2013). A new method of training users: Polimedia video for iOS and Android devices. En: Ally, Mohamed; Needham, Gill (ed.). M-Libraries 4: From Margin To Mainstream. Londres: Facet, pp. 147-151. ISBN: 978-1-85604-944-3.

Carnerero, Francesc; Bages, Taïs, (2012). Desarrollo de aplicaciones de bibliotecas para Android y IOS. En: XI Workshop REBIUN sobre proyectos digitales, Barcelona, 23 noviembre.

Carney, Stephen, Koufogiannakis, Denise; Ryan, Pam (2004). Library Services for Users of Personal Digital Assistants: A Needs Assessment and Program Evaluation. Portal: Libraries and the Academy, vol. 4, núm. 3, pp. 393-406.

Casden, Jason; Chapman, Joyce (2011). Building an Open Source Staff-Facing Tablet App for Library Assessment. En: Code4Lib Conference 2011, Bloomington, 10 febrero. http://www.slideshare.net/casden/building-an-open-source-stafffacingtablet-app-for-library-assessment

Castledine, Earle; Eftos, Myles; WheEler, Max (2011). Build Mobile Websites and Apps for Smart Devices. Collingwood: Sitepoint. ISBN: 978-0987090843.

CERnY, Jessica; Holcomb, JoLynn (2012). Using a QR Code Scavenger Hunt (iHunt) to Promote Library Services to Teens. Virginia Libraries, vol. 58, núm. 1, pp. 39-42. http://scholar.lib.vt.edu/ejournals/VALib/v58 n1/pdf/cerny.pdf

Ceynowa, Klaus (2013). Mobile Use - Scenarios for Digital Content and Digital Services - The Augmented Reality App "Ludwig II" of the Bavarian State Library. BIBLID, vol. 102, núm. 1, pp. 143-158.

http://www.ncl.edu.tw/upload/P1021204003/cats/10-Mobile UseScenarios for Digital Content and Digital Services.pdf

ChAn, Christopher (2012). Mobile sites made simple. College \& Research Libraries News, vol. 73, núm. 5, pp. 256-260. 
CHANG, Chiao-Chen (2013). Library mobile applications in university libraries. Library Hi Tech, vol. 31, núm. 3, pp. 478-492.

ChAPMAn, Joyce Celeste; WoodBury, David (2012). Leveraging quantitative data to improve a device lending program. Library Hi Tech, vol. 30, núm. 2.

Charland, Andre; Leroux, Brian (2011). Mobile Application Development: Web vs. Native. Communications of the ACM, vol. 54, núm. 5, pp. 49-53.

CHEN, Chih-Ming; TSAI, Yen-Nung (2012). Interactive augmented reality system for enhancing library instruction in elementary schools. Computers \& Education, vol. 59 , pp. 638-652.

Chen, Chin-Ming; Yang, Yu-Chieh (2010). An Intelligent Mobile Location-Aware Book Recommendation System with Map-Based Guidance That Enhances ProblemBased Learning in Libraries. En: Zeng, Zhigang; Wang, Jun (ed.). Advances in Neural Network Research and Applications. Berlin: Springer. ISBN: 978-3-642-12989-6.

CHIA, Wai Ying (2014). Mobile 3D Library Map: an innovative wayfinding tool for library users on the move. Library Hi Tech News, vol. 31, núm. 3, pp. 9-10.

Chickering, F. William; YAnG, Sharon Q. (2014). Evaluation and Comparison of Discovery Tools: An Update. Information Technology \& Libraries, núm. 33, vol. 2 , pp. 5-30.

Chоу, Fatt Cheong (2011). From library stacks to library-in-a-pocket: will users be around? Library Management, vol. 32, núm. 1/2, pp. 62-72.

Chudnov, Daniel (2010). A Mobile Strategy Web Developers Will Love. Computers in Libraries, vol. 30, núm. 4, pp. 24-26.

CILIP (2004). Information literacy - Definition. En: Chartered Institute of Library and Information Professionals website. http://www.cilip.org.uk/cilip/advocacycampaigns-awards/advocacy-campaigns/information-literacy/informationliteracy

Clark, Jason A. (2012a). Building Mobile Library Applications. Chicago: American Library Association. The Tech Set, 12. ISBN: 978-1-55570-783-5.

Clark, Josh (2012b). Why Jakob Nielsen is wrong on Mobile. En: Creative Bloq, 12 abril. http://www.creativebloq.com/josh-clark-why-jakob-nielsen-wrong-mobile$\underline{4124168}$

Clarke, Christopher Peter; HuI, Su; LI, Ruan (2013). Three Digital Platforms:

Hangzhou Public Library Widens Access to Resources. Library Trends, vol. 62, núm. 1, pp. 140-159. http://dorrstreet.org/librarytrends/62.1.clarke.pdf 
Clarke, Javier (2013). V Estudio sobre Mobile Marketing de IAB Spain y The Cocktail Analysis. Madrid: IAB; The Cocktail Analysis.

http://es.slideshare.net/TCAnalysis/olead

Cocciolo, Anthony; Rabina, Debbie (2013). Does place affect user engagement and understanding?: Mobile learner perceptions on the streets of New York. Journal of Documentation, vol. 69, núm. 1, pp. 98-120.

Connolly, Matthew; Cosgrave, Tony; Krkoska, Baseema B. (2011). Mobilizing the Library's Web Presence and Services: A Student-Library Collaboration to Create the Library's Mobile Site and iPhone Application. Reference Librarian, vol. 52, núm. 1-2, pp. 27-35.

Connors, Adam; Sullivan, Adam (2010). Mobile Web Application Best Practices. World Wide Web Consortium. http://www.w3.org/TR/2010/REC-mwabp20101214/

CREMIN, Ronan (2011). Mobile web content adaptation techniques. En: MobiForge, 1 noviembre. http://mobiforge.com/design-development/mobile-web-contentadaptation-techniques

Cuddy, Colleen (2005). Using PDAs in Libraries. A How-To-Do-It Manual. Nueva York: Neal-Schuman. ISBN: 1-55570-543-X.

Cummings, Joel, Merrill, Alex; Borrelli, Steve (2010). The use of handheld mobile devices: their impact and implications for library services. Library Hi Tech, vol. 28, núm. 1, pp. 22-40.

Cushon, Kate (2013). An education in privacy: best practices for academic libraries in the age of social media. En: Ally, Mohamed; Needham, Gill (ed.). M-libraries 4. From margin to mainstream - Mobile technologies transforming lives and libraries. Londres: Facet, pp. 91-99.

Cutshall, Tom C.; BlaKe, Lindsay; BAndy, Sandra L. (2011). Creating a Mobile Library Website. Computers in libraries, vol. 31, núm. 7, pp. 23-27.

Cyrus, John W. W.; BAGGETT, Mark P. (2012). Mobile Technology: Implications for Privacy and Librarianship. The Reference Librarian, vol. 53, núm. 3, pp. 284-296.

Dalton, Pete; Alcock, Jo; Graves, Yvonne; Kaur, Sukhvinder (2012). M-library community Support Project: Report on Current M-Library Activity. Birmingham. http://www.slideshare.net/evidencebase/report-on-current-mlibrary-activity/

DAns, Enrique (2012). La muerte del código QR. En: El blog de Enrique Dans, 11 septiembre. http://www.enriquedans.com/2012/09/la-muerte-del-codigoqr.html 
DeMars, J. Michael (2012). Smarter Phones: Creating a Pocket Sized Academic Library. The Reference Librarian, vol. 53, núm. 3, pp. 253-262.

DenEen, Linda; AllerT, James (2003). Hand-held computers in the classroom and the library: teaching and learning resource issues resulting from widespread deployment at the University of Minnesota Duluth. Library Hi Tech, vol. 21, núm. 4, pp. 419-425.

Deterding, Sebastian; Khaled, Rilla; NACKe, Lennart E.; Dixon, Dan (2011). Gamification: Toward a Definition. En: CHI 2011 Gamification Workshop, Vancouver, 7 al 12 mayo.

Di SERIo, Ángela; IBáñEZ, María Blanca; Delgado Kloos, Carlos (2013). Impact of an augmented reality system on students' motivation for a visual art course.

Computers \& Education, vol. 68, pp. 586-596.

DowD, Nancy (2011). Is Mobile Marketing Right for Your Organization? The Reference Librarian, vol. 52, núm. 1-2, pp. 166-177.

Dresselhaus, Angela; Shrode, Flora (2012). Mobile Technologies \& Academics: Do Students Use Mobile Technologies in Their Academic Lives and are Librarians Ready to Meet this Challenge? Information Technology \& Libraries, vol. 31, núm. 2. http://ejournals.bc.edu/ojs/index.php/ital/article/view/2166

Ebook -18. Los lectores niños y jóvenes y los libros electrónicos. Peñaranda de Bracamonte: Fundación Germán Sánchez Ruipérez, 2012 .

http://www.territorioebook.com/recursos/vozelectores/menos18/informe lecto res menos 18.pdf

Ebook +18 -40. Los lectores y los libros electrónicos. Peñaranda de Bracamonte:

Fundación Germán Sánchez Ruipérez, 2013.

http://www.territorioebook.com/recursos/vozelectores/19 39/informe lectores menos 19 39.pdf

Ebook Usage in U.S. Public Libraries. Freading Inside, 2014.

http://www.thedigitalshift.com/research/ebook-usage-u-s-public-libraries-2014report/

Eichenlaub, Naomi; Gabel, Laine; JakubeK, Dan; McCarthy, Graham; Wang, Weina (2011). Project iPad: Investigating Tablet Integration in Learning and Libraries at Ryerson University. Computers in Libraries, vol. 31, núm. 7.

http://www.infotoday.com/cilmag/sep11/Eichenlaub Gabel Jakubek McCarthy Wang.shtml

EKART, Donna F. (2010). Location, Location, Location: Making foursquare Work for Your Library. Computers in Libraries, vol. 30, núm. 9, pp. 42-44. 
El préstamo de lectores y libros electrónicos en las Bibliotecas Públicas del Estado. Madrid: Observatorio de la Lectura y del Libro, 2012. http://www.mcu.es/libro/docs/MC/Observatorio/pdf/proyecto ebook BPE.pdf EnIS, Matt (2014). “Beacon” Technology Deployed by Two Library App Makers. En: LibraryJournal, 18 noviembre, http://lj.libraryjournal.com/2014/11/marketing/beacon-technology-deployedby-two-library-app-makers/\#

Fagan, Jody Condit; Mandernach, Meris A.; Nelson, Carl S.; Paulo, Jonathan R.; SAUNDERS, Grover (2012). Usability Test Results for a Discovery Tool in an Academic Library. Information Technology \& Libraries, vol. 31, núm. 1, pp. 83-112. FARKAS, Meredith (2013). Mobile Learning: The Teacher un Your Pocket. En: Peters, Thomas A.; Bell, Lori (Eds.), The Handheld Library: Mobile Technology and the Librarian. California: Libraries Unlimited.

FARnEY, Tabatha; McHale, Nina (2013). Web Analytics Strategies for Information Professionals. Chicago: ALA TechSource.

FERnANDEZ, Peter (2014). Through the Looking Glass: Envisioning New Library Technologies" Augmented reality in the (real) library world " part two. Library Hi Tech News, vol 31, núm. 3.

FINLEY, Thomas Mr. (2014). Mobilizing the Technology Storm: App-based Stress Relief - Using Free or Low-cost Apps to Beat Work and Personal Stress. Library Hi Tech News, vol. 31, núm. 7.

FIRTMAn, Maximiliano (2013). Programming the Mobile Web. Sebastopol: O'Reilly. $2^{\underline{a}}$ ed., revisada. ISBN: 978-1-449-33497-0.

Firtman, Maximiliano (2014). You May Be Losing Users If Responsive Web Design Is Your Only Mobile Strategy. En: Smashing Magazine, 22 julio.

http://www.smashingmagazine.com/2014/07/22/responsive-web-designshould-not-be-your-only-mobile-strategy/

Forsyth, Ellen (2011). Ar U Feeling Appy? Augmented Reality, AppsS and Mobile Access to Local Studies Information. APLIS, vol. 24, núm. 3, p. 125-132.

FosTER, Clifton Dale (1995). PDAs and the library without a roof. Journal of Computing in Higher Education, vol. 7, núm. 1, pp. 85-93.

http://www.springerlink.com/content/eh647592j7463316/fulltext.pdf

Fox, Robert (2012). Being Responsive. OCLC Systems \& Services, vol. 28, núm. 3, pp. 119-125.

Francoeur, Stephen (2011). Apps vs. Mobile Web Optimized Interfaces for Search and Discovery. En: Beating the Bounds, 2 junio. 
http://www.stephenfrancoeur.com/beatingthebounds/2011/06/02/apps-vsmobile-web-optimized-interfaces-for-search-and-discovery/

FreDERICK, Kathryn (2013). Responsive Web Design 101. Computers in Libraries, vol. 33, núm. 6, pp. 11-14.

Frost, Brad (2011). Mobile-First Responsive Web Design. En: Brad Frost Web, 19 junio. http://bradfrostweb.com/blog/web/mobile-first-responsive-web-design/ GaLINDo, Luís Ángel (2010). Mobile 2.0: una oportunidad para las Telco. En: Telos, núm. 83, abril-mayo.

http://telos.fundaciontelefonica.com/docs/2010/09/08/0953000144 0.pdf

Gallagher, Paul (2010). Map it @ WSU: Development of a Library Mapping System for Large Academic Libraries. Code 4Lib Journal, núm. 10.

http://journal.code4lib.org/articles/3072

Gallo León, José Pablo (coord.) (2013). Prospectiva 2020: las diez áreas que más van a cambiar en nuestras bibliotecas en los próximos años. Consejo de Cooperación Bibliotecaria.

http://travesia.mcu.es/portalnb/jspui/bitstream/10421/7460/1/Estudio prospe ctiva 2020.pdf

Galvin, Denis; Sun, Mang (2011). Using Web Services for a Mobile OPAC. Code4lib Journal, núm. 13. http://journal.code4lib.org/articles/4810

Garrison, Julie A.; Anderson, Tiffany L.; MacDonald, Marlyse H.; Schardt, Connie M.; Thibodeau, Patricia L. (2003). Supporting PDAs: the experience of a health sciences library. Library Hi Tech, vol. 21, núm. 4, pp. 412-418.

GAYHART, Lisa; Khalid, Bilal; BELRAY, Gordon (2014). The Road to Responsive: University of Toronto Libraries' Journey to a New Library Catalogue Interface. Code4lib Journal, January, núm. 23. http://journal.code4lib.org/articles/9195

Getting Started with iBeacon. Version 1.0 (2014). En: Apple Developers Centre, 2 junio. https://developer.apple.com/ibeacon/Getting-Started-with-iBeacon.pdf

Giles, Nicola; Grey-Smith, Sue (2005). Txting Librarians @ Curtin. En: Information Online 2005, Sydney, 1-3 febrero.

http://conferences.alia.org.au/online2005/papers/a12.pdf

GodWIN, Peter (2009). Information literacy gets mobile in Vancouver. Journal of Information Literacy, vol. 3, núm. 2, pp. 91-95.

http://ojs.lboro.ac.uk/ojs/index.php/JIL/article/view/CC-V3-I2-2009

GöKER, Ayșe; Myrhaug, Hans; Bierig, Ralf (2009). Context and Information Retrieval. En: Göker, Ayse; Davies, John (ed.). Information Retrieval: Searching in the 21st Century. Chichester: Wiley, pp. 131-157. ISBN: 978-0-470-02762-2. 
Gómez-Gómez, Alberto; EnA-Rodríguez, Borja; Priore, Paolo (2007). RFID en la gestión y mantenimiento de bibliotecas. El Profesional de la Informacion, vol. 16, núm. 4, pp. 329-318.

Gómez Hernández, José Antonio; Benito Morales, Félix (2001). De la formación de usuarios a la alfabetización informacional: propuestas para enseñar las habilidades de información. Scire, vol. 7, núm. 2, pp. 53-83. http://eprints.rclis.org/20758/ GonZÁLEZ, Daniel; MARCos, Mari-Carmen (2013). Responsive web design: diseño multidispositivo para mejorar la experiencia de usuario. BiD: textos universitaris de biblioteconomia i documentación, vol. 31. http://bid.ub.edu/es/31/gonzalez2.htm GonZÁlEZ-FERnÁnDEZ-VILLAVICEnCIO, Nieves (2013). Tenemos que medir el tráfico vía móvil a la web de la biblioteca. En: Bibliotecarios 2020, 28 junio. http://www.nievesglez.com/2013/06/tenemos-que-medir-el-trafico-viamovil.html

GonZÁLEZ-FERnÁNDEZ-VILLAVICENCIO, Nieves (2014). El efecto ROPO y las bibliotecas. Anuario ThinkEPI, 2014, vol. 8, pp. 334-341. http://www.thinkepi.net/el-efectoropo-y-las-bibliotecas

GREEN, Jim (2013). Ebook QR code project. SCONUL Focus, 58. http://www.sconul.ac.uk/sites/default/files/documents/19 8.pdf

Greene, Courtney; Roser, Missy; Ruane, Elizabeth (2010). The Anywhere Library: A Primer for the Mobile Web. Chicago: Association of College and Research Libraries. ISBN: 978-083898542-7.

GRIFFEY, Jason (2010). Mobile Technology and Libraries. Nueva York: Neal-Schuman. ISBN: 978-1555707118.

GrigGS, Kim; Bridges, Laurie M.; RemPEL, Hannah Gascho (2009). Tips on Designing and Developing Mobile Web Sites. The Code4Lib Journal, noviembre, vol. 8. http://journal.code4lib.org/articles/2055

Grupo Web Móvil UPV (2012). Prohibido apagar el móvil en la biblioteca. Mi Biblioteca, núm. 29.

GuAJARDO, Richard (2011). Mobile Catalog Interfaces. A Report of the ALCTS Catalog Form and Function Interest Group Meeting, American Library Association Annual Conference, Washington, DC, June 2010. Technical Services Quarterly, vol. 28, núm. 4, pp. 426-430.

Hábitos de lectura y compra de libros en España, 2012. Madrid: Federación de Gremios de Editores, 2013. http://www.mcu.es/libro/docs/MC/Observatorio/pdf/Habitos lectura 2012.pdf 
HADRO, Josh (2009). Interfaces galore for mobile devices. Library Journal, vol. 134, núm. 4, pp. 19-20. http://www.libraryjournal.com/article/CA6639335.html HaEfEle, Chad (2011). One Block at a Time: Building a Mobile Site Step by Step. Reference Librarian, vol. 52, núm. 1/2, pp. 117-127.

Haefele, Chad (2013). Mobile Catalogs. En: Peters, Thomas A.; Bell, Lori (Eds.). The Handheld Library: Mobile Technology and the Librarian. California: Libraries Unlimited.

HAHN, Jim (2008). Mobile learning for the twenty-first century librarian. Reference Services Review, vol. 36, núm. 3, pp. 272-288.

HAHN, Jim (2011). Location-based recommendation services in library book stacks. Reference Services Review, vol. 39, núm. 4, pp. 654-674.

HAHN, Jim (2012). Mobile augmented reality applications for library services. New Library World, vol. 113, núm. 9/10, pp. 429-438.

HAHN, Jim; MoraLES, Alaina (2011). Rapid Prototyping a collections-based mobile wayfinding application. Journal of Academic Librarianship, vol. 37, núm. 5, pp. 416422.

HaHn, Jim; Ryckman, Nathaniel (2012). Modular Mobile Application Design. Code4lib Journal, núm. 18. http://journal.code4lib.org/articles/7336

HAHN, Jim; WARD, David (2013). Student Collaboration in Mobile Application Design. En: ACRL 2013 Conference, Indianápolis, 10-13 abril.

http://www.library.illinois.edu/nlg student apps/documents/ACRL Hahn Ward I MLS rev8.pdf

HAN, Hyejung; JEONG, Wooseob (2012). Mobile Web Interface of Academic Libraries. Proceedings of the American Society for Information Science and Technology, vol. 49, núm. 1, pp. 1-4.

https://www.asis.org/asist2012/proceedings/Submissions/279.pdf

Harmon, Charles; Messina, Michael (Eds.). (2013). Mobile Library Services: Best Practices. Plymouth: Scarecrew Press. ISBN: 978-0-8108-8752-7.

HavelKa, Stefanie; Verbovetskaya, Alevtina (2012). Mobile information literacy. Let's use an app for that! College \& Research Libraries News, vol. 73, núm. 1. http://crln.acrl.org/content/73/1/22

HEgarty, Ronan; Wusteman, Judith (2011). Evaluating EBSCOhost Mobile. Library Hi Tech, vol. 29, núm. 2, pp. 320-333.

HELSINGOR, Fleur (2009). Mobile Friendly Library Websites. Junio. http://www.lib.berkeley.edu/digicoll/libraryweb/mobile-websites.pdf 
HERnÁNDEZ SÁNCHEZ, Hilario (dir.) (2014). Servicios bibliotecarios para el siglo XXI: ciudadanos, usuarios y expertos opinan sobre los servicios de biblioteca pública de la CAPV. Vitoria-Gasteiz: Servicio Central de Publicaciones del Gobierno Vasco. http://www.liburuklik.euskadi.net/handle/10771/26106

Herzog, Brian (2011). Scanning Library Cards on Smartphones. En: Swiss Army Librarian, 8 febrero http://www.swissarmylibrarian.net/2011/02/08/scanninglibrary-cards-on-smartphones/

Hicks, Alison; Sinkinson, Caroline (2011). Situated Questions and Answers: Responding to Library Users with QR Codes. Reference \& User Services Quarterly, vol. 51, núm. 1, pp. 60-69.

HILL, Nate (2011). Scan Jose - lessons learned (so far). En: Internet Librarian, Monterrey, 27-28 octubre. http://www.slideshare.net/natenatenate/scan-joselessons-learned-so-far

HILl, J. B.; HILL, Cherie Madarash; Sherman, Dayne (2007). Text Messaging in an Academic Library: Integrating SMS into Digital Reference. The Reference Librarian, vol. 47, núm. 1, pp. 17-29.

Hodgkin, Adam (2013). Promotion by iBeacons. En: Exact Editions, 29 noviembre. http://blog.exacteditions.com/2013/11/29/promotion-by-ibeacons/

Honeybourne, Claire; SutTon, Sarah; Ward, Linda (2006). Knowledge in the palm of your hand: PDAs in the clinical setting. Health Information and Libraries Journal, vol. 23, núm. 1, pp. 51-59.

HoffElDER, Nate (2014). Adobe is Spying on Users, Collecting Data on Their eBook Libraries. En: The Digital Reader, 6 octubre. http://the-digitalreader.com/2014/10/06/adobe-spying-users-collecting-data-ebook-libraries/

Houghton, Sarah (2012). Mobile Services for Broke Libraries: 10 Steps to Mobile Success. The Reference Librarian, vol. 53, núm. 3, pp. 313-321.

Hu, Rachel; MeIER, Alison (2010). Mobile Strategy Report: Mobile Device User Research. California Digital Library.

http://www.cdlib.org/services/uxdesign/docs/CDL Mobile Device User Researc $\underline{\mathrm{h} \text { final.pdf }}$

HumPHRIES, Anthony (2012). A Dose of (Augmented) Reality: Exploring possible uses within a library setting. En: eLibrary, 5 diciembre.

http://bcuelibrary.wordpress.com/2012/12/05/a-dose-of-augmented-realityexploring-possible-uses-within-a-library-setting/

IAB SPAIN (2012). IV Estudio IAB Spain sobre Mobile Marketing: Informe de Resultados. Madrid: IAB Spain; The Cocktail Analysis. 
http://www.iabspain.net/wp-content/uploads/downloads/2012/09/IV-EstudioIAB-Spain-sobre-Mobile-Marketing-Versión-Completa.pdf

IBÁÑEZ-HERNÁNDEZ, Rafael (2012). Paseos literarios por Burgos: la biblioteca municipal al encuentro virtual de la ciudad. Mi biblioteca, núm. 28, pp. 52-55.

IFLA (2013). Riding the Waves or Caught in the Tide? Navigating the Evolving Information Environment. La Haya: International Federation of Library Associations and Institutions (IFLA).

http://trends.ifla.org/files/trends/assets/insights-from-the-ifla-trendreport v3.pdf

IgLESIAS, Edward; MeESANGnIL, Wittawat (2011). Mobile Website Development: From Site to App. Bulletin of the Association for Information Science and Technology, octubre/noviembre. http://www.asis.org/Bulletin/Oct11/OctNov11 Iglesias Meesagnil.html

Igoe, Tom; Coleman, Don; JePson, Brian (2014). Beginning NFC: Near Field Communication with Arduino, Android, and PhoneGap. Sebastopol: O'Reilly. ISBN: 978-1-449-37206-4.

IHS (2014). NFC-Enabled Cellphone Shipments to Soar Fourfold in Next Five Years. En: IHS Pressroom, 27 febrero. http://press.ihs.com/press-release/design-supplychain/nfc-enabled-cellphone-shipments-soar-fourfold-next-five-years

JaCOBS, Michelle Leigh (2009). Libraries and the mobile revolution: remediation=relevance. Reference Services Review, vol. 37, núm. 3, pp. 286-290. JAOKAR, Ajit; FISH, Tony (2006). Mobile web 2.0: the innovator's guide to developing and marketing next generation wireless/mobile applications. London: Futuretext. ISBN 0954432762.

JACKSON, Rebecca (2013). Mobile Academic Libraries: A Snapshot. Reference \& User Services Quarterly, vol. 52, núm. 3, pp. 174-178.

http://works.bepress.com/rebecca jackson/5

JENSEN, R. B. (2010). Optimizing library content for mobile phones. Library Hi Tech News, vol. 27, núm. 2, pp. 6-9.

JEONG, Hanho (2012). A comparison of the influence of electronic books and paper books on reading comprehension, eye fatigue, and perception. The Electronic Library, vol. 30, núm. 3.

JINGRU, Hoivik (2013). Global village: mobile access to library resources. Library Hi Tech, vol. 31, núm. 3, pp. 467-477.

JoBs, Steve (2010). Thoughts on Flash. En: Apple Hot News, abril. http://www.apple.com/hotnews/thoughts-on-flash/ 
JoHnSon, Doug (2013). BYOD to the library. En: Doug Johnson, 24 marzo. http://www.doug-johnson.com/dougwri/byod-to-the-library.html

Johnson, L.; Levine, A.; Smith, R. (2009). The 2009 Horizon Report. Austin: The New Media Consortium. ISBN: 978-0-9765087-1-7. http://www.nmc.org/pdf/2009Horizon-Report.pdf

Johnson, L.; Levine, A.; Smith, R.; Stone, S. (2010). The 2010 Horizon Report. Austin: The New Media Consortium. ISBN: 978-0-9825334-3-7. http://wp.nmc.org/horizon2010/

Johnson, L.; Smith, R.; Willis, H.; Levine, A.; Haywood, K. (2011). The 2011 Horizon Report. Austin: The New Media Consortium. ISBN 978-0-9828290-5-9.

http://wp.nmc.org/horizon2011/

Johnson, L.; AdAms, S.; Cummins, M. (2012). The NMC Horizon Report: 2012 Higher Education Edition. Austin: The New Media Consortium. ISBN 978-0-9846601-3-1. http://www.nmc.org/pdf/2012-horizon-report-HE.pdf

Johnson, L.; Adams Becker, S.; Cummins, M.; Estrada, V.; Freeman, A.; Ludgate, H. (2013). NMC Horizon Report: 2013 Higher Education Edition. Austin: The New Media Consortium. ISBN 978-0-9883762-6-7. http://www.nmc.org/pdf/2013horizon-report-HE.pdf

Johnson, L.; Adams Becker, S.; Estrada, V.; Freeman, A. (2014). NMC Horizon Report: 2014 Library Edition. Austin: The New Media Consortium. ISBN: 978-0-9914828-87.

Johnstone, Brian T. (2011). Boopsie and librarians: connecting mobile learners and the library. Library Hi Tech News, vol. 28, núm. 4, pp. 18-21.

Johnston, Nicole; Marsh, Sally (2014). Using iBooks and iPad apps to embed information literacy into an EFL foundations course. New Library World, vol. 115, núm. 1/2, pp. 51-60

Jones, Michael L. W.; Rieger, Robert H.; Treadwell, Paul; Gay, Gery K. (2000). Live from the Stacks: User Feedback on Mobile Computers and Wireless Tools for Library Patrons. En: Procceedings of the 5th ACM Conference on Digital Libraries, San Antonio, pp. 95-102.

Jones, Mike; Price, Simon; Rogers, Nikki; Steer, Damian (2011). MyMobileBristol. Ariadne, núm. 67. http://www.ariadne.ac.uk/issue67/iones-et-al/

JuÁrez URquiJo, Fernando (2012). Biblioteca pública y memoria local en la web móvil. Anuario ThinkEPI 2012, vol. 6, pp. 62-64.

http://www.thinkepi.net/biblioteca-publica-y-memoria-local-en-la-web-movil 
JuÁREZ-URquiJO, Fernando (2013). El papel y sus posibilidades multimedia en la biblioteca. El profesional de la información, vol. 22, núm. 1, pp. 62-67.

Karim, Nor Shahriza Abdul; Darus, Siti Hawa; Hussin, Ramlah (2006). Mobile phone applications in academic library services: a students' feedback survey. CampusWide Information Systems, vol. 23, núm. 1, pp 35-51.

KAUSHIK, Avinash (2010). Analítica web 2.0: el arte de analizar resultados y la ciencia de centrarse en el cliente. Barcelona: Gestión 2000.

Kelley, Keith; Kaugars, Karlis; Garrison, Scott (2011). An Android/LAMP Mobile In/Out Board Based on Wi-Fi Fingerprinting. Code4Lib Journal, núm. 15. http://journal.code4lib.org/articles/5859

Kendall, Susan; Nino, Mary; Stewart, Sandra (2010). Using the iPhone and iPod touch @work. Computers in Libraries, vol. 30, núm. 2, pp.14-19.

KIM, Boyun (2012). It's time to look at our mobile website again. En: LITA Mobile Computing Interest Group meeting at ALA Annual Conference, Anaheim.

http://www.slideshare.net/bohyunkim/its-time-to-look-at-your-librarys-mobilewebsite-again

KIM, Bohyun (2013). The Library Mobile Experience: Practices and User Expectations. Library Technology Reports, vol. 49.

KnEcht, Michael (2003). Cell Phone in the Stacks. American Libraries, junio-julio, pp. 68-69.

Koivisto, Antti; Ketamo, Harri; Hammais, Eero (2014). Combining the Dimensions of Written and Digital Media in a NFC-based Non-linear Adventure Game for Children. En: 80th IFLA General Conference and Assembly, Lyon, 16- 22 agosto.

http://library.ifla.org/872/1/168-koivisto-en.pdf

Koufogiannakis, Denise; Ryan, Pam; Dahl, Susan (2005). Just Another Format: Integrating Resources for Users of Personal Digital Assistants. The Acquisitions Librarian, vol. 17, núm. 33-34, pp. 133-145.

Kraft, Michelle (2010). Stop the app madness. En: The Krafty Librarian, 7 enero. http://kraftylibrarian.com/?p=349

Kroski, Ellyssa (2008). On the Move with the Mobile Web: Libraries and Mobile Technologies. Library Technology Reports, vol. 44, núm. 5.

La Counte, Scott (2012). Going Mobile: Developing Apps for Your Library Using Basic HTML Programming. Chicago: ALA Editions. ISBN: 978-0-8389-1129-7.

La sociedad de la información en España: presente y perspectivas 2000. Madrid: Telefónica, 2000. 
Lara-Navarra, Pablo; Serradell, Enric; Maniega, David (2014). App, movilidad de contenidos para la extensión de servicios de información. BiD: Textos Universitaris de Biblioteconomia i Documentació, núm. 32. http://bid.ub.edu/es/32/lara2.htm LARSSON, Laura C. (2003). Improving your productivity with a PDA: some suggestions. Library Hi Tech, vol. 21, núm. 4, pp. 426-439.

LipPincotT, Joan K. (2010). A mobile future for academic libraries. Reference Services Review, vol. 38, núm. 2, pp. 205-213.

LisTON, Samuel (2009). OPACs and the Mobile Revolution. Computers in libraries, vol. 29, núm. 5, pp. 6-17.

LITA (2003a). Top Technology Trends, 2003 ALA Midwinter Meeting. En: LITA Web Site. http://www.ala.org/lita/professional/trends/midwinter2003

LITA (2003b). Top Technology Trends, 2003 ALA Annual Conference. En: LITA Web Site. http://www.ala.org/lita/professional/trends/annual2003

LITA (2014). Top Tech Trends - 2014 Annual. En: LITA Top Technology Trends. http://www.ala.org/lita/ttt/

LIVERGOOD, Ryan (2011). Buh bye library card, hello smartphone? (or, how NFC might replace everything in your wallet). En: Ryan Livergood, 31 mayo.

http://ryanlivergood.com/?p=173

Lo, Leo; Coleman, Jason; TheISS, Danielle (2013). Putting QR Codes to the Test. New Library World, vol. 114, núm. 11/12.

LoGSDON, Lori (1990). Bookmobile online circulation via cellular telephone. Computers in Libraries, vol. 10, núm. 4, pp. 17-18.

LotTS, Megan; Graves, Stephanie (2011). Using the iPad for reference services: librarians go mobile. College \& Research Library News, vol. 72, núm. 4, pp. 217-220. http://crln.acrl.org/content/72/4/217.full

Lunden, Ingrid (2013). Nokia Confirms The PureView Was Officially The Last Symbian Phone. En: TechCrunch, 24 enero.

http://techcrunch.com/2013/01/24/nokia-confirms-the-pure-view-wasofficially-the-last-symbian-phone/

LYTTLE, Melanie A.; WALSh, Shawn D. (2013). Is Your Library Ready for BYOD?. En: Public Libraries Online, 6 junio. http://publiclibrariesonline.org/2013/06/is-yourlibrary-ready-for-byod/

MACDonaLD, Sarah (2012). Implementation of QR Codes at Indiana University's Fine Arts Library. Art Documentation: Bulletin of the Art Libraries Society of North America, vol. 31, núm. 2, pp. 276-284. 
MacKinnon, Paula; SANFord, Cathy (2010). Snap \& Go: a QReative case in point. Library Hi Tech News, vol. 27, núm. 4/5, pp. 5-8.

MAHON, Barry (1994). Las ventas de PDAs se ralentizan. Information World en español, núm. 22.

http://www.elprofesionaldelainformacion.com/contenidos/1994/marzo/las vent as de pdas se ralentizan.html

MAIRN, Chad (2012). Three Things You Can Do Today to Get Your Library Ready for the Mobile Experience. The Reference Librarian, vol. 53, núm. 3, pp. 263-269.

MaloneY, Michelle M.; Wells, Veronica A. (2012). iPads to Enhance User Engagement During Reference Interactions. En: Miller, Rebecca K.; Meier, Carolyn; Moorefield-Lang, Heather (ed.). Rethinking Reference and Instruction with Tablets. Library Technology Reports, vol. 48, núm. 8, pp. 11-16.

MarcotTe, Ethan (2010). Responsive Web Design. En: A List Apart, 25 mayo. http://alistapart.com/article/responsive-web-design/

Marcotte, Ethan (2011). Responsive Web Design. Nueva York: A Book Apart. ISBN: 978-0-9844425-7-7.

MARGaIX-ARnal, Dídac (2013). Los social media en las bibliotecas universitarias españolas: su presencia y las guías de usos y estilo. León: Universidad de León. [Trabajo de Fin de Máster]. https://buleria.unileon.es/handle/10612/2847 Marshall, Catherine C.; Golovchinsky, Gene; Price, Morgan N. (2001). Digital libraries and mobility. Communications of the ACM, vol. 44, núm. 5, pp. 55-56.

MaXine (2014). Virgin Atlantic lights the way with Apple's iBeacon technology at Heathrow. En: Virgin Atlantic Blog, mayo. https://blog.virgin-atlantic.com/t5/OurFuture/Virgin-Atlantic-lights-the-way-with-Apple-s-iBeacon-technology/ba$\mathrm{p} / 26359$

MCCARThY, Graham; WILSON, Sally (2011). ISBN and QR Barcode Scanning Mobile App for Libraries. Code4lib, núm. 13, http://journal.code4lib.org/articles/5014 MCCulLOUGH, John (2003). Redesigning library applications for PDAs: ILS vendor perspective. Library Hi Tech, vol. 21, núm. 4, pp. 393-399.

McFARLAND, Dana; MusSELl, Jessica (2006). Designing Library Services for the PDA. Journal of Library Administration, vol. 45, núm. 1/2, pp. 301-314.

McGrane, Karen (2012). Content Strategy for Mobile. Nueva York: A Book Apart. ISBN 978-1-937557-0-89. 
McHugh, Sheli; Yarmey, Kristen (2014). Near Field Communication: Recent Developments and Library Implications. Morgan \& Claypool. ISBN: 9781627054324.

Meredith, Tamara R. (2014). Using Augmented Reality Tools to Enhance Children's Library Services. Technology, Knowledge and Learning, septiembre.

Merlo-Vega, José Antonio (2012). Biblio USAL. La primera aplicación de bibliotecas nativa para dispositivos móviles realizada en España. Mi Biblioteca, vol. 8, núm. 29, pp. 54-60. http://gredos.usal.es/ispui/handle/10366/115738

Merlo-VeGA; José Antonio; Gómez-HernándeZ, José Antonio; HernÁndEZ-SÁnCHEZ, Hilario (2011). Estudio FESABID sobre los profesionales de la información Prospectiva de una profesión en constante evolución. Federación Española de Sociedades de Archivística, Biblioteconomía, Documentación y Museística (FESABID). ISBN: 978-84-930335-9-0.

http://www.fesabid.org/repositorio/federacion/prospectiva-de-una-profesionen-constante-evolucion-estudio-fesabid-sobre-los

MiEs, Ginny (2014). Accept Mobile Payments at Your Library: The Tools and Resources You Need. En: TechSoup for Libraries, 12 september.

http://techsoupforlibraries.org/blog/accept-mobile-payments-at-your-librarythe-tools-and-resources-you-need

Milgram, Paul; Takemura, Haruo; Utsumi, Akira; Kishino, Fumio (1994). Augmented Reality: A class of displays on the reality-virtuality continuum. Telemanipulator and Telepresence Technologies, SPIE, vol. 2351, pp. 282-292.

MILls, Keren (2009). M-Libraries: information use on the move. A report from the Arcadia Programme. University of Cambridge.

http://arcadiaproject.lib.cam.ac.uk/docs/M-Libraries report.pdf

MILLS, Keren (2012). Conclusions and recommendations. En: MACON, 31 agosto. http://www.open.ac.uk/blogs/macon/project/final-project-report/conclusionsand-recommendations/

Molina, Rosa; Ribera, Mireia (2012). Realidad aumentada en las bibliotecas de Barcelona. En: XIII Congreso Internacional de Interacción Persona-Ordenador, Elche, 3-5 octubre.

MolL, Cameron (2008). Mobile web design: a web standards approach for delivering contenit to mobile devices. Cameron Moll.

Moreno, María D.; Castaño, Bonifacio; Barrero, David F.; Hellín, Agustín M. (2014). Efficient Services Management in Libraries using AI and Wireless techniques.

Expert Systems with Applications, vol. 41, pp. 7904-7913. 
Morris, Carolyn; DAvIS, Mitchel (2011). Expanding effective 21st century access to historical and academic materials: Examples, strategies and implications. Collaborative Librarianship, vol. 3, núm. 3, pp. 154-156.

http://collaborativelibrarianship.org/index.php/jocl/article/viewFile/157/106

Mountain, David; Myrhaug, Hans; GöKer, Ayşe (2009). Mobile Search. En: Göker, Ayse; Davies, John (ed.). Information Retrieval: Searching in the 21st Century. Chichester: Wiley, pp. 103-130. ISBN: 978-0-470-02762-2.

Munro, Kay; Stevenson, K.; Stenson, R.; Walker, W. ; Fisher, C. (2011). Planning for the mobile library: a strategy for managing innovation and transformation at the University of Glasgow Library. Serials, vol. 24, núm. 3, pp. 26-31.

http://eprints.gla.ac.uk/57643/

MuraKami, Harumi; Kanata, Chizu (2008). Transaction Log Analysis of a Japanese Mobile Phone OPAC. En: Proceedings of the Sixth International Conference on Cognitive Science (ICCS 2008), pp. 433-436. http://murakami.media.osakacu.ac.jp/papers/iccs08.pdf

MurPhy, Joe (2011). The Mobile Revolution and The Handheld Librarian. The Reference Librarian, vol. 52, núm. 1-2, pp. 1-2.

MuRPHY, Joe (2012). Location-Aware Services and QR Codes for Libraries. Chicago: Neal-Schuman Publishers. The Tech Set, vol. 13. ISBN: 978-1-55570-784-2.

MurraY, Lilia (2011). The Best Things in Life Are Free (Or Pretty Cheap): Three Mobile Initiatives That Can Be Done Now. En: Woodsworth, Anne (ed.). Librarianship in times of crisis. Emerald Group Publishing Limited. Advances in Librarianship, vol. 34, pp.139-157.

NAGAO, Katashi; ReKimoto, Jun (1995). Ubiquitous Talker: Spoken Language Interaction with Real World Objects. En: Proc. 14th International Joint Conference on Artificial Intelligence, Montreal, 20-25 agosto.

NAVEGANTES EN LA RED. 17a encuesta AIMC a usuarios de internet. Asociación para la Investigación de los Medios de Comunicación, 2015. http://download.aimc.es/aimc/974 ryRa6/macro2014.pdf

NKeZe, Eman; PeArce, James; Womer, Matt (2007). Device Description Landscape 1.0. World Wide web Consortium, 31 octubre. http://www.w3.org/TR/2007/NOTE-dd-landscape-20071031/

Nichols, Joel A. (2013). iPads in the Library: Using Tablet Technology to Enhance Programs for All Ages. Santa Bárbara: Libraries Unlimited. ISBN: 978-1-61069348-6. 
NiELSEn, Jakob; Budiu, Raluca (2013). Mobile Usability. Berkeley: New Riders. ISBN: 978-0-321-88448-0.

NURSE, Richard (2014). Thinking about iBeacon in a library context. En:

Libwebrarians blog, 13 enero.

http://libwebrarian.wordpress.com/2014/01/13/thinking-about-ibeacon-in-alibrary-context/

NXP (2011). Ease of borrowing in RFID libraries through use of NFC phones. En: NXP News, 15 junio. http://nxp-rfid.com/ease-of-borrowing-in-rfid-librariesthrough-use-of-nfc-phones/

O'Donoghue, Ruadhán (2014). Geo-sorting: Using Device Geolocation to Sort by Distance. En: MobiForge, 22 julio. http://mobiforge.com/design-development/geosorting-using-device-geolocation-sort-distance

OHIGASHI OASAY, Luree H. (2011). QR Codes in the Library. Journal of Electronic Resources in Medical Libraries, vol. 8, núm. 3, pp. 294-301.

Pardo Merino, Antonio (2014). Análisis de datos en ciencias sociales y de la salud I. Madrid: Síntesis. ISBN: 978-84-995823-7-5.

PARFITT, Ben (2014). Google Play downloads tracking 45\% ahead of Apple App Store. En: MCV, 15 abril. http://www.mcvuk.com/news/read/google-playdownloads-tracking-45-ahead-of-apple-app-store/0131202

PARHIZKAR, Behrang; ZAMAN, Halimah Badioze (2009). Development of an Augmented Reality Rare Book and Manuscript for Special Library Collection (AR Rare-BM). En: 1st International Visual Informatics Conference on Visual Informatics, Kuala Lumpur, 11-13 noviembre.

PASTOR, Javier (2014). Qué es Android, qué es AOSP, qué es libre y abierto y qué no. En:Xataka, 18 febrero. http://www.xataka.com/moviles/que-es-android-que-esaosp-que-es-libre-y-abierto-y-que-no

PATERSON, Lorraine; Low, Boon (2011). Student attitudes towards mobile library services for smartphones. Library Hi Tech, vol. 29, núm. 3, pp. 412-423.

Pearce, Alexa; Collard, Scott; Whatley, Kara (2010). SMS reference: myths, markers, and modalities. Reference Services Review, vol. 38, núm. 2, pp. 250-263.

Pence, Harry E. (2011). Smartphones, Smart Objects, and Augmented Reality. Reference Librarian, vol. 52, núm. 1/2, p. 136-145.

Pendell, Kimberly D.; Bowman, Michael S. (2012). Usability Study of a Library's Mobile Website: An Example from Portland State University. Information Technology \& Libraries, vol. 31, núm. 2. http://ejournals.bc.edu/ojs/index.php/ital/article/viewFile/1913/pdf 
PÉREZ, Dora; ToRN, Pep (2009). M-Library in an m-University: Changing Models in the Open University of Catalonia. En: Second International m-Libraries Conference, Vancouver, 23-24 junio.

PÉREZ, Sarah (2014). iTunes App Store Now Has 1.2 Million Apps, Has Seen 75 Billion Downloads To Date. En: TechCrunch, 2 junio.

http://techcrunch.com/2014/06/02/itunes-app-store-now-has-1-2-million-appshas-seen-75-billion-downloads-to-date/

PÉREZ-Montoro GutiérRez, Mario (2010). Arquitectura de la información en entornos web. Gijón: Trea. ISBN: 978-84-9704-503-2.

PÉREZ YuSTE, Antonio (2002). El proceso de implantación de la telefonía móvil en España. Revista Antena del COITT. http://catedracoitt.euitt.upm.es/web socioeconomica/articulos/procesoimplantaciontelefoniam ovil.pdf

Pesquero Murillo, Julio (2008). La biblioteca en el teléfono móvil. En: IV Congreso Nacional de Bibliotecas Públicas, A Coruña, 24-26 de septiembre. http://travesia.mcu.es/portalnb/ispui/bitstream/10421/555/1/com 386.pdf

Peters, Thomas A. (2013). Bricks and Mortar and Wireless: The Impact of the Mobile Revolution on the Use of Physical Libraries. En: Peters, Thomas A.; Bell, Lori (Eds.). The Handheld Library: Mobile Technology and the Librarian. Santa Barbara: Libraries Unlimited, pp. 51-62.

Peters, Thomas A.; Bell, Lori (Eds.) (2013). The Handheld Library: Mobile Technology and the Librarian. Santa Barbara: Libraries Unlimited. ISBN: 978-161069-300-4.

Pianos, Tamara (2012). EconBiz to go: Mobile search options for business and economics - developing a library app for researchers. Library Hi Tech, vol. 30, núm. 3, pp. 436-448.

Podjarny, Guy (2014). RWD Ratio in Top 100,000 websites - refined. En: Guy's Pod, 9 enero. http://www.guypo.com/mobile/rwd-ratio-in-top-100000-websitesrefined/

PoHLA, Hans-Bodo (2011). Untersuchung bibliothekarischer Applikationen für Mobiltelefone hinsichtlich der technischen Realisierung und des Nutzens. B.I.T. innovativ, vol. 34. http://www.b-i-t-online.de/daten/BIT Innovativ 34 Auszug.pdf Polanka, Sue (2012). Off the Shelf: Reference--I've Got an App for That!. Booklist, vol. 108, núm. 9/10, p. 76.

Polanka, Sue (2014). De Gruyter introduces ePub3 format for all titles. En: No Shelf Requiered, 28 mayo. 
http://www.libraries.wright.edu/noshelfrequired/2014/05/28/de-gruyterintroduces-epub3-format-for-all-titles/

Pons, David; Vallés, Raquel; AbarCA, Marta; Marta; Rubio, Francisco (2011). QR codes in use : the experience at the UPV Library. Serials, vol. 24, núm. 3, pp. 47-56. http://riunet.upv.es/handle/10251/14112

Primary Research Group (2014a). Library Use of QR codes. Nueva York: Primary Research Group. ISBN: 9781574402797.

Primary Research Group (2014b). Survey of Policies to Assure Mobile Device Access to the Library Website. Nueva York: Primary Research Group. ISBN:

Pulgar Vernalte, Francisca; Maniega-Legarda, David (2014). "Liburutegiak" app: La biblioteca en la palma de tu mano. En: 80th IFLA General Conference and Assembly. Lyon, 16-22 agosto. http://eprints.rclis.org/23517/

Pulliam, Beatrice; LANDRY, Chris (2011). Tag, You're It! Using QR Codes to Promote Library Services. The Reference Librarian, vol. 52, núm. 1-2, pp. 68-74.

QR CoDEs (s. d.). Library success: A best practices Wiki. http://www.libsuccess.org/index.php?title=QR Codes

RAAB, Frederick H.; Blood, Ernest B.; STEInER, Terry O.; JonEs, Herbert R. (1979). Magnetic position and orientation tracking system. En: IEEE Transactions on Aerospace and Electronic Systems, AES-15, núm. 5, pp. 709-718.

Rabin, Jo; McCathieNevile, Charles (2008). Mobile Web Best Practices 1.0. World Wide Web Consortium, 29 julio. http://www.w3.org/TR/mobile-bp/

RaInie, Lee; Zickuhr, Kathryn; DugGan, Maeve (2012). Mobile Connections to Libraries. En: Pew Internet, 31 diciembre. http://libraries.pewinternet.org/2012/12/31/mobile-connections-to-libraries/ Ramos, Susana (2011). Teléfono móvil y biblioteca pública. Mi biblioteca, núm. 27, pp. 26-29.

RAMSAY, Marc; NiElSEn, Jakob (2000). WAP Usability. Déjà Vu: 1994 All Over Again. Nielsen Norman Group.

http://s3.amazonaws.com/media.nngroup.com/media/reports/free/WAP Usabili ty.pdf

RAMSDEn, Andy; JoRDAn, Lindsay (2009). Are students ready for QR codes? Findings from a student survey at the University of Bath. Bath.

http://opus.bath.ac.uk/12782/ 
RAPP, David (2012). Apps: What Do Patrons Want? Library Journal, vol. 137, núm. 2, p. 27. http://www.thedigitalshift.com/2012/02/mobile/the-state-of-mobile-inlibraries-2012/

REdDY, Y. Chandramohan; RAJu, K. Srujan; NEERAJA, K. (2010). E-Library using the Mobile OPAC. International Journal of Computers \& Technology, vol. 10, núm. 5. http://cirworld.org/journals/index.php/ijct/article/view/2006

REDondo, María Ángeles (2014). Lecturas de cabecera, una exposición dinamizada en el CDS mediante realidad aumentada. En: Lectura Lab, 13 febrero.

http://lecturalab.org/story/Lecturas-de-cabecera-una-exposicin-dinamizada-enel-CDS-mediante-realidad-aumentada 4748

REIDSMA, Mathew (2012). Control issues. En: Mathew Reidsm's blog, 25 abril. http://matthew.reidsrow.com/articles/19

ReIDSMA, Mathew (2013). Responsive Web Design for Libraries: Beyond the Mobile Web. En: Harmon, Charles; Messina, Michael (ed.). Mobile Library Services: Best Practices. Plymouth: Scarecrow Press. ISBN: 978-0-8108-8753-4.

ReIDSMA, Mathew (2014). Responsive Web Design for Libraries. Chicago: American Libraries Association. Lita Guides. ISBN: 978-1555709945.

REmPEL, Hannah Gascho; BRIDGes, Laurie M. (2013). That Was Then, This Is Now: Replacing the Mobile-Optimized Site with Responsive Design. Information Technology \& Libraries, diciembre, vol. 32, núm. 4, pp. 8-24. http://ejournals.bc.edu/ojs/index.php/ital/article/view/4636

Reitmayr, Gerhard; SchmalstiEG, Dieter (2003). Location based Applications for Mobile Augmented Reality. En: Proceedings of the 4th Australasian User Interface Conference, Australian Computer Society.

Revelle, Andrew; Polanka, Sue (2013). Reading Transformed by the Mobility of Ebooks. En: Peters, Thomas A.; Bell, Lori (eds.). The Handheld Library: Mobile Technology and the Librarian. California: Libraries Unlimited.

RiAnCHO, Gontzal; JuÁREZ-URQUiJo, Fernando (2011). Las batallas de Somorrostro, 1874: biblioteca, memoria local y patrimonio inmaterial. En: IV Encuentro de Bibliotecas y Municipio, Madrid, 17 noviembre.

http://travesia.mcu.es/portalnb/jspui/handle/10421/6146

Richardson, Douglas; LuRIA, Sarah; Ketchum, Jim; DeAR, Michael (2011). Introducing the geohumanities. En: Dear, Michael; Ketchum, Jim; Luria, Sarah; Richardson, Douglas (ed.). GeoHumanities: Art, History, Text at the Edge of Place. Nueva York: Routledge. ISBN: 978-0-415-58980-2. 
Rıos, Gabriel R. (2004). PDA librarian. Reference Services Review, vol. 32, núm. 1, pp. 16-20.

RoBInSON, Kate (2010). QR codes and their applications for libraries - a case study from the University of Bath Library. En: Ally, Mohamed; Neeedham, Need (ed.). $M$ libraries 2: a virtual library in everyone's pocket. Londres: Facet. ISBN: 978-185604-696-1.

Román-Molina, Juan (2010). Conectados.0: la web adaptada para dispositivos móviles de la Red de Bibliotecas del CSIC. Enredadera, núm. 17, pp. 11-13. http://hdl.handle.net/10261/20879

RUIZ TORRES, David (2013). La realidad aumentada y su aplicación en el patrimonio cultural. Gijón: TREA. ISBN: 978-84-9704-721-0.

RuMSEY, Eric (2012). Responsive Design Sites: Higher Ed, Libraries, Notables. En: Seeing the Picture, 3 marzo.

http://blog.lib.uiowa.edu/hardinmd/2012/05/03/responsive-design-siteshigher-ed-libraries-notables/

RYAN, Brendan (2011). Developing Library Websites Optimized for Mobile Devices. The Reference Librarian, vol. 52, núm. 1-2, pp. 128-135.

SARAVANI, Sarah-Jane; Haddow, Gaby (2012). Staff preparedness to implement mobile technology in libraries. En: Ally, Mohamed; Needham, Gill (ed.). M-libraries 3. Transforming libraries with mobile technology. Londres: Facet, pp. 76-83. ISBN: 978-1-85604-776-0.

SCHADE, Amy (2014). Responsive Web Design (RWD) and User Experience. En: Nielsen Norman Group, 4 mayo. http://www.nngroup.com/articles/responsiveweb-design-definition/

ScHmidT, Aaron (2013). The Mobile Challenge | The User Experience. Library Journal, vol. 138, núm. 8, pp. 19. http://lj.libraryjournal.com/2013/05/opinion/aaron-schmidt/the-mobilechallenge-the-user-experience

SCHOFIELD, Michael (2014). I'm Tired of Talking about Responsive Web Design. http://ns4lib.com/im-tired-talking-responsive-web-design/

SchulTz, Michelle K. (2013). A case study on the appropriateness of using quick response (QR) codes in libraries and museums. Library \& Information Science Research, vol. 35, núm. 3, pp. 207-215.

SEADLE, Michael (2003). Mental models for personal digital assistants (PDAs). Library Hi Tech, vol. 21, núm. 4, pp. 390-392. 
Seenolzer, Jamie; SAlem, Joseph A. (2011). Library on the Go: A Focus Group Study of the Mobile Web and the Academic Library. College \& Research Libraries, vol. 72, núm. 1, pp. 9-20.

SEKYERE, Kwabena (2012). QR Codes in Libraries: Uses and Usage Tracking. College \& Undergraduate Libraries, vol. 19, núm. 1, pp. 95-100.

Seonne, Catuxa (2003). Uso de la tecnología WAP en centros de información. En:

Deakialli, 6 julio. http://www.deakialli.com/2003/07/06/uso-de-tecnologia-wapen-centros-de-informacion/

SERrAno-Muñoz, Jordi (2000). Acceso a la Biblioteca de la UOC por medio de la telefonía móvil. En: I Jornadas de Bibliotecas Digitales, Valladolid, 6-7 noviembre. http://openaccess.uoc.edu/webapps/o2/bitstream/10609/341/1/3538.pdf

Serrano-Muñoz, Jordi; Rico Millán, Oriol; Prieto Jiménez, Antonio Juan; PÉrez GÁlvez, Andrés; Clavero Campos, Javier; Payan MuÑoz, Iván (2010). Geolocalización de documentos en las bibliotecas UPC. En: X Workshop Rebiun de Proyectos Digitales, Valencia, 7-8 octubre.

SERRANO-MuÑoz, Jordi (2013). Líneas de trabajo sobre movilidad en REBIUN. En:

Seminario Dispositivos móviles y bibliotecas: experiencias que conectan lo presencial y lo digital. XIII Jornadas Españolas de Documentación - FESABID, Toledo, 24-25 mayo.

SERRAnO-MuÑoz, Jordi (2014). ¿Mobile o APP? ¿Esta es la cuestión? En: Blok de BiD, 17 diciembre. http://www.ub.edu/blokdebid/es/content/¿mobile-o-app-iesta-esla-cuestion

Serrano-Muñoz, Jordi; Rico Millán, Oriol; Prieto Jiménez, Antonio Juan; PÉrez Gálvez, Andrés; Clavero Campos, Javier; Payan MuÑoz, Iván (2010). Geolocalización de documentos en las bibliotecas UPC. En: X Workshop Rebiun de Proyectos Digitales, Valencia, 7-8 octubre.

Shatte, Adrian; Holdsworth, Jason; LeE, Ickjai (2014). Context-Aware Mobile Augmented Reality for Library Management. Expert Systems with Applications, vol. 41, núm. 5, pp. 2174-2185.

Shipman, Jean P.; Morton, Andrew C. (2001). The new black bag: PDAs, health care and library services. Reference Services Review, vol. 29, núm. 3, pp. 229-238.

SIEGAL, Jacob (2014). Windows and Windows Phone app stores have reached 400,000 apps. En: BGR, 2 abril. http://bgr.com/2014/04/02/windows-windowsphone-app-stores-400000-apps/ 
Sierra, Tito; RyAn, Joseph; Wust, Markus (2007). Beyond OPAC 2.0: Library Catalog as Versatile Discovery Platform. The Code4Lib Journal, núm. 1. http://journal.code4lib.org/articles/10

Sierra, Tito; CaSden, Jasden (2011). Mobile Enhanced Access to Archives and Special Collections. En: LYRASIS Technology Ideas and Insights Series, Elon, 4 agosto. http://www.slideshare.net/tsierra/mobile-enhanced-access-to-archivesand-special-collections

Skilton, Laura; Ramirez, Matt; Armstrong, Guyda; Lock, Rse; VACHER, Jean; Gramstadt, Marie-Therese (2013). Augmented Reality in Education: The SCARLET+ Experience. Ariadne, núm. 71.

http://www.ariadne.ac.uk/issue71/skilton-et-al

SMith, Jonathan M. (2013). Digital Device Lending in Libraries. En: Bridging the Spectrum: A Symposium on Scholarship and Practice in Library and Information Science, Washington D.C., 1 febrero. http://works.bepress.com/jonathan smith/3

Smith, Michael M.; Pietraszewski, Barbara A. (2004). Enabling the roving reference librarian: wireless access with tablet Pcs. Reference Services Review, vol. 32, núm. 3, pp. 249-255.

SNELL, Jeremy (2013). Flexible Everything: Getting Responsive With Web Design. Information Today, abril.

SonG, Yang; MA, Hao; WAnG, Hongning; WAnG, Kuansan (2013). Exploring and Exploiting User Search Behavior on Mobile and Tablet Devices to Improve Search Relevance. En: International World Wide Web Conference, Río de Janeiro, 13-17 mayo.

Soto, Roberto (2013). Ampliación de contenidos en los bibliobuses de León. En: $6^{\underline{o}}$ Congreso Nacional de Bibliotecas Móviles. Burgos, 18 y 19 de octubre.

http://www.bibliobuses.com/documentos/AMPLIACIÓN\%20DE\%20CONTENIDO S\%20EN\%20LOS\%20BIBLIOBUSES\%20DE\%20LEÓN.pdf

SPIRES, Todd (2008). Handheld librarians: a survey of librarian and library patron use of wireless handheld devices. Internet Reference Services Quarterly, vol. 13, núm. 4, pp. 287-309.

https://confluence.ucop.edu/download/attachments/34668692/Handheld+Libra

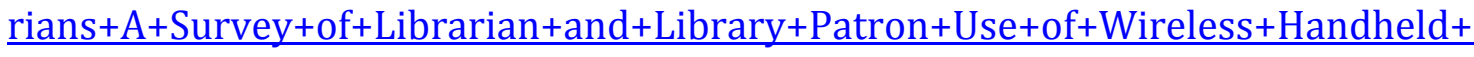
Devices.pdf

SPITZER, Stephan (2012). Make that to go. Computers in Libraries, vol. 32, núm. 5, pp. 10-14. 
STAHR, Beth (2011). Text Message Reference Service: Five Years Later. The Reference Librarian, vol. 52, núm. 1-2, pp. 9-19,

Stoddard, Mari J. (2001). Handhelds in the Health Sciences Library. Medical Reference Services Quarterly, vol. 20, núm. 3, pp. 75-82.

STORMER, Henrik (2005). Personalized websites for mobile devices using dynamic cascading style sheet. International Journal of Web Information Systems, vol. 1, núm. 2, pp. 83-88.

Subdirección GEneral de CoORdinación Bibliotecaria (2011). Realidad Aumentada: Una aplicación que guía al usuario con la pantalla del móvil. http://www.mcu.es/bibliotecas/docs/tutorial layar.pdf

Sunonos, M. J. (2010). Building a Location-aware Mobile Search Application with Z39.50 and HTML5. The Code4Lib Journal, núm. 10.

http://journal.code4lib.org/articles/2947

SumADIO, Dwesi Dwistratanti; RAmbli, Dayang Rohaya Awang (2010). Preliminary evaluation on user acceptance of the augmented reality use for education. En: Second International Conference on Computer Engineering and Applications, Bali, 19-21 marzo.

TAY, Aaron (2010a). What are Mobile friendly library sites offering? A survey. En: Musings about librarianship, 24 abril.

http://musingsaboutlibrarianship.blogspot.com.es/2010/04/comparison-of-40mobile-library-sites.html

TAY, Aaron (2010b). Library Mobile web apps vs. web apps. Some analysis. En: Musings about librarianship, 5 septiembre.

http://musingsaboutlibrarianship.blogspot.com.es/2010/09/library-mobile-appsvs-web-apps-some.html

TAY, Aaron (2010c). QR codes for libraries - some thoughts. En: Musings about librarianship, 27 febrero.

http://musingsaboutlibrarianship.blogspot.com.es/2010/02/qr-codes-forlibraries-some-thoughts.html

TAY, Aaron (2011). What are Mobile friendly library databases offering? A survey. Musings about librarianship, 21 agosto.

http://musingsaboutlibrarianship.blogspot.com.es/2011/08/what-are-mobilefriendly-library.html

TAY, Aaron; TRAVIS, Tiffini (2011). Is mobile really neccessary? In: World Library and Information Congress : 77th IFLA General Conference and Assembly. San Juan, 13-18 agosto. http://www.slideshare.net/T Travis/ifla-travis 
The 2006 Horizon Report. Austin: The New Media Consortium. ISBN 0-9765087-37. http://www.nmc.org/pdf/2006 Horizon Report.pdf

The 2007 Horizon Report. Austin: The New Media Consortium. ISBN 0-9765087-45. http://www.nmc.org/pdf/2007 Horizon Report.pdf

The 2008 Horizon Report. Austin: The New Media Consortium. ISBN: 0-9765087-61. http://www.nmc.org/pdf/2008-Horizon-Report.pdf

The M-Library Project. UK academic libraries going mobile (2011). University of the Highlands and Islands; Edinburgh Napier University http://mlib.blog.com/files/2011/09/The-M-Library-Project-UK-AcademicLibraries-Going-Mobile.pdf

Thomas, Lisa Carlucci (2009). Mobile Access To E-Books At Yale. http://es.scribd.com/doc/28984716/Mobile-Access-To-E-Books-At-Yale-LisaCarlucci-Thomas-2009

Thomas, Lisa Carlucci (2010). Gone Mobile? (Mobile Libraries Survey 2010). En: Library Journal, 15 octubre.

http://lj.libraryjournal.com/2010/10/technology/gone-mobile-mobile-librariessurvey-2010/

TidAL, Junior (2011). Using Web Metric Software to Drive Mobile Website Development. Computers in Libraries, vol. 31, núm. 3.

Tin, Tony; McMilliam, Colleen; McNeIL, Rachel (2014). Mobile Libraries of the Future: From Device to User. En: 5th International m-Libraries Conference, Hong Kong, 27-30 mayo. http://mlib5.lib.cuhk.edu.hk/files/pdf/presentation/2a 03.pdf

ToDE, Chantal (2012). Kraft NFC pilot delivers 12 times the engagement level of QR codes. En: Mobile Commerce Daily, 18 octubre.

http://www.mobilecommercedaily.com/kraft-nfc-pilot-delivers-12-times-theengagement-level-of-qr-codes

Tomlin, Patrick (2012). En: Miller, Rebecca K.; Meier, Carolyn; Moorefield-Lang, Heather (ed.). Rethinking Reference and Instruction with Tablets. Library Technology Reports, vol. 48, núm. 8, pp. 48-53.

Trainor, Cindi (2010). Planning for a Mobile Site. American Libraries, vol. 41, núm. 4, p. 26.

Travis, Tiffini (2011). Edupunk goes mobile: Mobile library sites with zero budget. En: Tiffinianne's Blog, 22 enero. http://tiffinianne.wordpress.com/2011/01/22/8/ Travis, Tiffini; TAY, Aaron (2011). Designing Low-Cost Mobile Websites for Libraries. Bulletin of the American Society for Information Science \& Technology, vol. 
38, núm. 1, pp. 24-29. http://www.asis.org/Bulletin/Oct11/OctNov11Travis Tay.pdf

UniverSIDAD DE ALICANTE (2000). Biblioteca Wap. Dulcinea, núm. 2. http://web.ua.es/es/secretaria-gral/memoria/200001/07documentos revistas/Dulcinea/Dulcinea2/Dulcinea.htm

VATTER, André (2011). Interview mit dem EDsync-Macher: "Die Idee mobiler Anwendungen ist bei vielen Bibliotheken noch nicht angekommen". En: $Z B W$ Mediatalk, 30 marzo. http://www.zbw-mediatalk.eu/2011/03/interview-mitdem-edsync-macher-die-idee-mobiler-anwendungen-ist-bei-vielen-bibliothekennoch-nicht-angekommen/

VázquEZ, José Antonio (2014). El uso de la tecnología iBeacon en los museos. En: Comunicación Cultural, 8 septiembre. http://www.comunicacioncultural.com/2014/09/08/el-uso-de-la-tecnologia-ibeacon-en-los-museos/

VERMA, Vijay Kumar (2013). Google Glass: Its use in Libraries and Issues involved. En: International Conference on Digital Libraries, Nueva Delhi, 27-29 noviembre. VILLEGAS LIRoLA, Manuel José (2013). Acceso a la información codificada. Los códigos QR en el servicio municipal de bibliotecas de Níjar. Mi biblioteca, núm. 35, pp. 66-71.

VolLMER, Timothy (2010). There is an app for that! Libraries and Mobile Technology, An Introduction to Public Policy Considerations. Policy Brief, núm. 3, junio.

http://www.ala.org/ala/aboutala/offices/oitp/publications/policybriefs/mobiled evices.pdf

WALSH, Andrew (2010a). QR Codes - using mobile phones to deliver library instruction and help at the point of need. Journal of Information Literacy, vol. 4, núm. 1, pp. 55-64.

WALSH, Andrew (2010b). Mobile phone services and UK Higher Education students, what do they want from the library? Library and Information Research, vol. 34, núm. 106, pp. 22-36.

WALSH, Andrew (2011). Blurring the boundaries between our physical and electronic libraries: Location aware technologies; QR codes and RFID tags. The Electronic Library, vol. 29, núm. 4, pp. 429-437. http://eprints.hud.ac.uk/7760/ WALSH, Andrew (2012a). Mobile information literacy: a preliminary outline of information behaviour in a mobile environment. Journal of Information Literacy, vol. 6, núm. 2, pp. 56-69.

http://ojs.lboro.ac.uk/ojs/index.php/IIL/article/view/PRA-V6-I2-2012-4/1698 
WALSH, Andrew (2012b). Using Mobile Technology to Deliver Library Services. A handbook. Londres: Facet. ISBN: 978-1-85604-809-5.

WanuCha, Meghan; Hofschire, Linda (2013). U.S. Public Libraries and the Use of Web Technologies, 2012. Library Research Service. Denver: Colorado State Library, Library Research Service. http://www.lrs.org/wpcontent/uploads/2013/11/WebTech2012 CloserLook.pdf

WASHBURN, Bruce (2011). Library Mobile Applications: What Counts as Success? Information Outlook, vol. 15, núm. 1.

http://www.oclc.org/research/publications/library/2011/washburn-io.pdf

West, Jessamin (2009). Mobility in and Around the Library. Computers in Libraries, vol. 29, núm. 5, pp. 30-31.

WeSt, Jessamyn (2010). Location @Your Library. Computers in libraries, vol. 30, núm. 10, pp. 38-40.

WEST, Mark; CHEW, Han Ei (2014). Reading in the mobile era: A study of mobile reading in developing countries. París: Unesco. ISBN 978-92-3-100023-2.

http://unesdoc.unesco.org/images/0022/002274/227436E.pdf

WeYL, Stelle (2014). Mobile HTML5. Sebastopol: O’Reilly. ISBN: 978-1-449-311414.

WidDows, Katharine (2011). Mobile technology for mobile staff: roving enquiry support. Multimedia Information \& Technology, vol. 37, núm. 2, pp. 12-15.

WiLSON, Sally; MCCARTHY, Graham (2010). The mobile university: from the library to the campus. Reference Services Review, vol. 38, núm. 2, pp. 214-232.

WILSON, Andrew M. (2012). QR Codes in the Library: Are They Worth the Effort? Analysis of a QR Code Pilot Project. Journal of Access Services, vol. 9, núm. 3, pp. 101-110. http://dash.harvard.edu/bitstream/handle/1/8705899/JAS QR Code.pdf

WiSNIEWSKI, Jeff (2010). Mobile Websites with Minimum Effort. Online, vol. 34, núm 54, p. 7.

WisNiEWSKI, Jeff (2011). Mobile That Works for Your Library. Online, vol. 35, núm. 1, pp. 54-57.

WiSNIEWSKI, Jeff (2013). Responsive Web Design from the Trenches. En: Internet Librarian, Monterrey, 28-30 octubre. http://es.slideshare.net/jeffwisniewski/responsive-27812909

WhitchuRch, Michael J. (2012). A Quick Response: QR Code Use at the Harold B. Lee Library. The Reference Librarian, vol. 53, núm. 4, pp. 392-402. 
Wong, Kae Perng (2013). Library services for mobile devices: the National Institute of Education Library experience. Library Hi Tech News, vol. 30, núm. 9, pp. 7-11. Wong, Shun Han Rebekah (2012). Which Platform Do Our Users Prefer -- Website or Mobile App? Reference Services Review, vol. 40, núm. 1.

WroBlEWSKI, Luke (2011a). Mobile First. Nueva York: A Book Apart. ISBN 978-1937557-02-7.

WROBLEWSKI, Luke (2011b). RESS: Responsive Design + Server Side Components. En: LukeW, 11 septiembre. http://www.lukew.com/ff/entry.asp?1392

Wu, Hsin-Kai; LeE, Silvia Wen-Yu; CHANG, Hsin-Yi; LIANG, Jyh-Chong (2013). Current status, opportunities and challenges of augmented reality in education. Computers \& Education, vol. 62, pp. 41-49.

YALE, Brad (2014). The Fight for The Mobile App Market: Android vs. iOS. En:

Informit, 9 junio. http://www.informit.com/blogs/blog.aspx?uk=The-Fight-forThe-Mobile-App-Market-Android-vs-iOS

YEE, Annie (2012). Mobile technology: academic libraries in Australia and beyond. En: VALA2012 16th Biennial Conference and Exhibition, Melbourne, 6-9 febrero.

YeE, Raymond (2008). Pro Web 2.0 Mashups: Remixing Data and Web Services. Berkeley: Apress. ISBN: 978-1590598580.

Yelton, Andromeda (2012). Bridging the Digital Divide with Mobile Services. Library Technology Reports, vol. 48, núm. 1.

Zickuhr, Kathryn; Rainie, Lee; PuRCELl, Kristen (2013). Library Services in the Digital Age. En: Pew Internet, 22 enero.

http://libraries.pewinternet.org/2013/01/22/library-services/

ZickuHR, Kathryn; RaInIE, Lee (2014). E-Reading Rises as Device Ownership Jumps. En: Pew Research Internet Project, 16 enero.

http://www.pewinternet.org/2014/01/16/e-reading-rises-as-device-ownershipjumps/

ZYLSTRA, Robert (2011). A Mobile application for Discovery. Computers in libraries, vol. 31, pp. 11-15. 

Anexos 



\section{Anexo 1. Plantillas de diseño en sitios web para móviles}
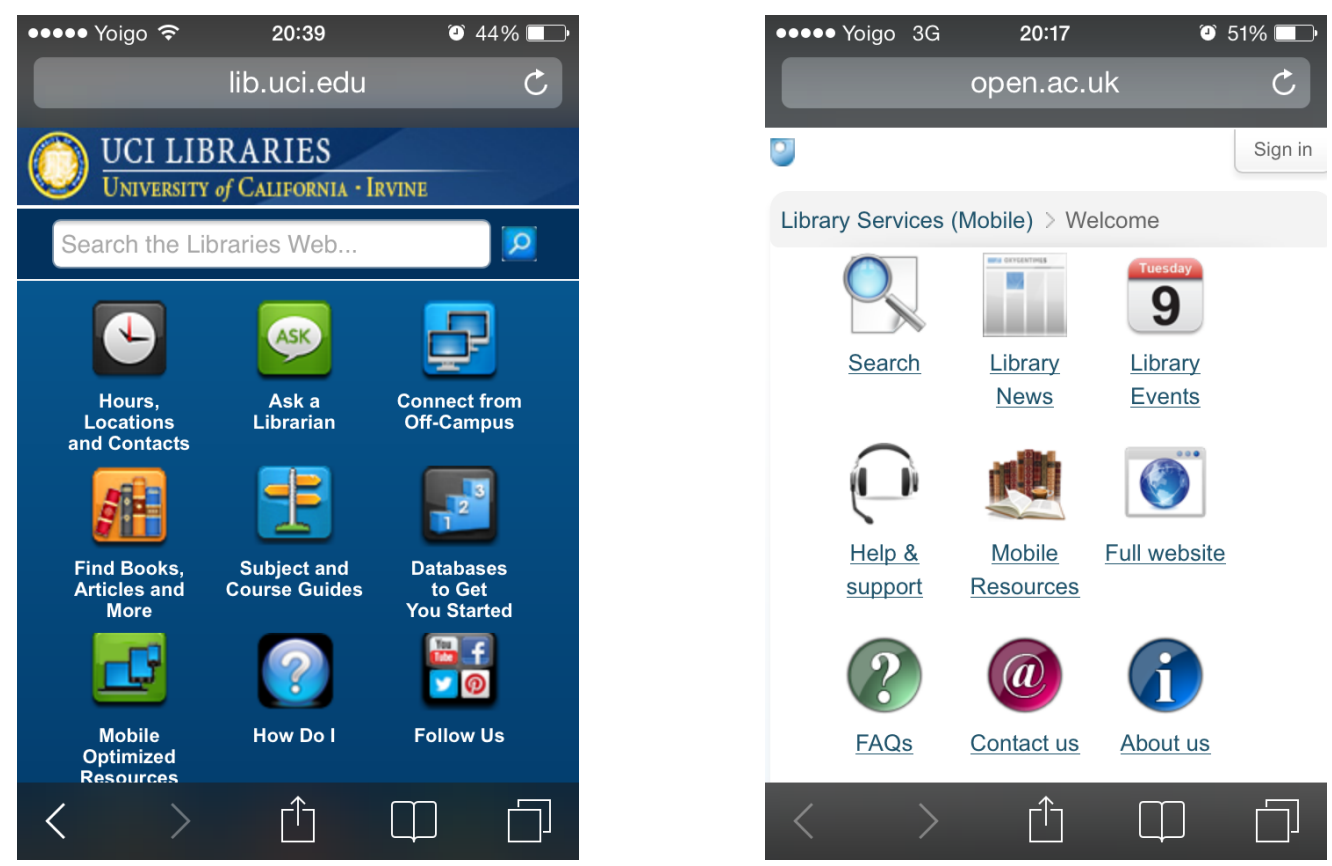

Sitios web con diseño de retícula de iconos.

\begin{tabular}{|c|c|}
\hline •••• Yoigo $3 G \quad 20: 17$ & 은 $50 \%$ \\
\hline lib.ncsu.edu & $c$ \\
\hline HAN & \\
\hline Books \& Media & $>$ \\
\hline Articles & $>$ \\
\hline Course Reserves & $>$ \\
\hline Hours \& Locations & $>$ \\
\hline Ask Us & $>$ \\
\hline Ф My Account & $>$ \\
\hline
\end{tabular}

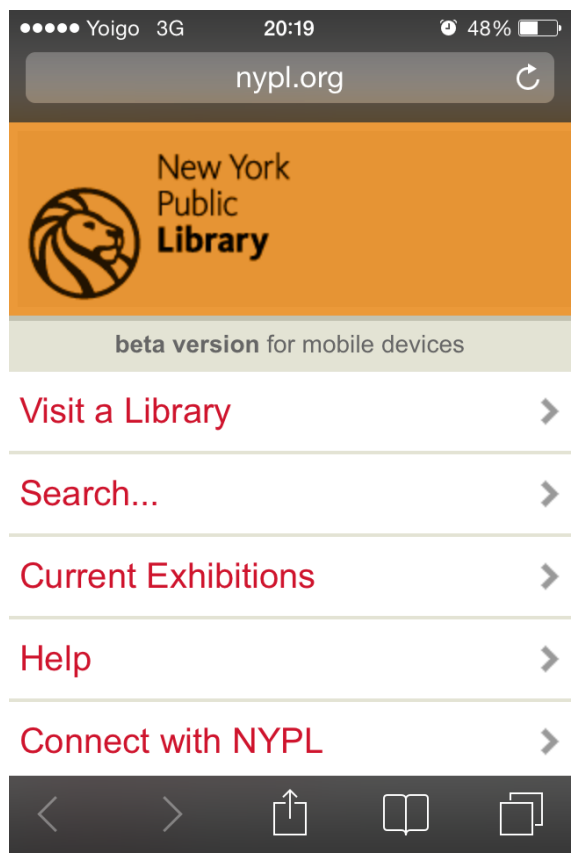

Sitios web con diseño de menú vertical, con y sin iconos. 

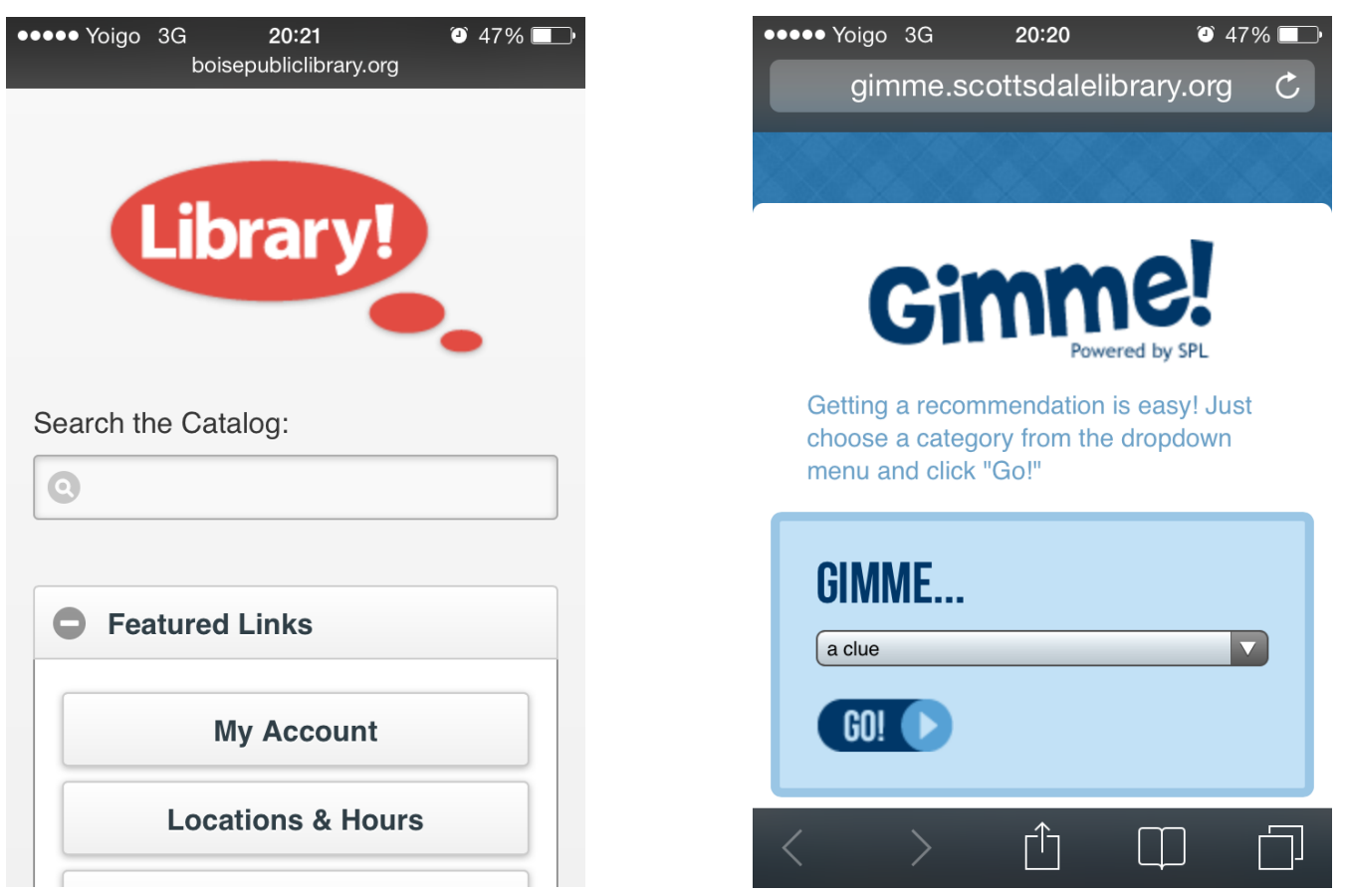

Getting a recommendation is easy! Just choose a category from the dropdown menu and click "Go!"

Sitios web con diseño de búsqueda y menú desplegable.

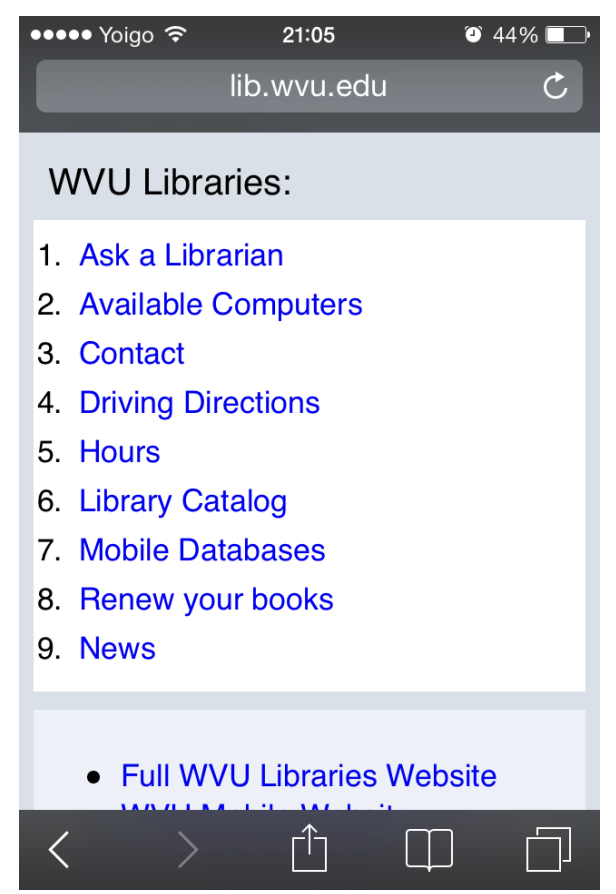

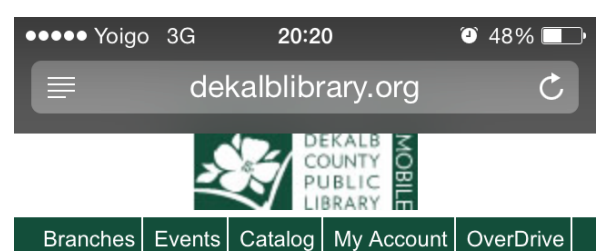

\section{LIBRARY NEWS}

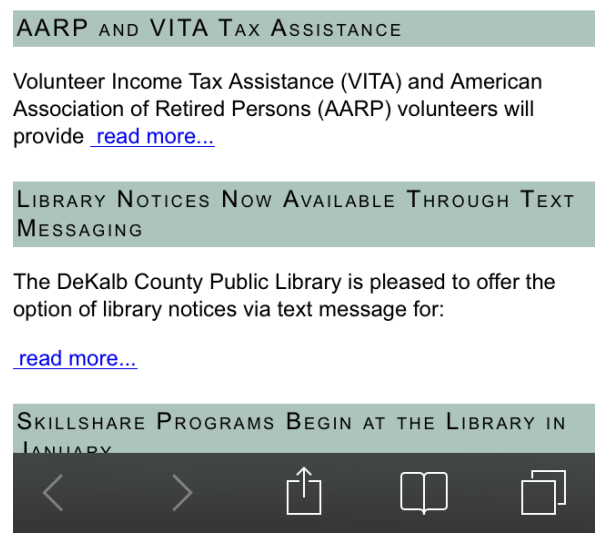

Sitios web con diseño textual. El primero de ellos en formato de menú vertical textual. 

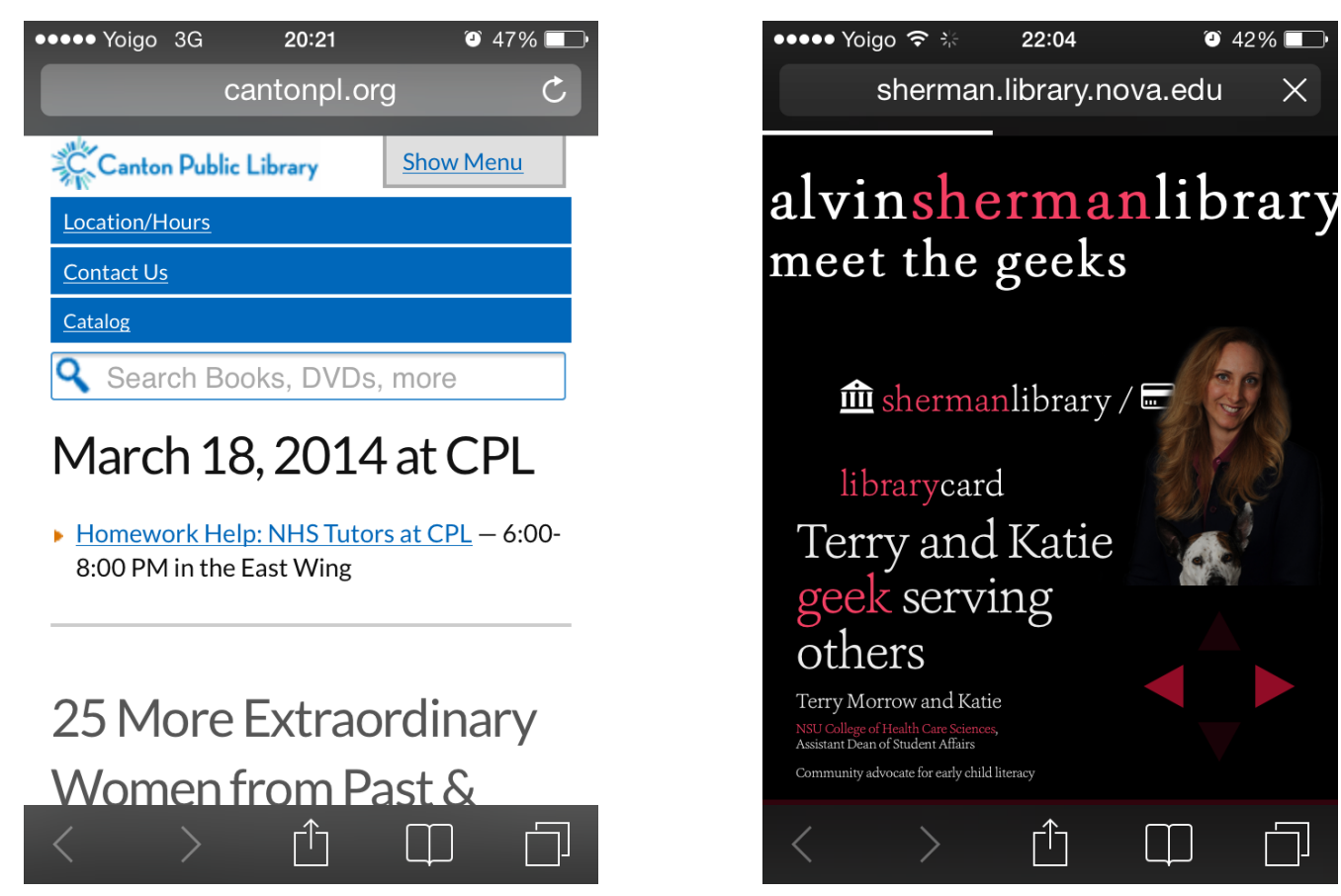

Diseño de módulos y banners 


\section{Anexo 2. Software móvil para herramientas de búsqueda}

\section{Software comercial}

Lanzamiento de AirPac (junio de 2001) http://www.librarytechnology.org/diglibfulldisplay.pl?SID=20140707998413085\&code=bib\&RC=9204\&Row=41\&

Módulo móvil de BicatWISE (abril de 2012)

http://www.librarytechnology.org/diglib-

fulldisplay.pl?SID=20140707998413085\&code=bib\&RC=18401\&Row=8\&

Adquisición de BicatWISE por OCLC http://www.librarytechnology.org/diglib-

fulldisplay.pl?SID=20140707998413085\&code=bib\&RC=18369\&Row=1\&

Lanzamiento de DDElibra Mobil (enero 2008)

http://www.librarytechnology.org/diglib-

fulldisplay.pl?SID=20140707485931396\&code=bib\&RC=15396\&Row=20\&

Flyer de DDElibra Mobiblio

http://www.axiell.dk/c/document library/get file?uuid=12299c99-b958-4cfb-

9cce-509329327be1\&groupId=13101

MOPAC de Baratz http://www.baratz.es/Home/Noticias/tabid/106/Default.aspx

http://www.fesabid.org/proveedor/noticia/mopac-el-opac-descubre-el-movil$\underline{\text { baratz }}$

Flyer sobre MOPAC http://www.baratz.es/Descargas/MOPAC.pdf

Polaris MobilePAC http://www.polarislibrary.com/polaris-products/pac/mobilepac/

Xerxes http://code.google.com/p/xerxes-portal/wiki/Implementations

\section{Software libre}

MobileCat http://code.google.com/p/mobilecat/

Interfaz del Universal College of Learning in New Zealand para WebVoyager http://www.exlibrisgroup.org/display/VoyagerCC/WebVoyage+Mobile+skin+swit cher 


\section{Software de terceros}

Library Anywhere http://www.libanywhere.com

Library Anywhere is live (octubre 2010)

http://blog.librarything.com/thingology/2010/10/library-anywhere-is-live-2/

\section{Herramientas de descubrimiento}

BiblioCommons http://www.bibliocommons.com

BiblioMobile http://www.bibliocommons.com/products/mobile

EBSCO Discovery Services http://www.ebscohost.com/discovery

http://www.ebscohost.com/discovery/user-experience/eds-mobile-access

Primo http://www.exlibrisgroup.com/category/PrimoOverview

Primo for Mobile http://www.exlibrisgroup.com/category/PrimoForMobile

Summon http://www.proquest.com/products-services/discovery-services/The-

Summon-Service.html

The Summon $^{\text {TM }}$ Service Goes Mobile (noviembre 2009)

http://www.proquest.com/about/news/2009/the-summon-service-goes-

mobile.html

VuFind http://vufind.org

WorldCat Local http://oclc.org/worldcat-local.en.html

WorldCat Local Mobile now in production (junio 2011)

http://www.oclc.org/news/releases/2011/201134.en.html

WorldCat Discovery Services is now available (abril 2014)

http://www.librarytechnology.org/diglib-

fulldisplay.pl?SID=20140708697540283\&RC=19071\&code $=$ pr $\&$ Row $=20$ 

Índices 



\section{Índice de gráficos}

Gráfico 1. Publicaciones sobre el uso de dispositivos móviles en bibliotecas entre 1995 y 2014 en el ámbito internacional. 24

Gráfico 2. Publicaciones de autores españoles sobre el uso de dispositivos móviles en bibliotecas entre 2008 y 2014.

Gráfico 3. Publicaciones sobre el uso de dispositivos móviles en bibliotecas por tipo de publicación. 26

Gráfico 4. Publicaciones en la bibliografía internacional sobre el uso de dispositivos móviles en bibliotecas por tema. 26

Gráfico 5. Publicaciones en la bibliografía española sobre el uso de dispositivos móviles en bibliotecas por tema.

Gráfico 6. Penetración de la telefonía móvil (azul) y de la banda ancha (rojo) en España entre el primer trimestre de 2011 y el último de 2013. Elaboración propia a partir de los datos de la Comisión Nacional de los Mercados y de la Competencia. 36

Gráfico 7. Equipos a través de los que se accede a internet. España, 2014. Elaboración propia a partir de los datos de Navegantes en la red. 17a encuesta AIMC a usuarios de internet (2015). 38

Gráfico 8. Smartphones vendidos por sistema operativo. Cuarto trimestre de 2013. Elaboración propia a partir de los datos de ABI Research 43

Gráfico 9. Evolución del acceso a internet desde los principales dispositivos en España, 2001-2014. Porcentaje de usuarios que acceden a internet desde diferentes dispositivos. Fuente: AIMC.. 67

Gráfico 10. Bibliotecas por número de sitios web para dispositivos móviles en la muestra ( $n=167$ bibliotecas).

Gráfico 11. Sitios web por área geográfica ( $n=196$ sitios web)................................... 281

Gráfico 12. Sitios web por tipo de biblioteca ( $n=196$ sitios web).............................. 283

Gráfico 13. Sitios web por año de creación ( $n=171$ sitios web).................................... 284

Gráfico 14. Sitios web por fecha de creación en Estados Unidos (izquierda) y España (derecha) ( $n_{1}=114$ sitios web y $n_{2}=23$ sitios web). 285 
Gráfico 15. Sitios web en función de su utilidad ( $n=196$ sitios web).......................... 286

Gráfico 16. Sitios web por tipo de dispositivo ( $n=196$ sitios web)............................. 288

Gráfico 17. Sitios web por métodos de adaptación a los dispositivos móviles $(n=196$ sitios web). 290

Gráfico 18. Evolución de los sitios web en función de la solución de movilidad que emplean ( $n=171$ sitios web) 291

Gráfico 19. Sitios web con páginas diferenciadas para dispositivos móviles por sistema de acceso desde la versión completa y por país ( $n=157$ sitios web). 292

Gráfico 20. Sitios web para dispositivos móviles enlazados desde la versión completa según la visibilidad de los enlaces y país ( $n=80$ sitios web). 295

Gráfico 21. Sitios web con páginas diferenciadas para dispositivos móviles con la opción «Ir al sitio completo», por años. 295

Gráfico 22. Sitios web para smartphones por plantilla de diseño y país ( $n=175$ sitios web). 299

Gráfico 23. Evolución de los sitios web para smartphones y tabletas con botones para enlaces y elementos seleccionables (niveles 2 y 3$)(n=70)$...... 302

Gráfico 24. Porcentaje de sitios web con páginas diferenciadas para dispositivos móviles por lenguajes de marcado ( $n=157$ sitios web). 303

Gráfico 25. Evolución de los lenguajes de marcado móviles (XHTML MP y XHTML Basic) en los sitios web de bibliotecas con páginas diferenciadas para dispositivos móviles ( $n=38$ sitios web)...... 304

Gráfico 26. Sitios web con páginas diferenciadas para dispositivos móviles por tipo de metadatos ( $n=157$ sitios web). 306

Gráfico 27. Uso de analíticas en los sitios web de la muestra ( $n=196$ sitios web).306

Gráfico 28. Sitios web con páginas diferenciadas para dispositivos móviles por elementos de navegación ( $n=157$ sitios web). 311

Gráfico 29. Sitios web adaptados mediante hojas de estilo (izquierda) y diseño adaptativo (derecha) $\left(n_{1}=9\right.$ y $n_{2}=30$ sitios web). 311

Gráfico 30. Sitios web por elementos de navegación en Estados Unidos (izquierda) y España (derecha) ( $n_{1}=131$ y $n_{2}=25$ sitios web).

Gráfico 31. Sitios web según el aprovechamiento de las funciones del dispositivo $(n=196$ sitios web).

Gráfico 32. Evolución en el número de sitios web que no aprovechan ninguna función del dispositivo ( $n=171$ sitios web) 
Gráfico 33. Sitios web por formatos de los contenidos y país ( $n=196$ sitios web).

Gráfico 34. Sitios web por formatos de los contenidos y solución de movilidad adoptada ( $n=196$ sitios web). 318

Gráfico 35. Contenidos y servicios en los sitios web para dispositivos móviles de la biblioteca con páginas diferenciadas en el conjunto de la muestra $(n=144$ sitios web).

Gráfico 36. Contenidos y servicios en los sitios web para dispositivos móviles de la biblioteca con páginas diferenciadas en Estados Unidos ( $n=100$ sitios web). 325

Gráfico 37. Contenidos y servicios en los sitios web para dispositivos móviles de la biblioteca con páginas diferenciadas en España ( $n=18$ sitios web). 326

Gráfico 38. Contenidos y servicios en los sitios web para dispositivos móviles de la biblioteca con páginas diferenciadas en bibliotecas universitarias $(n=112$ sitios web).

Gráfico 39. Contenidos y servicios en los sitios web de la biblioteca con páginas diferenciadas en bibliotecas públicas ( $n=22$ sitios web).

Gráfico 40. Sitios web para smartphones en los que la longitud del texto no se adecua a las características del dispositivo ( $n=189$ sitios web). 331

Gráfico 41. Sitios web para smartphones con enlaces a páginas web no adaptadas para dispositivos móviles. En amarillo, aquellos en los que se indica de alguna forma que se trata de una página no adaptada ( $n=189$ sitios web).

Gráfico 42. Bibliotecas en función del número de aplicaciones que han desarrollado ( $n=53$ bibliotecas).

Gráfico 43. Aplicaciones analizadas por área geográfica ( $n=73$ apps). 340

Gráfico 44. Aplicaciones por tipo de biblioteca ( $n=73$ apps).

Gráfico 45. Aplicaciones por tipo de biblioteca y país ( $\mathrm{n}=73$ apps). Leyenda: $\mathrm{BU}=$ bibliotecas universitarias. $\mathrm{BP}=$ bibliotecas públicas. $\mathrm{BN}=$ bibliotecas nacionales. $\mathrm{BE}=$ bibliotecas especializadas. $\mathrm{BD}=$ bibliotecas digitales. 342

Gráfico 46. Aplicaciones que reproducen los contenidos del sitio web de la biblioteca o el catálogo por el tipo de institución que las ha creado $(n=34$ apps).

Gráfico 47. Aplicaciones analizadas por año de creación ( $\mathrm{n}=72$ apps). 344

Gráfico 48. Aplicaciones por país y fecha de creación ( $n=72$ apps). 345 
Gráfico 49. Aplicaciones en función de su utilidad ( $n=73$ apps).................................. 348

Gráfico 50. Apps por tipo de dispositivo ( $n=73$ apps)................................................... 350

Gráfico 51. Aplicaciones por tipo de dispositivo y área geográfica ( $n=73$ apps)... 350

Gráfico 52. Aplicaciones por sistema operativo ( $n=73$ apps).

Gráfico 53. Aplicaciones por sistema operativo y área geográfica ( $n=73$ apps).... 352

Gráfico 54. Aplicaciones para iOS según su clasificación en las categorías en la App

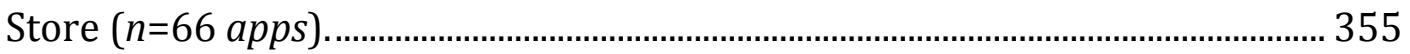

Gráfico 55. Aplicaciones para Android según su clasificación en las categorías en

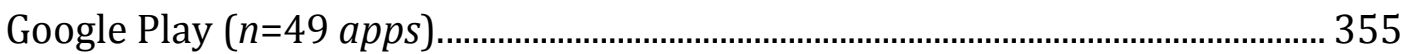

Gráfico 56. Aplicaciones en función del tiempo pasado desde su última

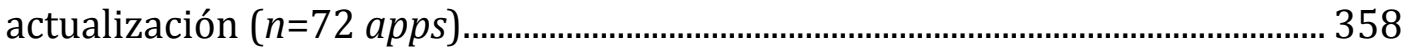

Gráfico 57. Aplicaciones en función del tamaño que ocupan y de la tienda de aplicaciones ( $n_{1}=66$ y $n_{2}=48$ apps)...

Gráfico 58. Apps según número de descargas y utilidad de la aplicación $(n=49$ apps).

Gráfico 59. Aplicaciones por número de valoraciones recibidas en las tiendas de aplicaciones de Apple y Android ( $n_{1}=66$ apps y $n_{2}=49$ apps). 364

Gráfico 60. Aplicaciones que reproducen los contenidos del sitio web de la biblioteca y del OPAC en función de su plantilla de diseño. Se señalan en amarillo aquellas que además incluyen un menú inferior y en verde las que no. $(n=34$ apps $)$.

Gráfico 61. Aplicaciones con fondos patrimoniales y otras utilidades en función de su plantilla de diseño. Se señalan en amarillo aquellas que además incluyen un menú inferior y en verde las que no ( $n=39$ apps).

Gráfico 62. Aplicaciones que reproducen el sitio web o el catálogo de la biblioteca según la frecuencia de aparición de los elementos de navegación ( $n=34$ apps). 371

Gráfico 63. Aplicaciones de uso patrimonial (a la izquierda) y con otras utilidades (derecha) según la frecuencia de aparición de los elementos de navegación $\left(n_{1}=21\right.$ y $n_{2}=18$ apps $)$.

Gráfico 64. Aplicaciones en función del uso de formatos de vídeo, audio y documentos y por utilidad ( $n=73$ apps).

Gráfico 65. Aplicaciones en función del uso de formatos de vídeo, audio y documentos y por área geográfica ( $n=73$ apps). 
Gráfico 66. Aprovechamiento de las funciones del dispositivo en las aplicaciones de bibliotecas ( $n=73$ apps).

Gráfico 67. Aprovechamiento de las funciones del dispositivo en las aplicaciones de bibliotecas estadounidenses ( $n=20$ apps)... 378

Gráfico 68. Aprovechamiento de las funciones del dispositivo en las aplicaciones de bibliotecas españolas $(n=14)$. 378

Gráfico 69. Aplicaciones que reproducen los contenidos del sitio web de la biblioteca por tipo de contenidos y servicios ( $n=25$ apps). 380

Gráfico 70. Aplicaciones que reproducen los contenidos del sitio web de la biblioteca por tipo de contenidos y servicios. Estados Unidos $(n=7)$................. 382

Gráfico 71. Aplicaciones que reproducen los contenidos del sitio web de la biblioteca por tipo de contenidos y servicios. España $(n=8)$. 383

Gráfico 72. Aplicaciones de utilidad patrimonial según los contenidos y servicios que incluye $(n=21)$. 384

Gráfico 73. Aplicaciones para smartphones con enlaces a sitios web no adaptados para dispositivos móviles, por países ( $n=63$ apps). 385

Gráfico 74. Catálogos móviles por solución de movilidad adoptada ( $n=83$ bibliotecas).

396

Gráfico 75. Catálogos móviles por solución adoptada y país ( $n=78$ bibliotecas). . 397

Gráfico 76. Herramientas de descubrimiento con interfaces móviles $(n=64$ bibliotecas).

Gráfico 77. Catálogos y herramientas de descubrimiento móviles de desarrollo propio según las funciones que incluyen $(n=41)$. 405

Gráfico 78. Catálogos y herramientas de descubrimiento móviles en el software comercial según las funciones que incluyen $(n=11)$. 405

Gráfico 79. Catálogos en aplicaciones nativas según las funciones que incluyen $(n=19)$ 408

Gráfico 80. Sesiones registradas desde smartphones y teléfonos móviles por sistema operativo y semestre.

Gráfico 81. Sesiones registradas desde tabletas por sistema operativo y semestre.

Gráfico 82. Sesiones desde dispositivos móviles por sistema de entrada de datos y curso. 


\section{Índice de tablas}

Tabla 1. Principales tiendas de aplicaciones móviles por número de apps. Elaboración propia a partir de diferentes fuentes.

Tabla 2. Contenidos y servicios más demandados por los usuarios de dispositivos móviles tal y como se recogen en la bibliografía.

Tabla 3. Contenidos y servicios en los sitios web para móviles de las bibliotecas de la AUCC. Elaboración propia a partir de los datos publicados por Canuel y Crichton (2011). 102

Tabla 4. Contenidos y servicios en los sitios web para móviles de las bibliotecas universitarias. Elaboración propia a partir de los datos publicados por Han y Jeong (2012).

Tabla 5. Longitud de las búsquedas desde smartphones, tabletas y ordenador. Fuente: Song, et al. (2013).

Tabla 6. Porcentaje de bibliotecas públicas con algún servicio para dispositivos móviles por tramos de población. Elaboración propia a partir de los datos de

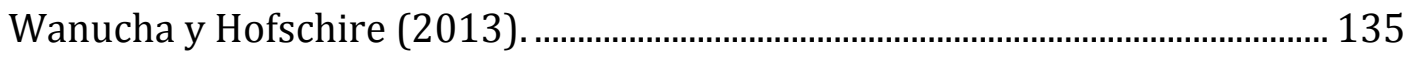

Tabla 7. Número de casos de la muestra por unidad de análisis y país...................... 222

Tabla 8. Bibliotecas con más de un sitio web analizado.................................................. 280

Tabla 9. Sitios web por tipo de biblioteca y país ( $n=196$ sitios web)........................ 283

Tabla 10. Sitios web en función de su utilidad y país ( $n=196$ sitios web)................. 287

Tabla 11. Sitios web por soluciones de movilidad y por países $(n=196) . . . . . . . . . . . . . . . .291$

Tabla 12. Sitios web con páginas diferenciadas para dispositivos móviles según el sistema de acceso de la versión completa y por país ( $n=157$ sitios web)....... 293

Tabla 13. Sitios web para smartphones y teléfonos móviles por longitud del URL y país ( $n=193$ sitios web).

Tabla 14. Sitios web para smartphones y tabletas por nivel de diseño táctil y país $(n=192$ sitios web). 301

Tabla 15. Sitios web con páginas diferenciadas para dispositivos móviles por lenguajes de marcado y país ( $n=157$ sitios web). 304 
Tabla 16. Sitios web por elementos de navegación y tipo de dispositivo $(n=196$ sitios web).

Tabla 17. Aplicaciones de la muestra y otras encontradas en las tiendas de aplicaciones según su utilidad ( $n=441$ apps).

Tabla 18. Correspondencia de las categorías en las tiendas de aplicaciones de Apple (Apple Store) y Android (Google Play). 354

Tabla 19. Aplicaciones que se han actualizado alguna vez o nunca por año de creación ( $n=72$ apps). 357

Tabla 20. Tamaño de las apps de bibliotecas en las tiendas de aplicaciones de Apple y Android ( $n=72$ apps).

Tabla 21. Descargas de apps según el número de usuarios de bibliotecas universitarias. 363

Tabla 22. Aplicaciones según el aprovechamiento que hacen de las funciones del dispositivo y por utilidad ( $n=73$ apps).

Tabla 23. Sitios web para dispositivos móviles que representan a la web de la biblioteca en función de si incluyen o no enlace al catálogo y/o herramienta de descubrimiento, por países ( $\mathrm{n}=181$ sitios web). 394

Tabla 24. Sitios web para dispositivos móviles que representan a la web de la biblioteca en función de si incluyen o no enlace al catálogo y/o herramienta de descubrimiento, por tipo de biblioteca ( $\mathrm{n}=177$ sitios web) 395

Tabla 25. Software comercial en los catálogos de la muestra ( $n=24$ catálogos)... 398

Tabla 26. Sesiones registradas en el sitio web de la Biblioteca de la Universidad de Salamanca por tipo de dispositivo y curso académico 416

Tabla 27. Número de páginas vistas por sesión y por tipo de dispositivo y curso. 416

Tabla 28. Duración media de las sesiones por tipo de dispositivo y curso. 417

Tabla 29. Duración media de las sesiones a la web desde smartphones por sistema operativo y curso. 417

Tabla 30. Porcentaje de rebote por tipo de dispositivo y curso. 419

Tabla 31. Porcentaje de nuevas sesiones por tipo de dispositivo y curso 419

Tabla 32. Páginas más vistas por los usuarios desde smartphones y tabletas durante el curso 2013-2014. Datos basados en el 59,1\% de las sesiones....... 423

Tabla 33. Páginas más vistas por los usuarios desde ordenadores durante el curso 2013-2014. Datos basados en el 59,1\% de las sesiones. 424 
Tabla 34. Número de sesiones al catálogo por tipo de dispositivo y curso. 429

Tabla 35. Duración media de cada sesión por tipo de dispositivo y curso.

Tabla 36. Número de páginas por sesión por tipo de dispositivo y curso. 429

Tabla 37. Porcentaje de rebote por tipo de dispositivo y curso. 430

Tabla 38. Visitas al catálogo WorldCat desde dispositivos móviles, curso 20132014.

Tabla 39. Páginas por visita al catálogo WorldCat desde dispositivos móviles, curso 2013-2014.

Tabla 40. Duración de las visitas al catálogo WorldCat por tipo de dispositivo, 2013-2014 431

Tabla 41. Número de descargas de la aplicación Biblio USAL desde la tienda de aplicaciones de Apple (App Store) e instalaciones activas en dispositivos Android.

Tabla 42. Número de sesiones en BiblioUSAL por tipo de dispositivo y curso....... 436

Tabla 43. Duración media de las sesiones en BiblioUSAL por tipo de dispositivo y curso. 436

Tabla 44. Número de páginas por sesión en BiblioUSAL, por tipo de dispositivo y curso. 436

Tabla 45. Porcentaje de rebote en la app BiblioUSAL, por tipo de dispositivo y curso.

Tabla 46. Páginas de BiblioUSAL más vistas desde smartphones y tabletas durante el curso 2013-2014. 438 


\section{Índice de figuras}

Figura 1. Evolución de los estándares de la web móvil. Imagen de Matthew Stuckwisch compartida bajo licencia CC BY 3.0 en la Wikipedia. 46

Figura 2. Servicios que consideran de utilidad desde el móvil los alumnos y el personal de la Universidad de Cambridge y la Universidad Abierta (Mills, 2009). 92

Figura 3. Servicios a los que acceden desde el móvil los estudiantes de las universidades de Highlands and Islands, Queen Margaret y Edinburgh Napier (The M-Library..., 2011). 95

Figura 4. Servicios demandados por los estudiantes de la Utah State University. Fuente: Dresselhaus y Shrode (2012). 96

Figura 5. Contenidos y servicios que los estudiantes de la Oregon State University buscan en el sitio web móvil de la biblioteca. Comparación entre los resultados de la primera y segunda entrevista. Fuente: Rempel y Bridges (2014). 97

Figura 6. Servicios de la biblioteca más demandados por los usuarios de dispositivos móviles según la bibliografía. Elaboración propia........................... 100

Figura 7. Contenidos y servicios en los sitios web diseñados para dispositivos móviles en las bibliotecas universitarias de Estados Unidos. Fuente: Jackson (2013)..... 104

Figura 8. Catálogo de la Biblioteca de la Universidad Politécnica de Cartagena en la aplicación nativa BookMyne. 116

Figura 9. Catálogo de las bibliotecas de la Universidad de Hartford, que funciona con Koha. 118

Figura 10. Catálogo de la Biblioteca Fondren, Rice University (Estados Unidos). 121

Figura 11. Resultado del escaneado del código de barras en un libro en la aplicación nativa de la Ryerson University (izquierda) y localización de los registros de la biblioteca de la Rice University en el mapa (derecha). 125

Figura 12. Opciones de personalización y búsqueda en la base de datos de Emerald. 130

Figura 13. Expectativas de los usuarios para las aplicaciones nativas de las bibliotecas. Fuente: Library Journal Patron Profiles (Rapp, 2012). 146 
Figura 14. Opciones de pago en la app 19th Century Collection, de la British Library.

Figura 15. Aspecto de un código QR. 166

Figura 16. Sitios web con sistema de navegación contextual y menú en la parte inferior. 308

Figura 17. Sitios web con banner con diapositivas y menú desplegable lateral.... 309

Figura 18. Diferentes formas de enlazar a la app desde el sitio web móvil.............. 366

Figura 19. Cortinilla y menú horizontal inferior en la aplicación BibliosBCN......... 368

Figura 20. Menús cronológico y numérico. 372

Figura 21. Menú gestual en forma de galería de imágenes de la aplicación Cartes Marines. 373

Figura 22. Información de disponibilidad y localización en el catálogo de la biblioteca de la Harvard College.. 402

Figura 23. Registros breve y largo. El de la izquierda corresponde a la Onondaga County Public Library y ha sido adaptado con el módulo Polaris Mobile Pac. El segundo es el catálogo de las Bibliotecas Públicas de Navarra, adaptado con el módulo Mopac de Baratz, y representa a un registro largo. 403

Figura 24. Búsqueda sencilla y con limitadores en la biblioteca Cal Poly Pomona (California State University), a la izquierda, y la National Library Board Singapore, a la derecha.. 404

Figura 25. Localización de los registros en el mapa en los catálogos de las bibliotecas de Ryerson University (izquierda) y Oxford University (derecha). 406

Figura 26. Sitio web de la Biblioteca de la Universidad de Salamanca en su versión de escritorio y móvil. 414

Figura 27. Catálogos de la Biblioteca de la Universidad de Salamanca: WebPAC PRO (izquierda) y la versión móvil de WorldCat (derecha). 428

Figura 28. BiblioUSAL, la aplicación de la Biblioteca de la Universidad de Salamanca. 
